

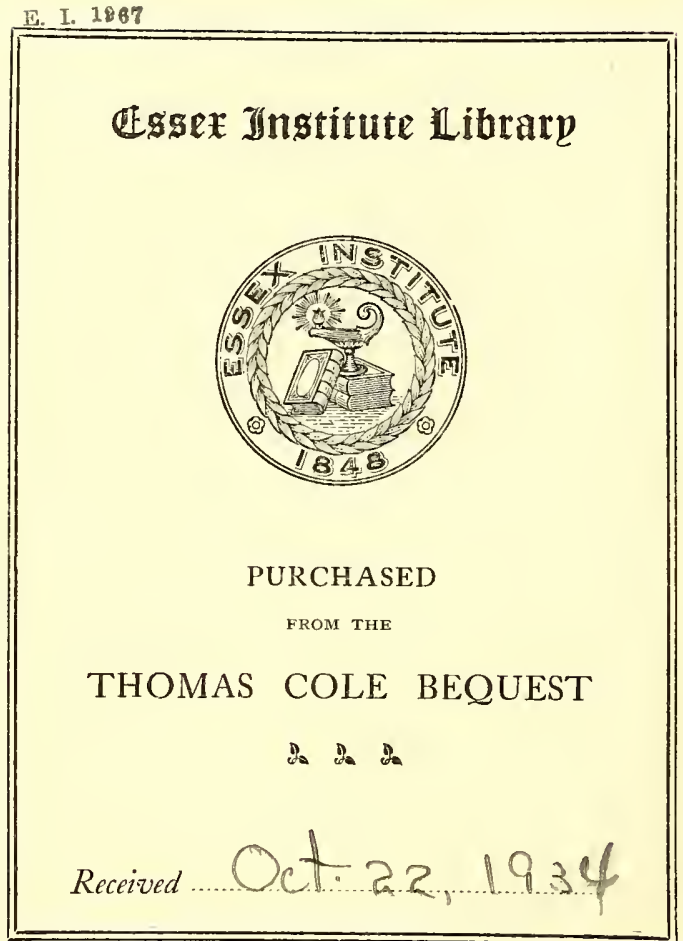



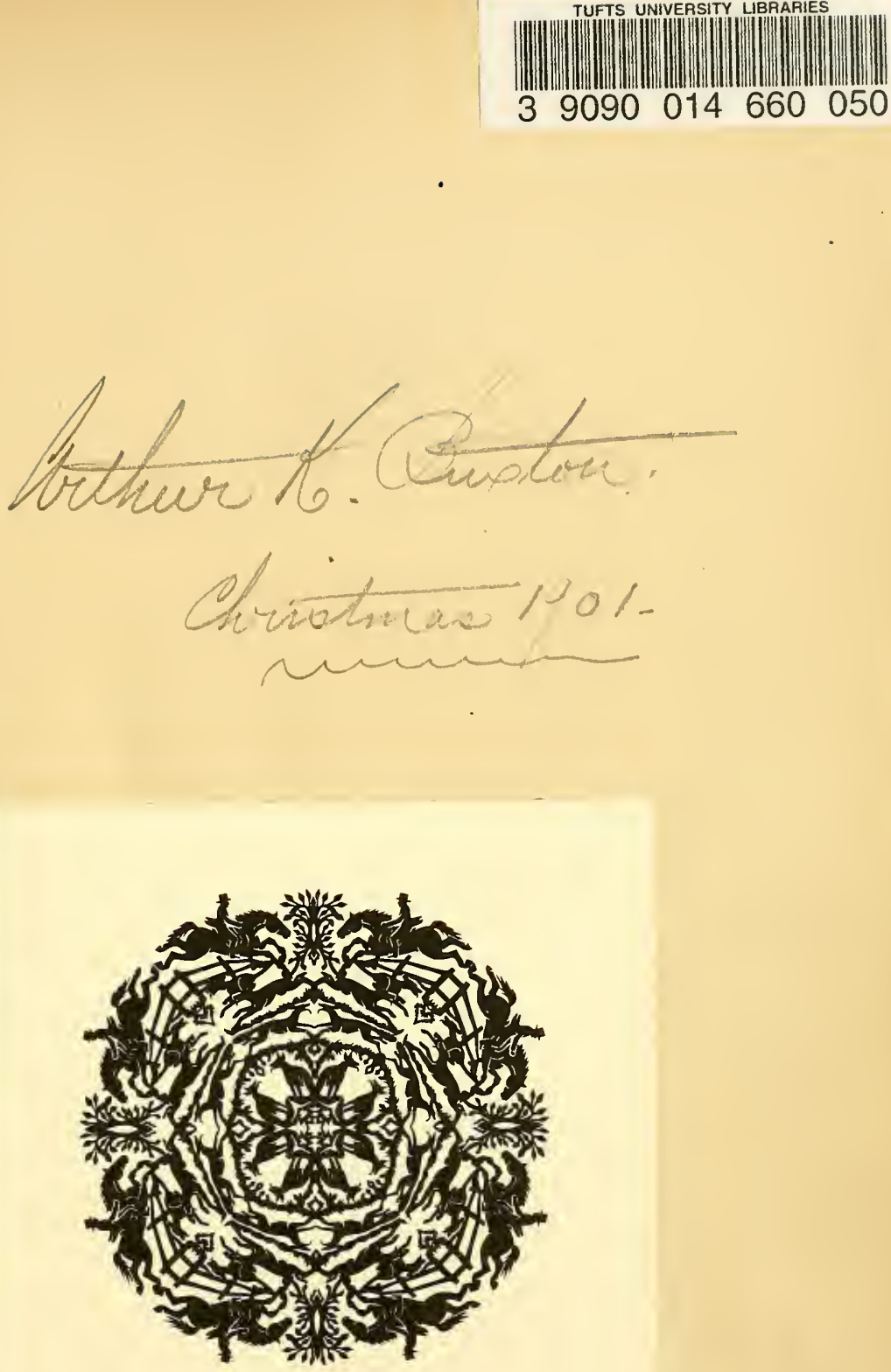

JOHN A.SEAVERNS 

Webster Family Library of Veterinary Medicine Cummings School of Veterinary Medicine at Tufts University 200 Westboro Road North Grafton, MA 01536 


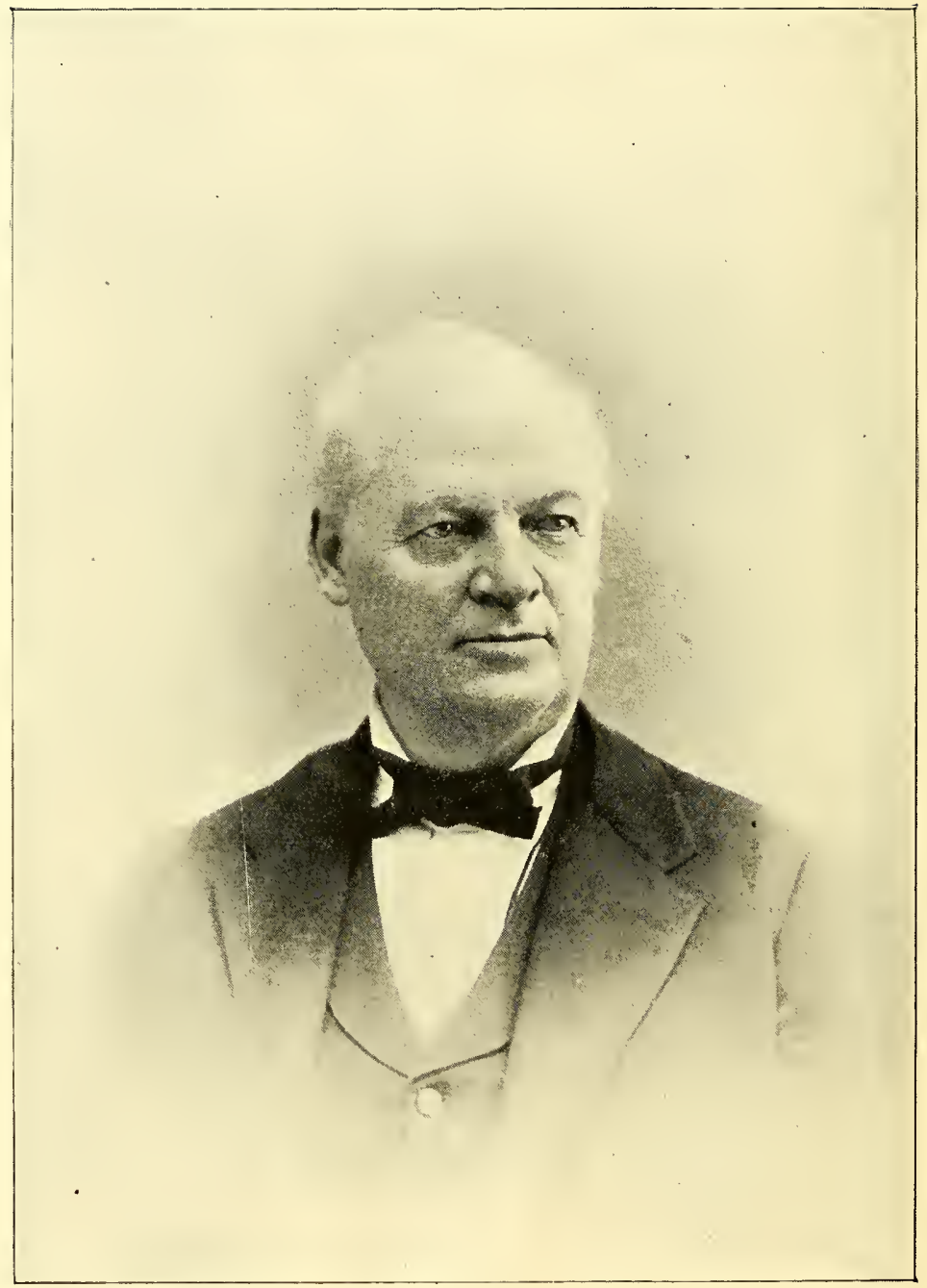

JOHN H. WALLACE. 
THE

\section{HORSE OF AMERICA}

IN HIS

DERIVATION, History, ANd DEVELOPMENT.

TRACING HIS ANCESTORS, BY THE AID OF MUCH NEWLY DISCOVERED DATA, THROUGH ALL THE AGES FROM THE FIRST DAWNINGS OF HISTORY TO THE PRESENT DAY.

INCLUDING THE HORSES OF THF COLONIAL PERIOD, HITHERTO UNEXPLORED, GIVING THEIR HISTORY, SIZE, GAITS AND CHARACTERISTICS

IN EACH OF THE AMERICAN COLONIES.

SHOWING HOW THE TROTTING HORSE IS BRED, TOGETHER WITH A HISTORY OF THE PUBLICATIONS THROUGH WHICH THE BREED OF TROTTERS WAS ESTABLISHED.

WITH MAPS AND ILLUSTRATIONS.

BY

\section{JOHN H. WALLACE,}

Founder of "Wallace's American Trotting Register," "Wallace's Monthly,"

"Wallace's Year Book," etc.

NEW YORK:

PUBLISHED BY THE AUTHOR.

$189 \%$. 
Entered according to act of Congress, by JOHN H. WALLACE,

in the year 1897, at Washington, D. C.

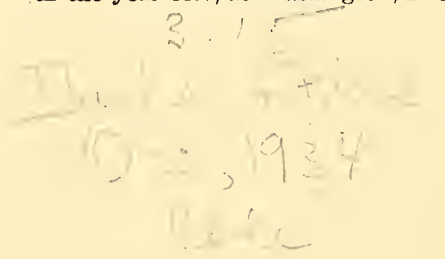




\section{PREFACE.}

The study of the Horse, from the first glimmerings of history, sacred and profane, and tracing him from his original home through his migrations until all the peoples of the globe had received their initial supply, may not be a new idea, but it is certainly a new nndertaking. Horse Books withont number have been written, mostly in the century just clusing, but in the history of the horse they are all alike-merely reproductions of what had been printed before. So far as my knowledge goes, therefore, this volume is the first attempt, in any language, to determine the original habitat of the horse and to trace him, historically, in his distribution.

The facts presented tonching the introduction of the horse into Egypt, and two thousand years later into Arabia, as well as the plebeian blood from which the English race horse has derived his great speed, will be a shock to the nerves of the romanticists of the old world as well as the new. Taking the facts of history and well-known experiences together, my readers can determine for themselves whether the claims for the superiority of Arabian blood is not pure fiction.: For my own part I cannot recognize any blood in all horsedom as "royal blood" except that which is found in the veins of the horse that "has gone out and done it," either himself or in his progeny.

In our own country there has always remained a blank in horse history that nobody has attempted to supply. This blank embraced a century of racing of which we of the present generation have been entirely ignorant. Believing that a correct knowledge of the horse of the Colonial period, in his size, gait, qualities and capacities was absolutely essential to an intelligent comprehension of the 
phenomena presented on our trotting and running courses of the present day, I have not hesitated to bestow on this new feature of the work great labor and research. In this I have felt a special satisfaction in the fact that while the field is old in dates, this is the first time it has ever been traversed and considered.

In the chapters which follow, many historical questions are treated at such length as their relative importance seems to demand, embracing the different families that have contributed to the building up of the breed of trotters; and the question of how the trotting horse is bred is carefully considered in the light of all past experiences and brought down to the close of 1896. These chapters will not surprise the old readers of the Wallace's Monthly, for they will here meet with many thoughts that will not be new to them, but they will find them more fully elaborated, in more orderly form, and brought down to the latest experiences.

It is not the purpose of this book to furnish statistical tables covering the great mass of trotting experiences, nor to consider the mysteries of the trainer's art that have been so ably discussed by experienced and skillful men. But the real and only purpose is to place mpon record the results of years devoted to historical research, at home and abroad; to dispel the illusions and humbugs that have clustered about the horse for many centuries; and to consider with some minnteness, which of necessity cannot be impersonal, the great industrial revolution that has been wrought in horse-breeding, and all growing out of a little unpretentious treatise written twenty-five jears ago, which contained nothing more striking than a little bit of science and a little bit of sense intelligently commingled. The battle between the principles of this treatise and selfish prejudices and mental sterility, was long and bitter, but the truth prevailed, and in the production of the Driving Horse the teachings of that little paper have placed our country first among all the nations of the earth.

JOHN H. WALLACE.

New York: 40 West 93D STreet. september 1, 18.97 


\section{CONTENTS.}

\section{CHAPTER I.}

I N T R OD UCT TON.

General View of the Field Traversed........................ 1-23

\section{CHAPTER II.}

\section{ORIGINAL HABITAT OF THE HORSE.}

No indications that the horse was originally wild-The steppes of High Asia and Arabia not tenable as his original home-Color not sufficient evidence-Impossibility of horses existing in Arabia in a wild state-No horses in Arabia until 356 A.D.-Large forces of Armenian, Median and Cappadocian cavalry employed more than one thousand seven hundred years B.C. - A breed of white race horses-Special adaptability of the Armenian country to the horse-Armenia a horse-exporting country before the Prophet Ezekiel-Devotion of the Armenian people to agricultural and pastoral pursuits through a period of four thousand years-All the evidences point to ancient Armenia as the center from which the horse was distributed. .......................24-35

\section{CHAPTER III.}

\section{EARLY DISTRIBUTION OF HORSES.}

First evidences of horses in Egypt about 1700 B.C.- Supported by Egyptian records and history-The Patriarch Job had no hor'ses-Solomon's great cavalry force organized-Arabia as described by Strabo at the beginning of our era-No horses then in Arabia-Constantius sends two hundred Cappadocian horses into Arabia A.D. 356-Arabia the last country to be supplied with horses-The ancient Phœnician merchants and their colonies-Hannibal's cavalry forces in the Punic WarsDistant ramifications of Phœnician trade and colonization-Commerce reached as far as Britain and the Baltic-Probable source of Britain's earliest horses..................................

\section{CHAPTER IV.}

THF ARABIAN HORSE.

The Arabian, the horse of romance-The horse naturally foreign to Arabia -Superiority of the camel for all Arabian needs-Scarcity of horses in Arabia in Molammed's time-Various preposterous traditions of Arab horsemanship-The Prophet's mythical mares-Mohammed not in any sense a horseman-Early English Arabians-the Markham Arabian -The alleged Royal Mares-The Darley Arabian-The Godolphin Arabian-The Prince of Wales' Arabian race horses-Mr. Blunt's pilgrimage to the Euphrates-His purchases of so-called Arabians-Deyr 
as a great horse market where everything is thoroughbred-Failure of Mr. Blunt's experiments-Various Arabian horses brought to America - Horses sent to our Presidents-Disastrous experiments of A. Keene Richards-Tendency of Arab romancing from Ben Hur..........51-66

\section{CHAPTER V.}

\section{THE ENGLISH RACE HORSE.}

The real origin of the English race horse in confusion-Full list of the " foundation stock" as given by Mr. Weatherby one hundred years ago - The list complete and embraces all of any note-Admiral Rous' ex. travaganza-Godolphin Arabian's origin wholly unknown-His history -Successful search for his true portrait-Stubbs' picture a caricature - The true portrait alone supplies all that is known of his origin and blood..........................................67-78

\section{CHAP'TER VI.}

\section{THE ENGLISH RACE HoRse (Continued).}

England supplied with horses before the Christian era-Bred for different purposes-Markham on uhe speed of early native horses-Duke of Newcastle on Arabians-His choice of blood to propagate-Size of early English horses-Difficulties about pedigrees in the seventeenth and eighteenth centuries-Early accumulations very trashy-The Galloways and Irish Hobbies-Discrepancies in size-The old saddle stock -The pacers wiped out-Partial revision of the English Stud Book..79-89

\section{CHAPTER VII.}

\section{THE AMERICAN RACE HORSE.}

Antiquity of American racing-First race course at Hempstead Plain, 1665 -Racing in Virginia, 1677-Conditions of early races-Early so-called Arabian importations-The marvelous tradition of Lindsay's " Arabian" -English race horses first imported about 1750 -'The old colonial st ock as a basis-First American turf literature-Skinner's American T'urf Register and Sporting Magazine, 1829-Cadwallader R. Colden's sporting Magazine, short-lived but valuable-The original Spirit of the 'Times-Porter's Spirit of the Times-Wilkes' spirit of the Times, 1859-Edgar's Stud Book-Wallace's Stud Book-Bruce's Stud Book -Their history, methods and value-Summing up results, showing that success has followed breeding to individuals and families that could run and not to individuals and families that could not run, whatever their blood.................................

\section{CHAPTER VIII.}

\section{COLONIAL HORSE HISTORT-VIRGINIA.}

Hardships of the colonists-First importations of horses-Racing prevalent in the seventeenth century-Exportations and then importations prohibited-Organized horse racing commenced 1677 and became very general-In 1704 there were many wild horses in Virginia and they were bunted as game-The Chincoteague ponies accounted for-Jones on life in Virginia, 1720-Fast early pacers, Galloways and Irish Hobbies-English race horses imported-Moreton's Traveler probably the first-Quarter racing prevailed on the Carolina border-Average 
size and habits of action clearly establišhed-The native pacer thrown in the shade by the imported runner-An Englishman's prejudices.........................................108-119

\section{CHAPTER IX.}

COLONIAL HORSE HISTORY-NEW YORK.

Settlement of New Amsterdam-Horses from Curagoa-Prices of Dutch and English horses-Van der Donck's description and size of horsesHorses to be branded-Stallions under fourteen hands not to run at large-Esopus horse-Surrender to the English, 1664-First organized racing-Dutch horses capable of improvement in speed-First advertised Subscription Plate-First restriction, contestants must " be bred in America"-Great racing and heavy betting-First importations of English running horses-Half-breds to the front-True foundation of American pedigrees-Half-bushel of dollars on a sideResolutions of the Continental Congress against racing-Withdrawal of Mr. James De Lancey-Pacing and trotting contests everywhereRip Van Dam's horse and his cost....................120-127

\section{CHAPTER $\mathrm{X}$.}

\section{COLONIAL HORSE HISTORY-NEW ENGLAND.}

First importations to Boston and to Salem-Importations from Holland brought high prices-They were not pacers and not over fourteen hands-In 1640 horses were exported to the West Indies-First American newspaper and first horse advertisement-Average sizes-The different gaits-CoNNECTICUT, first plantation, 1636-Post horses provided for by law-All horses branded-Sizes and Gaits-An Englishman's experience with pacers-Lindsay's Arabian-RHODE ISLAND, Founded by Roger Williams, 1636-No direct importations ever made - Horses largely exported to other colonies $1690-$ Possibly some to Canada-Pacing races a common amusement-Probibited, 1749-Size of the Narragansetts compared with the Virginians............128-134

\section{CHAPTER XI.}

COLONIAL HORSE HISTORY-PENNSYLVANIA, NEW JERSEY, MARYLAND, CARO-

$$
\text { LINA. }
$$

Penn's arrival in 1682-Horse racing prohibited-Franklin's newspaperConestoga horses-Sizes and gaits-Swedish origin-Acrelius' statement-NEW JERsEY-Branding-Increase of size-Racing, Pacing and Trotting restricted-MARYLAND-Racing and Pacing restricted 1747-Stallions of under size to be shot-NOR'TH CAROLINA-First settler refugees-SodTH CARoLINA-Size and gait in 1744-Challenges-No running blood in the colony, 1744-General view......135-141

\section{CHAPTER XII.}

\section{EARLY HORSE HISTORY-CANADA.}

Settlement and capture of Port Royal-Early plantations-First French horses brought over 1665-Possibly illicit trading-Sire of "Old Tippoo"-His history-" Scape Goat" and his descendants-Horses of the Maritime Provinces.... .................... 142-153 


\section{CHAPTER XIII.}

\section{ANTIQUITY AND HISTORY OF THE PACING HORSE.}

The mechanism of the different gaits-The Elgin Marbles-Britain becomes a Roman province-Pacers in the time of the Romans-Bronze horses of Venice-Fitz Stephen, the Monk of Canterbury-Evidence of the Great Seals-What Blundeville says-What Gervaise Marklam says-What the Duke of Newcastle says-The amble aud the pace one and the same-At the close of Elizabeth's reign-The Galloways and Hobbies-Extinction of the pacer-The original pacer probably from the North-Polydore Virgil's evidence-Samuel Purchas' evidence-The process of wiping out the pacer-King James set the fashion-All foreign horses called " A rabians"-The foreigners larger and handsomer-Good roads and wheeled vehicles dispensed with the pacer-Result of prompting Mr. Euren-Mr. Youatt's blunder-Other English gentlemen not convinced there ever were any pacers. ... 154-171

\section{CHAPTER XIV.}

THE AMERICAN PACER AND HIS RELATIONS TO THE AMERICAN TROTTER.

Regulations against stallions at large-American pacers taken to the West Indies-Narragansett pacers; many foolish and groundless theories about their origin-Dr. McSparran on the speed of the pacer-Mr. Updike's testimony-Mr. Hazard and Mr. Enoch Lewis-Exchanging meetings with Virginia-Watson's Annals-Matlack and AcreliusRip Van Dam's horse-Cooper's evidence-Cause of disappearanceBanished to the frontier-First intimation that the pace and the trot were essentially one gait- -How it was received-Analysis of the two gaits-Pelham. Highland Maid, Jay-Eye-see, Blue Bull-The pacer forces himself into publicity-Higher rate of speed-Pacing races very early-Quietly and easily developed-Comes to his speed quickly-His present eminence not permanent-The gamblers carried him thereWill he return to his former obscurity ?................ 172-189

\section{CHAPTER XV.}

\section{THE AMERICAN SADDLE HORSE.}

The saddle gaits come only from the pacer-Saddle gaits cultivated three hundred years ago-Markham on the saddle gaits-The military seat the best-The unity of the pace and trot-Gaits analyzed-Saddle Horse Register-Saddle horse progenitors-Denmark not a thoroughbred horse......................................

\section{CHAPTER XVI.}

\section{THE WILD MORSES OF AMERICA.}

The romances of fifty years ago-Was the horse indigenous to this country? - The theories of the paleontologists not satisfactory-Pedigrees of over two millions of years too lon :-Outlines of horses on prehistoric ruins, evidently modern-The linguistic test among the oldest tribes of Indians fails to discover any word for "Horse"-The horses aban. doned west of the Mississippi by the followers of De Soto about 1541 were the progenitors of the wild horses of the plains..........196-204 


\section{CHAP'LER XV̈II.}

\section{MESSENGER AND HIS ANCESTORS,}

Messenger the greatest of all trotting progenitors-Record of pedigrees in English Stud Book-Pedigrees made from unreliable sources-Messenger's right male line examined-Flying Childers' "mile in a minute" -Blaze short of being thoroughlored-Sampson, a good race horseHis size; short in his breeding-Engineer short also-Mambrino was a race loorse with at least two pacing crosses; distinguished as a progenitor of coach horses and fast trotters-Messenger's dam cannot be traced nor identified-Among all the horses claiming to be thoroughbred he is the only one that founded a family of trotters-This fact conceded by eminent writers in attempting to find others.......205-221

\section{CHAPTER XVIII.}

\section{HISTORY OF MESSENGER.}

Messenger's racing in England-His breeder unknown-Popular uncertainty about the circumstances and date of his importation-The matter settled by his first advertisement-Uncertainty as to his importer -Descriptiou of Messenger by David W. Jones, of Long Island-Careful consensus of descriptions by many who had seen Messenger-His great and lasting popularity as a stock horse-Places and prices of his services for twenty years-Death and burial. . . . . . . . . . 222-231

\section{CHAPTER XIX.}

\section{MES S E NGER'S S ON S.}

Hambletonian (Bishop's) pedigree not beyond doubt-Cadwallader R. Colden's review of it-Ran successfully-Taken to Granville, N. Y.Some of his descendants-Mambrino, large and coarse in appearanceFailure as a runner-Good natural trotter-His most famous sons were Abdallah, Almack, and Mambrino Paymaster-Winthrop or Maine Messenger and his pedigree and history-Engineer and the tricks of his owners-Certainly a son of Messenger-CommanderBush Messenger, pedigree and descripion-Noted as the sire of coach horses and trotters-Potomac-Tippoo Saib-Sir Solomon-Ogden Messenger, dam thoroughbred-Mambrino (Grey)-Black MessengerWhynot, Saratoga, Nestor, Delight-Mount Holly, Plato, Dover Messenger, Coriander, Fagdown, Bright Phœbus, Slasher, Sliaftsbury, Hotspur, Hutchinson Messenger and Cooper's Messenger-Abuse of the name "Messenger."...........................232-254

\section{CHAPTER XX.}

\section{MESSENGER'S DESCENDAN'TS.}

History of Abdallah-Characteristics of his dam, Amazonia-Speculations as to her blood-Description of Abdallah-Almack, progenitor of the Champion line-Mambrino Paymaster, sire of Mambrino Chief-History and pedigree-Mambrino Messenger-Harris' HambletonianJudson's Hambletonian-Andrus' Hambletonian, sire of the famous Princess, Happy Medium s dam......................255-266 


\section{CHAPTER XXI.}

\section{HAMBLETONIAN AND HIS FAMILY.}

The greatest progenitor in Horse History-Mr. Kellogg's description, and comments thereupon-An analysis of Hambletonian, structurally considered-His carriage and action-As a three-year-old trotter-Details of his stud service-Statistics of the Hambletonian family-History and ancestry of his dam, the Charles Kent Mare-Her gramdson, Green's Bashaw, and his dam........................... 267-283

\section{CHAPTER XXII.}

\section{HAMBLETONIAN'S SONS AND GRANDSONS.}

Different opinions as to relative merits of Hambletonian's greater sonsGeorge Wilkes, his history and pedigree-His performing descendants-History and description of Electioneer-His family-Alexander's Abdallah and his two greatest sons, Almont and Belmont-DictatorHarold-Happy Medium and his dam-Jay Gould-StrathmoreEgbert- $\Lambda$ berdeen-Masterlode-Sweepstakes-Governor Sprague, grandson of Hambletonian........................284-314

\section{CHAPTER XXIII.}

\section{MAMBRINO CHIEF AND HIS FAMILY.}

Description and history of Mambrino Chief-The pioneer trotting stallion of Kentucky-Matched against Pilot Jr.-His best sons-Mambrino Patchen, his opportunities and family-Woodford Mambrino, a notable trotter and sire--Princeps-Mambrino Pilot-Clark Chief-Fisk's Mambrino Chief Jr. -Ericsson. . . . . . . . . . . . . . . . . $315-320$

\section{CHAPTER XXIV.}

\section{THE CLAYS AND BASHAWS.}

The imported Barb, Grand Bashaw-Young Bashaw, an inferior individual - His greatest son, Andrew Jackson-His dam a trotter and pacerHis history-His noted son, Kemble Jackson-Long Island Black Hawk-Henry Clay, founder of the Clay family-Cassius M. ClayThe various horses named Cassins M. Clay-George M. Patehen-His great turf career-George M. Patchen Jr.-Harry Clay-The Moor, and his son Sultan's family..........................

\section{CHAPTER XXV.}

AMERICAN STAR, PILOT, CHAMPION, AND NORMAN FAMILIES.

Seely's American Star-His fictitons pedigree-Breeding really unknown -A trotter of some merit-His stud career-His daughters noted brood mares-Conklin's American Star-Old Pacing Pilot-History and probable origin-Pilot Jr. - Pedigree-Training and races-Prepotency -Family statistics summarized-Grinnell's Cliampion, son of Almack - His sons and performing descendants-Alexander's Norman and his sire, the Morse Horse-Swigert and Blackwond..............338-351 


\section{CHAPTER XXVI.}

THE BLUE BULL AND OTHER MINOR FAMILIES.

Blue Bull, the once leading sire-His lineage and history-His family rank-The Cadmus family-Pocahontas-Smuggler-Tom RolfeYoung Rolfe and Nelson-The Tom Hal Family-The various Tom Hals-Brown Hal-The Kentucky Hunters-Flora Temple-Edwin Forrest-The Drew Horse and his descendants-The Hiatogas.. . . . 352-365

\section{CHAPTER XXVII.}

THE BLACK HAWK, OR MORGAN FAMILY.

Characteristics of the Morgans-History of the original Morgan-The fabled pedigree-The true Briton theory-Justin Morgan's breeding hopelessly unknown-Sherman Morgan-Black Hawk-His disputed paternity-His dam called a Narragansett-Ethan Allen-His great beauty, speed, and popularity-The Flying Morgan claim baselessHis dam of unknown blood-His great race with Dexter-Daniel Lambert, the only successful sire of the Black Hawk line........366-389

\section{CHAPTER XXVIII.}

THE ORLOFF TROTTER, BELLFOUNDER AND THE ENGLISH HACKNEY.

Orloffs, the only foreign trotters of merit-Count Alexis Orloff, founder of the breed-Origin of the Orloff-Count Orloff began breeding in 1770 - Smetanka, Polkan, and Polkan's son, Barss, really the first Orloff trotting sire-The Russian pacers-Their great speed-Inported Bellfounder-His history and characteristics-Got little speed-His descendants-The English Hackney-Not a breed, but a mere typeThe old Norfolk trotters-Hackney experiments in America-Superiority of the trotting-bred horse demonstrated in show ring contests..............................................

\section{CHAPTER XXIX.}

\section{INVESTIGATION OF DISPUTED PEDIGREES.}

Tendency to misrepresentation-The Bald Galloway and Darley ArabianGodolphin Arabian-Early experiences with trotting pedigrees- Mr. Backman's honest methods-Shangliai Mary-Capt. Rynders and Widow Machree-Woodburn Farm and its pedigree methods-Victimized by "horse sharps" and pedigree makers-Alleged pedigree of Pilot Jr. conclusively overthrown - Pedigrees of Edwin Forrest, Norman, Bay Chief and Black Rose-Maud S. pedigree exhaustively considered-Captain John W. Russell never owned the mare Maria Russell-The deadly parallel columns settle it.............409-431

\section{CHAPTER XXX.}

\section{INVESTIGATION OF DISPUTED PEDIGREFS (Continued).}

How Belle of Wabash got her pedigree-Specimen of pedigree making in that day and locality-Search for the dam of Thomas Jefferson-True origin and history of Belle of Wabash-Facts about the old-time gelding Prince-The truth about Waxy, the grandam of SunolRemarkable attempts to make a pedigree out of nothing-How "Jim" 
Eoff worked a "tenderfoot"-Pedigree of American Eclipse-Pedigree of Boston-Tom Bowling and Aaron Pennington-Cluenery's Grey Eagle-Pedigree of George Wilkes in doubt................ $432-455$

\section{CHAP'TER XXXI.}

\section{HOW THE TROTTING HORSE IS BRED.}

Early trotting c.nd pacing races-Strains of blood in the first known trotters-The lesson of Maud S.-The genesis of trotting horse literature - The simple study of inheritance-The different forms of heredityThe famous quagga story not sustained-Illustrations in dogs-Heredity of acquired characters and instincts-Development of successive generations necessary-Unequaled collections of statistics-Acquired injuries and unsoundness transmitted.....................

\section{CHAPTER XXXII.}

\section{HOW THE TROTTING HORSE IS BRED (Continued).}

Trotting speed first supposed to be an accident-Then, that it came from the runner-William Wheelan's views-Test of powers of endurance -'I'he term " thoroughbred" much abused-Definition of "thoroughbred" - How trotters may be made " thoroughly bred"-How to study pedigrees-Reward offered for the production of a thoroughbred horse that was a natural pacer-The trotter more lasting than the ruunerThe dam of Palo Alto-Arion as a two-year-old-Only three stallions have been able to get trotters from running-bred mares-" Structural incongruity"-The pacer and trotter inseparable-How to save the trot and reduce the ratio of pacers-Development a necessity-Table proving this proposition-The "tin cup" policy a failure-Woodburn at the wrong end of the procession.............................

\section{CHAPTER XXXIII.}

\section{HOW THE TROTTING HORSE IS BRED (Continued).}

Breeding the trotter intelligently an industry of modern developmentPlethora of turf papers, and their timidity of the truth-The accepted theories, old and new-Failure of the "thoroughbred blood in the trotter" idea-" Thoroughbred foundations," and the Register"Like begets like," the great central truth-Long-continued efforts to breed trotters from runners-New York the original source of supply of trotting blood to all the States-Kentucky's beginning in breeding trotters-R. A. Alexander, and the founding of Woodburn -The "infallibility" of Woodburn pedigrees-Refusal to enter fictitious crosses in the Register and the results-The genesis and history of the standard-Its objects, effects, and influence-Establishing the breed of trotters-The Kentucky or "Pinafore" standardIts purposes analyzed-The "Breeders' Trotting Stud Book" and how it was compiled-Failure and collapse of the Kentucky project -Another unsuccessful attempt to capture the Register-How honest administration of the Register made enemies-The National Breeders' Association and the Chicago Convention-Detailed history of the sale and transfer of the Register, the events that led up to it, and the results-Personal satisfaction and benefits from the transfer, and the years of rest and congenial study in preparing this book-

The end........................................... 


\title{
APPENDIX.
}

\section{HISTORY OF THE WALLACE PUBLICATIONS.}

\author{
By a Friend of the Author.
}

Mr. Wallace's early life and education-Removal to Iowa, 1845-Secretary Iowa State Board of Agriculture-Begins work, 1856, on "Wallace's American Stud Book," published 1867-Method of gathering pedigrees -Trotting Supplement-Abandons Stud Book, 1870, and devotes exclusive attention to trotting literature-" American Trotting Register," Vol. I., published in 1871-Vol. II. follows in 1874-The valuable essay on breeding the forerunner of present ideas-Standard adopted 1879-Its history-Battles for control of the "Register"Wallace's Monthly founfed 1875-Its character, purposes, history, writers, and artists-"Wallace's Year Book" fonnded 1885-Great popularity and value-Transfer of the Wallace publications, and their degeneration................................. $547-559$ 



\section{ILLUSTRATIONS.}

Portratt of the Author $\ldots \ldots \ldots \ldots \ldots \ldots \ldots \ldots \ldots \ldots \ldots \ldots \ldots$ Frontispiece.

Map of Armenia, Cappadocia, Syria, Etc........... To face page 24

Map of Phenician Colonies and the Mediterranean... “ " " 36

Godolphin arabian, True Portrait $\}$ In one view..... . “ “ 67

Godolphin Arabian, Distorted ..... $\}$ In one view...... ،

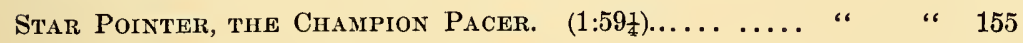

John R. Gentry, Pacer. $\left(2: 00 \frac{1}{2}\right) \ldots \ldots \ldots \ldots \ldots \ldots \ldots \ldots$ “ “ " 173

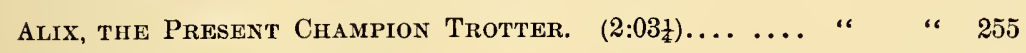

HAMBLETONIAN (RYSDYK's)................... ، " 267

George Wilkes, Son of Hambletonian............ “ “ " 284

Electioneer, Son of Hambletonian............. “ “ “ 289

Abdallah (Alexander's), Son of Hambletonian...... “ " " 294

NANCY Hanks, By Happy Medidm. (2:04)........... “ “ 306

Ethan Allen, by Vermont Black Hawk............ “ “ “ 381

Nore.-Nine of the above engravings have been reproduced, by permission, from the Portfolio issued by The Horse Review. 



\section{THE HORSE OF AMERICA.}

\section{CHAPTER I.}

I N T RO D U C TION.

General View of the Field Traversed.

Is undertaking to fulfill a promise made years ago, to write a history of the American Trotting Horse and his ancestors, I am met with the inquiry: What were his ancestors and whence did they come? To say that the American Trotter, the phenomenal horse of this century, is descended from a certain horse imported from England in 1788, does not fully meet the requirements of the truth, for there are other and very distinctive elements embodied in his inheritance that are not indebted to that particular imported horse. In searching for these undefined elements, I have found myself in the fields of antiquity, reaching out step by step, further and further, until the utmost boundaries of all history, sacred and profane, were elearly in view. There I found a field that was especially attractive because it was a new field, and the relations of the peoples of the earliest ages to their horses had never been investigated nor discussed. Having no engagements nor necessities to hurry me, the careful exploration of this hitherto unknown territory has afforded me very great enjoyment.

As the result of these investigations, the breadth and scope of this volume will be greatly widened, touching upon the originals of most of the lighter types of horses, and many of the idols of the imagination will be demolished. The objective point is the history of the Trotting Horse, but before reaching that point we must consider the beginnings of, practically, nearly all the varieties of horses in the world. The assistance that I may be able to gain from modern writers will be very limited, and restricted 
to a few citations. Many Englishmen have written books on the horse, mostly horse doctors, who have been very learned in veterinary matters, but wholly unlearned in the history of the horses of their own country. The editor of the "Hackney Stud Book" was the first Englishman to make known to his readers that the most popular horse in all England for many centuries was the despised little pacer, and this historical fact he first learned from this side of the water. Most of the Engiish books on the horse are practically reprints of what somebody said before, and given without credit. In some of them nothing is changed but the title page and, possibly, the name of the author. An examination of the leading magazines of our own country discloses the fact that an astonishing number of gentlemen have been afflicted with an itch for writing on the horse, without ever having given the honest study of an hour to the subject. This is the kind of "literature of the horse" with which the whole English-speaking people have been long afflicted.

To go back to the fountain head and consider in what country and among what people the horse was indigenous, or, in other words, to seek to determine his original habitat, may strike some of my readers as going too far away to either interest or instruct them. But in the very center of all popular horse knowledge will be found a vital error that has dominated, to a large extent, the whole horse history of the past three hundred years. If you ask a dozen horsemen of average intelligence, What country was the original habitat of the horse? a majority of them will answer, Arabia. If you put the same question to the same number of writers on the horse, every one of them will answer, Arabia. As this question is more fully considered in the second chapter of this work, I will here pass it over by giving a few dates. Armenia, Media, Cappadocia, and indeed all the countries bordering on the Black and Caspian Seas, were abundantly supplied with horses at least eighteen hundred years before the Christian era. At this time Egypt had no horses, but about one hundred years later, as shown by the history of Joseph and the inscriptions on her monuments, she had received a supply. At the very beginning of the Christian era, Strabo, the Greek geographer and historian, informs us Arabia had no horses. In the year 356 A.D. the Emperor Constantius sent to the prince of the country now called Yemen, in Arabia Felix, two hundred "well-bred Cappadocian horses" as a present. 'This is the first introduction 
of the horse into Arabia, so far as we have any tracings or indications of history, and thus the error of more than two thousand years is exposed.

Many of the more conservative and thoughtful writers have maintained that the original habitat of the horse was on the steppes of Asia, but I have never been able to discover any reasonable basis for such an hypothesis. It seems to rest chiefly on two conditions, viz., that there were vast multitndes of horses running wild on the steppes; and, second, that the Barbarians brought their horses with them when they overran Europe; hence, as they argue, the horse must have been indigenous in that region. The first of these ideas will not hold without some shadow of proof, for it is overthrown by our own experience on our own continent; and as to the second, the whole of Southern Europe, including Britain, and the whole of Northern Africa, were amply supplied with horses many centuries before the hordes from Asia made their appearance. Besides ail this, there is no evidence, either in reason or bistory, that there ever was a period when the horse was not the companion, friend, and servant of man.

The several facts, conditions, and circumstances pointing to Armenia as the original home of the horse, and which are considered in the next chapter, have afforded me a succession of most agreeable surprises in their approximate completeness. The salubrity of the climate, the varied and abundant productions of the soil, and the ten thousand streams of pure water flowing from the mountains furnished a home and a breeding place just suited to the best of all animal creation, whether man or beast. To this fitness of the environment we can add the historical fact that more than eighteen hundred years before the Christian era horses abounded there in great numbers and of most excellent quality. To this we may add the other fact, that this is the first instance in all history, sacred or profane, so far as we have discovered, in which horses are so spoken of. The Armenians are the oldest people on the face of the earth, inhabiting the same territory in which they grew into a nation. They are the direct descendants of Japheth, the son of Noah, and they spread ont from their original home, at the foot of the mountains of Ararat. They grew into a mighty nation, and at one time their dominion extended from the Mediterranean to the Caspian. The supremacy of the tribal relation was maintained until Haic or 
Haicus, the great grandson of Japheth, became the ruler of his people. Descending from him, in the direct male line, there were five or six long reigns before the dynasty was overthrown by the Assyrians. They were largely an agricultural people, and the ancient historians have told us they were famous for the great numbers and fine quality of the horses they produced. The market for their horses, the prophet Ezekiel tells us, was in the great commercial city of Tyre, whence they were carried "in the ships of Tarshish" by the Phœnician merchants to all portions of the known world. Having here reached back to the Noachic period and country, with all that this implies, I will leave the problem, with the more extended consideration that will be given it in the chapter on the general distribution of horses in all parts of the commercial world.

Horsemen of average intelligence and writers on the horse, oftentimes much below average intelligence in horse matters, all seem to unite on the Arabian horse as their fetish, when in fact they know nothing about him. The songs of the poets and the stories of the novelists have taken the place, in the minds of the people of all nations, of solid history and sober experience. When a story writer wishes to depict an athletic and claring hero, he never fails to mount him upon an "Arab steed," when some blood-curdling adventures are to be disclosed. When Admiral Rous, the great racing anthority in England, announced some years ago, that the English race horse was purely descended from the horses of Arabia Deserta, withont one drop of plebeian blood, all England believed him, and this rash and gromndless dictum has served all writers as conclusive evidence ever since. Now, it is not probable that more than two or at most three per cent. of the blood of the English race horse as he stands to-day is Arabian blood. The greatness and value of the Arabian horse is purely mythical. He has been tested hundreds of times, both on the course and in the stud, and in every single instance he has proved a failure. This is what all history and experience teach. There are but few horses bred in Arabia and there are, comparatively, but few there now. From the time of their first introduction into Yemen-Arabia Felix-up to the time of Mohammed, about two hundred and seventy years, they were still very scarce. Mohammed was not a horseman nor a horse breeder, nor is it known that he ever monnted a horse but once, and then he had but two in his army. When he made his first pilgrimage to Mecca he rode 
a camel; and when he went the second time in triumph, mounted on a camel, he made the requisite number of circuits round the holy place, then dismounted and broke the idlols that had been set up there. 'Then came the triumphant shout of his followers; "There is no God but Allah and Mohammed is his prophet." Since then, this cry has rung over a thonsand battlefields, and as I write it is still heard in the homes of the slaughtered Armenians. From a great, warlike, and conquering people, the followers of Mohammed have degenerated into an aggregation of robbers and murderers of defenseless Christians. Since the days of Mohammed, horses no doubt have increased in numbers, but all modern travelers express their surprise at the small numbers they see. The horse is an expensive luxury in Arabia, and none but the rich can afford to keep him. He fills no economic place in the domestic life of the Arab, for he is never used for any purpose except display and robbery. Nobody is able to own a horse but the sheiks and a few wealthy men. Nobody would think of mounting a horse for a journey, be it long or short. The camel fills the place of the horse, the cow and a flock of sheep, all in one, and surely the Arabs are right in saying, "Job's beast is a monument of God's mercy." It is very evident that nearly all the horses said to have been brought from Arabia never saw Araija. As an illustration of the uncertainty of what a man is getting when he thinks he is buying an Arabian, in the Orient, I will give, in some detail the experiences of Mr. Wilfrid S. Blunt, a wealthy Englishman who had an ambition to regenerate the English race horse by bringing in fresh infusions of Arabian blood. He went to Arabia to buy the best, but he didn't go into Arabia to find it. He skirted along through the border land where agriculture and civilization prevailed, while away off to the south the wild tribes roamed over the desert, and to the north, not far away, was the land of abundance that had been famous for more than three thousand years for the great numbers and excellence of the horses bred there. Here on the banks of the Euphrates Mr. Blunt found the town of Deyr, and he soon discovered it was a famous horse market. The inhabitants were the only people he met with who seemed to understand and appreciate the value of pedigrees, and there were no horses in the town but "thoroughbreds." Here Mr. Blunt made nearly all his purchases which amounted to eighteen mares and two stallions "at reasonable prices." As will be seen in the extracts from his book, 
he was strikingly solicitous that the friends at home should have no doubt about the quality of the stock he purchased being all "thoroughbred." No doubt he realized the awkwardness of the location as not the right one in which to secure "thoronghbred" Arabians and hence the vigorous indorsement of the honesty of the "shick and experienced" dealers as honest men and true descendants of the Bedonins of the desert. In this "he doth protest too much" and thus suggests that while the pedigrees came from the tribes of the desert to the South, it might be possible that the horses came from the farmers who bred them to the North. However this may have been, the whole enterprise turned out to be a flat failure, and after a number of years spent in begging for popular support, the whole collection was dispersed under the hammer of the auctioneer, not realizing a tithing of the cost.

While it is not necessary that I should express any opinion as to whether Mr. Blunt was deceived in the breeding of the animals which he brought home, I will make brief allusion to an American experience which is more fully considered elsewhere. Some forty or more years ago Mr. A. Keene Richards, a breeder of race horses in Kentucky, became impressed with the idea that the way to improve the race horse of America was to introduce direct infusions of the blood of Arabia. He did not hesitate, but he started to Arabia and bronght home some horses and mares and put them to breeding. The pure bloods could not run at all and the half-breeds were too slow to make the semblance of a contest with Kentucky-bred colts. He concluded that he had been cheated by the rascally Arabs in the blood they put upon him. He then determined to go back and get the right blood, and as a counselor he took with him the famous horse painter, Troye, who was thoronghly up on anatomy and structure. They went into the very heart of Arabia and spent many weeks among the different tribes of the desert. They had greatly the advantage of Mr. Blunt or any other amateur, for they were experienced horsemen and knew just what they were doing. When they were ready to start home they believed they had found and secured the very best horses that Arabia had produced. When the produce of this second importation were old enough to run it was found that they were no better than the first lot, and thus all the bright dreams of enthusiasm were dissipated. Thus was demonstrated for the thousandth time that the blood of even the best 
and purest Arabian horse is a detriment and hindrance rather than a benefit to the modern race horse. Mr. Richards, with all his practical knowledge and experience, was no more successful than the amateur, Mr. Blunt. The blood which Mr. Richards brought home was, no doubt, purer and more fashionable, as estimated in the desert, than that brought home by Mr. Blunt, but when tested by modern advancement it was no better.

A careful study of the chapter on the English Race Horse will present to the minds of all my intelligent readers the consideration of several points to which they will be slow in yielding assent. These points run up squarely against the preconceived opinions and prejudices of two centuries, and these preconceived opinions and prejudices are well-nigh universal. The first point upon which the public intelligence has gone wrong is in the general belief that horse-racing had its origin in the seventeenth century, when Charles II. was restored to his throne. The truth is we have accounts of racing by contemporaneous historians in the twelfth century, and indeed, we might say from the time of the Romans in Britain. 'To go back four centuries, however, is far enough to answer our present purpose. After selecting, breeding, and racing four hundred years we must conclude that the English had some pretty good race horses. This is fully verified by the writers at the close of Queen Elizabeth's reign as well as at the beginning of Charles II.'s. 'They had native English horses that were able to beat all the imported exotics, including the Arabian owned by King James. We must, therefore, conclude that the race horse was not created by Charles II., but that racing was simply revived by him, after the restrictions of Cromwell's time, and that the old English blood was the basis of that revival. The importations of so many exotics in his reign were simply so many reinforcements of the old English racing blood.

The next point to which exception will be taken is the conclusion reached as to the character and influence of the exotics that were introduced in the reign of Charles II. These exotics have been designated in a general way, by the phrase "foundation stock," which has been introduced more out of deference to the popular understanding than to its legitimate and true meaning. For the real "foundation stock" we must look away back in the centuries, long before Charles was born. The analysis of the data furnished by Mr. Weatherby as "foun- 
dation stock" clearly shows that the Turks predominated in numbers, but, possibly, the Barbs in influence. The Arabian element, in both numbers and influence, seems to be practically nil, and this is the "gist of my offending." The one great horse -Godolphin Arabian-exerted a greater and more lasting influence upon the English race horse than any other of his century and probably than all the others of his century, and his blood is wholly unknown. Fortunately, a few years ago I was able to unearth his portrait and prove it a true portrait, and in that picture we must look for his lineage. He was a horse of great substance and strength on short legs, with no resemblance whatever to a race horse. About fifty years after his death $\mathrm{Mr}$. Stubbs, the artist, who prided himself upon representing the character of a horse rather than his shape, came across this picture, from which he made an "ideal" copy of what he thought the horse should have been, which is a veritable monstrosity. These two pictures will appear together in their proper places, where they can be leisurely studied, and the honest and the dishonest compared.

'The American race horse is the lineal descendent of the English race horse, and like his ancestor he is very largely dependent upon the "native blood" for his existence as a breed. 'The first English race horse was imported into Virginia about 1\%50, and he there met a class of saddle mares that had been selected, bred, trained, and raced at all distances up to four-mile heats, for nearly a hundred years. 'These mares were the real maternal foundation stock upon which the American race horse was established, as a breed. "The phrase "native blood" is here used as applying to the animals and their descendants, that were brought over from England at and soon after the plantation of the American colonies. Up to the time of the Revolntion there were but few racing mares brought over-as many as you could count on your fingers-but they must have been marvelonsly prolific, for thirty or forty filly foals each would hardly have accommodated all the animals with pedigrees tracing to them. Quite a number of our greatest race horses and sires of forty or fifty years ago traced to some one of these mares through links that were wholly fictitions. Indeed, from the period of the Revolution, and even before that, down to our own time, the pernicions and dishonest habit of adding fictitious crosses beyond the second or third dam became the rule in the old American families, and an animal with a strictly 
honest pedigree was the exception. In spreading abroad these dishonest fictions as true pedigrees, the press-perhaps not venally, but ignorantly-was made the active agent. Whenever a rogue could get a pedigree into print, however absurd, nothing could prevent its spread as the truth. The early sporting and breeding press was not in the hands of men remarkable for conscience and still less remarkable for knowledge. But the worst of all was the "professional pedigree maker" who knew so many things that he never knew, and stopped at nothing. In all this dirty work of manufacturing pedigrees there is a very striking resemblance between the awkward efforts of the early English and the early American pedigree maker. This whole topic of the ignorance of the press and the dishonesty of the pedigree makers will be considered fully in its proper place. Fortunately, although still far from perfect, the methods and care in the preservation of the true lineage of the race horse in our own day have been greatly improved. The many efforts to improve the American race horse by introducing fresh infusions of Saracenic blood will receive due attention, especially as they have nearly all been made within the newspaper period, and their uniform and complete failure will not be new to American horsemen.

When we reach the horses of the colonial period, we are in a field that never has been explored and cannot be expected to yield a very rich harvest. Here and there I have been able to pick up a detached paragraph from some contemporaneous writer, and occasionally a record, or an advertisement, from which, in most cases, I have been able to construct a fair and truthful outline and description of the horses of the different colonies, down to the Revolutionary war. The collection of the material has required great patience and great labor, but it has not been an irksome task, for many things have been brought to light of great interest to the student of horse history. The knowledge of the colonial horse in his character and action, that may be gathered from the chapters devoted to his description and history, I flatter myself, will not only be interesting as something new, but will throw a strong light on the lineage of the two-minute trotter and pacer.

The colonists of Virginia were subjected for a number of years to great suffering, privation, and want. They were badly selected and many of them were improvident and never trained to habits of industry and thrift. There were quite too many "penniless 
gentlemen's sons"' among them, who had been sent out with the hope that the change might improve their habits and their morals. They were too proud to work, and when they were driven to it by necessity they didn't know how. After suffering untold hardships for a succession of years, those that survived learned to adapt themselves to their environment and to make their own way in the world. Their first supply of domestic animals were all consumed as food, embracing horses, cattle, swine, and goats, and everything had thus been consumed except one venerable female swine, as reported by a board of examiners. Their second supply of horses, cattle, swine, and goats was more carefully guarded, and from them in greater part came the countless denizens of the barnyard.

There were several shipments of horses at different times, by the proprietors in London, down till about 1620 and possibly later, but they do not seem to have increased very rapidly, for in 1646 all the horses in the colony were estimated at about two hundred of both sexes. This estimate was probably too low, for ten years after this the exportation of mares was forbidden by legislative enactment, and eleven years later this restriction was removed, and both sexes could then be exported. From this legislation and from writers who visited the colony we learn that horses were very plenty, and they are described as of excellent quality, hardy and strong, but under size. It was the custom in Virginia, and indeed in all the other colonies at that period and for long afterward, to brand their young horses and turn them out to hustle for their own living. They increased with wonderful rapidity and great numbers became as wild and as wary of the habitation and sight of man as the deer of the forest. About the close of the seventeenth century the chasing and capture of wild horses in Virginia became a legitimate and not always an unprofitable sport, for an animal caught without a brand became the unquestioned property of his captor. It is a noteworthy fact that off the coast of Virginia the island of Chincoteague has been occupied for probably two hundred years by large bands of wild horses. They are still there, and not till within the last few decades have there been any efforts made to domesticate some selections from them. They are of all colors, but quite uniform in size, not averaging much over thirteen hands, with clean limbs, and many of them are pacers. There is only one way to account for them in that location, and that is, that they were originally a 
band of Virginia wild horses that wandered or was chased out onto this sandy peninsula, and while there some great storm set the mysterious ocean currents at work and cut off their retreat by converting a peninsula into an island, and there they have lived and multiplied ever since.

The colonial horses of Virginia were of all colors and all very small in size, as we would class them in our day. An examination of a great many advertisements of "Strayed," "Taken up," etc., of the period of about 1750 , clearly establishes the fact that at that time the average height was a small fraction over thirteen hands and one inch. More were described as just thirteen hands than, any other size, and they were nearly all between thirteen and fourteen. From this same advertising source I was able to glean conclusive evidence as to their habits of action, and found that just two-thirds of them were natural pacers and one-third natural trotters. Thus for more than a hundred years they had retained the peculiarities of their English ancestors in the reign of James I., in color, size, and gait. This in no way differs from the description of the Chincoteague Island ponies of to-day. As early as 1686 a law was enacted that all stallions less than thirteen and a half hands high found running at large should be forfeited; but this, like Henry VIII.'s laws in the same direction, had failed to increase the average size of the horses. From the indomitable passion for horse-racing which prevailed universally among the colonists, we may safely conclude that some animals were carefully selected and coupled with a view to the speed of the progeny, both at the gallop and at the pace, but the great mass were allowed to roam at large, and under such conditions no variety or tribe of horses has ever improved in size, or indeed. in any other quality.

The early horses of the Dutch colony of New Netherlands, afterward New York, were brought from Utrecht in Holland. As we would look at them to-day, they were small, but they were larger and better, and brought higher prices than the English horses of the Eastern colonies or than the Swedish on the West. It was conceded, however, that for the saddle they were not so good as the New England horses, and hence it may be inferred that they were not pacers. It is very evident, however, that the two breeds were soon mixed, as the saddle was then the universal means of travel, whether for long, or short distances. During the time of the Revolutionary war a large accumulation of data 
bearing on the size and action of the horses of that period goes to show that the average size had then increased to fourteen hands and one inch, and in gait fifteen both paced and trotted, nine trotted only, and seven paced only. It is not pretended that these data represent the horses of the early colonial period, but only of the period above indicated. Strains of larger breeds had been introduced, but the little New England pacer had made his mark on the habits of action.

In 1665, the next year after the Dintch had surrendered the country to the English, Governor Nicolls established a race-course on Hempstead Plains and offered prizes for the fleetest runners, and his successors kept up annual meetings on that course for many years. This was the first official and regularly organized race-course that we have any trace of in this country. These meetings seem to have been well supported from the very first by both town and country, and as the people were then practically all Dutch, it is a fair inference that the horses engaged in the races were Dutch horses. This was before the English race horse had reached the character of a breed, and a hundred years before the first of that breed was imported into New York. From this beginning many tracks were constructed or improvised in and about the city, upon which racing at all forms and at all gaits has been carried on to the present day. When honestly conducted the sport has always been favorably received by reputable people; but at successive periods it has degenerated into a mere carnival of gambling that placed it under a ban.

The horses of the New England colonies fill a very important place in the horse history of the country. This is especially true of a remarkable tribe of swift pacers, produced in Rhode Island and known throughout the whole country as the "Narragansett. Pacers." To the description of these a special chapter will be devoted. The first horses imported into New England reached Boston harbor in 1629 and were sent direct from England by the proprietary company in London. The same year a small consignment reached Salem. The next year about sixty head were shipped to the plantation, but many of them were lost on the voyage. In 1635 two Dutch ships landed at Salem with twentyseven mares and three stallions, and were sold there at remunerative prices. Other shipments followed, no doubt, that have not been noted. In 1640 the colonists seem to have been supplied with all the horses they needed, for that year they shipped a 
cargo of eighty head to the Barbadoes. From these importations into Boston and Salem, all the New England colonists received their supplies. The field specially gleaned to determine the size and gaits of the Massachusetts horses covered the years 1756-59, from which it appears that the average height was then fourteen hands and one inch; and as to gait, just throc-fourths were pacers and one-fourth trotters. In comparing this average size with the Virginians of the same period we find that the Massachusetts horses were about one hand higher, which would indicate the influence of the early Dutch blood. Besides this we must make some allowance for a possible different habit of estimating size.

When the plantation was made at Hartford, Connecticut, in 1636 , the planters brought their horses and other domestic animals with them. In 1653 the General Court, at New Haven, made provision for keeping public saddle horses for hire, and all horses had to be branded. After passing over a period of more than a hundred and twenty years we find that in $17 \% 6$ the average size of the Connecticut horse was thirteen hands and three inches, thus ranging below the other New England colonies. At that period it is found that the ratio of pacers and trotters was as fifteen pacers, or trotters and pacers, to four that trotted only. The very interesting experience of two English travelers, mounted on Connecticut pacers, in $1 \% 69$, and their enthusiasm about their superlative qualities, will be fonnd in its place.

The colony of Rhode Island was planted in 1636 by Roger Williams and his followers, and eleven years later they obtained their charter. Their supply of horses came wholly from the colony of Massachusetts, and in a short time the new plantation became greatly distinguished for the superiority and speed of its, pacers. From the official report of the colony for 1690 , we learn that horses constituted their leading item of exports, and that they were shipping horses to all the colonies of the seaboard. At that early day the fame of the Narragansett pacer extended through all the English colonies, and probably also through the French plantations on the St. Lawrence. All trade with Canada was strictly prohibited, but in the then condition of the borders how could such regulation be enforced, if a Frenchman, with a bale of peltry, wanted to exchange it for a Narragansett? Freed from the Puritan restrictions of New England, of that day, the Rhode Islanders aleveloped the speed of their pacers by racing 
them, and thus the best and fastest of all New England were collected there. In 1\%68 the average height of the Narragansetts was fourteen hands and one inch, which shows them to have been abont three and a quarter inches higher than the Virginia horses of the same period. They were not all pacers, for ont of thirtyfive there were eight that did not pace, and some others that both trotted and paced. A full account of these famons pacers will be found in the chapter on the Colonial Horse History of New England, and that on The American Pacer and his Relations to the American Trotter.

William Penn did not visit his princely gift from Charles II. until 1682, and it was then under the government of the Duke of York. In giving a description of things as he found them he remarks: "The horses are not very handsome, but good," and this is all he says of them. Knowing that Pennsylvania, in the early part of this century, produced larger and heavier horses than any other portion of the country, it was a great surprise to me to find the undoubted proof that a hundred years earlier she had produced the smallest and the lightest horses of any of the colonies. In the first half of the last century the average size of the horses of Eastern Pennsylvania was thirteen hands one and a quarter inches, and they were remarkably uniform in size. This was one-quarter inch below the average of the Virginians. Of the twenty-eight animals examined as to gait, twenty-four of them were natural pacers, three both paced and trotted, and a single one trotted only. Finding these two facts of uniformity of size and uniformity of gait together, we are prepared for another fact that follows, viz., in Philadelphia the pacers were more popular and fashionable than in any other city, so far as we can learn, and they were selected with great care and bred for their speed, and that speed was highly tested on the race-course. They were breeding for speed without much regard to size, and hence the uniformity.

It has not been discovered that the colonists of New Jersey made any direct importations of horses from England. Their original supplies were obtained from New York on the one side and Pennsylvania on the other. From these sources, therefore, we can form a correct estimate of the size and gaits of the Jersey horses, without going into particular investigation. The ouly object, then, in referring to this colony is to prove that before 1748 all kinds of racing had become so common in the colony as 
to be a nuisance. Consequently the legislative anthority passed an act in 1748 for the suppression of "Running, Paeing and Trotting Races." 'This was in striet harmony with the well-known condition of things in Philadelphia and vicinity very early in the century. If there had been no pacing races there would have been no legislation suppressing them.

The horses of the colony of Maryland would necessarily partake of the characteristies of Virginia and Pennsylvania, from which she probably received her supply. There seems to be no evidence of direct importation. This colony was really the first, in point of time, to legislate for the suppression of pacing races. In 1747, one year before New Jersey, an act was passed forbidding pacing races in eertain locations at certain times, and the avowed object was the protection of the Friends in holding their yearly meetings. Here, then, we have historic evidence that the three colonies of Rhode Island, Pennsylvania, and Virginia had frequent paeing races, and legislative evidence that Maryland and New Jersey had quite too many pacing races, early in the last century. It follows, then, that the other colonies indulged their sporting fancies in pacing races also.

The colonies of North and Sonth Carolina obtained their supply of horses from Virginia, and they possessed the same characteristics as the parent stock. The first permanent settlement in North Carolina was in 1653, but before this it had become the refuge of Quakers and others fleeing from the proscriptions that prevailed in Virginia against all who did not eonform to the English ehureh. South Carolina received her eharter in 1663, at a time when horses were beginning to run wild in Virginia. In 1747 thirty horses were advertised in which the size was given, and the average is within a small fraction of thirteen and a half hands high, and in this number two were given as fifteen hands, which was a very large horse for that day. The gait is given in only twelve cases-ten of which were pacers, one paced and trotted, and one trotted only.

The chapter on the "Early Horse History of Canada" is very brief. It was not till the year 1665 that the first horses were bronght over from France, and as they came from ancient Picardy, right across the Channel from England, it is reasonable to assume that they partook of the same characteristies as the English horses, and that many of them were paeers. Another theory of the origin of the Canadian pacer is the probability of clandestine trad- 
ing with the New Englanders. Among the many impossible stories about the breeding of Old Tippoo, the greatest sire of Canada, the truth seems to come to the surface at last, and there can be no reasonable donbt that he was got by "Scape Goat." However much or little dependence can be placed upon many of the claims of fast pacing stallions coming from Canada, it must be conceded that some of these claims seem to be well fonnded, and that the pacing element has been greatly strengthened by blood from the other side of the border.

The most striking fact in the history of the pacing habit of action is its great antiquity. The average Englishman of to-day and the average American of twenty years ago have been nnited in insisting with the greatest vehemence that the pace is not a natural bnt an acquired gait, resulting from some injury or malformation. One of the great leaders on that side of the discussion called it "structural incongruity" arising from the breeding of the "thoroughbred" horse on the "slab-sided" mares of the West and South, and thought the idea was unanswerable, but never cited any instances to prove it. Now, the truth is, the earliest unquestioned evidence we have that horses paced is that furnished by the chisel of Phidias when he sculptured the horses on the frieze of the Parthenon at Athens, and that is two thousand three hundred and thirty-three years old. From the period when the sons of Japheth turned their attention to horsebreeding on the fruitful plains and valleys in the regions of the mountains of Ararat down to this cnlmination of Greek art, I have not been able to find any contemporaneous evidence of the existence of the lateral habit of action; but as we know it existed more than two thonsand years ago, we are justified in concluding that among the original bands of horses, in their original habitat, pacers as well as trotters abounded. From the erection of the Parthenon in Athens, the occupation of Britain by the Romans, and through all the centuries down to the plantation of the colonies in this country, we have mountains of indisputable evidence of the antiquity of the pacer. In its place this topic will be quite fully diseussed.

The relation which the pacer bears to the American Trotting Horse has for twenty-five years been a topic of much senseless discussion. In the historical sketch which served as an introduction to the first volume of the "American Trotting Register," the attention of the breeding public was first called to this question, 
in a form that was somewhat tentative, and much less didactic than my judgment suggested, but it served as an introduction to the study of the question which it foreshadowed. From this initial paragraph grew the discussion that has been going on ever since, much of which has been the merest jargon. The essential oneness of the trot and the pace has been clearly demonstrated by thousands of experiences. The trotting inheritance that produces the fast trotter also produces the fast pacer; and the pacing inheritance that produces the fast pacer also produces the fast trotter. The trotting-bred John R. Gentry, with his pacing record of a mile in two minutes and one-half a second, is but a single instance of very many of the same character. The fastest harness racers in the world are the pacers, and it seems to make no difference whether the inheritance of speed comes from the trotter or the pacer. The subject of the pacer in his diversified historical relations to the American trotter will be found in different portions of this work, and all tending to show the significant fact that he is again rapidly attaining the position of honor among the equine race which he maintained for so many centuries in the far-distant past.

Early in this century the American Saddle Horse, the real saddle horse of all time, past and present, began to vanish from sight. Improved roads and wheeled vehicles superseded him, in great measure, long before the days of railroads. For business and travel he was the sole dependence of our forefathers for two hundred years, and in point of health it is a great misfortune that he has gone so completely out of use. The horse that camnot take the "saddle gaits" and carry his rider without discomfort or fatigue is not a saddle horse. Springing up and down at every revolution of the horse is not riding for pleasure, but to avoid punishment and a torpid liver. In the chapter devoted to his description, origin, and breeding, it will be clearly shown that he is indebted to his pacing ancestry of the past centuries for his saddle gaits. As the mere matter of great speed cuts no figure in the qualifications of a saddle horse there is a wide field here for the production of style and beanty in the breeder's art. The aims of a goodly number of intelligent breeders are now moving in this direction, and with the foundations so well laid as they now are, we can look forward to a grand superstructure. As the breeder of speed at the trot goes to the horse that can do it himself, and as the breeder of speed at the gallop goes to the horse that can 
beat all the others, so the breeder of the saddler will go to the handsomest and best of all his tribe, and when we reach the horse that is perfect in symmetry, style, quality, and disposition, he will be a saddle horse and no questions will be asked about what particular combinations of blood he may possess. He will be strictly eclectic, with the one exception of the inheritance of gait, and he will be the result of wise choosing in his size and structure, and of skillful handling in lis disposition and manners.

The Wild Horse of the plains and pampas of North and Sonth America was at one time an object of great interest and curiosity with all our people. No schoolboy of sixty or seventy years ago knew any lesson in his geography so well as the one which pictured and described the millions of wild horses that roamed over the Western plains. In the field of imagination and exaggerated fiction he was a fairly good second to the Arabian-both arrant humbugs, at least so far as their merits have been tested. In the past, the question has sometimes been asked, tentatively, whether the horse may not have been indigenous on this continent? The paleontologists have undertaken to answer this question in the affirmative and have produced the bones of what they call the horse to prove it. This "horse" is scant fifteen inches high and he has three, four or five toes on each foot. These toes resemble "claws" more than anything else. They tell us these little animals flourished over two millions of years before man was placed on the earth, and that they are now found imbedded in the solid rock, say two hundred feet below the general surface. The outline drawing of horses on works supposed to have been erected by a prehistoric and lost race, and also the linguistic question as to whether any of the oldest Indian tribes had any word representing the horse, will be fully considered, with that presented by the paleontologists, in the chapter devoted to the Wild Horse. Too much prominence has been given to the horses of Cortez in his conquest of Mexico, as the progenitors of the American wild horse. He had very few horses in his command, and it is very doubtful whether any of them escaped the slaughter of battle and found a home in the wilderness. The horses in the army of the unfortunate Ferdinand De Soto, that were abandoned on the confines of 'Texas, after his death, became the progenitors of all the wild horses of North America.

The remarkable pre-eminence to which Messenger attained as the founder of a great race of trotters, in his own right and by 
his own power, and more especially as he was the only Englishimported rumning horse that ever showed any terdency whatever in that direction, the study of Messenger's lineage becomes a question of very great interest and value to all students of trotting history. His sire, Mambrino, was a great race horse, and was distinguished above all others of his generation, or indeed of any other generation, before or since, as the progenitor of a tribe of coach horses of great excellence and value. In addition to this, the evidence seems to be conclusive that he had a natural and undeveloped trotting step that far surpassed that of all other running horses of his day. His sire, Engineer, was notoriously short on the side of his dam, and his grandsire, Sampson, was a half-breed of great size and bone, and ran some winning races, in the best of company, for that day.

The history of Messenger himself is still clonded in mystery, and the blood he inherited from his dam remains hopelessly unknown. The identity of his importer and owner has never been established, which of itself throws a suspicion upon the pedigree that is said to have come with him. He ran several races at Newmarket, England, and proved himself a second or third-rate race horse. The racing records there show that he was by Mambrino, and that is all that is known about his inheritance. He left a few tolerably good race horses, for their time, but he filled the country with the best road and driving horses that the horsemen of this country had ever known. A chapter each to Messenger's ancestors and to himself will be found in their proper places in this volume. The twenty years of Messenger's life and service in this country fell in a period of indifference to all kinds of racing except running. The English race horse was then the popular idol, and it is not known that any of his sons or daughters were ever trained to trot. Neither can it now be certainly determined that any of them were disposed to pace, but if we may judge of the habits of action of his immediate progeny by what we know of succeeding generations, we can hardly doubt. that there were pacers among them. As the custom then was, and as it so remained for at least half a century later, all pacers were hidden away from public sight, as they were supposed to furnish evidence of ignoble breeding.

The chapter on "The Sons of Messenger" will be long, but it will be of exceeding interest. They constitute the connecting link that brings together the peculiar trotting instincts of the: 
sire and develops them in their own progeny. Several of them were not only trained to run, but did run successfully. It is not known that any of his sons was ever trained to trot, but it is known from contemporaneous evidence that several of them were fast natural trotters, notably Bishop's Hambletonian, Bush Messenger, Winthrop Messenger, Mambrino, ete., all of which will be considered in their proper place. When we reach the second remove from Messenger we begin to enter into the full fruition of all the promises, and in considering such animals as Abdallah, Almack, Mambrino Paymaster, Harris' Hambletonian, etc., we kagin to feel that we are well within the trotting latitudes, for this remove began to found families and tribes that attracted the attention of all intelligent breeders.

In the next remove from Messenger we strike the most famous of all trotting progenitors in Rysdyk's Hambletonian. At one time there was an active and determined difference of opinion among breeders as to which of three horses, Hambletonian, Ethan Allen, or Mambrino Chief, would in the end prove to be the most successful sire. 'This controversy may not be remembered by the younger of the present generation of horsemen, but it was bitter and uncompromising, and it presents a lesson so important that it may be here referred to. The adherents of Ethan Allen argued that as he was handsomer, that his gait was the very perfection of trotting action, and that he was incomparably faster than either of the other two, he must of necessity prove the most successful in begetting trotters. The adherents of Mambrino Chief used the same argument, with the exception of beauty and style, and dwelt strongly on the fact that he was a faster horse than Hambletonian, and would consequently get faster offspring. Both these arguments were good, so far as they went, but they lacked completeness and hence were not sound. Neither Ethan Allen nor Mambrino Chief had a dam, and so far as we know the inheritance of both was restricted to the male side of the house. Development of speed is a valuable and real qualification in any sire, but all experience goes to show that it is only a help to an inheritance. Hambletonian was not much developed, but it is conceded on all hands that he conld show a $2: 40$ gait at any time and that his action was very perfect. He was got by a grandson of Messenger, whose dam, Amazonia, was one of the fastest mares of her generation, whatever her blood may have been. Abdallah got more and faster trotters than any other grandson of Messenger, 
and his danghters were very famous as the producers of trotters. Hambletonian's dam, the Kent Mare, was by imported Bellfounder, a horse that got no trotters practically, but this mare was the fastest four-year-old of her time, and that because she was ont of a very fast mare, One Eye, that was a double granddaughter of Messenger. That is, One Eye was by Hambletonian, the son of Messenger, and out of Silvertail, a daughter of Messenger. This donble Messenger mare was unknown to the trotting turf, but she was well known throughout Orange Connty as a remarkably fast trotter. Hence Hambletonian not only possessed more Messenger blood than any horse of his generation, but that blood came to him through developed trotter's, and he had a right to surpass all competitors, especially the two that were, at one time, the most prominent.

Several of the sons of Hambletonian, as shown by the tabular statistics which will be introduced, became greater than their sire, not only in getting trotters from their own loins, but in transmitting the trotting instinct to their descendants. The growth and spread of this family is far and away beyond any precedent that can be cited in any age or country, and is simply marvelous. It is said that fully ninety per cent. of the fast trotters now on the turf have more.or less of the blood of Hambletonian in their veins, and I think it is a safe conclusion to say that. no intelligent breeder in all the country is trying to produce trotters without it. All the other tribes are dropping out of sight, and at the present ratio of rise and fall it will be but a few years till every trotter on the turf will be credited in some degree to the one really great progenitor, Hambletonian. The other tribes will not be blotted out nor will their merits be lost, but absorbed into the mightier tribe.

Such families as the Bashaws, the Clays, the Black Hawks, the Mambrino Chiefs, the Pilots, the American Stars, the Blue Bulls, etc., will be fully considered throngh several chapters, according to their strength and merit. As these families have not been able to hold their own in the rush to the front, and as they seem to be falling further to the rear in the number and quality of their performers each succeeding year, we may as well begin to designate them as "the minor families." Their inheritance was feeble and unsatisfactory, and more or less sporadic, and we never had any right to expect a brilliant and permanent success from such beginnings. 
As the investigation of disputed, spurious and fraudulent pedigrees was a prime necessity in order to reach safe and honest grounds upon which to build up a breed of trotters, much of my time through all my editorial life was devoted to this kind of investigation. From the first page of the first volume of the "Register"' I was deeply impressed with the importance of having all pedigrees absolutely correct, and this impression grew into a vital conviction that without this a breed of trotters never could be established. I soon found that I had accepted from some breeders of the very highest respectability a goodly number of pedigrees that were thoronghly rotten in their extensions. This taught me that I must study the moral fiber of breeders critically, as well as their pedigrees, and that from the highest to the lowest. Some men are honest from principle and because it is right to be honest, while others are honest because "honesty is the best policy." Some men are dishonest because of ignorance, others because they were born cheats, but the most dangerous of all rogues is the man who will utter a false pedigree and then prove it by trained witnesses who, for half a dollar, can remember whatever is necessary and forget whatever might be against their employer's interest. By this kind of evidence a man can prove anything. Not very long ago a man proved that a certain mare came out of a certain other mare, and when that was shown to be impossible he turned round and proved (?) that she was out of another mare, and there was just as much truth in the one as the other, and not a single word of truth in either. So long as there are men in the world there will be rogues among them, but the intelligence of the public in breeding matters has so greatly advanced that many an honest man would begin to doubt his own sanity if he were even to think of breeding in lines that he was once ready to fight for as the only right and successful way to breed. The brainless advocacy of "more running blood in the trotter," was substantially the basis of the whole brood of dishonest pedigrees, against which it became my duty to wage war; but to-day no intelligent man in all the land can be found to advocate any such balderdash unless it be in the foolish support of thoughtless opinions previously expressed.

The subject of "How the Trotting Horse is Bred," is a most interesting one because it is entirely new in animal economy and is distinctively American. The initial thought that opened the door to the practical and scientific consideration of the subject 
was the happy conception, in the spring of 1872, of the little phrase, "Trotting Instinct." Following this with the definition of the word "instinct" as being "the sum of inherited habits," the term expressed in two words and the definition of it in five words, put the whole subject in a form that was easily comprehensible and flashed upon the mind as thoroughly practical. This little phrase, with its definition, when once comprehended, is a very complete epitome of all that has been taught and all that has been learned of the art of breeding the trotter. It not only embraces, but requires, the trotting inheritance as the only starting point, which must be strengthened and the instinct intensified by the development of the speed of succeeding generations. It stood some years at the parting of the ways between intelligence and ignorance, between enlightened judgment and stupid prejudice, between honesty and dishonesty, but now it is accepted, in practice, as the universal law from one end of the land to the other. Thus, we have not only added millions to the wealth of the country, but without any outside assistance or instruction we have produced a horse that by way of pre-eminence, throughout the world, is justly entitled to be designated, "The Horse of America." 


\title{
CHAPTER II.
}

\author{
ORIGINAL HABITAT OF THE HORSE.
}

No indications that the horse was originally wild-The steppes of High Asia and Arabia not tenable as his original home-Color not sufficient evidenceImpossibility of Lorses existing in Arabia in a wild state-No horses in Arabia until 356 A.D. - Large forces of Armenian, Median, and Cappadocian cavalry employed more than one thousand seven hundred years B.c.-A breed of white race horses-Special adaptability of the Armenian country to the horse-Armenia a horse-exporting country before the Prophet Ezekiel-Devotion of the Armenian people to agricultural and pastoral pursuits through a period of four thousand years-All the evidences point to ancient Armenia as the center from which the horse was distributed.

Is undertaking to consider and determine what particular portion of the earth was the original habitat of the horse, we must not forget that we are in a field that antedates all history, both sacred and profane. When we have gone back to the very first dawnings of historical records we are still far short of the period in which initial light can be reached. In profane history, with more or less safety, we can get back to a point about seventeen hundred years before the Christian era; and in sacred history abont two hundred years less. At both of these dates the horses referred to were not in a feral state, but were the companions and servants of man.

There have been two separate theories advanced which demand some attention, because of the eminence and learning of the men who have advanced them. The first is that the original habitat of the horse was on the steppes of High Asia, east and north of the Caspian and the Black Sea. The only argument I have ever seen advanced in support of this theory is based upou the great number of wild horses that are found in that part of the world, and that so many of them are of a dun color. From the frequency of the recurrence of the dun color another theory has sprung up to the effect that the original color of the horse was. 


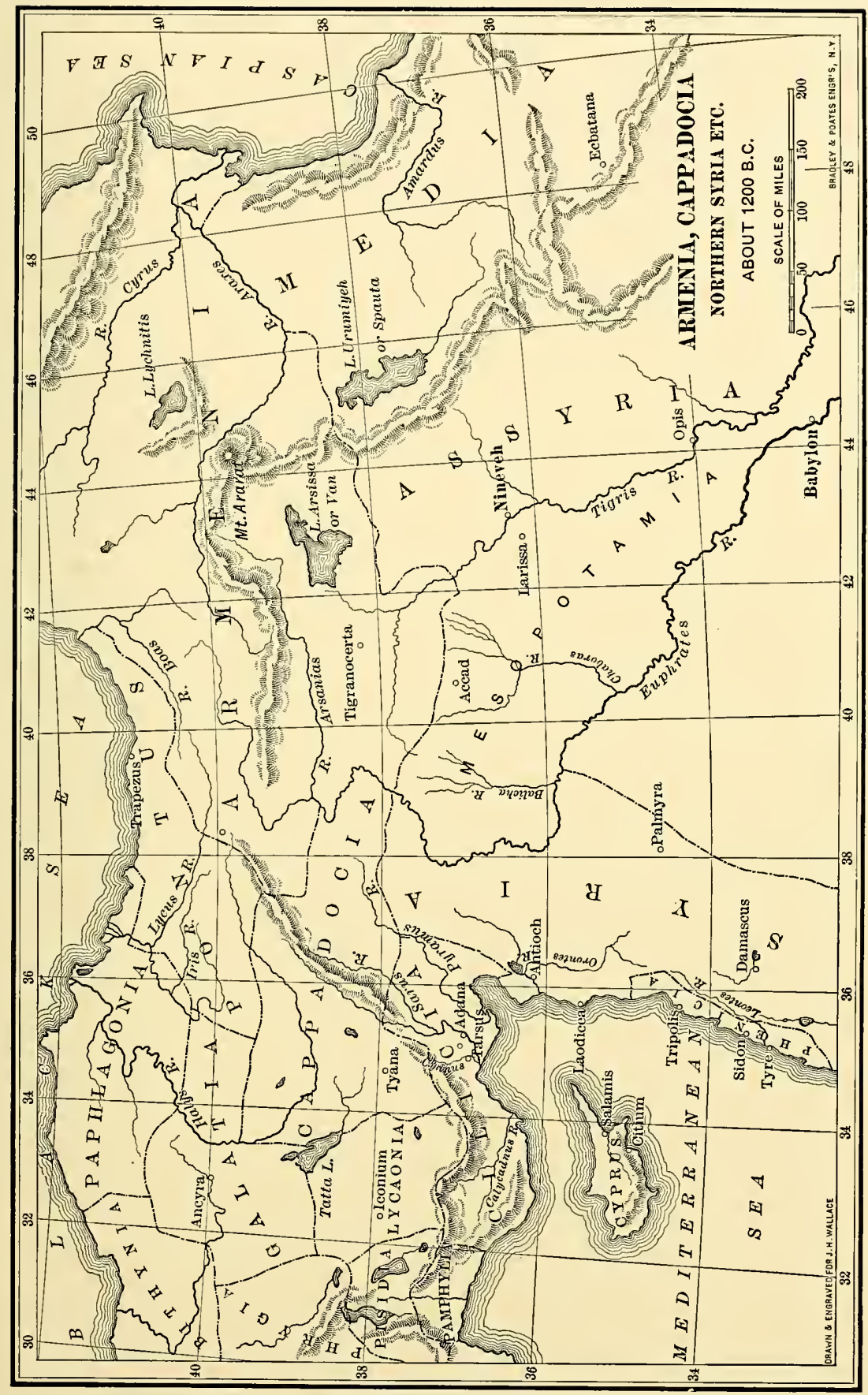



dun, and hence it is argued that when the dun color appears in our own day it must be taken as evidence that the original color of the horse was dun. This reasoning is very far from being conclusive, for there are dun horses and dun tribes in all breeds, just as there are greys, and the color is just as liable to be transmitted as any other color. In the last century there were many dun horses in England, and at least one of that color was advertised very widely as "the Dun Arabian," probably a foreign horse, but it is hardly possible that he was an Arabian. It was then the custom of the country to call all foreign horses "Arabians," no difference from what part of the world they came. It has been stated on what seemed to be good authority that a dun horse once won the Derby, but whether the color may result from line breeding or from atavistic tendencies, the argument advanced does not seem to have any weight in it for the purpose intended.

Another argument in favor of the wild and unknown regions east and north of the Caspian as the habitat of the horse has been urged with much more power and effect. It has been accepted and reiterated by so many learned men, one after another, that I doubted the wisdom of attempting to overthrow it, until I found the spot in which it was fatally weak. This view of the question seems to rest upon the fact that the successive hosts of Barbarians that overran Europe in the early centuries of the Christian era brought their horses, as well as their flocks and herds, with them, and it is assumed that these horses were the first brought into Europe. This involves a total misconception of dates; not of a few years merely, but of many centuries. All of Europe, including Britain, and all of Northern Africa, were abundantly supplied with horses, probably a thousand years before the first destructive wave of Barbarians touched Europe. Linguistic and ethnological facts clearly prove that those people came from Asia, and possibly from a part of Asia where there were horses running wild, but that does not prove that they came from the original habitat of the horse. With no dates, either definite or approximate, to support this theory, and with no specific portion of the earth fixed upon as the general locality from which they came, it resolves itself into a mere speculation with nothing to support it, except the fact that different writers have been copying it from one another, without throwing any additional light upon it, for a number of generations.

The most remarkable and at the same time the most untenable 
of all the claims that have been urged abont the horse is that he was indigenous in Arabia. We can tolerate any number of foolish claims set up to show that the Arabian horse is superior to all others, for such assertions can be tested and disproved, as they have been a thousand times, but the claim that Arabia was the original habitat of the horse is so utterly preposterous, and yet so widely advocated by writers and others who know nothing abont it, that we must consider it with some brief deliberation. When the maimed and crippled horses of De Soto were turned loose and abandoned on the plains of Texas, they had all around them the means of an abundant and healthy subsistence, and they multiplied and grew into an innumerable host that made the earth tremble when they moved in great masses. Under the same favorable conditions of water and pasture, the same results followed on the pampas of South America. Upon the early settlement of Virginia, as well probably as in some of the other colonies, and within two hundred years, many of the horses of the colonists strayed away, became wild and remained so, propagating and increasing for generations, and nntil the growing numbers of their former masters captured or exterminated them. The varied herbage of the forest and its grassy swales, and streams of pure water everywhere, made Virginia a paradise for the horse in his feral state.

Buffon, the French naturalist of a hundred and fifty years ago, notices the theory of the wild horses of Arabia, but he is careful not to commit himself nor indorse it in any form. In Vol. I., p. 237, he says: "According to Mamol, the Arabian horses are descended from the wild horses in the deserts of Arabia, of which, in ancient times, large studs were formed," etc. In going further, to find where Mannol got his information, it appears that somebody, with an unpronounceable name that I have forgotten, told him so. Major Upton, a very intelligent but very credulous modern writer on what he saw and learned in the desert, says he never heard of this story of wild horses in Arabia, and pronounces it a "fallacy." When we consider that Arabia never was conquered and the reason why, although Rome, at the very culmination of her power, followed by Assyria and Egypt, all failed of their purpose without meeting an enemy in battle, we must accept the fact that nature had interposed a barrier that military power could not surmount. The barrenness and aridity of the desert has always protected the Arabs against the most power- 
ful armies of the mightiest nations. Now, to maintain that wild horses could not only live, but flourish and increase, in a country where there was not enough edible herbage on a thousand acres to keep a grasshopper alive, and not a running stream of water within five hundred miles, requires a measure of mental sterility that can be found nowhere but among a few of the writers on the Arabian hnrse. Of all the euriosities in which the literature of the Arabian horse abounds and in the multitudinons efforts to give him the primacy among horses, there seems to be nothing quite so absurd as this story about his being indigenous to the desert. Animals in a wild state are never found except in countries and districts where the conditions surrounding provide them with food and water. How long would a band of strong, healthy horses live if turned loose to seek their own subsistence in the desert of Arabia? Of all the countries on the face of the globe there is no one where the horse is so completely dependent upon the care and support of his master as Arabia.

Fortunately, we are not left for data to unwritten traditions two thousand years old, nor to the fervid imaginations of a race of cutthroats and thieves of the very lowest order of civilization, but we can tum, with full confidence, to anthentic contemporaneous history, from which we can settle this question, at once and for all time. Strabo, the great Greek geographer and philosopher, flourished in the reign of Augustus, at the very beginning of the Christian era. He describes Arabia just as we know it to-day, for all countries have changed in their boundaries and government except Arabia. He describes the people as chiefly nomadic, and as breeders of camels. The most remarkable thing in this description is the fact, found in his great work, Vol. III., p. 190, that they had no horses at that time. The exact langnage used in this statement will be found in the next chapter of this work. The question now arises, If there were no horses in Arabia at the beginning of the Christian era, when and how did they become possessed of them? Fortunately, again, written history supplies the answer to this question. In my next chapter will be found, quoted at some length, the circumstances bearing on this question. In brief, the facts are as follows: Philostorgius, a distinguished Greek theologian, wrote an ecclesiastical history in the fifth century which is no longer extant. Photius, at one time Patriarch of Constantinople, in the ninth century wrote an epitome of the work by Philostorgius and to this epitome we are: 
indebted for the facts we here relate. Constantius, at the time of which Philostorgius wrote, was on the throne of the Eastern empire, and was exceedingly zealous in spreading and strengthening the Christian religion. He learned that the prince of Arabia Felix (that part of Arabia which we will designate by its modern name Yemen) was strongly disposed to come out with his people and embrace Christianity. Constantius therenpon determined to encourage both prince and people in the movement they were contemplating, and he sent them a grand embassy with many valuable presents, the most noted of which were two bundred "well-bred Cappadocian horses." The embassy was completely successful, and Theopholis, who had been made a bishop and placed at the head of it, remained there several years. This was in the year 356 of the Christian era, and is the first intimation we have in all history of horses in Arabia. These are the facts, so far as any facts are known, upon the consideration of which I am not able to assent to the claim that either High Asia or Arabia was the original habitat of the horse.

I have been surprised at the number of coincidences that seem to point to ancient Armenia as the first habitation of the horse. This country at one time was a very powerful kingdom, extending from the monntains of Caucasus on the north to Media or Assyria on the south, and from the Caspian Sea on the east to the Enphrates on the west, and at one time even to the Mediterranean. It was intersected by several ranges of mountains and not only gave rise to the Euphrates and the Tigris, but to a number of smaller rivers. It was well watered everywhere, and produced in great abundance all varieties of herbage, cereals, and fruits. It was originally called Ararat by the Hebrews, probably after a range of mountains about central to the territory embraced, and because Noah's Ark rested somewhere "on the mountains of Ararat." It is also called Togarmah in Scripture, after Torgom, son of Gomer, who was the son of Japheth, the son of Noah. Japheth seems to have been the oldest son of Noah, and he chose this fruitful region as the future home of his descendants. The Rev. Michael Chamich, a native Armenian, went back into the old Armenian records, translated the language as originally used, and wrote a history of the country from its first settlement; and this history has been Englished by Johamnes Adval, another native Armenian, and published in Calcutta in 182\%. This work seems to be worthy of credence, and it clearly 
establishes the lineal descent of the governing family back to Japheth, the son of Noah. The order of succession as the head of the tribe continues through several generations unbroken, from father to son. Gomer, the son of Japheth, was succeeded by his søn Togarmah, then followed Haicus, Armenac, Aramais, Amassia, Gelam, Harma, Aram, Arah, who was slain in battle, his son Cardus (at twelve years old), Anushaven, who died without issue and was succeeded by Paret, who reigned fifty years and during his reign the patriarch Joseph died in Egypt, B.c. 1635. These princes all had long reigus. Haicus was the first of the line to assume the title of king, and he was greatly distinguished for extending the boundaries of his kingdom. Gelam extended his borders to the Caspian. Aram was fiftyeight years on the throne, during which time he had a war with the Medes, and also with the Cappadocians, in both of which he had a large force of cavalry in the field. This was about seventeen hundred years before the Christian era, and is the first mention of cavalry that I have found in history, either sacred or profane. In both these wars his cavalry was met by the cavalry of the enemy, equal to or greater than his in numbers. How long before this troops may have been mounted on horses it is impossible to say, but from the numbers so used at that period of the world by the neighboring nations and tribes, as the Medes, the Cappadocians, etc., it is fair to conclude that the horse had then been an important factor in all military movements for many generations. When we consider two opposing armies, each provided with divisions of five thousand cavalry, the period being about B.c. 1700, with no dates beyond that are known as relating to the horse, we are shut up to our own reasoning as to the number of centuries that may have been. required to produce these great numbers. It must have been at least one century, or it may have been three or four, and this would carry us back to the head of the house of Japheth.

If we accept Egyptian chronology, which still lacks much of being reliable, one of the Pharaohs, named Thutmosis I., invaded Syria, passing up through Palestine till he reached the latitude of Aleppo, and then turned eastward and crossed the Euphrates. His campaign was successful; he fought many battles and returned laden with spoils, especially horses and chariots of war. This was before the Israelites reached the promised land, and before Joshua's battle with the "Northern kings," in which they had 
"horsemen and chariots very many," and which is the earliest Scriptural instance in which horses were employed in battle.

The territory embracing the ancient countries of Eastern Asia Minor, bounded on the north by the Black Sea and the Cancasian monntains, on the sonth by the thirty-seventh degree of north latitude, and extending to the Caspian Sea, has always been remarkable for the variety, value, and abundance of its agricultural products. Many of the very early historians have noted the fact that each one of the countries embraced in this territory was distinguished for the excellence and numbers of horses produced, and they appear in about the following order, namely, Armenia, Cappadocia, Cilicia, Media. The last-named country embraced what is now the northern part of Persia, and as between the "Medes" and the "Persians" there is no little confusion in the public mind, as sometimes one was on top and sometimes the other. Then, to add to the confusion, the Assyrians came in, occupying the same country and the same capitals. For onr present purposes it is not necessary to enter into the consideration of these snccessive dynasties. The Medes were comparatively newcomers, and as they were a great military people their prominence in horse history resulted more from the spoils of war and the tribute in horses that they collected from their neighbors than from their own production. Kitto says that in the time of the Persian empire the plain of Nissæum was celebrated for its horses and horse races. This plain was near the city of Nissæa, around which were fine pasture lands, producing excellent clover. The horses were "entirely white" (probably grey) and of extraordinary height and beanty, as weil as speed. They constituted part of the luxury of the great, and a tribute in kind was paid from them to the monarch, who, like all Eastern sovereigns, used to delight in equestrian display. Some idea of the opulence of the country may be had when it is known that, independently of imposts rendered in money, Media (then the undermost dog), paid a yearly tribute of not less than three thonsand horses, four thousand mules, and nearly one hundred thousand sheep. The races, once celebrated through the world, seem to exist no more.

When Darius the Mede had extended his empire over the whole of Western Asia and Egypt, he exacted heavy tribute in horses from all subjngated provinces. This was about 520 B.c., and antedated the racing referred to above. In all parts of his 
extended empire he built roads and established lines of couriers, mounted on fleet horses, that there might be no delay in receiving at his capital and sending out again intelligence of what was transpiring in any part of his dominions. For this service the best and fleetest horses were required, and the only guide we have to determine how these horses were selected we find in the fact that the tribute collected from the little kingdom of Cilicia, formerly a part of Cappadocia, was, in addition to a stated sum of money, one white horse for every day in the year. It is possible that these white Cilician horses may have been the progenitors of the white (grey) race horses spoken of in Media.

In describing the general fruitfulness of Cappadocia, Strabo says: "Cappadocia was also rich in herds and flocks, but more particularly celebrated for its breed of horses." Strabo speaks of this as a leading characteristic of the country and doubtless it had held pre-eminence in this respect for generations before he wrote. Three hundred and fifty-six years later, when Constantius was selecting his presents of horses for the prince and people of Yemen, in Arabia, he knew just where to look, in all his dominions, for the best of their kind, and selected two hundred "well-bred" ones for Arabia. Sir R. Wilson, in discussing the quality of the Russian cavalry horses about 1810, had evidently heard of this Cappadocian origin of the Arabian horse, but, unfortunately, he got all the parties badly mixed in his reference. He makes Constantine instead of Constantius the donor of three hundred Cappadocian horses, instead of two hundred, and they are given to one of the African princes, instead of to an Arabian prince. The African traveler, Bruce, found some excellent horses in Nubia, Africa, and from their high quality and unusually large size he seems to have jumped to the conclusion that these were the descendants of the three hundred from Constantine.

After glancing over all the different countries in this great zone as defined above, and extending from the Bosphorus to the Caspian Sea, one cannot fail to be impressed with its special adaptation to the production and sustenance of all varieties of domestic animals, in their greatest perfection. Here the country seems to have been made for the horse, and the horse for the country. Here was a country suited to his nativity, and here we find records of his existence centuries earlier than in any other country. The wild ass flourished in this country, but I have not been able to find any evidence or indication that the horse was 
not always the companion and servant of man. Wherever he is found in a feral state reasons that are amply satisfactory are never wanting to account for that state. Ancient historians have specially noted each of the principal countries embraced in this zone for the superiority and numbers of its horses, but no one has made any allusion to wild horses, nor suggested that there may have been a time when their ancestors were wild.

Now, as we have designated a long and wide region of Western Asia, embracing a number of different nationalities and governments, as the probable original habitat of the horse, can we go further and designate the particular nationality or government in which was his original home and from which he was distributed to adjoining nations or peoples? In answer to this question, we cannot present any dates of record earlier than about 1700 B.c., and this date will apply as well to Media and Cappadocia as to Armenia. We must, therefore, consider it in the light of other facts and circumstances, not dependent upon specific dates. In the first place, and taking the Mosaic account of the deluge as the starting point, "the ark rested on the mountains of Ararat." This is the original name of a country, intersected by a mountain range, and that range took its name from the country in which it was found. "Mount Ararat" was simply a very high peak in that range. The distinction should be observed here between "the mountains of Ararat" and "Mount Ararat." In the second place, it is clearly established by all history that near the base of this monntain range Japheth and his descendants had their homes. His son Gomer was highly distinguished in his day, and his grandson, Togarmah, son of Gomer, became a powerful chief. To such prominence did he rise in the affairs of his age that for centuries after his day his country was called "Togarmah." Hence we have the three names, Ararat, Togarmah and Armenia applied in sacred and profane history to the same country that we are now considering.

During the continuance of the dynasty of King Haic or Haicus, the son of Togarmah, the Armenians became a very prosperous and powerful people. They did not seem to be an aggressive or warlike people, althongh their boundaries were greatly extended, but a thrifty agricultural and industrious people. Breeding and marketing horses seem to have been their leading employments. In the twenty-seventh chapter of the Prophet Ezekiel he gives a catalogue of the different peoples trading with the great. 
Phœnician merchants and the products of their countries, in which they traded. This catalogne was written five hundred and fiftyeight years before the Christian era, and is very remarkable for its extent and completeness. It not only shows what the Phœnicians carried away to the West, in their "Ships of Tarshish," but also what they brought back for distribution among their customers in Western Asia. I willquote, from the revised version, two or three of the classes of articles enumerated, embracing both import and export trade. Of foreign imports he says: "Tarshish" (Spain and beyond) "was thy merchant by reason of the multitude of all kinds of riches; with silver, iron, tin, and lead, they traded for thy wares." Of articles for export he says: "They of the house of Togarmah traded for thy wares with horses and war-horses and mules." "Togarmah" here means "Armenia," and this is the only instance in which horses are mentioned in the catalogue. I will give another quotation, not because it is conclusive in itself, but becanse it is confirmatory of Strabo's statement that there were no horses in Arabia in his day. He says: "Arabia and all the princes of Kedar, they were the merchants of thy hand; in lambs, and rams, and goats, in these were they thy merchants." Other products from more southern portions of Arabia are enumerated, but no horses. This is the initial step toward the general distribution of horses, by the Phonician merchants, which will be developed in the next chapter.

In speaking of Media (Vol. II., p. 265), Strabo says: "The country is peculiarly adapted, as well as Armenia, to the breeding of horses." Of one district not far from the Caspian he remarks: "Here, it is said, fifty thousand mares were pastured in the time of the Persians, and were the king's stud. The Nessæan horses, the best and the largest in the king's province, were of this breed, according to some writers, but according to others they were from Armenia." Again he says: "Cappadocia paid to the Persians, yearly, in addition to a tribute in silver, one thousand five hundred horses, two thousand mules, and fifty thousand sheep, and the Medes contributed nearly double this amount."

Of Armenia he says, p. 271: "The country is so well adapted, being nothing inferior in this respect to Media, for breeding horses that the race of Nessæan horses, which the king of Persia used, 
is found here also; the satrap of Armenia used to send annually to the king of Persia twenty thousand young horses."

The Nessæan horses, so famous for their speed, were the "thoroughbreds" of their day, and there can hardly be a doubt they originated in Armenia, and, just like our own "thoroughbreds," they were essentially the result of careful selection through a series of generations, and of breeding only from animals possessing the desired qualifications in the highest degree. In the earlier days of racing in Media, it appears that white was the fashionable color, but I am disposed to think that grey, growing white with age, was the color intended to be expressed by the writers of that period. The "albino" color is abnormal and supposed to indieate tenderness and lack of stamina.

There is one fact, in considering this question, to which I have probably not given sufficient prominence and weight. So far as the records go, the three countries of Armenia, Cappadocia, and Media are synchronous in having mounted troops in their armies seventeen hundred years before the Christian era. We must, therefore, consider the conditions of these countries antecedent to the period of $1 \% 00$ B.c. Of Cappadocia we know absolutely nothing historically until it was conquered by Cyrus, king of Persia, about 588 B.c. Of Media the earliest knowledge we have of a historical character does not go back further than about 842 в.c. It should be observed that I here speak of "historical" knowledge and not of uneertain traditions of many centuries earlier. Both of these nations with their distinctive nationalities have, long since, been wiped off the surface of the earth.

When we reach Armenia, we reach a people with a most remarkable history, extending back for more than four thousand years. This history, although not wholly free from criticism or doubt, seems to be honestly written and worthy of a liberal measure of confidence. That the children of Japheth should have settled at the foot of the mountains of Ararat strikes every one as a very natural event, but that their descendants should still be there, through all the triumphs and oppressions of four thousand years, is one of the most stupendous facts in the history of the world. From the very first we know of them they seem to have been an agricultural people, strongly attached to their native soil. When they ruled over the land from the Caspian to the Mediterranean, they built no great cities, but adhered steadfastly to the rural pursuits of their fathers, and this, probably, 
was the chief canse of their weakness. Their wealth and sources of wealth were chiefly in their horses, and these they sold to the merchants of Sidon and Tyre, who earried them to all the nations of Europe and Africa, commencing with Egypt, and supplying all wants as far as Spain and Moroceo, and beyond, probably, as far as Britain. The Phœnician merchants were the first to open commercial transactions with Europe and Africa, and they were in control of the commerce of the world long before King Solomon entered into commercial partnership with Hiram, king of Tyre. Armenia had horses to sell long before they had horses in Egypt, and Phonicia had ships and enterprise to carry them there. There is a fitting of interests here that seems to point to Armenia as the great original source of supply, and as the original habitat of the horse. 


\section{CHAPTER III.}

\section{EARLY DISTRIBUTION OF HORSES.}

First evidences of horses in Egypt about 1700 B.C.-Supported by Egyptian records and history-The Patriarch Job had no horses-Solomon's great. cavalry force organized-Arabia as described by Strabo at the beginning of our era-No borses then in Arabia-Constantius sends two hundred Cappadocian horses into Arabia A.D. 356-Arabia the last country to be supplied with borses--The ancient Phœnician merchants and their colonies - Hannibal's cavalry forces in the Punic Wars-Distant ramifications of Phonician trade and colonization-Commerce reached as far as Britain and the Baltic-Probable source of Britain's earliest horses.

HAVING considered the different theories or opinions as to the original habitat of the horse and the means and facilities by which distribution to the different portions of the earth may have been effected, I have omitted land migration, which will be self-evident to all as an important factor in the problem. It is now in order, therefore, to consider such dates and facts as are pertinent and may ive gleaned from history, sacred and profane.

When Abraham, with Sarah his wife, visited Egypt about 1920 B.c., the Pharaoh for her sake bestowed upon him many gifts: "Sheep and oxen and he asses and men servants and maid servants and she asses and camels." Among these great gifts there were no horses, evidently because Egypt had no horses at that time. There is no mention nor reference to horses in Egypt till Joseph became prime minister two hundred years later, when there were a few horses, and they were traded or sold to Joseph by their owners in exchange for food, not in droves, but as individuals. These scriptural facts in the experiences of Abraham and Joseph seem to be circumstantially sustained by the discoveries of those learned Egyptologists who, in late years and with the spade in their hands, have resurrected so much of history that had been buried for thousands of years. It was during the reign of the Hyksos, or Shepherd Kings, that Abraham and Joseph were in Egypt, and in order to approximate the time when horses were first introduced, we must glance at a few facts in connection with 


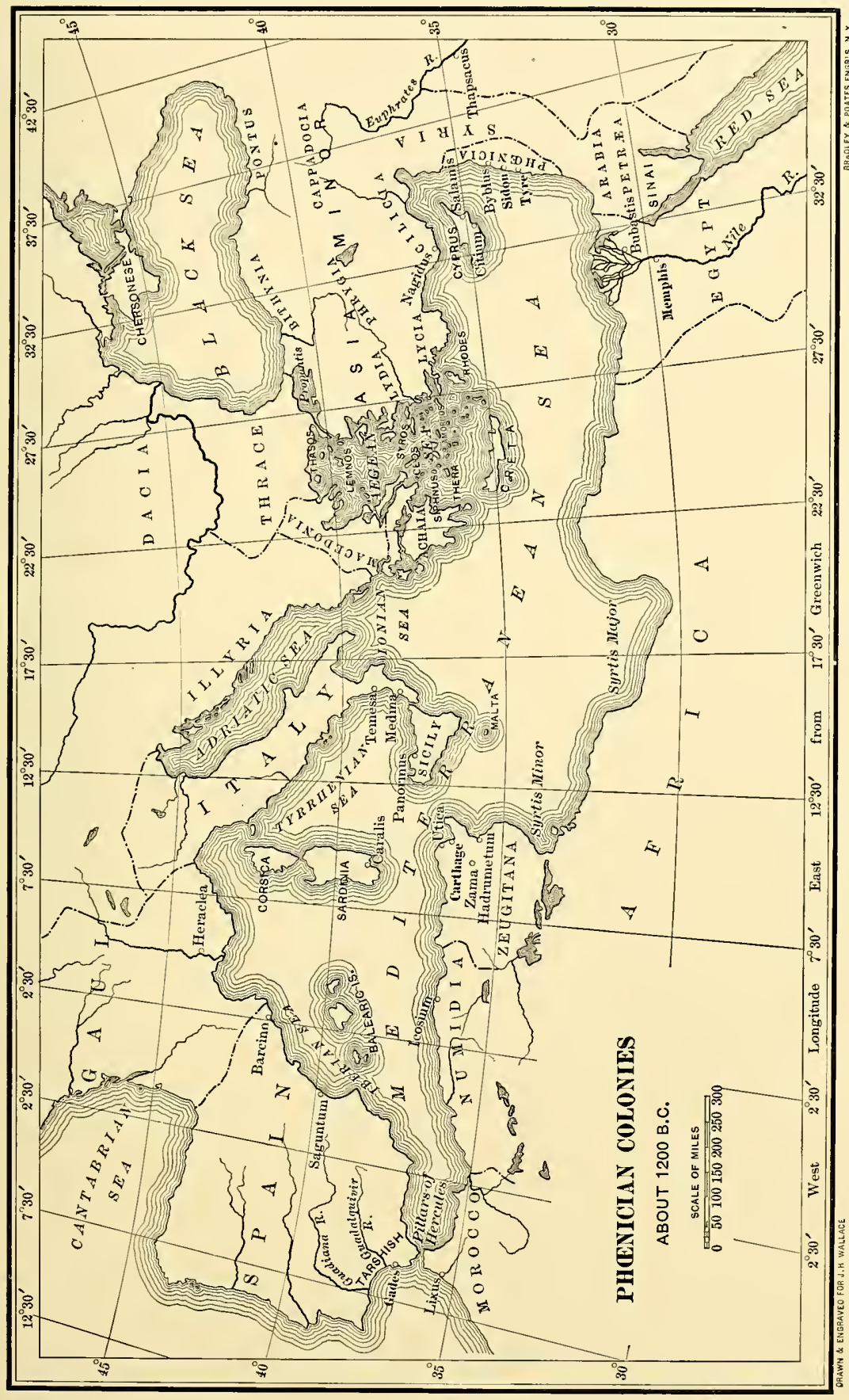



what is known of the Hyksos. Some have claimed they were from Chaldea, some from Northern Syria and Asia Minor, and some again from Phœnicia, and it is one of the strangest things in history that a great nation should be overthrown and held in subjection for over five hundred years and nobody know who did it. Then again, it is equally incomprehensible that any nation should have subdued Egypt and held it in bondage so long and yet never have claimed the honor of having done so. Still another mystery remains that never has been solved, and that is, what became of the Shepherds and their followers when they were driven out? At the period of the conquest the governing class was rent by factions and under a weak and tyrannical king. The Delta and the Valley of the Nile were crowded with slaves, many of them of Asiatic origin. The elevated plains and nountain sides were covered with fierce and intractable nomads, all of Asiatic origin, tending their flocks. Some brave and skillful shepherd organized the shepherds and the slaves and at their head swept down upon the government with a power that was so mighty as to be irresistible. Manetho, the great Egyptian historian of more than two thousand years ago, thus describes the event: "Under this king, then, I know not wherefore, the god cansed to blow upon us a baleful wind, and in the face of all probability bands from the East, people of ignoble race, came upon us unawares, attacked the country and subdued it easily and without fighting." In remarking upon this same event Professor. Maspero, who stands at the very head of the Egyptologists, says: "It is possible that they (the shepherds) owed this rapid victory to the presence in their armies of a factor hitherto unknown to the Africans-the war chariot-and before the horse and his driver the Egyptians gave way in a body." In view of the direct declaration of Manetho that the question of the succession was settled "withont fighting," the mere suggestion of an unsustained "possibility" from Naspero that the result may have been determined by the war chariots cannot be accepted. All the authorities agree that the horse was introduced into Egypt at some period during the rule of the Shepherd Kings, but there is absolutely no evidence that this was at the beginning or anywhere near the beginning of that rule.

No records or delineations of the horse have been found in any of the temples or tombs of Egypt prior to the beginning of the eighteenth dynasty, which was probably about the year $15 \% 0$ B.c. 
and contemporaneous with the birth of Moses. If the Shepherd Kings left behind them any records or delineations of the horse it would be quite natural for the true kingly line to destroy and erase every vestige of whatever would revive a memory to them so bitter and hateful. But the absence of all traces of horses under the serenteenth dynasty of the Shepherds does not prove that there was none, for we have direct proof in Joseph's case that they were there one hundred and fifty-six years, and in Jacob's burial one hundred and nineteen years before the beginning of the eighteenth dynasty.

The question as to the time when they procured their horses having now been approximately settled, the inquiry naturally follows as to where they came from? In answering this question there seems to be no hesitation or doubt. They came from Northern Syria, which embraces not only the northeastern coast of the Mediterranean, including Phœnicia, but the countries north and east of it trading there, which means the great horsebreeding countries of Armenia and Cappadocia. Being largely engaged in the Egyptian trade for many centuries, it is probable the Phœnician merchants were the principal agents in supplying them. In speaking of the horse in Egypt, Prof. Maspero says: "The horse when once introducsd into Egypt soon became fairly adapted to its environment. It retained both its height and size, keeping the convex forehead-which gave the head a slightly curved profile-the slender neck, the narrow hind-quarters, the lean and sinewy legs and the long, flowing tail which had characterized it in its native country. The climate, however, was enervating, and constant care had to be taken, by the introduction of new blood from Syria, to prevent the breed from deteriorating. The Pharaohs kept studs of horses in the principal cities of the Nile valley, and the great feudal lords, following their example, vied with each other in the possession of numerous breeding stables."

There are some facts here that are worthy of special emphasis: (1) There were no horses in Egypt till the period of the Shepherd Kings, i.e., about the time of Joseph. (2) All Egyptologists down to the present day agree that the supply of Egyptian horses was procured from Northern Syria. (3) The Egyptians and the Arabians were adjoining nations in constant, friendly intercourse, exchanging the products of their respective countries, and yet. there is no shadow of an intimation that the Arabians had then 
ever owned a horse. It is reasonable to conclude, therefore, not only from what is written, but from what is implied, that the Arabians at about the period of 1600 B.c. had no horses. Northern Syria, as the source of Egyptian supply, points directly to Armenia, adjoining on the east, as the original source. When Strabo wrote at the beginning of the Christian era that there were no horses in Arabia at that time, he would still have been within the bounds of the truth if he had said there had been none there for more the sixteen hundred years before his day. All these considerations confirm the history that has come down to us from Philostorgius.

As early as the dynasties of the Shepherd Kings and while the Israelites were still in Egyptian bondage, the Phœnician merchants had accumulated great wealth and great power and were literally the masters of the seas. The Phonicians were a commercial and maritime people and the Egyptians were, in fact, dependent upon them for all their foreign supplies. These conditions leave hardly a doubt that Egypt's first supply of horses came through the Phœnicians. But upon the establishment of the eighteenth dynasty under the old Thebans, the spirit of war and conquest revived, and under Thutmosis I. and Thutmosis III., notably, numerous and successful campaigns were made against Northern Syria and then extending eastward across the Euphrates into the borders of Armenia and Assyria. And from the number of horses and chariots captured in battle and collected as tribute, the careful student cannot avoid the conclusion that this kind of spoil was the chief incentive to the various campaigns. "Besides the usual species," Maspero informs us, "powerful stallions were imported from Northern Syria, which were known by the Semitic name of Abiri, the strong." This is the first mention in history of an improved type of horse noted for his strength.

Whatever may have been the precise period in which the Patriarch Job lived, he was the anthor of the grandest panegyric on the war-horse that ever was written. Yet it seems strange that he owned seven thousand sheep, three thousand camels, five hundred yoke of oxen and five hundred she asses, but did not own a horse. To draw his picture of the war-horse he must have seen him in action, on the field, and it is not improbable in his younger days he witnessed, or possibly participated in, some great battle between the Babylonians and the Persians, north of the latitude and country in which he lived. It is now generally con- 
ceded, I think, among learned men that the "land of Uz" was in the southeastern portion of Arabia Deserta, bordering on the Persian Gulf, where the horse is a useless luxury. Job was a very rich man, he certainly did not lack in admiration of the horse, and if he had thought that horses would add to his comfort and enjoyment he could easily have obtained them from the great herds in the north. But the camel is the great beast of service and utility in Arabia; it was so in Job's time, it is so to-day, and it always will be so because it is suited to the environment.

When Joshua was subduing the tribes of Canaan, в.c. 1450, he found that the Phonicians had several well-fortified cities and did not attack them, but he encountered a combination of "Northern Kings" with a vast army and "with horses and chariots very many." His victory was complete, and he houghed their horses and burned their chariots with fire.

Jabin, called the King of Canaan, in the time of the Judges, had his kingdom on the northern border of Palestine and east of Phœnicia, at the southern extension of Mount Lebanon. Sisera, one of the greatest commanders of the time, B.c. 1285, commanded his army and he had nine hundred chariots of iron, but the victory of the Israelites was complete.

In the year B.c. 1056, David pursued some of the tribes of Western Arabia that had made a raid on Southern Palestine and carried away many captives and much spoil. He overtook them with his own followers and subdued them, and none escaped except four hundred young men who fled on camels. He recovered all the captives and brought back all the flocks and herds, but there were no horses among them. About the same time, historians inform us, the tribes of Eastern Arabia were paying their tribute to the Assyrians in camels and asses, while the northern countries were paying theirs in horses and money.

The Queen of Sheba visited King Solomon B.c. 992, to learn of his wisdom and "to prove him with hard questions." Her kingdom was in that part of southeastern Arabia now called Yemen, bordering on the Red Sea. Her journey was a very long one and she "came with a rery great train of camels that bare spices and very much gold and precious stones." It will be observed that there were no horses in this "very great train." It will be observed further, from the incidents above related, that whenever the Israelites met their neighbors north of them, whether in peace or war, they met horses with them; and whenever they met 
their neighbors south of them, they were mounted only on camels.

When the dominions of Solomon had become vastly extended, embracing numbers of tributary kingdoms, as well as nomadic tribes, and when his ships had gathered in untold riches from all parts of the world, he found it prudent to reorganize his army for the defense of his kingdom and his wealth, and on a scale commensurate with the dangers that might arise from a combination of the jealous and envious neighbors with whom he was surrounded. Among the northern kingdoms of that day it had been often demonstrated in battle that the effective force of an army must be estimated by its strength in horsemen and chariots of war. Solomon, therefore, bought horses and chariots from Egypt, and horses from all lands that had them for sale. It is probable that the superiority of the Egyptian chariots was the special reason for buying them in that country, as he paid six hundred shekels of silver for the chariots and one hundred and fifty for the horses to bring them home. The reorganized army consisted of one thousand four hundred chariots and twelve thousand horsemen, and they were quartered in the different large cities in his dominions. In the interval of seven hundred and twenty-eight years that had elapsed since Joseph was Prime Minister, and horses introduced in Egypt, they had greatly multiplied. When Solomon died and his kingdom was divided into two hostile camps, Hiram, King of Tyre, his lifelong friend and associate, became virtually his successor to the trade of the world.

The great Greek geographer, Strabo, traveled and wrote in the reign of Augustus, and died A.D. 24. For descriptions of all countries of that period and their industries and productions, he has been quoted for eighteen hundred years as the best if not the only anthority. Writing as he did, at the very initial point of the Christian era, he gives us a landmark that fixes itself in the mind. He gives a brief, but quite satisfactory, description of Arabia, in which he notes the general topography and boundaries as they are understood to-day; and then he enters, somewhat, into the climate, productions of the soil, character and industries of the people, etc. Of one part of the country he speaks of the inhabitants as breeders of camels, and of another, that is more productive, he remarks: "The general fertility of the country is very great; among other products there is in particular an abundant supply of honey. Except horses, there are numerous 
herds of animals, asses and swine, birds also of every kind, except geese and the gallinaceous tribes."

Here we have from the very highest authority the pivotal fact that there were no horses in Arabia at the commencement of the Christian era. This does not rest upon argument, nor is it a deduction from some condition of things that might have existed; but it is a distinct declaration of what Strabo saw with his own eyes and wrote down when he saw it. It must, therefore, stand as an undispnted fact, until some reputable authority is brought forward to contradict it. This description from Strabo applies to that rich portion of Arabia, bordering on the Red Sea along its full length. With the fact established, circumstantially and historically, that there were no horses in Arabia at the beginning of the Christian era, it now remains to consuler how and when they were first introduced in that country.

Philostorgins, a distinguished Greek theologian, born A.D. 425, as related in the preceding chapter, wrote an ecclesiastical history, which is no longer extant, but fortunately Photius, at one time patriarch of the Eastern ehurch, born A.D. 853, prepared an epitome of it. This epitome of Philostorgius comes down to A.D. 425 , and is to be found in the Lenox Library of this city, bound up in the same volume with Sozomen's Ecclesiastical History. I will here quote literally from this epitome so much as is pertinent to the question before us. Constantius was then on the throne of the Eastern Empire, and labored for the promotion of the Christian religion.

" Constantins sent ambassadors to those who were formerly called Sabæans, but are now known as Homeritæ, a tribe descended from Abraham, by Ketural. As to the territory which they inhabit, it is called by the Greeks Magna Arabia and Arabia Felix, and exteud; $t$, the most distant part of the ocean. Its metropolis is Saba, the city from which the Queen of Sheba went forth to see Solomon. . . Constantius, accordingly, sent ambassadors to them to cone over to the Christian religion. . . . Constantius, wishing to array the embassy with peculiar splendor, put on board their ships two hundred well-bred horses from Cappadocia, and sent them, with many other gifts.

The embassy turned ont successfully, for the prince of the nation, by sincere conviction, came over to the true religion."

Other facts might be quoted from this epitome, showing that Theopholis was made a bishop and placed at the bead of this embassy and that he remained in Arabia Felix several years, prose- 
cuting his work successfully. It might also be quoted to show that the people of the cities of Yemen (Arabia Felix) were, at that day, well advanced in civilization and refinement, and that wealth and luxury abounded on all sides. Their lands, from the sea to the desert, were wonderfully productive, and their people lived in the cities and on their farms, but few leading a nomadic life. In later generations this part of the country, which is in Arabia Felix, has been called Yemen, and I believe it is universally conceded among the Arab tribes and by writers who have studied the subject that the best horses come from Yemen.

Taking the administration of Joseph as indicating the time when the first horses were introduced into Egypt, about B.c. 1720, and the actual date when Constantius sent the first into Arabia, A.D. 356, we find that Egypt led Arabia by two thousand and seventy-six years. And yet numbers of men have written great pretentious books on the horse, in which they tell us that the Egyptians got their horses from the Arabians; while others equally pretentious and voluminous tell us the Arabians got their horses from the Egyptians; and neither class probably ever gave the labor of an honest hour to settle this question. The one is over two thousand years out of the way, and still they know just as much about it as the other knows. They are both equally ignorant and equally dishonest, for they simply copied, as their own, what somebody had said before them.

It is conceded on all hands and by all men who have gone beneath the mere surface, that the literature of the ages furnishes no evidence that there were horses in Arabia before the fourth or fifth century of our era. General Tweedie, by far the ablest writer on the Arabian horse that we have examined, concedes the pertinency and force of the absence of all literary evidence, until the fifth century is reached, and as a reply he says: "The several Roman invasions of Arabia, in the reigns of Augustus, Trajan, and Severus, must have left foreign horses behind them." This is, in fact, conceding the accuracy of Strabo's representations and that there were no horses in Arabia at the beginning of the Christian era. The truth of the historical allusion is that the Romans never overran nor conquered Arabia. They could skirmish around the border and capture a few towns or cities, but the death-dealing desert was too much for them. Trajan at last made it a Roman province by his proclamation, and not by his sword, and for the excellent reason that "the game was not worth 
the candle." What a strange fact it is that Arabia, instead of the first, should have been the last country in all the old world to be supplied with horses!

It is very difficult to comprehend or even imagine the changes that may be wrought in a thousand years by a strong, enterprising, and aggressive people, colonized in a rich country occupied by semi-barbarians and savages. This was the condition in Northern Africa, when the Phøenician colonies were planted there, a thousand years before the Christian era. The colony at Utica in Algeria was planted about eleven hundred years before the Christian era, which was contemporaneous with the reign of Saul as king of Israel. The colony of Carthage, that afterward contested with Rome for universal dominion, was planted in the same country, about two hundred years later, and was contemporaneous with Jehu. The whole southern shore of the Mediterranean was dotted with Phœnician colonies, from Egypt westward.

The oldest of the Phønician colonies so far from home was probably Gades, now called Cadiz, on the Atlantic coast of Spain and outside of the Pillars of Hercules. This colony was planted about fifteen hundred years B.c. and was contemporaneous with Moses and the forty years' journeying of the Israelites in the wilderness. The more recent scholarship seems to have developed the fact that still north of Gades and extending from the mouth of the Guadelete to that of the Guadiana, there was a very large and flourishing colony planted by the Phonicians, possessing within itself many of the requisites and functions of statehood, and that this was the ancient "Tarshish" of scripture. This plantation became a secondary Tyre, and the "ships of Tarshish" not only made their voyages back and forth through the length of the Mediterranean, but extended them northward, up the European coast and to Britain, and southward along the African coast for a great distance, establishing trading posts wherever the products of a country promised profitable exchange.

The planting of colonies in that age, even for the one ostensible purpose of trade, involved more than the mere erection of a "trading post" at some selected harbor. A strong and wellequipped and well-trained military force had to be employed to protect and defend them. The Phœnicians were great traders, and at the same time they were excellent fighters. Their numerous solonies on both shores of the Mediterranean required a. 
strong military force that was made up very largely of slaves and the nomadic tribes of the country, but always commanded by prominent and influential Phønicians. It is impossible to tell what the very early experiences of the colonists may have been with regard to horses; nor do we know whether they found horses already there when they arrived at their new plantations. My belief is, however, that they were not only the first to carry horses to Egypt, but they were the first to carry them to the western extremities of the Mediterranean. It will be remembered that the early trade of the Armenians with the Phonician merchants was not only in horses, but in horsemen, and it is probable that these "horsemen" were slaves, expert and skillful in managing the horse. It has been said by historians that certain classes of their ships were ornamented with a carved horse's head, at the prow; and it has been inferred that the ships so designated vere specially constructed and fitted up for the safe carrying of horses. It is true that in the course of the centuries horses may have found their way from Egypt westward to Algeria, and by crossing the Bosphorus they might have found their way from Asia Minor to Spain, but it is also true that from small beginnings at the plantation of the colonies there was ample time for them to increase to almost countless herds before the period when the colonists became a mighty military power in the earth.

Historians tell us that the military establishment of the city of Carthage alone, when on a peace footing, consisted of three hundred elephants, four thousand horses and forty thousand foot soldiers. When Hannibal started out to fight Rome, in the second Punic war, say B.c. 218, he had with him eighty thousand footmen and twelve thousand horsemen; and he left thirty-two thousand soldiers at home to guard his Spanish and his African dominions. With a proportional division of the home troops, he then had about seventeen thousand mounted men in his army. These were not war levies, but hardened and trained soldiers, and it is, therefore, not remarkable that he held nearly the whole of Spain in subjection, and practically all of Northwestern Africa. Polybius, the soldier historian, tells us that "his Numidian cavalry formed the strongest part of his army, and to their quick evolutions, their sudden retreat, and their rapid return to the charge, may be attributed the success of Hannibal in his great victories." At an earlier period, we learn that in the organization of the Phœnician armies the numerous nomadic tribes were 
placed on their flanks, and wheeled about on unsaddled horses. guided by a bridle of rushes.

At a very remote period there were two tribes in the interior of Spain, the Celtæ and Iberi, that were greatly distinguished for their love of independence and their bravery in defending it. The antiquarians have failed to give us any information as to what they were or whence they came. They were contemporaneous with some of the early colonies of the Phœnicians. Their tactics in battle seemed to have been to break the enemy's ranks by a charge as cavalry, and to then dismount and fight on foot. They united as one people and called themselves Celtiberi. Where they got their horses, or whether they had them before the Phonicians arrived, are questions that cannot be answered.

The Visigoths, or western Goths, overran Northern Italy, settled in Sonthern France and eventually passed over into Spain, where they established a dynasty that lasted over two centuries and until it was overthrown by the Saracens, A.D. 711. Roderick, the king of the Visigoths, went out to battle with the Saracens, arrayed in his most showy apparel, and mounted on his splendid chariot, made of ivory and set with precions stones. As the battle progressed he saw what he had good reason to believe was treachery on the part of one wing of his army and he alighted from his chariot, monnted his horse called Orelia and rode away while his soldiers were being butchered. He was the last of the Gothic dynasty. There had been a battle between the navies of the Saracens and the Goths, A.D. 680, fifty-one years earlier, in which the fleet of the Saracens had been entirely destroyed, and at that time the Saracens occupied the whole of the southern shore of the Moditerranean. 'The word "Moors," as often used to designate the people of Northern Africa, is not well chosen, for it really belongs to but one of many different tribes of different names. The term "Saracen" anciently meant only an Arab born, but since the middle ages it has come to mean any and all adherents to the Mohammedan religion, in the nsage of Christian people, and is particularly apposite when speaking of a number of tribes engaged in a common canse.

The people of Northern Africa were not negroes as we understand the word, but a mixture of different races. When the Phœnicians settled among them they were nomadic barbarians, possessing a country of great riches without knowing it. Under the tuition of their new masters they made great advances in 
many of the arts of peace and in all the arts of war. The Phœnician blood was liberally commingled with that of the natives. The blood carried the brains, and hence the beautiful structures that came from their hands and heads. No purely bred nomad ever could have conceived or constructed the Alhambra. The Phœnicians were refined and educated idolaters, as refinement and education were understood in their day, while the native people were literally barbarians.

The then recent and rapid spread of Mohammedanism among all the people of Northern Africa is, on its surface, one of the most remarkable facts in history. As a religion it served to unite, under the banner of the Crescent, all who accepted it, and guaranteed to all who fell in its defense immediate admission to paradise. All who did not accept it were enemies and only fit to perish by the sword of the Saracen. The founder of this religion died A.D. 632, and seventy-nine years afterward his followers, in Northern Africa alone, won their great victory over the Gothic dynasty of Spain. When once on Spanish soil they appeared to take root there and held possession of a large part of Spain for nearly nine hundred years.

Now that I have traversed the field of Spain and Northern Africa, from the first dawnings of history down to the beginning of the seventeenth century, in order to gather in all that history reveals touching the introduction and propagation of the horse in those regions, we are ready to summarize the facts that we have gleaned. At the periods of six hundred (when Carthage became independent of the mother country), four hundred, and two hundred years before the Christian era, there is undoubted evidence, over and over again, that Spain and Northern Africa were abundantly supplied with horses. Then, how is it possible that the hordes of Barbarians from Asia could have supplied these countries with horses, when they did not arrive there until several centuries after the supply is established to have existed? Take, if you please, the shortest of the periods suggested above, when Hannibal's cavalry almost annihilated a great Roman army, two hundred and sixteen years before the Christian era. This was five hundred and seventy-two years before Arabia had any horses; and how can "the blind leaders of the blind" supply Hannibal's cavalry with Arabian blood? When the people of Northern Africa, west of Egypt, fought their way into Spain it is not known that there was a single Arabian soldier nor a single 
Arabian horse in the whole army. They were all called Arabians, however, and that pretense has existed ever since.

The Phœnicians were the most remarkablo people of all the early ages and indeed of any age. They belonged to the Aramaic or Semitic race; they settled in Canaan long before the days of Abraham and attained their greatest prosperity in the days of Solomon, when his fleets and those of his friend Hiram, King of Tyre, controlled and monopolized the commerce of the world. More than five hundred years before this alliance, however, they had established commercial relations with all the countries bordering on the Mediterranean, and their ships were trading in the ports of every comntry from Egypt to the Pillars of Hercules and far beyond. There seems to be no donbt that they carried tin from Britain and amber from the Baltic, and, of course, they had to bring something to exchange for what they carried away. What did they bring? As amber did not enter into the necessary arts it is not probable the trade was very large, but tin was required by many nations in their everyday life, especially the Egyptians, who had no foreign commerce and were thus dependent upon the Phœnician merchants. We may conclude, therefore, that the trade in tin was large, and as there was no Phœnician colony in extreme southwestern Britain, the foreign traders would bring just what the Britons most needed. If they were already in possession of horses they would not need that kind of exchange, but if they were not in possession of horses, that would be just the kind of exchange they would want, and probably this was the source from which they obtained their supply. The question, however, of how or when our British ancestors obtained their first supply of horses has never been positively answered. That they had them in great abundance at the begiming of the Christian era is fully established by the experience of the Romans when they captured Britain. From their great numbers and the skill displayed in their management in battle, it cannot be doubted that they were there for many generations before the Roman armies came in contact with them. Many theories have been advanced as to how the horse may have reached Britain, but no one of them rests on so reasonable a basis of probability as that of the Phœnician traders. If from this source, which I am strongly disposed to believe was the true source, it must have been during the maritime supremacy of the Phœnicians and their colonies, and this would place the date several centuries before 
the Christian era. If we were able to reconstruct the original line of the migration of the early English horses, we would, probably, first find them in "the land of 'Togarmah" starting to market at Tyre, where they were exchanged for supplies needed in Armenia. There they were put on board one of the great "ships of 'larshish," and when they next touched the land it was at one of the ports at the southwestern portiur of England, where they were exchanged for tin and other products of the mines.

In aldition to the argument furnished by this known course of trade between nations and peoples, in prehistoric times, we have an additional one in the natural perpetuation of racial qualities, extending through many centuries. In reply to some questions submitted to a friend of mine who was born in Western Persia, educated in this country, and then returned to the land of his nativity, I have replies to my questions bearing date of July, 1896. He is located at Oroomiah, not far from the modern line between Persia and Turkey, and in what may be considered the very center of ancient Armenia. He is not skilled in horse lore, but he uses horses a great deal and is a very intelligent observer. He says that the Persian horses have been greatly overrated and that the country is full of very ordinary horses. He says that they are all colors, with bays probably predominating. There is a great variety of mixed greys, shading into white, and a few that are dappled. Then there are chestnuts, sorrels, "mouse-color" (duns), and not many blacks. They are small, as a rule, and a harness of small size from this country has to be cut down for them. From this I infer that they are generally under fourteen hands. On the whole the horses are nicely shaped, have slender, clean limbs, small ears, and carry the head and tail well up. As a rule they are great stumblers. With regard to gaits he says that stress is laid on a rapid walk-a half walk and half trot. In this country we would call it the "running walk" that may be kept up for days in succession. In speaking of the pace, my correspondent says: "There are some horses trained to pace, while some pick it up naturally, that is, are born pacers. The greater number are natural pacers. Now and then one will find a rapid pacer, but commonly the pace is a five or six miles an hour gait. There are some that single-foot naturally, and from birth."

He then says horses are not bred with any care. They are turned loose in herds and the breeding is such as would naturally oceur.

It will be observed that my Persian friend speaks of the differ- 
ent colors "of grey, shading into white," which suggests a possible descent from the famous breed of white Nissæan horses kept. by the great Darius and other Medo-Persian monarchs for racing purposes. But the striking feature in this description of the horses of Persia, or more properly, of ancient Armenia, of this day, is the fact that they are of the same size and color and habits of action as the horses of Britain when first visited by the Romans, as well as when they were more minutely described twelve hundred years later, and as they were at the beginning of the seventeenth century, and as they still were at the middle of the eighteenth century. As evidence on these points reference. is made to the chapters on horses of the colonial period that will follow in their place. In ancient Armenia, as with all pastoral. people of the early ages, horses were turned out to run in herds. and literally left to Mr. Darwin's law of "natural selection and the survival of the fittest." So it was in Britain to a great extent, until the eighteenth century, and so it was in the American colonies until fifty years later; hence the same types and characteristics prevailed and were perpetuated in all these countries.

It is sad to contemplate the present debased and semi-barbarous. condition of the descendants of a great people who for centuries stood first among all the nations of the earth in commercial enterprise, in learning, and in the arts. The banishment of the Saracens from Spain in the beginning of the seventeenth century of our era was in fact the banishment of the descendants of the Phœnicians who first colonized Spain. The architectural structures which they left behind them, and which for their marvelous: beauty have challenged the admiration of the world, were not the work of nomads and barbarians. They were the flashes of the old Phœnician taste and genius as exemplified by the descendants of the men whom Hiram sent to construct and decorate. the buildings of Solomon. The Alhambra and some other structures in Spain are all that we have to remind us of the genius. and grandeur of Phœnicia. Whatever may have been the character and attainments of the descendants of the colonists at the time, the change from idolatry to Islamism was a bad one. Wherever, throughout the world, the teachings of the "Prophet" have been accepted, whole nations have become intolerant, murderous and brutalized, and the modern Phonicians are no exception. They have now lost their identity in the follies and crimes: of Islamism and we can have no sympathy for them. 


\section{CHAPTER IV.}

\section{THE ARABIAN HORSE.}

The Arabian, the horse of romance-The horse naturally foreign to ArabiaSuperiority of the camel for all A rabian needs-Scarcity of horses in Arabia in Mohammed's time-Various preposterous traditions of Arab horsemanship-The Prophet's mythical mares-Mohammed not in any sense a horseman-Early English Arabians-the Markham Arabian-The alleged Royal Mares-T'he Darley Arabian- The Godolphin Arabian-The Prince of Wales' Arabian race horses-Mr. Blunt's pilgrimage to the EuphratesHis purchases of so-called Arabians-Deyr as a great horse market where everything is thoroughbred-Failure of Mr. Blunt's experiments-Various Arabian horses brought to America-Horses sent to our Presidents-Disastrous experiments of A. Keene Richards-Tendency of Arab romancing from Ben Hur.

Admiration always leads to exaggeration. This is true in most of the relations of life, but in our admiration of the horse it becomes greatly intensified, so greatly indeed that in magnifying his excellent qualities we find ourselves telling downright falsehoods about him before we know it. This "amiable weakness," as we might call it, is true of our everyday life and our everyday horses; but when we come to the horse that is the universal ideal of perfection, everybody seems to lay aside all the restraints of truth in extolling the superiority of his qualities. The "Arabian horse" is the ideal horse of all the world. He is the "gold standard" in all horsedom, with the one important distinction that the one is real and the other is mythical. Not one so-called horseman in a million ever saw a genuine Arabian horse, nor any of the descendants of one; and in all the discussions of the past three hundred and fifty years it has never been shown in a single instance that a horse from Arabia, with an authenticated pedigree and tracing as such, has ever been of any value, either as a race horse or as a progenitor of race horses. The superior qualities of "the Arabian horse," like the superior qualities of "The Arabian Nights," are purely works of the imagination. There is just as much truth in the stories of Sindbad the Sailor and 
Aladdin's Lamp as there is in most of the literature relating to the Arabian horse.

I am fully satisfied that these views of the Arabian horse will not meet with a ready acceptance by the vast majority of the horsemen of this or any other country, but my reasons for presenting them will become apparent as the discussion progresses. They smash too many idols and dispel too many chimeras of the brain to be readily accepted. It takes the average man a long time to get clear of the prejudices in which he was born, and the first question that will be asked by the doubter is, "Why could not Arabia have supported a race of indigenous wild horses, as well as any other cointry?" Because the horse, wild or tame, has never learned to dig a well forty feet deep, nor to draw water after it is dug. Neither has he learned to lay up a store in time of plenty against a time of famine. The horse could not live in Arabia without the care of man. And, second, "Why were all the civilized and semi-civilized nations west of Asia supplied with horses a thousand years before Arabia, when so near the original habitat of the horse?" It is the first law of our nature to supply ourselves with what we need. The camel always has been a necessity to the Arab, not only to carry him and his burdens, but to furnish nourishment and sustenance to him and his family. The camel is adapted to the country and the country to the camel, and no other created animal can fill that place. He is, literally, "the ship of the desert." The horse in Arabia is a luxury that can be indulged in only by the rich; hence his ownership is practically restricted to the chiefs of tribes. He is never used except for display and war. Palgrave, in speaking specially of the Nejd tribe, says: "A horse is by no means an article of everyday possession, or of ordinary or working use. No genuine Arab would ever dream of mounting his horse for a mere peaceful journey, whether for a short or a long distance."

When we consider the immeasurable superiority of the camel to the horse in meeting the wants and necessities of the Arab, we will not be surprised at the immense herds of the former and the small numbers of the latter that are bred and reared in that country. A camel can go four days withont water, and under stress, it is said, a good one can cover the distance of two hundred miles in twenty-four hours. The camel and the country are suited to each other, while the horse is an exotic, and has no part in any industrial interest except raiding and robbery. $\mathrm{My}$ 
attention was first called to this unexpected smallness in the numbers of Arabian horses in the seventh century, two hundred and sixty years after the introduction of the original stock from Cappadocia. The flight of Mohammed from his enemies in Mecca to Medina took place A.D. 622. There, setting up as a Prophet, and as holding communications with Heaven, he soon gathered around him a number who believed in his divine inspiration. Understanding the habits and instincts of his followers, he soon found he must give them something to do. $\mathrm{He}$ called them about him, mounted a camel, and at their head he was successful in plundering two or three caravans, which greatly enraged his old enemies at Mecca. Whether the anger of his enemies was kindled anew because some of the plunder belonged in Mecca, or whether he merely deprived the Meccans of the opportunity of doing the plundering themselves, the historian fails to make clear. Whichever may have been the underlying reason, it led to war. In the first campaign of the Meccans and in the first battle fought, they far outnumbered the followers of the Prophet. There were some camels in Mohammed's train, but no horses. He did not lead the battle himself, but remained in his tent and promised his followers that all who fell in battle would be forthwith admitted into Paradise. They believed the promise, as millions and millions have believed it since; it inspired them with a recklessness of life, and they were completely victorious. The result of this victory was the capture of one hundred and fifteen camels and fourteen horses, besides the entire camp of the enemy. In the battle of the next year (A.D. 625) between the same parties, the forces were much increased on both sides. Sir William Muir, the historian, informs us that Mohammed had but two horses in his army, one of which he mounted himself and took command of his forces. This battle was not decisive. In subsequent raids he captured many enemies and traded his female captives for horses with the surrounding tribes, so far as he was able to obtain them. The next year' he had an army of three thousand men and thirty-six horses, while the enemy had an army of three thousand men, of whom two hundred were cavalry, but there was no fighting. The fame of Mohammed as a successful and relentless pillager and destroyer had now spread far and wide, and as a means of escape the chiefs of the larger portion of the tribes of Arabia hastened to tender their allegiance and obey his commands. From this forward, therefore, we must. 
consider Mohammed as the representative of the whole of Arabia, in both its religious and military power. The next year his old enemies, the citizens of Mecca, surrendered the sacred city to him without a blow, and thus Islamism became a mighty power in the worldi.

It is evident from many sources other than the history of Mohammed that horses have always been a very sparse production in Árabia. Burckhardt, the famons traveler in the East, journeyed very extensively in Arabia about 1814, and he gives the result of his observations on this point of numbers as follows: "In all the journey from Mecca to Medina, between the mountains and the sea, a distance of at least two hundred and sixty miles, I do not believe that two hundred horses could be found, and the same proportion of numbers may be remarked all along the Red Sea." This is in strict conformity with the observations of other writers, the reasons for which have already been given.

Time out of mind, everybody has heard of the insuperable difficulty of prevailing upon an Arab to part with his genuine, high-caste mare for either love or money. He will expatiate, as the story goes, upon "the beanty and graces of his mare as the light of his household and the joy and playmate of his children, and above all as she is royally bred he cannot, as a good Moslem, disobey the injunctions of the Prophet not to sell such mares, but to keep them forever that their descendants may enrich the children of the faithful to all generations." If you ask him more particularly about her lines of descent, he will give you fifty or a hundred generations and land you safely on the name of the particular one of the five mares of the Prophet from which she is descended. To illustrate the sham of all this Major Upton's experience, in purchasing horses in Arabia for the East India service, may be cited. It is evident the major understands his dealers and they understand him. He says: "In the desert we never heard of Mrohammed's mares, nor was his name ever mentioned in any way as connected with the Arabian horse." $\mathrm{He}$ says there is no restriction.nor difficulty in buying as many mares as you want, in any part of Arabia. This disposes of the tricky pretenses of the Arab horse dealer when he is negotiating a sale to a man without Arabian experience.

Some modern writers make mention of a tradition that still prevails among some tribes as to the origin of the Arabian horse, and it is to the effect that their best horses came originally from 
Yemen. This tradition is met with in Arabia Deserta, a long way from Arabia Felix, of which Yemen is a portion. While this tradition is of no possible value as evidence, it is suggestive of what might be unearthed in that strange country. The people were not nomadic, but agricultural and commercial, and the cities were rich. 'The people were well advanced in the arts and comforts of civilized life, and in their cities they had many beantiful temples and palaces. Such a people would of necessity produce learned men who would leave records of their national history behind them, and especially that of such an event as the conversion of the whole people to Christianity. Possibly the researches of scholarly men may yet bring to light more of the facts connected with the embassy from the Emperor Constantius and the introduction of the Cappadocian horses into Yemen, as related in the preceding chapters.

There are many other traditions, so called, that are burnished up and brought out whenever the crafty dealer finds he has a Richards from America, or a Blunt from England, with his mind already made up that all the best horses of the world have come from Arabia. To such a customer, with his mind already at high tension in search for the longest pedigree and the purest blood, the dealer casts his hook in something like the form following:

"When King Solomon had completed the temple he turned his attention to supplying his army with horses and chariots. $\mathrm{He}$ searched every nation that had horses for sale and would have none but the very best that the world could produce. He spent much of his time in admiring his beautiful horses, and one day he was so thoroughly absorbed that the hour of prayer passed without his observing it. He felt that this neglect to pray at the proper time was a great sin, and that his horses had led him into it. He did not hesitate longer, but he at once ordered all his horses to be turned loose to the public. Some of my ancestors succeeded in securing six of these mares, and from these six mares all the good horses of Arabia are descended."

Other dealers are a little more modest in their claims for the antiquity of the pedigrees of their horses, and generously knock off about sixteen hundred years, being content to trace to the mares of the Prophet instead of the mares of Solomon. This still leaves them with a pedigree only about twelve hundred years long, which beats our modern romancers in making stud books. In order to test and select the mares that were worthy of becom- 
ing the dams of the best horses, as the story goes, the Prophet shut up a herd of mares, in plain sight of water, and kept them there till they were almost famished with thirst; and then at a signal they were all released at once, and when rushing headlong to the water the trumpet sounds, and notwithstanding their sufferings they turn and align themselves up in military order. In this test of obedience and discipline, it is said, only five of the mares obeyed the signal (some say only three) and thus the mares that obeyed, notwithstanding their sufferings, became justly entitled to the distinctive and honored name of "The Prophet's Mares." Another story is told of the particular markings which, in the Prophet's estimation, indicated the best horses. By one authority he always selected a black horse with a white "forehead," and some white mark or marks on his upper lip. Another authority says he always chose a bay horse with a bald face and four white legs, and so we might go on till we had embraced every color and every combination of marks, and we would then find that each "authority" had a horse to sell corresponding with the Prophet's preferences. Now the fact is that Mohammed was neither a horseman nor a horse breeder, and the whole tenor of history goes to show that he neither knew nor cared very much about horses. In his first pilgrimage to Mecca, after the battles referred to above, the privilege for which was secured by negotiation, a hundred horsemen, it is said, were started and kept one day's journey in advance of the main body of pilgrims. The great numbers following Mohammed on this pilgrimage admonished his old enemies of Mecca of the futility of attempting to resist his power longer, and they fled from the city during the continuance of the ceremonies. A year or two later he summoned all the tribes of Northern and Eastern Arabia to follow him again to Mecca, and they had too lively a sense of their own safety to disobey. Due time was given for preparation, the rendezvous was at Medina, and a vast host from all Northern and Western Arabia congregated there for a purpose that might be to fight, or it might be to pray. Mohammed mounted his camel and the word was passed, "On to Necca." As against such a multitude the Meccans saw that resistance was hopeless, and the city was surredenred without either side striking a blow. Arrayed in great splendor and mounted on his camel, the Prophet made the reqnisite number of circuits round the holy place and then entered and ordered all the idols that had been set up there to be de- 
stroyed, and his followers then shouted, "Allah is Allah, and Mohammed is his Prophet!" 'Thus he became master of all Arabia-and woe to the Christian or the Jew who stood in his way. Two years afterward he died, and there is nothing in his life or history to indicate that he ever owned a horse or that he ever mounted one, except on a single occasion. In the ten short years of his public life he had something more important on hand than to determine how to breed horses.

In studying the Arabian horse in the light of what he has done and what he has failed to do, we are indebted to English writers for little snatches of experiences extending back for a period of about two hundred and fifty years. The earliest English writer who has had anything to say about the Arabian horse was the Duke of Newcastle, who seems to have known a great deal about the various types and breeds of horses of his day. During the period of the Commonwealth it appears he devoted his time, in the Netherlands, to training horses in the manege of that day. From his experience in this employment he became an expert in the form, structure, and docility of the different kinds of horses that he handled. When Charles II. was brought back and placed upon the throne, the duke also came to his own, and being a personal friend of the king he became his counselor and adviser in all matters relating to the improvement of the horses of the realm. In 1667 the duke published his famous book upon the horse, in which he speaks right out on any and every question that he touches. There can be no doubt that he knew more about horses and horse history than any man of his day. In speaking of the Arabian horse he says: "I never saw but one of these hor'ses, which Mr. John Markham, a merchant, brought over, and said he was a right Arabian. He was a bay, but a little horse, and no rarity for shape, for I have seen many English horses far finer. Mr. Markham sold him to King James for five hundred pounds, and being trained up for a course (race), when he came to run every horse beat him."

It is generally held that this Markham Arabian was the first of that breed ever brought to England, and this seems to be established by the fact that historians antedating his arrival make no mention of any Arabian horse before this one, and those following always speak of this horse as the first. In speaking of the powers of endurance of the Arabian horse, the duke says: "They talk they will ride fourscore miles in a day and never draw the 
bridle. When I was young I could have bought a nag for ten pounds that would have done as much very easily." 'The duke's masterful knowledge of the subject, as well as his special official relations to the king, gave him control of whatever was done or attempted in the direction of improving the racing stock of England. Tradition informs us that "King Charles II. sent abroad the master of the horse to procure a number of foreign horses and mares for breeding, and the mares bronght over by him (as also many of their produce) have since been called Royal Mares." It is very doubtful whether any such importation was ever made. The question has been discussed, from time to time and even recently, but nobody has ever yet discovered who was "Master of the Horse," to what country he was sent or what the character of the mares he brought home, or where he got them. The fair presumption is that these "Royal Mares" were myths and that they were created merely for the purpose of putting a finish on certain very uncertain pedigrees, just as a trotting-horse man would finish a pedigree that he knew nothing about by saying, "out of a thoroughbred mare." As a matter of conrse it has always been assumed that these "Royal Mares" were of distinctively pure Arabian blood. But, if we admit that such an importation was really made, we must consider that it was made under the direction and control of the Duke of Newcastle, the king's mentor in all horse affairs, and this is sufficient proof that there was no Arabian blood about the "Royal Mares." As the size of the English race horse and especially his weight of bone commenced to increase soon after this time, it strikes me as probable that this was the wise and guiding motive of the duke in making his selections of the "Royal Mares."

When we come down a little nearer to our own times and step across the border from the seventeenth to the eighteenth century, we are still in the realm of traditions, and many of them very preposterous. The deceptions practiced in nomenclature were so common as to be well-nigh universal. Everybody who owned a foreign horse must have "Arabian" attached to his name. To illustrate this evil and the misleading effects flowing from it, I will give two instances of the most famous horses in all English history. The Darley Arabian and the Godolphin Arabian stand pre-eminent and before all others as progenitors of the English race horse. The former of these two was purchased at Aleppo, in Asia Minor, and brought: to England in $17_{11}$, by Mr. Darley of 
Yorkshire who secured him through a brother in trade in that region. He was the sire of Flying Childers and many others, and his blood carried from generation to generation. Aleppo is in Northern Syria and far distant from Arabia. At one time it was embraced in Armenia Minor, the original home of the horse, and adjoined Cappadocia and Cilicia, all famous for the excellence of their horse stock more than two thousand years before there was a single horse in Arabia. Upon the restoration of the ancient Theban line of Pharaohs in Egypt, at the beginning of the eighteenth dynasty, no time was lost by Thutmosis I. in leading a great army into Northern Syria for no other purpose that is apparent except to replenish and reinvigorate the horse stock of Egypt, from the region of Aleppo and further east, for this is the region from which they had secured their original stock. His successors pursued the same course, year after year, and the number of horses and chariots captured in battle, as well as the number of mares sent as tribute by the frightened people, were duly recorded in the annals of their achievements. If the Darley Arabian, so called, bore any relationship whatever to the Arabian horse, it can only be established by tracing him back to some one of the animals in Cappadocia that the Emperor Constantius sent to Arabia in the year A.D. 356. A writer of the seventeenth century, Dr. Alexander Bursell, in speaking of Aleppo, says: "Formerly this part of the country was famous for fine horses; and though many good ones are still bred here, it may be said they are much degenerated." This is the observation of an intelligent man, written and published in 1756 , about forty years after Mr. Darley's horse was brought from there.

The other illustration is that of Godolphin Arabian. As a progenitor of race horses this was the greatest horse of his century, or indeed of any other century in the history of the English race horse. He died in 1753, and absolutely nothing is known of his origin or his early history. The story is generally accepted, and I suppose is true, that he was bought out of a cart in Paris, as an act of humanity, by a Mr. Coke, taken to London, presented to Mr. Williams, the keeper of a coffee-house, and passed from him to Lord Godolphin, who kept him till he died. The story that he was presented to Louis XV. by the Bey of Tunis in 1731 has never been verified in any manner, and breaks down on the vital point of date. Some intelligent Englishmen insist that he must have been an Arabian, while others insist that he must have been a. 
Barb, while no man knows whether he was either one or the other. With the most prominent horses of the nation and of their century thus used to mislead the public mind as to their lineage, what are we to expect from the great ruck of the obscure and less prominent? But, as a more elaborate and methodical discussion of this topic will be found in the chapter on the English and American Race Horse, we will now turn our attention to the actual experiences with the Arabians in recent times.

When we come down to the present century we get into the era of newspapers that really begun to give the news, and thus educate their readers, not very authentically, but circumstantially, in what was passing in the world in every department of knowledge and enterprise. Under these wide sources of information, a few authentic experiences will serve to illustrate the true status of the Arabian horse and his influence, or lack of influence, on English and American horses. More than twenty years ago the Prince of Wales made a royal progress through Her Majesty's dominions in the East. The enthusiasm was unbounded and he was loaded down with many valuable presents, among them several elegant, high-caste Arabian horses. It appears that some of these horses had already won reputation and money on the turf, and were considered the very best that could be found in the East. On their arrival they were greatly admired and praised, especially by the sporting friends of the prince, who seemed to have no doubt, nor did they conceal their opinions, that they could beat any horses in all England. This was a conclusion that a great many racing men, with longer memories, could not accept, and after a good deal of diplomacy a match was finally concluded between the prince's best horse and an old horse that was third or fourth-class, in his prime, but was unsound and liable to break down any time he was extended. The prince was popular, had many supporters, and much money was pending. The old horse was patched up as well as possible, the day came, the race was started, and the old cripple was so much faster than the Arab that his managers had the hardest work in the world to prevent him from rumning clear away and disgracing the prince. This account of the race I had from one of the most eminent and successful trainers that England has produced. He witnessed the race and knew all the facts concerning it. Notwithstanding the popularity of the prince and the universal feeling of loyalty toward him, it was a long time before his Arabs ceased to be a laughing-stock among horsemen. 
Some sixteen or eighteen years ago, an English gentleman of wealth and intelligence-Mr. Wilfrid S. Blunt-got it into his head that the way to improve the English race horse was to secure fresh infusions of pure Arabian blood. He was industrious in propagating his fad, in an amateurish way, through the columns of the English newspapers, evincing great zeal and a great lack of knowledge of the hundreds of experiments in the same direction and in the history of his own country that had proved disastrons. But he had a will of his own and a bank account that enabled him to carry out his views to their own realization. In the autumn of 1877 he made up a pleasant family party, consisting of his wife, Lady Ame, and two of her lady friends and started for Arabia, with the full determination to find the best and to buy nothing that was not of the purest and best lineage that could be found in all that country. Fortunately, Lady Anne carefully noted down everything that transpired in their journeyings and after the return wrote a very pleasant and readable book, understood to have been edited by her husband in some of its features. The title of the book- "The Bedouin Tribes of the Euphrates"-did not strike me pleasantly, for I never knew that any of the numerous Bedouin tribes were to be found on the Euphrates. But my purpose is not to criticise either the book or its title, but to follow the party over its itinerary and discover just where Mr. Blunt found the blood he was looking for, and upon what evidence he accepted it as "the best blood." With this view I will carefully give his own language, so far as it applies to the point in view.

His first purchase was at Aleppo, where he got a mare he named Hagar, as he says, "for a very moderate sum." "She was of the Kehilan-Ajuz breed." "When purchased she was in very poor condition, having just gone through the severe training of a campaign." "She was bred by the Gommussa, the most able of the horse-breeding tribes, had passed from them to the Roala, and had now been captured and riddęn some two hundred miles, in hot haste, for sale to Aleppo." "We never met anything in our travels that could compete with her over a distance, and she has often run down foxes and even hares, without assistance, carrying thirteen stone on her back." This was the first experience of the English "tenderfoot" among Syrian horsethieves. According to his own showing, he bought her from the fellow who had stolen her and had ridden her two hundred miles to escape, and he accepted what the thief told about the breeding of 
the mare as true. The thief knew just what Mr. Blunt wanted and he shaped the pedigree and tracing to suit the purchaser. Mr. Blunt had no knowledge of this mare's breeding, nor where she came from; still, her blood was to become one of the great influences in renovating the English race horse. This incident is of no importance, in itself, except as it illustrates the universal conditions under which amateurs buy horses in the Orient.

Upon leaving Aleppo, the party traveled eastward till they struck the Euphrates and then down the right bank of that river. The first town of any importance was Deyr, on the river, and just across was ancient Mesopotamia. They were still in the border land between the productive north and the desert south, with the Syrian desert between them and the Arabian desert. All this region is occupied with a mixture of races, employed in varied pursuits, with but a feeble trace of tribal ainthority, as all are under the direct government of the Sultan of Turkey.

" Deyr is well-known," Mr. Blunt says, " as a horse market, and is, perhaps, the only town north of the Jebel Shammar where the inhabitants have any general knowledge of the blood and breeding of the beasts they possess. The townsmen, indeed, are but a single step removed from the Bedouins, their undoubted ancestors. They usually purchase $t$ eir colts as yearlings either from the Gomussa, or some of the Sabaa tribes, and having broken them thoroughly, sell them at three years old to the Aleppo merchants. They occasionally, too, Lave mares left with them, in partnership, by the Anazah, and from these they breed according to the strictest desert rules. It is, therefore, for a stranger, by far the best market for thoroughbreds in Asia, and you may get some of the best blood at Deyr that can be found anywhere, besides having a guarantee of its antlienticity, impossible, under ordinary circumstances, to get at Damascus or Aleppo. There are, I may say, no horses at Deyr but thoroughbreds"

He made some purchases at Deyr and then they pursued their journey down the river, and at the most convenient point he crossed over to Bagdad, on the Tigris. Here he inspected the stud of the Turkish pasha, but the prices were high and he seemed to lack confidence in the purity of their breeding. Whatever the cause, he made no purchases, and soon started on his journey up the Tigris. Upon reaching Sherghat on the Tigris, he turned westward, and crossing ancient. Mesopotamia, he was again at Deyr, where he seems to have made more purchases, and then started, in a southwesterly direction, with eighteen mares and two stallions for Damascus and the coast. This closed the search of Arabia for Arabian horses of the highest caste and purest blood, 
without really being in Arabia, and this is all that can be said of "The Bedouin 'Tribes of the Euphrates"-without having seen a real Bedouin.

No doubt Mr. Blunt thinks he is right in his high appreciation of the town of Deyr as a horse market; that it is "the best market for thoroughbreds in Asia;" and that "there are no horses in Deyr but thoroughbreds," or he would not have bought his horses there. Dealing in horses seems to be the principal business of the people, they are all well informed on the best and purest strains of blood, according to Mr. Blunt, and all their own horses are thoroughbred. Truly an ideal market, an ideal people, and ideal horses, just suited to the needs of enthusiastic amateurs like Mr. Blunt. This remarkable horse town is located on the border between the rich grain fields and luxuriant meadows on the north, and the comparatively barren deserts of the south. On the north the country has been famous for thousands of years for the great numbers and excellence of the horses produced, and they are still produced of excellent form and quality, and are sold at very low prices. On the south is the land of the camel, and but few horses and those few held at high prices, and the simple term "Arabian horse" always brings them purchasers. Here, then, we find that Deyr is the very paradise of horse traders-a tribe, wherever we find them on the face of the eartl, distinguished for elasticity of conscience. The north furnishes the horses and the south furnishes the pedigrees, and no wonder the Deyrites had nothing but "thoroughbreds" when Mr. Blunt came along. In the line of their business and from their southern neighbors, they had picked rp enough "Arabian horse talk" to satisfy all inexperienced buyers that they knew all about the value of the different strains of Arabian blood, and could supply them from their own studs, ai very reasonable prices. And thus Mr. Blunt brought home to England eighteen "Arabian" mares and two stallions, without any satisfactory evidence that they ever had seen Arabia. In this enthusiastic venture, resulting in utter failure, there is one alleviating fact that Mr. Blunt can call to mind, and that is that his horses were just as good for the purpose of improving the English race horse as any others that have been brought from the Orient in the past hundred years. Whatever their blood, whether genuine or counterfeit Arabians, they have all alike been failures, and all alike good for nothing.

Early in the history of our own government it became not an 
unusual thing for the Sultan of Turkey, the Emperor of Morocco, or some other potentate of the Saracenic races, to present to the President two horses, and as they were presents from royalty to what they esteemed royalty, they were necessarily of the highest caste and of the greatest value of any horses in all their dominions. It is probable that Mr. Jefferson was the first president to receive these royal gifts, and under the requirements of the constitution and without any disrespect to the donor, he ordered them to be sold to the highest bidder, and turned the money into the treasury. Several of the presidents received these presents of horses, and without knowing the fact, I will presume disposed of them the same way. In the case of President Lincoln, $\mathrm{Mr}$. Seward seemed to be more highly favored and the sultan sent the horses to him. Through the State Agricultural Society, Mr. Seward presented his royal presents to the State of New York. My recollection is not very distinct, but my impression is that. Mr. Van Buren had disposed of his in the same way. When General Grant received his, he was not in public office and hence they became his personal property. A number of the first of these importations, together with some others that were brought. from Arabia, individually and by private persons, were, in the. early part of the century, carried into the South, which was then the "race-horse region," but the breeders there very soon discovered that in breeding from them they were taking a backward instead of a forward step. Their progeny could neither run nor trot, and as they were too small for the ordinary uses of the farmer and planter, they were almost unanimonsly rejected, with nothing left but the ignorant "fad" that was embodied in the name "Arabian."

The most notable example of the folly of attempting to regenerate the American race horse by the introduction of the "blood of the desert" is furnished in the sad experience of the late A. Keene Richards, of Kentucky. He inherited a large estate, and when he came into possession he proved himself an intelligent and successful breeder, and ran the colts of his own breeding, with a full share of winnings. He was not a spendthrift nor a gambler, but he was not content with mediocrity in sharing triumphs with his neighbors, for he was ambitious to beat. them all. He soon had his head full of such horses as the Darley Arabian and the Godolphin Arabian, and he argued if that blood founded the English race horse, he would go to Arabia and get it, 
and it could not fail to regenerate the American race horse. $\mathrm{He}$ did not stop to inquire whether either of his great ideals might have had a drop of Arabian blood in his veins, but he started for Arabia at once. He brought home a few stallions and felt sure he was on the eve of the greatest triumph of his life. When the half-Arab produce of his strong and elegantly bred race mares were old enough to run the jockey club allowed the half-breeds seven pounds the advantage in weight and they were beaten. The club then allowed them fourteen pounds and they were again beaten; and finally the allowance was raised to twenty-one pounds, and they were still in the rear rank. Under these humiliating defeats a careful man would have hesitated before he went further, but he at once jumped to the conclusion that his defeat was not in the fact that Arab blood could not run fast enough to win, but in the fact, as he supposed, that the rascaliy Arabs had sold him blood that was not Arab blood. In a short time he was off for Arabia again, taking with him as companiou and adviser the distinguished animal painter, Troye, who had a long and successful experience as a delineator of race horses and knew all about the anatomy of the horse. They spent several months among the different tribes, and in order to get "inside of the ring," as it were, they ate with the Arabs, slept with the Arabs, and worshiped with the Arabs, as Mr. Richards told me himself. They came home full of the highest expectations, bringing several mares as well as stallions with them, and fully assured that every one was of the highest caste and the best form for racing that could be found on all the plains of the desert. After the foals of this importation were old enough to start in the stakes, they were given the same advantages in weight as before, and they proved no better than the first lot. Poor Mr. Richards was crushed in spirits, not only by the vanishing of his air castles, but by the importunacy of his creditors. In his heroic, but misguided, efforts to improve the American race horse by infusions of pure Arabian blood, he involved his once handsome estate, and he died hopelessly insolvent. He had bred a number of pure Arabs of several generations, but the abundant feed and luxuriant blue grass of Kentucky did not increase their size, for whon they came under the auctioneer's hammer they were but little "tackeys," and they brought only the price of little "tackeys."

The number of horses brought to this country, whether as gifts to statesmen or as private ventures, and called "Arabians," 
is not very large, and it is safe to say that not one in ten of them ever saw Arabia. They came from Turkey or some of the Barbary States. But in the ease of Mr. Richards there can be no doubt that he made his selections in Arabia itself. Those selections having been made personally and with care and skill, we are bound to accept them as genuine Arabians. When we find, therefore, that having been tested they are no better than the horses bronght from Turkey or from Africa, we must conclude that the whole scheme is mere moonshine, and that Arabian blood as a means of improvement, has failed to develop the value that enthusiasts and dreamers have claimed for it since "time whereof the memory of man runneth not to the contrary." Practical and thinking men always judge of the value of a breed of horses from what the representatives of that breed can do or what they fail to do. The emotional and unpractical are always looking for an ideal horse, and the poets and story writers are always furnishing them one. Where a horse figures in a story he is uniformly endowed with an almost snpernatural intelligence and sense. To finish up the ideal horse, he always traces back to the "Courser of the Desert." If his triumph is in a flight of speed, he distances all competitors becánse he is a pure Arabian. The story of "Ben Hur," written by General Lew Wallace, furnishes a fitting illustration of this tendency of the public mind. The story of the chariot race at Antioch is a masterpiece of most exciting ingenuity, and one of the finest specimens of word painting in the English language. The irascible old sheik is quite overdrawn, but the juaggment and skill of Ben Hur cannot be surpassed. As a matter of course, the team of black Arabians was bound to win. Every bright schoolboy in the country has read. the story, and he has joined in the triumph of the black Arabians. The wide interest in the chariot race seemed to demand its pictorial delineation, and soon the public was gratified with a large and elegant etching, which hangs before me as I write. The only trouble about this excellent work of the imagination and the team of black Arabians is that there were no horses in Arabia till about three hundred and fifty years after the date of this supposed scene. We must let the poets sing and the norelists work out their plots, but it is well to pay some attention to the facts and experiences of history. 



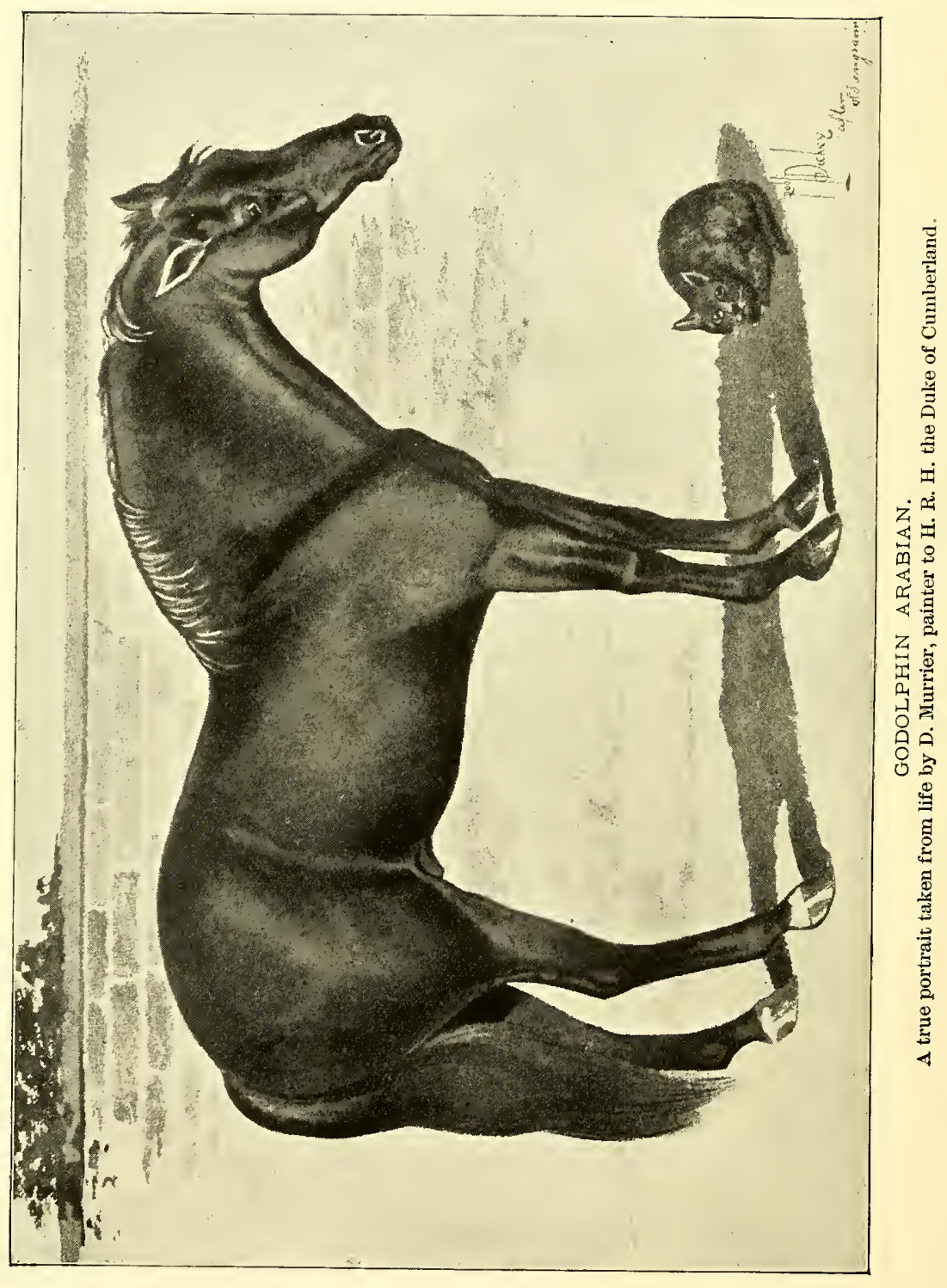




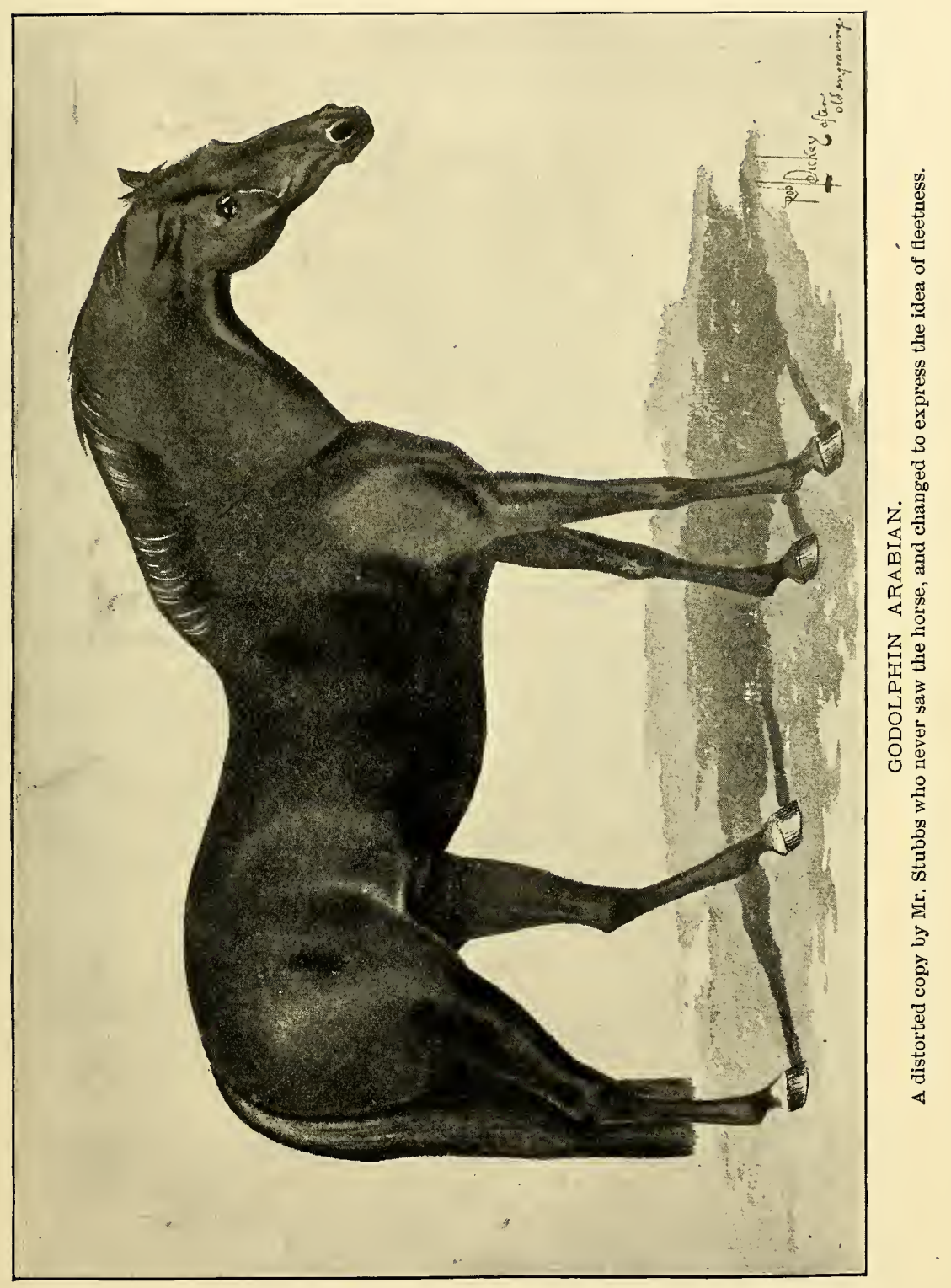





\section{CHAPTER V.}

THE ENGLISH RACE HORSE.

The real origin of the English race horse in confusion-Full list of the "foundation stock" as given by Mr. Weatherby one hundred years agoThe list complete and embraces all of any note-Admiral Rous' extravaganza-Godolphin Arabian's origin wholly unknown-His historySuccessful search for his true portrait-Stubbs' picture a caricature-The true portrait alone supplies all that is known of his origin and blood.

THe English Race Horse is the great central figure of all the horse literature of the past two hundred years. Much has been claimed for him and much has been written about him, in a haphazard way, by people who know but little of the subject. A few men of independent and real thought have written on this subject, but they have devoted their attention to the comparing of family with family or individual with individual. Of the books that have been written by brainless people on the English horse there is no end, and they are generally mere repetitions, without giving credit, of what somebody has said before. Among all the books that have been written on this subject I have never yet found one that even pretended to make a serious attempt at discovering the real origin of the English Race Horse. They all seem to agree with Admiral Rous that he is purely descended from the Arabian horse, and without one drop of the blood of the indigenous English horse. The average writer for the two past centuries has been content with just this much knowledge, and he wants nothing more. Occasionally it is modestly suggested in some magazine article that this exclusively Arabian origin may not be true, and I am glad to note that these suggestions are becoming more frequent of late years. It has been claimed that the pure Arabian origin of the race horse "is as solid as i pyramid,".all of which may be accepted-but, unfortunately for the claimant, the "pyramid" is standing on its apex, and when the facts breathe upon it, as gently as a zephyr, it will topple over. The most convenient and the most anthoritative collec- 
tion of facts relating to the earliest exotic horses that were brought in is to be found in the English Stud Book itself, and as but few of my readers have access to this work, I will copy that portion of it entire, as it appears in the first volume, and the edition of 1803 . In the edition of 1808 the list was reprinted with four additional animals and some verbal changes, which, when important, will be noted.

\section{"ARABIANS, BARBS AND TURKs."}

1. The Helmsley Turk was an old Duke of Buckingham's and got Bustler, etc.

2. Place's White Turk was the property of Mr. Place, studmaster to Oliver Cromwell, when Protector, and was the sire of Wormwood Commoner, and the great grandams of Windham, Grey Ramsden and Cartouch.

3. Royal Mares: King Charles the Second sent abroad the master of the horse, to procure a number of foreign horses and mares for breeding, and the mares brought over by him (as also many of their produce) have since been called Royal Mares.

4. Dodsworth, though foaled in England, was a natural Barb. His dam, a Barb mare, was imported in the time of Charles the Second, and was called a Royal Mare. She was sold by the studmaster, after the king's death, for forty gu neas, at twenty years old, when in foal (by the Helmsley Turk) with Vixen, dam of the Old Child Mare.

5. The Stradling or Lister Turk was brought into England by the Duke of Berwick, from the siege of Buda, in the reign of James the Second. He got Snake, the D. of Kingston's Brisk and Piping Peg, Coneyskins, the dam of Hip, and the grandam of Bolton Sweepstakes.

6. The Byerly 'Turk was Captain Byerly's charger in Ireland, in King William's wars (1869, etc.). He did not cover many bred mares, but was the sire of D. of Kingston's Sprite, who was thought nearly as good as Leedes; the D. of Rutland's Black Hearty and Archer, and the D. of Devonshire's Basto, Ld. Bristol's Grasshopper, and Ld. Godolphin's Byerly Gelding, all in good forms: Halloway's Jigg, a middling horse; and Knightley's Mare, in a very good form.

7. Greyhound. The cover of this foal was in Barbary, after which both his sire and dam were purchased, and brought into England by Mr. Marshall. He was got by King William's White Barb Chillaby, out of Slugey, a natural Barb Mare. Greyhound got the D. of Wharton's Othello, said to have beat Chanter easily in a trial, giving him a stone, but who, falling lame, ran only one match in public, against a bad horse; he also got Panton's Whitefoot, a very good horse; Osmyn, a very fleet horse and in good form for his size; the D. of Wharton's Rake, a middling horse; Ld. Halifax's Sampson, Goliah and Favorite, pretty good 12-stone Plate horses; Desdemona, and other good mares, and several ordinary Plate horses, who ran in the North where he was a common stallion and covered many of the best mares.

8. The D'Arcy White Turk was the sire of Old Hautboy, Grey Royal, Cannon, etc. 
9. The D'Arcy Yellow Turk was the sire of Spanker, Brimmer, and the great-great-grandam of Cartouch.

10. The Marshall or Selaby Turk was the property of Mr. Marshall's brother, studmaster to King William, Queen Anne, and King George the first. He got the Curwen Old Spot, the dam of Windham, the dam of Derby Ticklepitcher, and great-grandaw of Bolton Sloven and Fearnought.

11. Curwen's Bay Barb was a present to Louis the Fourteenth from Muley Ishmael, King of Moroceo, and was brought into England by Mr. Curwen, who being in France when Count Byrain and Count 'Thoulouse (two natural sons of Louis the Fourteentb) were, the former, master of the horse, and the latter an admiral, he procured of them two Barb horses, both of which proved excellent stallions, and were well known by the names of the Curwen Bay Barb and the Thoulouse Barb. Curwen's Bay Barb got Mixbury and 'Tantivy, both very excellent formed Galloways. The first of thein was only thirteen hands two inches high, and yet there were not more than two horses of his time that could beat him at light weights. Brocklesby, Little George, Yellow Jack, Bay Jack, Monkey, Dangerfield, Hip, Peacock, and Flatface, the first two in good forms, the rest middling; two Mixburys, full brothers to the first Mixbury, middling Galloways; Long Meg, Brocklesby Betty, and Creeping Molly, extraordinarily high-formed pares; Whiteneck, Mistake, Sparkler, and Lightfoot, very good mares, and several middling Galloways, who ran for Plates in the North. He got two full sisters to Mixbury, one of which bred Partner, Little Scar, Soreheels and the dam of Crab; the other was the dam of Quiet, Silver Eye aud Hazard. He did not cover many mares except Mr. Curwen's and Mr. Pelhaw's.

12. The Thoulouse Barb became afterward the property of Sir J. Parsons and was the sire of Bagpiper, Blacklegs, Mr. Panton's Molly, and the dam of Cinnamon.

13. Darley's Arabian was brought over by a brother of Mr. Darley, of Yorkshire, who, being an agent in merchandise abroad, became member of a hunting club, by which means he acquired interest to procure this horse. He was the sire of Childers, and also got Almanzor, a very good horse; a whitelegged borse of the D. of Somerset's, full brother to Almanzor, and thought to be as good, but meeting with an accident, he never ran in public; Cnpid and Brisk, good horses; Dædalus, a very swift horse; Dart, Shipjack, Maica and Aleppo, good Plate horses, though out of bad mares; Ld. Lonsdale's Mare in very good form, and Ld. Tracy's Mare in a good one for Plates. He covered very few mares except Mr. Darley's, who had very few well-bred mares besides Almanzor's Dam.

14. Sir J. William's Turk (more commonly called the Honeywood Arabian) got Mr. Honeywood's two True Blues; the elder of them was the best Plate horse in England, for four or five years; the younger was in very bigh form and got the Rumford Gelding, and Ld. Onslow's Grey Horse, middling liorses out of road mares. It is not known that this Turk covered any bred mares except the dam of the two True Blues.

15. The Belgrade Turk was taken at the siege of Belgrade, by Gen. Merci, and sent by him to the Prince de Craon, from whom he was a present to the Prince of Lorraine. He was afterward purchased by Sir Marmaduke Wyvill, and died in his possession about 1740 . 
16. Croft's Bay Barb was got by Chillaby, out of the Moonah Barb Mare.

17. The Godolphin Arabian was imported by Mr. Coke, at whose death he became (together with Cade, Regulus, etc., then young) the property of Ld. Godolphin. His first employment was that of a teaser to Hobgoblin, who, refusing to cover Roxana, she was put to the Arabian, and from that cover produced Lath, the first of his get. He was also sire of Cade, Regulus, Blank, etc., and what is considered very remarkable, as well as a strong proof of his excellence as a stallion, there is not a superior horse now on the turf without a cross of the Godolphin Arabian, neither has there been for several years past. He was a brown bay, with no white, except on the off heel behind, and about fifteen hands high (a pi ture of him is iu the library at Gog Magog, Cambridgeshire). It is not known to what particular race of the Arab breed, indeed it has been asserted that he was a Barb. He died at Grog Magog in 1753, in or about the 29th year of his age. The story of his playfellow, the black cat, must not be omitted here, especially as au erroneous account has got abroad, copied from the first introduction to the present work. Instead of his grieving for the loss of the cat she survived him, though but for a short time; she sat upon him after he was dead in the building erected for him, and followed him to the place where he was buried under a gateway near the running stable; sat upon him there till he was buried, then went away, and never was seen again, till found dead in the hayloft.

18. The Cullen Arabian was brought over by Mr. Noseo and was sire of Mr. Warren's Camillus, Ld. Orford's Matron, Mr. Gorges' Sour Face, the dain of Regulator, etc., etc.

19. The Coomb Arabian (sometimes called the Pigot Arabian and sometimes the Bolinghroke Grey Arabian) was the sire of Methodist, the dam of Crop, etc., etc.

20. The Compton Barb, more commonly called the Sedley Arabian, was sire: of Coquette, Greyling, etc.

\section{(AdDitions in 1808 Edition.)}

21. King James the First bought an Arabian of Mr Markhain, a merchant. for $500 \mathrm{gs}$., said (but with little probability) to have been the first of the breed ever seen in England. The Duke of Newcastle says, in his treatise on Horsemanship, that he had seen the above Arabian, and describes him as a small bay horse, and not of very excellent shape.

22. Bloody Buttocks; nothing further can be traced from the papers of the late Mr. Crofts than that he was a grey Arabian, with a red mark on his hip. from whence he derived his name.

23. The Vernon Arabian was a small chestnut horse. He covered at Highflyer Hall, and was the sire of Alert, etc. Alert had good speed for a short. distance.

24\& 25. The Wellesley Grey, and Chestnut Arabians (so called) were brought from the East, but evidently not Arabians. The former was a horse of good shape, with the size and substance of an English hunter.

This list of twenty-seven different animals, which for the sake of convenience I have numbered, was presented to the public: 
more than a hundred years ago by Mr. Weatherby, the highest of all English anthorities, as the foundation stock from which the English race horse was propagated. The uniform omission of dates of importations, etc., discloses the fact that the compiler had no accurate knowledge of the animals or their history, and that he was dependent largely upon very uncertain traditions for his information. It must not be understood that the animals in this list were contemporaneous, or that the list embraces all the foreign animals that were brought in, but only those that were recognized as of value in founding the breed.

To understand just what we have to consider, I will place here, in juxtaposition to the above list, the remark of Admirai Rous, at one time the great race-horse anthority of England, which expresses the popular opinion as to the origin of the race horse, that is practically universally held in all lands. The admiral says: "The British race horse is a pure Eastern exotic whose pedigree may be traced two thousand years, the true son of Arabia Deserta, without a drop of English blood." To reach the approximate truth on the issue here made, and to puncture this extravaganza is the work now before us.

Numbers 1, 2, 5, 6, 8, 9, 10, 14, 15, were Turks, and to these we may add Mr. Darley's horse, known as the Darley Arabian, number 13, for he was brought from Aleppo in Turkey, far removed from Arabia, and famous for the great numbers and excellence of its horses many centuries before Arabia had any horses. To carry horses, for sale, from the deserts of Arabia, where they are scarce, to the region of Aleppo, where they gre very plenty, and of the highest quality, would be simply "carrying coals to Newcastle." We may therefore safely conclude that the ten horses here enumerated were Turks.

Numbers $4,7,11,12,16,20$ were Barbs, as they are named in the list. It is a surprise to me that these six horses should be designated as "Barbs," for it has been the usage of many generations to call these horses "Arabians." As late as 1819 the Dey of Algiers sent several Algerine horses as a present to the Prince Regent of England, and they were always spoken of as "Arabians."

Numbers $1 \%, 18,19,21,22,23,24,25$ are all unsatisfactory as to their origin. Number 17-Lord Godolphin's horse-is wholly unknown as to his blood elements, and further on his history will be considered. Number 18 "was brought over," but from whence nobody knows. Number 19 is in the same condition, and 
not one of his different owners has been able to teli us anything about his origin. Number 21 was, possibly, an Arabian, but the Duke of Newcastle, who knew the horse well, seems to have doubted his genuineness on account of his inferiority. However this may have been, he preceded other importations so many years that it is not known that he ever sired a colt, and as a progenitor we may as well strike him out. Number 22 seems to be in darkness, and all efforts to find his origin having failed he may as well be classed as unknown. Number 23 is furnished with no evidence that he was entitled to be classed as an Arabian. Numbers 24 and 25 were confessedly not genuine.

This reduces the analysis to its lowest form and shows that in the original foundation stock, including Mr. Darley's horse (13), there were ten Turks and six. Barbs that can be accepted with reasonable certainty. This leaves eight so-called "Arabians," from which we must eliminate numbers $1 \%, 21,24,25$, leaving numbers $18,19,22,23$, without any evidence whatever that they were Arabians except in name. From these four rather obscure animals, therefore, according to the Rous dictum, the English race horse must have derived every drop of his blood; and yet there is not a scintilla of evidence either direct or inferential that any one of them, or the ancestors of any one of them, ever saw Arabia. From the custom of calling every horse from abroad an "Arabian," that has prevailed in England for more than two hundred years, it is fair to conclude that there was no Arabian blood in the foundation stock. It was the blood of the Turks and the Barbs, commingled with that of the native blood that had been bred to race for centuries, that furnished the foundation of the modern English and American race horse.

Blood in the race horse is an imperative necessity, but it must be blood that has been carefully selected from winners, and raced for generations, or it is of no value as an element of speed. If the English race horse had been a strictly pure exotic from Arabia Deserta, as Admiral Rous maintained, he would have been of no value either as a race horse or the progenitor of race horses, without many generations of careful selection and development of speed.

The Godolphin Arabian was altogether the greatest horse of his century. He flonrished during most of the reign of King George Il., but the horsemen of the world, even Englishmen themselves, know far more about him than they do about the 
reign of that monarch. Still, nobody knows anything of his birthplace, his origin or his blood. He was to the English race horse what Rysdyk's Hambletonian has been to the American trotter. Neither of them was ever in a race, but each of them stood immeasurably superior to all others of his day as a progenitor of speed, at his own gait. From the latter we had reason to expect speed because we knew he inherited speed, but from the former we had no reason to expect anything, for we knew nothing of what he inherited until he proved his inheritance by what he transmitted to his progeny. Some of the principal semitragic incidents, so far as known in the early life of Godolphin Arabian, were seized upon by the great novelist Eugene Sue, and out of them grew a "horse novel" from his gifted pen. The horse was foaled about 1724, was brought to England from France about 1730, and died at Magog Hills, 1753. There seems to be a substantial agreement among those who had the best opportunities to know that the horse was employed on the streets of Paris as a common drudge in a cart and driven by a brutal master. A Mr. Coke, who is represented to have been a Quaker, was in Paris on business and he happened to witness the brutality of the ruffian who was this horse's master in trying to make him draw a load of wood up a steep acclivity on to a new bridge, which the horse after repeated trials and clubbings was unable to accomplish. To relieve the poor brute from his sufferings, Mr. Coke's feelings of humanity asserted themselves, and he stepped forward and bought the horse on the spot and had him released from the cart. Mr. Coke, it is said, brought the horse to London and presented him to Mr. Williams, the proprietor of a famous coffeehouse, and Mr. Williams presented him to Earl Godolphin.

In September, 1829, Mr. John S. Skinner commenced the publication of the first horse magazine that ever appeared in this country, and in the first number there appeared a steel engraving purporting to be executed by the famous Stubbs and to represent the great horse, Godolphin Arabian. Not many years afterward I came into possession of a copy of this publication from the beginning, and the sight of this picture always impressed me as the most ludicrous abortion of the likeness of a horse that could be conceived of. The neck was absolutely longer than the body, the legs were about strong enough for a sheep, and all over it lacked strength of both muscle and bone to a most absurd extent. When this picture appeared in London, some years before, it was 
laughed at by all artists as well as by all men who knew anything about the shape of a horse, as a monstrosity, and it was received in the same spirit on this side of the water; but it bore the name of a great artist and that was sufficient to secure the approbation of the unthinking and the unknowing. The only key to the origin of the horse, the only pedigree that can be given, must be found written in his own structure of bone and muscle and brain. A true delineation, therefore, of his form and shape became a matter of the highest moment, not merely to satisfy the curiosity of the curious, but as a study of the true sources of his wonderful prepotency.

Sixty-five year's ago a correspondent of Mr. Skinner's magazine, referred to above, and a descendant of Mr. Samuel Galloway of Maryland, spoke of an oil painting of Godolphin Arabian that had hung in the hall at Tulip Hill from the days of his childhood as still hanging there, and said that it was wholly unlike the Stubbs engraving. Mr. Galloway was one of Maryland's land barons, an enthusiastic horse breeder, and a successful horse racer. He was edncated at Cambridge, I think; and if so, no doubt he saw Godolphin Arabian many times before he died, for he was within four or five miles of him, and his sporting instincts could not fail to take him to see so great a horse when so near at hand. As he was a young man of great wealth and great ambitions, it is quite probable he was on terms of friendly acquaintance, if not intimacy, with Lord Godolphin, and thus secured the oil painting from that distinguished friend himself. This theory is strengthened by the fact that the picture still bears the coat of arms of Lord Godolphin.

To reach and secure this picture, or at least a faithful copy of it, became an object of continuous effort that was never intermitted for more than twenty years. At last, in the spring of 1877, one of the correspondents of Wallace's Montllyy, Prof. M. C. Ellzey, of Blacksburg, Virginia, wrote me that the picture was then the property of Dr. J. H. Murray (whose wife was a lineal descendant of $\mathrm{Mr}$. Galloway) of Cedar Park, adjoining Tulip Hill, West River, Maryland, and that he would have the picture sent to me. In a few days it arrived, and when my eyes rested upon it, it was like the feast of a lifetime; for there was all that could ever be known of the greatest horse of his century. The painting was in a state of excellent preservation and the coat of arms of Lord Godolphin was plainly traceable. The horse is shown 
from his right side, in his rough, paddock condition, with his right hind foot a little advanced, and his head low and without any animation or excitement. The standpoint of the artist is a little forward of the shoulders, and he must have been a tall man or the horse must have been a low horse, or perhaps both, for he sees over the horse and portrays the fine spring of muscle over the loin, on the opposite side of the vertebra. From the position of the artist the drawing is slightly foreshortened, and this, together with the advance of his right hind foot, intensifies the droop of the rump, to some degree, in the outline. From the proportions, as shown in the painting, I would conclude he was below fourteen and a half hands high rather than above it. His head is striking and unusually large for an animal of his size, with remarkable width between the eyes, and without a star to lighten it up. His ear is not fine, and it droops backward as he stands, as if half-asleep. His mane is sparse and in disorder. His throat-latch is very good, and the windpipe large and well developed. The neck is of a fair length for a horse of his blocky formation, and there is nothing unusual about it except its great depth at the collar place. The slope of the shoulder is very marked and shows his ability to carry his head in the air when he wished to do so, but the shoulder itself is coarse and angular to an unusual degree. His withers rise very abruptly and there is great perpendicular depth through the carcass at this point. His back is remarkably short and the spread and arch of his loins is simply magnificent. But the point of superlative excellence is in the remarkable development of power in his quarters. His limbs, instead of being "spider legs," are unusually strong for an animal of his size; indeed, they might be considered coarse for any horse that was pretended to be a race horse. His tail is of the usual weight and somewhat wavy. With the addition that there is a little white at the coronet of the right hind foot, and not forgetting his friend and companion the cat, I have made a somewhat detailed description of what is represented in the painting. Several artists examined the picture, and they pronounced it the work of an artist of ability and experience. The signature "D. M. pinxt" was carefully examined, but no one was able to throw any light upon the name represented by the initial letters "D. M."

While this painting contained within itself evidence of its great value as a likeness of its subject, it lacked confirmation 
as "true to the life;" and nothing could supply this lack but to find a portrait of the same horse, painted by another artist, and then if the two agreed, the proof would be fully satisfying to the understanding. A little over a hundred years ago Lord Francis Godolphin Osborne, Duke of Leeds, and heir to Lord Godolphin, wrote Sir Charles Bumbury, a great race-horse man, that he had a painting of Godolphin Arabian, by Wootton, at Gog Magog Hills. Over sixty years ago an American gentleman wrote to Mr. Skinner's magazine that he had seen a painting of Godolphin Arabian hanging in Houghton Hall, Norfolk. In $18 \% 8$ my physician told me I must quit work for awhile, and that I had better visit the great Exposition at Paris that year. I was anxious to see the Fair, but I was a great deal more anxions to see those two paintings of Godolphin Arabian, if they were still in existence. Gog Magog Hills is a quaint old place, and the origin and meaning of its name is lost in a very remote antiquity. As it has not been the residence of its owners for more than a hundred years, it is much neglected. The people in charge were very obliging, and I was immediately admitted to the view of Wootton's painting of Godolphin Arabian. The first glance was a complete vindication of the truthfulness of the Maryland painting as a true likeness in every important feature of the outline and proportions. The canvas is about four and a half by four feet, inclosed in a massive frame. After studying it and comparing it, point by point for more than an hour, with a copy of the Maryland painting, it became evident they were not painted by the same hand, although the horse had the same position in both pictures, with the exception that the right hind foot was thrown backward in the Wootton painting instead of forward, and thus gave a less abrupt droop of the rump. The head was. precisely the same shape, but in the "large painting the articulations were less distinct and expressive.

After a little peregrination through Norfolk, studying the "Norfolk Trotter" as then called, but since called "Hackney," on his "native heath," I reached Houghton Hall, in Norfolk. This grand old place was built over a hundred and sixty years ago by the famons Sir Robert Walpole, and at that time it was considered the most splendid structure, as a gentleman's country seat, in all England. For many years it has been the property of the Marquis of Cholmondeley, but is not often occupied as a residence. Here too, I was lucky, for upon my entrance to the 
picture gallery, about the first object upon which my eye rested was the painting of the Godolphin Arabian, and the first impression was that there must be "spooks" around, for that seemed certainly the Maryland picture I was looking at. I had it taken down and removed to a good light, and there the whole mystery was removed. It is difficult to compare two peas. All you can say about them is that they were just alike, and that is all I can say about the Galloway picture in Maryland and the Houghton Hall picture in England. The paintings were the same size, and the pigments used were of precisely the same shades of color and quality. The colors were peculiar in the fact that the artist had used no varnish nor oil that would leave a shiny appearance. The Houghton Hall picture had a black, glossy margin all around it of abont five inches in width on which the names of the most noted of his progeny were inscribed in gold letters, and at the bottom was this inscription: "The original picture taken at The Hills, by D. Murrier, painter to H. R. H. the Duke of Cumberland." This explained the modest signature attached to the Maryland picture, which was a replica of the originul. "The Hills" is the local designation of "Gog Magog Hills." The word "original" not only implies that the picture was made from life, but that one or more replicas were made at the same time.

Here, then, in this picture, we have all that we know or probably ever will know of the origin and pedigree of this horse. It does not tell us what he was, but it does tell us in the most clear and unmistakable language what he was not. There is no feature nor element in his make-up that does not say that he was neither an Arabian nor a Barb. He was a stont, strong-boned, heavily muscled, short-legged horse. In his form and shape he was very far removed from an ideal progenitor of race horses, but he was that progenitor all the same. About forty years after his death Mr. Stubbs, who never saw the horse, brought out a painting of him which all artists laughed at as the picture of an impossible horse. This picture, however, was engraved on steel and became the standard representation of Godolphin Arabian, in England, till this day. Both these pictures are here given, and a comparison of many points makes it evident that Stubbs copied from the original of Murrier or from the painting by Wootton, which was probably also a copy of Murrier, and he followed his copy just as closely as he could while converting a big-boned, stout saddle horse into a long-necked, spindle-shanked race horse. 
By actual measurement the neck is longer than the body, but it. is not necessary to point out the Stubbs absurdities, as they are apparent to every eye. It was simply an awkward and dishonest. attempt to express in his form and shape such a pedigree as a great racing sire should have had. In these two pictures we have the real and the imaginary-the honest and the dishonest.

The search for this picture and then for its verification was a. labor of many years. I never expected to find the horse's origin, but the discovery of his likeness seemed to be in the bounds of a possibility that was finally realized. Murrier's picture, as a. mere work of art, is of no mean value. It contains within itself undoubted evidence that it is a true picture of a horse, and it is shown circumstantially that this horse was the great "unknown and untraced founder" of the English race horse, with nothingof the race horse in his appearance.

The name of this horse has been a misnomer ever since the day he fell into the hands of Lord Godolphin, and it has misled a multitude of men to their financial hurt. Of late years the more intelligent class of writers, instead of calling him an "Arabian" call him a "Barb," but there is just as much propriety in using one name as the other, and not a scintilla of authority for using either. Whatever may have been his origin, his marvelous structural combination of propelling power supplied what was wanting in the English stock of his day, and gave him success. Since then thousands of Arabians and Barbs have been tried and all of them have failed. 


\section{CHAPTER VI.}

\section{THE ENGLISH RACE HORSE (Continued).}

England supplied with horses be ore the Christian era-Bred for different purposes-Markham on the speed of early native horses-Duke of Newcastle on A rabians-His ch ice of blood to propagate-Size of early English horses-Difficulties about pedigrees in the seventeenth and eighteenth centuries-Early accumulations very trashy-The Galloways and Irish Hobbies-Discrepancies in size-The old saddle stock-The pacers wiped out-Partial revision of the English Stud Book.

BrITAIN was fully supplied with horses when first invaded by the Romans, but as there is no history beyond that period we are only groping in the dark when we attempt to discover when or whence this supply was procured. The most reasonable theory is 'that the first supply came from the Phœnician merchants, when they were trading for tin in the southwestern part of Britain. If this theory be correct, the trading between the Phœenicians and the Britons could hardly have been later than the fourth century before the Christian era, and it is more probable that it was several centuries earlier. This topic, however, has been considered in a preceding chapter. Another theory is that when the tides of migration struck the Atlantic, in the higher latitudes, there was a natural deflection toward the warmer countries of the south, the people carrying their horses with them. But from the primitive condition of the arts and of maritime affairs among the Norsemen of that very early period, and from the insular position of Britain, it seems to me that to reach it with horses, the most probable source of supply was from that great nation whose "ships of Tarshish" had been trading to all lands more than a thousand years before the Christian era. But, laying all theories aside, there are some facts and dates that we know, and the particular one to which I wish here to call attention is the historical record that when the Romans first visited Britain they found an abundant supply of horses; and this was about four hundred years before Arabia received her supply from the Emperor Constantius. 
From the time of the Romans in Britain, horse-racing has been a popular and favorite amusement of our ancestors, and from that time horses have been bred for special purposes. The "Great Horse," as he was called, was bred for war, parade, and show, and was large enough and strong enough to carry a knight in armor. The smaller horses were bred for the race or the chase, others for the saddle on accuunt of their easy, gliding motion, and the comfort of the rider, while others, again, were stout of back and limb and able to carry burdens. In regard to the speed of the horses bred for that purpose, Mr. Gervase Markham, the second Englishman who undertook to write a book on the horse, has given us some very interesting and valuable information. $\mathrm{He}$ brought out his work in the latter part of the sixteenth century, and it passed through several "enlarged and improved" editions. In the edition of 1606 he says:

"For swiftness what nation has brought forth the horse which excelled the English ? When the best Barbaries that ever were in their prime, I saw them overcome by a black Hobbie, of Salisbury, and yet that black Hobbie was overcome by a horse called Valentine, which Valentine neither in hunting nor running was erer equalled, yet was a plain English horse, both by syre and dam."

From this we must conclude that some horses from the Barbary States had been brought over previous to 1606, which doubtless antedated the arrival of King James' Arabian. This is the horse known as the Markham Arabian, and is in the above list of foundation stallions. In speaking of the Arabian horses as a breed, the Duke of Newcastle remarks as follows upon this particular representative of that breed:

"I never saw but one of these horses, which Mr. John Markham, a merchant, brought over and said he was a right Arabian. He was a bay, but a little horse, and no rarity for shape, for I have seen many English horses far finer. Mr. Markham sold Lim to King James for five hundred pounds, and being trained up for a course (race), when he came to run every horse beat him."

The duke then goes on to speak of the staying qualities of the Arabians:

"They talk they will ride fourscore miles in a day and never draw the bridle. When I was young I could have bought a nag for ten pounds that would have done as much very easily." 
These remarks are repeated here because they are specially pertinent in this connection.

It will be conceded by every one who has any knowledge of the horse history of this period that the Duke of Newcastle was the best-informed man of his generation on all subjects connected with the history and breeding of the horse. His preference for blood was in the following order: The Barb, the Turk, the Spaniard, the Neapolitan, and the handsomest of the English stock. It will be observed that in this classification the Arabian has no place.

From these illustrations, to which other similar ones might be added, it seems to be evident that the native English stock did not lack speed so much as they lacked quality, finish, and beauty. Perhaps size should be included in this enumeration. They had been bred and trained to run for centuries, and they were as stout and fleet as the exotics, but they lacked the qualifications of beanty and style. The foreigners possessed what the natives lacked, and more than all they furnished both the climatic and the blood outcross that were needed to re-invigorate the native character. It was the custom of the people in the seventeenth century to let their horses of both sexes roam at will through forests and glades, and in this way the average size had been reduced and the law of Henry VIII. (prohibiting the running at large of stallions under a certain size) had become a nullity. At the time of the restoration of Charles II. (1660) the average size of the traveling stock of England was very small-perhaps not over thirteen hands high-and then commenced the serious work of increasing the size and improving the speed of the light horse stock, under the direction and influence of the Duke of Newcastle. The introduction of the new blood wonld give vigor to the stock, but as that blood was the blood of Turks and Barbs, probably but little if any larger than the native stock, the mys. tery still remains unsolved. In about one hundred years from that time the average size of the race horse had been brought up from less than fourteen to about fifteen hands. This increase of size cannot be accounted for on any other grounds than the introduction of the blood of some larger breed. We cannot conceive of this being the blood of the old Flanders stock that had been brought over centuries before; hence I am strongly of the opinion that the duke knew just what he was doing when he brought in a lot of stallions and mares (the latter called the 
"Royal Mares") without telling anybody what they were or where they came from. This view is strengthened by the fact. that none of the descendants of these mares, for several generations, ever made a mark upon the turf. If we reject this theory of the "Royal Mares," we are then forced to the conclusion that the increase of size came chiefly from the large cold-blooded mares of the native stock. The fleet running families of the natives were small, and the imported Turks and Barbs were but. little if any larger; hence, if we accept the evidence of our own senses and study the great variations in height, we cannot reject. the conchnsion that these variations had their origin in the size. of the original elements entering into the formation of the breed.

What was the extent of the influence of the speed of the old English race horse upon the new race horse that sprang up in the seventeenth and eighteenth centuries? This is a question that has not been very much discussed, but every intelligent and. thinking man has given it more or less thought. Britain was not rapid in the progress of civilization and refinement, but through all the centuries of her history she had her race horses and she ran them. There can be no doubt that many of these native horses could outrun and outlast the best of the exotics. that were brought in. None of those exotics, so far as we know, could run and win. Their value, then, was measured, not by what they conld do themselves, but by what their progeny could do; and that progeny, at the foundation, carried half the blood of the old tribes. There were no racing calendars in the seventeenth century and none till the second decade of the eighteenth, and during all that time the blood of every man's horse would, naturally, be fashionable blood. When the racing calendars. were established they were a partial check upon untruthful representations, but this check only extended to the sire of the animal, and was then not always trustworthy. T'his left the whole maternal side open to all kinds of misrepresentation, and as the Anglo-Saxon race is fond of liberty, every man exercised the liberty of making his pedigrees to suit himself. Thus, throngh advertisements, sale papers, etc., great multitudes of fictitious pedigrees, all shaped on fashionable lines, gained currency and were propagated from owner to owner, from generation to generation. On this point I speak from the personal knowledge of a. long lifetime in connection with such affairs in our own country, and I take it for granted that our English ancestors were no 
better and no worse than we are ourselves. This was the condition of things in England for about one hundred and fifty years, and when Mr. Weatherby was at work on the Stud Book he was overflowed with a flood of those bald-headed fictions, concocted by generations long past, and nobody could disprove them. In this way a large portion of the accumulated rubbish of past generations found its way into the English Stud Book and there it stands to-day, serving only to misguide the seeker after truth.

The earliest records of English racing commence with the year 1709, and at Newmarket 1716. There have been several racing calendars published at different times, but probably the best and most convenient for office nse is the Racing Register published by Bailey Bros., commencing with the first and now filling several large volumes. In the early days very few of the winners even had any pedigree, but after the lapse of about fifty years we find it the rule to insert the sire of all winners, although there were still some exceptions. Under this usage it became possible in the course of time to establish the leading facts on the paternal side, and thus the work of the stud-book compiler was greatly facilitated. Those racing calendars, although intended merely to serve the convenience of men who bet their money, caring nothing for blood, served the more permanent and valuable purpose of fixing the paternal lines in the genealogy of the English race horse.

In 1786 Mr. William Pick, of York, England, published "A Careful Collection of all the Pedigrees it was then Possible to Obtain," thus antedating Mr. Weatherby's "Introduction" by five years. In $1785 \mathrm{Mr}$. Pick had commenced the publication of a racing calendar called "The Sportsman and Breeder's Vade Mecum," which was continued a good many years. These little annual volumes were well received, and they were the forerunners of Pick's Turf Register, the first volume of which was brought out in 1703. This was the same year that the first volume of Weatherby's Stud Book appeared, and there was a sharp rivalry between the two authors, not merely as two men, but as representing two divisions of the country. Mr. Pick was a Yorkshire man and Mr. Weatherby was a Londoner. Yorkshire claimed to be the "race-horse region" of England, and the Southrons were ready to fight rather than concede that claim. This rivalry survived two or three generations of racing men, and it is a question 
whether it has yet subsided. In the north Pick was the authority and in the south, Weatherby.

These two men worked on different plans, and each had its advantages. Pick limited his labors to the great animals of the past, and took them up in chronological order, giving a brief sketch of the history and performances of each. This plan required space, and when he had completed his first volume of five hundred and twenty-eight pages he had only reached the close of 1763. The second volume, bringing the work down to the close of $17 \%$, made its appearance in 1805 . Mr. Pick did not live to continue the work, and it fell into the hands of Mr. R. Johnson, who brought ont the third volume in 1822, which continued the chronological order to the close of 178\%. After the lapse of fortyfive years, namely $186 \%$, the fourth volume appeared under Mr. Johnson's name, bringing the work to the close of 1792, and I am not aware that the work has been continued. These four volumes contained much that cannot be found elsewhere, and are very valuable.

When we come to study these assemblages of impossible things put together and called pedigrees, we begin to realize the absolute rottenness of the alleged pedigrees of that whole early period. Take, for instance, the case of the horse called the Bald Galloway. He bore this name because he had a bald face, and was of the Galloway breed. This Galloway breed took its name from the old Province of Galloway, in the southwestern part of Scotland. They were small, active horses and were famous for many generations as a breed of pacers. It has been said that the last pacers in Great Britain were found in Galloway. This horse, Bald Galloway, was foaled some time about $1 \% 08$ and was famous as a fast race borse till he trained off at five years old. I think there is no doubt about his being a genuine Galloway, and if so how could he have a pedigree all of foreign blood and ending in a "Royal Mare?" This Galloway horse was the sire of the famous Roxana, that produced Lath and his full brother Cade, that made the early reputation of the great Godolphin Arabian. I will ask my readers to refer to the Curwen Bay Barb, No. 11, near the commencement of this chapter. This was one of the very best of all the Barbs imported, and his origin and history are given with unusual fullness, as well as an enumeration of the best of his get. In examining this enumeration it will be seen that a good number of his best foals were out of Galloway mares and 
are called "Galloways." Brocklesby Betty was one of the great mares of her day, and the Stud Book says that "as a runner, she was thought to be the superior of any horse or mare of her time." She was foaled 1\%11, was got by Curwen Bay Barb and out of Mr. Leedes' Hobby Mare. She was a brood mare before she was trained, and her performances were soon after the establishment of the Racing Calendars, which show her great superiority. The "Hobbies" were a breed of Irish pacing horses that had been noted for more than a hundred years, on both sides of the Irish channel, as saddle horses, hunters, and runners. The theory that these "Irish Hobbies" were descended from the horses on board one of the ships of the Spanish Armada, that was wrecked on the Irish coast, is purely fanciful, for they were known as a breed long before the Spanish Armada was projected. The Hobbies were larger and better formed, as a rule, thau the Galloways, and more highly esteemed. These illustrations of the influence and power of indigenous blood in the formation of the breed known throughout the world as the English race horse might be extended indefinitely, but let these suffice. With the "Galloways" and the "Hobbies," well known to our ancestors two hundred years ago as established breeds or tribes of horses, we cannot avoid the conclusion that they were very prodigal of fancy and very economical of truth when they attempted to clothe Bald Galloway, Leedes' Hobby, etc., in foreign pedigrees to make them fashionable. Aside from the matters of evidence here introduced going to show the composite material entering into the constitution, structure and instincts of the race horse as he is today, there is another that plays a very promineht part in the combination. When we see a race horse fourteen hands high, and another of equally pure blood standing beside him seventeen hands high, we naturally wonder, and ask, Why this difference in size? The Turk, the Barb, the Hobby, the Galloway, and indeed all the old English racing stock, were very small, scarcely averaging fourteen hands. After we have made every allowance for a salubrious climate and a generous and unstinted dietary we must concede a gradual increase of growth, but these things fail to account for a difference of twelve inches in the height of two horses bred in the same lines for untold generations. The conclusion seems to be inevitable that there were big horses as well as little ones in the original combination of ancestors. From these diverse sources of his inheritance, it becomes plain to the 
mind of every one that the English race horse is thoroughiy composite in the blood he inherits, and it is beyond the powers of analysis to determine whether one element did more than another in making him the fastest ruming horse in the world.

While it might be forcibly, if not conclusively, argued that the native English horse had in him all the elements necessary to the development of a breed of race horses as great as the breed of our own day, there is one fact ever present to the senses which goes to show that the influence of exotic blood was very wide and very powerful in controlling the action of the race horse. The popular and prevailing pacing action of the Hobbies, the Galloways, and other hunting, racing and saddle tribes was completely wiped out more than a hundred years ago. Any attempt to account for this revolution in the gait of the English horse as a fancy of fashion, or on the introduction of wheeled vehicles, fails to satisfy the miderstanding. In the first half of the seventeenth century pacers were popular, common, and abounded everywhere. In the second half of the eighteenth century not one could be found in all Britain, "from Land's End to John O'Groat's House." Of all the facts that are known and estabIished in the history of the English horse, the wiping out of the pacer is the most striking and significant. This exterminating process was not limited to the families that were intended for hunting or racing purposes, but extended to all types and breeds of English horses. The little English pacers that had been the favorites of kings and princes and nobles for so many centuries were submerged in the streams of Saracenic blood that flowed in upon them, and their only legitimate descendants left upon the face of the earth found homes in the American colonies. Their blood is one of the principal elements in the foundation of the English race horse, but the "lateral action" in his progeny was esteemed a bar-sinister on the escutcheon of the stallion, and it was sought to be covered up with something more fashionable in name. The old saddle horses of England were not all pacers, although that habit of action was very general among them, and in some families it was more uniform and confirmed than in others, and my authority for this conclusion will be found in the detailed account of the horses brought from England to the American colonies early in the seventeenth century. It is evident that from the day the blood of the Saracenic horse was brought in contact with that of the indigenous saddle horse, they 
were antagonistic, if in nothing more, certainly in the habit of action. The one never moved in the lateral action and the other very generally adopted that form of progression because it was his inheritance. What might have been the result if left to the laws of "natural selection," it would be impossible to decide; but with the dictates of profit to the master, the mandates of fashion, and above all the accepted teachings of the Duke of Newcastle, the little pacer had no "friends at court," and all he could do was to get out of the way, with his lateral action. In our own country and under the observation of everybody the pacer shows great tenacity to his long-inherited habit of action, and although buried in non-pacing blood, as supposed, for two or three generations, the pace is liable to appear again, at any time. So it was, donbtless in English experiences, but as the revolution was not retarded by the development of pacing speed, in one hundred years from the restoration, in 1660 , there was no longer a pacer on British soil.

When the first Mr. Weatherby assumed the task of making and keeping a registry of English race horses, he seems to have had only a very faint conception of the magnitude of the undertaking. The first volume of his "General Stud Book" was published in 1803 , and when it appeared it was found to contain so many things that were not true that the necessary work of revision and excision rednced its contents fearfully. In these eliminations he started in with a free hand, as is shown by comparison with later editions, but soon found that his book was disappearing very rapidly, and not much of it wonld be left, if he did not stay his hand. At this point he seems to have adopted some new rule, unfortunately, either of evidence or of date, probably the latter, for his work discloses the fact that he declined all responsibility for pedigrees as they came to him, of an earlier period than abont 1780 . Beyond that date nearly all the crude and impossible things of fiction were allowed to remain and are thus propagated as true, down to our own day. There was one rule, however, adopted very early in the management of this compilation that saved it from degeneracy, and that was the difficulty of getting into it. In all its history, from the beginning, it has been a kind of "close corporation," and the animals in the volume of the last year are almost uniformly descended from the animals to be found in the first volume. The application of this rule, no doubt, worked an injustice in very many cases, 
but it made the English race horse a BREED, pre-eminent above all other horses for his unequaled speed as a running horse. This general rule restricting admissions to the descendants of such as had places in preceding volumes seems to have been followed and maintained with a good share of rigidity, by the different generations of the Weatherby family, in whose hands the compilation still remains. Whatever may have been the ratio of fables and forgeries in the first volume, they were there compacted and neither the Weatherbys nor the breeders have been much annoyed with them since. The plan of the Stud Book itself is very unsatisfactory to the careful student, for the reason that it admits of no details of breeder, owner, etc., that are of vital importance in tracing and identifying an unknown or disputed pedigree. While the plan is very desirable and effective in placing the produce of mares underneath the dams, it is very defective in relation to breeders, and subsequent owners. Unless the identity of the animal can be traced and established by the records, the pedigree is always doubtful. But notwithstanding the unsatisfactory plan of its construction, it has been honestly compiled, and we may safely accept its contents, back as far as the beginning of the nineteenth century, when Mr. Weatherby began his work; but when we reach the period of the eighteenth century, facts, fables and frauds are so inextricably mixed that whatever we accept must be cum grano salis. Beyond that period Mr. Weatherby furnishes nothing but the wildest fancies and traditions shaped up by those contributing them with a view to lengthen a pedigree and a price accordingly. All that we can ever know of the horses of that period we must. gather from the little snatches dropped by contemporaneous historians.

In establishing his "General Stud Book," Mr. Weatherby's work may be compared to the building of an embankment around a great field which contained all the race horses of the realm. They were of all colors, all markings and all sizes, except the monster cart horse and the diminutive Shetland. They had all raced or possessed blood that had raced, and they all had pedigrees of various lengths and various degrees of reliability. They all. walked and trotted and galloped, and there was not a pacer among them, for the last pacer had disappeared from England probably fifty years before this. The antagonism of the Saracenic horse had triumphed, and that antagonism was bred in the blood 
and bone of every animal in the field. They were placed there to be inter-bred and to produce race horses. Every one of the thousand owners was anxious to produce a great winner, and he was left to the exercise of his own fancy and judgment as to what cross would be most likely to prove successful, and to vindicate his superior intelligence. With all experimenting outside of the breed practically barred, the instincts of the breed ripened and intensified until its representatives are able to beat the fleetest in the world at the gallop, but they could neither walk fast nor trot fast. It is doubtful whether any person in the world has ever seen a true-bred race horse that could trot a mile in four minutes. At this gait they show no aptness nor speed whatever. By breeding to fit the modern methods of racing, the speed of the race horse has been greatly increased, for short distances, but his stamina and endurance no longer command admiration as in former generations.

In the latter half of the last century there were a good many excellent trotters in England, but the further we get away from the blood of the old English pacer, the fewer the trotters we find, until at last there are none at all. It seems to be true of all countries that where there are no pacers there are no trotters. It was not the purpose nor wish of the English people to banish the trotter, but when the pacer was banished the trotter soon followed him. 


\section{CHAPTER VII.}

THE AMERICAN RACE HORSE.

Antiquity of American racing-First race course at Hempstead Plain, 1665Racing in Virginia, 1677-Conditions of early races-Early so-called Arabian importations-The marvelous tradition of Lindsay's "Arabian"English race horses first imported about 1750 - The old colonial stock as a basis-First American turf literature-Skinner's American Turf Register and sporting Magazine, 1829-Cadwallader R. Colden's Sporting Magazine short-lived but valuable-The original Spirit of the Times-Porter's 'pirit of the Times-Wilkes' Spirit of the Times, 1859-Edgar's Stnd Book -Wallace's Stud Book-Bruce's Stud Book-Their history, methods, and value-Summing up results, showing that success has followed breeding to individuals and families that could run and not to individuals and families that could not run, whatever their blood.

Honses were kept for running, and horse racing was a common amusement in some of the American Colonies for about a hundred years before the first English race horses were imported. 'This embraces a century of horse history that, hitherto, has been practically unexplored and unknown. For the details of what I have been able to glean of this neglected and unknown century my readers are referred to the chapters on the different colonies. The first racing in this country of which we have any historical knowledge was organized by Governor Nicolls. In 1664 the Dutch surrendered the province of New Netherlands to the English, and the next antumn, 1665, the new race course at Hempstead Plains was inaugurated by the new governor of the colony. This course was named Newmarket, after the famous English course, and Governor Nicolls' successors continued to offer purses on this conrse for many years, and after a time there were two regular meetings held there, spring and autumn. Owing to the distance of this course from the city, other courses, near at. hand, were soon constructed and racing of all kinds and at all gaits held high carnival. The principal prizes were called "Subscription Purses," the distance almost invariably two miles, and the weight carried ten stone. The horses that ran were known 
as "Dutch horses," and were descended from the original stock bronght from Utrecht, in Holland. They were larger than the English horses, and brought better prices, although the latter were esteemed more highly for their saddle gaits. I think the Dutch horses, originally, had no natural pacers among them, but for the pleasures and uses of the saddle they were inter-bred with the English horses and the mixed blood soon produced many pacers. It is probable also that this mixture increased the speed of the whole tribe. Thus racing continued with but few interruptions and without any known changes in the rules or conditions governing performances, except that after fifty years or more the weight to be carried was reduced from ten stone to eight stone. In the year 1751, which was eighty-six years after Governor Nicolls had established the Newmarket course on Long Island, we find the following significant condition inserted in the terms of entrance to the races, for the first time: "Free to any horse, mare, or gelding bred in America." The simple meaning of this new condition was to "head off" the scheme of some "sharp" fellows who were, probably, then on the ocean with two or three English race horses, with which they expected to "gobble up" whatever stakes or purses came within their reach.

The first record we have of racing in Virginia is to be found in the court records of Henrico County, in the year 16\%\%-twelve years after the establishment of racing in New York. For fuller particulars of this, the reader is referred to the chapter on that colony. The Virginians were a horse-racing people from the start, and it is impossible to tell how long before racing first commenced, but probably just as soon as any two neighbors met, each owning a horse, a few hundred pounds of tobacco were put up the next day, to make it interesting, in determining which was the faster. This racing feeling was not confined to neighbors nor to neighborhoods, but it pervaded the whole colony, and the people of every county had their annual and semi-annual meetings, which everybody attended. Their methods of handicapping will strike the present generation as somewhat peculiar. In their advertisements of the meetings, such language as the following was very common: "Sized horses to carry one hundred and forty pounds and Galloways to be allowed weight for inches." From this we learn that the tribe of little Scotch pacers were still to the fore on this side of the water and that they 
were just as fleet as the larger horses, provided the weight was gradnated to their inches. There was one feature in these race meetings that will be a surprise to many of my readers, as it was to myself, and that is the fact that at most of these meetings there was one four-mile race. Smaller prizes were run for by horses classed as to size, and it may be noted that there was one class "not exceeding thirteen hands." At these meetings the distance never seems to have been less than one mile, while on the southern border of the colony and in North Carolina, quarter racing was very popular and very common from the earliest dates, and it was kept up through the greater part of the eighteenth century. For a fuller account of the racing of those early days the reader is referred to the chapter on Virginia.

In this old English, Irish and Scottish blood, full of the pacing element, which we may now call "native" blood, we have the real foundation npon which the English race horse was bred and from which has come the approximate if not the complete equal of the highest type of the English horse, in both speed and stamina. The English and the American race horse came from the same source and possess the same blood, with this trifling distinction-the native mares in England were bred to horses of exotic, Saracenic origin, while the native mares of America were bred to the descendants of that native-exotic combination. Hence, with the original maternal ancestry of the same blood, the combined and improved English descendant of that blood became the paternal ancestor of the American race horse. We must not forget that this "paternal ancestor" had been the result of crossing and recrossing, selecting, breeding and developing for nearly a hundred years, and that he was, therefore, a far better horse and far more prepotent as a sire than the produce of the first cross made under the direction of the Duke of Newcastle. We must not ignore the fact that while there were many stallions brought over in the early days there were also a few mares, but they were so few in number that their influence was hardly appreciable in the new breed to be established. Saracenic blood was tonched very sparingly in the colonial days, as even the names of not more than three or four have been preserved in history. The only one of that period fully identified was named Bashaw and was kept on Long Island about the year 1\%68. Like all the others, he was called an Arabian, but according to the showing of his advertisement he was bred by the Emperor of 
Morocco, and was not an Arabian. Of the later period and coming down to about 1860 there are twenty-five or thirty that have been called "Arabians." Near the head of the list stands one called "Arab Barb" or "Black Arabian Barb." ITe was claimed to be an imported Barb from Algiers, and was seventeen hands high "and coarse in proportion." Many other so-called "importers" were equally absurd and dishonest in their claims, but there horses all passed as genuine "Arabians." Out of the whole number called "Arabians" not more than five or six seem to have had a shadow of right to the name, and these exceptions were practically restricted to the animals imported by $\mathrm{Mr}$. A. Keene Richards, of Kentucky. That each and all of these exceptions were irredeemable failures is a fact well known to all intelligent horsemen. This motley erew of "Arabian" importations came from all the countries bordering on the Mediterranean, except Arabia, were all called "Arabians," and they were all flat disappointments both as race horses and as producers of race horses.

Out of this list of thirty-five or forty so-called Arabian horses, there is one that requires special mention, not only because a correction may be made in his history, but because I have frequently spoken of him as the only Arabian that had left any mark upon the horse stock of the country. Lindsay's Arabian, as he was called, was a grey horse and representer to be over fifteen hands high. The story is that he was a Barb and had been presented to the commander of a British man-of-war, when a colt, by the ruler of one of the Barbary States, as an expression of gratitude to the captain for having saved the life of his son. The captain sailed away for a South American port, and while lying there he took his present ashore to let him have a little exercise. The colt was given the free range of a lumber-yard, as the story goes, and in his playfulness a pile of lumber fell upon him and broke three of his legs. The British officer was greatly grieved at his loss and proposed to put the colt out of misery by knocking him on the head. There happened to be an American trading vessel in port and the skipper "allowed if he had that critter on his vessel he could save him." The officer at once gave him to the skipper and told him his history. Yankee ingenuity and thrift soon got him aboard the trader and he was swung up and his legs properly bandaged. The surgical treatment was good, the bones knit, and in due time the vessel arrived at New London,. 
and the colt was taken to the vicinity of Hartford. Just where this story originated it is not possible now to say, nor do I know that it ever had currency in Connecticut, but it was certainly rehearsed and probably believed in Maryland. He was owned by Colonel Wyllis of Hartford, and was advertised in 1\%:70 under the single name of Ranger, and described as "a fine English stallion of the Barbary breed, bred in England." From this it would appear that nothing was then known of his romantic history. As a part of his Maryland history it was said that General Washington's attention had been attracted to a body of Connecticnt cavalry by the excellence of their horses, and at his instance Captain Lindsay bought Ranger, becanse he was the sire of many of those horses, and took him to Maryland, where he was ever afterward known as "Lindsay's Arabian." The story of the indorsement of Washington made an excellent stallion card, and it is not necessary that we should inquire into it too closely, for the dates might raise a question. The horse passed from Colonel Wyllis to James Howard, of Windham, and was advertised by him as "The Imported Arabian Horse called The Ranger to stand at his stable the season of 17\%8." Hence we must conclude that he was not taken to the Sonth before the season of 1779 , or possibly later. Then, as now, to catch the popular fancy, North and South, the horse is no longer an "English stallion of the Barbary breed" but an "Imported Arabian Horse." His cross was well esteemed in his day, and it has held its place in the estimation of all the experienced horsemen as a good cross in an old pedigree. We now see that he was bred in England, that he was got by a Barb horse or the son of a Barb horse, and that it is not probable there was a single drop of Arabian blood in his veins. This little sketch will serve to illustrate the methods, general and particular, that were invariably used to place a fictitious valne upon the so-called imported "Arabians." In no other department of human knowledge luas there been such a mniversal and persistent habit of misrepresenting the truth of history as in matters relating to the horse. It seems to have been, and still is, a kind of pyschical contagion that has been generating dishonesty and a lrabit of lying in the minds of the great body of horsemen for the past two hundred and fifty years. If a horse is brought from Turkey, or Syria, or Egypt, or Spain, or Morocco, or any of the Barbary States, he is at once called an "Arabian." This is worse than a misnomer, for it is an essential 
untruth, and its universal nse does not redeem it from its essence of deception and frand. It must be conceded, however, that this deception may have sprung from bad teaching and ignorance rather than from a depraved moral sense, for many people, as well as the poets and the novelists, may have concluded that as the nations named above got their religion from Arabia, so they got their horse stock from the same conntry, and thus the horses brought from Turkey, or Syria, or Egypt, or Spain, or Morocco, or any of the Barbary States, are descendants of the Arabian horse and thus entitled to the name "Arabian." This seems to be the only theory upon which this universal misrepresentation can be palliated. Let us repeat a sentence or two here, to show what history reveals on this point. Strabo says there were no horses in Arabia at the beginning of the Christian era. Philostorgins says that in the year 356, two hundred "well-bred" Cappadocian horses were sent as a present to the prince of Yemen, by the Emperor Constantius. These were the first horses in Arabia. In the days of Mohammed horses were exceedingly scarce in Arabia, and they have remained so to the present time. The horse is an expensive exotic in Arabia, as he is never used for any domestic purpose, nor for any other purpose except robbery or display. For all domestic and commercial uses the camel is far better. All the countries named above were abundantly supplied with horses, at least eight hundred or a thousand years before there were any horses in Arabia. The Moslems got their religion from Arabia, but not their horses. This topic is more fully discussed in the chapter on the Arabian horse.

The importation of English race horses to this side of the water commenced about the year 1750 , and that being the middle of the last century it is easy to remember the date when the line was drawn between the old and the new elements appearing on the race course. The following six animals were brought over within a year or two of that date-Monkey, Traveller, Dabster, Childers, Badger, and Janus. A few others might be named, but some at least are mythical. Of those here named, Trareller was the great horse. Janus became the progenitor of a tribe of very fast quarter horses, and although he did not found that tribe, which had been in existence for a hundred years on the border line between Virginia and North Carolina, he doubtless improved it. Monkey was twenty-two years old when he came 
and did not live long. The whole number imported into all the: colonies before the war of the Revolution counts up to about fifty, and some of these are practically unknown, and a few of them. were wholly fictitious. Maryland, I think, was first in the field of importations, and then followed Virginia, New York, and North Carolina. Possibly the very earliest importations were. made in South Carolina, but there is not much evidence that those importations were utilized to any extent for racing purposes, and hence we know but little of the doings of that colony till a later date. There were not more than abont twenty mares. of English race-horse blood imported, in the quarter of a century preceding the Revolution, into all the colonies. As many of these animals of both sexes were stolen or destroyed during the war, we can approximate with some degree of certainty the great reduction in this producing force by the time the war ended and importations again commenced.

Now, we have before us the old colonial running stock that had been tested in many a battle and found able to cover the distance of two to four miles, and we have also the new running stock that had never been asked to go any further, but we have no actual, anthentic and reliable knowledge of the comparative speed of the two classes. There were no stop watches nor records of time kept in those days. This much only we know, that prizes were offered for "half-breds" for a few years, but when it was found that some of the half-breds conld run just as fast and as far as some of the whole-breds, this class of prizes was withdrawn. Then commenced the manufacture of fraudulent pedigrees, for, it was argued, "How could an American horse beat an English horse unless he had English biood and plenty of it?" Hence, when a horse won that fact was taken as proof that he was full bred, and no time was lost in investing him with a. first-class, pure-bred pedigree. This was a little onerous on the few imported mares that were known and named, as in the case of imported Mary Gray, for she had to produce eleven filly foals by imported Jolly Roger in order to accommodate her numerous progeny, as alleged, and how many more claims were made of the same pedigree it would be very difficult to estimate. When it began to appear a little awkward to require Mary Gray to have, on paper, more than eleven filly foals by Jolly Roger, it was soon. discovered that it was less perplexing and at the same time less. liable to be "cornered" by saying "dam an imported English 
mare." No doubt there was a great deal of sharp practice, to say nothing of cheating and lying, about horse matters in Colonial times, but those little venialities were only the blossoms indicating the mature fruits of deceptions and frauds that were to follow when pedigrees wonld be considered an element of value in the running horse, and when every man would have the power, in fact, to make and print his pedigrees to suit himself. This brings us to a very brief consideration of what has been done in the direction of correcting the frands of the past and preventing them in the future.

The period of fable and of falsehood in the genealogy of the American race horse seems to have commenced not long after the first importations of English race horses. In the first generations from the imported English horse and the native mare, it was rather difficult for a man to fix up a pedigree for his half-bred colt that would show him to be full bred, but after forty, fifty, or sixty years had elapsed the events became misty, and then every man exercised the right to make his own pedigrees to suit his own fancy. This seems to have been the condition of things for many years, and while there were a few honest men who would stick to the truth, the great majority either made their pedigrees to suit themselves or employed some "expert" to make them for them. The confusion which ensued was most perplexing, and the slipshod manner in which editors and writers on the horse did their work was most discouraging. Whatever was found in print on a crossroads blacksmith shop door was taken as authentic, because it was in print.

In 1829 Mr. John S. Skinner, of Baltimore, Maryland, commenced the publication of a monthly magazine, entitled "The American Turf Register and Sporting Magazine," and as it really "filled a long-felt want," it received a very encouraging support. As its name indicated its field, it at once became the authority on sporting events and the receptacle of a great amount of valuable correspondence on the horses of the day, as well as the earlier race horses. Mr. Skinner was industrious in collecting material for his magazine, but unfortunately be published whatever was sent to him relating to the horse, and just as it was sent. If a communication was well written, no difference how many errors of fact it might contain, it never seemed to occur to Mr. Skinner to use his blue pencil. Pedigrees were sent in, amounting to many thousands, during his ownership, with fictitious and untruthful 
remote extensions, and published without any possibility of tracing the different crosses to a known or responsible sonrce or name. Hore was the opportunity of a lifetime to "fix up" the pedigrees of stallions to suit the public demand and the fees sought by their owners, send them to Mr. Skinner, and have them duly spread before the public in all their dishonest finery. The early volumes are very rich in the accumulations of pedigrees, such as they are, and hence very valuable. The magazine received less and less attention from its proprietor each succeeding year and finally it was transferred to the Spirit of the Times, of New York, and died aiter an existence of some fifteen years.

Mr. Cadwallader R. Colden, of New York, commenced the publication of another sporting magazine, that was of very great merit, and did much to correct some of the errors that abounded in Mr. Skinner's publication. In the controversies which naturally sprang up he had greatly the advantage of his adversary, for he knew horse history and Mr. Skinner did not. Mr. Colclen was a man of marked ability, and over the signature of "An Old Turfman" he made himself famous as a writer. He hated a fraud and wherever he saw one he did not hesitate to hit it. His publication was a large and expensive one, racing was then under the periodical interdict of public opinion, and after about two or three years, and greatly to the loss and misfortune of the truths of horse history, the publication was discontinued. The weekly press had no representative in the field of "horse literature and sporting subjects" until early in the thirties, when the Spirit of the Times was founded by William 'T. Porter. The conception of a weekly paper devoted to all kinds of sports, such as hunting, fishing, racing, gaming, etc., was not only new in this country, but it was brilliant. Mr. Porter was not only a gentleman in his appearance and manners, but he had fine social qualities and was a writer of ability and polish. Such a personage would naturally gather about him friends and correspondents that were congenial, and very soon The Spirit of the Times became noted as the organ of a great body of educated men who loved sport and enjoyed wit. It was the only publication of its kind on the continent, and it soon obtained a very wide circulation. Mr. Porter knew very little of horses, either theoretically or practically, but ho was a ready adapter and wrote some fine descriptions of famous racing contests. His habits were sportive rather than industrious, hence he left nothing behind him of value to his friends 
or to the world except the mere fact that he was the founder of the first sporting paper in this country. In conrse of time the paper with all its belongings became the property of John Richards, the former pressman, and Mr. Porter had to look for a living wherever he could find it. Mr. George Wilkes then took him under his wing, and started a new sporting paper called Porter's Spirit of the Times. The nse of this name carried with it the support of a good many friends, but as he was not able to write anything, practically, for the new paper, from its very commencement in September, 1856, it failed to yield any support to Mr. Porter, and not much to Mr. Wilkes and his partners. Litigation arose and Mr. Wilkes finally withdrew from Porter's Spirit of the Times, and started Wilkes' Spirit of the the Times in September, 1859. We then had three sporting papers all claiming to be the original and only legitimate Spirit of the Times. Among their readers they were distinguished as the Old Spirit, Porter's Spirit, and Wilkes' Spirit. The circulation of the Old Spirit was largely in the Sonthem States, and the war destroyed it, in 1861. Porter's Spirit having but little money and still less brains, died about the same time. This left Mr. Wilkes in open possession of the field, and his remarkably trenchant articles on the condnct of the war gave Wilkes' Spirit of the Times a very wide circulation, even among those who cared nothing for sporting matters. At the same time he was fortunate in securing the services of $\mathrm{Mr}$. Charles J. Foster, an able writer on horse subjects, and a very industrious and capable man in managing and discussing affairs connected with the horse. Some years later, Mr. Wilkes dropped his own name from the title of his paper, and not long afterward he added twenty-five or thirty years to its age by changing the numbers so as to cover the period of the original Spirit of the Times founded by William 'T. Porter. The old sporting publications, one and all, maintained the view, so far as they ever had any view to maintain, that all that was of any value in the American horse, for whatever purpose, had come down to us from the Arabian through the English race horse. Their value, therefore, consists wholly in the naked statistics which they contain.

The first attempt made in this country, in the direction of publishing a stud book of American race horses, was the product of Patrick Nesbitt. Edgar, an eccentric and apparently not well- 
balanced Irishman, who was a resident of North Carolina. This book, which purported to be a "first" volume, was very remarkable in many respects, two or three of which I will enumerate. The prevailing absence of dates and all means by which the truth or falsity of a pedigree could be determined; the astounding number of crosses given, even to the immediate descendants of imported sires; the multitude of animals never heard of before nor since, with pedigrees extended a dozen crosses; the absence of many animals that everybody had heard of. 'I'his book had been in print about thirty years before I ever saw it, and the first impression it made on my mind was that the author was "clean daft." At the same time, through all his work there was a "method in his madness," going to show the care he had taken to exclude or suppress any little fact that might lead to detection and exposure. As an illustration of his methods I will take the following pedigree, at random, as given by him and copied, literally, by Mr. Bruce, following the particular form of the latter:

CENTAUR, b. h. foaled 1767 , bred by — ; owned in Virginia, got by imported Stirling (Evans') (foaled 1762).

1st dam by imp. Aristotle (imported 1764).

2d dam by imp. Dotterel.

3d dam by imp. David (imported 1763).

4th dam by imp. Ranter (imported 1762).

5th dam by imp. Othello (imported 1755).

6th dam by imp. Childers (imported 1761).

7th dam an imported, thoroughbred mare.

Now, what do we know about this pedigree that has been indorsed and published, just as here stated, by two stud-book makers? They do not pretend to know by whom he was bred, nor do they know in what part of Virginia he was owned, but they assume to know perfectly well each cross in his pedigree and that his seventh dam was an imported, thoroughbred mare. The dates of importations in parentheses in the foregoing have been placed there by myself for the sake of the exhibit. The horse Dotterel, the original of that name and by the same reputed sire, never left England, and it is probable this I)otterel is mythical. Now, let us analyze this pedigree by the aid of the searchlight of dates. Ranter, imported 1762, might have had a filly to his credit in 1763 . This filly at two years old might have been bred to David and produced a filly in 1766 . This filly at two 
years old might have been bred to Dotterel and produced a filly in 1769. This filly at two years old might have been bred to Aristotle and produced a filly in 1772. This filly, at two years old, might have bred to Evans' Stirling (or Starling), and produced the colt Centaur in 1775-but he was foaled in 176\%. Not once in a million times would this succession of possibilities occur, but if they did occur in this case the pedigree of Centaur still remains absolutely impossible, for four generations of horses cannot be crowded into five years. This exhibit fairly illustrates the character of Mr. Edgar's work, and being right on the border line between the "native" race horse and the modern "thoroughbred"we see just how they compressed the breeding of eight generations into the space of fifteen or sixteen years. If we were to compare the English with the American methods of manufacturing pedigrees, it would be hard to determine which was the more shamefully dishonest. Mr. Edgar was fiercely dissatisfied with the indifference of horsemen to his enterprise, and with the lack of support which they rendered him. He went forward with his second volume and professed to have completed it, but announced that it should never be put in type until the horsemen of the country should assist and support him. In the event of their failing to do so he threatened to sink his manuscript twenty feet deep in the center of the Dismal Swamp, where no mortal wonld ever find it. The second volume never appeared, and it is to be hoped he carried out his threat.

For the second attempt at compiling a stud book of American Race Horses I must, myself, plead guilty. Some time in the "fifties" I came into posssesion of a number of volumes of the "old" Spirit of the Times, Skinner's American Turf Register, three or four volumes of the "English Stud Book" and a large number of volumes of the English Sporting Magazine. As I was then dabbling slightly around the edges of "horse literature," I found this little nucleus of a library very convenient, but very unsatisfactory in answering questions that came to me, and which an official position seemed to require that I should be able to answer. When asked for the pedigrees of other domestic animals I could take down the Herd Books of the different leading breeds and give precise information, but when asked about the pedigree of a horse, unless he was greatly distinguished as a racer, days of solid labor might be expended on the one question and then not discover the information sought. It was, perhaps, ten years after 
this time before I ever saw or heard of the misbegotten and foolish compilation of pedigrees made by Edgar. For some years this labor of compilation was prosecuted at odd hours, for my own personal use and satisfaction, and without the remotest purpose of ever publishing a stud book. As I plodded my way along, finding what I supposed to be a fact here and another there, and often conflicting, I found myself invariably accepting what was longest as a pedigree, as this feature seemed to be evidence not only of completeness, but of truthfulness at the same time. As my gleanings grew in volume my interest in what I was doing became more absorbing and intense, and when I had completed the search of every page and paragraph of my published sources of information, up to the close of the year 1839, I found I had enough matter for a large volume. About this time I came into possession of a copy of "Edgar's Stud Book" —and I was. greatly perplexed to know what to do with it. The copyright was dead and it contained a good many unimportant and utterly unknown things that I had not met with in all my gleanings. Under these circumstances and considering the fact that it abounded in the crudest uncertainties, to call them by no harsher name, I concluded to use his work in all cases where I did not. have a pedigree from other sources, to cut off all imaginary extensions and to insert his name, in every case, as the source of information and responsibility. The work then went to press and the first volume of "Wallace's American Stud Book" made its appearance in 18\%1. The time and labor expended on the first volume made me quite familiar with the leading performers of the several generations embraced therein, and the work on the second volume went forward with more ease and rapidity, and in $18 \% 1 \mathrm{I}$ had completed the gleaning of all publications relating to the race horse, up to the close of $18 \%$.

This second volume, being about the size of the first, was completed and put in due form for the compositor, but never was published. The reason why it was never published may not be without interest to the student of horse genealogy, and I will, in a few words, state that reason. Sile by side with the progress of the second volume of the runners, I was carrying forward a careful investigation of the lineage of the early trotters and their progenitors. As there were no trotting records giving pedigrees, I was compelled to go back to the breeders as the only source of reliable information. When I obtained this from intelligent and 
reputable people I accepted the information and stood by it as the truth; and when I came to compare it with the representations of pedigree made in advertisements of some stallion scion of the family, the truth began to dawn upon me that advertisements, whether in newspapers or on crossroads blacksmith-shop doors, with scarcely an exception, were made up of statements that were utterly false and fictitious. They were made up for the single purpose of securing patronage, and generally traced in different directions to famous and well-known horses. The fictitious extensions of stallion advertisements have served as the basis for the fictitious extensions of families and tribes. When I came to compare the extensions of trotting pedigrees with running pedigrees, I could not discover that the one was any more or less reliable than the other. They rested on precisely the same basis of stallion pedigrees, and no difference whether they appeared in Mr. Skinner's Turf Register or in a big poster, there was no censorship, and they were both in type-and whatever was in type was generally supposed to be worthy of belief. In one respect the pedigrees of rumning horses are more reliable than the early advertisements of trotting horses, particularly with those that raced, for they were required to give the sire and dam when they were entered in races, and a failure to comply with this rule was penalized. The sires, therefore, are generally right, but unfortunately the rule did not require the dam to be named and definitely specified, hence any one of a dozen unnamed mares by a given horse could be represented in after years as the dam of that particular horse. Here commenced the trouble in the unnamed and untraced mares that never have been nor ever can be identified. On a careful and sorrowful review of my work of many years I found that I had been working on a wrong basis from the start. Instead of discovering and arranging a great many valuable truths, as I supposed, I had devoted years to perpetuating thousands and thousands of fictions in these unknown, unnamed, and unidentified dams. This is the reason the second volume of "Wallace's American Stud Book" never was published. The only benefit I ever derived from the work was in its educational aspects. The work marle me familiar with the early running-horse history of this country and of England, and taught me what so many horsemen should learn-that a truth is always better than a lie. The more carefully and thoroughly I went into the origin, lineage and history of what we 
may call the modern race horse, the more evident it became to my mind that the great mass of the running horses of our own generation are carrying, in their pedigrees, the frauds and fictions of the seventeenth and eighteenth centuries, to say nothing of the innumerable deceptions and tricks of our own century. To accept and propagate these untruths is simply to, in a manner, indorse them, and an attempt to eliminate them would invoke the clamors of a continent. Hence, more than twenty years ago, I washed my hands of all responsibility for the pedigrees of English race horses, and turned my attention to establishing the lineage of the American trotter, on sure fonndations, and building him up into a breed.

The third attempt at compiling the pedigrees of running-bred horses was made by Mr. Sanders D. Bruce, of New York, and as it followed Edgar and Wallace, it was made up chiefly of what he found in these works. The conscienceless fictions of Edgar were accepted without hesitation or remorse, and the central aim seemed to be to make every pedigree as long as possible, whether true or false. No fietitious stallion advertisement was ever too absurd to serve as a basis for the pedigrees of all his kindred. Mr. Bruce accepted everything and rejected nothing, and it is not probable he ever investigated a pedigree in his life. His rule of action seems to have been to please his customers, and to fcrupulonsly avoid all public discussions of pedigrees. This was the politic course to pursue, for any attempt to defend the monstrosities it contained would have wiped it out of existence very quickly. Bruce's Stud Book seems to have been supported by a few individuals, from the beginning, as a kind of eleemosynary institution, and it is not likely it will ever rise above that condition.

The substantial correctness of the generations extending back for a period of sixty or eighty years, and in some cases even a little further, is a very valuable contribution to our store of knowledge in this department of industry, but, unfortunately, the generations beyond those that may be classed as recent very largely rest upon foundations that are fictitious and fraudulent.

These fictions and frands are so general and common in the remote extensions on the female side of the pedigree that when we find a string of ten or perhaps twenty dams and not one 
of them named, known or identified nntil we strike the twentyfirst, and she described as "thoroughbred, imported mare," we know that this is the work of the professional "pedigree maker," and not more than once in a hundred times will we be mistaken. This is alike true of both English and American pedigrees of race horses. The modern crosses are comparatively honest, but the remote extensions, through the maternal lines, in both countries are chiefly the products of a venal imagination.

There are some foundation truths in the bistory and development of the English and American race horse-for they are both one in blood-to which I must briefly advert before dismissing this topic. In announcing the conclusions which I have reached, I am fully conscions that I will come in contact with pre-conceived opinions that have been very prevalent, if not universal, for at least two centuries.

1. There were race horses in England that had been racing and breeding for centuries before the first Saracenic borse was brought there, and it was not an uncommon thing for the native to beat the exotic, when he first arrived. There had been racing in America, by what we will call the native stock-but they were all English and Dutch-for about one hundred years before the first English race horse reached this country.

2. These horses had been selected with care and bred for centuries with more or less intelligence, with the single purpose of increasing their speed. During those centuries there were not so many writers on biology, heredity, etc., as we have now, but the old aphorism, "Like begets like"-a complete epitome of all science on this subject-was just as well known and as universally believed a thousand years ago as it is to-day. We may, therefore, safely conclude that at the close of the sixteenth century there were many native English horses, descended from lines and tribes that had been selected, raced and bred for generations, that were fully the equals of the best of the exotics, that were brought in about that time.

3. The native stock of England at the close of the sixteenth century, was the stock from which the American colonies received their first supplies, except the few brought from Utrecht, in Holland, to the Dutch colonists in New York. When brought across the Atlantic, especially in Virginia, no time was lost in continuing their development as race horses, which was carried for- 
ward for nearly one hundred years before the first English race horse was imported for their improvement. Their regular racing was at all distances, up to four miles.

4. On this basis of the native English blood, common to both countries, the breed of English and American race horses was built up. The foreign elements brought into England were chiefly from the Barbary States and from Turkey. This exotic blood certainly had a very marked effect upon the horse stock of Britain, but it cannot be said, with certainty, that it increased the speed of the race horse. All the experiences of the past hundred years with these foreign strains have gone to show that instead of increasing the speed they have retarded it.

5. The list of the foundation stock of the English race horse as given by Mr. Weatherby, in the first volume of the English Stud Book, and reproduced in the preceding chapter, is worthy of very careful study, especially by those who seem to think that the English race horse is descended, without admixture, from the Arabian horse. The striking feature of that list is the overwhelming preponderance of other blood than the Arabian, even if we accept all that is called Arabian as genuine. Mr. Darley's horse, called an Arabian, and Lord Godolphin's horse, called an Arabian, count for more than all the others put together, in the make-up of the English race horse. Mr. Darley's horse came from a region remote from Arabia and where a thousand good horses are bred for one in Arabia, and should be called a Turk. Lord Godolphin's horse-“the great unknown"-will ever remain unknown. He seems to have been traced to France, and, after studying his portraiture, it is probable he was a French horse.

6. Taking this list of foundation stock and viewing it from the standpoint of the greatest lenity and liberality that a sound and careful judgment can accord, we find that the inheritance of Arabian blood in the veins of the English race horse, if there was any such inheritance at all, was strictly infinitesimal. This historical fact in the foundation of the race horse, showing the inutility of Arabian blood, whether genuine or spurious, has been fully confirmed in great multitudes of trials, in both nations, during the past hundred years. In no case has it been a benefit, but always a detriment.

\%. The race horse has been bred through centuries for the single purpose of speed. Through all his generations he has 
been the product of the brains, judgment and skill of his successive masters. Parents were selected that could go out and win the prizes from their fellows. The next generation was not only the product of running parents, but parents that were from running families. Thus grew up the pedigree of the race horse under the direction of thought and judgment. Pedigrees are practical things and full of winners, and in no sense made more valuable by having some supposed "Arabian" cross away back ten generations, that never ran in his life. 


\title{
CHAPTER VIII.
}

\author{
COLONIAL HORSE HISTORY-VIRGINIA.
}

Hardships of the colonists-First importations of horses-Racing prevalent in the seventeenth century-Exportations and then importations prohibitedOrganized horse racing commenced 1677 and became very general-In 1704 there were many wild horses in Virginia and they were hunted as gameThe Chincoteague ponies accounted for-Jones on life in Virginia, 1720Fast early pacers, Galloways and Irish Hobbies-English race horses imported-Moreton's Traveler probably the first-Quarter racing prevailed on the Carolina border-A verage size and habits of action clearly establishedThe native pacer thrown in the shade by the imported runner-An Englishman's prejudices.

The colony of Virginia, settled at Jamestown, May 13, 160\%, was subjected to a succession of dissensions, privations and disasters extending through a number of years. The elements of which this first plantation was composed were heterogeneous, and many of them wholly unsuited to battle with the hardships and privations of the wilderness. A very large proportion of the adventurers were mere idlers at home, descended from good but impecunious families, and had never done an honest day's work in their lives. Too proud to labor even if they had known how, hunger and rags soon made them the most unhappy and discontented of mortals. The governmental affairs of the colony fell into confusion, like the people forming it, and we have no official record of what was done for a number of years. All that is known to-day of what transpired in the early years of the colony has been gleaned from the personal correspondence of actors in the many strifes that came so near destroying them all. These letters are, generally, so strongly imbued with partisan feeling that there seems to be no room left to tell us anything about the industrial growth of the colony, either in planting or breeding. The excerpts, therefore, relating to the early horses of Virginia which I have been able to gather from a great many sources, will fall far short of being complete, but I think they will serve as a basis upon which to form an intelligent estimate of the Virginia 
horses of the seventeenth and eighteenth centuries, and as to the nineteenth, the newspapers will furnish everything what is needed.

It is evident that the fleet of three vessels which took out to Virginia the first adventurers took also some horses and mares with them; for the governor and council, who went out the next year, in reporting the condition of the colonists to the home company, under date of July $\%, 1610$, use this language:

" Our people, together with the Indians, had, the last winter, destroyed and killed up all our hogs, inasmuch as of five or six hundred, as it is supposed, there was not above one sow that we can hear of left alive, not a hen or a chick in the fort, and our horses and mares they had eaten with the first."

From a letter written by M. Gabriel Archer, who arrived in Virginia August 31, 1609, we gather the following facts:

"From Woolwich, the fifteenth day of May, 1609, seven sail weighed anchor and came to Plymouth the twentieth day, where George Somers, with two small vessels, consorted with us. There we took into The Blessing, being the ship wherein I went, six mares and two horses, and the fleet layed in some necessaries belonging to the action; in which business we spent time till the 2d of June, and then set sail to sea, but crossed by South West winds, we put into Falmouth, and there stayed until the 8th of June, then gate out."

Now, as The Blessing was probably about the average size of the rest of the fleet, I think it is reasonable to conclude that each of the other vessels took some horses also. In a report of a voyage to Virginia, dated November 13,1611 , we find the following statement: "They have brought to this colony one hundred cows, two hundred pigs, one hundred goats, and seventeen horses and mares." In 1614 the Virginians made a raid on Port Royal, in what was then called New France, and carried off to Virginia, among other captures, a number of horses, mares and colts. A second raid in the same quarter seems to have resulted in carrying off wheat, horses, clothing, working tools, etc.

Mr. Harmor, writing in 1614, in his "True Discourse on the Present State of Virginia," says: "The colony is already furnished with two hundred neat cattle, infinite hogs in herds all over the woods, some mares, horses and colts, poultry, great store, etc."

In 1894, in the Public Records Office in London, I found that the Virginia Company had sent out four mares, February, 1619, on The Falcon. And further, I found a kind of summary of 
what the company had done in the past toward populating and supplying the colonists with live stock. It is stated that they had sent twelve ships, taking out one thousand two hundred and sixty-one persons, making the total number in Virginia at that date about two thousand four hundred. The exportations include five hundred cattle, with some horses and goats, and an infinite number of swine. In 1620 the company ordered twenty mares to be sent over, at a cost, delivered, of fifteen pounds each. From the price of horses in England at that day, I would infer that somebody was making money out of the colonists.

In a little work published in London, 1646, entitled "A Perfect Description of Virginia," the author says that "There are in Virginia, of an excellent raise (race), about two hundred horses and mares." It is evident that this statement is a mere estimate, and I am disposed to think it a very wild estimate from what follows in a very few years. It is true that horses do not propagate and increase as fast as any other variety of domestic animals, but under the circumstances every effort would be made to increase the stock, and from what follows, I think my criticism will be sustained.

In the legislation of the colony we find no mention of horses till the year 165\%, when the exportation of mares was prohibited. Eleven years after this (1668) this restriction was removed and the exportation of both mares and horses permitted. The very next year, 1669, the importation of more horses was prohibited by legislative enactment. From this it would seem that there were already too many horses in the colony, or possibly some horse breeder had begun to realize that there were better horses in some of the other colonies that were finding a market in Virginia, and they thus sought "protection" for their own stock.

This prohibition conld not have been aimed at the mother country, for the prices obtained would not justify the cost and risk of a sea voyage. We must, therefore, conclude that it was intended to shut out the New England colonies, which were already shipping horses to all the settlements on the seaboard, as well as to some of the West India Islands. In this we see at what an early date commenced the interchange of commodities among the colonies. As early as 1647 the Dutch authorities at New Amsterdam authorized Isaac Allerton to sell twenty or twentyfive horses to Virginia.

The court records of Henrico County, Virginia, for the year $16 \%$ r 
contain three distinct trials growing out of horse races for that year. In one case the contest was for three hundred pounds of tobacco; in another the winner was to take both horses; in the third the amount at issue does not appear. From the readiness at sharp practice and from the cunning dodges to get clear of paying a bet it is very evident that the principals and the witnesses were well up in all the tricks of racing as it was practiced at that early day. How long before 1677 racing was practiced in Virginia I have no means of determining, but the next year and the next, continuing to the end of that century, the records of the court speak for themselves. In these trials I find the names of Thomas Jefferson, Jr., grandfather of President Jefferson, and also the name of Benjamin Harrison, the ancestor of two presidents, although they were not principals in any of the cases.

In Beverley's History of Virginia, published in London, 1\%05, at section ninety-four, we have the following:

"There is yet another kind of sport, which the young people take great delight in, and that is the hunting of wild horses; which they pursue, sometimes with dogs and sometimes without. You must know they have many horses foaled in the woods of the uplands, that never were in hand and are as shy as any savage creature. These having no mark upon them belong to him that first takes him. However, the captor commonly purchases these horses very dear, by spoiling better in the pursuit, in which case he has little to make himself amends, besides the pleasure of the chase. And very often this is all he has for it, for the wild horses are so swift that 'tis difficult to catch them; and when they are taken 'tis odds but their grease is melted, or else being old they are so sullen that they can't be tamed."

In the number of Wallace's Monthly for September, 187\%, p. 684 , will be found a very interesting article from the pen of the late Dr. Elwood Harvey, on "The Chincoteague Ponies," that have from time immemorial occupied, in a wild state, the islands of Chincoteague and Assoteague off the eastern shore of Virginia and Maryland. The traditions relating to their origin are very hazy and improbable, and the most reasonable one, because it is within the range of possibilities, is that a Spanish ship was wrecked off this part of the coast and the original ponies were on board and swam ashore. It is weli estabiished that they have occupied the isiands for more than a hundred years. They are about thirteen hands high, uniform in shape and resembie each other except in color, for all colors prevail. Some of them pace a little, and they have rather light manes and tails, and no superabundance of hair on the fetlocks. Now, the horses of 
Virginia, at the period of which Mr. Beverley writes, and of which I will have something further to say as we progress, were but little if any larger than these semi-wild inhabitants of the islands; they were of all colors and many of them paced. As it is well known that the action of the ocean, so unaccountable to all human ken, one year builds up a dike connecting islands with the mainland, and the next year, perhaps, washes it out again, we can thus easily understand how a herd of these semi-wild animals may have been caught and kept there. In this way, it seems to me, the origin of the Chincoteagne ponies may be easily and rationally accounted for, without any shadow of violence to the clearest reasoning. Mr. Hugh Jones, who, in many directions, seems to have been a closer observer of the life of the colonists than any of the other tourists whose writings we have examined, wrote a little work entitled "The Present State of Virginia," which was published in London, 1724, expressing himself as follows, on page 48 :

“'l'he common planters, leading easy lives, don't much admire labor or any manly exercise except horse-racing, nor diversion except cock-fighting, in which some greatly delight. This easy way of living, and the heat of the summers, make some very lazy, who are then said to be climate struck. The saddle horses, although not very large, are hardy, strong, and fieet; and will pace naturally and pleasantly at a prodigious rate. They are such lovers of riding that almost every ordinary person keeps a horse, and I have known some spend the morning in ranging several miles in the woods to find and catch their horses only to ride two or three miles to church, to the courthouse or to a horse race, where they generally appoint to meet on business, and are more certain of finding those they want to speak or deal with than at their home."

Mr. Jones here places us in close contact with the character and habits of the people of that day, as well as with the character and qualifications of their horses. It is not to be inferred, I think, that all their horses were pacers, but that all their saddle horses were pacers there can be little donbt. This is the first intimation we have from Virginia that some of their pacers were very fast, and when $\mathrm{Mr}$. Jones says "they could pace naturally and pleasantly at a prodigious rate," he means that the speed was marvelous, wonderful, astonishing. This "prodigious rate." in a good measure, balances Dr. McSparran's account of the Narragansett, which he had seen go a mile "in a little over two minutes and a good deal less than three," and gives strength to the statement of Mr. Lewis, that when a boy he had ridden in pac- 
ing matches and return matches between the Rhode Islanders and the Virginians.

In the Virginia Gazette, under date of January 11, 1739, we find the following advertisement, to which we invite special attention, as it brings out some facts which, inferentially, throw a great deal of light upon horse racing, up to that period:

" This is to give notice that there will be run for at Mr. Joseph Seawell's, in Gloucester County, on the first Tuesday in April next, a Purse of Thirty Pistoles, by any horse, mare or gelding; all sized horses to carry $140 \mathrm{lbs}$. and Galloways to be allowed weight for inches, to pay one Pistole entrance, if a subscriber, and two if not, and the entrance money to go to the second horse, etc. And on the day following, on the same course, there will be a Saddle, Bridle and Fousing, of five pounds value, to be run for by any horse, mare or gelding that never won a prize of that value, four miles, before. Each horse to pay five shillings entrance and that to go to the horse that comes in second. And on the day following there is to be run for, by horses not exceeding thirteen hands, a hunting saddle, bridle and whip. Each horse to pay two shillings and sixpence at entrance, to be given to the horse that comes in second. Happy is he that can get the highest rider."

The first point suggested by this advertisement is that there were no distinctions made except by size, and that, at this date, 1739, there were no English race horses then in Virginia. The second point is that there was such a thing as "horse size" but what size this was I have not been able to discover. The third point is that Galloways were allowed weight for inches. They were evidently below "horse size." But they were expected to enter for the big purse of the meeting, and they must, therefore, have ranked as good race horses; but what did they mean by "Galloway?" 'This is the only instance in which I have met the term in Virginian history, although it is well known in general horse lore. "Galloway" is an old name of a territorial division of Scotland, embracing Wigtonshire, part of Ayrshire, etc., in the sôthwestern part of that country, and was at one time famons for the excellence of its pacers, and it is probable they were to be found there after the influx of eastern blood had driven the pacer from all other portions of Great Britain. The Irish Hobbie, always undersized, was a famous race horse, as well as a pacer, many generations before the period now under consideration. The name "Galloway" is only known in history and is not to be found on any modern map. I have learned by many experiences that the name is very generally believed to be Irish and is confounded with "Galway," an Irish county. It is 
known that an Irish gentleman shipped many cattle to the colony, and it is quite possible that he shipped horses also, and if this reasoning be right, these "Galloways" may have been Irish "Hobbies." It will be observed, also, that the distance to be run is not definitely stated, but it is fairly to be concluded that the race of the second day was to be four miles, and none of them less than one mile, and that in heats. Races of four-mile heats were very common long before the first English race horse was imported.

We here have a stock of horses that the people of Virginia have bred and ridden and raced for a hnndred years, and we know comparatively nothing about them. They seem to have been specially adapted to the saddle, but they could run four miles, or they could run a quarter of a mile, like an arrow from a bow. They were not a breed, althongh selecting and crossing and interbreeding for a hundred years would make them quite homogeneous. There is a romantic interest attaching to these little horses, for we have reached the middle of the eighteenth century, and all the successive idols of this race-loving people are abont to be dethroned by their own act, and their homage transferred to a stranger-a larger and finer animal and faster over a distance of ground. Whatever of glory and honor, to say nothing of money, that was to be achieved from this time forward was to be ascribed to the newly arrived English race horse. But the truth should not be concealed that this old stock furnished half the foundation, in a vast majority of cases, for the triumphs of future generations of the Virginia race horse, and the same may be said of the old English stock upon which the eastern blood was engrafted. About the middle of the eighteenth century the line was drawn, and there was thereafter developed the engrafting of the new upon the old. In 1751-52, Moreton's imported Traveller was there, and he was the only English race horse advertised that year. There may have been two or three others, but they had not made themselves known to the public, and I very much doubt whether there was any other. A very few years later there were many others, and some of them of great celebrity.

Mr. J. F. D. Smith made an extended tour of the colonies, especially of Virginia, before the Revolutionary war, and he suffered some of the inconveniences growing out of the rising hostility to the mother country. In speaking of quarter racing. he says: 
"In the southern part of the colony and in North Carolina, they are much attached to Quarter Racing, which is always a match between two horses to run one quarter of a mile, straight out, being merely an exertion of speed; and they have abreed that perform it with astonishing velocity, beating every other for that distance with great ease, but they have no bottom. However, I am confident that there is not a horse in England, nor perhaps in the whole world, that can excel them in rapid speed; and these likewise make excellent saddle horses for the road."

It will be observed that Mr. Smith speaks of these heavily muscled horses as a breed, which expression, I suppose, is intended to be used in a restricted sense. In the many generations of horses that would necessarily succeed each other in a century, in the hands of a people so devotedly fond of racing, it is merely an exercise of common sense, among barbarous as well as civilized people all over the world, to "breed to the winner." In this way, and without any infusion of outside blood, there wonld be improvement in the strength and fleetness of all animals bred for the quarter path. He remarks further that "these likewise make excellent saddle horses for the road." In that day nothing was accepted as a "saddle horse" that could not take the pacing gait and its various modifications. This was true of Virginians of that day, and it is still true of their descendants who have built up new States further west.

In the early days, as already intimated, it was the habit of Virginians to brand their horses and then turn out all not in daily use to "hustle" for their own living. As a matter of course these animals would often stray long distances away, and not a few never were found. In due time, legislation provided for the recovery of estrays, embracing all kinds of domestic animals as well as negro slaves. Fortunately this enables me to reach what may be considered "original data," in determining the size and habits of action of the early Virginian horses. As the field of my examination, I have taken the Virginia Gazette, for the years 1751 and 1752 , published at Williamsburgh, and in these volnmes I find a great many advertisements of "Strayed or Stolen" animals scattered throngh the pages; and in the second especially a great many "Taken Up" advertisements appear. In a very large proportion of these notices, perhaps a majority of them, all the description that is given is the color, sex and brand, with occasionally some natural mark. As a matter of course these are of no value for the object in view. In some cases the size is given withont the gait, and in others the gait is given without the size, 
in a few both size and gait are given. The range of size is from one of fifteen hands down to one of twelve hands, with more of thirteen hands than any other size, either above or below. The true average of the whole number is a little over thirteen hands and one inch, and none of them are called ponies. As further evidence of the small size of the colonial Virginia horses we find that in 1686 the legislature of Virginia passed an act providing for the forfeiture of all stallions under thirteen and a half hands high found running at large. It provided that any person might take up such stallion and carry him before a justice of the peace, and if he measured less than thirteen and a half hands, the justice was required to certify to the measurement and the facts, and the horse passed legally to his new owner.

As to the gaits I find just twice as many pacers as trotters. Double-gaited animals, of which there were a few, I have here classed with the pacers. That many of these little fellows were very stout and tough is fully demonstrated by the fact that they could run heats of four miles with a hundred and forty pounds on their backs. This closes the first epoch in the history of the Virginia horse. The fleet and compact little horse of thirteen to fourteen hands had had his day, and he was now about to be overshadowed by a greater in speed and a greater in stature. Much of the blood of the little fellow that conld run four miles and pace "at a prodigious rate," was commingled with the blood of the English race horse, but whatever its triumphs, the lately arrived "foreigner" took the credit. A man wonld have been pronounced "clean daft" if at that time he had dreamed that one hundred and forty years later the blood of this little pacel would stand at the head of the great trotting interest of the world. The tongh little fellow has retained his qualities throngh all the generations in which he has been neglected, despised and forgotten, until he was taken up twenty odd years ago, and now the names and achievements of the great pacers are as familiar to the whole American people as ever were the name of the greatest running horses. It is not known how long he continued to be a factor in the racing affairs of Virginia, but probably not later than about $1 \% 60$.

From about 1750 to $17 \% 0$ seems to have been a period of great prosperity in Virginia and, notwithstanding the general improvidence of the times, many of the large landholders and planters were getting rich from their fine crops of tobacco and their 
negroes. This prosperity manifested itself strongly in the direction of the popular sport of horse racing and improving the size, quality, and fleetness of the running horse. England had then been selecting, importing Eastern blood, and "breeding to the winner" for a hundred years, with more or less intelligence and success, while the colonists had rested content with the descendants of the first importations from the mother country. Doubtless progress had been made here too, but it was as the progress of a poor man against another with great wealth and backed by the encouragements of royalty. The English horse could then run clear away from the Saracenic horse, his so-called progenitor, and he was very much larger than that "progenitor." We can understand how the speed might be increased by its development in a series of generations and by always breeding to the fastest, but the increase of size cau hardly be accounted for as the result of climatic causes-but we are getting away from the thought before us. When the Virginia planter found he had a handsome balance in London, subject to his draft, he at once ordered his factor to send him over the best racing stallion he could find. The action of one planter stirred up half a dozen others who felt they could not afford to be behind in the matter of improvement, but more especially that they could not afford to be behind in the fimish at the fall and spring race meetings of the future. These importations went on continuously for about twelve years, and until they were interrupted by the excited relations and feelings between the colonies and the mother country and the preparations for the War of the Revolution, which was. then imminent. After the close of the Revolution a perfect avalanche of race horses was poured upon us, some of which were good, but a great majority of them were never heard of after their arrival, on the race course or elsewhere. But up to the close of the century they had not succeeded in exterminating the pacer-the saddle horse of a hundred generations.

As a specimen of how absurdly a man can talk and even write on subjects of which he knows nothing, I cannot refrain from giving the following from what an Englishman had to say in 1796 about the horses and horsemanship of Virginia:

"The horses in common use in Virginia are all of a light description, chiefly adapted for the saddle; some of them are handsome, but are for the most part spoiled by the false gaits which they are taught. The Virginians are wretched horsemen, as indeed are all the Americans I have met with, excepting 
some few in the neighborhood of New York. They ride with their toes just under the horse's nose, and their stirrup straps left extremely long, and the saddle being put three or four inches on the mane. As for the management of the reins, it is what they have no conception of. A trot is odious to them, and they express the utmost astonishment at a person who cain like that uneasy gait, as they call it. The favorite gaits which all their horses are taught are a pace and a wrack. In the first the animal moves his two feet on one side at the same time and gets on with a sort of a shnffling motion, being unable to spring from the ground on these two feet, as in a trot. We should call this an unnatural gait, as none of our horses would ever move in that manner without a rider; but the Americans insist apon it that it is otherwise, because many of their colts pace as soon as born. These kind of horses are called "natural pacers" and it is a matter of the utmost difficulty to make them move in any other manner. But it is not one horse in five hundred that would pace without being taught."

There can hardly be a doubt that our English friend in his "Travels Throngh the States" noted and wrote down just what he thought he saw, and when he saw anything that he never had seen in England, he was ready to either deny its existence altogether or to insist that there was some mistake about it. Poor man, he could not understand how there could be anyihing outside of England that could not be found in England. His vision, mental and physical, seems to have been restricted to the shores of his own island home, and he was probably'a descendant of a very good man we once heard of. As you sail np the Firth of Clyde you pass an island of three or four miles in extent, called Cumbrae. At the head of ecclesiastical affairs in the island was a very pions man, some generations back, and every Sumday morning he prayed that the Lord wonld bless the "kingdom of Cumbrae and the adjacent islands of Great Britain and Ireland." The author of "Travels 'Through the States" was evidently one of the very numerous descendants of this good man, as they are scattered all over England, and as I am a strong believer in the laws of heredity, I can hardly avoid this conclusion. Indeed, some of the numerous tribe, tracing their genealogy through many generations back to "The kingdom of Cumbrae," have found their way across the water, and at another place I will pay my respects to them. But to return to our traveler: there can be no doubt about his never having seen a pacer in England, for the last one had disappeared before his day, unless an occasional one might have been found in the old province of Galloway, in the southern part of Scotland. If he had known 
the history of the horses of his own country he would have known that from the time of King John down to that of James I., the pacer was the most popular and fashionable horse in England, and that the nobility and gentry used no other kind for the saddle. He was always of "a mean stature," but he was compact, hardy and strong, and could carry his burden a long journey in a day with great ease and comfort to his rider. In the reign of Elizabeth, be was kept separate from others, and bred as a breed on account of his easy, gliding motion, which he transmitted to his progeny. At the time of the plantation of the English colonies in this country the pacers were very numerous, and as they were just the type of horse suited to wilderness life, a very large proportion of those selected were pacers. The pacers our traveler saw in Virginia were the lineal descendants of the original English stock brought over by the adventurers, and the awkward riding charged upon the Virginians, with some evident exaggerations, was wisely and sensibly adapted to the action of the horses they were riding. The criticism of the long stirrups is wholly unjust, as they are just the right length for the "military" seat, and nobody in this country when mounted on a real saldle horse would ever think of taking any other. The Englishman, when mounted on his "bonesetter," is compelled to have his stirrups short so that he can rise and fall with every revolution the horse makes on the trot to save himself from being shaken to death. This up and down, up and down, tilt-hammer seat, if it can be called "a seat" at all, is one of the most ungraceful things, especially for a lady, that can be conceived of in all the displays of good and bad equestrianism. The English hare been compelled to adopt it because they have no trained saddle horses, and a lot of brainless imitators about our American cities have followed them because "it is English, you know." If the English had pacers and horses trained to the "saddle gaits," they never would have anything else, and the tilt-hammer "seat" would disappear from Rotten Row and everywhere else. 


\section{CHAPTER IX.}

COLONIAL HORSE HISTORY - NEW YORK.

Settlement of New Amsterdam-Horses from Curaçoa-Prices of Dutch and English horses-Van der Donck's description and size of horses-Horses to be branded-Stallions nuder fourteen hands not to run at largeEsopus horse-Surrender to the English, 1664-First organized racingDutch horses capable of improvement in speed-First advertised Subscription Plate-First restriction, contestants must" be bred in America" -Great racing and heavy betting-First importations of English running horses-Half-breds to the front-True foundation of American pedigrees - Half bushel of dollars on a side-Resolutions of the Continental Congress against racing-Withdrawal of Mr. James De Lancey-Pacing and trotting contests everywhere-Rip Van Dan's horse and his cost.

For several years after Henry Hudson, an Englishman in the employ of the Dutch, discorered the harbor of New York and the great river which took his name, in the year 1609, there is. uncertainty and doubt as to the nature of the settlement. For a. time it seems to have been merely a trading post, occupied only by those in the employment of the company that owned it, and without many of the elements requisite to make up a permanent colony. At Fort Orange (Albany) and at Esopus (Kingston), the conditions were the same as at New Amsterdam, as New York was then named. The first party of immigrants that seemed to have the elements of permanent colonization about it arrived in 1625 , and consisted of six families and several single men, making in all forty-five persons, with furniture, utensils, etc., and one hundred and three head of cattle. Doubtless some of these "cattle" were horses, and the general instead of the specific term was used in enumerating them. Very little is known of the early horse history of the New Netherlands, as the whole region was then named; there can be no doubt, however, that they increased and multiplied. Some time, probably about 1643, a cargo or two of horses were brought up from Curaçoa and Azuba, in the Dutch West Indies, but the climatic change was too great for them, and they did not do well, being specially subject to diseases 
from which the Dutch horses seemed to have complete immunity. In 1647, Isaac Allerton, as agent, was authorized to sell twenty or twenty-five of these horses to Virginia, and whether the authorities were able thus to get clear of a bad investment does not appear from the existing records. In a report to the home company, made in 1650 , I find the following prices were given at that time: A young mare with second foal, one hundred and fifty florins; stallion, four or five years old, one hundred and thirty florins; milch cow, one hundred florins. The same report makes a comparison by giving the prices of New England horses, as follows: A good mare one hundred to one hundred and twenty florins; stallion, one hundred florins; milch cow, sixty to seventy florins. Neither horses nor cows were then allowed to be shipped out of the province without permission of the council.

Adrien Van der Donck wrote a description of New Netherlands which was published 1656, in which he speaks of the horse stock as follows:

"The horses are of the proper breed for husbandry, having been brought from Utrecht for that purpose; and this stock has not diminished in size or quality. There are also horses of the English breed which are lighter, not so good for agricultural use, but fit for the saddle. These do not cost as much as the Netherlands breed and are easily obtained."

From a large number of facts collected for the years 1777 and 1778 the horses then averaged about fourteen hands and one inch, and when compared with earlier data it is evident they had increased in height. In the gaits of those advertised, fifteen both paced and trotted, nine trotted only, and seven paced only. As this was in the period of the Revolution, and right in the center of hostilities, some allowance should be made for horses from other colonies.

The people of this colony, like those of all the others, branded their horses and turned them out to seek their own living in the summer season, and this resulted in many losses, and oftentimes in much bad feeling. The Dutch were not accustomed, in the "old country," to building fences around their crops high enough and strong enough to keep out all the droves and herds of animals running at large. In the line of improvement and increase of size in their horses, they provided that all stallions running at large, of two years and nime months old, must be fourteen hands high or be castrated. This law was in force in 1734 , and no doubt 
was effective. Among the many laws for the suppression of vice of different kinds, I find one prohibiting horse racing on Sunday, and from this we might infer that it was not forbidden on other days 'of the week.

In old newspapers, advertiseménts, etc., we sometimes come across "Esopus Horses, Esopus Mares," and, for years, I was not able to tell what this term meant. The locality of Kingston was originally called Esopus, and in that neighborhood there were several farmers who bred horses largely, at an early day in the history of the colony, and the locality became famous for the character and quality of the horses produced there. They were of the best and purest Dutch blood, and for what we would call "all-purpose horses" their fame was very wide in that day. Hence I infer that the term "Esopus" was used to indicate what was considered the best type of Dutch horses. There is danger of going astray in the meaning of the term "Dutch horses," as in later times it was applied to the great, massive draft horses of Pennsylvania. They were better "for agricultural purposes," as Van der Donck puts it, than the Connecticut horses, because they were larger and stronger, but they were sprightly and active and some of them could run very well. They had a fine reputation in the adjoining colonies.

New Amsterdam, and consequently all the plantations in New Netherlands, surrendered to Colonel Nicolls, commanding the British forces, August 27, 1664. Colonel Nicolls remained as governor of the colony three or four years and until he was succeeded by Governor Lovelace. Among his early official acts, Governor Nicolls laid out a race course on Hempstead Plains, and named it Newmarket, after the famous course in England. No engineering or grading was necessary, as nature had already made a perfect course without stick or stone or other obstruction. The first race was run 1665, and although it was a long distance from the city, the presence of the governor gave the occasion prestige and there was a great gathering of the gentry from town, and the farmers of Long Island. These meetings were kept up annually by the appointment of succeeding governors, and after a time they were held twice a year, spring and fall. There are some very important facts about these races that are not known and probably never will be known, namely, who were the nominators and what breed of horses were entered in these contests. With these two essential facts left out the value of the informa- 
tion is greatly impaired. As it is known, however, that there were but two breeds or types of horses that could have been engaged in these contests, it becomes a matter of interest to reach a conclusion as to which were the victors. Mr. John Austin Stevens has done some very excellent work on this part of the horse history of New York, but I cannot agree with him in his characterization of the Dutch horses as being Flemish. They did not come from Flanders, but from Utrecht. They were not great unwieldy brutes, such as we would associate with Flanders, but hardy, compact animals that could make their way in the wilderness. Although larger, it does not follow that they could not run as fast or even faster than the New England ponies. All breeds of horses were very much smaller two hundred years ago than they are now. These races were instituted, evidently, for the improvement of the breed of horses in the colony, and the great majority of these horses were the descendants of the original stock brought from Utrecht. We must, therefore, conclude that they were not slow, heavy, unwieldy animals with no action, as the language of Mr. Sterens would seem to imply, but capable of improvement in the direction of speed. No doubt there were very many New England horses in the colony, "lighter and better adapted to the saddle," but neither the interests nor the pride of the old Dutch settlers would have permitted them to support racing for a period of more than eighty years, unless the early Utrecht blood was represented. Besides this, the weights carried, one hundred and forty pounds, and the distance, generally two-mile heats, were conditions that were strongly against the New Englanders, even if they were lighter of foot. With these two breeds in the field, we may accept it as an inevitable sequence that the superior qualities of the one would very soon be engrafted on the other, and by this process of breeding, a better type would be produced than either of the originals. This first step was only a prelude to the next, and that again to the next, until the common, plain lesson was thoroughly learned, that if a running horse was wanted the way to get him was to breed to a running horse that had proved he was a running horse. The improvement became very wide and general, and occasionally an animal was produced with such phenomenal speed that he was barred from stakes and purses. On this foundation, and this alone, the running turf was built up and continued for about 
eighty years, with occasional intervals, when the gamblers made it so nasty that no decent people would go near it.

The first subscription plate race of which we have any trace is to be found in the New Iork Gazette, of September 2\%, 1736, of which the advertisement is given below. The course indicated is believed to have been on the Church Farm, west of Broadway, and not far from where the Astor House now stands. There is no account of what horses won, and all we know is just what is in the advertisement.

"On Wednesday, the 13th of October next, will be run for, on the course at New York, a plate of twenty pounds' value, by any horse, mare or gelding, carring ten stone (saddle and bridle included), the best of three heats, two miles each heat. Horses intended to run for the plate are to be entered the day before the race, with Francis Child, on Fresh Water Hill, paying a halt pistole each, or at the post on the day of running, paying a pistole. And the next day being the 14th, will be ruu for, on the same course, by all or any of the horses that started for the twenty-pound plate (the winning horse excepted) the entrance money, on the conditions above. Proper judges will be named to determive any disputes that may arise. All persons on horseback or in chairs, coming into the field (the subscribers and winning horse only excepted) are to pay sixpence each to the owner of the grounds."

Passing on to 1747 we find a duplication of the foregoing for the plate race of that year, with some variations. Entries are restricted to animals that never won a plate before "on this island," and a horse named Parrot is not permitted to compete. This race was advertised to take place on the Church Farm. The next that $I$ will notice is the advertisement of this same stake for 1751, when the weight was reduced to eight stone, and in addition to the usual exclusion of previons winners, we have for the first time a restriction of the entries to animals "bred in America." At the May meeting at Hempstead Plains, the year following, 1\%52, the entries are again restricted to animals "bred in America." From this, then, we are able to fix the precise period when English Race Horses were first bronght to this colony. At this time there were two or three other conrses on Manhattan Island, besides several noted speeding grounds on the roads and elsewhere, for the trotters and the pacers, of which no advertisements appear, and consequently no notice was taken by the newspaper press.

From about 1760 up to the time when the Rerolntionary strug. gle began to engross and absorb all thought and all action, racing 
received a tremendous impetus, not only in this colony but in others. Ten or twelve years before this a very few rich men in Maryland, Virginia and South Carolina commenced importing English ruuning-bred horses with great success, and Mr. James De Lancey and other rich men of this colony were only a year or two behind them. This fancy grew and spread until a great many breeders and planters of the richer class had imported stock of their own, while their less wealthy neighbors were well supplied with half-breds. These half-breds were, for a short time, classed by themselves and purses were offered and run for, restricted to this class. After experimenting with animals bred in this way it was found that not a few of them were able to hold their own in any company. Mr. Morris' mare Strumpet was only half-bred, but she was able to beat many of the imported animals, as well as the full-breds that started against her. From this it would appear that breeding for speed for a hundred years had produced results in this country as well as in England. These experiments led many owners of old-fashioned stock to try it, and right there is where thousands and thousands of our best old American pedigrees end. The decade from 1750 to 1760 witnessed a complete transformation from the old methods to the new, from the old blood to the new, and more than all from the old managers to the new. During the next decade, from 1760 to $17 \% 0$, the new blood came out in great strength, and the saturnalia of horse racing grew more and more furious. Purses of a hundred dollars, as in the olden time, sprang up to ten times that sum, and matches were made for sums that were fabulous in that day. One match, between Mr. Delaney of Maryland and Mr. De Lancey of New York, specified the consideration on each side as a half bushel of silver Mexican dollars, and the Marylander had the satisfaction of carrying home a bushel of silver dollars. The great struggle, in New York, for supremacy on the turf was between the De Lancey family and the Morris family. These two families had been bitter political rivals for years, and when they met on the turf it was for "blood." The De Lanceys were Tories and the Morrises were Whigs, and this intensified the feeling that had so long existed between them. When the Continental Congress adopted that remarkable resolution, advising the people to abstain from horse racing, cock fighting, garnbling and some other more slight offenses, on the grounds of "economy," in view of the approaching conflict with the mother country, the effect was 
thrilling and electrical. Every man who loved his home and his country obeyed it. True, as I have said, it was drawn in the form of advice and in the interests of "economy," but there was but one great evil, one great prodigality at which it was aimed, and that was the gambling connected with horse racing. It was well aimed and struck the bull's eye. It came in the midst of preparations for the greatest race meetings ever then projected, but everything was dropped and there it lay throngh all the years of the bloody struggle and until peace again smiled upon a land of free men. Before avowed hostilities commenced, Mr. James De Lancey, one of the first and largest importers and breeders of his day, sold out every animal of the horse kind that he possessed and retired to England. Thus, as the colonial period drew to its close, the brave little colonial horse that had weathered the storms of a hundred winters and carried his master in safety and comfort throngh all that time, is superseded by another race, and no oine has ever attempted to write even so much as his epitaph.

As the contests of speed considered, up to this point, have all been at the running gait, I must not close my review of this colony without giving some attention to the pacers and the trotters. At these gaits all sources of information are almost hopelessly barren of facts and incidents. We know that the running horses of the colonial period were the saddle horses of the country, and we know that the best and most fashionable saddle horses were pacers. When we connect these two facts and place them alongside of the pacing and trotting experiences of Pennsylvania and New Jersey, we have no difficulty in reaching the safe conclusion that the same conditions would produce the same results as in those two States. Pacing and trotting contests were just as frequent and as exciting in this colony as in any other, but they were sustained chiefly by road-house keepers and butchers, and were never advertised. Matches were made one hour and decided on the road in the next. In the "Annals of New York," compiled and published in 1832, by John F. Watson, we find the following curious, but very valuable, scrap of horse history:

“Sonie twenty or thirty years before the Revolution, the steeds most prized for the saddle were pacers, since so odious deemed. To this end the breed was propagated with much care. The Narragansett pacers of Rhode Island were in sucb repute that they were sent for, at much trouble and expense, by some few 
who were choice in their selections. It may amuse the present generation to peruse the history of one such horse, spoken of in the letter of Rip Van Dam of New York, in the year of 1711, which I have seen. He states the fact of the trouble he had taken to procure him such a horse. He was shipped from Rhode Island in a sloop, from which he jumped overboard when under sail, and swam ashore to his former home. Having been brought back he arrived in New York, in thirteen days' passage, much reduced in flesh and spirit. He cost thirty-two pounds and his freight fifty shillings. This writer, Rip Van Dam, was a great personage, he having been president of the Council in 1731, and on the death of Governor Montgomery that year, he was governor, ex-officio, of New York. His mural monument is now to be seen in St. Paul's Church."

As New England saddle horses were only worth forty dollars in 1650 , and this horse cost more than four times as much, when horses were more plentiful, we must conclude that he was a fine specimen of the breed, and was, probably, bought for stock purposes. The date of this transaction is a significant fact that should not be forgotten, as 1711 is the same year in which the first of the two great founders of the English race horse, Darley Arabian, was brought to England. 


\section{CHAPTER X. \\ COLONIAL HORSE HISTORY-NEW ENGLAND.}

First importations to Boston and to Salem-Importations from Holland brought high prices-They were not pacers and not over fourteen handsIn 1640 horses were exported to the West Indies-First American newspaper and first horse advertisement-Average sizes-The different gaits -CoNneCTICUT, first plantation, 1636-Post liorses provided for by lawAll horses branded-Sizes and Gaits-An Englishman's experience with pacers-Lindsay's A rabian-Rhode Island, Founded by Roger Williams, 1636-No direct importations ever made-Horses largely exported to other colonies 1690 -Possibly some to Canada-Pacing races a common amusement-Prohibited 1749 -Size of the Narragansetts compared with the Virginians.

Is 1629 the London founders of the plantation of Massachusetts Bay sent out six vessels laden with emigrants, horses, cattle, goats, etc. These vessels brought some twenty-five head of mares and stallions, that were valued at six pounds each and all owned by the company in London, except three mares from Leicester, that were owned by private parties. At that time there seems to have been some rivalry between Boston and Salem as a shipping point, but this fleet came to Boston harbor. This same year (1629) Salem seems to have had six or seven mares and one stallion, besides forty cows, and forty goats. From this it might be safely inferred that a part of this fleet put into Salem harbor, or that there may have been another and somewhat earlier shipment of which we have no details. Salem was really founded in 1626, and the settlement at Charlestown, Boston, dates from the same year. The next year about sixty head were shipped to the plantation, but many were lost during the voyage, of both horses and cattle. Several other shipments followed, but nothing worthy of special note, till 1635, when two Dutch ships. arrived at Salem with twenty-seven mares, valued at thirty-four pounds each, and three stallions. Some writers have spoken of these mares as "Flanders mares," but I have not been able to find any evidence or even indication that this might have been. 
the fact. The records show they were Dutch ships, and that on a given day they sailed out of the Texel, a Dutch port, far away from. Flanders. I think, therefore, we are safe in concluding they were "Dutch mares," and they should be so designated. Just about this period they were bringing Dutch horses from Utrecht, in Holland, to the Dutch colony at New Amsterdam, and it was well known in Holland as well as in New England that the Dutch horses brought much better prices in New England than the English importations. It is probable, further, that these Dutch traders were looking out for a choice of markets, as between New England and New Netherlands. These mares were valued at thirty-five pounds each, the record says, but we are not informed as to the price that was really paid for them. There is a very wide discrepancy between the figure at which these mares were "valued" and the cost of the mares that were brought from England. The English company charged the colony six pounds each for the horses sent from there, and ten pounds freight.

I have labored assiduously to get at such data as would afford a safe basis upon which to determine the size and other qualities of these Dutch horses. They were larger than the English horses of that period and they were more muscular, with greater weight of bone. They were, doubtless, better adapted to the various offices of the "general purpose" horse than their English contemporaries, in every respect, except the saddle. There is no distinctive evidence that they were pacers or could go any of the saddle gaits, in their own right. It is probably safe to conclude that the original importations would not average more than fourteen and a half hands high, and very likely the exact truth, if it could be reached, would place them below that figure rather than above it. The process of reducing the size commenced as soon as they arrived; for the English horses had saddle qualities which the Dutch did not possess, and everybody wanted a saddle horse. Still the Dutch blood was highly prized, and a hundred and fifty years afterward it was no uncommon thing, especially in the valley of the Connecticut, to meet with the advertisements of stallions seeking patronage on the strength of "Dutch blood." This, for a time, was a puzzle to me, but as we consider the horse interests of the region of the Hudson and the Mohawk Valley extending eastward and that of eastern Massachusetts extending westward along with the current of emigration, it is not difficult to understand how the blood of the Dutch horse should have be- 
come so generally diffused. On the one hand we had the muchdesired saddle qualities, and on the other we had the much-desired increase of size without deterioration in appearance. Thus owners were accommodated and the horse stock of the country was improved by the interbreeding of the two nationalities. It is not necessary to further particularize different importations. It is sufficient to say that they were very numerous, and the multiplying of the stock was carried forward with vigor and success. Five years later-1640-the colonists not only had all the horses they needed, but they shipped a cargo of eighty head to Barbadoes. From the colony of Massachmssetts Bay all the plantations of New England secured their foundation stock of horses, hence they are here considered collectively.

The people of the Plymouth plantation were very slow in providing themselves with horses, and it was not till after 1632 that they had any. It is hard to conceive of a colony like that of Massachusetts Bay living and flourishing for a period of, say, eighty years withont a newspaper, and yet such is the fact. The Boston News-Letter, the first newspaper, so called, in this conntry, was established May 29, 1\%04, and it lived many years. The early colonial newspapers, from one end of the land to the other, were anything and everything but newspapers, as we understand the meaning of the title in our day. If a boy fell off a building in London and broke his leg, six weeks before, it was liable to appear as an item of "news" in the local American newspaper, but if the same accident happened the week before, in a neighboring town, it was never mentioned. The name "newspaper" attached to such publications was a fraud.

The following is a copy of the first horse advertisement ever published in this country, and for that reason it is worthy of preservation. It was taken from the Boston News-Letter of November 19, 1705:

“Strayed from Mr. John Wilson of Braintree, at Mr. Havens' in Kingston, in Narragansett, about a fortnight ago, a sorrel mare, low stature, four white feet, a white face, shod all round, her near ear tore, has a long white tail and mane. Whoever will give any intelligence of her . . . will be sufficiently rewarded."

As this was in the period when the Narragansett pacers had reached their greatest fame, we might argue that this mare had been sent down to Kingston from Braintree, Massachnsetts, to be win- 
tered and to bo bred in the spring to some famous horse in Kingston, the very center of the horse-breeding interests of that day.

Under the date of June 17, 1706, I find a bay horse advertised as "strayed or stolen; fourteen hauds high, hardly possible to make him gallop," and October 28, 1\%06, a black gelding "fourteen hands high, paces, trots, and gallops." 'Then in the years 1731 and 1732 I find a "black mare fourteen and three-quarter hands, trots and paces;" a "black horse twelve hands," no gait given; "black gelding, fourteen hands, races, trots, and gallops:" "bay horse large, good pacer:" "roan mare, fourteen hands, paces and trots." But the field which I specially gleaned was for the years 1756-59, where I found the average height was fourteen hands one inch, the data including eight pacers and two trotters. This, I think, may be taken as fairly representative of the size and habit of action of Massachusetts horses in the first half of the eighteenth century.

In 1636 the first plantation was made in Connecticut at Hartford by the Rev. Thomas Hooker and over a huudred of his congregation with him. They left nothing behind, but brought all their domestic animals to their new home. I have not been able to discover just how many horses they brought with them, but in a few decades they had a great abundance and to spare. In 1653 the General Court at New Haven made provision for keeping public saddle horses for hire and fixed the rate of charges for their use. It also prohibited the saie of horses outside of the colony. In 1658 all horses, young and old, had to be branded by an officer appointed for that purpose, and it required several years of legislation before the system of branding, selling and recording could be so perfected as to prevent dishonesty and frauds. In 1674 an act was passed providing and enjoining that all coits entire and stallions running at large, under thirteen hands high, should be gelded. This law also required a good deal ot amending before it could be made to work smoothly. The size of the Connecticut horses about the time of the Revolution was an average of thirteen hands three inches, thus ranging below the other New England colonies. In $17 \% 8$ horse racing was prohibited under the penalty of forfeiture of the horse and a fine of forty shillings. In 1776 a careful compilation of the gaits of the horses of that period, embracing nineteen individuals, taken as they came, showed that fifteen were pacers, or pacers and trotters, 
and four were trotters only. As an evidence of the quality of the Connecticut pacers, take the following passage from a little volume published 1769, in England, entitled "A Voyage to North America," by G. Taylor, Sheffield, England, 1768-69:

" After dinner at New London, Conn., Mr. Williams and I took post horses, with a guide to New Haven. Their horses are, in general of less size than ours, but extremely stout and hardy. A man will ride the same horse a hundred miles a day, for several days together, in a journey of five or eight hundred miles, perhaps, and the horse is never cleaned. 'Tuey naturally pace, though in no graceful or easy manner, but with such swiftness and for so long a continuance as must seem incredible to those who have not proved it by experience."

This is a very different view of the pacer from that expressed by another Englishman who visited Virginia in 1796. He had never seen a pacer before and he was wholly unwilling to believe his host when he assured him it was a natural gait and that many colts paced from the day they were foaled. This, to the mind of the Englishman conld not be true, he says, "for none of our horses ever move in that manner." (See Virginia, pp. 117-118).

The most noted horse ever owned in Connecticut, at least in colonial days, was the horse named and known in later times as Lindsay's Arabian. When I was younger I accepted the marvelons story of the origin and early history of this horse, of which a brief account is given in the chapter on the "American Race Horse," to which reference is here made. 'This acceptance on my part of the romantic story was largely superinduced by a statement made by a justice of the Supreme Court of the United States, that he had examined the animal when he was old and found on three of his legs undoubted physical evidence that they had at one time been broken. This appeared in a reputable publication, but when compared with some other facts in the history of the horse that are known, there can hardly be a doubt that the examination by the justice was a fiction. When I began to realize that the marvelous story was a mere fiction my "wrath waxed hot" against the people of "the land of steady habits," to say nothing of "wooden nutmegs," until Mr. O. W. Cook made it very plain that the people of Connecticut never had heard of the remarkable story. (See Wallace's Monthly, Vol. VI., p. 251). Thus it became evident that the whole story had been fabricated in Maryland and was a kind of "green goods" method for catching the unwary. These are my apologies to the general public 
and especially to the Connecticut public for supposing them guilty of any such fraud. The naked truth of the matter is, that while this horse may have been imported from England, his public advertisements clearly indicate that his owners knew nothing of his blood or early history.

The colony of Rhode Island was planted by Roger Williams and his followers in 1636, and the first patent giving it a legal existence was obtained $164 \%$. It was an offshoot from Massachusetts and a protest against the intolerance of that colony in religious affairs. For several years I made renewed and persistent efforts to discover whether in the early colonial period Rhode Islaud had ever imported any horses from foreign countries, and after exhausting every source of recorded information, I have not been able to find a single intimation of such importation. It is evident, therefore, that the famous Narragansett pacer is simply the result of carefully selecting and breeding from the best and the fastest of the descendants of the English pacers, to be found everywhere in the colony of Massachusetts. The superiority of the Narragansett pacer over all others of his kind seemed to suggest the probability that he must have possessed blood that was superior to all others, and to supply this "want," a Rhode Islander advanced the claim that his grandfather had imported the original stock from Spain. Unfortunately for this "claim" there were two difficulties in the way of accepting it. First, there were no pacers in Spain, and second, the Narragansett pacers were famous for their speed and valne before the grandfather was born, or at least before he was out of his swaddling clothes.

The horse interests of Rhode Island seem to have been active and successful from the very founding of the colony, and the fame of her pacers extended to all the American colonies at a very early day. When the authorities made their report to the Board of Trade at London, in 1690, showing what they had produced and where and how they had disposed of their surplus, they place horses at the head of their products and state that they are shipped to all the English colonies on the American coast. This statement is sustained by corresponding facts that are known in New York, Pennsylvania, and Virginia. Trading with the French colonies in Canada was rigorously prohibited, but it is quite probable that many a good pacing horse found his way to the St. Lawrence in exchange for pelts and furs. But, 
as the Narragansett and the pacer generally will be fully considered in another part of this volume, the reader is referred to the chapters wholly devoted to those topies.

That racing was a common amusement of the people of Rhode Island is fully established by the very best of contemporaneous evidence, and by the silver plate prizes won, that are said to be still in existence in some of the old families. Attempts have been made to laugh this statement out of court, on the grounds that. Rhode Island was a Puritan colony, and such a thing as a horse race would not be tolerated for a single day. This attempt shows a great deal more smartness than knowledge, for Rhode Island was not a Puritan colony, as that term is generally understood, but had for its very foundation opposition to the spirit of intolerance that prevailed in all the other New England colonies. But, what is still more conclusive, the legislature of the colony in 1 49 enacted a law prohibiting all racing, under a penalty of forfeiture of the horse and a fine of one hundred dollars. As in other colonies not in New England racing and betting had become so common that the moral sense of the people rose up and abolished it. If there had been no racing there would have been no law to wipe it out.

When the Rev. Dr. McSparran, of Rhode Island, made a trip in Virginia and rode the Virginia pacers some hundreds of miles, early in the last century, he seems to have observed them closely and spoke very highly of them, but he said they were not so large and strong as the Narragansetts, nor so easy and gliding in their action. It might be suggested that this opinion was the natural result of esteeming one's own as better than those of a neighbor, but he was certainly right in the matter of size. In 1768 the Rhode Island horses averaged fourteen hands one inch, while the Virginia horses averaged (1750-52) thirteen hands one and three-quarter inches, making a difference of three and one-quarter inches in height. In the matter of gait they were not all natural pacers, for out of thirty-five there were eight that did not pace, and some of the others both paced and trotted. From this it may be inferred that breeders, in order to increase the size, had incorporated more or less of the blood of the early Dutch importations. 


\section{CHAPTER XI.}

COLONIAL HORSE HISTORY-PENNSYLVANIA, NEW JERSEY, MARYLAND, CAROLINA.

Penn's arrival in 1682-Horse racing prohibited-Franklin's newspaperConestoga horses-Sizes and gaits-Sweedish origin-Acrelius' statement. New Jersey-Branding-Increase of size-Racing, Pacing, and Trotting restricted-MARYLAND-Racing and pacing restricted 1747-Stallions of under size to be shot. NorTh Carolina-First settlers refugees-South Carolina-Size and gait in 1744-Challenges-No running blood in the colony 1744 -General view.

Whes William Penn arrived on this side of the water (1682) and took possession of his princely gift from Charles II., he found the eastern border of his new province already occupied, though sparsely, by an industrious and enterprising people. The old Swedish colonists as well as a sprinkling of Englishmen and other nationalities had been there for a good many years, and were beginning to get the necessaries as well as the comforts of life about them. For their numbers, they had a fair supply of horses, cattle, sheep, and swine; and the growing of cereals and fruits of all kinds showed encouraging progress, with the promise of plenty. The new proprietor was gladly welcomed and his rule proved kindly and beneficent. In a letter to Lord Ormonde, after his arrival, Mr. Penn, in describing the condition of things in his new colony, says: "The horses are not very handsome, but good." The public affairs of Penn's grant, before his arrival, had been administered in the name of the Duke of York, from about the time New Amsterdam had surrendered to the English, and hence we find sundry regulations with regard to the horse in force before that event.

The first of these, having the efficacy of law, was in the year 1676, requiring all horses to be branded, and officers appointed to do the branding and keep a record of the fact. Besides the individual brands, each town had its own brand that had to be applied, and by this double marking it was supposed that strays 
could be identified with certainty. Another provision was that no mares should be exported to Virginia or Barbadoes or other foreign plantations. Again, every owner was supposed to keep a certain number of horses at home, for daily use, and he was allowed to keep twice that number running at large. In 1682 no stone horse under thirteen and one-half hands high was allower to run at large. This was afterward changed to thirteen hands. In 1\%24 this law was revised and re-enacted so that colts "of comely proportions" and not more than one year and a half old, if thirteen hands high, might run at large; but if older than eighteen months they must be fourteen hands high or suffer the penalty, which was castration. In 1750 horse racing of all kinds was prohibited, under a severe penalty.

In that grand old repository of ancient, curions, and valuable things relating to colonial affairs, the New York Historical Society, to which I am greatly indebted, I found a file of the Pennsylvania Gazette, commencing with the year 1\%29, published by "B. Franklin, printer." In that day the term "editor" or "reporter" was not known in the vocabulary of any well-regulated newspaper office, and for anything of a local character you had to look in the advertising columns. To these I resorted, as usual, and they presented results that were a great surprise to me. Pennsylvania has long been famous for the production of great massive draft horses, and before the days of railroads just suited, with six or eight of them in a team, for the transportation of freights from the seaboard to the Ohio River. This was a great business at the beginning of this century and for forty or fifty years afterward. The fame of those great teams, the great wagons and the great loads they hauled over the mountains, spread far and wide, and as a special designation that went with them they were called Conestoga horses, and the wagons were called Conestoga wagons, named after a creek in Lancaster Connty, Pennsylvania, where many large horses were bred. There was no particnlar line of blood to be followed, for a large horse bred west of the mountains was just as certainly a Conestoga as though he had been bred in Lancaster County. The Conestoga was simply the horse that was best suited for a big team with an enormons" load, and he varied in size from sixteen and one-haif to eighteen hands in height and from one thousand six hundred to one thousand nine hundred pounds in weight. These measurements he reached by breeding for the one purpose of strength and 
weight. It is safe to conclude that in the latter part of the last century breeding animals of large size were bronght over the water, for we can hardly conceive of their being descended from the little pacers proceding them only tifty or sixty years.

The Pennsylvania horses of the first half of the last century were remarkably uniform in size, and from a large number of cases in which the size is given I find the exact average was thirteen hands one and one-quarter inches. Of the twenty-eight animals in which the habit of action is given, twenty-four were pacers, three both paced and trotted, and just one is given as a natural trotter. Here we have two very striking facts-the low stature and the uniformity of the pacing gait. These horses average a quarter of an inch below the Virginians, the next lowest, and a higher ratio of pacers than in any other colony. There must have been some reason or reasons for this, and I will suggest two which strike me as probably effective in producing these results. The earliest settlers in Southeastern Peunsylvania were the Swedes. They brought their horses with them from the old World, and they were undoubtedly pacers, but I have no means of determining anything abont their size. This may be an important factor in determining the uniformity of the gait, as well as the diminutive size. The other consideration that I will present is the fact that the pacer was more fashionable in and abont Philadelphia, then the leading city of the continent, than in any other section or portion of the colonies. It is a fact that seems to be fully established, that early in the last century the breeding of pacing horses was carried on in the region of Philadelphia, with much spirit and intelligence, and that pacing stallions for public service were carefully selected for their shapelinesss and speed. It is also a fact that ali horses that could not pace were, in the public estimation, classed as bascly bred.

The Swedes and Finns planted a colony on the west bank of the Delaware in 1638, and as they were an industrious and thrifty people they prospered and extended their plantation up the river as far as Philadelphia. This territory was then claimed by the Dutch of New Netherlands, and they overcame the Swedes in 1655, and ten years later they in turn had to surrender to the English. Of the early Swedes, the Rev. Acrelins wrote and published, in the Swedish language, a very valuable account of his people. In speaking of their horses he says: "The horses are real ponies and are seldom over sixteen hands high 
[evidently a misprint and should read "thirteen" instead of "sixteen"]. He who has a good riding horse never employs him for draft; which is also the less necessary, as journeys are for the most part made on horseback. It must be the result of this, more than of any particular breed in the horses, that the country excels in fast horses, so that horse races are often made for very high stakes." Such horses often sold for sixty dollars in our modern money. The question of the pacers of Philadelphia will be considered more at length in the chapters devoted to the history of the pacer.

New JERSEY is not known to have made any direct importations of horses from the old country. Lying between New York on the east and Pennsylvania on the west, she had abundant opportunity to get her supply of horses from her neighbors on either side, to say nothing of the overflow from Virginia about 1669. Like all the other colonies, as early as 1668 her horses were ordered to be branded and then suffered to roam at large and find their own living. Not much attention seems to have been given to the idea of improvement in the size and quality of the stock till 1731, when it was provided by law that all colts of eighteen months old, running at large and under fourteen hands high, should be gelded. I have not made any attempt to get at the exact average size of the Jersey horses, nor to ascertain the ratio of pacers among them, for we know the environments and the sources of supply, and in knowing these we know just what the Jersey horses were-a large majority of them were pacers and they were not over fourteen hands high.

The statutes of this colony, enacted 1\%48, furnished the first real evidence of record, with one exception, going to show that pacing and trotting races, as well as rumning races, were the common amusement of the people in the first half of the last century. They were so common, indeed, that the legislative authorities declared them a nuisance and restricted them to certain days in the year. That this was not a "moral spasm," as some might call it, that had seized the legislative authorities of that particular year, is evident from the fact that, afterward and from time to time, this statute was amended, and always in the direction of greater restrictions and greater severity. This is sufficient evidence that the moral sense of the community sustained the lawmakers in pronouncing it a nuisance, to be abated. It is not probable that pacing and trotting races were any more common 
or more demoralizing in New Jersey than in some of the other colonies, but they seem to have been content with fulminating against "horse racing" without specifying the different gaits at which the horses might go in the race. Until this old colonial statute was discovered, it was not possible to prove by contemporaneous evidence that there had been any pacing or trotting races before the first decade of the present century. This, however, adds to their antiquity more than a hundred years.

MARYLAND was really the first in point of time to legislate for the suppression of pacing, as well as rumning races, but the oid statute, enacted in 1747 , was not discovered till very recently. This proves that pacing races were very common in Maryland one hundred and sixty years ago, but it says nothing about trotting races. It will be observed that in the New Jersey statute the different kinds of racing are placed in this order: "Racing, pacing and trotting," and I take this to mean the order of their prominence. Applying this method to Maryland, it may be inferred that trotting races were infrequent and practically unknown, and hence not enumerated as offensive. Taking these two cases together, I think we are justified in concluding that the pacer antedated and preceded the trotter in all turf sports. No doubt he was faster then than the trotter, and he has maintained his superiority, in that respect at least, to this day. Maryland was a great racing colony and it was afterward a great racing State. This statute did not sweep over the whole colony, but applied only to the race course at Newmarket, and Anne Arundel and Talbot counties. As I understand the matter, this statute was enacted specially at the request of the Society of Friends, and for the protection of their yearly meetings.

With Pennsylvania on the one side and Virginia on the other, it is not necessary to spend any time on the sizes and gaits of the horses of Maryland, for they were simply duplicates of those in the two colonies with which they were in constant intercourse and trade. In the matter of undersized stallions running at large Maryland was more in earnest and more savage than any of the other colonies. For, by an act of Legislature, passed 1715, it was provided that any person finding an entire colt eighteen months old, or an unbroken stoned horse, running at large, no difference what his size, might shoot him upon the spot.

North Carolina was first permanently settled by a colony from Virginia, led by Roger Green, July, 1653. For some years pre- 
vious to this it had been the refuge of Quakers and others fleeing. from the persecutions and proscriptions that prevailed in Virginia at that time, against all who did not conform to the ritual of the English church. These refugees and colonists took their horses and all they had with them, and as this was but a few years before there was an overproduction of horses in Virginia, and great droves were running wild withont an owner, we may conclude they cost but little and that they spread rapidly in the new colony. As we thus know whence they came, we necessarily know what they were in size and gait, and we need not trace them any further.

Sovth Carolina received her colonial charter in 1663 , and the earliest newspaper that I have found was for the year 1744, from the advertisements in which $I$ have extracted the following data as to size and gait. In the first four and the last four months of the South Carolina Gazette for 1744 I find thirty horses advertised as strayed or stolen, in which the size is given, and they average within a small fraction of an inch of thirteen and one-half hands, and of this number three are given as fifteen hands, which was. considered, in that day, a large horse. Ont of this number the gait is given in only twelve cases, ten of which were pacers, one paced and trotted, and one trotted only. The foundation horse: stock of Sonth Carolina was obtained chiefly, if not wholly, from Virginia, and the practice of branding and turning out, to roam at large, prevailed everywhere.

In the issnes of the Gazette for this year (1744) I find but one. advertisement of a stallion for public service, and he is called the "famous racing horse named Roger," and is advertised as a great. race horse, but there is no attempt to give a pedigree or to claim that he possessed any blood that was not the inheritance of all others. Another advertisement is a lengthy challenge from Joseph Butler to run his gelding Chestnut against any horse, mare or gelding for five hundred or one thousand pounds "inch and weight," the lowest horse carrying thirteen stone. No mention or reference is made to his blood, and from these two facts we may reasonably infer that at that time there were no strains. of blood, known to the Carolinians, specially bred to run. The distance to be run is not definitely mentioned, but it was on a road from one point to another, and I suppose it was about two and a half, or possibly three miles. This was three years before the first English race horse was imported into Virginia. It has. 
been represented that an old gentleman, whose name is forgotten, imported into South Carolina a number of English race horses at a period long anterior to this, but that claim has never been in a shape that placed it above very grave suspicion and doubt; and the claim accompanying it, in the way of apology, that the old man would never allow any of his horses to race, did not improve its credibility. From the advertisements just referred to, it seems evident that there was no distinctively English running blood in the colony till after this date.

This review of the horses of the colonial period embraces all that I have been able to glean of the character, qualifications, size and habit of action of the earliest importations and their descendants. Their diminutive size will be a surprise to my readers as it has been to me, and the overwhelming ratio of pacers to trotters wili be a still greater surprise. The importance of increasing the size by judicious selections of the largest seems to have been ever present to the minds of the colonists, but not much could be accomplished in that direction, under the system prevalent everywhere of roaming at large. The little pacers were great saddle horses, and down to the days of good roads and wheeled vehicles they were deemed indispensable. That there were race horses among them at the running, pacing and trotting gaits there is indisputable evidence, covering about a hundred years of the colonial period, but there is no record of the rate of speed. The pacer was the favorite and fashionable horse of that period, and after something has been said about the Canadian horse we will take up his history and treat it with that fullness its importance demands. 


\title{
CHAPTER XII.
}

\author{
EARLY HORSE HISTORY-CANADA.
}

Settlement and capture of Port Rnyal-Farly plantations-First French horses brought over 1665-Possibly illicit trading-Sire of "Old Tippoo" -His history-"Scape Goat" and his desceudants-Horses of the Maritime Provinces.

BEFore taking up the two provinces of the Dominion-Quebec and Ontario-to which reference is made in this volume as. "Canada," there is an incident in the history of Nova Scotia, full of sadness, that $\bar{I}$ cannot pass over without mention. The French made a settlement here in 160\%, and named the country New France. The settlement to which I refer was at Port Royal, afterward named Annapolis by the English. This seems to have been a thrifty and flourishing little plantation, far removed from all ontside associations, except the savages of the forests, with whom they lived in peace. The first horses brought to North America were owned and bred by the people of Port Royal. In November, 1613, Captain Argall, of Virginia, organized a plundering expedition, and having learned of the defenseless condition of Port Royal from Captain John Smith, he sailed up there with two or three ships, captured the place and carried away horses, cattle, sheep, wheat, farming utensils, and indeed everything their ships would carry, and then sailed away to Virginia. This raid was without anthority or orders, but it was winked at by the officials, and forthwith a second raid was made by Argall, and all that had been left in the first was carried away in the second, as well as some of the inhabitants.

The pacer of Canada, generally believed to be of French origin, has long been an object of diligent investigation, without reaching any satisfactory results. Again and again I have gone over the first half-century of the history of the French plantations on the St. Lawrence; examining everything in the English language that held out any hope of throwing light upon the question, but nothing was revealed. The trouble was that my search: 
stopped a little short of the date when the first horses arrived. The management of the affairs of the plantations on the St. Lawrence being in a company located in France, there was a lack of vigor, not much growth, and still less profits to the projectors of the colony. The energies of the people seemed to be directed almost wholly to collecting and trading in peltry instead of building up a commonwealth from the productions of the soil. For half a century these primitive people lived without horses. Their farms, if they conld be called farms, all had a frontage on the water, running back in narrow strips to the highlands. They did their plowing with cattle and their canoes supplied the place of the saddle horse, the family carriage and the lumber wagon to carry the scanty surplus of their little farms to market. At last the company in France, holding direction and control, got out of the way, and the king of France assumed direct authority over the affairs of the plantation. On June 30, 1665, the Marquis de Tracy arrived at Quebec, as viceroy, with a numerous suite of retainers and a regiment of French soldiers. Two months later a large fleet arrived bringing many colonists, embracing artisans, farmers, peasants, etc., with their families, and a good number of horses, the first that had ever been scen on the St. Lawrence. There is a tradition that a horse had been sent over to the governor in 1642 , bnt it is probable he was lost on the royage, as the older people of the colony had no recollection or knowledge of any such animal. These colonists came from the ancient province of Picardy, not now to be found on the modern maps of France, but it lay on the English Channel in the extreme northwest of France. As it is expressly stated that these colonists came from Picardy, it is fair to conclude that the horses came from that portion of the kingdom also. At this period in history there had been no wars between France and England for many years, and commercial as well as social intercourse had long been cultivated between the people on both sides of the channel. We know but little of the early horse history of France, but in our own time we know that France has been largely benefited by the diffusion of the English blood among her horse stock, so we may conclude that if a man in Kent had a horse that a man in Picardy wanted, he very soon got him in the way of legitimate trade. I think, therefore, it is safe to conclude that the horse stock of Northwestern France and the horse stock of England were very much the same in appearance, action 
and blood. On this basis of reasoning, which inrolres no improbabilities, we may conclude that the same proportion of the horses from Picardy were natural pacers.

There is another theory, giving the Canadian pacer an AngloAmerican origin, that commends itself to the unbiased judgment with even greater force than the one just suggested. Various writers have talked about the "French characteristics" of the Canadian pacer, and all that, when probably not one of them ever saw a horse that he knew to be French. The early pacers-the pacing-bred pacers-all have more or less strongiy marked resenblances, especially in conformation, and it makes no difference whether they come from Canada or whether their habitat has been south of Mason and Dixon's line for two hundred and fifty years. When we look at a pacer, therefore, we may as well be honest and say we don't know whether he resembles the horses that reached the St. Lawrence in 1665, or those that reached Massachusetts Bay in 16:9. The theory that the French Canadians got the foundation of their pacing stock from the New England colonies rests upon two well-known facts. First, the colonies had a great abundance of such horses for sale; and second, they were within reach of and purchasable by the Canadians. To these two facts rendering the theory possible, we have others which render it probable. The jealons restrictions songht to be imposed on both the English and French colonists by the home governments of both people strongly indicate that there was no small amount of illicit trading, and this trading, in the very nature of things, must have been between the English and French. Toward the close of the serenteenth century the English colonies, especially Rhode Island, had far more horses than they needed for home use, and they did a thriving business in exporting them to different parts. These were just the kind of horses the Canadians needed for their wild life in the wilderness; they were cheaper than they conld be brought from France; the water way of Lake Champlain was convenient; pelts and furs were a desirable commodity of exchange, and there was no cordon of customs officers to keep the willing traders apart. Of these theories we consider the second the more probable of the two, and if we accept it we reach the conclusion that the so-called "French" Canadian pacer is merely a descendant of the old English pacer brought over by the early New England colonists. Objection has been presented to this theory, on the grounds that 
the powerful confederation of the Six Nations Indians interposed an unsurmountable barrier to all trade, whether legitimate or illicit, between the Canadians and the colonists of New England. This objection is certainly conclusive as applied to the different periods of hostilities, but the hostilities were not continnous. During both the seventeenth and the eighteenth centuries there were periods of years at a stretch when there were no bostiiities, and when there was nothing to prevent the Canadian and the Yankee from coming together and exchanging what they each had that the other wanted. The border abounds in traditions of the incidents comnected with this illicit trading, but we need not go to the border in the wilderness to learu that the desire to "beat the customs" is almost universal. We can see it manifested every day at the docks in New York, when a steamer arrives from abroad. The fine lady, with her gloves and lots of other lingerie that she has been contriving all the way across how best to keep from the sight of the officer, is no better and no worse than the "Cannck," who in a retired place at midnight trades his peltry to the Yankee for his horse. If the Canadian pacer did not have his origin in New England it was not because he could not be carried across the border.

When we enter upon the consideration of the actual performers descended from the original Canadian stock, we find both pacers and trotters of speed and merit, but in attempting to trace them to their particular ancestors we find ourselves in a labyrinth from which there seems to be no deliverance. In the midst of this darkness I am glad to be able to say there is a ray of light that illumines much that has been obscure. The greatest progenitor of trotters and pacers that Canada has produced, "Old Tippoo," has been fully identified in his true origin, and he has been well named "The Messenger of Canada." He seemed to be known all over Canada as the greatest of their trotting and pacing sires, and many attempts were made through several years to give his pedigree, but in all these attempts there were elements of weakness and in many of them very bald absurdities.

When the roan gelding Tacony made his record of 2:2\%, away back in 1853, the performance was looked upon as something that would not be surpassed in a generation at least. Then when Toronto Chief made his saddle record of $2: 24 \frac{1}{2}$, ten or twelve years later, and it was found that he and Tacony were both descended from a Canadian horse called Tippoo, the inquiry be- 
came quite active as to what Tippoo was, and all kinds of imaginable: stories were told about him. In the search for the history and. breeding of the horse Tippoo, extending through more than twenty years, many curious and some impossible things were developed, and as these old "fads" may come as new discoveries in future generations, I will mention two or three of them here. The first of these untruthful statements to assume tangible form was to the effect that Tippoo was imported from England, and that he was got there by Nesthall's Messenger. I never could tell how or where this story originated, but it first appeared in the pedigree given to Toronto Chief when he went into the stud on Long Island. 'This was settled by the facts, expressed in very few words, that the horse was not imported, but bred in Canada, and that there was no such horse in England as "Nesthall's. Messenger."

The next representation came from an old horseman, Mr. V. Sheldon, of Canton, New York, a very intelligent and careful correspondent, who had given much labor to the question. $\mathrm{He}$ had learned from different sources, that were satisfactory to his mind, that a Mr. Howard, a traveling preacher, had ridden a mare from Lowville, New York, over into Canada; that this mare was in foal "by a very noted horse that stood at Lowville;" that when the mare became too heavy for his use under the saddle he sold her to Isaac Morden, and that the foal she dropped was the famous Tippoo. The name of the "very famous horse that stood at Lowville" was not remembered, but as Ogden's Messenger was there at that time-1816-17-the conclusion followed that he was the horse. This representation was far from complete, but as there was nothing unreasonable about it, and nothing known to be untrue, I accepted it for a time, awaiting further light.

The third representation came from Mr. Lewis 'T. Leavens, of Bloomfield, Ontario, who was born 1792, and was, therefore, old enough to have had some personal knowledge of the horse. But whether his knowledge was personal or only traditional cannot now be made to appear. He says that Tippoo was got by a horse called Escape, and I will ask the reader to note this name "Escape" as we progress. He says that "when Escape was on the ocean, the ressel encountered a severe gale, and the horse had to be thrown overboard, and he was picked up the ninth day off the coast of Newfonndland, on a bar, eating rushes." 'This. silly and ridiculous story had been told and possibly believed by 
some fools more than a hnndred years before the dates here implied by Mr. Leavens. It is probable it was first told as a joke, by some wag in Rhode Island, when asked about the origin of the Narragansett pacers. He replied that the original Narragansett "was canght swimming in mid-ocean, when a ship came along, lassoed him, pulled him on board, and landed him safely in Narragansett Bay." The vitality of the joke probably had its origin in the experience of Rip Van Dam, when in 1711 he went up to Narragansett for a flying pacer, which is related in another part of this volume. Mr. Leavens speaks of the Rev. Erastns as the owner of the dam, and the breeder of the horse; but he says the horse did not come into possession of Isaac Morden till he was six or eight years old. The date of his death is fixed by Mr. Leavens in 1835, and while he is more definite than our information from other sources, all agree he died from a kick about that year.

The next representation that seems to be worthy of noticing is a communication that appeared in the New York Sportsman, written by somebody who signs himself "Dick." Whether "Dick" is in earnest and believes what he writes, or whether he is merely trying to "sell" somebody, we will leave for him to decide. He seems to depend upon Mr. Morden, at one time the owner of the horse, as the source of his information. "Dick" says the sire of Tippoo was imported into New York in 1811, and was called Fleetwood. Why did he not tell us by whom the horse Fleetwood was imported? If there was a man in New York in 1811 so big a fool as to import an English stallion at great expense, and then send-him up to the wilderness of Canada where there was. neither money nor mares, his name should be handed down as a. historical curiosity. The whole story is a "fake."

In January, 1883, I received from the Hon. J. P. Wiser, of Prescott, Ontario, the following letter, which he had just received from the writer:

Wellington, December 27, 1882.

As the origin of the Tippoo horses seems to be a mystery to you I will tell you. Erastus Howard was a traveling preacher in those days, and he traveled on horseback. He bought in Kingston a dark chestnut mare and bred her to a horse called "The Scape Goat," brought from Narragansett Bay, in Rhode Island. The horse was a large brown horse, und could rack (pace) faster than he could run. The colt was coal black and large, and was sold to Mr. Wilcox, who named him Tippoo Sultan. His gait was like the "Scape" some, but soon squared off to a trot, and the way he could go was dreadful. In June, 1836, he broke his leg and was lost.

WILSON SERLS. 
This short letter was a great surprise, for never before had I heard of Mr. Serls. Throngh the kindness of Mr. Wiser he had entered the discussion, evidently withont knowing anything about what representations had been made by others. I I is short, crisp sentences seemed to be an epitome of a history of this horse, which he might be able to give. It will be observed that the traveling preacher, Erastus Howard, is still in the foregronnd, and that Mr. Leavens" "Escape" and Mr. Serls' "Scape Goat" are evidently one and the same horse, and thus these two men practically confirm each other, so far as the identity of the horse is concerned. No time was lost in preparing a series of questions to be submitted to Mr. Serls, embracing the sources of his information, for although well advanced in years he certainly conld not have had personal knowledge of what he testified. These questions not only covered the minute points in the history of the matter, but they were so framed as to test the accuracy and honesty of his memory. In due time they came back fully and satisfactorily answered, and as these answers embrace many things that my readers care nothing about I will condense them into narrative form.

Mr. Serls derived his information from his uncle, Stephen Niles, the brother of his mother. In 1798 Stephen Niles took a band of horses to Prince Edward County, and stopped with an uncle of his who was then a member of the provincial parliament, living on the Bay of Quinte. His uncle prevailed upon him to settle there. In 1800 he was married, and bought a farm of two hundred acres four miles west of Wellington, where he lived many years, and the place is still known as Niles' Corners. He was an orthodox Quaker in his religions belief, and for a number of years he was one of the bench of magistrates for Prince Edward County. When the War of 1812 broke ont he was employed by the British forces in procuring hay and grain for the mounted troops. In 1858 he died, leaving an honorable name behind him.

At the close of the war the military authorities sold off a large number of horses to the highest bidder, and Mr. Niles was present when the traveling preacher, Erastus Howard, bid off a dark chestnnt mare for ninety-three dollars, at Kingston. This mare afterward became the dam of the famous Tippoo, and as a matter of conrse nothing can ever be known of her breeding. In 1816 a man from Rhode Island, whose name is not definitely remembered, but believed to be Williams, traveled the horse Scape Goat 
through Prince Edward Connty, and he stopped one day and night in each week at the house of Stephen Niles, and during that season Mr. Howard bred his chestnut mare to this horse, and, as already said, the produce was Tippoo. 'This black colt passed into the hands of Mr. Wilcox, who gave him his name, and he afterward passed through several other hands before he reached Mr. Morden abont 18:6, and he died ten years later from the effects of a kick. As the horse Scape Goat was brought from Narragansett Bay, and as he was a remarkably fast pacer, there can be no mistake in ealling him a "Narragansett Pacer." He was considerably larger than the average of that tribe, but this does not vitiate his title to a place in that family. It seems he was only kept in Prince Edward County the one season, and his owner, not being satisfied with the extent of his earnings, took him back to Rhode Island. Thus, the horse that has been proudly designated as "Canada's Messenger," was the son of a Narragansett pacer. In his younger days, Tippoo paced like his sire, but as he grew older the trotting gait was more fully developed.

It is safe to say that the immediate progeny of Tippoo were numerous, and it is safe to say that some of them, either as trotters or pacers, were fast for their day, but it must be confessed that we know very little about the way they were bred. One son was called Sportsman, but nothing is known of his dam and very little of the horse himself beyond the fact that he was the sire of the roan gelding Tacony, that trotted some great races about 1853, and made a record of 2:2\%. This horse had a son called Young Sportsman, that was more widely known as "the Sager Horse," and his horse became the sire of the trotting mare Clara, or Crazy Jane, as she was at one time called, that made a record of $2: 2 \%$ in 186\% Beyond these two representatives of the Sportsman line, I have not been able to go. It has been claimed that amother son of Tippoo, called Wild Deer, was the sire of the Sager Horse, but it does not seem to be well sustained. There was a son called Wild Deer, and several others that have been mentioned by turf writers, but no particulars of any value have been given.

Warrior, or Black Warrior, as he is sometimes called, was a brown horse and not a black, as his latter name would imply. He was a son of old Tippoo and his dam was a black mare owned and ridden by an officer in an English regiment, known as the 
First Royals. She was a black mare and after she was sold out of the service she was called "Black Warrior," and this name was transmitted to her son. This mare was for a long time represented as the dam of Royal George, but she was the dam of his sire. This horse was bred at Belleville, Ontario, and about 1840 a certain Mr. Johnston was moving from Belleville to Michigan. He had this horse with him, which, becoming lame on the way, he traded to a Mr. Barnes, living about twenty miles south of London, Ontario. He was a valuable horse and left many very useful animals. Many of his get were pacers, and he was kept by Mr. Barnes till he died.

Royal George was a brown-bay horse, foaled about 1842, and was got by Warrior, son of Tippoo. His dam was the off one of a pair of bay mares taken to that vicinity from Middlebury, Vermont, by a Mr. Billington. This mare got her foot in a $\log$ bridge and the injury made her a comparative cripple for life. Being thus unfitted for road work, Mr. Billington sold or traded her to Mr. Barnes. She was bred to Warrior and produced Royal George. It is said by those who knew both animals, that this mare was a better trotter than Warrior, and from this springs the argument that Royal George had a trotting inheritance from his dam as well as from his sire. To learn whence this inheritance came, I have labored assiduously for years without being able to technically determine it. The single fact that her sire in Vermont was known as "the Bristol Horse," is beyond all doubt, but as Mr. Billington was not living when this search was commenced, it has not been possible to determine just what horse is meant by "Bristol Horse." At one time Harris' Hambletonian was known very widely as "Bristol Grey" or "Bristol Horse," and this is the only horse in the records so designated. It may, therefore, be assumed as more than a probability that this was the sire of the dam of Royal George.

When three or four years old he was sold by Mr. Barnes to James Forshee, and he was known as "the Forshee Horse" for several years. He was sixteen hands high, not very handsome, but well formed, with plenty of substance and stamina, good action, and a first class "business" horse for anything that was wanted of him. In the stud, at low prices, he was largely patronized, and during the other months of the year he was employed in all kinds of drudgery. From Forshee he passed to Frank Munger, and from Munger to Mr. Doherty, of St. Cather- 
ines, for four hundred dollars, and he gave him the name of Royal George, and kept him many years. In 1858 W. II. Ashford, of Lewiston, New York, bought him and kept him two or three years there and at Buffalo. He seems to have passed into Doherty's hands again, and died at St. Catherine's, December, 1862. It is not known that he ever had any training as a trotter except what he got from his owner on the road, and there is no tradition of his ever having been in a race but once, and that was on the ice at Hamilton, about 1852, against the famous State of Naine, for a considerable wager. In this contest he was the winner. His highest rate of speed was about 2:50 under the saddle. He was strongly disposed to pace, but when he got down to his work his gait was a square, mechanical trot. $\mathrm{He}$ left a numerous progeny with a heavy sprinkling of pacers among them; they were generally of fine size and very useful animals. Many of his sons were kept entire and that whole region of Ontario was filled up with Royal Georges, to say nothing of the large numbers that were brought across the border. He left one representative in the $2: 30$ list, and five sons that became sires of performers.

Toronto Chief was the best son of Royal George, according to the records. He was a brown horse, foaled 1850, and was bred by George Larue, of Middlesex County, Ontario. His dam was a small bay mare by a horse called Blackwood, and his grandam was by Prospect. The horse Blackwood "was bought of a Frenchman below Montreal in 1837,"' and that is all that can be said of his blood. He was a horse of fine size and went with great courage. Toronto Chief passed through several hands before he reached his owner, A. Bathgate, of New York. He was a horse of great speed for his day, having a record of $2: 31$ in harness and $2: 24 \frac{1}{4}$ under saddle. He left three representatives in the $2: 30$ list, and among them the famous Thomas Jefferson, $2: 23$, with thirty-nine heats to his credit. Six of his sons became sires of trotters, and five of his daughters producers. Like all the other minor families, the Royal George family is surely being absorbed or submerged in trotting strains of more positive and uniform prepotency.

It is probably true that Old Columbus and Old St. Lawrence were both descended from the Tippoo family, as they were both bred in Canada and seemed to possess and transmit the same characteristics as the Royal Georges possessed, in conformation 
and gait. Their descendants were not numerous, but so many of them were able to show snch a rate of speed, either at the lateral or diagonal gait, that they left a distinct trace on the trotting stock of the United States. Old Pacing Pilot has always been classed as a Canadian, but no trace of his origin has ever been secured, and it is impossible at this day to give any definite information as to whether he was bronght from Canada or not. Some forty or fifty years ago the "Canadian pacers" were so highly esteemed for their speed that very many horses were called "Canadians" that never saw Canada. The original Tom Hal was purchased in Philadelphia as early as $18 \% 8$, and was always called a Canadian. He was the progenitor of the great pacing family still bearing his name, that is donbtless the most noted pacing family now in existence. Sam Hazzard, it is said, was brought from Canada about 1844, and left some noted descendants. Many others might be named, but as they never gained great celebrity, and as their origin is not fully established, I will leave the Canadians for future investigator's.

The rich province of Ontario has always been, in all its ways, the most English section of the Canadian Confederation, and in nothing more than in horsemanship. True, it is now a great trotting region, but running is and always has been the sport of the rich and fashionable, and almost all the English horses imported in Canada have gone to Western Ontario. On the other hand, in the Maritime Provinces-New Brnnswick, Nova Scotia, and Prince Edward Island-running races have never been popular, except at Halifax, which is a great military station and socially and otherwise mnch inflnenced by its English army and navy residents. It is the only point in the provines where running meetings are given or where the rmning horse is at all cherished. For generations the principal sport of the people of these provinces has been trotting and pacing races, winter and snmmer, for ice racing is very general and very popular, through Maritime as well as Western Canada, the numbers of great bays and wide rivers affording ample conrses, everywhere, throughont the long winters. Though there is, throngh these provinces, a generous sprinkling of horses called French Canadian, it is a fact that when we write the horse history of Maine we have written that of the Maritime Canadian provinces. The best of the early trotting stock of these provinces came from Maine, and the most and the best of the old-time trotters of New Brmswick, Nova 
Seotia, and Prince Edward Island were of tribes lonsely described as Maine Messengers. For this there are ample geographical and natural reasons. That part of Qnebee nearest them has never been rich in horses nor in anything else which the Provincials want, or in which they trade. The people of eastern New England are their natural trading neighbors, and the city of St. John, New Brunswick, especially in the past, the common market place; and almost all the earlier Maritime trotting sires trace throngh St. John to Maine, or some of the other New England States. It is a fact, too, that for generations enterprising horsemen, in the lower proviuces, have been importing American trotting stallions for service, and to-day the trotting stock of these provinces is very thoroughly Americanized. While the exportation of horses, principally to Boston and Bangor, is one of the industries of Nova Scotia and of Prince Edward Island especially, almost without exception trotting and pacing stallions in use there are imported American liorses, or the descendants of American trotting sires; while, as we have noted, the foundation stock came chiefly from Maine, and in very small degree from Ontario or Quebec. In either of the Maritime provinces it is a rarity to find a trotting horse that has not more or less of Ameri. can blood. 


\section{CHAPTER XIII.}

\section{ANTIQUITY AND HISTORY OF THE PACING HORSE.}

The mechanisu of the different gaits-The Elgin Marbles-Britain becomes a Roman province-Pacers in the time of the Romans-Bronze borses of Venice-Fitz Stephen, the Monk of Canterbury-Evidence of the Great Seals-What Blundeville says-What Gervaise Markham says-What the Duke oi Newcastle says-The amble and the pace one and the same-At the close of Elizabeth's reign-The Galloways and Hobbies-Extinction of the pacer-The original pacer probably from the North-Polydore Virgil's evidence-Samuel Purchas' evidence-The process of wiping out the pacer-King James set the fashion-All foreign horses called "Arabians" -The foreigners larger and handsomer-Good roads and wheeled vehicles dispensed with the pacer-Result of prompting Mr. Euren-Mr. Youatt's blunder-Other English gentlemen not convinced there ever vere any pacers.

In considering the antiquity and history of the pacing horse, it seems to be necessary that we should have a clear perception of the mechanism of the gait from which he takes his distinctive name and the relation which that mechanism bears to other gaits or means of progression. In the study of this mechanism we learn the combination by which we unlock the mystery that has puzzled so many breeders of the past and present generations. Some have maintained that the pace is a combination of the trot and the gallop, while a smaller number have maintained that the fast trot was a combination of the pace and the gallop. It is quite evident, as I will be able to show, that neither of these parties has ever given any careful attention and study to the mechanism of the different gaits. The most simple and least complicated method of illustrating this mechanism of movement is furnished in the human means of progression. At the walk, a man steps off with his left foot and the heel of that foot strikes the ground before the toe of the right foot leaves it. Then the right foot advances and strikes the ground before the toe of the left foot leaves it. This is the natural "heel and toe" walk, and the speed may be increased by quickening the step and extending tha stride, so far as physical conformation will permit. Still 


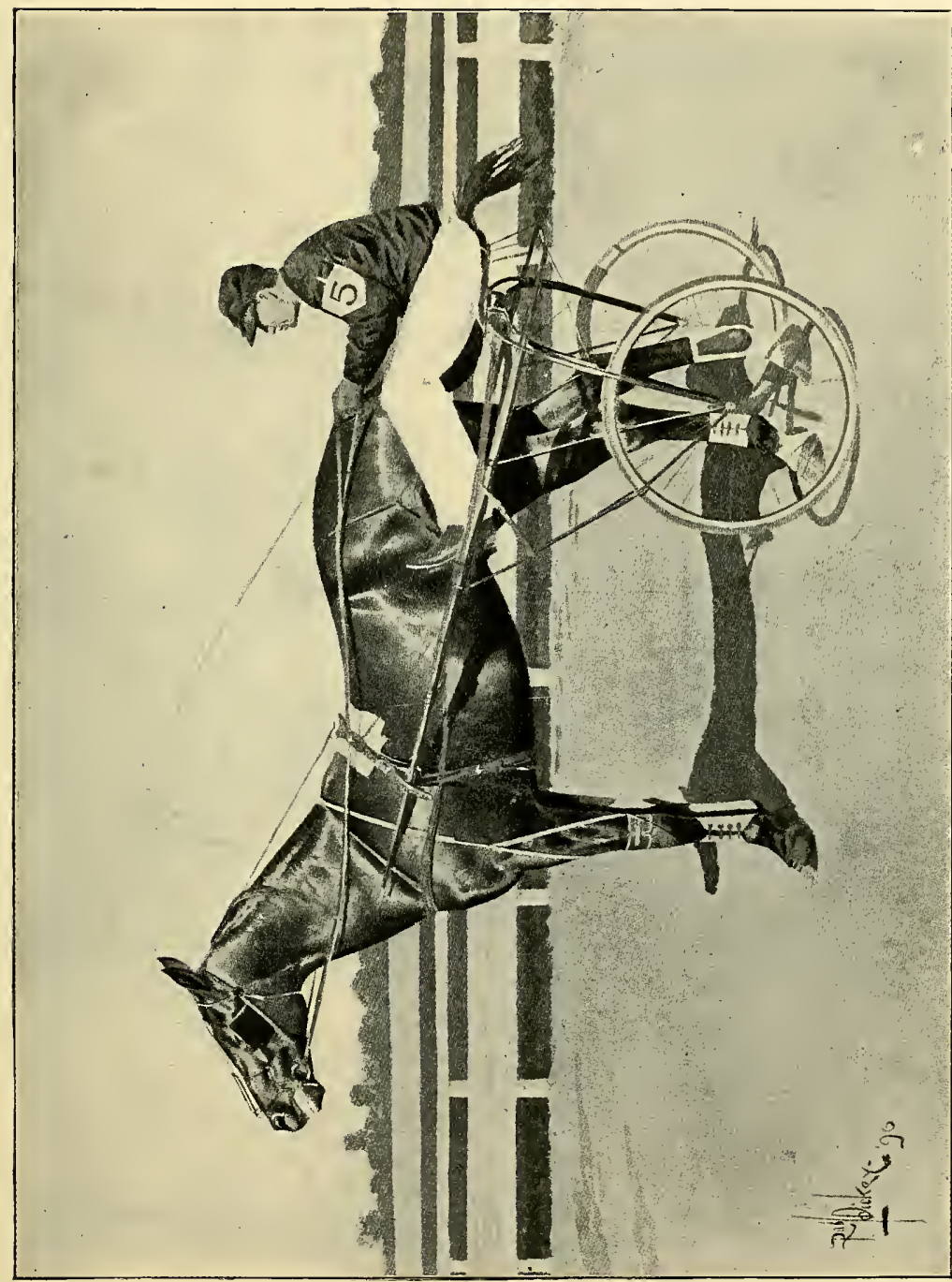

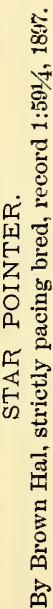



greater speed becomes a succession of bounds, the propelling foot leaving the ground before the advanced foot strikes it. 'This is rumning, the highest rate of speed attainable, and in every revolution, for a space, the whole body is in the air. In the action of the horse, with four legs, we find greater complication, which I will try to make clear.

First, all horses walk, all horses pace or trot, and all horses gallop. The walk is easily analyzed, for it is slow and the movement of each limb can be followed by the eye. Each foot makes its own stroke upon the ground, and we count one, two, three, four in the revolution.

Second, at the gallop, which is a succession of leaps, each limb, as shown by the instantaneous photograph, performs its own function, whether in rising from the ground, flying through the air, or in striking the ground again. There is harmony in all, but there is no unity in any two or more of them, and when they strike the ground again you hear the impacts, one, two, three, four, in a cluster. The conventional drawing of the running horse in action is impossible in nature, and a wretched caricature of the action as it is: As in the walk, so in the run, we count four impacts in the revolution.

Third, at the pace the horse advances the two feet, on the same side, at the same time, and when they reach the ground again there is but one impact; then the two feet on the other side are advanced and strike in the same way. 'Thus, the rhythm of the action strikes the ear as that of the movement of an animal with two feet instead of four. In this there can be no mechanical mistake, for $i$ in the revolution of the four-legged pacing horse we count one, two, and in the revolution of the two-legged man we count one, two. The conclusion, therefore, seems to be inevitable that the two legs on the same side of the pacing horse. act in perfect unison in performing the functions of one leg. At the trot the horse advances the two diagonal feet at the same time, and when they reach the ground again there is but one impact; then the two other diagonal feet are advanced and strike in the same way. Thus, the rhythm of the action strikes the ear as that of the movement of an animal with two feet instead of four. In this there can be no mechanical mistake, for in the revolution of the four-legged trotting horse we count one, two, and in the revolution of the two-legged man we count one, two. The conclusion, therefore, seems to be inevitable that the two. 
diagonal legs of the trotting horse act in perfect unison in performing the function of one leg. In the mechanism of the gait then that is midway between the walk and the gallop there is no difference in results, nor distinction in the economy of motion, except that the pacer uses the lateral legs as one, and the trotter the diagonal legs as one. In use, there is a vertical distinction, if that term should be allowed, between the gait of the pacer and the trotter. The action of the pacer is lower and more gliding which fits him for the saddle, while the action of the trotter is higher and more bounding which makes him more desirable as a harness horse. In the processes of inter-breeding to the fastest, this distinction, if it be a distinction, seems to be coming less real, or at least less observable.

While the essential oneness of the pace and the trot is indicated above from the mechanism and unity of the two gaits, there is a great mountain of evidence to be developed when we reach the consideration of breeding subjects, in which we will meet multitudes of fast trotters getting fast pacers, and fast pacers getting fast trotters; fast pacers changed over to fast trotters and fast trotters changed over to fast pacers, and the final evidence that speed at the one gait means speed at the other. Having briefly explained what a pacer is, it is now in order to take up the question of whence he came.

On the summit of the Acropolis, in Athens, stand the ruins of thie Parthenon, a magnificent temple erected to the goddess Minerva. The building was commenced in the year B.c. 437, and was completed five years afterward. All the statuary was the work of the famons Phidias and his scholars, made from Pentelic marble. This noted building resisted all the ravages of time, and had, in turn, been converted into a Christian temple and a Turkish mosque. In 1676 it was still entire, but in 1687 Athens was besieged by the Venetians, and the Parthenon was hopelessly wrecked. As a ruin it became the prey of the Turks and all other devastators, and in order to save something of what remained of its precious works of art, Lord Elgin, about the year 1800, brought home to England some portions of the frieze of the temple, with other works of Phidias, in marble, sold them to the government, and they are preserved in the British Museum. This frieze is a most interesting subject to study, not only as a specimen of Greek art of the period of Pericles, but as a historic record of the type and action of the Greek horses of that day. 
It consists of a series of white marble slabs, something over four feet wide, upon which are sculptured, in high relief, the heroes and defenders of Athens, mounted on horses, and some of these horses are pacing, while others are trotting and cantering. 'This is the first undoubted record we have of the pacer, and it is now over two thousand three hundred and thirty years old.

Britain became a Roman provinee in the reign of Claudius, in the first part of the first century of the Christian era, and it continued under the Roman yoke until A.D. 426, when the troops were withdrawn to help Valentinian against the Huns, and never returned. When Julius Cras first invaded Britain, in the year B.c. 55, he found the inhabitants fierce and warlike and abundantly supplied with horses and war chariots. These chariots were driven with great daring and skill, and the fact was thus demonstrated that this kind of warfare was not a new thing to the Britons, and that they were not to be easily subdued. 'The next year he returned again, but the second seems to have been no more suceessful than the first expedition. But little is known of the extent of territory overrun or the result of these invasions beyond the fact that no sett,tlement was made then, and none till about ninety years afterward, when under the reign of Claudius, a strong military colony was planted there and Britain became a Roman province. During these centuries of bondage we know practically nothing of the lives of the slaves and but little of their masters, except the remnants of military works for aggression and defence, and the magnificent roads they constrneted whereever they moved their armies. In relation to their horses, I will make a few extracts from a work published about the beginning of this century, by Mr. John Lawrence, a man of great research and intelligence, besides of a wide acquaintance with the practical affairs of the horse, and, I may add, altogether the most reliable writer of his period. He says:

"In forming the paces, if the colt was not naturally of a proud and lofty action, like the Spanish or Persian horses, wooden rollers and weights were Lound to their pastern joints, which gave them the habit of lifting up their feet. This method, also, was practiced in teaching them the ambulatura, or amble (pace), perhaps universally t e common traveling pace of the Romans.

"That natural and most excellent pace, the trot, seems to have been very little prized or attended to by the ancients, and was, indeed, by the Romans beld in a kind of contempt, or aversion, as is demonstrated by the terms which served to describe it. A trotting horse was called by them succussator, 0 : shaker, and sometimes cruciator, or tormentor, which bad terms, it may be pre- 
sumed, were applied specially to those which in these days we dignify with the expressive appellation of "bone-setters.'"

The statuary of the early ages furnishes some excellent illustrations of the gait of the horse at that period of the world's history. The four bronze horses on St. Mark's in Venice are known throughout the world, and they are in the pacing attitude. The forefoot that is advanced is possibly a little too much elevated to strike the ground the same instant the hinder foot should strike it, but the whole action indicated is nndoubtedly the lateral action. The date of these horses is lost in history, but it is supposed they were cast in Rome, abont the beginning of the Christian era. Their capture in Rome and transfer to Constantinople, then their capture by the Venetians and transfer to Venice, next their capture by Napoleon and transfer to Paris, and then their restoration to Venice, are all matters of history.

William Stephanides, or Fitz Stephen, as he was called, a monk of Canterbury, was born in London, lived in the reigns of King Stephen, Henry II., and Richard I., and died 1191. He wrote a description of London in Latin, which was afterward translated by John Strype, and printed, from which I take the following extract:

"There is without one of the gates, immediately in the suburb, a certain smooth field (Smithfield) in name and reality. There every Friday, unless it be one of the more solemn festivals, is a noted show of well-bred horses exposed for sale. The earls, barons and knights who are at the time resident in the city, as we l as most of the citizens, flock thither either to look or to buy. It is pleasant to see the nags with their sleek and shining coats, smoothly ambiing (pacing) along, raising and setting down, as it were, their feet on either side; in one part (of the field) are horses better adapted to the esquires; those whose pace is rongher, yet expeditious, lift up and set dmon, as it were, the two oppowice fore and hind feet (trotting) together."

After locating and describing the pacers in one part of the field and the trotter's in another, Fitz Stephen goes on to take a look at the colts, then horses of burden, "strong and stout of limb," and then their chargers in their galloping action. He next gives a very spirited description of the race, when the people raise a shout and all the other horses, cattle, etc., are cleared away, that the contestants may have an unobstructed field. It is a fact worthy of note that every English writer on the race horse, for the past century or two, has quoted a part of the above paragraph from Fitz Stephen as the first known and recorded instance of 
racing in England, but left one of the most important parts out. Even Mr. Whyte, one of the most prominent of modern writers, in his "History of the British 'Turf," seems to have followed some other writer, in the omission; or possibly, as he never had seen a pacer in England, he concluded that Fitz Stephen had only imagined that he saw, in one part of the field, horses moving at the lateral gait. In the paragraph quoted above, I have italicised that part of the description which English writers on turf subjects have omitted with remarkable uniformity.

This seems to have been the period in which the pacing horse reached the highest point in official and popular appreciation, at least since the days of the Roman occupation of Britain. In speaking of this period, Mr. Lawrence says: "All descriptions of saddle horses were tanght to amble" (that did not amble naturally), "and that most excellent and useful gait, the trot, was almost entirely disused." In addition to the evidence of Fitz Stephen, we have that furnished by the Great Seals of a succession of sovereigns commencing with Richard I., and continuing to Elizabeth. These seals represent a knight in armor, mounted on a pacing horse in action, and perhaps the most conspicuons, at least the clearest, impression that has come down to us is that of King John, used at Runnymede, when he yielded to the demands of his barons and granted the Magna Charta. This act secured the liberties of the Anglo-Saxon race for all time and in all climes.

Mr. Thomas Blundeville was, probably, the first writer on the horse who undertook to publish a book in the English language on that subject. This book, entitled "The Art of Riding," was merely a translation from the Italian, with some brief observations on English horses added to it. The first edition, it is said, was published iir London, 1558, the year that Queen Elizabeth ascended the throne. The only edition which I have been able to find in the British Museum is that of 1580, in old English black letter. In quoting from the old authors of that perior I will seek to avoid confusion by using the modern orthography. In speaking of the horses of his day he says:

“Some men would have a breed of great trotting horses meet for the war and to serve in the field. Some others again would have a breed of ambling horses of a mean stature for to journey and travel by the way. Some, again, would have a race of swift runners to run for wagers or to gallop the buck, or to serve for such like exercise for pleasure. But the plain countryman would have a breed only for draft or burthen. 
“ The Irish Hobbie is a pretty fine horse, having a good head and a body indifferently well proportioned, saving that many of them be slender and pinbuttocked. They are tender-mouthed, nimble, pleasant and apt to be taught, and for the most part they be amblers and thus very meet for the saddle and to travel by the way. Yea, and the Irishmen, both with darts and light spears, do use to skirmish with them in the field, and many of them do prove to that. use very well, by means they be so light and swift.

" Let those mares that shall be put to the stallion be of a high stature, strongly made, large and fair, and have a trotting pace as the mares of Flanders aud some of our own mares be. For it is not meet, for divers reasons, that horses of [service stallions] should amble. But if any man seeks to have a race of ambling horses, to travel by the way, then $I$ would wish his stallion to be a fair jennet of Spain, or at least a bastard jennet, or else a fair Irish ambling Hobbie; and the mare to be also a bastard jennet, bred here within this realm, having an ambling pace, or else some other of our ambling mares, so that the mare be well proportioned. And if any man desires to have swift runners let him choose a horse of Barbary or a Turk to be his stallion, and let the mare, which shali be put unto him, be like of stature and making unto him, so nigh as may be, for most commonly, such sire and dam such colt."

It is evident Mr. Blundeville was not much of a friend of the pacer, but as an honest writer he considers things as he finds them. Unfortunately he throws no light upon just what he means by the term "Spanish Jennet," and a definition of that term, as used in the sixteenth century, would throw much light on passages from following writers in later periods. Everybody knows he was a small Spanish saddle horse, but nobody knows just what gait he took. To use Blundevilles own language, "The pace of the jennet of Spain is neither trot nor amble, but a comely kind of going like the Turke."

Mr. Gervaise Markham published several revised and enlarged editions of his work on the horse, the last of which I have been able to examine being printed in London, 160\%, the same year the colony was planted at Jamestown, Virginia. In this edition he devotes nine short chapters or paragraphs to the pacer. In quoting from him I will again use the modern methods of spelling. He says:

"First to speak of ambling in general. It is that smooth and easy pace. which the labor and industry of an ingenious brain hath found out to reliere the aged, sick, impotent and diseased persons, to make women undertake journeying and so by their community to grace society; to make great men try the ease of travel, more willing to thrust themselves into the offices of the commonwealth, and to do the poor both relief and service. It makes them whens necessity, or as the proverb is, "when the devil drives," not to be vexed with the two torments, a troubled mind and a tormented body. To conclude, am- 
bling was found out for the general ease of the wlole world, as long as there is either pleasure, commerce or trade anıngst the people. Now for the nanner of the motion and the difference betwixt it and trotting. It cannot be described more plainly than I have set down in my former treatise; which is that it is the taking up of both legs together upon one side and so carrying them smoothly along to set them down upon the ground even together, and in that motion he must lift and wind up his fore foot somewhat high from the ground, but his hinder foot he must no more than take from the ground, as it were, sweep it close to the earth. Now, by taking up both his legs together on one side, I mean he must take up his right fore foot and his right hinder foot. For, as in the contrary pace, when a horse trots be takes up his feet crosswise, as the left hinder foot and the right fore foot, etc."

Mr. Markham, in his edition of $160 \%$, then goes on in six or eight chapters acknowledging that many foals pace naturally, and to show how the foal may be trained to pace. His methods are very cruel, in many cases, and very crude throughout; but it clearly demonstrates the fact that in the sixteenth century the pace was a very general gait among English horses. In these chapters we find the toe weight first introduced as well as the trammels or hopples. The most striking fact brought ont in these chapters is the discovery that more than three hundred years ago Englishmen were using the same devices to convert trotters into pacers that we are now using to convert pacers into trotters. He takes notice that Mr. Blundeville had advised those who wished to breed amblers to select a Spanish jennet or an Irish Hobbie, and objects to the former on the grounds that their paces are weak and uncertain. From this I conclude that the gait of the jennet, whatever it might have been, was not a habit of action fixed in the breed, and that its transmission was doubtful.

Mr. Markham then goes on further to explain the mechanism of the trot and the pace and incidentally introduces the rack or single-foot action, which, I think, is the first time I have found it in any English writer. He says:

"The nearer a horse taketh his limbs from the ground, the opener and evener and the shorter he treadeth, the better will be his pace, and the contrary declares much imperfection. If you buy a borse for pleasure the amble is the best, in which you observe that he moves both his legs on one side togethe" neat with complete deliberation, for if he treads too short he is apt to stumble, if too large to cnt and if sbnffling or rowling he does it slovenly, and besides rids no ground. If your horse be designed for hunting, a racking pace is most expedient, which little differs from the amble, only is more active and nimble, whereby the horse observes due motion, but you must not force him too eagerly, 
lest being in confusion he lose all knowledge of what you design him to, and so handle his legs confusedly. The gallop is requisite for race horses. . . . If he gallop round and raise his fore legs he is then said to gallop strongly, but not capabie of much speed, and is fitter for the war than racing."

In $166 \%$ the Duke of Newcastle published his famous work on the horse under the title, "A New Method and Extraordinary Invention to Dress Horses, and Work them According to Nature and also To Perfect Nature by the Subtilty of Art which was Never Found Out, but by the Thrice Noble, High, and Puissant Prince, William Cavendish, Duke, Marquess, and Earl of Newcastle, etc., etc.," followed with twelve other titles and offices. The book was dedicated to "His Most Sacred Majesty, Charles the Second," and is pretentions and magniloquent in its letter press and its make-np as it is in its title. In this work there is a great deal of bad English, some sense, and much nonsense, all mixed np with a strut of superiority that His Grace, no doubt, felt justified in enjoying after his long years of beggary in Antwerp. In giving the natural gaits of the horse he places the walk first, then the trot and next the amble, which he describes very minutely as follows:

"For an amble he removes both his legs of a side, as, for example, take the far side, he removes his fore leg and his hinder leg at one time, whilst the other two legs of the near side stand still; and when those legs are on the ground, which he first removed, at the same time they are upon the ground the other side, which is the nearer side, removes fore leg and hinder leg on that side, and the other legs of the far sidestand still. Thus an amble removes both his legs of a side and every remove changes sides; two of a side in the air and two upon the ground at the same time. And this is a perfect amble."

The duke seems to have been somewhat profuse in the use of words, and not very happy in his use of them, but after all we know jnst what he means. The description of the movement is that of the clean-cut pace, and our object in introducing it here is not only to show that the pace was then a. well-known and natural gait in England, bnt also to show that the pace and the amble are one. In itself, the word "amble" is a better word than "pace," for the latter is often used in referring to a rate of speed withont regard to the particular gait taken by the horse, but in this country it is now universally understood to apply to the lateral motion, and it would not be wise at this day to attempt to change it. There is an undefined supposition in the mind of some people that the amble is something different from the pace, 
that it is a slower and less pronounced gait, and hence we are often told a given horse did not pace, but "he ambled off." In all that we have found in the writings of the past, and in all that I have seen with my own eyes, I have not been able to discover that there is any distinction between the amble and the pace. The only distinction is not in the gait itself, but in the fact that our ancestors, four hundred years ago, used the word "amble" to express precisely the same thing that their descendants now express by the word "pace." The only sense in which the word "amble" is used among the horsemen of this country is to describe a kind of slow, incipient pace that many horses, both runners and trotters, show when recalled for a fresh start in scoring for a race. This probably indicates, whether in the case of a runner or a trotter, that somewhere, not very far removed, there is a pacing inheritance, and this incipient amble, as it is sometimes called, comes from that inheritance. It is also possible that it may arise from the excitement of the start and the confusion consequent upon the contest.

At the close of Queen Elizabeth's reign, about the beginning of the seventeenth century, the pacing horse of England was at the highest point of his utility and fame. He was the horse for the race course, he was the horse for the hunting field, and he was the horse for the saddle. He was able to beat King James' Arabian, and with the few Barbs that had then been brought in, the historian informs us, he was able to hold his own. There were two tribes of his congeners, the Galloway and the Irish Hobbie, the former from Southwestern Scotland and the north of England, and the latter from Ireland. These tribes were chiefly pacers, and not a few of them were distinguished as rumning horses. The Bald Galloway, as he was called, was a grand representative of his tribe. He was simply a native pony with a bald face, and he was a capital runner for his day, and a number of his get were distinguished runners. True, he is tricked out in the Stud Book with a pedigree, wholly fictitious, and that nobody ever heard of for a hundred years after he was foaled, but that did not prevent his daughter Roxana, when bred to Godolphin Arabian, from producing two of his greatest sons, Lath and Cade. This topic, however, has already been considered in the chapter on the English Race Horse. The Galloways were very famous as pacers in their day, and it seems they were about the last remnants of the pacing tribes to be found in England. It 
seems, also, that long after they had ceased to be known on the other side their descendants were still known by the same designation in Virginia. From the history of the times, it appears that a wealthy Irish gentleman invested quite largely in shipping live stock to Virginia, and there can hardly be a doubt that his. shipments included some of the Irish Hobbies.

While the opening of the seventeenth century witnessed the supremacy of the English pacer, in the uses'and enjoyments of the lives of the people, during the whole course of its succeeding years he was battling for his existence, and at its close he was nearly extinct. At the close of Queen Anne's reign there were still a few Galloways left, but in the early Georges there were no longer any survivors, and Great Britain was without a pacer in the whole realm. The extinction of a race of horses that had been the delight of the kings, queens, nobility, and gentry of a great nation for many centuries is, perhaps, without a precedent in the history of any civilized people, and the canses which produced this wonderful result are well worthy of careful study. In looking into these causes we must consider the facts as we find them.

As we have no guide, either historic, linguistic or ethnographic, by which we can certainly determine the blood of the original inlabitants of the British Isles, it is not remarkable that we should be in profound ignorance as to the blood of their horses. They were, doubtless, like their masters, of mixed origin, and throngh all the centuries their appearance would indicate that they have been bred and reared in a nomadic or semi-wild state, in which only the toughest and fleetest had survived. A good many years ago I met with a theory, advanced by somebody, that. the original horse stock of Britain came from the North, but there were no reasons given to support it. I have no hesitation in accepting this theory, as far as it distinguishes between the North and the South, for some Northern countries produce vast. numbers of natural pacers, as Russia, for instance, but I have never learned that any Southern country produced pacers. Certainly the shaft horse of the Russian drosky has been a flying pacer for generations, and great numbers of them are produced in Russia, especially in the eastern part of the empire. As these pacers are produced in a natural and semi-wild state, it must be conceded that habits of action have been inherited from their ancestors in the remote past. Historically, we know that the 
Phœnicians, when they ruled the trade of the world, supplied the whole of the northern coast of Africa, from Egypt to Algiers, and the southern coast of Spain, with horses, abont a thousand years before the Christian era. Now, the horses of those regions are the descendants of the original stock carried there by the Phœnicians, and we know their habit of action is not that of the pacer. Hence the conclusion that the English pacer came from the North and not from the Sonth. In speaking of the difference in the gaits of Northern and Southern horses, Mr. John Lawrence specifies the horses of Norway, Sweden, Denmark, etc., and says: "They are round made, but with clean heads and limbs; their best pace is the trot (or pace), which indeed is the characteristic pace of the Northern, as the gallop is of the Southern horse." Other writers speak of the trot (or pace) as common to Northern horses, but as not common to Southern horses. Now, as all Southern horses do trot, and as these writers could not fail to know that they trotted, at some rate of speed, we must construe their terms so as to be consistent with plain, common sense. There was something in the "trot" of the Northern horse altogether different from the "trot"" of the Southern horse that rendered his habit of action more conspicuous, probably by his higher rate of speed, but still more probably by the peculiar mechanism of his lateral action. If we insert the word "pace" instead of the word "trot," the meaning of these old writers becomes very plain and in harmony with other known facts. Neither does it militate against the theory that the inhabitants of Britain may have secured their original horse stock from the Phœnician merchants; but if they did, it seems quite evident that at a later date they supplemented their supply from the pacing element from the North.

At the close of the fifteenth century Polydore Virgil, an Italian ecclesiastic, came to England and wrote a descriptive history of the British Islands in Latin, which was published about 1509. Part of this history was very clumsily translated about the time the English language began to assume its present form in literature and learning. In speaking of the horses of the country, he seems to have been greatly surprised with the pacers, and treats them as a curiosity. He says: "A great company of their horses do not trot, but amble, and yet neither trotters nor amblers are strongest, as strength is not always incident to that which is most gentle or less courageous." It will be observed 
that these observations were made nearly four hundred years ago, and that the surprise of the Italian was not at merely seeing a few pacers which he had never seen in his own country, but that "the great company" of English horses were pacers. As I have here given an instance showing the surprise of an Italian at finding pacers, I will follow it with another showing the surprise of an Englishman at not finding any pacers. The chaplain of the Earl of Cumberland, on his several voyages of discovery in South America and the West India Islands, about 1596, made elaborate note of what he saw and learned of the new countries which the English then visited for the first time. These notes passed into the hands of that wonderfully prolific writer, or rather compiler, Samuel Purchas, from whose fourth volume, page 1171, the following paragraph is taken:

“And I wot not how that kind of beast [speaking of cattle] bath specially a liking to these Southerly parts of the world above their horses, none of which I have seen by much so tall and goodly as ordinarily they are in England; they were well made and well mettled, and good store there are of them, but methinks there are many things wanting in them which are ordinary in our English light horses. They are all trotters, nor do I remember that I have seen above one ambler, and that was a little fiddling nag. But it may be if there were better breeders they would have better and more useful increase, yet they are good enough for hackneys, to which use only almost they are employed."

The surprise of the Englishman at finding no pacers in South America seems to have been as great as that of the Italian at finding so many of them in England, one hundred years earlier. These horses were strictly Spanish, and probably were descended from those brought from Palos in 1493 by Columbus, the first horses that ever crossed the Atlantic. The "one little fiddling nag" that showed some kind of a pacing gait may have been of English blood and captured from some English expedition, several of which were unfortunate; or his failure to trot may have been the result of an injury. It should not be forgotten that in that period every sea captain was out for what he could capture, and this was especially the case as between the English and the Spanish. These are the outlines of the principal points of evidence that the pacing habit of action came from the North and not from the South. That there were pacers in both Greece and Rome before the Christian era, and perhaps later, there can be no doubt, for they were both overrun and devastated again and again by the hordes of Northern Barbarians, bringing their flocks 
and their herds and their families, as well as their horses, with them.

This question naturally suggests itself here: "If the English pacer had been the popular favorite of the English people for so many centuries, how did it come that he and his habit of action had been so completely wiped out in one century, the seventeenth?" This question might be answered in very few words, by saying the people thought they were getting something better to put in his place. In reaching this conclusion I will not pretend to say the judgment of the people was not right, that is, if they exercised any judgment in the case. "Jamie the Scotsman" when on the throne set the fashion in the direction of foreign blood by paying the enormous price of five hundred pounds for the Markham Arabian. The Duke of Newcastle, when he was young, had personally seen this horse, and while he thought he was a true Arabian, he described him as a very ordinary horse in his size and form, and an entire failure as a race horse. It seems that any average native pacer could outrun him, but he carried the badge of royalty, and that was sufficient to make him fashionable, as he was not only the king's horse, but was himself a royal Arabian. The weak place in the character of James I., in addition to his intolerable pedantry, was his inordinate ambition to be considered the wisest sovereign who ever sat upon a throne since the days of Solomon. His courtiers, nobility, and all who approached him understood his weakness, and a little quiet praise of the great superiority of the Arabian blood in the horse, over all other breeds and varieties, was always grateful to the monarch, for he was the original discoverer and patentee of that blood. Then and there, in order to praise the wisdom of a foolish king, a foolish fashion grew into a foolish notion that has afflicted all England from that day to this. No humbug of either ancient or modern times has had so long a run and so wide a range as the miserable fallacy "that all excellence in the horse comes from the Arabian." Notwithstanding the thousand tests that have been made and the thousand failures that have invariably followed, from the time of King James to the present day, there are still men writing books and magazine articles on the assumption that "all excellence in the horse comes from the Arabian," without ever having devoted an honest hour to the study of the question as to whether this is a truth or a fallacy. This craze for Arabian blood was the primary cause of the 
extinction of the pacer, and this craze was so strong in its influence that when a foreign horse was brought in, no difference from what country, if he were of the lighter type he was called an Arabian and so advertised in order to secure the patronage of breeders. Horses brought from the African coast were invariably classed as Arabians, notwithstanding they and their ancestors were in Africa more than a thousand years before there were any horses in Arabia; and the same may be said of Spain. But as this line of inquiry has already been considered in another chapter, I will get back to the immediate topic.

The process of breeding out the pacer did not commence in real earnest until the middle of the seventeenth century, when the Stuarts regained the sovereignty of Great Britain in the person of Charles II. Released from the restraints of Puritan rule, the Restoration brought with it a carnival of immorality and vice, for the court and the courtiers set the fashion and the people followed. As the breeding interest of the period of which we now speak has already been considered in the chapter on the English Race Horse, I will not further enlarge upon it. The light, or ruming and hunting, horses of England of that day were not all pacers, but they were all of the same type and the same blood, hence when I speak of the pacers I include their congeners. They were small-less than fourteen hands high-and not generally handsome and attractive. In general utility they were ahead of the importations, and doubtless many of them could run as fast and as far as the foreign horses, but the foreigners had the advantage in size, especially the Turks and the Neapolitans; besides this, they were more uniformly handsome and attractive in their form and carriage. It is also probable that the ontcross from the strangers to invigorate the stock was needed and resulted in the increase of the size of the progeny. This latter suggestion is inferential and has been sustained by many similar experiences, but without this as a start it would be exceedingly difficult to account for the rapid increase in the height of the English race horse. It is certainly true that the chief aim of the English breeder of that day was to increase the size, without losing symmetry and style, and if he found that foreign upon native blood gave him a start in that direction, he was wise in the commingling. Another consideration, growing out of the rural economy of the people, doubtless had a very wide influence in the direction of wiping out the pacer, in this period of transition. 
Long journeys in the saddle became less frequent, good roads began to appear and vehicles on wheels took the place of the saddler and the pack horse. To get greater weight and strength for this service, recourse was had to crosses with the larger and courser breeds, and through these channels have come the giants and the pigmies of the modern race course. Under the changed conditions of travel and transportation it is not remarkable that the people should have been willing to see their long-time favorites disappear, for it is known to every man of experience that the pace is not a desirable gait for. harness work. No doubt the pacer is as strong as the trotter of the same size and make-up, but in his smooth, gliding motion there is a suggestion of weakness communicated to his driver that is never suggested by the bold, bounding trotter. The antagonism between the pacers and the new horses of Saracenic origin was irreconcilable and one or the other had to yield. As the management of the contest was in the hands of the master the result could be easily foreseen, for if one cross failed, another followed and then another, till the Saracenic blood was completely dominant in eliminating the lateral and implanting the diagonal action in its stead.

As no home-bred pacer, of any type or breed, has been seen in England for nearly two hundred years, it is not remarkable that Englishmen of good average intelligence, for the past two or three generations, have lived and died supposing they knew all about horses, and yet did not know there had ever been such a thing in England as a breed of pacing horses. When, some eighteen or twenty years ago, I called the attention of Mr. H. F. Euren, compiler of the Hackney Stud Book, to the early English pacers as a most inviting field in which to look for the origin of the "Norfolk Trotters," he was surprised to learn that such horses had existed in England, but he went to work and gathered up many important facts that appear in the first volume of the Hackney compilation. Many of these facts, but in less detail, had already appeared, from time to time, in Wallace's Monthly, but Mr. Euren's was the first modern English publication to place them.before English readers. From this prompting, $\mathrm{Mr}$. Euren did well, but we must go back a little to see how this subject was treated by English writers of horse books, who wrote without any promptings from this side.

Mr. William Youatt was a voluminous writer on domestic animals, and at one time was looked upon as the highest author- 
ity on the horse, both in England and in this country. He seems to have been a practitioner of veterinary surgery, and from the number of volumes which he published successfully, he must have been a man of ability and education. There can be no question that he knew a great deal-quite too much to know anything well. The first edition of his work on the horse was published in 1831, and soon after its appearance several publishing houses in this country seized upon it as very valuable, and each one of them soon had an edition of it before the public. It purports to have been written at the instance of "The Society for the Diffusion of Useful Knowledge." This declaration was a good thing, in a commercial view, and no doubt it did much in extending the circulation of the book. Without tarrying to note several minor historical blunders, I will go direct to one relating to the gait of the horse, which is now under consideration. In his fourth edition, page 535, he incidentally discusses the mechanism of the pace, and after speaking of the Elgin Marbles, to which I have referred at the beginning of this chapter, and after conceding that two of the four horses are not galloping but pacing, he says:

"Whether this was then the mode of trotting or not, it is certain that it is never seen to occur in nature in the present day; and, indeed, it appears quite inconsistent with the necessary balancing of the body, and was, therefore, more probably an error of the artist."

This remark is simply amazing in an author who pretentiously undertakes to instruct his countrymen in the history of the horse when he knows nothing about that history. If he had gone back only twenty-two years, "Old John Lawrence," in his splendid quarto, would have told him abont the pacer. If he had gone back one hundred and sixty years, the Duke of Newcastle would have explained to him the complete and perfect mechanism of the pacing gait. If he had gone still further back and examined Gervaise Markham, Blundeville, Polydore Virgil, and Fitz Stephen the Monk, of the twelfth century, any and all of them wonld have explained to him the pacing habit of action and shown him that for many successive centuries the pacing horse was the popular and fashionable horse of the realm. If Mr. Youatt had

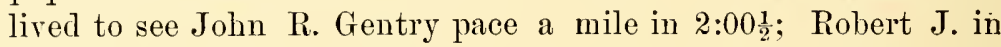

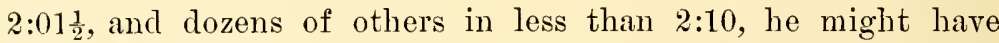
shanged his mind and concluded that it was possible, after all, for 
a horse to travel at the lateral gait without toppling over. From Mr. Youatt and a few other modern English authors, most of our American writers on the horse have derived what little mental pabulum they thought they needed, and thus an error at the fountain has been carried into all the ramifications of our horse literature. Only two or three years ago a very intelligent gentleman, who had attained great eminence as a veterinary surgeon, especially for his knowledge and treatment of the horse's foot, seriously and in good faith stoutly maintained that the pacing habit of action was merely the result of an abnormal condition of the foot, and that all pacers would trot just as soon as their feet were put in the right shape. We must not laugh at this wild notion, for it is really no worse than Mr. Youatt's doubting whether it was possible for a horse to balance himself at the lateral motion. Neither gentleman seemed to know anything about the fact that it was a matter of inheritance, and that the lateral habit of action had come down by transmission through all the generations for a period of more than two thousand years. It is hardly necessary to say that the gentleman who was so confident that the pace was merely the result of the abnormal condition of the feet brought his notions about the pacer from across the water. He was an Anglo-American, and could make a pacer into a trotter in a jiffy, by using the paring-knife. He was an intelligent man and a skillful veterinarian, but there were no pacers in England and there should be none here. Toward the close of the chapter on The Colonial Horses of Virginia, will be found the observations of an English tourist in 1795-96 who is very certain that there is some mistake about the pacer, and will not be convinced there are any, unless they are artificially created. Having now completed what I had to say about the old English pacer, it is next in order to consider his descendants in this country and the relations they bear to the American trotter. 


\section{CHAPTER XIV.}

THE AMERICAN PACER AND HIS RELATIONS TO THE AMERICAN TROTTER.

Regulations against stallions at large-American pacers taken to the West. Indies-Narragansett pacers; many foolish and groundless theories about their origin-Dr. McSparran on the speed of the pacer-Mr. Updilie's testimony-Mr. Hazard and Mr. Enoch Lewis-Exchanging meetings with Virginia-Watson's Annals-Matlack and Acrelius-Rip Van Dam's horse-Cooper's evidence-C'ause of disappearance-Banished to the frontier-First intimation that the pace and the trot were essentially one grait - How it was received-Analysis of the two gaits-Pelham, Highland Maid, Jay-Eye-See, Blue Bull-The pacer forces himself into publicityHigher rate of speed-Pacing races very early-Qtietly and tasily developed-Comes to his speed quickly-His present eminence nut permanentThe gamblers carried him there-Will he return to his former obscurity?

Is the several chapters devoted to "Colonial Horse History" will be found all the leading facts that I have been able to glean from the early sources of information. With the exceptions of the horses brought from Utrecht in Holland to New Amsterdam (New York), two shiploads that sailed out of the Zuider Zee and landed at Salem, Massachusetts, and those brought from Sweden by the colonists that settled on the Delaware, all the early importations came from England. As much the larger number of those from England and Sweden were pacers, the breeds and habits of action were soon mixed up, as those who had no pacers wanted pacers for the saddle, and those who wanted more size, regardless of the gait, were always ready to supply their want by an exchange of their saddle horses for more size. The Dutch horses were certainly something over fourteen hands and the English and Swedish horses were perhaps nearer thirteen than fourteen hands. The colonists from the first, and from one end of the land to the other, seem to have appreciated the importance of increasing the size and strength of their horse stock, and this was very hard to do under the conditions then prevailing of allowing their horses to roam at large. Hence, stringent regulations were 


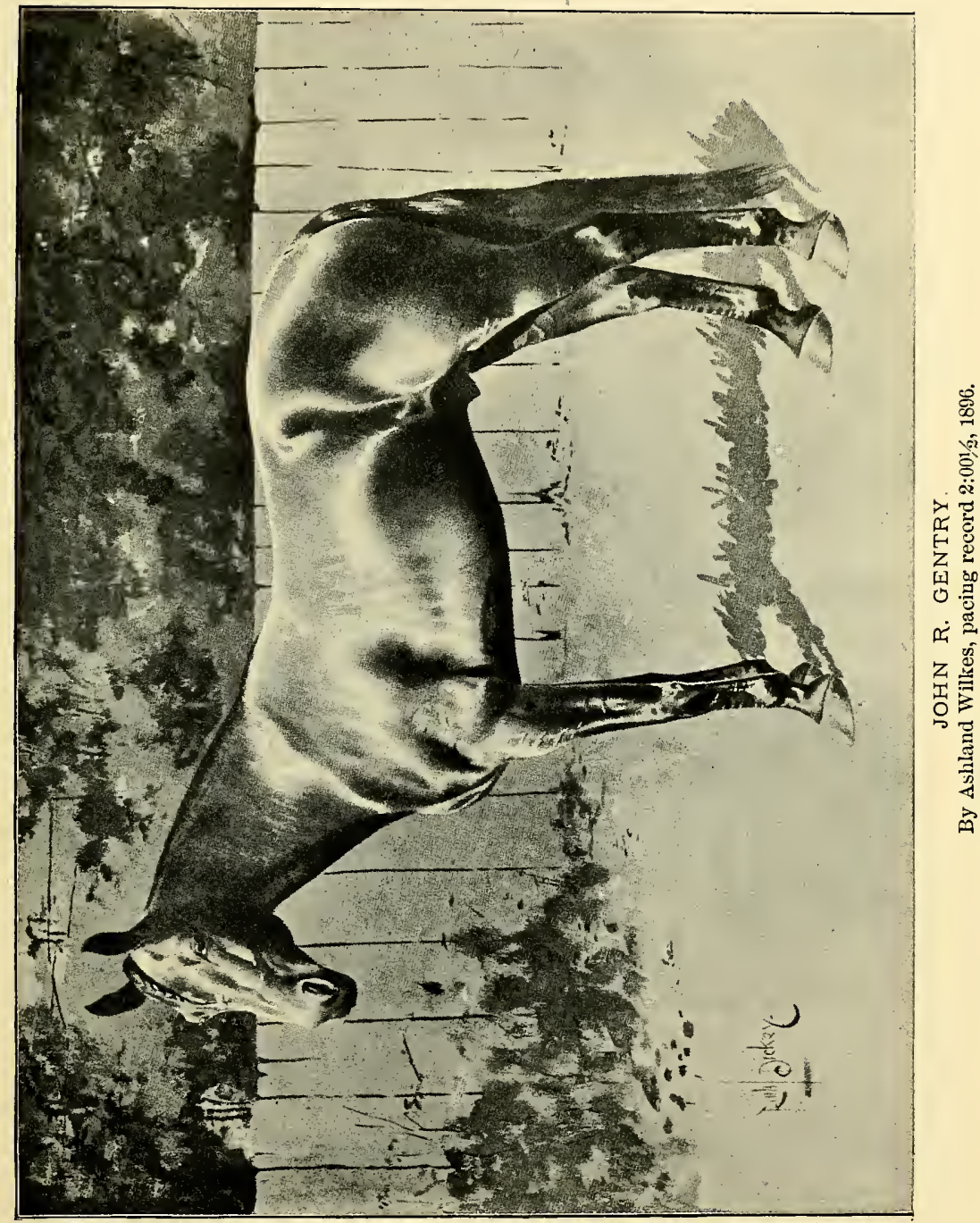



adopted in all the colonies against permitting immature entire colts and stallions under size to wander where they pleased. It is doubtful whether these regulations were any more effective than those of Henry VIII., for while there was some increase, it was hardly perceptible until after the close of the colonial days. The real increase did not commence till the farmers had provided themselves with facilities for keeping their breeding stock at home.

It is very evident from the statistics of size and gait, as given in the chapters referred to above, that our forefathers wisely selected the most compact, strong and hardy animals they could find in England as the type best adapted to fight their way against the hardships of a life in the wilderness of the new world. There have been some attempts, wholly fanciful and baseless, to trace importations from other countries, outside of those mentioned above, but all such attempts have proven wholly imaginary and worse than futile. In less than twenty years after the New England colonies received their first supply they commenced shipping horses by the cargo to Barbadoes and other West India Islands. This trade was cultivated, extended to all the islands, and continued during the remainder of the seventeenth and practically the whole of the eighteenth century. The pacers of the American colonies were exceedingly popular and sought after by the Spanish as well as the Dutch and English islands. Indeed, the planters of Cuba alone carried away at high prices nearly all the pacers that New England could produce. They knew nothing about pacers for the saddle until they had tried them and then they would have nothing else. These continuous raids of the Spaniards of the West Indies upon the pacers of New England, and Rhode Island especially, has been assigned, by the local historians of that State as one of the principal causes of the decadence and practically final disappearance of the Narragansett pacer from the seat of his triumphs and his fame. It is just to remark here, in passing, that if there had been pacers among the horses of Spain, the Spanish dependencies would have secured their supplies from the mother country and not have come to Rhode Island and paid fabulous prices for them.

As all the pacing traditions of this country to-day point to the horses of Narragansett Bay as the source from which our modern pacers have derived their speed, we must give some attention to the various theories that have been advanced as to the 
origin of the Narragansett horse. In time past, and extending back to a period "whereof the memory of man runneth not to the contrary," the horse world has been cursed with a class of men who have always been ready to invent and put in circulation the most marvelous and incredible stories about the origin of every remarkable horse that has appeared. Some of these wiseacres have maintained that the original Narragansett pacer was caught. wild in the woods by the first settlers on Narragansett Bay, while others (and this seems to be of Canadian origin) have insisted that when being bronght to this country a storm struck the ship and the horse was thrown overboard, and after nine days he was found off the coast of Newfoundland quietly eating rushes on a sand bar, where he was rescued and brought into Narragansett Bay. This story of the marine horse probably had its origin in the experiences of Rip Van Dam, which will be narrated further on. Another representation, coming this time from a very reputable source, has been made as to the origin of the Narragansett horse, and as many, no doubt, have accepted it as true, I must give it snch consideration as its prominence demands. $\mathrm{Mr}$. I. T. Hazard, a representative of the very old and prominent Hazard family of Rhode Island, in a letter to the Rev. Mr. Updike, makes the following statement:

"My grandfather, Governor Robinson, introduced the famous saddle horse, the Narragansett pacer, known in the last century over all the civilized parts of North America and the West Indies, from whence they have lately been introduced into England, as a ladies' saddle horse, under the name of the Spanish Jennet. Governor Robinson imported the original from Andalusia, in Spain. and the raising of them for the West India market was one of the objects of the early planters of this country. My grandfather, Robert Hazard, raised about a hindred of them annually, and of ten loaded two vessels a year with them, and other products of his farm, which sailed direct from the South Ferry to the West Indies, where they were in great demand."

This theory of the origin of the Narragansett came down to Mr. Hazard as a tradition, no doubt, but like a thousand other traditions it has nothing to sustain it. Opposed to it there are two clearly ascertained facts, either one of which is wholly fatal to it. In the first place, there were no pacers in Andalusia or any other part of Spain, and in the second place, these horses, according to official data, were the leading item of export from Rhode Island in 1680, and Governor Robinson was not born till about 1693. As impossibilities admit of no argument, I will not. 
add another word to this "Andalusian" origin tradition, except to say that a hundred years later, when the pacing dam of Sherman Morgan was taken from Cranston, Rhode Island, up into Vermont, she was called a "Spanish mare," because Mr. Hazard had said the original Narragansett had come from Spain. The story of the descendants of the Narragansetts haring been carried from the West Indies to England, and there introduced under the name of the Spanish Jennet as a lady's saddle horse, is wholly imaginative. The Spanish Jennet, whatever its gait may have been, was well known in England many years before the first horse was bronght to any of the American colonies. (See extracts from Blundeville and Markham in Chapter XII.)

After several years of fruitless search for some trace of the early importations of horses into the colony of Rhode Island, I have reached the conclusion that probably no such importations were ever made. The colony of Massachusetts Bay commenced importing horses and other live stock from England in 1629, and continued to do so for several years and until they were fully supplied, as stated above. In 1640 a shipload of horses were exported to the Barbadoes, and it was about this time that Rhode Island began to assume an organized existence. Her people were largely made up of refugees from the religious intolerance of the other New England colonies, and they brought their families and effects, including their horses, with them. The blood of the Narragansett pacer, therefore, was not different from the blood of the pacers of the other colonies, but the development of his speed by the establishment of a pacing course and the offering of valuable prizes, naturally brought the best and the fastest horses to this colony and from the best and fastest they built up a breed that became famous throughout all the inhabited portions of the Western Hemisphere. The race track, with the valuable prizes it offered and the emulation it aroused, was what did it. As the question of origin is thus settled in accordance with what is known of history and the natural order of things, and as the Narragansett is the great tribe representing the lateral action then and since, we must consider such details of history as have come down to us.

The Rev. James MoSparran, D.D., was sent out by the London Society for the Propagation of the Gospel in Foreign Parts, to take charge of an Episcopal church that had been planted some years before in Rhode Island. He arrived in 1721, and lived till 
1759. He was an Irishman, and appears to have been somewhat haughty and irascible in his temperament, and was disposed to find fault with the climate, the currency, the people, and pretty much everything he came in contact with. He was a man of observation, and during the thirty-eight years he spent in ministering to the spiritual wants of his flock, he was not unmindful of what was passing around him, and made many notes and reflections on the various phases of life as they presented themselves to his mind, and especially on the products and industries of the colony. These notes and observations he wrote out, and they were published in Dublin in 1753, under the title of "America Dissected."

His writings do not discover that he was a man of very ardent piety, but he was honored as a good man while he lived, and was buried under the altar he had served so long. His duties sometimes called him away into Virginia, and, in speaking of the great distance of one parish from another, he uses the following language:

"To remedy this (the distance), as the whole province, between the mountaius, two hundred miles up, and the sea, is all a champaign, and without stones, they have plenty of a small sort of horses, the best in the world, like the little Scotch Galloways; and 'tis no extraordinary journey to ride from sixty to seventy miles or more in a day. I have often, but upon larger pacing horses, rode fifty, nay, sixty miles a day, even here in New Englaud, where the roads are rough, stony and uveven."

The reverend gentleman seems to assume that his readers knew the Scotch Galloways were pacers, and with this explanation his observations are very plain. He makes no distinction between the Virginia horse and his congener of Rhode Island except that of size, in which the latter had the advantage. In speaking of the products of Rhode Island he says:

"'The produce of this colony is principally butter aud cheese, fat cattle, wool, and fine horses, which are exported to all parts of English America. They are remarkable for fleetness and swift pacing; and I have seen some of them pace a mile in a little more than two minutes, and a good deal less than three."

When I first read this sentence in the reverend doctor's book I confess I was not prepared to accept it in any other light than that of a wild enthusiast, who knew but little of the force of the language he used. To talk about horses pacing, a hundred and fifty years ago, in a little more than two minutes and a 
good deal less than three, appeared to be simply monstrous. The language evidently means, according to all fair rules of construction, that the mile was performed nearer two minutes than three, or in other words, considerably below two minutes and thirty seconds. I doubt not my readers will hesitate, and perhaps refuse, to accept such a performance, just as I did myself till I had carefully weighed not only the character of the author of the statement, but the circumstances that seemed to support it. If the learned divine had known no more of the world and its ways than many of his profession, I would have concluded he was not a competent judge of speed; but he was a man of affairs, and knew perfectly well just what he was saying. The question naturally arises here as to what opportunities or facilities the doctor had for timing those pacers of a hundred and fifty years ago. In a note appended to the above extract by Mr. Updike, the editor of the work, I find the following:

"The breed of horses called Narragansett pacers, once so celebrated for fleetness, endurance and speed, has become extinct. These horses were highly valued for the saddle, and transported the rider with great pleasantness and sureness of foot. The pure bloods could not trot at all. Formerly they had pace-races. Little Neck Beach, in South Kingston, of one mile in length, was the race course. A silver tankard was the prize, and high bets were otherwise made on speed. Some of these prize tankards were remaining a few years ago. Traditions respecting the swiftness of these horses are almost incredible.

The facts stated by Mr. Updike in this note are corroborated from other sources, and may be accepted as true. These were the opportunities and facilities the doctor had for holaing his watch, and nobody will doubt they were sufficient to enable him to be a competent witness. In connection with this subject, and as another footnote, Mr. Updike introduces a letter from Mr. I. T. Hazard, which brings ont another very curious fact in the history of the pacer. The Hazard family was very eminent in Rhode Island, and many of its members have occupied positions of high honor and responsibility for several generations. The date of the letter is not given, and we may infer it may have been written fifty years ago, or perhaps more. Mr. Hazard says:

“ Within ten years one of my aged neighbors, Enoch Lewis, since deceased, informed me he had been to Virginia as one of the riding boys, to return a similar visit of the Virginians in that section, in a contest on the turf; and that such visits were common with the racing sportsmen of Narragansett and Virginia, when he was a boy. Like the old English country gentlemen, from 
whom they were descended, they were a horse-racing, fox-hunting, feasting generation."

This paragraph from Mr. Hazard's pen has been the subject of very deliberate consideration. The first promptings of my judgment were to doubt and reject it, especially on account of the absence of date to the letter, and of the remote period in which Mr. Enoch Lewis must have visited Virginia. Another question, as to why we have not this information from any other source except Mr. Hazard, presented itself with no inconsiderable force. After viewing the matter in all its bearings $I$ am forced to concede that it is likely to be true. These visits must. have taken place before the Revolution, and from the construction we are able to place upon the dates, this was not impossible. It is a fact that I do not hesitate to announce that before the Revolution racing in all its forms was more universally indulged in as an amnsement than it ever has been since. This was before the days of newspapers, and all we can possibly know of the sporting events of that period we must gather up from the detached fragments that have come down to us by tradition. There was a strong bond of sympathy and friendship between the followers of Dr. MeSparran in Rhode Island, surrounded as they were by Puritans, and their co-religionists in Virginia. They were accustomed to maritime life, and had abundance of vessels fitted up for the shipment of horses and other live stock to foreign ports. To take a number of their fastest pacers on board one of their sloops and sail for Virginia would not have been considered much of an adventure. These visits were not only occasions of pleasure and festivity, with the incidental profits of winning purses and bets, but they were a most successful means of advertising the Narragansett pacer; and through these means alone the market was opened, as Dr. MoSparran expresses it, in all parts of British America. When we consider the widespread fame of these Rhode Island horses, and that there were no other means by which they could have achieved it, except by their actual performances, we are forced to the couclusion that they were carried long distances, and in many directions, for purely sporting purposes. 'That these visits would result in the transfer' of a good number of the best and fastest horses from Narragansett to Virginia would be a natural sequence, and thus, in after year's, we might look for a strong infusion of Narragansett blood in the Virginian pacing-horse. 
It appears to be a law of our civilization that each generation prodnces somebody who, ont of pure love for the curious and forgotten, devotes the best years of his life to hunting up old things that have well-nigh slipped away from the memory of man. In this class Mr. John F. Watson stands conspicuous in what he has done for Philadelphia and New York. In 1830 he published a work entitled "Annals of Philadelphia and Pennsylvania," in two volumes, and among all the antiquated manners and habits that he again brings to our knowledge, he has something to say about the horse of an early day:

"The late very aged T. Matlack, Esq., was passionately fond of races in his youth. He told me of his remembrances about Race Street. In his early days the woods were in commons, having several straggling forest trees still remaining there, and the circular course ranging through those trees. He said all genteel horses were pacers. A trotting-horse was deemed a base breed. These Race Street races were mostly pace-races. His father and others kept pacing stallions for propagating the breed."

Mr. Watson further remarks, on the same subject: "Thomas Bradford, Esq., in telling me of the recollections of the races, says lie was told that the earliest races were scrub and pace-races on the ground now used as Race Street."

The Rev. Israel Acrelius, for many years pastor of the Swedish church of Philadelphia, wrote a book early in the last century, under the title, "History of New Sweden," which has been translated into English. In describing the comntry and people, in their habits and amusements, he thus speaks of the horse:

"The horses are real ponies, and are seldom found over thirteen hands high. He who has a good riding horse never employs him for draught, which is also the less necessary, as journeys, for the most part, are made on horseback. It must be the result of this, more than to any particular breed in the horses, that the country excels in fast horses, so that horse races are often made for very high stakes."

It will be noted that Mr. Acrelius does not say that these races were pacing-races; but when his remark is taken in connection with what Mr. Matlack said about the pacers, and when it is considered that he is speaking of the speed of the saddle horses as such, we can easily understand his true meaning. In our turf history I supposed I was getting well back when I reached the great race between Galloway's Selim and Old England, in 1767 , but here we find that race was comparatively modern, and that the pacers antedated the gallopers by many, many years. 
In 1832 Mr. Watson did the same service for New York that he had done for Philadelphia, and published his "Annals of New York," in which we find the piece of horse history embodied in the extract printed on pages 126 and $12 \%$, to which the reader will please turn.

It is hardly possible to be mistaken in assuming that Rip Van Dam's letter was written to some person in Philadelphia, and that Mr. Watson saw it there. I would give a great deal for the sight of it; and if it has been preserved in any of the public libraries of that city, either in type or in manuscript form, I have good hopes of yet inspecting it. In one point of view it is of exceeding value, and that is its date. It is fully established by this letter that, as early as 1711, the Narragansetts were not only established as a breed or family, but that their fame was already widespread. This, of necessity, carries us back into the latter part of the seventeenth century, when their exceptional characteristics were first developed, or began to manifest themselves. In reaching that period we are so near the first importations of horses to the colonies that it is no violence to either history or good sense to conclude that the original Narragansett was one among the very earliest importations. This plays havoc with some Rhode Island traditions, as will be seen below; but with 1711 fixed as a point when the breed was famous, traditions must stand aside.

While on this matter of dates, it may not be unprofitable to compare the advent of the Narragansett with the well-known epochs in horse history. Every schoolboy knows that the Darley Arabian and the Godolphin Arabian, say twenty years after, were the great founders of the English race horse. The Narragansetts had reached the very highest pinnacle of fame before the Darley Arabian was foaled. Darley Arabian reached England about the same year that Rip Van Dam's Narragansett jumped over the side of the sloop and swam ashore, and this was eighty years before there was an attempt at publishing an English stiud book. When Janus and Othello, and Traveller, and Fearnanght, the great founders of the American race horse, first reached Virginia, they found the Narragansett pacer had been there more than a generation before. On the point of artiquity, therefore, the Narragansett is older than what we designate as the thoroughbred race horse, and if he has a lineal descendant living to-day the pacer has a longer line of speed inheritance, at his gait, than the galloper. 
The only attempt at a description of this breed that I have met with is that given by Cooper, the novelist, in a footnote to "The Last of the Mohicans." This note may be accepted as history, so far as it goes, and pretends to be history; but I am not prepared to admit that all the breed were sorrels. This color, no doubt, prevailed in those specimens that Mr. Cooper had seen or heard of, but I think all colors prevailed, as in other breeds. He says:

"In the State of Rhode Island there is a bay called Narragansett, so named for a strong tribe of Indians that formerly dwelt on its banks. Accident, or one of those unaccountable freaks which nature sometimes plays in the animal world, gave rise to a breed of horses which were once well known in America by the name of Narragansetts. They were small, commonly of the color calied sorrel in America, and distinguished by their habit of pacing. Horses of this race were, and still are, in much request as saddle-horses, on account of their hardiness, and the ease of their movements. As they were also sure of foot, the Narragansetts were much sought for by females who were obliged to travel over the roots and holes in the new countries."

Without having a minute description of so much as a single individual of the race, I can only infer, from general descriptions, as to what their family peculiarities of form and shape may have been. It is fully established that they were very compact and hardy horses, and that they were not large; perhaps averaging about fourteen and a quarter hands in height. I have met with no intimation that they were stylish or handsome, and we think it is safe to conclude that they were plain in their form,and low in their carriage. From my conceptions of the horse I think one of the better-shaped Canadian pacers, of fifteen hands or thereabonts, might be accepted as a fair representative of the Narragansett of a hundred and fifty years ago. He was fleet, hardy, docile, and sure-footed, but not beautiful, and it is reasonable to suppose that the lack of style and beauty was one of the leading canses of his becoming extinct in the land of his nativity.

In considering the causes which resulted in what we may call the dispersal of the Narragansett pacers, and their extinction in the seat of their early fame, we must be governed by what is reasonable and philosophical in the industrial interests of the people, rather than look for some great overwhelming disaster, like an earthquake, that ingulfed them in a night. In speaking of this dispersal, and the causes which led to it, Mr. Hazard says: 
"One of the causes of the loss of that famous breed here was the great demand for them in Cuba, when that island began to cultivate sugar extensively. The planters became suddenly rich, and wanted the pacing-lorse for themselves and their wives and daughters to ride, faster than we could supply them, and sent an agent to this country to purchase them on such terms as he could, but to purchase them at all events. I have heard wy father say he knew the agent very well, and he made his home at the Rowland Brown House, at Tower Hill, where he commenced purchasing and shipping until all the good ones were sent off. He never let a good one escape him. This, and the fact that they were not so well adapted to draught as other horses, was the cause of their being neglected, and I believe the breed is now extinct in this section. My father described the motion of this horse as differing frow others in that his backbone moved through the air in a straight line, without inclining the rider from side to side, as the common racker or pacer of the present day. Hence it was very easy; and being of great power of endurance, they would perform a journey of a hundred miles in a day, without injury to themselves or rider."

We can understand very well how an enormous and unexpected demand from Cuba, without restriction as to price, should reduce the numbers of the breed very materially. But it is a poor compliment to the intelligence and thrift of the good people of Narragansett to say that, because there was a lively demand, they killed the goose that laid the golden egg every day. It is a slander upon that Yankee smartness which is proverbial to conclude that they deprived themselves of the means of supplying a market that was making them all rich. We must, therefore, look for other causes that were more potent in producing so marked a result.

After more than a hundred years of faithful service; of great popularity, and of profitable returns to their breeders, the little Narragansetts began to disappear, just as their ancestors had disappeared a century earlier. Rhode Island was no longer a frontier settlement, but had grown into a rich and prosperous State. Mere bridle paths through the woods had developed into broad, smooth highways, and wheeled vehicles had taken the place of the saddle. Under these changed conditions, the little pacer was no longer desirable or even tolerable as a harness horse, and he was supplanted by a larger and more stylish type of horse, better suited to the particular kind of work required of him. This was simply the "survival of the fittest," considering the nature of the services required of the animal. The average height of the Narragansett was not over fourteen hands and one inch. His neck was not long, even for his size; he dropped 
rapidly on the croup, and his carriage was low, with nothing of elegance or style in his appearance. His mane and tail were heavy, his hind legs were crooked, his limbs and feet were of the very best, but aside from his great speed and the smoothness of his movements under the saddle, there was nothing very desirable or attractive about him. In a contest with a type of the harness horse, at least one hand higher, of high carriage and elegant appearance, there could only be one result, and that soon decided.

As in England, so in this country, the blood of the rumning horse soon worked the extermination of the pacer; not because it was stronger in reproducing itself, perhaps, but because it had the skill and fancy of the breeder enlisted in selecting and mating so as to make the expunging process complete. Only a few years ago a pacing horse could hardly be found in any of the older settled portions of the country, especially where running blood had become fashionable. He was literally banished to the frontiers of Canada, Indiana, Missouri, Kentucky, and Tennessee, and especially in the latter two States, where his blood is still appreciated and preserved for the luxurious saddle gaits which it alone transmits. In many individual cases he has shown wonderful power in meeting and overcoming antagonistic elements, but with the tide of running blood all against him, it was only a question of time as to how soon he would be totally submerged.

It is only a quarter of a century ago that the first volume of "Vallace's Americau Trotting Register", was published, and then began the great task of bringing order out of chaos. In a historical introduction to that work, I inserted the following:

"So many pacing horses have got fast trotters, so many pacing mares have produced fast trotters, and so many pacers have themselves become fast trotters, and little or nothing known of their breeding, that $I$ confess to a degree of embarrassment, from which no philosophy relieves me. If the facts were limited to a few individual cases we could ignore the phenomena altogether, but, while they are by no means universal, they are too common and apparent to be thus easily disposed of. I am not aware that any writer has ever brought this question to the attention of the public; much less, attempted its discussion and explanation. Indeed, it is possible that the observations of others may not sustain me in the prominence given these phenomena, but all will concede there are some cases coming under this head that are unexplained, and perhaps unexplainable. It is probable trotters from this pacing origin, and that appear to trot, only because their progenitors paced, will not prove reliable producers of trotters. Such an animal being in a great degree phenomenal, should not be too highly prized in the stud, till he has proved himself a trotting sire as well as a trotter." 
This very comprehensive little paragraph, put modestly and tentatively rather than positively, contained a germ of thought that is to-day exerting a very wide influence. So far as my knowledge goes, this was the first time in which the public attention had ever been called to the intimate relations between speed at the pace and speed at the trot. Some langhed at it as not practical, others sneered at it as a theoretical abstraction, a few gave it some thought, while the writers who never think left it severely alone. It required the cumulative experiences of nearly ten years before horsemen generally began to think about it, and then ten more before the germ had matured itself in the minds of all intelligent men who were able to divest themselves of their earlier prejudices. The great primary truth now stands out in high relief that the pace and the trot are simply two forms of one and the same gait, that lies midway between the walk and the gallop. At last the truth, dimly foreshadowed in the paragraph above, is received and accepted, in some form or other, almost if not quite universally. This fact and its acceptance are now shown in all the recorded experiences of racing, and especially in the origin and habits of action of many of the heads of trotting and pacing. families, to which the reader is referred.

At the beginning of Chapter XIII. I have labored to make plain the proposition that the pace and the trot are simply two. forms of one and the same gait. This is evident from the fact. that this gait, in one form or the other, is the intermediate link between the walk and the gallop, and this is true among nearly all quadrupeds. I have also there shown, and I think beyond cavil, that the mechanism of the pace and the trot is the same, and especially in the fact that in both forms two legs are used as one leg. That is, if the two legs on the same side move together, we call it the pace, and if the diagonal legs move together we call it the trot. The rhythm is the same and the sound is the same, and by the ear no man can tell whether the movement is at the lateral or diagonal motion. In all the varieties of steps that a. horse may be taught, and in all the methods of progression that he may naturally adopt, there is no step or movement in which he uses two legs as one except in the pace or the trot. From the place, therefore, which these two forms of the gait hold, indifferently, in animal movement, between the walk and the gallop; from the unity of action and result in the use of the same mechanism, and from the wide disparity between the mechanism of 
this gait and that of all other gaits in the action of the horse, we must conclude that the pace and the trot are one and the same gait.

Another evidence of the unity of the two forms of the trot is to be found in the great numbers of pacers that have been changed over to trotters and the astonishing readiness with which they took to the new form of action. To go back no further than the records sustain us, we find that the converted pacer Pelham was the first horse that ever trotted in 2:28. 'This was in 1849, and four years later the converted pacer Highland Maid trotted in 2:2\% Twenty years later, Occident, another, trotted in $2: 16 \frac{3}{4}$. These were champions of their day, and when we come a little nearer we find that Maud $\mathrm{S}$. was a pacer and Sunol was a pacer, although neither of them ever paced in public, and the fact that they ever paced at all was held as a kind of "home secret." Since the days of Pelham, literally thousands of horses have been changed from pacers to trotters, and some hundreds have been changed from trotters to pacers successfully. Then there are quite a number, like Jay-Eye-See, 2:10 trotting and $2: 06 \frac{1}{4}$ pacing, that have made fast records at both gaits.

At one time the pacing horse Blue Bull stood at the head of all sires of trotters in this country, and it is not known or believed that he possessed a single drop of trotting blood. He was a very fast pacer and could do nothing else, and a large percentage of the mares bred to him were pacers, and practically all the others had more or less pacing blood, but his great roll of trotter's in the 2:30 list was the wonder of all horsemen of that period. Certainly the average of the elements in his inheritance would place him very low in theory, but in practice he struck back to some ancestor that was strongly prepotent. The trouble in his case is practically the same as in all other pacing stallions - the inheritance traces back to a period more remote than any of the fast trotting stallions, but at intervals it has been neglected and not developed until it has become weak and uncertain from lack of use. The same may be said of the Copperbottoms, Corbeaus, Flaxtails, Hiatogas, Davy Crockets, Pilots, Rainbows, Redbucks, St. Clairs, Tippoos, and Tom Hals, as well as other heads of minor families that will be considered in their proper places.

The changes that have been wrought in the status of the pacer have been truly wonderful. Instead of being hidden away as an 
outcast and a disgrace to the family, condemned to a life of inferiority and drudgery, he has been brought out and exhibited to the public as a son and heir and the equal of the best. In looking back over the trotting records of twenty years ago, any one will be surprised to observe that at all the leading meetings of the whole country there were no pacing contests. Occasionally at the minor and local meetings of the middle Western States, a pacing contest would be given for a small purse, in which local and obscure horses only would be engaged. Very naturally the owners of pacing horses protested against this practical exclusion of their favorites from the trotting meetings, and employed all their energies in begging for admission. When they began to be really clamorous the managers of trotting tracks argued that there could be no profit to them in opening pacing contests, for nobody cared about seeing a pacing match, that the entries would not fill, and especially that there would be no betting, that, consequently, the pool-sellers would have nothing to divide with the management. As the receipts for pool-selling and all other gambling privileges were making the track managers rich, they were very slow about admitting an untried element that might diminish their profits. But gradually and patiently the pacers worked their way into the exchusive circle, and when they appeared everybody, especially in the Eastern States, was surprised to see what excellent horses they were and the terrific speed they showed. Instead of the typical pacer, as formed in the popular mind, with the low head, bull neck, low croup, hairy legs, exuberant mane and tail, and generally "Canuck" all over, that. would stop at the end of the first half-mile, here was an array of horses that in make-up and gameness would average just as well as the same number of trotters. This was a revelation to great multitudes of people, and from that time forward the pacer had a fair show, on his merits. For hundreds of years the pacer, with very few exceptions, has been able to show a little higher rate of speed than the trotter. When Flora Temple smashed all records in 1859 by trotting in 2:193. Pocahontas had drawn a wagon, five years earlier, in $2: 17 \frac{1}{2}$; and when Maud S. trotted in $1885 \mathrm{in} 2: 08 \frac{3}{4}$, this beat all laterals as well as diagonals, except Johnson, who the year before had paced in $2: 06 \frac{1}{4}$. In 1894 Alix trotted a mile in $2: 03 \frac{3}{4}$, which stands the best at this writing, but the same year Robert J. paced in $2: 01 \frac{1}{2}$, and John R. Gentry in $2: 00 \frac{1}{2}$ in 1896. 
It is not my purpose here to undertake to discuss the reasons for the almost continuous supremacy of the pacer over the trotter, for there is no data from which I might frame a conclusion that wonld really "hold water." At best, therefore, I can only suggest two or three thoughts. Speed at the pace is older, and has been longer in the process of development, than speed at the trot. In 1747 pacing races had then been fashionable in Maryland, and had been carried on in that colony time out of mind, but we have no trace of trotting races. One year later (1748) "running, pacing and trotting" races had become so numerous and so common in the colony of New Jersey that they were declared a nuisance and suppressed by the legislative authority. $\mathrm{My}$ impression from the language of the act is that it was aimed chiefly at the running and the pacing races, and that the trotters were not very numerous. It seems to be a reasonable conclusion that this racing mania in New Jersey took its rise about 1665, when Governor Nicolls established the Newmarket race course on long Island, and if so, it had been growing in strength for over eighty years, and if we add the time from then till now we find that the speed of the pacer has been going on almost continuously for over two hundred years in our own country. There is another fact entering into the rural life of colonial times that must not be left out of consideration. The pacer was the universal saddle horse, and the trotter never was tolerated for that service. Every farmer's son had his saddle horse, and when two of them met what so naturat and common as to determine then and there which was the faster, if a little stretch of road offered? In these neighborhood rivalries, if not in actual racing, the instinct of speed at the pace was kept alive and developed, from generation to generation. If I am right in this little study of colonial life, we can understand that the inheritance of speed at the pace has come down to our own time through a great many generations of pacers, and hence the pace is the faster gait. There is one fact in our own experience that seems to sustain this with great force, and that is the small amount of "pounding" that the pacer requires in order to reach the full development of his powers. There is no need of driving a pacer to death in order to teach him how to pace, for he already knows how to pace, and all that is needed in the way of training is to get him into high condition. It may be possible that the lateral action is faster than the diagonal because it is less compli- 
cated, but I can see no anatomical reason for this, as the two legs in both gaits act as one leg. The only difference I can see in practice is that the trotter has more up-and-down motion than the pacer; that is, he bounds in every revolution, describing a series of depressed curves with his back as he moves, while the pacer rises less from the ground with his hind feet and seems to glide instead of bound; in other words, there is less action thrown away by the pacer than the trotter, and this may arise from the more complex action in the diagonal than in the lateral motion.

The pacer has reached a higher acclivity than the trotter, but he is not so well assured in his footing. His present popularity and his upward flight are phenomenal, but the causes that have sent him there are abnormal and not lasting. In his best individualities he is simply a gambling machine when in the hands of unscrupulous men, to be manipulated in whatever direction he will make the most money. Racing, at whatever gait, is not necessarily demoralizing nor disreputable, but when it falls into the control of the "professionals" it becomes both. So long as it remains under the control of the breeders it is not only honorable and legitimate for them to develop and race their stock, but it is a necessary adjunct to their business, for they must thus bring their products before the public, if they expect to make their business pay. Breeders should not own race tracks, or if they do, they should have no part nor lot in the percentage mniformly paid for the gambling privilege.

The history of racing in this country teaches over and over again that whenever the breeding and racing interest falls into the control of gamblers, down goes the whole interest and honest men suffer with the rogues. The grasping track managers are to-day complaining loudly that they cannot afford to give trotting meetings unless they are allowed to bring in the pool-sellers and make them divide the "swag" with the track. Every attempt by legislatures to make gambling on races a felony ontside the race track and a virtue inside is a most arrant humbug and most destructive in its results. It makes the race track a cesspool of every vice, and a stench in the nostrils of every honest man and decent woman. The moral sense of the people all over this country is being aroused, and if public gambling cannot be suppressed on horse races, then history will repeat itself and horse racing will be wiped out. The gamblers and their friends 
will sneer at this as "puritanism," but no difference about the name-it will come.

But, destructive and ruinous as gambling on races may be to the life and moral character of young men, as well as to the material interests of honest and reputabie breeders, it hardly comes within my province to discuss it further in this place, and therefore I will return to the consideration of the pacer. As the historical periodicity is now looming in sight when the moral sense of the people will command the suppression of racing of every kind, the question becomes exceedingly pertinent as to what is to become of the pacer? He will no longer be of any value as a gambling machine, the days of the saddle horse are past as a means of travel, except by a few about the parks of the cities, and however uppish and handsome he may be, he is not and never will be a desirable driving horse in harness. We have already used sufficient of his blood to create the American Saddle Horse, and if the saddle horse shall produce "after his kind" we need no more infusions from the pure pacer. In the trotter his blood has leavened everything, and in some lines more than we desire or need. He has been a great source of trotting speed, and if, as I am inclined to believe, Messenger's power to transmit trotting speed came from the old English pacer, then the pacer is the only source of that speed. Under the condition of things as here foreshadowed he will probably sink back into the obscurity from which he emerged twenty years ago. 


\section{CHAPTER XV.}

\section{THE AMERICAN SADDLE HORSE.}

The saddle gaits come only from the pacer-Saddle gaits cultivated three hun. dred years ago-Markham on the saddle gaits-The military seat the best - The unity of the pace aud trot-Gaits analyzed-Saddle Horse RegisterSaddle horse progenitors-Denmark not a thoroughbred horse.

IN the preceding chapters the pacer has been considered from the standpoint of his antiquity, history, speed at the pace, and his contributions to speed at the trot. We now come to consider him as the founder of the best and most delightful type of saddle horses in the world. This estimate of his quality and value had a solid foundation in the judgment and habits of our ancestors at an early period in our history. When our patriotic forbears entered upon the struggle for independence, they were fully alive to the necessity of foreign sympathy and aid. For this purpose agents were sent abroad to enlist the good feelings and, if possible, secure co-operation of foreign governments, especially that of France. Mr. Silas Dean was sent to Paris, and in a communication to the secret committee of Congress, under date of November 28, 1\%\%6, he writes: "I wish I had here one of your best saddle horses, of the American or Rhode Island breed-a present of that kind would be money well laid out with a certain personage." This was probably intended as a present to Marie Antoinette, or some other person having great influence at court. It further indicates that "the American or Rhode Island Saddle Horse" was at that period, in Mr. Dean's opinion at least, the best in the world. (See Dean Papers, New York Historical Society, Vol. I., p. 37\%.)

To the man of average intelligence and candor on horse subjects it certainly is not necessary to enter upon an elaborate discussion to show that the saddle gaits come from the pacer, but a certain class of writers, who neither declare nor attempt to prove their position, constantiy imply that the saddle gaits came from the "thoroughbred." As it is better, therefore, to make every- 
thing plain as we go along, I will very briefly consider this point. Twelve years ago, through Wallace's Monthly, I presented the following questions to all gentlemen interested in saddlehorse affairs and acquainted with saddle-horse history: "Are all the tribes and families noted for their saddle qualities descended in whole or in part from pacing ancestry?" In order to cover the whole question, no difference from what standpoint it might be considered, I added the following: "Has any family or subfamily of saddle horses come from pure running ancestry and without any admixture of pacing blood?" To these questions Major Hord, then editor of the Spirit of the Farm, at Nashville, Tennessee, a gentleman of very wide and accurate knowledge on this subject, but strongly in favor of running blood, made the following response through his paper:

“We can only draw conclusions from established facts in reference to these questions, for we do not think they can be answered otherwise, as the original ancestry of our best saddle families is more or less clouded in obscurity. It is an established fact, demonstrated by experience, that in order to get a saddle horse, the quickest and most successful way is to get in the pacing blood; it matters not how good or bad the other blood may be, a strong dash of pacing blood will almost invariably improve the animal for saddle purposes, and never, under any circumstances, does a pacing cross detract from an animal's qualities for the saddle. Judging from these facts, we conclude that all our saddle families are descended, at least in part, from pacing ancestry. On the other hand, all our best saddle families have a strong infusion of thoroughbred running blood. This blood, however, is valuable only for the courage, bone, and finish it gives the animal, for it imparts none of the saddle gaits; and while we have secured the best results in breeding the saddle horse by mixing the running and pacing blood, we have observed that too much running blood in the stallion detracts from his success as a sire of saddle stock. As a rule, no trainer's skill can make a good saddle horse out of a thoroughbred runner, whereas if you mix two or more strong pacing crosses on top of the running blood, a child can gait the produce to the saddle. We have sometimes seen good saddle horses that were thoroughbreds, but have never seen a perfect one. Our observation and experience lead us to the conclusion that the natural saddle gaits come from the pacers, but to the runner we are indebted for the size, style, bone and finish of our saddle stock."

In this reply, when the author says "all of our saddle families are descended, at least in part, from pacing ancestry," and when he adds to this that "running blood imparts none of the saddle gaits," he has answered both questions very fully and very satisfactorily. The argument that running blood gives bone and finish, and all that, is very well as a theory of breeding, but it 
has nothing to do with the questions propounded. As all families of saddle horses have pacing blood, and as there is no family without it, it may be taken as settled that the saddle gaits come from the pacer.

I notice that at least one of the present saddle gaits was cultivated more than three hundred years ago. Mr. Gervaise Markham, a writer of the sixteenth century, and probably the second English author on the horse, says: "If you buy a horse for pleasure the amble is the best, in which you observe that he moves both his legs on one side together, neat with complete deliberation, for if he treads too short he is apt to stumble, if too large to cut and if shuffling or rowling he does it slovenly and besides rids no ground. If your horse be designed for hunting, a racking pace is most expedient, which little differs from the amble, only is more active and nimble, whereby the horse observes due motion, but you must not force him too eagerly, lest being in confusion he lose all knowledge of what you design him to, and so handle his legs carelessly." The orthography of the work "rack" as used by Markham is "wrack," and this is the only place I have met with it in any of the old authors. Webster defines the word "rack" as "a fast amble," but Markham uses it in contradistinction from the amble. It is worthy of note here that the word "rack" is older than the word "pace," in its use as designating the particular gait of the horse, and through all the centuries it has been retained. Of all the gaits that are subsidiary to the pace and derived from that gait, the rack is probably the most common, and in many sections of the country the pacer is called a racker. Racking is often designated as "single-footing," and in this gait as well as in the running walk and fox trot, there are four distinct impacts in the revolution. It follows, then, that they are not susceptible of a very high rate of speed.

In all the services which the horse renders and in all the relations which he bears to his master, there is no relation in which they can be made to appear to such great mutual advantage as when the one animal is carrying the other on his back. There is no occasion on which a beautiful horse looks so well as when gracefully mounted and skillfully handled by a lady or gentleman. And, I will add, there is no occasion when a lady or gentleman, who is at home in the saddle, looks so well as when mounted on a beautiful and well-trained American horse. Eng- 
land has no saddle horses, and never can have any till she secures American blood and adopts American methods. The shortening of the stirrups and the swinging up and down like a tilt-hammer is not, with our English friends, a matter of choice, but a necessity to avoid being jolted to death. Their very silly imitators, on this side, think they can't afford to be out of the fashion, because "it's English, yon know." For safety, true gentility, and comfort the military seat is the only seat, and if you have a horse upon which you can't keep that seat without punishment, he is no saddle horse. If your doctor tells you that your liver needs shaking up, mount an English trotting horse, but if you ride for pleasure and fresh air, get a horse that is bred and trained to the saddle gaits. There is just as much difference between the two horses as the difference between a springless wagon on a cobble-stone pavement and a richly upholstered coach on the asphalt.

The American Saddle Horse has an origin as well as a history. His origin dates back thousands of years, and his history has been preserved in art and in letters since the beginning of the Christian era. For centuries he was the fashionable horse in England, and the only horse ridden by the nobility and gentry. Away back in the reign of Elizabeth it was not an uncommon thing to use hopples to teach and compel trotters to pace, just as in our day hopples are often used to teach and compel pacers to trot. In the early settlement of the American colonies pacers were far more numerous than trotters, and this continued to be the case till after the War of the Revolution. The great influx of running blood after that period practically banished the pacer to the western frontiers, where a remnant has been preserved for the uses of the saddle; and on account of his great speed and gameness he has again returned to popular favor in our own day.

The walk and the canter, or short gallop, are gaits that are common to all breeds and varieties of horses, but what are known as "the saddie gaits" are derived wholly from the pace and are therefore considered modifications or variations of the pace. In regions of country where the saddle horse is bred and developed these gaits are well known among horsemen and riders as the rack (single-footing), the running-walk, and the fox-trot. These gaits are not easily described so as to be understood without an example before the eye. The rack is the most easily explained so as to be comprehended, and it is sometimes called the slow 
pace. In this movement the hind foot strikes the ground an instant before the fore foot on the same side, then the other two feet are moved and strike in the same way; thus there are four strokes in the revolution, in pairs. As each foot has its own stroke we see the appositeness of the phrase "single-footing." The four strokes are in pairs, as one, two-three, four, and in many cases as the speed of the horse increases the interval between the strokes is lost and the horse is at a clean rapid pace. As a matter of course none of these gaits in which the horse makes four strokes instead of two in the revolution can be speedy. They are not developed nor cultivated for speed alone, but for the comfort and ease of the rider and the change from one to another for the rest and ease of the horse.

These "saddle gaits" are always derivatives from the pace, and I never have seen one that did not possess more or less pacing blood. A careful examination of the first and second volumes of "The National Saddle Horse Register" establishes this fact beyond all possible contradiction. This work is a very valuable contribution to the horse history of the country, but it is a mis. fortune that more care has not been taken in the exclusion of fictitious crosses in a great multitude of pedigrees. This trouble is specially apparent among the supposed breeding of many of the old stallions that are inserted as "Foundation Stock." The tendency throughout seems to be to cover up and hide away the very blood to which we are indebted for the saddle horse, and to get in all the blood possible that is in direct antagonism to the foundation of the saddle gaits. It can be accepted as a fundamental truth in horse lore, that from the day the first English race horse was imported into this country to the present day, which covers a period of about one hundred and fifty years, nobody has ever seen, either in England or in this country, a thoroughbred horse that was a pacer. When the old race horse Denmark covered the pacing daughter of the pacer Cockspur, the pacing blood of the dam controlled the action and instincts of the colt, and in that colt we have the greatest of saddlehorse sires, known as Gaines' Denmark.

As this loorse Denmark was by far the greatest of all saddlehorse progenitors, and as his superiority has been widely attributed to his "thoroughbred" sire Denmark, the son of imported Hedgford, I have taken some pains to examine his pedigree. His sire was thoroughbred, his dam and grandam, were 
mongrels, and the remoter crosses were impossible fictions. The fact that he ran four miles cuts no figure as evidence of purity of blood, for horses were running four miles in this country before the first "thoroughbred" was born. Of the fourteen stallions that are inserted as "Foundation Stock," it is unfortunate that the choice seems to be practically restricted to the State of Kentucky, while the States of Ohio, Indiana, and Tenmessee, to say nothing of Illinois, Missouri, etc., have produced numbers of families and tribes that are much more prominent and valuable from the true saddle-horse standpoint than some that appear in the select list of fourteen. It is doubtless true, however, that more attention has been paid to symmetry and style, and to the correct development and culture of the true saddle gaits, in Kentucky than in any of the other States. With such horses as Gaines' Denmark, John Dillard, Tom Hal, Brinker's Drennon, 'Texas, Peters' Halcorn, and Copperbottom the list is all right, but the other half-dozen are mostly young and have hardly been heard of outside of their own inmediate neighborhoods. It is a notable fact that old Pacing Pilot does not appear as the progenitor of a saddle family.

In considering the comparative merits of the leading foundation stallions we find that Denmark was not a success in any direction except as the sire of handsome and stylish saddle horses. John Dillard may not have been the equal of Deumark in the elegance of his progeny, but he far surpassed him in his valuable relations to the trotter. His danghters became quite famous as the producers of trotters of a high order, and they have over twenty in the 2:30 list. The Tom Hals have developed phenomenal speed at the pace, and a great deal of it, interspersed with but few trotters.

Of late years many owners of the very best material for saddle stock have given their whole attention to the development of speed, either at the lateral or diagonal motion, because it has been deemed more profitable. In thus selecting, breeding and developing for extreme speed, the adaptation to saddle purposes has been lost or bred out. While it is true that some colts come into the world endowed with all the saddle gaits, it is also true that skill and patience are requisite in teaching the saddle horse good manners. There is no imaginable use to which the horse can be put where he will show his beautiful form and thorough education to so great advantage as under the saddle. 


\section{CHAPTER XVI.}

THE WILD HORSES OF AMERICA.

The romances of fifty $z$ ears ago-Was the horse indigenous to this country?The theories of the paleontologists not satisfactory-Pedigrees of over two millions of years too long-Outlines of horses on prehistoric ruins evidently modern-The linguistic test among the oldest tribes of Indians fails to discover any word for "Horse"-The horses abandoned west of the Mississippi by the followers of De Soto about 1541 were the progenitors of the wild horses of the plains.

FIFT' years ago there was much that was romantic and mysterious in our conceptions of the real character and origin of the vast herds of wild horses that abounded on our Western plains, and the same remark applies to their congeners on the pampas of South America. The wild horse and the Indian opened up a. most inviting field for the writers of romance, and current literature was flooded with "Wild Western" stories, with the horse and the Indian as the leading characters. We are now one generation, at least, this side of the time when stories of this kind are either songht or read, but we are not past the period when the origin or introduction of the horse on this continent may be considered with interest and profit. Before touching upon the wild horse, as known in our early history, however, it may be well to consider, briefly, the question as to whether he may not have been indigenous to this continent.

In our generation the spade has become a wonderful developer of the truths of ancient history. The buried and forgotten cities. of the old world are being unearthed in Europe, Asia and Africa, and thousands of works of art and learning that had vanished from the face of the earth are again restored to the knowledge of the human race. In a kindred branch of investigation the geologists and paleontologists have been delving into the bowels. of the earth-not to find what previous generations of men had left behind them, but to find what life was myriads of ages before man was placed on the earth. Out of the rocks they have, 
literally, quarried many strange examples of animal life that have been buried millions of years, and hundreds of feet below the present surface. Among these strange petrefactions that were thus buried when the earth was young, there is one that has been widely exploited as the "Primal Horse," that is, the animal from which our present horse was finally evolved. There are three or four specimens of this petrefaction now on exhibition in this country, the first having been discovered by Professor Marsh, of Yale College, and now in the museum of that institution. Nearly twenty years ago Professor Huxley, the great English naturalist, delivered a lecture in this city on the Marsh petrefaction as his text, in which he told us that the "Primal Horse" had, originally, five toes on each foot, that after an indeterminate geological period he lost the two outside toes on the hind feet, and after another million years, more or less, he lost the outside toes of the fore feet, thus leaving him ready to go on developing the middle toe into the foot and hoof of the horse while the outside toes disappeared. In proof of this he offered the fact that horses of this day have splint bones on each side of the leg, under the knee, and these bones are the remnants of the outside toes. This was the explanation which the learned professor gave in disposing of the outside toes when there were but three toes on each foot, but he failed to explain what had become of the outside toes when there were five on each foot, and there his whole explanation toppled to the ground.

In the American Museum of Natural History, in this city, there is a very fine representative of this particular type of petrefactions. It is about fifteen inches high, with a head that is disproportionately large, and a tail that is long and slender, suggesting that of a leopard. On each fore foot this animal has four toes, or claws, as we might call them, and on each hind foot three claws. With these claws this little animal might dig in the ground, or he might climb a tree when necessary for either safety or food. Each one of these toes nas its own distinct column of joints and bone extending to the knee, and there is no material difference in the size and strength of these different columns. Now, with three toes and three columns only, we can accept or reject, as we please, Professor Huxley's method of getting the two superfluous ones out of sight by pointing to the splint bones on the leg of a modern horse and saying these are the remnants of the outside toes. But, in the meantime, neither 
Mr. Huxley nor anybody else has told us what became of the outside toes and their columns in cases where there were five toes. It will not do to chuck these ont of sight and say nothing about them; they must be accounted for or the theory fails. In the specimen now under examination the fore feet are each supphied with four toes, and each toe is supported by its own distinct column of bone. Here we meet with the same difficulty as in the case of five toes, for we have more material than the Huxley theory is able to provide for. This theory has been generally accepted among specialists, in this line of investigation, and they all point to the splint bones, as already stated, as the remnants of the two toes, adhering to the main column. This leaves the one superfluous toe wholly unprovided for, and thus the theory discredits itself and leaves the question in a shape that is entirely unsatisfactory and unacceptable to the understanding.

The teeth of this specimen, in their shape and arrangement, very strongly resemble the teeth of the horse. Upon this one fact is placed the chief reliance to sustain the claim that this was the "Primal Horse," but this fact, when taken without the support of other facts, simply proves that the animal was herbivorous, subsisting on the same kind of food as the horse, but it does not prove that he was a horse. The teeth are an excellent starting point, and we admit their arrangement and resemblance to the teeth of the horse, but the rules of comparative anatomy, as well as common sense, require that at some other point or points there should be at least a suggestion of resemblance. In this case there is absolutely no resemblance, but a very marked and unmistakable divergence. The foot of this little animal, fifteen inches high, bears no more resemblance to the foot of the horse than the foot of the $\mathrm{dog}$ bears to the foot of the horse. Indeed, the foot of the specimen before us, whether provided with three, four or five claws, very strikingly resembles the foot of the dog. The arrangement of the different specimens of the feet, commencing with the smallest with four toes and ending with the perfect and full-grown foot of the horse as we know him, intended to illustrate the process of evolution, is a very interesting study, but. when you have done with the last foot with claws and reach forward for the first foot with a hoof, you find there is an impassable gulf between them, over which the theory of Evolution has not been able to construct a bridge. But there is another consideration that is final and that cannot be overcome by any theory 
whatever. According to the chronology widely accepted among geologists, this little animal was buried in the sand more than two millions of years ago, and in a grave more than a hundred feet below the general surface of the country in which he was found. In some great upheaval or cataclysm of the earth's surface, this little animal, with all his contemporaries, perished, and there perished with him all possibility of propagating his race. It is only a waste of time, therefore, to speculate upon what a certain race of animals might have produced in our day, when they were all cut off two millions of years ago. With this disposition of the little animal with the variety of toes, quarried from the rocks and by courtesy here called the "Primal Horse," we reach another prehistoric epoch in our inquiry, but much less remote than the one just considered.

From the incredible numbers of wild horses on our Western plains and on the pampas of South America, at a very early period in history, it became a question of some interest with many thinking men as to whether the horse was not indigenous on this continent. It is within the knowledge of everybody that this continent was inhabited by a mysterious and unknown race of people long before it was visited by Europeans. These mysterious people seem to have been driven out by the fierce and warlike savages who occuplied the country at the time of its discovery, and even they knew nothing about the people who had preceded them. In very many localities the vanished people left behind them marks, numerous and unmistakable, that they had made considerable progress in the arts of civilized life. Writers have generally designated them as "the Mound Builders," because they heaped great tumuli of earth over the graves of their distinguished dead, but the real "Mound Builders" did far more than this, for with immense labor they built great, strong defenses for their protection against their enemies. When we go further West and South, into the fertile valleys among the moun. tains, we find still later traces of these unknown people in the ruins of buildings and dwellings erected, with infinite labor, traces of irrigating canals, etc., but we still fail to come up with them, or any trace of their history. In that region ruins of this type are designated as "Aztec Ruins," but this title puts us no further on the way of who the builders were. In 1877 a correspondent of a Colorado newspaper, who seemed to write intelligently and candidly, described some of those ruins which he 
found in the valley of the Las Animas, in Southwestern Colorado. He speaks of a valley fifteen miles long and seven miles wide, on the Animas River, and says this valley was covered with dwellings built of stone, but he gives particular attention to a row of buildings built of sandstone laid in adobe mud. These buildings are about three hundred feet long and three hundred feet apart, as I understand the writer, and extend a distance of six thousand feet. The outside walls are four feet thick and the inside ones from one and a half to three feet thick; there are rooms still left and walls remaining that indicate a building four stories high. In some of the rooms there are writings that never have been deciphered, and in one of them there are drawings of tarantulas, centipedes, horses and men. The word "horses" riveted my attention, and connected with it there were several things to be considered. First, were the drawings really intended to represent horses? Second, if so might they not have been placed there long after the builders had disappeared and in recent years? Third, if placed there by the builders, what was their date, and were they before or after the introduction of the horse into Mexico by the Spaniards? 'The possibility of ever obtaining any satisfactory information about these drawings and their date seemed very remote, but after watching and waiting for about eighteen years, I have recently received two letters that settle the whole matter so far as these particular ruins are concerned.

Mr. Charles McLoyd, a very intelligent gentleman of Durango, Colorado, who has made a special study of the Cliff Dwellers and kindred subjects, in that part of the world, writing under date of January 10, 1895, says:

"I am unable to inform you in regard to the pictures on those particular ruins, but can say that in no other locality have I found pictures of horses or anything to indicate that these prehistoric races had any knowledge of the animal. If such pictures existed we would be unable to determine anything definite from them; or in other words, it would not show that the horse was on this continent before the Spaniards brought him, but rather that the people who constructed the buildings lived here after the Spaniards came. I have often seen pictures of horses on the walls of cañons, but there is no question but they were the work of the present Indians. We often find associated with them pictures of railroad trains, etc., that indicate that some of them are of very recent date. To sum the matter np, would say that, so far, there is no evidence that these races had any knowledge of the horse, or had ever seen the Spaniards."

Mr. John A. Koontz, of Aztec, New Mexico, writes under 
date of January 24, 1895. He knows all about the ruins in question, for he owns the land on which they are situated, and puts the whole matter very clearly, as follows:

"I know nothing of the drawings of horses and other animals on the walls of the 'Aztec Ruins' here that Mr. Wallace speaks of. I think the drawings were all in the imagination of the correspondent to whom Mr. Wallace refers. I have been familiar with the ruins for fourteen years and this is the first time I have ever heard of any drawings of horses on any of the walls. There are drawings on some rocks some miles from the ruins, but from their narure I have considered them the work of the modern Indians. These ruins were visited by a party of archeologists two years ago, who spent several weeks liere, and made a survey, with maps and general drawings of the same. They decided that the main building had, originally, over seven hundred rooms."

These letters are conclusive, so far as the region of the Las Animas is concerned, and with that region knocked out there is not enough left to justify further search for evidence that the prehistoric races had any knowledge of the horse. Nothing remained then but the linguistic test, and in 1885 I had such an opportunity for applying this test as may never occur again. This test formulated itself in my mind, in this shape: "Did any of the nations or tribes of the aboriginal inhabitants of this continent have a word in their language indicating a horse?" When in California I applied to Mr. Bancroft, the compiler and publisher of the great documentary history of the Pacific coast, who then had a large corps of skilled translators at work on his famous compilation, and submitted my question. He introduced me to his principal linguist, who knew not only Spanish, English and other modern languages, but also the langnage of the Indians of the coast, the mountains and the plains, of the period covered by the question. The question did not seem to be new to him, and he answered with the candor and conscientionsness of a man who knew what he was saying, that there was no word in any of the Indian tongues, ancient or modern, that represented the horse. This settled the question of the supposed prehistoric character and rank of the horse, and we are thus driven to accept the infinitesimally small number left behind by Cortez, Nnnez and De Soto as the seed from which sprang the countless thousands of wild horses that for generations roamed the Western plains.

The story of the Conquest of Mexico is full of blood and cruelty, but as we have nothing to do with any part of the story 
except so much of it as relates to the introduction of the horse to the continent of North America, it will require but small space to tell it. Cortez sailed from Cuba for Yucatan, Feburary, 1519, with an army of six hundred and sixty-three men, two hundred Indians and sixteen horses. This wholly inadequate supply of cavalry was the weak place in his venture, but the horses could not be had in Cuba, without paying an incredible price. Those he was able to secure cost from four to five hundred pesos de oro each. The peso was the Spanish dollar. The expedition was nominally fitted out for Yucatan, but its real aim was the heart of Mexico. In his first fight with the Indians near the coast, men mounted on horses were feared by the natives as monstrous apparitions. This overwhelming fear of the horse may seem to some of my readers as overdone by the historian, but it seems to have been the common experience of all the different nations and tribes of Indians wherever the horse made his first appearance in battle. In the first battle two of the horses were killed, and in the second another was killed, and all that remained were more or less severely wounded. Cortez was afterward joined by Alvarado, at Vera Cruz, with twenty horses and one hundred and fifty men. In making his official reports directly to the home government in Spain instead of the governor of Cuba, Cortez gave mortal offense to that dignitary, and he sent out an armada under Narvaez to supersede Cortez and return him in chains to Cuba. This armada consisted of eighteen vessels, carrying nine hundred men, eighty of whom were cavalry. After some diplomacy, Cortez, feeling that with his little handful of men he was wholly unable to meet Narvaez, he did all he could to avoid a conflict. Each party knew the exact strength of the other, and as Narvaez began to threaten, Cortez determined to fight for his rights and his liberty. He then had but five men mounted, but he took advantage of the carelessness of his adversary, made a night attack in the midst of a tempest, and captured Narvaez and his whole army. The private soldiers of that day, like their commanders, had no idea or principle to ight for except for plunder, and they were always ready to attach themselves to the most successful robber. Cortez was their ideal leader, and at once he had a new army of devoted followers. He then had eighty-five mounted men, and he felt strong enough to hold and rule the great country he had conquered. Mexico was conquered in 15\% $\mathrm{l}$, and the news of the vast amount of treasure captured bronght a great 
crowd of emigrants from Spain and from all her dominions. The Spaniards, like other nations of Southern Europe, kept their horses entire and whenever representatives of both sexes strayed away, reproduction would follow. As the country became more tranquil, and as the tide of European settlers kept pouring in, we can easily understand how the little bands of estrays should grow into larger bands and soon become as wild as though they had never seen a human being except to flee from him.

The explorer De Soto sailed for Florida in 1539, in search of gold. He had in his command five hundred and thirteen men, exclusive of sailors, and two hundred and thirty-seven horses, besides some for the purpose of bearing burdens, the number not given. In all his weary journey of three years he found the Indians active, hostile, and courageous fighters. In one of his first battles he lost twelve horses, and had seventy wounded. He pursued many phantoms in search of gold, in different directions, but his general course was westward and northwestward. He was the first European to discover the Mississippi River, not far from the mouth of the Arkansas, and there he was buried in the middle of the river, to prevent the Indians from discovering he was dead and from desecrating his remains. His followers then determined to push on westward to Mexico, and reached as far as the borders of Texas, probably, when they became discouraged with the magnitude of the difficulties that surrounded them, and determined to return and seek an outlet from the wilderness by water. On this last journey, west of the Mississippi, they suffered their greatest loss of horses.' They had not been shod for more than a year, and a great many were lame and unable to travel. When the Spaniards had completed their boats and were ready to leave the scenes of their sufferings and disasters, they turned loose upon the bank of the river their four or five remaining horses, which manifested great excitement, rumning up and down the bank neighing for their masters, as they sailed away. This alarmed the Indians and they ran into the water for safety.

The Indians were afraid of the horses and the horses were afraid of the Indians. It seems to be a fact, observed in all the early intercourse of the Spaniards with the Indians, that universally they had a kind of superstitions awe of the horse as a superior being, and it is probably due to this awe that the Indians did not utterly destroy every horse that fell out of the ranks or that escaped in the wilderness. As I understand the history of 
this terrible exploration, when the Spaniards crossed the Mississippi they had two hundred and fifty men and one hundred and fifty horses, and when they came back and were ready to sail they had but four or five horses left. It is fair, therefore, to conclude that the greater portion of these hundred and fifty head was scattered in the wilderness as they went out and as they returned. This provides a sufficient breeding basis for the countless multitudes of descendants, and places that nucleus in the right region to nourish them in a feral state.

While this exploration of De Soto seems to furnish a breeding basis of sufficient breadth to account for all the wild horses that have appeared on this continent, there is another consideration that we must not overlook, and that is the inborn tendency of the domestic horse to become wild when in wild associations. By turning to the chapter on the colony of Virginia you will see that there were many wild horses there at the beginning of the last century. On the frontiers, near the habitat of wild horses, they became a great nuisance to the settlers in "coaxing" away their domestic horses and making them as wild as the wildest. These accretions to their strength from the domestic horse have been going on for generations, and thus the wild horse became conglomerate in the elements of his blood, with the Spanish traits still predominant. Fifty or a hundred years ago the pens. of many writers were employed in idealizing "The Wild Horse of the Desert." He was made the leading figure in many a romance, and the hero of many a triumph. Tom Thumb, the great trotter that was taken to England, astonished all the world with his speed and his endurance, and, following the fashion of the day, he was represented to have been caught wild on the Western plains. For many years the wild horse was the "fad" of American writers, just as the Arabian was of English writers, and the writers on one side were just about as far from intelligence and truth as those on the other. When, forty years ago, great droves of the half-breeds, Mustangs, were brought from the plains to the border prairie States, seeking a market, the scales began to drop from the eyes of the worshipers of the wild horse. They were homely little brutes, and they were as tough as whit-leather. But the countless multitudes that roamed at will over their grazing grounds, making the earth tremble when they moved, have dwindled down to a few insignificant bands, and the whole glamour around the wild horse of the desert has vanished. 


\section{CHAPTER XVII.}

\section{MESSENGER AND HIS ANCESTORS.}

Messenger the greatest of all trotting progenitors-Record of pedigrees in Englisb Stud Book-Pedigrees made from un reliable sources-Messenger's right male line examined-Flying Childers' "mile in a minute"-Blaze short of being thoroughbred-Sampson, a good race horse-His size; short in his breeding-Engineer short also-Mambrino was a race horse with at least two pacing crosses; distinguisbed only as -a progenitor of coach horses and fast trotters-Messenger's dam cannot be traced nor identifiedAmong all the horses claiming to be thoroughbred be is the only one that founded a family of trotters-This fact conceded by eminent writers in attempting to find others.

HAVING completed a brief historical sketch of horse history from the beginning, and many events connected therewith, we are now ready to consider the American Trotting Horse, as the culmination of what has been written. Thus far we have met with much pretentious nonsense, claiming to be history and written by men who never gave the subject the study of an honest hour. The horse is honest enough, but the rule seems to be almost universal that whenever men commence to write about him they are guided by their imagination and not by the facts. As to what we are to meet in the coming chapters, I can only say that, unfortunately, "the fathers have eaten sour grapes and the children's teeth are set on edge." The instinct to misrepresent has been transmitted, and I cannot promise that we will find any great moral improvement among the horsemen of our own country and generation.

For more than three-quarters of a century, and indeed from the first trotting experiences of this country that have been preserved, it has been the unanimous judgment of all who have given any thought or attention to the subject that the imported English horse, Messenger, was the great central source of trotting speed. As the years have rolled by this opinion has increased in strength until it has become an intelligent and demonstrated belief. When, forty years ago, a horse was found 
able to trot a mile in two minutes and thirty seconds, the speed was deemed wholly phenomenal, but that speed has been increased, second by second, until we are now on the very brink of two minutes. In this process every second and fraction of a second that has been ent off has been so much additonal proof of the universal belief that Messenger was the chief progenitor of the American trotter. He is not the only source of trotting speed, but he is the chief source. Whence he derived this distinctive power to transmit trotting speed will be made more clear as we proceed. His blood left no deep nor lasting impress upon the running horses of the comntry, and it is seldom we meet with any trace of it in the running horse of to-day, but it is prominent and conspicuous at the winning post of every trotting track on this continent. This will be made apparent. when we come to consider the details and the merits of the mighty tribes and families that have descended from him.

Several years ago I promised to write a volume on "Messenger and his Descendants," and I have often been reminded of that unfulfilled promise, which I will here try to redeem. When that promise was made I had written many things about Messenger, but since then I have secured very many valuable facts that, I think, will far more than compensate for the delay. There is still much that is unknown and much that is only partially known of the origin and history of Messenger and his ancestors, and in considering the questions that will arise as the discussion progresses, I will not submit to a slavish acceptance of whatever has come down in the shape of stallion advertisements, or as unsupported traditions, and then recorded as facts by people who knew nothing about them, and made no effort to know. I shall look for the facts that are known to be facts, or such evidence as is reasonable and commends itself to an unbiased judgment, and then reach such conclusions as right reason shall dictate. The pedigree of Messenger, or rather the pedigree of Messenger's reputed grandam, appears in the English Stud Book in the editions of $\mathbf{1} 803$ and $182 \%$, in the following form:

Regulus Mare (Sister to Figurante). Her dam by Starling, out of Snap's dam.

$\left.\begin{array}{l}1769, \text { b. f. by Herod (dam of Alert). } \\ 1770 \text {, bl. c. Hyacinth, by Turf. }\end{array}\right\}$ Mr. Vernon.

1771, bl. c. Leviathan (aft. Mungo), by Marske. Lord Abingdon. 
$1773,-\mathrm{f}$. by 'Turf.

$1774,-\mathrm{f}$. by Ditto (dam of Messenger').

1777 , bl. f. by Dux.

Lord Grosvenor.

1780, b. f. by Justice (dam of Equity).

1782 , b. c. $\dot{V} u l c a n$, by Justice. Mr. Panton.

$\left.\begin{array}{l}1783 \text {, b. c. Aavage, by Sweetbriar. } \\ 1784 \text { b. f. Ariel, by Hightiflyer (dam of Mr. }\end{array}\right\}$ Mr. Bullock.

Hamilton's Swindler, by Bagot).

This is all we have of the pedigree of Messenger as recorded in the English Stud Book, and this record, on its face, has a very suspicious appearance. Messenger had run some races at Newmarket and a place must be provided for him in the Stud Book. He always ran as a son of Mambrino, and there is no doubt this is correct, as it so appeared in the Racing Calendar, long before the days of the Stud Book. But nobody, either then or later, seemed to know anything about his dam. Toward the close of this chapter I will give an exhaustive review of the many troubles in which these two fillies by Turf seem to be involved.

Messenger was by Mambrino, he by Engineer, he by Sampson, he by Blaze, he by Flying Childers, and he by the Darley Arabian. We give the right male line here for the reason that there can be no doubt as to the accuracy of this line, for it has been preserved in contemporaneous racing records. The tronble, where any trouble exists, is all with the dams of these horses which at best are only matters of the most uncertain tradition. A writer in the Edinburgh Review for July, 1864, covers the whole ground when he says: "The early pedigrees (in the Stud Book) are but little to be relied upon, as they seem for the most part to have been taken from traditional accounts in the stable, from descriptions at the back of old pictures, and from advertisements, none of which had to pass muster at the Herald's College." This is in full accordance with our American experiences and it is entirely safe to say that the great body of our old American pedigrees, especially in their remote extensions, are more or less fictitious. The industry of producing great pedigrees out of little or nothing has long been pursued on both sides of the water, and it would be very difficult to determine which side had the better of it.

Before attempting to analyze the pedigree of Messenger, or rather that of his dam, with which the chief difficulty lies, we will go back to the head of the male line and consider each successive generation. The Darley Arabian, one of the most distinguished of all the founders of the English thoroughbred horse, 
was brought from Aleppo, about the year 1710. He did not eover many mares except those of his owner in Yorkshire, but he was very successful. Childers, commonly called Flying Childers, was foaled 1315. He was got by the Darley Arabian ont of Betty Leeds, a distinguished lightweight rumner, by Careless. Childers was the most distinguished race horse of his day, and the fabulous story of his having run a mile in a minute was circulated, believed and written about for generations. He ran a trial against Almanzor and Brown Betty over the round course at Newmarket (three miles, six furlongs and ninety-three yards) in six minutes and forty seconds, "and it was thought," says the old record, "that he moved eighty-two feet and a half in a second of time, which is nearly at the rate of one mile in a minute." This was the basis of the legend "A Mile in a Minnte," and it has lived till our own clay, just as many a traditional pedigree has lived. If we accept the time as given by the old chroniclers, of which we have very grave doubts, Childers ran at the rate of one minute and forty-five seconds to the mile, and he covered a distance of fifty feet and about two inches to the second of time. The pedigree of Childers on the maternal side is one of the oldest in the Stud Book, and we are not aware that any charges have ever been made against its substantial authenticity.

BLAzE, the son of Childers, was foaled 1733, and was out of a mare known as "The Confederate Filly," by Grey Grantham; her dam was by the Duke of Rutland's Black Barb, and her grandam was a mare of nnknown breeding, called "Bright's Roan." Here the maternal line runs into the woods, but this is not the only defect in the pedigree, for the dam of Grey Grantham was also unknown. In order to give a clear idea of just how Blaze was bred, taking the Stud Book for our authority, we will here tabnlate the pedigree for a few crosses.

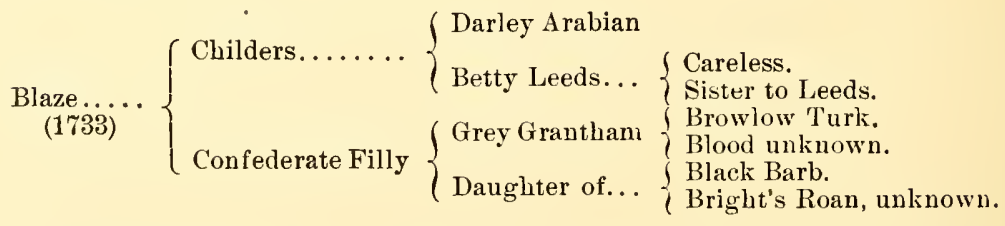

Certainly this horse cannot be ranked as thoroughbred under any rule, Engìsh or American, that has ever been formulated. Only three generations away we find two animals of hopelessly 
unknown breeding. Mr. Henry F. Euren, compiler of the English Hackney Stud Book, has given Blaze a new place in horse genealogy, and this new place affects the American trotter, remotely, ontside of the line through Messenger. Mr. Lawrence, the best English authority on horse matters in the latter part of the last and the beginning of the present century, had maintained, eonfessedly on tradition only, that Old Shales, the great fountain head of the English trotters of a hundred years ago, was a son of Blank, by Godolphin Arabian. On this point Mr. Euren has got farther back and found earlier evidence in printed form that Blaze and not Blank was the sire of Old Shales. We combated this claim for a time, but in the introduction to his Stud Book he has made out a very good ease, and we have hardly a doubt but that he is correct. In speaking of the breeding of Shales, and of his dam being a "strong common-bred mare," he says: "It is of interest to examine the pedigree of the sire (Blaze) to determine whether yet stronger raeing or pacing elements existed on that side." After giving a tabulation of the pedigree he eontinues: "There would thus appear to have been a large proportion of English (native) blood in the dam of Blaze, though no one can say what was its character-whether running, trotting, or ambling." In referring to the fact that Bellfounder was a descendant of Old Shales, the son of Blaze, Mr. Euren makes this practical application of the incident:

"The fact that in the seventh generation from Blaze, on each side, the reunion of the blood in Rysdyk's Hambletonian, the sire of so many fast American trotting horses, should have proved to be of the most impressive character, would appear to warrant the conclusion that there was a strong latent trotting tendency in the wear ancestors, on one. if not on both, sides of Blaze."

These two points from a very high English anthority-that Blaze was not thoroughbred and that he was the sire of Shales, a great trotting progenitor, must have due weight in reaching sound conclusions.

Saypson, the son of Blaze, was foaled 1745 , and he lias occupied a very prominent and at the same time unique place in running-horse history. He was not only a great race horse, at heavy weights, but he was considered phenomenal in his size and strength, and in his lack of the appearance of a race horse. Some of his measurements have come down to us, and as they are reliable data as to what was considered a remarkably large and 
strong race horse a hundred and forty years ago, we will reproduce them here in order that the curious may compare them with the average race horse of this generation:

Height on the withers, 15 hands 2 inches; dimensions of fore leg from the hair of the hoof to middle of fetlock joint, 4 inches; from fetlock joint to bend of the knee, 11 inches; from bend of knee to elbow, 19 inches; round fore leg below knee, narrowest part, $8 \frac{1}{2}$ inches; round hind leg, narrowest part, 9 inches.

These measurements may not seem to merit any particular attention at this day, but a hundred and fifty years ago they were considered phenomenal in the race horse. But we are not left to the dry details of a certain number of inches and fractions of an inch upon which to base a just conception of the strength and substance of this horse. A number of historians have told us of the merriment among the grooms and jockeys when Sampson made his first appearance on the turf. The question was, "Has Mr. Robinson brought a coach horse here to run for the plate?" The laugh was on the other side at Malton that day, however, when the "coach horse," carrying one hundred and forty pounds, won the plate in three heats. The distance was three miles, and Sampson was then five years old. At long distances and at high weights Sampson was a first-class race horse for his day. But, notwithstanding all this, we are told that his blood never became fashionable, for there was a widespread conviction that he was not running-bred on the side of his dam. The historians tell us. that he transmitted his own coarseness and lack of the true running type in a marked degree, which was very evident in his. grandson, Mambrino.

His pedigree has been questioned from the day of his first. appearance to the present time, and we have made a very careful study of all the facts at our command. In the first edition of his Stud Book (1803) Mr. Weatherby gives his dam as by Hip; g. d. by Spark, son of Honeycomb Punch; g. g. d. by Snake aud out of Lord D'Arcy's Queen. This has not been materially changed in any of the subsequent editions, and we think it may be taken for granted that the horse was advertised under this pedigree. Mr. Weatherby commenced work on pedigrees in 1791, and avowedly accepted the best information he could get with regard to old pedigrees, regardless of the sonrce. We are not aware that he ever investigated anything outside of his office work, or if he did. he never gave the public the benefit of the details of his investi- 
gations. John Lawrence commenced work on horse history long before Mr. Weatherby commenced as a compiler of pedigrees, and he was altogether the ablest writer of his day, or perhaps we might add, of any other day. He was a clear and independent thinker and a vigorous writer. In his "History of the Horse in all His Varieties and Uses," on page 281, he thus discusses the question of Sampson's pedigree:

"Nobody yet ever did, or ever could assert positively that Jigg was not thoroughbred, but the case is very different with respect to Sampson: since nobody in the sporting world, either of past or present days, ever supposed him so. Nor was the said world at all surprised at Robinson's people furnishing their stallion with a good and true pedigree, a thing so much to their advantage. Having seen a number of Sampson's immediate get, those in the Lord Marquis of Rockingham's stud and others, and all of them, Bay Malton perhaps less than any other, in their heads, size and form, having the appearance of being a degree or two deficient in racing blood, I was convinced that the then universal opinion on that point was well grounded. I was (in 1778) an enthusiast, collecting materials for a book on the horse. It happened that I wanted a trusty and steady man for a particular service, and opportuvely for the matter now under discussion, a Yorkslire man about threescore years of age was recommended to me, who had recently been employed in certain stables. I soon found that his early life had been spent in the running stables of the North, and that he had known Sampson, whence be was always afterward ummed by us 'Old Sampson.' He was very intelligent on the subject of racing : trek and his report was as follows. He took the mare to Blaze, for the cover which produced Sampson, helped to bit and break the colt, rode hiu in exer- ise and afterward took him to Malton for his first start, where, before the race, in was ridiculed for bringing a great coach horse to contend against racers. On the sale of Sampson this man left the service of James Preston, Esq., and went with the colt into that of Mr. Robinson. His account of Sampson's dam was that she appeared about three parts bred, a hunting figure and by report a daughter of Hip, which, however, could not be authenticated; and the fact was then notorious and not disputed in the Yorkshire stables. . . . Mr. Tattersall lately stowed me a portrait of Sampson in his flesh, in which this defect of blood appears far more obvious than in one which I had of him galloping."

Again, in his great quarto work, issued 1809, Mr. Lawrence reiterates his belief that Sampson was not thoroughbred. He says:

"I am by no means disposed to retract my opinion concerning Robinson's Sampson. Not only did the account of the groom appear to me to be entitled to credit, but the internal evidence of the horse's having had in him a cross of coinmon blood is sufficiently strong by the appearance both of the horse himself and of his stock; an idea in which every sportsman, I believe, who re-members Engineer, Mambrino and others will agree with me." 
Here then, we have the answer to the whole inquiry reduced to its simplest form. The groom who coupled the mare with Blaze from which came Sampson says the mare was called a Hip mare, but that her pedigree was really unknown. For the intelligence and honesty of this groom Mr. Lawrence does not hesitate to vonch, and he adds the common belief of all the Yorkshire sportsmen of that day, who knew the mare, that she was of unknown breeding. This evidence is further supplemented by the family characteristics of the stock descended from Sampson, to say nothing of the great lack of "blood" in the appearance of Sampson himself. As against this we have the dry, unsupported assertion of Mr. Weatherby, forty years after the event, and probably copied from an advertisement of the horse. In view of all this we must tabulate the pedigree of Sampson as follows:

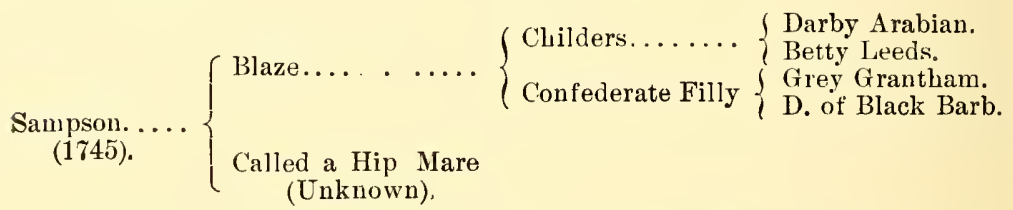

Exgineer, son of Sampson, was a brown horse. foaled 1755, and was out of Miner's dam, by Young Greyhound; grandam by Curwen's Bay Barb, and the next dam unknown. This is all the pedigree that has ever been even claimed for this horse, and it falls far short of the rank of thoronghbred. That the eye may take it all in at a glance we will here put it into tabular form. There is a discrepancy of one year between Weatherby and Pick in the age of the horse, and we find Pick is right in giving his date as 1755 .

$\underset{(1755) .}{\text { Engineer..... }}\left\{\begin{array}{l}\text { Sampson.... }\left\{\begin{array}{l}\text { Blaze. .......... } \\ \text { Unknown. }\end{array}\right. \\ \text { Miner's dam. }\left\{\begin{array}{l}\text { Childers. } \\ \text { Confederate Fil ly. }\end{array}\right. \\ \left.\begin{array}{l}\text { Young Greyhound. } \\ \text { D. of Bay Barb } \ldots\end{array}\right\} \begin{array}{l}\text { Greyhound. } \\ \text { Pet mare. } \\ \text { Unknown. }\end{array}\end{array}\right.$

Notwithstanding the absence of Eastern blood, Engineer was a race horse of above average ability, although not so good as another son of Sampson called Bay Malton. A few of his sons aside from Mambrino ran respectably, and his daughters were, at one time, highly prized as brood mares. 
Mambrixo, the son of Engineer, was a great strong-boned grey horse, bred by John Atkinson near Leeds in Yorkshire, and was foaled 1768. His dam was by Cade, son of the Godolphin Arabian; g. d. by Bolton Little John; g. g. d. Favorite by a son of Bald Galloway, etc. The Cade mare produced Dulcine, a a noted performer, and the mare Favorite was a distinguished performer herself. The poverty of this pedigree is all on the side of the sire, as will be seen by a brief tabulation.

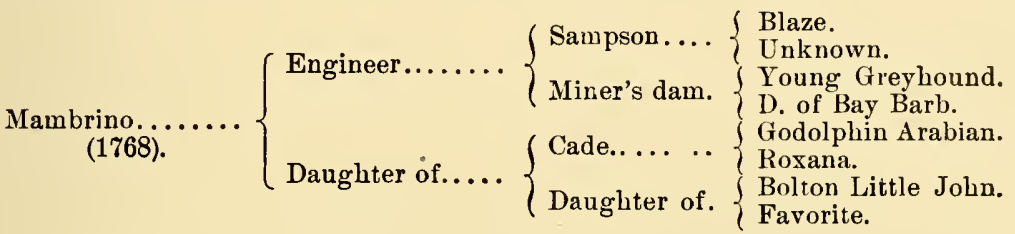

It is worthy of note here, as a curious fact, that Mambrino had two pacing crosses. Roxana, the dam of Cade, was by Bald Galloway and Favorite was by a son of Bald Galloway. 'This horse Bald Galloway was a distinguished representative of the famous old tribe of pacers known as the "Galloways," from the province of Galloway in Southwestern Scotland.

Mambrino was not put upon the turf till he was five years old, and he proved himself a great race horse in the best company and for the largest class of stakes. He was on the turf most of the time for five or six years and until he was beaten by Woodpecker in 17\%9, in which race he broke down. He was beaten but four times, and paid four forfeits. He went into the stud in the spring of 1777 , although he ran after that, at $10 \mathrm{gs} .10 \mathrm{~s} .6 \mathrm{~d}$. to cover thirty mares besides those of his owners. In 1779 he was again in the stud, in Cambridgeshire as before, at the same price; 1781 he covered at 50gs. $10.6 \mathrm{~d} . ; 1784$ at $15 \mathrm{gs} .10 .6 \mathrm{~d}$. ; 1785 at $25 \mathrm{gs} .10 \mathrm{~s} .6 \mathrm{~d}$.; 1786 he dropped back to $15 \mathrm{gs} .10 \mathrm{~s} .6 \mathrm{~d}$.

We give these prices to show the variations in the estimated value of his services. As a sire of race horses Mambrino was not successfnl. Some fifteen or twenty of his progeny ran more or less respectably, but none of them was at all comparable with himself. While he was a comparative failure as a racing sire there was another qualification in which he attained great eminence and distinction. In the second volume of Pick's Turf Register, published 1805, on page 266, we find the following paragraph appended to the history there given of this horse: 
"Mambrino was likewise sire of a great many excellent hunters and strong, useful road horses. And it has been said that from his blood the breed of horses for the coach was brought nearly to perfection."

This paragraph, considering its date (1805), the authority from which it comes, and the peculiar circumstances which prompted its utterance, has a most striking significance. After years of familiarity with Mr. Pick's works we can say freely that we never have been able to find any allusion or reference to the qualities of any horse portrayed by him other than his running qualities. This reference to the adaptabilities of the progeny of Mambrino stands alone. The "blood that brought the breed of coach horses nearly to perfection" must have been blood that gave the "breed" a long, slinging, road-devouring trot, as well as size and strength. The very same qualifications were observed and noted in the descendants of Mambrino in this country forty and fifty years ago, and at no time in our history have we had such unapproachable coach horses as the great-grandsons of Mambrino. What has been said, therefore, by Mr. Pick of the "coach-horse" qualities of the descendants of Mambrino in England has been fully realized and verified in his descendants, through Messenger, in this country.

The question here arises whether Mambrino ever showed any remarkable trotting action himself that would seem to justify this estimate of the trotting action of his descendants? Several writers, and among them Mr. Lawrence, have spoken of this peculiarity of Mambrino's incidentally, but the most tangible account we have of it is furnished by an English writer to the Sporting Magazine, who dates his letter from the "Subscription Rooms, Tattersall's, 1814." These "subscription rooms" were the very focus of sporting events, and this writer seems to be unusnally intelligent on this class of subjects. The object and point of his communication is to prove that no thoroughbred hor e conld be developed into a fast trotter. "Hence," he says, "no thoroughbred was ever known capable of trotting sixteen miles within the hour, and only one stands on record as having trotted fifteen miles within one hour. That was Infidel, by 'Turk, who performed it in the North, carrying nine or ten stone. Several race horses have been supposed capable of trotting fonrteen miles in one hour, and it is reported that the late Lord Grosvenor once offered to match Mambrino to do it for a thousand guineas." Now this writer does not say that Lord Gros. 
venor really made such an offer, but only that he was "reported", to have made it. This does not prove that the offer was formally made, but it does prove that Mambrino had a very remarkable trotting step or such a topic would not have been considered at Tattersall's subscription rooms. As this writer seems to refer to Mambrino and Infidel only as exceptional horses for their trotting step among thoroughbreds, we may take it for granted that Mambrino was considered exceptional, in his day. It is not probable that he was ever trained an hour at the trot, and we must conclude, therefore, that whatever speed he showed was his natural and undeveloped gait. It will be observed that Mr. Pick's paragraph was dated 1805, and the letter from the "subscription rooms" 1814, so that they could not have been mere reflections of theories advanced on this side of the Atlantic in relation to Messenger being a great source of trotting speed. These two facts were on record long before any "Messenger theories" were in existence, and those "theories" were formulated long before these two facts were known. The conclusions reached on both sides of the water are entirely harmonious, but they were reached in complete independence of each other.

Messencer, son of Mambrino, was a grey horse about fifteen hands two inches high, with strong, heary bone and a generally coarse appearance for a horse represented to be thoroughbred. From the Racing Calendar, and not from the Stud Book, we learn that he was foaled 1780 , and came out of a mare represented to be by Turf, and she out of a mare by Regulus, son of Godolphin Arabian, etc., as represented by Mr. Weatherby in his Stud Book. By looking back to the beginning of this chapter the form in which the entry appears in the Stud Book will be fully comprehended. The identity, history, and breeding of the dam of Messenger is the central point in this inquiry, and we must do our work carefully and thoroughly. From the form of the entry in the Stud Book, it will be understood that the breeder of each animal is supposed to appear opposite the foals of his own breeding, but this we have found in'more than a thousand instances to be wholly imaginary on the part of the compiler. If the animal ran, the name of the party running him is far more apt to appear than the name of the breeder. It will be observed, also, that the Turf fillies of $17 \% 3$ and $17 \% 4$ appear without their color being known. These fillies seem to be put in there to partially fill the gap between $1 \% \% 1$ and $1 \% 7 \%$ Mr. Pick says the dam 
of Messenger was black, but he gives no account of her further than that. Whether Mr. Pick was indebted to Mr. Weatherby, or Weatherby to Pick, I cannot say, but they both give the pedigree just as we have given it in this country. I am not inquiring whether these authorities agree on this pedigree, but whether they knew anything about it, and whether there is such agreement in details between them as will support each other.

The first question that arises in every man's mind is, whether there is any further trace of this Turf mare, the reputed dam of Messenger, in the Stud Book, by whom was she bred and owned, and by whom was Messenger bred? Pick says the Turf mare was. bred by Lord Bolingbroke, and Weatherby says she was bred by Lord Grosvenor. To test the question whether either is right, I have gone through the English Stud Book, page by page, and pedigree by pedigree, wherever I found the name of Lord Bolingbroke, or Lord Grosvenor, to see if any trace of the Turf mare could be found. I found no shadow of trace. The certificate of pedigree that came across the ocean with Messenger represents him to have been bred by John Pratt, and Mr. Pick, or rather his successor, Mr. Johnson, says he was bred and owned by Mr. Bullock. These clear and explicit declarations gave new hopes of finding something of the 'Turf mare, and at it I went again, and searched every pedigree that had the name of Mr. Pratt or Mr. Bullock attached to it, with no better results. than before. Now, Lord Bolingbroke, Lord Grosvenor, Mr. Pratt and Mr. Bullock were all breeders, and if any of them ever owned the dam of-Messenger and bred from her, none of her produce was ever recorded or ever started in a race.

Thus, the more we search for the truth about Messenger and his origin, the more dense becomes the mystery. When we find an English authority that seems clear, we find another that contradicts him, and probably neither of them knows anything about it beyond uncertain tradition. When we consider these contradictions of authorities in connection with the fact that. men were just as prone to lie and fix up a bogus pedigree a hundred years ago as they are to-day, and that stud-book makers were just as liable to be deceived then as now, we must conclude that there is room for very serious doubts as to whether Weatherby or Pick knew anything about the pedigree of Messenger, or by whom he was bred.

In pushing our inquiries still further in search of this mare, 
we must consider somewhat in detail Mr. Weatherby's methods and the degree of responsibility he assumed for the accuracy of his compilations. In 1791 he published what he called "An Introduction to a General Stud Book," containing, as he says, "a small collection of pedigrees which he had extracted from racing calendars and sale papers, and arranged on a new plan." In May, 1800 , he issned a supplement to his "Introduction" bringing down the produce of mares to 1799 . In 1803 he issued what we stippose is the first edition of the first volume of the Stud Book. The title-page reads, "The General Stud Book, containing pedigrees of race horses, etc., from the Restoration to the present time." The imprint is, "Printed for James Weatherby, 7 Oxenden Street, etc., London, 1803." The volume contains three hundred and eighty-four pages, while the edition of 182\% contains four hundred and forty-eight pages. There is no "Volume I." on the title-page, nor is there any indication that this is a continuation or revision of any preceding work. It brings down the list of produce in many cases to and including 1803 , but none later than that year, so there can be no mistake as to when it was issued.

I have been thus particular in identifying this first edition of the first volume of the English Stud Book, for it gives us an insight into the methods employed by Mr. Weatherby in the progress of his work. Upon a careful comparison of the editions of 1803 with $182 \%$ extending through the letters $\mathrm{A}, \mathrm{B}$, and $\mathrm{M}$, we find that he has thrown out more than ten per cent. of the entire families in the edition of 1803. By "entire families" I mean brood mares, with their lists of produce. In making these exclusions he seems to have confined himself to what may be considered the historic period, at that day, and did not go back further than about twenty years. Beyond that period everything was traditional, and he appears to have shrunk from all responsibility of attempting the exclusion of families. On and near the border line between these periods he seems to have taken the responsibility of cutting off a great many individuals of doubtful identity, even though the family was left to stand on its uncertain basis of tradition. I cannot say positively that the dam of Messenger and her sister were cut off with the multitude of others, but I can say that neither of them ever appeared again in the Stud Book. Other members of the family of the Regulus mare have places for their descendants in subsequent volumes, 
from which I wonld infer that $\mathrm{Mr}$. Weatherby considered her breeding all right, but the two fillies, one of them the dam of Messenger, have been treated as spurious and wholly omitted from the records. These are the facts relating to these two fillies claimed originally to be by Turf, and there can be no moral doubt that they were omitted or exchded becanse Mr. Weatherby deemed them unsustained and probably spurions.

In confirmation of the facts and circumstances already adduced, going to show that Messenger was not thoroughbred, we are now ready to consicer one of the strongest arguments that can be advanced in support of that conclusion. This argument is founded on the laws of nature and is not dependent upon the mere writing down of uncertain traditions. Messenger possessed and transmitted qualities that no thoronghbred horse has ever transmitted, from the period when the breed of race horses was formed to the present day. It is practically conceded on all hands that Messenger, by his own power and by his own right, founded a family of trotting horses, and this fact will be fully demonstrated in coming chapters. It is equally plain and, with honest and intelligent people, it is accepted with equal readiness, that no thoronghbred horse has ever done this. This declaration has been much controverted, but always in a general way and withont specifying any particular thoroughbred horse that had succeeded in establishing a family of trotters. In the progress of a discussion of this point with the late Charles J. Foster, a very clear and able writer, he was directly challenged, in ar manner that conld not be dodged, to name the thoroughbred horse ontside of Messenger, that had accomplished this feat. Greatly to my surprise, and I might say, gratification, he came back at me with two of Messenger's sons-Hambletonian and Mambrino. Thus he conceded the whole contention, for out of, literally, thousands he had to come back to two sons of Messenger.

In reply to an article in Wallace's Monthly for December, 188\%, going to show that Messenger was not a thoroughbred horse, $\mathrm{Mr}$. Joseph Cairn Simpson, of California, an able man and a lifelong advocate of more running blood in the trotter, wrote a review of the article in question. After admitting the full force of the demonstration that Messenger was not a thoroughbred horse, there is one sentence to which Mr. Simpson cannot subscribe, and he quotes it as follows: "Complete and conclusive as these facts may be. there is still another fact equally complete and 
still more convincing. Messenger possessed and transmitted qualities that no throughbred horse, in the experience of man, ever possessed and transmitted." This was a declaration of Messenger as a progenitor against the whole world of thoroughbreds, and Mr. Simpson felt that he could not let it pass unchallenged, and after scratching about among the thousands of thoroughbreds without finding anything, like poor Mr. Foster, he "acknowledges the corn," and comes back with Mambrino, the son of Messenger, without, seemingly, once realizing that he was proving my contention.

'The theory that if any other English race horse had been in Messenger's place and bred upon the same mares and had his progeny developed as Messenger's were developed, he would have produced the same results, has always been very popular with the advocates of "more running blood in the trotter." No doubt there are still some honest, but not well-informed people, who hold to this view merely because they have never heard of any other imported English horses that were contemporaneous with Nessenger, and hence have concluded there were none. If Messenger had been all alone during the twenty years of his stud services, as this theory assumes, there might be some reason to doubt whether some other English race horses might not have done just as well in establishing a line or tribe of trotters. But was he alone? From the close of the Revolntionary War to the end of the last century was a period of great activity and enterprise in the way of importing rumning horses from Great Britain: The blood of Herod and English Eclipse was in the highest estimate, not only in the old but in the new world, and a great many distinguished horses were brought over possessing those favorite strains. During that period racing was carried on with just as much spirit and éclat on Long Island and the river counties of New York, New Jersey, and some of the eastern counties of Peunsylvania as it was in Virginia and South Carolina. Horses of the most fashionable lineage were sought after and patronized, not by a few great breeding establishments, but by the farmers generally, in all the region here designated. 'The following list of imported English race horses is made up of animals that were contemporaneous with Messenger, covering the same mares and the offspring subjected to precisely the same treatment and conditions. The list is limited to what may be called the trotting latitudes, and embraces such animals only as were brought into 
New Jersey, New York and Eastern Pennsylvania. We will not only give their names, but the blood elements also, so that all can see that Messenger not only had competitors but competitors of the highest grade of running blood.

Admiral, by Florizel, son of King Herod.

Ancient Pistol, by Ancient Pistol, son of Snap.

Arrakooker, by Drone, son of King Herod.

Baronet, by Vertumnus, son of Eclipse.

Benjamin, by Ruler, son of Young Marske.

Creeper, by Tandem, son of Dainty Davy.

Deserter, by Lenox, son of Delpini, by Highflyer.

Dey of Algiers, Arabian.

Diomed (Tate's), by Phenomenon, son of King Herod.

Driver, by Saltram, son of Eclipse.

Drone, by King Herod.

Dungannon (Young), by Dungannon.

Expedition, by Pegasus, son of Eclipse.

Express, by Postmaster, son of King Herod.

Exton, by Highflyer, son of King Herod.

Florizel, by Florizel, son of King Herod.

Grand Seignor, Arabian.

Highflyer (1792), by Highflyer.

Highflyer (1792), by Highflyer.

Highlander (Brown), by Paymaster.

Highlander (Gray), by Bordeaux.

Honest John, by Sir Peter Teazle.

Joseph, by Ormond, son of King Fergus.

King WVilliam, by King Herod.

King William, by Paymaster.

Light Infantry, by Eclipse.

Magnetic Needle, by Magnet.

Magnum Bonum, by Matchem.

Nimrod, by King Fergus.

North Star, by North Star, son of Matchem.

Payuaster. by Paymaster.

Prince Frederick, by Fortunio.

Punch, by King Herod.

Revenge, by Achilles.

Rodney, by Paymaster.

Royal George, by Jupiter, son of Eclipse.

Royalist, by Saltram.

Slender, by Ǩing Herod.

Sour Cront, by Highflyer.

Venetian, by Doge.

Yorkshire, by Jupiter, son of Eclipse.

Here we have forty-one imported English stallions, contem- 
poraneous with Messenger, occupying the same territory and covering the same mares that he covered. With the exceptions of two or three they were all ranked as not only thoronghbred, but they possessed the most fashionable and successful blood that England had then produced. - A few of them were taken southward after a time, but the great body of them lived out their days here.

To this great array of imported English running horses we might add hundreds of their sons, and yet not find one that claimed to be thoroughbred that ever became a trotting progenitor or founded a family of trotters. Mr. Foster and Mr. Simpson, by far the two ablest writers on the wrong side of the question that this country has prodnced, with this list of forty English stallions before them from which to select their proof that Messenger was not the only progenitor of trotters, were at last compelled to take two of Messengers sons, as trotting progenitors, to prove that their sire was not a trotting progenitor. If the intellectual powers of these two gentlemen had enabled them to scratch ever so little beneath the glittering surface of the word "thoroughbred," they would have saved themselves from this humiliating exhibition of absurdity.

What was true of. Messenger's contemporaries is equally true of all the strictly thoroughbred stallions that have lived on the earth from his day to the present. No one of them has ever founded a trotting family and no one of them has ever got a trotter ont of a mare of his own kind. Ont of the half-dozen instances on record where a thoroughbred horse has got a trotter there is no one instance in which the dam did not have a strong pacing or trotting inheritance. If we accept the known and recorded experiences of the past seventy years, in the trotting world, we find two great facts on every page of the record. First, Messenger left a family of trotters; second, no other thoroughbred horse did that. It follows, then, that if Messenger transmitted capacities different from those transmitted by thoroughbred horses, he must have had a different inheritance from thoroughbred horses, and if different, then that inheritance conld not have been thoroughbred. From the facts we have developed in the history of his English ancestors; from the ten thonsand demonstrations of his American descendants, and from the great laws which govern the transmission of special capacities, we are forced to the conclusion that Messenger was not a thoroughbred horse. 


\section{CHAP'TER XVIII.}

\section{HISTORY OF MESSENGER.}

Messenger's racing in England-His breeder unknown-Popular uncertainty about the circumstances and date of his importation-The matter settled by Lis first advertisement-Uncertainty as to his importer-Description of Messenger by David W. Jones, of Long Island-Careful consensus of descriptions by many who had seen Messenger-His great and lasting popularity as a stock horse-Places and prices of his services for twenty years -Death and burial.

Messenger made his first appearance on the turf in October, 1783 , then three years old, and ran twice, successfully, that year. He continued on the turf till November, 1785, winning eight races, losing six and receiving forfeits in two. Most of his races were practically matches, and all were single dashes but one, in which he was beaten. Two of his winnings were less than a mile, five at the distance of a mile and a quarter, and one at two miles. These distances are approximate. He was beaten at two and a quarter miles, three, and three and a half miles. $\mathrm{He}$ never appeared in any great racing event, but seemed to be managed with a special view to picking up small prizes at short distances. His owner and manager, Mr. Bullock, was a very shrewd "professional" at Newmarket, he had quite a number of horses in the same stable with Messenger and some of them seem to have been selected always to run for the more valuable prizes. Considering the short distances he was able to run and the unimportant character of the contests in which he was engaged, we must conclude that Messenger was a very ordinary race horse.

It is not known by whom Messenger was bred. In his first advertisement in this country it is stated that he was bred by John Pratt, of Newmarket, but in the fourth volume of Pick's "Turf Register," continued by Johnson, it is stated explicitly that he "was bred by and the property of Mr. Bullock, of Newmarket." Mr. John Pratt was a breeder as well as a racing man of some prominence, in his day, and the certificate of pedigree from him and purporting to have been issued by him was probably a fraud, 
as he died May 8, 1\%85. This was while Messenger was still on the turf, and owned and controlled by Mr. Bullock for two years previous to this, still no mention is made of the fact, and Mr. Pratt is made tu say that he sold him to the Prince of Wales, while all the evidence, which must necessarily be of a negative character, goes to show that the Prince of Wales never owned him. Mr. Pratt was a Yorkshire man, of Askrigg, in the North Riding, and althongh he died at Newmarket we have no trace of any of the family from which the dam of Messenger was said to have descended ever being in his possession. Besides this, it is not likely that the importer of Messenger got a certificate from him two years after his death.

The different representations that have, been made about Messenger's importation would fill a much larger space than would be profitable. About no horse has there been so much written, and about no horse has there been so little really known. His character and memory have never suffered defamation, for every writer was a eulogist of the most enthusiastic type, whether he knew anything of his hero or not. As a specimen of the admiration which he excited, it has been told a hundred times that when the horse came cavorting down the gangplank from the ship, with a groom hanging on to each side of his head, literally carrying them for some distance before he could be checked, an enthusiastic horseman shouted out, "There, in that horse a million dollars strikes American soil." This story has been told so often, even in England, that no doubt many people believe the startling prophecy was really uttered. Indeed we have heard the name of the prophet, but as he was a distinguished New Yorker and as debarkation took place at Philadelphia, we never have been able to fully reconcile the actor with the occasion. The reputed prophecy, like the reputed pedigree, seems to have been an afterthought, but unlike the pedigree it proved true, whether uttered or not. Some said he was imported 1785, while others dribbled along through the intermediate years till 1800 was fixed upon with great positiveness as the precise year. One of these gentlemen, we remember very well, was entirely confident he returned to England and was brought back again after a number of years. Less than twenty years ago the breeding world was favored with scores upon scores of this kind of teachers, not one of whom knew what he was talking about. The most surprising example of this kind of writing, however, is furnished by Mr. C. 
W. Van Ranst, himself, who was part owner of the horse a number of years. In a communication published in Skinner's "Turf Register," 1831, he says Messenger was imported into New York in 1792, and in the same publication for 1834 he says he was imported into New York 1791. As the sequel will show, Mr. Van Ranst, although his owner, had no definite knowledge of the early history of the horse.

From some slight investigations I became satisfied, years before, that Messenger made his first appearance in this country at Philadelphia, and that he was imported into that city instead of New York. In that view all the writers of the whole country were opposed to me; but, as it became more and more evident that those writers were merely copying from one another and that none of them had ever made an honest search for the truth, I resolved to follow my own convictions and to commence there an investigation that would settle the matter one way or the other. In a few hours after reaching that eity I found a file of the old Pennsylvania Packet, and in the number dated May 27,1788 , an advertisement of which the following is a true copy:

\section{JUST IMPORTED}

The capital, strong, full blooded, English stallion, MESSENGER.

To cover mares this season at Alexander Clay's, at the sign of the Black Horse, i. Market Street, Philadelphia, at the very low price of three guineas. each mare, and one dollar to the groom.

Messenger was bred by John Pratt, Esq., of Newmarket, who certifies the following pedigree. The grey horse Messenger was bred by me and sold to the Prince of Wales; he was got by Mambrino (who covered at twenty-five guineas. a leap). His dam by 'Turf, his grandam by Regulus; this Regulus mare was sister to Figerant and was the dam of Leviathan. John Pratr.

The performance of Messenger has been so very great that there need only be a reference to the racing calendar of the years 1783,1784 and 1785.

Any mare missing this season shall be served the next gratis, provided. they continue the same properties, on paying the groom's fees.

This is a literal copy of the first printed announcement of Messenger in this country, and there are two very striking features connected with it, namely, its bad grammar and the absence of the name of the importer and owner. The former we may attribute to the times, but to the latter I have been disposed to attach no trifling significance. It is a fact that till this day we have no direct information as to who imported this horse. The name "Benger" was developed indirectly as the man, but not: 
till years after the horse was dead, and probably the importer too, did I learn from an advertisement of a son of his that stood in Jersey that the importer's name was "Thomas Benger." In 1791 and for two years afterward he was advertised to stand at "Mount Benger, two miles from Bristol, Pennsylvania." When I visited Bristol for the purpose of identifying "Mount Benger," which I supposed was the country seat of the owner of Messenger, I was greatly surprised to find that none of the "oldest inhabitants" had cver heard of such a place, and when $I$, was informed that there was no locality within half a dozen miles of Bristol where the ground rose to a hundred feet above the level of the Delaware River, the name "Mount.Benger" assumed the character of an absurdity as well as a myth. From a very intelligent man of middle age, who had learned the blacksmith trade with his grandfather, I learred that he had often heard his grandfather speak of Messenger, and as having put the last set of shoes on him when he was taken away to New York the fall the yellow fever was so bad in Philadelphia. The tradition was still preserved in the family that Messenger reared up in crossing the river in a boat, and struck his groom on the head with one of those shoes, from the effects of which he died. As our informant was able to name two other horses, Governor and Babel, brought over by $\mathrm{Mr}$. Benger, we were ready to accept his tradition that he lived at a point known in old times as "China Retreat," two miles below Bristol on the Delaware. This point has been known later as "White Hall.",

After all traditions were exhausted, without yielding anything tangible or satisfactory, we turned with great confidence to the records of the county of Bucks, in which Mr. "Benger" had lived for a number of years. After a diligent and protracted search, embracing a number of years before and after his known residence in the county, we were not able to discover that any person by the name of "Benger" had ever owned a foot of real estate in the county or had been in any way publicly connected with its affairs or its administration. We had search made in Philadelphia with the same fruitless results. There is a faint tradition that Thomas Benger, if that was his name, was a foxhunting Irish baronet, and if this was so, it is probable he returned to the old country about the time he sold Messenger in 1793. However this may be, the owner is forgotten, but his horse will live forever. 
Among the many eulogies and word-paintings of Messenger, by writers who knew the horse personally, we select the following from the pen of the late David W. Jones, of Long Island, as the most striking and picturesque. He says:

"Having scanned in "y boyhood the magnificent form and bearing of this noble old horse, and for more than half a century having drawn reins over his descendants, $I$ have for a length of time felt it incumbent to furnish such facts and inpressions, as, when considered with those of others, will give the younger portion of the present generation, as well as posterity, a fair knowledge of the general characteristics of the noblest Roman of them all. The first time I ever saw old Messenger my father sent me to the farm of Townsend Cock, Esq., of the County of Queens, L. I., where the horse was then standing, to receive his services. On my arrival at his harem, I found the groom, whom I knew, and he at once placed me with the mare a short distance from the stable, by the side of a barrier erected for security. Having at home heard frequent and long discussions in relation to the wonder I was now to behold, you may suppose I was all eyes. Presently the stalwart groom, James Lingham, with, at the extreme end of the bridle rein, all the blood of all the Howards, turned the angle of the stable and came in full view. The moment the old horse caught sight of the paragon of beauty I had brought to his embrace, he threw himself into an attitude, with the grandeur of which no other animal can compare, and at the same moment opened his mouth, and distending his nostrils, raised his exultant voice to such a pitch as gave unmistakable evidence of the capacity of his lungs and the size of his windpipe. Indeed, if his nostrils were as much larger than ordinary as my boyish vision pictured them, I can almost suppose that Mr. McMann with his little bay mare (Flora Temple), and sulky, could drive in at one, down the windpipe, turn under his immensely long arching loin and out at the other. . . . At that early day I was only impressed by those extraordinary developments; but in after years as I sit behind his offspring, they invariably remind me of what was then to my youthful judgment less apparent-the extraordinary strength of his loin, the length and beantiful molding of the buttock, the faultless shape of the crupper bone, giving an elegant set to his fine flowing tail, as well as the remarkable swell of his stifle, altogether forming a most perfect and powerful hind quarter."

A good many years ago I made a special study of all that had been written about Messenger, and I was fortumate in being able to supplement this information by interviews with a few old gentlemen who knew the horse personally. Nearly all that generation of horsemen had passed away before I commenced this personal search for them. But a few then remained with excellent memories and with characters above suspicion or reproach. From these sources I gathered a great many incidents, facts and descriptions which I succeeded in harmonizing, to my own mind 
at least, and thus was able to compile a complete description of the horse at every point. That description was written out more than twenty years ago, and in presenting it now I will not change a single word. At the time it was written, as will be seen from its perusal, I had really no doubt the horse was thoroughbred. It will not be charged, therefore, that the coarse traits brought out in the description were influenced in any degree by a theory of his breeding:

"Messenger was a grey, that became lighter and flea-bitten with age. He was fifteen hands three inches high, and for a thoroughbred his appearance was coarse. He did not supply the mind with an idea of beauty, but he impressed upon it a conception of solidity and power. His head was large and bony, with a nose that had a decided Roman tendency, though not to a marked degree. His nostrils were unusually large and flexible, and when distended they were enormous. His eye was large, full, very dark and remarkably brilliant. In this particular he doess not appear to have inherited the weakness of his great-grandsire, Sampson. His ear was larger than usual in the blood horse, but thin and tapering and always active and expressive. The windpipe was so unusually large and stood out so much as a distinct feature that it marred what otherwise would have been a gamelike throat-latch and setting on of the head. His neck was very short for a blood horse, but was not coarse and thick like a bull's; neither did it rise into such an enormous crest as that of his sire. It was not a bad neck in any sense, but like Lexington's of our own day, it was too short to be handsome. His mane and foretop were thin and light. His withers were low and round, which appears to have been a family characteristic in the male line, back for three generations at least. His shoulders were heavy and altogether too upright for our ideas of a race horse. His barrel was perfection itself, both for depth and rotundity. His loin was well arched, broad and strong. His hips and quarters were 'incomparably superior to all others.' The column of the vertebra being of unusual depth and strength, gave the setting on of the tail a distinctive, but elegant character. The tail was carried in fine style; like the mane, it was not in superabundant quantity, but there was no such scantiness as to detract from the beauty and grace of the animal. His stifles were well spread and swelling, but there appears to have been no unusual development at this point. From the stifle to the hock 
and from the elbow to the knee, no writer that we can now recall has given us any lescription of either length or strength. We may, therefore, take it for granted that these points had no unusual development of muscle, but were in harmony with the general contour and make-up of a great strong horse. His hocks. and knees were unusually large and bony, with all the members strong and clearly defined. The cannon bones were short and flat and the ligaments back of them were very large and braced a. good way off, so that the leg was broad and flat. Mr. Jones says this part of the limb was of medium size, but other writers all agree that he had an unusual amount of bone at this point. Considering the whole style and character of the horse, and especially the character of his ancestors in the male line, and of Turf, the [reputed] sire of his dam, all of whom were distinguished for their quantity of bone, we are disposed to think Mr. Jones' memory has not served him with entire accuracy in this particular. The conviction is reasonable and grows out of evidence that comes from every quarter, and we have no disposition to surrender it, that the bones of Messenger's limbs were unusually large and strong for those of a thoroughbred. His pasterns and feet were all that could be desired, and as an evidence of the excellence and health of his underpinning several writers have put it on record that whether in the stable or on the show ground he never was known to mopingly rest one leg by standing on the other three, but was always prompt and upright. This is our conception of the form and appearance of the horse as we have reached it after a diligent and careful study of all that has been said by those who saw him while he lived. From this description it is a very easy matter to pick out the features which gave him his coarse and badly bred appearance. His big head, long ears, short neck, low withers, upright shoulders, large bones and, possibly, coarse hair, complete the catalogue. From these features the purity of his blood has been doubted and denounced, just as that of his sire, his grandsire and his great-grandsire had been denounced. The coarseness, the carthorse appearance was in the family, but it did not seem to prevent some of them from beating some of the best that England produced in successive generations. There are many traditions that have been handed down to ns concerning his temper, some of which, no doubt, have accumulated and gathered strength and ferocity in the years through which they have rolled. There: 
have been perhaps half a dozen stories abont his killing his keepers, but we are not able to say whether any one of them is true. It is known with certainty, however, that he was willful and vicious and would tolerate no familiarity from strangers."

The ownership of Messenger, after he was transferred from Philadelphia to New York, like his earlier history, seems to be very much muddled. Henry Astor, a New York butcher, certainly bought him in the fall of 1793, and located him at Philip Platt's, four miles from Jamaica, on Long Island. In the spring of 1796 Mr. Cornelius W. Van Ranst bought one-third interest in him and removed him to Pine Plains in Dutchess County, New York, and, without specifying the time, he says he afterward purchased the remaining two-thirds, for which he paid two thousand seven hundred and fifty dollars. There appears to have been some mistake about this, for in 1802 we find Henry Astor, of New York, conveying one-third interest in the horse to Benjamin B. Cooper, of Camden, New Jersey. Some other parties also claim to have owned arr interest in the horse, and I heard that there was a lawsuit about him between Astor and Van Ranst. The latter claims to have owned an interest in him till the time of his death, in 1808. It is not known how much Mr. Astor paid for him when he bought him, nor have I any data from which to determine the probable market value of the horse except that Mr. Van Ranst says he paid two thousand seven hundred and fifty dollars for two-thirds of him. If we accept this as a basis, he must have been valued at about four thousand one hundred and twenty-five dollars. It is true, beyond doubt, that for several years he brought to his owners a net annual rental of one thousand dollars. This would indicate a very large patronage at very high prices for those times. For the twenty years of his stud services in this country, we find him located as follows:

1788, at Alexander Clay's, Market Street, Philadelphia, at $\$ 15$ the season and $\$ 1$ to the groom, privilege of returning.

1789, at Thomas Clayton's, Lombard Street, Philadelphia, at $\$ 10$ the season and $\$ 1$ to the groom.

1790 , at Noah Hunt's, in the Jersies, near Pennington, at $\$ 8$. 1791, at "Mount Benger," two miles from Bristol, Bucks Co., Pa., at $\$ 16$.

1792 , at the same place and the same price. 1793 , at the same place and the same price. 
1794, at Philip Platt's, firteen miles from New York and four from Jamaica, Long Island, at \$25 the season.

1795, at the same place and the same price, when, as Mr. Van Ranst expressed it, "he took with our horsemen."

1796, at Pine Plains, Dutchess County, N. Y., where he covered 106 mares at $\$ 30$ the season.

$179 \%$, I have no advertisement for this year, but it is probable he was at the same place at the same price.

1798 , at Pine Plains, as before, and the terms $\$ 30$ for the season and $\$ 40$ to insure.

1799, I have no definite trace of him this year, but there are some indications he was in West Jersey.

1800 , for the spring season he is not located, but he made a fall season at John Stevens' in Maidenhead, Hunterdon Co., N. J.

1801, at Goshen, Orange Co., N. Y., and I have seen the book account of expenses, etc., while he was there.

1802, At Cooper's Ferry, opposite Philadelphia, Pa., but the price of services is not mentioned.

1ð03, at 'Townsend Cock's, near Oyster Bay, Long Island, at $\$ 20$ the season.

1804, at the same place and the same price.

1805, at Bishop Underhill's, in Westchester Co., N. Y., fifteen miles from Harlem Bridge. Price reduced to $\$ 15$.

1806 , back again at Townsend Cock's, and the terms fixed at $\$ 15$ for the season, and $\$ 25$ to insure.

$180 \%$, again at Bishop Underhill's on the same terms as before, and this was the last of his twenty years' stud services. It will be observed that the horse is located every year except two, and these locations are determined, not by tradition or hearsay, but by copies of his advertisements for each year. In giving the prices charged for his services I have given the value of the guinea or the pound as five dollars.

Messenger died January 28, 1808, in the stable of Townsend Cock, on Long Island, in his twenty-eighth year. This date has been as familiar to all intelligent horsemen for the last forty years as any prominent event in the history of the nation. The news of the death of the old patriarch spread with great rapidity, and soon the whole countryside was gathered to see the last of the king of horses and to assist at his burial. His grave was prepared at the foot of a chestnut-tree some distance in front of the house, and there he was deposited in his holiday clothing. 
In response to the consciousness that a hero was there laid away forever a military organization was extemporized, and volley after volley by platoons was fired over his grave. Some of the young men and boys who witnessed and participated in the ceremonies of the occasion were still living twenty years ago, and as they related the incidents of the occasion to me, their recollections seemed to be as clear and bright as though the occurrence had been of yesterday. 


\title{
CHAPTER XIX.
}

\author{
MESSENGER'S SON
}

Hambletonian (Bishop's) pedigree not beyond doubt-Cadwallader R. Colden's review of it-Ran successfully-Taken to Granville, N. Y.-Some of his descendants-Mambrino, large and coarse in appearance-Failure as a runner-Good natural trotter-His most famous sons were Abdallah, Almack and Mambrino Paymaster-Winthrop or Maine Messenger and his pedigree and history-Engineer and the tricks of his owners-Certainly a son of Messenger-Commander-Bush Messenger, pedigree and description - Noted as the sire of coach horses and trotters-Potomac-Tippoo SaibSir Solomon-Ogden Messenger, dam thoroughbred-Mambrino (Grey)Black Messenger-Whynot, Saratoga, Nestor, Delight-Mount Holly, Plato, Dover Messenger, Coriander, Fagdown, Bright Phœbus, Slasher, Shaftsbury, Hotspur, Hutchinson Messenger and Cooper's MessengerAbuse of the name "Messenger."

IT is not my purpose to write a history of all the descendants of Messenger, for that would fill several volumes and would be simply writing over again the trotting and pacing records of the past twenty years. I will, therefore, limit the chapters on this topic to such of his descendants as have demonstrated the value and prominence of their blood, as a factor, in the make-up of the American Trotter. Naturally, the immediate progeny of Messenger will first demand consideration, and then will follow the succeeding generations that have written their own history in the official records of trotting and pacing. Completeness of description and space occupied will be determiñed, chiefly, by the prominence and historic value of the animal under review. In this scope and withont following any chronological order, I will try to embrace all that is known that would be of value to the student of trotting-horse history.

Hambletonian (Bishop's), originally called Hamitonias.This was a dark-bay horse about fifteen hands two inches higli. He was bred by General Nathaniel Coles, of Dosoris, Long Island, and was foaled 1804. He was got by Messenger, his dam Pheasant (the Virginia Mare), said to be thoroughbred, by imp. Shark and grandam by imp. Medley. I first unearthed the pedigran 
of this "Virginia Mare" in the advertisement of Hambletonian for 1814 when he was owned by Townsend Cock and standing that year at Goshen, New York. The "Old Turfman," Cadwallader R. Colden, was thoroughly familiar with all turf subjects in the early years of this century, and was the best turf writer of his generation. He had no patience or tolerance with frauds in pedigrees and always exposed them without mercy. He stoutly maintains that the pedigree of the "Virginia Mare" was bogus, and, to use his own language, he says:

“When Hambletonian became a public stallion, his owners were in a dilemma; a pedigree was necessary, so to work they went, and, as many had done before and as many are doing now, made one; and in his handbiils his dam was given as bred in Virginia, and got by imported Shark, with a train of maternal ancestors, with as much truth, and affording as much ability to trace it or discover the breeder of the dam, as though they had said hi, cockalorum jig."

Mr. Colden goes into the pedigree of this mare and the non-racing character of her family at great length, and it cannot be denied that he has the whole argument. As a specimen of sharp and interesting turf writing of that period and from that pen, I must commend my readers to turn to this article, which will be found in Wallace's Monthly, Vol. II., p. $6 \%$.

With the probabilities all against the truthfulness of the pedi. gree of the dam, as given, it is certainly true that he was a running horse and attained distinction in his day. I have no full list of his performances at hand, but the following may be taken as a fair summary of his principal achievements. He ran at Newmarket in the spring of 1807 (then three years old), one mile, beating General Coles' colt Bright Phœbus, Mr. Terhune's bay filly, and distancing two others. He also ran, two days after the above race, four heats of a mile each, beating Bright Phœbus again and distancing three others. In the fall of 1808 he ran five weeks successively, and the three last weeks he won three four-mile purses, running the distance in shorter time than it ever had been run in the State of New York. I must say here that these races were run on the then Harlem course, which was not a full mile in length.

While Hambletonian was on the turf, Tippoo Sultan, a grandson of Messenger, beat Bond's First Consul in a famous four-mile race, and Mr. Bond determined that he would find a horse that would be able to lower Tippoo Sultan's colors, and it was thought 
there was nothing in the North able to do it except Miller's Damsel, so he made a match for four thousand dollars a side on condition that Damsel should prove not to be in foal. But the mare proving to be in foal the match was off. He then took Hambletonian into his stable and offered to match him for the same amount against Tippoo Sultan, but he went amiss and the match was off. This incident is here introduced to show that whatever his real merits, Hambletonian had some reputation as a running horse. It was said that the secret of Mr. Colden's hostility to the "Virginia Mare" and her descendants was because those descendants were always able to beat the descendants of his fashionably bred mare Matilda. Whatever the motive in exposing a pedigree that has never been fully established, there is one particular and that the most important of all particulars, in which Mr. Colden has done justice to Hambletonian. He says: "Hambletonian got some excellent roadsters, good trotters."

There seems to be no description of this horse extant that is fully satisfactory. For some seasons he was in the hands of $\mathrm{Mr}$. Daniel T. Cock, who in 1869 furnished me the following: "He was a dark bay, a little heavy abont the head and neck, fifteen and a half hands high, and rather an upright shoulder. Back, loin and hind quarters as good as were ever put on a horse. Fore legs a little light, but hind legs strong and good-pretty straight. He was a beautiful saddle horse, notwithstanding his head and ear were a little coarse." Other persons who had seen him have described him as "a great strong horse, with bone and substance enough to pull the plow or do any other kind of drudgery." It has been said that he had a fine open trotting gait and that, in a cutter with old Isaac Bishop behind him, he was able to show the boys the road.

In $180 \%$ he became the property of Townsend Cock, of Long Island, and he remained on the turf till 1810, when he was put in the stud. That and the following season he was at the stable of his owner; 1812 at Cornwall; 1813 at Fishkill; 1814 at Goshen; 1815-16 at Fishkill; $181 \%$ at White Plains. In the winter of 1819 Mr. Cock sold him to Stephen and Smith Germond of Dutchess County, New York, and Isaac Bishop of Granville, New York. The latter was probably the real owner, and the horse then became known as "Bishop's Hambletonian." He made several seasons in the region of Granville and was back in Dutchess County 1823 and 1824. The next year he was at Granville- 
1825. He made one season, at least, at Burlington, Vermont, and some seasons or parts of seasons at Poultney, Vermont. It is said he lived till 1834 .

At Wallingford, Vermont, he was bred upon the "Munson Mare," said to be a daughter of imported Messenger, and doubtless either by him or one of his earlier sons, and the produce was Harris' Hambletonian, also known as "The Remington Horse" and Bristol Grey, and this son became the progenitor of a great tribe of trotters, known as the "Vermont Hambletonians," some of which were very fast pacers, among them the famous Hero, the fastest of his generation. Another son of Mr. Bishop's horse was the Judson Hambletonian, that was the sire of the Andrus horse, that got the famous Princess, that was pitted against Flora Temple. He was also bred on his half-sister, Silvertail, by Messenger, and produced One Eye, a very fast mare, the grandam of Rysdyk's Hambletonian, and I have always thought that this combination was the very cream of the pedigree of that great horse. He was also bred on a daughter of Mr. Coffin's son of Messenger and produced Whalebone, that was the phenomenal long-distance trotter of his generation. His son, Sir Peter, out of an unknown mare, was also a famous old-time trotter. One of his daughters was bred to Coriander, son of Messenger, and the produce was Topgallant, the fastest horse of his time. These individual enumerations might be extended indefinitely, but I have given enough to show that he was not merely a progenitor of trotting speed in remote generations, but that speed came directly from his own loins. Another most significant fact is here brought to light, namely, that when bred back upon the blood of his own sire he achieved his greatest successes.

Mambrino.- This great son of Messenger was a bright bay with a star and one white ankle. He was fully sixteen hands high, with great length of body and generally of coarse appearance. He was foaled 1806, and was bred by Mr. Lewis Morris, of Westchester County, New York. His dam was by imported Sour Crout, ont of a mare by imported Whirligig, and she ont of the famous Miss Slammerkin, that is a well-known landmark reaching beyond the Revolution. The late William T. Porter, of the Spirit of the Times, stoutly maintained that Mambrino was not a thoroughbred horse, and his reasons seemed to rest wholly xpon his coarse and cart-horse appearance. Technically, Mr. 
Porter was right, but the trouble did not rest with the dam, as he seems to have supposed, for I have seen the original certificate of breeding in the handwriting of Mr. Morris, his breeder, and there is no slip on that side of the pedigree. Mr. Morris was a prominent breeder and racing man for many years and his character was without taint. The pedigree is a very long one and I would be very far from vouching for the truth of the remote extensions, but back to the mare by Cub, imported by Mr. De Lancey, who bred Miss Slammerkin, there can be no mistake.

In the spring of 1810 , then four years old, he was purchased of his breeder by Major William Jones, of Queens County, Long Island, and in the autumn of that year he was trained and ran for the two-mile purse at the old Newmarket Course, Long Island, and it is said gave some evidence that he could run, but after that he was never trained nor started in a race, from which we may conclude he was not a race horse, or his owner, who bred and ran his horses, would have given him another trial.

In 1811 he was put in the stud and made the season at Huntington, Long Island, in charge of Ebenezer Gould. It is not known where he made the season of 1812 , but probably in Orange or Dutchess County. The years 1813-14-15 he was in charge of my late highly esteemed and venerable correspondent, David W. Jones, on the borders of Queens and Suffolk counties, Long Island, where he covered about two hundred and fifty mares. In 1816 he was in one of the river connties, in $181 \%$ at Fishkill, and 1818 at 'Townsend Cock's, Long Island. In later years he changed hands many times, at from two hundred to two hundred and fifty dollars, and there is no published trace of him till we find that he made the seasons of 1825 and 1829 at Pleasant Valley, Dutchess County, and he died the property of Benjamin Germond, on the farm of Azariah Arnold in Dutchess County, about. 1831.

He took his beantiful color from his dam and transmitted it with great uniformity. His general structure was after the Messenger model, especially in the large bones and joints of his limbs. His head was long and bony and his ears were large and somewhat heavy. He was too high on his legs and his general appearance was coarse, all of which he transmitted. In speaking of his offspring Mr. Jones remarks: "When young they were somewhat leggy and lathy, but spirited, stylish and slashing in action. When matured, he must indeed be fastidious who would 
crave another." With regard to his gait Mr. Jones uses the following very emphatic language: "I have been the breeder" of some, and the owner of many good horses, and with the best opportunities of judging, having ridden him (he was never driven) many, many miles, I say, with entire confidence, he was the best natural trotter I ever threw a leg over. His walk was free, flinging and elastic; his trot clear, square and distinct, with a beantiful roll of the knee and great reach of the hind leg." In the absence of actual training and timing, it is hardly possible to get better evidence that Mambrino was a natural trotter that might have been developed to a considerable rate of speed. It would be interesting to know just why the horse "never was driven." Did he show an unconquerable aversion to harness, and did Abdallah inherit this aversion? This description of Mambrino's gait was written in 1866 , and the writer had spent a long lifetime in an intimate personal knowledge of many, or indeed most, of the best early trotters that this country had produced.

The only one of his immediate progeny that attained distinction as a trotter was the famous Betsey Baker. This mare was very prominent among the best of her day, and was able, on one occasion at least, to beat the great Topgallant, and in tandem

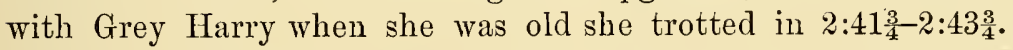
Others of his progeny were trotters of some merit, but none of them especially distinguished on the turf. His three sons, Abdallah, Almack and Mambrino Paymaster, are the bright links in the chain extending from Messenger to the two-minute trotter that will keep his memory green as long as there is a trotting horse on the earth. Abdallah at the head of the Hambletonians, Almack at the head of the Champions, and Mambrino Paymaster at the head of the Mambrino Chiefs embrace the major portion of the great trotters of this generation.

Winturop, or Maine Messenger.-Perhaps no son of Messenger, not excepting Hambletonian and Mambrino, produced a more marked effect upon the stock of any part of the country than this horse did in the State of Maine. The impress he there made was not only remarkable at the time, but it is still felt and acknowledged in his descendants to this day. There have been many conflicting statements made to the public about him and his history, but I think I am now able to give, in authentic and reliable form, all that is really known of his origin and history. He was foaled about 1807 and was among the last colts by the 
imported horse, but unfortunately we know nothing of the blood of his dam. Mr. Alvan Hayward, for many years a citizen of Kennebec County, Maine, but more recently of York, Livingston County, New York, says his dam possessed some imported blood; but as all his records and memoranda were burned up in 1845 he is not able to give the pedigree of the mare that produced him.

Mr. Hayward bought the horse about 1817 or 1818, in the village of Paris, Oneida County, New York, of a man by the name of Rice or Wright, but did not remember which. He took him to Winthrop, Maine, where he was first known as "Messenger," then as "Kennebec Messenger," or "Winthrop Messenger," and when he became old, as "Old Messenger." The earliest contemporaneous account I have of this horse is his advertisement for the season of 1819, which I copy from the Hallowell Gazette of May 12, of that year, and is as follows:

\section{" the Valuable horse Messenger.}

"The subscriber hereby recommends to the public and all who feel interested to improve in the breed of good and serviceable horses, the good horse Messenger, that stock so well known and approved of on Long Island, New York. and Pennsylvania. Said horse was raised on Long Island, and owned by Mr. Rylander, a gentleman who has taken the greatest pains to import the best breed of horses that came to his knowledge. Said horse is a silver grey, well proportioned, of a large size, and a good traveler. Gentlemen who are desirous of raising good horses will do well to call and see for themselves.

"The Messenger will stand for the most part of the time in the village at Withrop Mills.

ALVAN HaYward.

“Winthrop, May 1st, 1819."

From the foregoing it will be seen that the new element brought out in the history of this horse is the statement that he was owned at one time by Mr. Rylander, of Long Island. There were two brothers of this name, and they imported a great many horses, but never before had I heard their names connected with Winthrop Messenger. This carries us back to a period in the history of the horse before he was taken to Oneida County.

Colonel Stanley, a prominent banker of Augusta, and at one time a leading horseman and stage proprietor, bought Messenger of his kinsman, Hayward, and owned him some seven years. He says the horse was brought to Maine as early as 1816, and that his Uncle Hayward had certificates that he was got by imported Messenger, out of a mare well-bred and part of imported blood.

In a communication from Mr. Sanford Howard, who had been 
prominently connected with the breeding interests of the country for many years, the following description is given:

"I saw him several times, first in 1828. In the latter years of his life he stood mostly at Anson, on the Kennebec River, and I think died there about 1831 [he died at Dixfield]. He appeared like an old horse when 1 first saw him, older, perhaps, from being much afflicted with grease, which had become chronic, and at length had almost destroyed his hoofs; so that the last time I saw hiu he was nearly incapable of locomotion. His feet and legs looked like those of an elephant. This tronble was transmitted to his offspring through several generations (though not invariably so), and eonstituted, perhaps, in connection with, in many cases, a flat foot and low heels, their greatest defect.

"Mr. Hayward states, in concluding his letter, that he has no doubt the horse he took to Maine was got by imp. Messenger. The remark is probably elicited by intimations that he might have been gotten by a son of Messenger. I presime Mr. Hayward's belief was well founded. As imported Messenger did not die until the 28th of January, 1808, there is no discrepancy between that event and the age of Mr. H.'s horse. At the same time I must admit that Maine Messenger hardly looked like a half-blood horse. He was pretty large, rather short-legged, thick-set, with heavy mane and tail, very hairy legs, long hair on his jaws, and was heavy coated (in winter) all over his body. These characteristics were sometimes acçounted for by saying he was probably out of a Dutch mare, meaning such mares as the Dutch farmers of New York kept. I never heard of any claim being set up for his speed in trotting, and I presume he was never tried at running. He was strong and plucky, and the story was told at Winthrop that on an occasion when all the stallions of the neighborhood were brought out to be shown, they were put to a trot in sleighs for half a mile or so, and Messenger was beaten. Whereupon his owner proposed that the horses should each draw a sled with six men on it up to Winthrop hill, and be timed. It was done, and Messenger beat them all. I think the first of his offspring that became noted for fast trotting was a gelding called Lion, taken to Boston by a well-known horse dealer by the name of Hodges, of Hallowell, Maine. He was sold, I think, for four hundred dollars, which made quite a sensation among the Kennebec farmers who had any stock of the same sort. I do not recollect the rate of speed this horse showed, but a mile in three minutes was then considered wonderful, and probably this was about his rate. Other horses of the stock were soon brought out as fast travelers. I remember a friend of mine showing me some young horses be was training, and I rode with him after several of them. They were natural trotters, and would do nothing but trot, even under severe applications of the whip. But I think the secoud generation from Mr. Hay ward's horse were generally faster trotters than the first. They were also generally handsomer horses, not so rough looking. Nearly all the horses of this stock which have acquired a reputation in Massachusetts, New York, etc., as fast trotters, had not more than a quarter of the blood of the horse that Mr. Hayward took to Maine, and consequently had not more than an eighth of the blood of imported Messenger.

"The mares that produced these horses were of no particular blood. Various stallions had been kept in that section. Morgans from New Hamp- 
shire and Vermont, with an occasional change to the French Canadians, and now and then a quarter or half bred horse from New York or New Jersey."

This excellent communication from Mr. Howard is especially valuable, as the conclusions drawn by an acourate and competent observer from a personal acquaintance with the original horse and his progeny. There are some inferences, however, that may be drawn from Mr. Howard's letter that would be mujust to this distingnished animal. His general coarse appearance, in connection with which Mr. H. says, "he hardly looked like a half bred horse," was a prominent feature in the family. Mambrino, a very high-bred son of old Messenger, was very coarse, and the same remark was often made about him. The quantity and length of his coat in the winter of his old age are not conchisive against his pretensions to a large share of good and pure blood. They are the results oftentimes of neglect and ill health. It is somewhere stated that the famous Sir Archy before he died looked exceedingly shaggy, his hair being fully three inches Iong. Mr. Howard expresses the opinion that "the second generation from Mr. Hayward's horse were generally faster trotters than the first." In many instances this, no doubt, is true, for it would be altogether contrary to the uniform laws which govern these thiugs if development and use did not strengthen and intensify the instinct to trot in successive generations. If Mr. Howard is right, and we do not doubt he is, the increased capacity did not grow out of the dilution of the blood, but ont of the strengthening of the instinct by culture and use. At the time Mr. Howard made this remark he evidently did not know that the famous old-time trotters, Daniel D. Tompkins and Fanny Pullen, were both immediately from the loins of Winthrop Messenger. In their day these two were classed among the best and fastest trotters that the world had then produced. The facts that both these animals were the immediate progeny of Winthrop Messenger were never brought to light for many years, and all I will say abont them now is that they do not rest on shadowy traditions or suppositions, but are fully and circumstantially established.

In a letter written by Mr. Mayward, May 12, 1852, in speaking of the nseful and everyday qualities of this horse's progeny, he used the following language:

“"The stock produced by that horse I consider superior, as combining more properties useful in a horse than any other stock I have ever been acquainted 
with, being good for draft, for carriage, for travel, for parade, or any place where horses are required. They had great bottom and strength, and were of hardy constitution. 'l'here are some horses in this town twenty-two years old, that were by a son of Winthrop Messenger, which I brought with me when I leit Maine. They have always ieen accustomed to draw the plow and to perform other hard labor, and yet they have the appearance of young horses, and will now do more service than many horses of seven or eight years old."

Among the several sons of imported Messengor whose names are conspicnons as the progenitors of great tribes of the most distinguished trotters I know of no one entitled to a higher place on the roll of fame, all things considered, than this one that went to Maine, and there laid a foundation that has made the State famous throughout the length and breadth of the land for the speed and stoutness of its trotting horses.

With such noted performers from his own loins as Fanny Pullen and Daniel D. Tompkins, and in the next generation the famous Zachary Taylor, this horse made about the best showing of all the sons of Messenger, but as his line failed to produce a Rysdyk's Hambletonian or a Mambrino Chief, it dropped to a place somewhat removed from the front of the procession.

ExGINeER was a grey horse, about sixteen hands high and very elegant in his form, style and proportions. The earliest account we have of him is in the spring of 1816, when he was advertised in The Long Island Star to stand at the stable of Daniel Seely, near Suffolk Court House, and at Jericho, in Queens County. He was in charge of Thomas Jackson, Jr., generally designated as "Long Tom." He was then well advanced in years, but no attempt was made to give his age. Mr. Daniel T. Cock, in charge of Duroc and one or two other stallions, was then in sharp competition with Engineer, and he assures me he was a horse of large size, great share of bone and sinew, most elegant form, and a fine mover. His elegant appearance was so captivating that he was a very troublesome competitor.

The advertisement referred to contains the following very unsatisfactory paragraph relating to his pedigree, viz., "The manner he came into this country is such that I cannot give an account of his pedigree, but his courage and activity show the purity of his blood, which is much better than the empty sound of a long pedigree." This was a most unexpected discovery, for I had always understood that Engineer was a son of Messenger and never had heard of this mystery before. It is here intimated 
that the horse was imported, and the story that Jackson told was that he was brought from England to Canada by a British officer, and by some surreptitious means found his way from Canada to Long Island. What appears to be the real history of the horse, and the version accepted afterward by everybody on the island, will be found in the following extract from a letter written by David W. Jones, February 28, 18\%0. He says:

"I can well account for Mr. Cock's recollections of the history of the first Engineer. Thomas Jackson and George Tappan, noted owners and keepers of stallions on Long Island and in the counties of Orange and Dutchess, in the conrse of their peregrinations met with a person in possession of this horse, who offered him for sale. Impressed with his fine appearance and pedigree, they at once entered into negotiations for his purchase, and finally obtained him at so low a price as to cause strong suspicions that he was not honestly iu his vendor's possession. They, however, determined to take the chances, and at once brought him to Long Island, their place of residence, and determined on what they deemed a harmless representation in regard to his history; for this they had several motives. First, Messenger stallions were then very numerous on Long Island; their blood coursed in the veins of nearly every brood mare. Secondly, imported stallions were much desired, and by a little added fiction they could give him considerable éclat, and thirdly, in case of his having been unjustly obtained this would afford the best means of disguise. Accordingly they represented him as having been imported from England to Canada and ridden in the army by Gen. Brock, who, in an engagement with our troops, was shot and killed. The horse, escaping into our lines, was secured by our soldiers and brought to the State of New York. On these representations they claimed to have purchased him. No pedigree, as I recollect, was attempted to be given, and though many doubted the truth of this statement, there was no evidence to controvert it. For a length of time this story was adhered to; but after several years, when all fears of difficulty had subsided, they acknowledged the deception. Mr. Tappan, who resided but a few miles from me, was a man of more than ordinary candor and fairness, for one of his position and employment. I knew him well, and occasionally rendered him a favor by preparing his horse bills. On one of these occasions, at my house, he gave a full and particular statement of the whole affair. Some of the details have escaped me, but the essential facts are distinctly recollected. The owner, with Engineer in possession, was met at some public place and the purchase completed, and this statement then made, 'that he had become involved in debt, and that his creditor had begun a prosecution, with a view to levy on the horse, the only property he possessed, and he was determined not to lose all.' This was certainly enough to arouse their suspicions with regard to his history. He declared the horse was bred and raised in Pennsylvania and that he was got by imported Messenger. Whether any further pedigree was given is not recollected. He was at this time (1814) a horse considerably advanced in years and perfectly white. Mr. Tappan also told me that he had afterward traced the horse, and was entirely satiffied of the former owner's veracity. I will 
not apologize for the length of this statement, being desirous of giving you all the information here possessed and probably all that can now be obtained."

I am not aware that in the past sixty years any question has. ever been raised as to the truth of the universally accepter statement that Engineer was a true son of Messenger, and I would not have disturbed it now, nor thonght of doing so, had it not been for that remarkable advertisement discovered in the obscure Long Island paper. That was contemporaneous history, however, and it must either be explained or accepted. The question has been examined down to the bottom by one of the most conscientious and capable men of his generation, in this department o ${ }_{\mathrm{i}}^{\mathrm{e}}$ knowledge. His verdict has been accepted as the truth by all parties of that day, and I camnot reject it.

It is not known that any of his immediate progeny attained distinction on the trotting turf. Several of his sons bore his name in the stud and while their blood seemed to be helpful in the right direction, only one of them made any mark as a sire of speed, and that was the horse known as Lewis' Engineer, the sire of the world beater, Lady Suffolk. Burdick's Engineer, another son, was taken to Washington County, New York, and got the dam of the famous Princess, which produced the great Happy Medium. In all these instances there was commingling with other strains from Messenger.

COMMANDER.-This was a grey horse, fully sixteen hands high and of massive proportions. He was a son of imported Messenger and out of a mare by imported Rockingham. This Rockingham was not a thoroughbred horse. Commander was bred in Bucks County, Pennsylvania, and found his way to Long Island about 1812, where he was liberally patronized. His name frequently occurs among the remote crosses of good pedigrees, but his fame rests wholly on the progeny of his son, Young Commander, who was the sire of Screwdriver, Screws, Bull Calf and other good ones. This horse Young Commander was sometimes called "Bull" and sometimes "American Commander."

Messenger, (Bush's), 'generally known as Bush Messenger. This son of Messenger was bred by James Dearin, of Dutchess County, New York, and was foaled 180\%. His dam was a Virginia mare, named Queen Ann, by Celer, son of imported Janus, and out of a mare by Skipwith's Figure, son of imported Figure, and she out of a mare imported by Colonel Miland, of Virginia. This pedigree was not accepted without some misgivings, but as 
it was possible and as it had been indorsed sixty years ago by Cadwallader R. Colden and published before that by Mr. Dearin, I am disposed to accept it as reliable.

He was sixteen hands high, a light grey, becoming white with age. He was excellent in form and probably the most handsome and attractive of all the sons of Messenger. The first public notice we have of him, he was advertised at the stable of his breeder, six miles south uf Poughkeepsie, in 1813. Soon after this he became the property of Philo C. Bush, and this was the first horse, he says, that he ever owned. This Mr. Bush was a noted "character"' in his day. From early manhood, through good and evil report, and until he died a very old man in poverty and want, he was a habitue of the race track. He knew all about race horses and their breeding, and he could prattle pedigrees from morning till night. Added to this knowledge which his life pursuits had placed in his possession, he was endowed with a most vivid imagination which was brought into the most active play whenever he found it necessary. To maintain his "reputation" it seemed to be a necessity that he should be able to extend all pedigrees laid before him and give the remote crosses, whether he knew anything about them or not. He was the anthor of the ruming pedigree given to the dam of Major Winfield-Edward Everett, son of Hambletonian-and on it money was won in a bet. An investigation of just two minutes disclosed the facts that by established and known dates the whole thing was utterly impossible. He was literally a very "racy" raconteur, but his reminiscences soon became tedious, notwithstanding their brilliancy, and it was always important to have a call to some business that cut off further entertainment from his répertoire.

Mr. Bush says he paid one thousand seven hundred and forty dollars and a silver watch for this horse, and with him he got an elegant suit of clothing that had belonged to imported Express. It is said that he never ran but one race and that was at Pine Plains, in which he distanced all his competitors in the first heat. In 1816 Mr. Bush kept him at Kinderhook; $181 \%$ at Kinderhook and Schodack; 1818 at Kinderhook and Albany; 1819-20 at Utica. In the autumn of 1820 he was sold to Dr. Millington, of Crooked Lake, Herkimer County, and he was kept there 182122. He was then sold to Edward Reynolds, of East Bloomfield, where he was kept three or four years, after which he made one or more seasons at Le Roy, and he died at East Bloomfield in 
July, 18:9. This horse had probably more trotting speed than any of the other sons of Messenger. Mr. Bush assured me that he could trot very fast for a horse of that day, and when led by the side of another horse he could beat three minutes very easily, but as we have to take Mr. Bush's assertions cum grano sulis, we fortunately have very reliable testimony of contemporaneous date and from a source wholly disinterested. I have before me a letter written by Judge J. Porter, of East Bloomfield, dated June 4, 1828, in reply to inquiries from some correspondent about the horse, his terms, etc. He writes as follows:

"I should think he was a very swift trotter from what I have seen, and very sprightly and nearly white. He has got a great number of fine colts in this town which are three years old; and the probability of their drawing on the old horse's business is the reason of his being removed to Le Roy and Batavia."

Whether Judge Porter was a horseman or not he certainly reflected, in this remark which I have emphasized, the leading quality for which Bush Messenger was distinguished in that region and in that day.

Although he was certainly a very fast natural trotter, it is not known that he was ever trained an hour in his life, neither is it known that any fast or trained trotters ever came from his loins. This was the period of fast mail coaches running from Albany to Buffalo, and as the old proprietors of those great lines were pushed westward from State to State until they finally were driven across the Mississippi, I have many times heard them talk of the great slashing grey Messenger teams that would carry their coaches along at ten miles an hour, and lament that there were no such horses nowadays. There were other sons of Messenger and many grandsons, all known as "Messengers," but as a progenitor of horses suited to the stage coach this particular one that broke his neck in trying to get out of his inclosure was the premier. He probably came nearer filling the place in this country that his grandsire filled in England-English Mambrino - than any other one of the tribe, for we can truly say of him, as Pick said- of his grandsire, "from his blood the breed of horses for the coach was brought nearly to perfection."

Pотомa was a bright bay, fifteen and a half hands high, and was bred by Daniel Youngs, of Oyster Bay, Long Island. He was foaled 1796 and got by imported Messenger; dam by imported Figure; grandam by Bashaw. He was put on the turf in the 
spring of $1 \% 99$ and was a respectable race horse at short distances. He ran against and beat some of the best of his day. He was on the turf about three years. In the midst of his racing career he was purchased by Mr. Van Ranst for five hundred pounds. In 1802 he was owned by Major William Jones, of Cold Spring Harbor, and made some seasons there. In 1806 he was at New Windsor, Orange County, New York. In 1808 he was in charge of Thomas Jackson, at Rahway, New Jersey, and 1811 at Crosswicks, near Trenton, New Jersey. It is probable he died about this time, as we find no further trace of him. Most of his stock were bays, of good size, and very salable animals. Nothing can now be recalled that connects him with any of the trotting strains coming from his sire. He was not strictly running-bred on the side of his dam.

Trppoo SAIB was a bay horse with one white foot and was fully sixteen hands high, with plenty of bone. He was foaled 1795, got by imported Messenger; dam Mr. Thompson's imported mare by Northumberland; grandam by Snap, etc. His fine size and elegant pedigree made Tippoo Saib a very desirable horse to breed to, but for some cause he did not appear much on the turf. He ran a few races and went into the stud early, in the neighborhood of Trenton, New Jersey, and in the following year was at Goshen, Fishkill, and Pine Plains, New York. My impression is he was then returned to West Jersey and Bucks County, Pennsylvania, where he was probably owned in his latter days. His sons Tippoo Sultan, Financier and others, acquired great fame on the turf. His connection with the trotting lines of descent is very distinct, but not very prominent.

Sin Solomor was got by imported Messenger; dam Camilla by Cephalns; grandam Camilla by imported Fearnought and out of imported Calista, etc. He was foaled about 1800, bred by General Gunn, of Georgia, who seems to have kept Camilla and perhaps others in the North for the purpose of breeding. The pedigree on the side of this dam is an excellent one and would seem to justify the owner in seeking to get the best crosses possible into his stud. When five years old he was sold to Mr. Bond, of Philadelphia, for two thousand dollars. His races were numerous and often successful, beating some of the best horses of his day, and among them the famous Miller's Damsel, also by Messenger, over the Harlem Course in heats of four miles. Not much is known of his stud services, and he seems to have been kept 
several years in Union County, New Jersey. He seems to have labored under the disadvantage of having a greater horse of the same name-Badger's Sir Solomon by Tickle Toby-in competition with him, and thus the son of Tickle Toby would steal many a chaplet from the brow of his namesake, the son of Messenger.

Ogden Messenger was a grey horse, foaled 1806, got by imported Messenger; dam Katy Fisher, by imported Highflyer; grandam a mare imported by H. N. Cruger in 1786, by Cottager; great-grandam by Trentham; great-great-grandam by Henricus; great-great-great-grandam by Regulus. The pedigree of this dam is correct, and she was doubtless entitled to rank as thoroughbred. This horse was bred by Mr. Cruger, and at three years old was sold to David Ogden, and that summer he was pastured on the farm of Major William Jones, of Long Island, from whose books we have the foregoing facts. Mr. David W. Jones remarks: "I retain a perfect recollection of him. He was at that time a large overgrown colt, not particularly ugly nor exceedingly coarse, but having no special beauty nor finish. I cannot better describe him than to say he was a coarse pattern of a fine horse, with marked traits of his lineage." Mr. Jones evidently saw him at his worst age and before he fully reached his maturity.

Judge Odgen, his owner, was a large landholder in St. Lawrence County, New York, and in the spring of 1810 he removed from New Jersey to an island of eight hundred acres in the St. Lawrence river, opposite the village of Haddington, and took the horse, then four years old, with him. It is not known that he ever ran a race for money, and it is not probable he ever did, for it was his owner's aim and object to 'improve the stock of the country as well as his own, in which he was successful. After five or six years he was taken to Lowville in Lewis County, and made several seasons there in charge of Charles Bush, and from this fact he came to be known there, locally, as Bush Messenger. Thus it happened that there were two sous of imported Messenger in the State of New York at the same time, and both known as Bush Messenger, and to these we might add a grandson and a great-grandson in the State of Maine, and at later date both named "Bush Messenger." It was at one time supposed that Mr. Ogden's horse while at Lowville became the sire of the famous Tippoo of Canada that became the head of a very valuable tribe of trotters and pacers, but later developments showed 
that this was a mistake. (He appears to have alternated in his services between Lewis and Jefferson comnties, but whether weekly or yearly I cannot state. He was taken to Lowville as early as 1815 and was there five or six years.)

The facts about this horse have been developed from much correspondence with different parties, but more especially from Mr. V. Sheldon, of Canton, New York, and from Mr. P. F. Daniels, of Prescott, Ontario. Both men knew the horse personally, and Mr. Daniels was seventy-tive years old when he wrote. He still had a very clear recollection of the horse in his appearance and style of action. In describing him he says: "He was peculiarly marked about his hocks and knees, having a series of dark rings about his limbs, continuing at intervals down to his hoofs, and many of his sons and daughters were marked the same way." Having ridden him many times he says: "He had a long flinging step and was a fast trotter. His action was high and not easy to the rider, and he conld not widen behind as some of our modern trotters."

When Mr. Daniels was a young man he was engaged in carrying the mail, and in March, 1821, he believes it was, Judge Ogden gave him an order to bring the horse home from Lewis County. He led him all the way behind his mail conveyance and delivered him safely to young Mr. Ogden, who gave him to an Irish groom named Daley, and Daley remarked he would soon make him look like another horse. That night he gave him an overfeed of corn and he died of colic. He was never advertised while at home and he was not very liberally patronized. The Freemans and the Archibalds, however, Mr. Daniels says, bred to him largely. His stock were good and many of them excellent, especially those descended throngh his sons Blossom and Freeman's Messenger.

Mambrino (Grey).- This son of Messenger was foaled about 1800, his dam was by Pulaski, grandam by Wilkes; great-grandam by True Briton. He was bred by Benjamin C. Ridgeway, near Mount Holly, New Jersey. In $180 \%$ he stood at Flemington under the name of Fox Hunter. He was purchased by Richard Isaac Cooper, who resold him to William Atkinson for about one thousand two hundred dollars. He was a flea-bitten grey, mane and tail white, handsome and stylish, about sixteen hands high, head medium size, and a good, well-formed horse at every point, except his feet, which were big and flat. He was probably never 
harnessed and was a very popular stallion in Salem and adjoining counties for many years. Mr. Atkinson was a very proninent and influential member of the Society of Friends, and "Billy" Atkinson was always a welcome guest as he traveled through Salem, Gloucester, and Burlington counties with his horse, and his genial good humor made him as popular as his horse. He always, claimed great speed for his horse, but owing to his position in the society he never could gratify his friends by showing it. When his offspring came into service they were not only performers of great merit on the road and the course, but they had bone and substance that fitted them for every kind of labor required of them. All the Quakers had Mambrinos and nothing else, after "Billy" Atkinson and his horse had been among them a few years. Some of his descendants attained to great local fame as trotters and some did well as runners. $\mathrm{He}$ was a very valuable horse and left a wonderfully numerous and valuable offispring.

Black Messenger.-Among all the progeny of Messenger, this is the only one that I can now recall that was black. $\mathrm{He}$ was bred by William Haselton, of Burlington County, New Jersey, and out of a mare highly prized in the Haselton family, but her blood cannot now be traced. He was foaled in 1801 and on the death of Mr. Haselton in 1804 he was sold to Charles or Richard Wilkins of Evesham, ten miles from Camden, New Jersey, who owned him till he died at an advanced age. As the birth of this horse is fixed by documentary evidence at 1801 it suggests that Messenger was kept in Burlington County, New Jersey, the unplaced season of 1800 . Still as he was at Lawrenceville in the fall season of 1800 it is possible the mare was sent to him there. He was full sixteen hands high and possessed great muscular development and strength of bone. He was not handsome, but his figure and style were very commanding. In his day he was regarded as one of the best natural trotters ever in Burlington or Gloucester counties. This was not the claim of his owner merely, but the unprejudiced opinion of all the horsemen who knew him. His stock were very highly prized as horses suited to all purposes and especially for fast road work. Some of them were greatly distinguished locally as fast trotters, and among them was Nettle, the dam of the famous Dutchman, that was the greatest trotter of his day.

Whynot Messenger, Pizzant's Messenger, Austin's Messen- 
ger, and Cousin's Messenger were all sons of Messenger and got by him while he was in West Jersey, but as nothing has been developed concerning their maternal breeding nor the character of their progeny, I will pass them over with this bare record that such horses existed.

Saratoga.-This son of Messenger was a flea-bitten grey and was foaled abont 1805. It is believed he was bred on Long Island, but nothing is known of the blood of his dam. He was driven in harness and did service in several comnties in Pennsylvania, and was sold at auction in Philadelphia to James Dubois of Salem, New Jersey. He was a great, strong horse, and was. kept at work on the farm of his owner, covering mares only as opportunity offered. He was a slashing trotter, but it was only when his owner was away from home and got an extra drink or two that anybody ever had an opportunity to see how fast he could go. A number of his progeny were fast trotters; among them a mare called Charlotte Gray that was the fastest of her day in all that region. Among his sons, one called Dove was greatly distinguished in the stud.

Nestor and Delight. - These were sons of Messenger, the former bred in Orange County, New York, in 1802, and was at Warwick in that county, $180 \%$ in charge of Nehemiah Finn. The latter was bred in Westchester County in 1806, and made the season of $182 \%$ at Warwick, New York, in charge of John G. Blauvelt, and is probably the horse that was more widely known as Blanvelt's Messenger. The breeding of the dams of both these horses is very uncertain.

Mount Holly was a grey horse, fifteen and a half hands high. He was foaled about 1807 and was bred by Colonel Udell, of Long Island. His dam was by Bajazet, and his grandam was by Bashaw. Not much is known of him till he was well advanced in years and was taken to Dutchess County. Daniel T. Cock knew him well on the island, and he assured me he was a trotter in the true sense of the word. The late Mr. Daniel B. Haight, a horseman of excellent judgment and knowledge, knew him very well, and he describes him as of the true Messenger grey, and a smooth, well-finished horse all over. His offspring were smooth, handsome, and remarkably tough, and from their kindly tempers they were easily managed and made horses fit for any service. The most noted of his get were the famous trotters Paul Pry and Mr. Tredwell's grey mare that went to England. His cross appears 
in the pedigrees of many trotters and is very highly prized to this day. In the latter part of his life he was owned by Jacob Husted, of Washington Hollow, New York, and made several seasons there. His sight failed entirely as he grew old, and he died about 1835. With two such performers from his own loins as Paul Pry and the Tredwell mare, it cannot be doubted that. he inherited and transmitted the true Messenger "trotting instinct," and that without any assistance from the blood of his dam.

Plato was a large brown horse, fully sixteen hands high, and was a full brother to Bishop's Hambletonian, being by Messenger, out of Pheasant. He was bred by General Coles, of Long Island, and was foaled 1802. As he matured the general judgment was that his limbs were too light for his body, and this is the only instance that I can recall where the get of Messenger failed at this vital point. He was trained and ran a few races, and from a trial with Miller's Damsel General Coles said he was the best horse that ever ran against that famous mare. In a race against his half-brother, Sir Solomon, he won the first heat of four miles and broke down in the second, which finished him as a race horse. He was a larger and a handsomer horse than his full brother Hambletonian, but at no other point was he so good. When they stood in the same stable he was advertised at a lower price. He was a number of years in the stud on Long Island, New Jersey, and the river counties of New York, and after 1816 at Pine Plains there is no further trace of him. In his physical structure and doubtless, in his mental structure also, he took after his dam, and the only link now recalled coupling him with the trotter is the fact that he was the sire of the dam of Lewis' Engineer, that was the sire of the great Lady Suffolk.

Dover Messenger was a grey horse, and was got by imported Messenger, but the blood of his dam and the year he was foaled are unknown. He was kept several seasons at South Dover, Dutchess County, New York, and left a very valuable progeny strongly endowed with the instinct to trot. He was taken to the town of Russia, in Herkimer County, where he died. There was a younger horse bearing practically the same name, a son of Mambrino Paymaster, with which this horse has often been confounded.

Coriander. - This son of Messenger was a bay horse, about fifteen and a half hands high; was foaled in Queens County, New 
York, about 1796, and his dam was by Allen's Brown Figure; grandam by Rainbow; great-grandam by Dauphin. He seems to have been kept on Long Island as long as he lived. His progeny was much like their sire, and Mr. D. W. Jones describes them as "clean, wiry, and brilliant. In their make-up there seemed nothing wasted and nothing wanted." He ran some races, as did many of his get. He was bred apon one of the early daughters of Hambletonian, and she produced the great trotter "Old Topgallant," the sensation of his period and one of the most famous of the very early trotters. One of the most remarkable facts in the history of this remarkable old gelding is that he ran some races before he was trained to trot.

FAGDOWx.-This son of Messenger was bred on the Jersey side of the Delaware, not far from Philadelphia, and was foaled, I think, in 1803 . His dam was represented to be by Diomed, and if this be correct it must have been 'Tate's imported Diomed that was imported into New Jersey and kept there a number of years. This was a bay horse and must not be confounded with the chestnut horse of the same name imported into Virginia. Fagdown became vicious and dangerous, and from this trait in his character he was generally called the "Man Eater." He was kept in the region of Philadelphia and south of there for many years, and left a very unmerous and very valuable progeny. They were noted for their superior qualities as road horses, and some of them were very fast, for their day. For a number of years no family of horses were so popular abont Philadelphia as the Fagdowns. He had a son called Cropped Fagdown that was fast, and another son called Jersey Fagdown that trotted some races against the great Andrew Jackson. Another son, named after his sire, was bred in Northeastern Maryland, and was taken to Eastern Ohio in 1829, and he was kept in Columbiana, Mahoning, and Jefferson counties for at least ten years. He was never in a race nor never trained, but his Quaker patrons all insisted that when led by the side of another horse he could trot as fast as a pretty good horse conld run. This grandson of Messenger was the sire of the grandam of Wapsie, the well-known trotter and sire of Iowa.

Bright Phebus was foaled 1804, the same year as Hambletonian. He was out of the imported Pot-8-os mare, and his breeeder, General Coles, of Long Island, sold him to Bond and Hughes, of Philadelphia. His most noted achievement was at 
Washington, D. C., in 1808, when in a sweepstakes he more than distanced the great Sir Archy, by catching him when he had the distemper. His racing eareer was respectable, but not brilliant, and when that ended it is not known what became of him.

Slasher, Shaftsbury, Hotspur. -l'here was quite a famous brood mare owned somewhere in Jersey called Jenny Duter, or Jenny Oiter, as some authorities have it. She was got by T'rue Briton; dam Quaker Lass by imported Juniper; grandam Molly Pacolet, by imported Pacolet, etc., tracing on six or eight more crosses that are all fudge. This mare was bred to Messenger about 1801, and produced Shaftsbury; her daughter by Liberty was bred to him about the same time and produced Slasher, and about the same time her granddanghter by Slender was also bred to him and produced Hotspur. These three sons of Messenger do not seem to have ever been trained, and very little of their history can be traced, except that they were kept as stallions in different parts of New Jersey. It is not known that their blood has had any influence upon the American trotting horse.

Messenger (Hutchinson's). - This was a large grey horse, foaled in 1792, and bred by Mathias Hutchinson, of Pennsylvania, near Philadelphia. His dam was by Hunt's Grey Figure, son of imported Figure. He was kept in Monmouth County, New Jersey, $179 \%$, and it is probable that he was often represented as imported Messenger himself. I have no knowledge of this horse or his progeny beyond the mere facts here given.

Messenger (Cooper's).-This son of imported Messenger was. generally known as "Cooper's Grey" and sometimes as Ringgold. He was sixteen hands high and was foaled about 1803 . He was bred in Montgomery County, Pennsylvania, and was kept about Philadelphia, on both sides of the Delaware, till 1821, when he was sold by the administrators of Jacob Kirk, and it has been said he was taken to the Wabash by Amos Cooper. He ran some races when he was young, and was a horse of a good deal of local fame. He was liberally patronized in the stud and left valuable progeny. It has been suggested that probably he was the sire of Amazonia, the dam of Abdallah; but as there is nothing to support this suggestion except the mere matter of location, and as all that has ever been claimed for her paternity is that she was by "a son of Messenger," we must not forget that there were plenty of other sons of Messenger in the same locality that might. have been her sire. 
The name "Messenger" was more sady abused 11 its duplication in the closing of the last and the early decades of the present century than that of any other horse, or perhaps of all other horses of that period put together. Multitudes of his sons were called "Messenger," and, in the next generation, multitudes of his grandsons gloried in the same cognomen, and thus generation after generation perpetuated it, in widening circles, till "confusion became worse confounded," leaving the historian in helpless and hopeless ignorance as to what was true and what was false. When grey horses in the second, third, or fourth remove from the imported horse became old, it required but little "diplomacy" to satisfy the public that they were true sons of the original, and this became the custom. 


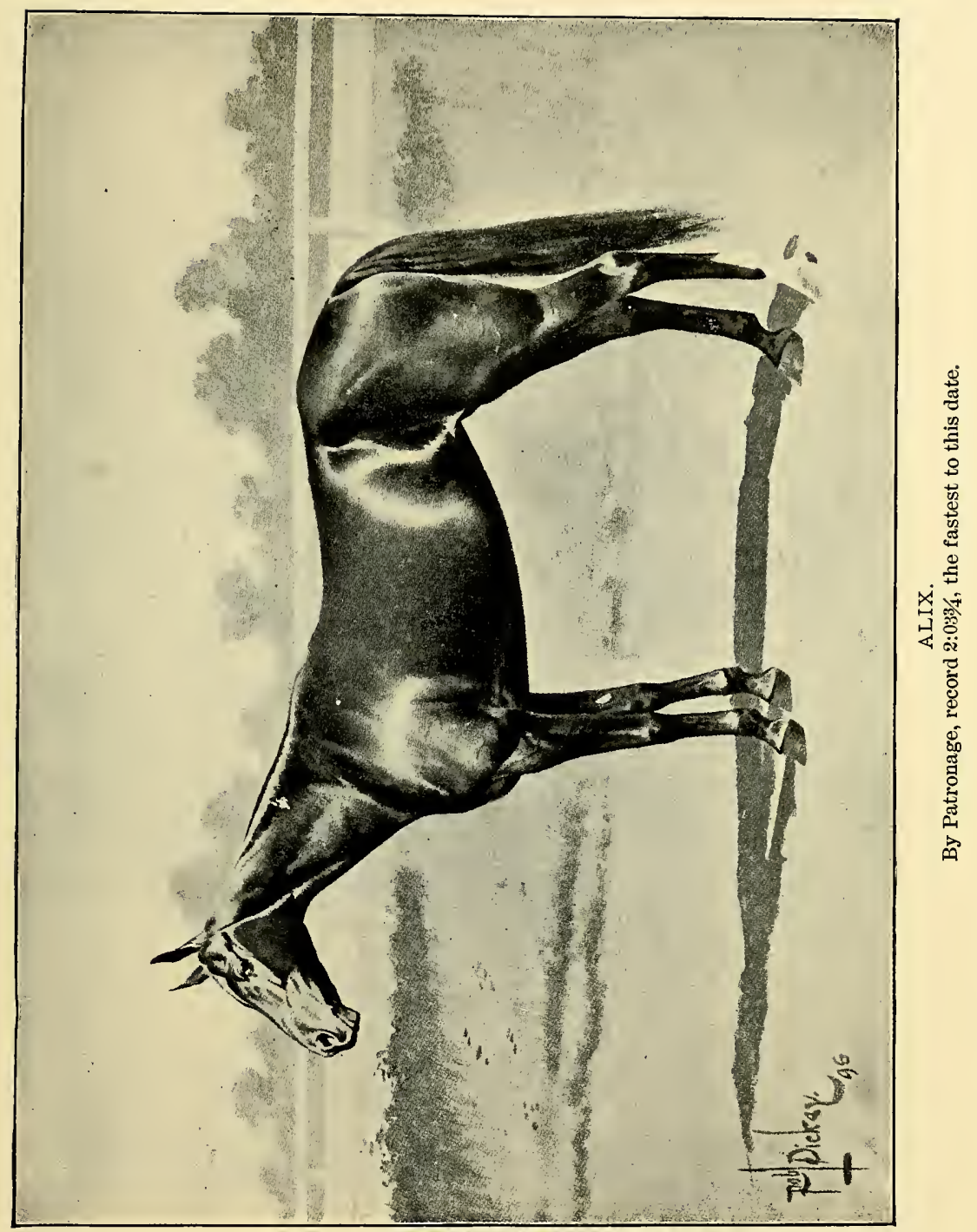





\section{CHAPTER XX.}

\section{MESSENGER'S DESCENDANTS.}

History of Abdallah-Characteristics of his dam, Amazonia-Speculations as to her blood-Description of Abdallah-Almack, progenitor of the Clampion line-Mambrino Paymaster, sire of Mambrino Chief-History and pedigree -Mambrino Messenger-Harris' Hambletonian-Judson's HambletonianAndrus' Hambletonian, sire of the famous Princess, Happy Medium's dam.

AbDallah.-C'This grandson of Messenger has been popularly and justly designated as the "king of trotting sires of his generation." He was bred by John Tredwell, of Queens County, Long Island, and was foaled 1823. His sire was Mambrino, son of Messenger, and his dam was Amazonia, one of the most distinguished trotters of her day. Concerning the breeding and origin of Amazonia there has been great diversity of opinion among horsemen and a great amount of controversy among writers. It is not my purpose to enter into a discussion of the questions raised on this point, but I would hardly be doing justice to history to pass it over unnoticed. I will, therefore, try to give a brief synopsis of the history and the arguments urged, and refer the reader to the first and second volumes of Wallace's Monthly for a more extended consideration of the questions raised.

The first representation of her pedigree was that she was a daughter of imported Messenger, and the next was that she was by a son of Messenger. On the first claim, that she was by Messenger, no argument was possible, one way or the other, on account of dates; but against the second claim, that she was by a son of Messenger, the arguments were numerous and vehement. All these arguments were based wholly upon her coarse external conformation and the absence of all resemblance to the Messenger family. Among the supporters of this view were many of the most intelligent and trustworthy horsemen of the whole country. Indeed, the preponderance of intelligence as well as numbers seemed to be on that side. That she had "coarse, ragged hips," that she had a "rat tail," that she "had hair 
enough on her legs to stuff a mattress," that she was "a muddy sorrel," etc., were all urged to prove that she was not by a son of Messenger. It is true that many entered into this controversy who never saw the mare and who knew nothing about her appearance, but there were others who knew her perfectly, among them my venerable friend David W. Jones, to whom we are all indebted for so many treasures from his storehouse of very valuable memories.

On the other side there were some little scraps of history, that at the vital point may have been history or may have been fiction. In the certificate of sale of Abdallah, April 2\%, 1830, to Mr. Isaac Snediker, his breeder, Mr. John Tredwell, says: "And believe him to be the very best bred trotting stallion in this country, and be it enough to kuow that his sire was Mambrino and his dam Amazonia." It has been argued that it would be very inconsistent for a man of Mr. Tredwell's standing to certify that Abdallah "was the very best bred trotting stallion in this country," if he knew nothing of the blood of his dam, drawing the inference that he must have known and believed the representations of his nephew, B. T. Kissam, from whom he got Amazonia. The story of the original purchase of Amazonia by B. T. Kissam and given to me by his brother, Timothy T. Kissam, in 1870, is as follows: Amazonia was purchased by B. T. Kissam, a dry goods merchant of New York, when on an excursion of pleasure in the vicinity of Philadelphia about 1814. She was brought ont of a team and was then four years old past, his attention having been called to her as an animal of much promise. He used her for his own driving a short time and sold her to his uncle, John Tredwell. "Amazonia was represented to my brother to have been a get of. imported Messenger."

Now, in considering whether this scrap of history is probably true, the geographical question has been urged with telling effect. Messenger had been kept a number of years on both sides of the Delaware, right on the way to Philadelphia, his fee had been above that of any other stallion, and a large percentage of his. colts had been kept entire. In no part of the country, perhaps, were there so many sons of Messenger seeking public patronage. The geography and the chronology of the question, therefore, both sustain the probability of its truthfulness. Whether $\mathrm{Mr}$. Kissam crossed the river at Trenton, or Burlington, or Camden he was right in the hotbed of the sons of Messenger. "If. 
Amazonia" it has been asked, "was as coarse and forbidding as represented in her appearance, what induced Mr. Kissam to buy her?" He wanted a carriage horse and he wanted one that conld not only show good action, but one that had a right of inheritance to good action. He knew the Messengers and knew that beauty and style were not family traits in that tribe. Nany of them were coarse, and possibly as coarse as Amazonia. Her very coarseness and lack of style is, under the circumstances, a strong argument that in choosing her $\mathrm{Mr}$. Kissam had regard for her Messenger blood.

Another argument, resting on "the internal evidences," has been urged with considerable force and it is very hard to answer it. Amazonia was a mare of tested and known speed. She was in a numiber of races to saddle and had won several of them in less than three minutes along about 1816-18, and when Major William Jones, in 1820, accepted the challenge to produce a horse that could trot a mile in three minutes for one thousand dollars, he knew very well what he was doing, for he had seen Amazonia do it a number of times. Her best time was about $2: 54$, which in that day was considered phenomenally fast. If we were to meet a running horse out on the plains that could run away from all others, we would naturally and justly conclude that he had some of the blood of the race horse in his veins. If we have a pacer and we learn he came from a section of the country where a certain tribe of pacers abounded, we would naturally conclude that he belonged to that tribe, especially if we knew there were no other pacers in that section. If we have a trotter that can go away from all other trotters, and we know that this trotter came from a section abounding in a family of trotters, and in nothing else that can trot, we naturally and justly conclude that this trotter came from some member of that family of trotters. This argument from the "internal eviclences" seems almost axiomatic, and when taken in connection with the historical argument, unsatisfactory though it be, they together lay the foundation for a very strong probability that Amazonia was by a son of Messenger.

Abdallah was in color a beautiful bay, about fifteen and a half hands high, and there was a measure of coarseness about him that he could not well escape, as both his sire and dam were endowed with that undesirable quality. The one exception to this was in the character of his coat, which was very fine and glossy when in 
healthy condition. His reputation as a great trotting sire was very widely extended during his lifetime, but his lack of symmetry and his "rat tail," which he inherited from his dam, so impaired his acceptability with the public that he never was very largely patronized. Besides this he had an unconquerable will of his own, which he transmitted to his offspring very generally. This willfulness was not a desirable quality in a horse for drudgery, and hence most of his patrons were such as were seeking for gameness and speed. When he was four years old he was not in the stud, and it is understood that Mr. Tredwell undertook to break him thoronghly and train him that year. It is also understood that when put in harness he kicked everything to pieces within his reach and that all thoughts of training were soon abandoned. He never was in liarness again until, in extreme old age, he was sold for five dollars to a fish peddler, and the peddler's wagon was soon rednced to kindling wood.

He was kept at different points on Long Island, and one season in New Jersey, till the fall of 1839, when he, with Commodore, another son of Mambrino, was sold to Mr. John W. Hunt, of Lexington, Kentucky, where they made the season of 1840. Commodore was much the more attractive horse of the two, and did a large business, while Abdallah was almost wholly neglected, leaving only about half a dozen colts. Meantime his progeny on the island began to show their speed and their racing qualities; a company was formed and he was brought back from Kentucky and made the seasons of 1841 and 1842 at the Union Course, Long Island. He was at Goshen, New York, 1843, at Freehold, New Jersey, 1844 and 1845, at Chester, New York, 1846-47-48, at Bull's Head, New York, 1849, and did nothing, then at the Union Course and Patchogue, Long Island, and was not off the island again. After the period of his usefulness was past his inhuman owners turned him out on a bleak, sandy beach on the Long Island shore, and there he starved to death in the piercing November winds, without a shelter or a friend.

Abdallah was the sire of Hambletonian, 10, the greatest of all trotting progenitors and greater than all others combined. This fact alone has made his name imperishable in the annals of the trotting horse. A number of his other sons were kept for stal. lions and some of them lived to old age, but they were all failures in the stud. His daughters, generally, proved to be most valuable brood mares, producing speed to almost any and every cross. 
A pedigree tracing to an "Abdallah mare" has always enhanced the value of a family.

Almack.-Mr. John 'Tredwell bred his famous team of driving mares, Amazonia and Sophonisba, to Mambrino in the spring of 1822, and the next year they each produced a bay horse colt that he named Abdallah and Almack. Sophonisba, the dam of Almack, was a superior mare, but she was not fast enough for her mate. Almack, however, was a good horse and left some trotters. I have no particular description of him at hand and nothing can now be given of his history further than that some of his daughters produced well and that he seems to have been kept all his life on Long Island. His dam Sophonisba was got by a grandson of imported Baronet, as represented, but this is so indefinite as to be unsatisfactory and suspicions. As none of the Baronets could ever trot, even "a little bit," it is evident that whatever" trotting inheritance Almack possessed came to him from his sire. Aside from a number of his descendants that were recognized trotters of merit there was one in particular that established Almack as a progenitor of a great family of trotters. A son of his bred by George Raynor, of Huntington, Long Island, in 1842, and known as the "Raynor Colt," ont of Spirit by Engineer II., sire of Lady Suffolk, was led behind a sulky at a fair at Huntington, when he was eighteen months old, and he went so fast and showed snch a magnificent way of doing it, that he was named "Champion" by William T. Porter, editor of the Spirit of the Times. At three years old he was driven a full mile in 3:05 and this was a "world's record" for colts of that age at that time. In 1846 he was purchased by William R. Grinnell for two thousand six hundred dollars and taken to Cayuga Connty, where he founded a great tribe of trotters that is now known everywhere as the "Champion Family." A fuller account of this horse will be found at another place in this volume.

Mambrino Paymaster (widely known in later years as Blind Paymaster).- This was a large, strong-boned, dark-bay horse, sixteen hands and an inch high. When young he was somewhat light and leggy, but with age he spread ont and became a horse of substance. He was bred by Azariah Arnold, of the town of Washington, in Dutchess County, New York. There is some uncertainty about the year this horse was foaled, but it was somewhere between 1822 and 1826. He was got by Mambrino, son of Messenger, and his dam was represented to be by imported Pay- 
master. The late Mr. Edwin Thorne made a statement a few years ago that in an interview with Azariah Arnold he said that he did not know or remember the horse that was the sire of the dam. At that time Mr. Arnold was very old, and doubtless his. mental faculties very much impaired, so it would not be remarkable that he should have forgotten all about it. On the other hand, Nelson Haight, Daniel B. Haight, Seth P. Hopson, and others of like high character, maintain that Mr. Arnold, in his. younger days, always represented the mare to be by Paymaster, and the name of the horse itself is very strong evidence that he did so represent it, and is a standing proclamation to that effect. There can be no possible doubt that in earlier life Mr. Arnold constantly represented this mare to be by Paymaster; neither can there be any reasonable doubt that when his faculties were impaired with age he told $\mathrm{Mr}$. Thorne that he did not remember her pedigree. Mr. Arnold's neighbors all agree that he was a man of unblemished character and incapable of a willful misrepresentation, when in possession of his faculties. Again, that this Paymaster cross was not only possible, but probable, is shown by the fact that imported Paymaster was kept by Ebenezer Haight, in the year 180\%, in the same township with Azariah Arnold, and the years 1808 and 1809 in the same part of the county. Therefore, Mr. Thorne to the contrary notwithstanding, I have but little doubt that the Paymaster cross is correct.

He had a small star in his forehead and a little white on one hind foot. His back, loin and hips were altogether superior, and those who knew him best say they never saw his equal at these points. His head was large and bony, with an ear after the Mambrino model. His neck was of medinm length and his shoulder good. His hind legs were quite crooked and too much cut in below the hock in front, giving the legs at that point a narrow and weak appearance; his hocks were large and at the curb place showed a fullness. His eannon bones, all round, were short for a horse of his size, and his feet were excellent. He was slow in maturing, but when he filled out he lost all that narrow, weedy appearance which characterized his colthood. He was not beautiful, but powerful.

About 1828 he was sold and taken to Binghamton, New York. Meantime his colts came forward and proved to be so valuable that Nelson and Daniel B. Haight and Gilbert Jones purchased and brought him back to Dutchess County about the year 1840 . 
He was not a sure foal-getter, but his stock proved to be of great value. When brought back from Broome County he was blind. He made one season on Long Island in charge of George Tappan; the other seasons till 1847 he was kept in Dutchess County in the neighborhood of his owners. In 1847 he was sold to Mr. Gilbert Holmes and taken to Vermont, where he died after getting one colt. Many of his sons were kept as stallions, but the most famous of his get were the mares Iola and Lady Moore, and last but not least, his famous son Mambrino Chief, the founder of a great family of trotters in Kentucky. His stock were probably more noted and more highly prized than that of any of the sons of Mambrino that stood in Dutchess Connty. As Abdallah was the link by which the greatest of all trotting families are connected with Messenger, so Mambrino Paymaster is the link through which the family easily entitled to second place reaches the same illustrious original.

Mambrino Jr. (Bone Swinger) was a beautiful bay horse, foaled 18:-, got by Mambrino, son of Messenger; dam not traced. He was bred on Long Island and was owned by George Tappan, near Jericho, Long Island. About 1833-4 he made some seasons at Washington Hollow, Dutchess County. He was about fifteen hands three inches high and was considered more blood-like and handsome than most of his family. $\mathrm{He}$ was a strong breeder, giving most of his colts his own elegant color.

Mambrino Messenger (commonly known as the Burton Horse) was foaled about 1821. He was got by Mambrino, son of Messenger; dam by Coffin's Messenger, son of Messenger; grandam by Black and All Black; great-grandam by Feather. He was bred by Abram Burton, of Washington Hollow, New York. He was a beautiful bay, about fifteen hands three inches high, and was the same age as Mambrino Paymaster, and they were rivals for a number of years, each having his friends and adherents. He was finer in the bone, having more finish and beauty than his rival, and what was still more effective with the public, he conld outtrot him. Many of his offspring proved to be most excellent roadsters and some of them were fast. He was probably taken to Western New York, but I have not found any trace of his location or history. This name, Mambrino Messenger, was borne by several other horses of different degrees of affinity to the originals.

Hambletonian (Harris') (also known as Bristol Grey and 
Remington Horse). - This was a grey horse, about sixteen hands high, and possessed great strength and substance. When young he was an iron grey and probably pretty dark, but as he advanced in age he became lighter in color. His head was large and bony, with great width between the eyes. He was short in the back, with long hips, and the rise of the withers commenced far back, showing a fine, oblique shoulder. He was a horse of unusually large bone formation; his limbs were large, but flat and clean, with a heary growth of hair at the fetlocks. He was of docile and kindly disposition and worked well either alone or with another. His gait was open and decided and at a walk his long slinging steps carried him over the ground unusually fast. His speed as. a trotter was never developed, but his action at that gait was so free, open and square that those who knew him well have insisted that his manner of going indicated the possibility of great. improvement, if he had been handled with that view. His offspring were slow in maturing, and for many years, indeed till toward the end of his life, he was not appreciated as a stallion. He was in constant competition with the little, plump, trim and trappy Morgans, and at three and four years old his long, lathy, plain colts cut but a sorry figure against the well formed and fully developed Morgans of their own age. With such a rivalry, sustained by the question of profit to the breeder by early sales, it is not remarkable that he should have been neglected, till it was clearly demonstrated that he transmitted the true Messenger trotting instinct in greater strength than any of his competitors.

He was bred by Isaac Munson, of Wallingford, Vermont; foaled 1823, got by Bishop's Hambletonian, son of 'Messenger; dam the Munson mare that was brought from Boston, 1813. There never has been any question about the sire of this horse, but up to 1869 the representation made by Mr. Harris that his dam was. an imported English mare was generally accepted as the truth. I was led to doubt this, and in December of that year I made a thorough search of the records of the custom-honse in Boston, and found the claim was without any foundation whatever. Through the kindness of Mr. Henry D. Noble I was enabled to get beyond Mr. Harris, who really knew nothing about the mare, back to the Munson family, and to Mr. Joseph Tucker, the earliest and best authority living in 18\%0. In order that this evidence may be preserved I will here insert Mr. Tucker's letter entire. 
“Milford, N. H., May 4th, 1870.

"Mr. J. H. Wallace, Muscatine, Iowa.

"DEAR SIr: Yours of 22d of April is duly received and contents noted. I was 24 years old when first acquainted with the da!n of the 'Harris Horse,' so called, in the fall of 1813 . Was then carrying on a farm, now owned by Wm. Randall, Esq., in this town, for Mr. Israel Munson, a commission merchant then doing business on India Street, and afterward on Central Wharf, Boston. I was in Boston in the fall of 1813, as above, and found the dam (of Hambletonian) and mate in Mr. Munson's possession. He said they had been 'leaders' in a stage team, and they acted as if green about holding back, etc. He never said she was imported from England, neither did I Lear such a story till two or three years ago. The dam was called 'a Messenger.' All the description I can give of her is that she was a strong, well-built, light dapple grey, and would weigh ten hundred, certain. The span was well matched. The nigh one (the dam) was more serviceable than the other. Led them ali the way from Boston behind an ox team; kept them till the middle of April and then returned the pair to Boston. Mr. Munson drove them up, only stopping to dinner, when on his way to Vermont in August, 1814, and I didn't see them again until December. I then drove them from Boston to Vermont, and used them a year on the Munson farm, on Otter Creek, in Wallingford. In June, 1815, I took them to Plıœnix Horse (bay, black mane and tail, good looking and smart) in Clarendon Flats. Both stood and had foals the spring after I left Mr. Munson's employ. The off mare was occasionally a little lame, I think in the off fore foot, when hard drove, but the nigh one was perfectly free from lameness or limping. I left Mr. Munson in the spring of 1816, and know nothing of mares afterward.

"Yours truly,

JOSEPH TUCKER, "(By Geo. W. Fox)."

I have given this letter entire, with the exception of a few elosing sentenees, that the public may be able to judge of its authenticity. That these mares were leaders in a stage team when Mr. Munson bought them is confirmed by members of the Munson family, and that the nigh mare was represented to be a Messenger at the time of the purchase I have not the least doubt. But whether she was really a Messenger is quite another question. All I can say is, it was possible in the nature of things; and the employment and qualities of the mare, together with the representations of $\mathrm{Mr}$. Munson, appear to make it probable. During the mare's lifetime I find she was spoken of in the Munson family and about Wallingford as "the imported Messenger mare" and in this phrase, no doubt, was the origin of the story that she was herself imported. When this phrase, through her son, reaehed the next outer eirele, "imported Messenger mare" no longer meant a mare by imported Messenger, but an imported mare by Messenger. 
At the point where Mr. Tucker's knowledge of this mare ceases, fortunately Mr. Isaac B. Munson, of Wallingford, takes up the history and carries it forward, with great particularity, to the time of her death about 1826. She produced several foals by different horses, and while they were all valuable animals, the only one that is known to history is the subject of this sketch. When Hambletonian of Vermont was two years old Mr. Munson sold him to Samuel Edgerton and others, of Wallingford, and they kept him in the stud till about 1828, when they sold him to Mr. Eddy, of Bristol, Vermont, and in the hands of the Eddy family he was kept at Bristol, New Haven, and other points in and about Addison County till about 1835, when he was kept one or two years again in Wallingford and adjacent towns. Abont 183\% he was sold to Joshua Remington, of Huntington, Vermont, and was taken there. He stood in various parts of Chittenden County, and became well known as the "Remington Horse." Unfortmnately there is no guide to dates in these transfers and it is not known just how long Mr. Remington owned him. He next passed into the hands of Mr. Russell Harris, New Haven, Connecticut, and remained his till he died late in the year 184\%.

The location of this horse was unfavorable either to a large or to a numerous progeny of trotters. He was surrounded with Morgan blood, trappy and stylish and fast growing in popularity on the supposition that they were trotters-a most valuable tribe as family horses, but none of them were able to trot fast without the introduction of trotting blood from the outside. He lived in a period antedating the real development of the trotter and the keeping of records of performances, and hence we must not judge of his merits as a trotting sire by comparing the list of his performers with lists of later generations. Green Momtain Maid was one of the best of her day and made a record of $2: 28 \frac{1}{2}$ in 1853, and the same year the famous pacing gelding Hero made a record of $2: 20 \frac{1}{2}$. Probably the best trotter from his loins was Sontag, with a wagon record in 1855 of $2: 31$. This mare was originally a pacer, and whether his dam was by imported Messenger or not we must conchude that the tendency to the lateral action was strong in his progeny. Lady Shannon, Trouble, Vermont, Modesty, and True John were all famous performers in their day. The last named was kept in the stnd a few years and was known as the Hanchett Horse. He fell into the hands of Sim D. Hoagland, of this vicinity, became ngly and 
was made a gelding. As a weight puller he had no equal in his day. His daughters became the dams of many noted producers and performers, and through the doubling of his blood and its predominating influence we have the famons General Knox and his tribe. Bnt few of his sons were kept as stallions; among them the best known is Hambletonian, 814, known as the Parris IIorse and the sire of the stout campaigner, Joker, '2:22 $\frac{1}{2}$. Vermont Hambletonian (known as the Noble or Harrington Horse) was one of his best and best-bred sons. He died in 1865, leaving a valuable progeny.

HaMBLETONian (JUDSON's) was a brown horse and resembled his sire very much in both size and form. He was foaled 1821, got by Bishop's Hambletonian, son of Messenger; dam by Wells' Magnum Bonum. This Magnum Bonum family abounded in that region, and it was a very good one, whatever the blood may have been. This horse was bred by Judge Underhill, of Dorset, Vermont, and sold, 1829, to Dr. Nathan Judson, of Pawlet, Vermont. He was kept in that region till he died about 1841 . His progeny were very numerous and valuable.

Haybletonian (ANDRUs') was a brown horse néarly sixteen hands high. He was a well formed and evenly balanced horse, all over, with an objectionable lack of bone just below the foreknee. His head and ear were strongly after the Messenger model. I have never been able to determine just who bred him, and consequently his blood on the side of the dam is not fully established. He was foaled about 1840, got by Judson's Hambletonian, and out of a mare which Mr. B. B. Sherman says was by old Magnum Bonum. He seems to have known this mare well and speaks of her as a very superior animal. This would indicate inbreeding to the Magnum Bonums, and as they were a lightlimbed family we may account for this horse's defects in that respect. He was owned a number of years by Mr. Andrus, of Pawlet, and passed into the hands of G. A. Austin, of Orwell, Vermont. In 1853-4 Mr. Austin sent him to Illinois, along with Drury's Ethan Allen, Black Hawk Prophet, Morgan Tiger and some other stallions, in charge of $\mathrm{Mr}$. Wetherbee, for sale. In 1854 they were removed to Muscatine, Iowa, and several of them sold there, among them the Andrus Horse. He was then stiff in his limbs, showing the effects of previous neglect and abuse. $\mathrm{He}$ died at Muscatine in 185\%. His progeny there were defective in bone. I am told several of his daughters in Vermont have left 
good stock there and thus perpetuated his name in the second and third generations. But his chief title to fame has been secured to him by his renowned daughter Princess, the dam of the great Happy Medium. In $18 \tilde{1} 1$ Mr. L. B. Adams, who then owned her, bred the Isaiah Wilcox mare, by Burdick's Engineer, son of Engineer by Messenger, to Andrus' Hambletonian, and, in a nutshell, the union of this great-grandson of Messenger with this great-granddaughter of Messenger produced Princess. This pedigree of Princess is incontrovertibly established and will be given in fuller detail in the history of her son, Happy Medium. 


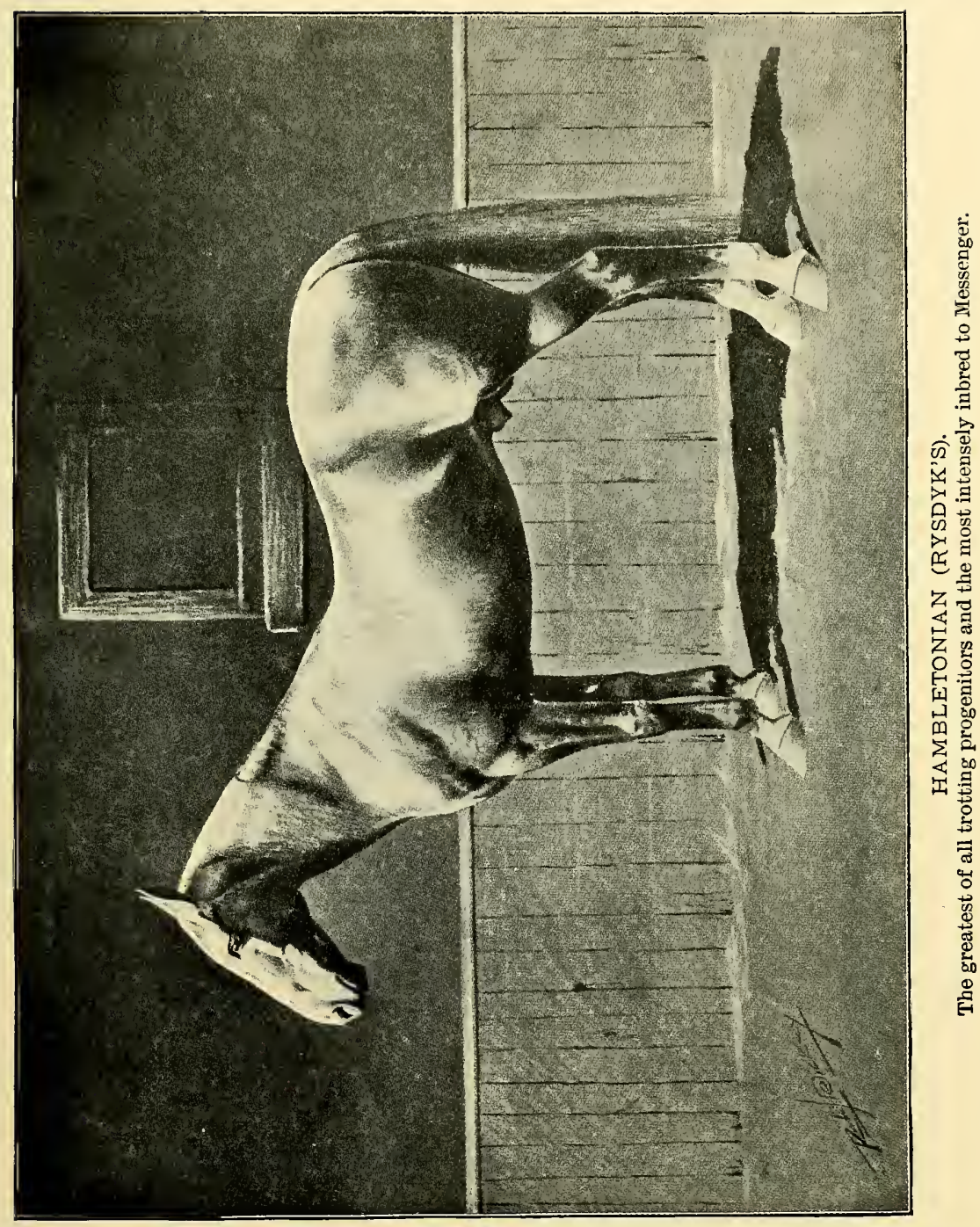





\section{CHAPTER XXI.}

HAMBLETONIAN AND HIS FAMILY.

The greatest progenitor in Horse History-Mr. Kellogg's description, and comments thereon-An analysis of Hambletonian, structurally consideredHis carriage and action-As a three-year-old trotter-Details of his stud service-Statistics of the Hambletonian family-History and ancestry of his dam, the Charles Kent Mare-Her grandson, Green's Bashaw and his dam.

Hambletonian, 10.-It has been a matter of constant regret that in the compilation of the first volume of the Register I attached the name "Rysdyk's" to this horse, and this misstep has served as a kind of apparent justification for very many men to seize upon the name "Hambletonian," with their own name as a prefix. This has led to great confusion and annoyance to all that body of men who have anything to do with records and correct pedigrees. Fortunately, however, the evil has become so apparent that many writers are beginning to use the numbers, and we now very frequently hear men speak of "Hambletonian, 10 ," as the true designation of this horse.

As no horse of any blood or period in this or any other country has excited an interest so universal, or represented such a vast sum of money in his offspring and descendants, I must try to give an account of him and his family-ancestors and descendants-as full and accurate as the materials at hand will enable me. He was a beautiful bay color, bred by Jonas Seely, of Sugar Loaf, Orange County, New York, foaled 1849, got by Abdallah; dam the Kent Mare, by imported Bellfounder; grandam One Eye, by Hambletonian, son of Messenger; great-grandam Silvertail, by imported Messenger; great-great-grandam Black Jin, breeding unknown. He was sold with his dam, when a suckling, to Mr. William M. Rysdyk, of Chester, in the same county, and he remained his till he died in March, 1876. He has been described by a great many writers, but the most minute and accurate description I have ever seen is from the pen of "Hark Comstock" (Peter C. Kellogg), which I will here present, and after it 
note any point upon which my own judgment differs from his. It should be remembered that this description was made when the horse was breaking down with the weight of years:

Hambletonian, now twenty-six years old, is a rich deep mahogany bay, with blacik legs, the black extending very high up on the arms and stifles. His mane was originally black, and in his younger days very ornamental; rather light, like that of the blood-horse, and of medium length, nerer reaching below the lower line of the neck, but uniform throughout. His foretop was always light. At the present time not a vestige of either remains, they having gradually disappeared until crest and crown are bald. His tail is long and full. When we first knew him it was very full, but is also thinning with his advancing years. The hair of both was black as a raven's wing, and entirely devoid of wave or curl. His marks are a very small star and two white ankles behind, but the coronets being dotted with black spots, the hoofs are mainly dark. Muzzle dark. Head large and bony, with profile inclining to the Roman order; jowl deep; jaws not as wide apart as in some of his descendants, yet not deficient. Eye very large and prominent, and countenance generally animated and expressive of good temper. We found him to measure $10 \frac{1}{2}$ inches across the face. Ear large, well set, and lively. Neck rather short and a little heavy at the throatlatch, but thin and clean at the crest. His shoulders are very oblique, deep and strong; withers low and broad; sway very short, and coupling. smonth. The great fillets of muscle running back along the spine give extraordinary width and strength to the loin, which threatens to lose the closely-set. hip in the wealth of its embrace. But it is back of here that we find lodged the immense and powerful machinery that, imparted to his sons and daughters, has ever placed them in the foremost ranks of trotters. His hip is long and croup high, with great length from hip-point to hock. Thighs and stifles swelling with the sinewy muscle, which extends well down into his large, clean, bony hocks, hung near the ground. Below these the leg is broad, flat, and clean, with the tendons well detached from the bone, and drops at a considerable angle with the upper part of the limb, giving the well-bent rather than the straight hock. Pasterns long, but strong and elastic, and let into. hoofs that are perfection. In front his limbs in strength and muscular development comport with the rear formation. His chest is broad and prominent; his forelegs stand wide apart (perhaps in part the result of much covering), and he is deep throngh the heart; yet notwithstanding this, and the fact of his roundness of barrel, there is no appearence of heaviness or hampered action.

Taken at a glance, the impressive features of the horse are his immense substance, without a particle of coarseness or grossness. No horse we can recall has so great a volume of bone, with the same apparent firnmess of texture and true blood-like quality. Though short-hacked, he is very long underneath. Indeed, he is a horse of greater than apparent length. We found his measurement from breast to breeching, in a straight line, greater by four inches than his height at the withers-a very unusual excess. We also found him two inches higher over the rump than at the withers, and the whole rear, or propelling portion of the machinery, would upon measurement seem to have been molded for an animal two sizes larger than the one to which it is at- 
tached; yet so beautifully is its connection effected with the whole that there is no disproportion apparent, either in the symmetry or the action of the horse. As an evidence of the immense reach which this admirable rear construction enables him to obtain, it is often noticed by visitors that in his favorite attitude, as he stands in his box, his off hind foot is thrown forward so far under him as to nearly touch the one in front of it-an attitude which few horses of his proportionate length could take without an apparent strain, yet which he assumes at perfect repose. When led out upon the ground his walk strikes one as being different from that of any other horse. It cannot be described further than to say that it shows a true and admirable adjustment of parts, and a perfect pliability and elasticity of mechanism that shows out through every movement. Many have noticed and endeavored to account in different ways for the peculiarity, some crediting it to the pliable pastern, others to surplus of linee and hock action, et ' - but the fact is, there seems to be a suppleness of the whole conformation that delights to express itself in every movement and action of the horse. "In his box," said a Kentucky horseman, who recently looked him over, " $I$ thought him too massive to be active, but the moment he stepped out I saw that he was all action."

There is so much in the foregoing description that is intelligent and just that I hardly feel like reviewing a single phrase. In judging of the conformation of a horse and determining whether it is good or bad, at different points, we must have in our mind some ideal standard, by which we mentally compare one thing with another. The popular conception of the perfect horse is the picture of the "Arabian," painted by artists who never saw an Arabian horse. The next approach to perfection is the English race horse, but others may insist that the Clydesdale comes nearer perfection and that he should be the ideal with which the standard of comparison should be made. It is unfortunate that Mr. Kellogg should have described Hambletonian as possessing "immense substance, without a particle of coarseness, or grossness." He had a remarkably coarse head in its size and outline, but this is greatly softened by saying "with a profile inclining to the Roman order." The ideal muzzle of the English race horse is so fine that, figuratively speaking, he can drink out of a tin cup, but Hambletonian conld not get his muzzle into a vessel of much smaller dimensions than a half-bushel measure. "Ear large, well set and lively." This is true as to the size of the ears, but not correct, in my judgment, as to the setting on. As they habitually lopped backward when in repose, giving a sour and ill-tempered expression, I corld not concede that they were "well set." "The hocks were good and clean, but the abrupt angle at that point was certainly a coarse feature. The 
round meaty withers and the round meaty buttocks were both "coarse and gross" when looked at from the point of good breeding. His two great, meaty ends, connected with a long and perfect barrel, two or three sizes too smail for the ends, showed such. a marked disproportion that I often wondered at it. Not one of these eriticisms is made in the sense of a criticism of $\mathrm{Mr}$. Kellogg's description, but merely as the expression of a different. view on some points, and on those points not mentioned I most heartily agree with him. He has omitted to give the height of the horse for the reason that he had shrunken from his normal height just one inch. When at his best he measured fifteen hands one inch and a quarter. This shrinkage, in addition to. the ordinary resnlts of great age, is thus explained by Mr. Guy Miller, who knew him better than any other man except his: owner. "His splendid fore hoofs had been ruined by an operation whereby the arch was lost and the horse during the remainder of his days stood on his frogs." He was two inches higher on the hips than on the withers.

When the horse was led out his movements were so frictionless and faultless that he impressed me as the most wonderful horse that I had ever seen. He seemed as supple as a cat with the power of an elephant. As he walked he kept pushing those crooked hind legs away under him in a manner that gave him a. motion peculiarly his own, and suggested the immense possibilities of his stride when opened ont on a trot. Plain and indeed homely as he was he was a most interesting and instructive study whether in his box or taking his daily walks. The question has. been asked a thonsand times whether the speed of Hambletonian. had been developed and how fast he could go. This question I considered very important, in a philosophical and breeding. sense, and in starting in to investigate it I found two statements, one that the time made at the Union Conrse was honest and true, and the other that it was a "pnt up job" to make. Mr. Rysdyk feel good, and that the time in fact was much slower than that announced. Each side had its advocates, and it did not take long to discover that the enemies of Mr. Rysdyk were all on one side and the more bitter their enmity the more blatant they were in denying the truth of the time given ont for the performance. This party was headed by one "J. M.," long distinguished, and will be long remembered in Orange County, for the virnlence of 
his dislike to Mr. Rysdyk, and as the most unreliable of all unreliable horsemen.

In the autumn of 1852 Mr. Rysdyk and Mr. Seely C. Roe, the owner of Roe's Abdallah Chief, then four years old, concluded to exhibit their sons of Abdallah at the fair of the American Institnte, in New York, and after the fair to take their colts, three and four years old respectively, for a light training for a few weeks. The programme was carried out, and after reaching the course they started the two colts together, and much to Mr. Roe's surprise Hambletonian beat his colt in 3:03. In a short time $\mathrm{Mr}$. Roe gave his colt another trial in $2: 55 \frac{1}{2}$. A few days later Mr. Rysdyk drove his colt in 2:48. Believing then he had the making of the best trotter in the world and being thoroughly homesick, he packed up his traps and started for Orange County, and this was the first and the last training that Hambletonian ever had. When we consider the age of the colt and how few of that age had then ever reached that mark, the little then known by amateurs of the arts of training and driving, and the very limited preparation, we must conclude that this was a remarkably good performance.

Was it honestly made? Mr. Roe has been dead a good many years, but the next day after he returned from Long Island with Mr. Rysdyk he called at the house of his brother-in-law, David R. Feagles, a very responsible man, and in the course of the conversation he asked Mr. Feagles if he had heard the news? "No," said Mr. Feagles, "what is it?" "Rysdyk's colt trotted the Union Conrse in 2:48. I held my watch and I know it is true." Mr. Roe was always steadfast and immovable in this declaration while he lived. Mr. W. H. Wood, the breeder of Abdallah Chief, says he told him the time was $2: 48$, and he had several times heard it disputed in Mr. Roe's presence and he had always settled the dispute by giving the same fact. Mr. David R. Seely said he could not remember the time made, but he had heard the matter disputed, and Mr. Roe settled it by saying it was true, that he saw it and held the watch on him when he did it. These men were as reliable as any in Orange County and their statement of Mr. Roe's assertions cannot be donbted. Considering the circumstances, it will occur to any mind that Mr. Roe was the very best witness to the truth of this performance that could be produced. He was not only disinterested, but in building up the reputation of a rival stallion he was testifying to his own hurt. 
There are other evidences of Hambletonian's development and speed, but nothing so definite as the foregoing. He was driven in double team sometimes with the great trotter Sir Walter. Mr. Kinner, at one time owner of Sir Walter and other good ones, a horseman of experience and knowledge of trotting affairs, assured me that Sir Walter had shown a trial at Centerville track to wagon in 2:32, and this was before he was driven double, occasionally, with Hambletonian; and that Hambletonian could ontfoot Sir Walter for the first half-mile, but as the young horse was green and unseasoned, he conld not keep up the clip to the finish. He did not hesitate to express the belief that the team could have trotted the mile in considerably less than $2: 40$. There is one fact in connection with the trial at Union Conrse that I have omitted in its proper place. Mr. Rysdyk was a remarkably careful man and always aimed to be inside of the truth rather than beyond it. He advertised his horse as having made the trial in $2: 48 \frac{1}{2}$, as it is probable some of the watches gave that as the time, instead of $2: 48$ flat.

Like all the Abdallah family, Hambletonian matured early, and at three years was as well advanced as many colts a year olde:. His stud services commenced early. When two years old he was allowed to cover four mares without fee and he got three colts, one of which was afterward known as the famous Alexander's Abdallah. When three years old he was offered for public patronage at twenty-five dollars to insure, and he covered seventeen mares and got thirteen colts. The next season, at the same price, he covered one hundred and one mares and got seventy. eight colts. The next season (1854), being then five years old, the price was advanced to thirty-five dollars, and he covered eighty-eight mares, getting sixty-three foals. The price remained at thirty-five dollars till 1863 , when it was advanced to seventy-five dollars. At which price he covered one hundred and fifty mares. The next season the price was advanced to one hundred dollars, and he covered two hundred and seventeen mares, getting one hundred and forty-eight foals. In 1865 the price was alvanced to three hundred dollars and one hundred and ninety-three mares were covered. In 1866 the price was put at five hundred dollars and one hundred and five mares were covered. At this price his services remained ever afterwardone hundred dollars down and the remainder when the mare proved in foal. In 1867 he covered seventy-seven mares and got 
only forty-one foals. This large percentage of failure indicated beyond question that his procreative powers had been overtaxed and that there was a general letting down of his vital energies. In 1868 he was not allowed to cover any mares. In 1869 he again manifested his usual vigor and he covered twenty-one mares, getting fourteen foals. In $18 \% 0$ he covered twenty-two mares and got thirteen foals. From this time forward his procreative powers dwindled, and in 18\%5, I think, he got but two foals, and died the following March.

It has been estimated that he got about one thousand three hundred foals, and for several years it was one of the amusing features of horse literature to see how many writers were able to demonstrate that as a progenitor of speed he was a failure. This item of one thousand three hundred foals was taken as the basis of computation, and then with the small number of forty trotters out of the one thousand three hundred, the percentage of trotters was very small. The next step was to find some unknown horse, generally a pacer, that had only two or three foals to his credit and one of them had made a record of $2: 30$, thus showing a much larger percentage than Hambletonian, and by that much he was a greater sire than Hambletonian. All this foolishness has now subsided in the face of the fact that the great mass of the trotters of to-day have more or less of his blood in their veins, and in a very short time that blood will abound in greater or less strength in every American trotter. The tables which here follows will make this fact evident to all who will study them.

[Prefatory to these tables and to the other statistics concerning the present rank of the trotting families given in the pages following, an explanatory paragraph is in order so that they may not be misunderstood. (1) They are based on the tables given in the Year Book for 1896, and I regret to say that these tables are so emasculated, incomplete, unsatisfactory and in many cases contradictory one of the other that it is literally impossible to compile from them statistics that may be accepted as absolutely correct and letter perfect. However, as this work is not intended as one for statistical reference, the tables being approximately correct serve my purpose, which is merely to show relatively and with substantial accuracy the standing of the sires and families embraced to the close of 1896. (2) By the term " staudard performers" is meant horses that have acquired trotting records of $2: 30$ or better, or pacing records of 2:25 or better. The Year Book no longer gives a 2:30 pacing list, and it should be noted that pacers with records between $2: 30$ and $2: 25$ are not credited in these tables. (3) The tables are designed to show $(a)$ the number of standard performers got by each sire named. (b) The number of his sons that are sires of standard performers. (c) The number of his daughters that are dams of 
standard performers. (d) The number of standard performers produced by these sons and daughters, and finally, in the last column, the total number o standard performers produced in the two generations-i. e., by the sire himself, and by his sons and daughters. The dates of foaling and death are important. in considering the opportunities of the families embraced.]

The first table following gives some idea of the supremacy of the Hambletonian family over all others. When we seek a rival to Hambletonian as a trotting progenitor we must do so among his sons; and by turning to the second table it will be noted that many of these outrank the founders of any and all the other. great trotting families.

FOUNDERS OF THE GREAT TROTTING FAMILIES.

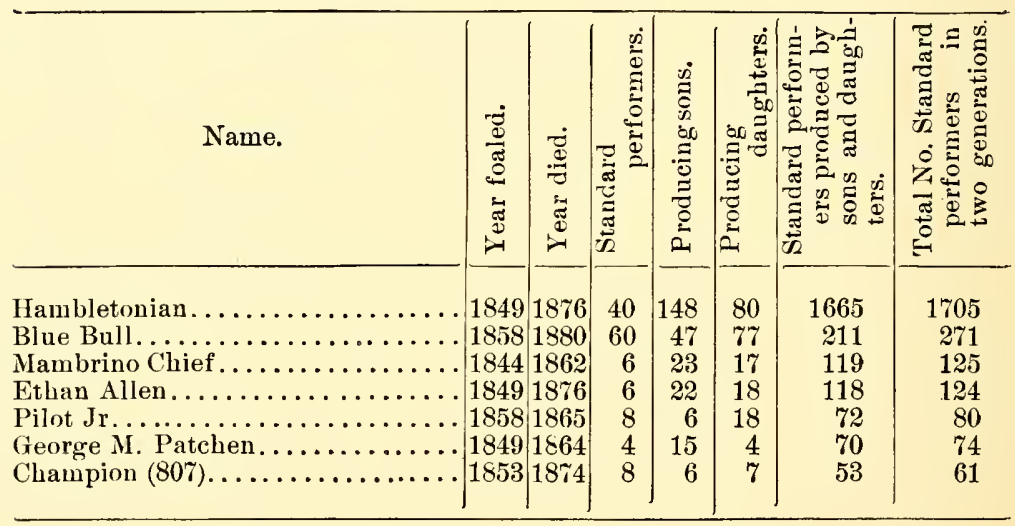

In this table Ethan Allen is given as the representative of his: family in preference to his sire, Black Hawk, the real founder, for the reasons that he was a far greater horse, and makes a better showing than his sire, and further because he was a contemporary of Hambletonian. For exactly the same reasons: George M. Patchen is given as the representative progenitor of the Clay line.

The next table demonstrates what the Hambletonian family has done in the second and third generations, and the relative standing of the leading sub-families of the greatest trotting line. It embraces separately every sire that has to his own credit and to. the eredit of his sons and daughters an aggregate of fifty or more standard performers, twenty-three in all, while the totals to the: 
credit of all the other sons of Hambletonian are grouped in the last line:

FAMILIES OF HAMBLETONIAN'S SONS.

\begin{tabular}{|c|c|c|c|c|c|c|c|}
\hline Name. & 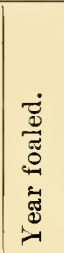 & 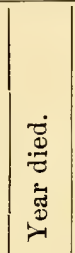 & 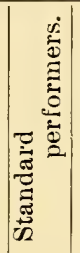 & 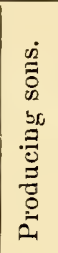 & 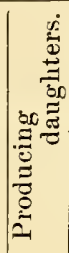 & 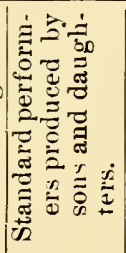 & 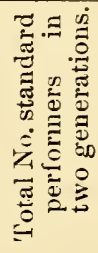 \\
\hline George Wilkes. & 1856 & 1882 & 83 & 94 & 81 & 1801 & 1884 \\
\hline Electioneer. . & 1868 & 1890 & 154 & 65 & 43 & 493 & 647 \\
\hline Happy Medium & 1863 & 1888 & 92 & 51 & 47 & 272 & 364 \\
\hline Harold............ & 1864 & 1893 & 44 & 43 & 45 & 248 & 292 \\
\hline Dictator.................. & 1863 & 1893 & 52 & 44 & 42 & 234 & 286 \\
\hline Volunteer..... & 1854 & 1888 & 3.34 & 40 & 48 & 221 & 255 \\
\hline Strathmore... & 1866 & 1895 & 71 & 26 & 54 & 158 & 229 \\
\hline Abdallah (15). & 1852 & 1865 & 5 & 14 & 29 & 199 & 204 \\
\hline Aberdeen...... & 1866 & 1892 & 45 & 25 & 19 & 110 & 155 \\
\hline Egbert ....... & 1875 & & 75 & 25 & 18 & 74 & 149 \\
\hline Messenger Duroc............ & 1865 & 189 & 23 & 24 & 41 & 125 & 148 \\
\hline Edward Everett & 1855 & 1878 & 13 & 12 & 16 & 112 & 125 \\
\hline Administrator... & 1863 & 1892 & 14 & 20 & 44 & 93 & 107 \\
\hline Jay Gould. & 1864 & 1894 & 29 & 14 & 28 & 76 & 105 \\
\hline Victor Bismarck. & 1867 & $189-$ & -31 & 13 & 13 & 64 & 95 \\
\hline Cuyler. . & 1868 & 1894 & 15 & 15 & 36 & 74 & 89 \\
\hline Masterlode. & 1868 & 189- & 28 & 17 & 16 & 57 & 85 \\
\hline Sweepstakes. & 1867 & 189 & -35 & 4 & 20 & 39 & 74 \\
\hline Sentinel..... & 1863 & 1873 & 8 & 9 & 14 & 57 & 65 \\
\hline Middletowr & 1860 & 1891 & 14 & 9 & 11 & 49 & 63 \\
\hline Squire Talmage & 1866 & | 1891 & 23 & 9 & 14 & 35 & 58 \\
\hline Dauntless...... & 1867 & 189 & 31 & 6 & 9 & 20 & 51 \\
\hline Echo... & 1866 & 3189- & 16 & 9 & 15 & 34 & 50 \\
\hline Other sons (12: & & $\cdots$ & 618 & 229 & 412 & 980 & 1600 \\
\hline
\end{tabular}

This table shows what each horse himself produced, and how his blood is breeding on through his sons and daughters; and above all it demonstrates the stupendous fact that in three generations the Hambletonian family has produced upward of seven thousand standard performers, and all facts and all experience now beyond cavil justify what I ventured to declare in Wallace's Monthly many years ago: "The Hambletonian line stands above all other lines and must survive becanse it is the fittest."

The Charles Kent Mare, dam of Hambletonian, was a bay, fifteen and three-quarter hands high, with a star, left forward ankle roan, and left hind foot white. Her son was long and round, just the opposite of her sire. Hips rather coarse, and might. 
be considered a little ragged. Stifles very powerful and weildeveloped. Her hocks and legs were exactly represented in her son Hambletonian. Her neck was fine and bloodlike, but not long. Her head was good, and her eyes remarkably full and bright, showing considerable white. Her mane was long, but thin, and her tail was light. Her shoulders were well-sloped, her withers ran up high, and were thin. Jonas Seely, Sr., having given the old mare One Eye to his son Charles, she was sold to Josiah S. Jackson, of Oxford, Orange County. Mr. Jackson bred her to Bellfounder and the produce was the Kent mare. Although the Seely family owned the stock, originally and afterward, Mr. Jackson was really the breeder of this mare. Mr. Jonas Seely says she was got the year Bellfounder stood at Poughkeepsie (1831), bnt Mr. Rysdyk says she was got in 1832, when Bellfounder stood at Washingtonville. Mr. Jackson sold her at three years old to Peter Seely for three hundred dollars; Mr. Seely sold her soon after to Mr. Pray, of New York, for four hundred dollars; Mr. Pray sold her to William Chivis for five hundred dollars; and Mr. Chivis sold her to a gentleman, who was a banker in New York-name not remembered-to match another as a fast road team. This team ran away after a time, and she was injured, and became lame. Charles Kent, a butcher in New York, then bought her and bred her to Webber's Tom Thumb, before he came to Orange County. At this juncture, on the earnest recommendation of Mr. Pray, who had tested the quality of three or four of the family, Mr. Jonas Seely -Jonas, second-bought the mare of Kent for one hundred and thirty-five dollars, and took her back to the old place, where she was bred and produced as follows:

1843. Brown filly Belle, by Webber's Tom Thumb.

1845. Black gelding, by Webber's Tom Thumb.

1846. Chestnut filly (died at 4 years old), by Abdallah.

1848. Brown filly (died at 4 years old), by Abdallah.

1849. Bay colt Hambletonian, by Abdallah (mare and colt sold to William M. Rysdyk, for $\$ 125)$.

1850. Brown filly (went to Maryland), by Young Patriot.

1851. Lost foal, by L. I. Black Hawk.

1852. Brown colt Tippoo Saib, by Brook's Black Hawk.

1853. Chestnut colt (died young), by Fiddler.

1856. Brown gelding, by Plato.

1859. Bay colt, by Almack, son of Hambletonian. 
In the preceding list there are but two fillies that lived to produce anything, and one of them is lost from sight. 'The produce of the first will be given below. The Patriot filly that went to Maryland was a brown, and of good size, but nothing further is known of her.

The Tom Thumb gelding of 1845 was in 1869 a good road horse, and was owned by George S. Conklin. He was showy and stylish without very much speed. Her fifth foal, Hambletonian, is known wherever the trotting horse is known.

This mare was a trotter of no ordinary merit. She was never in any races, so far as known, except they might have been of a private nature, but after she passed into the hands of Peter Seely her speed was pretty well developed. This is not only shown by the advance in her price from owner to owner, but it appears to be a well-established fact that when four years old Peter Seely had her at the Union Course, and he there gave her two trials to saddle, the first in $2: 43$ and the second in $2: 41$. For a time I was skeptical about these trials, but they seem to be beyond question. This is considerably faster than any other of the get of imported Bellfounder ever trotted in this country, and from this we may conclude that her inheritance from her dam was the great factor in her speed.

ONe Ere, the dam of the Kent mare, was a brown, abont fifteen hands and an inch high, with two white feet and perhaps a little white in her face. With the taste Mr. Seely had of the Messenger blood in Silvertail he wanted more of it; and when Townsend Cock sent the famous Bishop's Hambletonian to Goshen in 1814, Mr. Seely bred his daughter of Messenger to this son of Messenger and the produce was One Eye. I do not learn that this mare was handsome, but she was an animal of most remarkable courage and endurance. The load was never too heavy nor the road too long. Withal, she had a will of her own and was a little hard to manage unless she was worked constantly. One day when on her mettle she got an eye knocked out by accident, and, hence, her name; but the great quality of this mare was her remarkable trotting action. Those familiar with her gait, and entirely competent to judge, are enthusiastic in the opinion that no trotter of the present day ever surpassed her in a grand open trotting step. If the patience and skill brought into use in developing the modern trotter had been expended on her, she doubtless would have surpassed all of her 
day, not eren excepting her near relation, old Topgallant. This mare illustrates a point of very great importance. She was got by a son of Messenger that was a running horse of merit and able to beat some of the best of his day, and her dam was a daughter of Messenger. The trotting action of neither sire nor dam had ever been developed, but when these two Messengers came together, the clean, open, unmistakable trotting gait was the result. Right at this point and in this mare, One Eye, we have the incipient cause of all Hambletonian's greatness. 'This mare was bred by Jonas Seely, Sr.; given to his son Charles, who sold her to his brother-in-law, Josiah Jackson, of Oxford in Orange County. According the recollection of Mr. Rysdyk, who was entirely familiar with the Seely family and their affairs, she produced as follows:

1829. Bay gelding Crabstick, by Seagull.

1830. Bay gelding Pray Colt, by Seagull.

1831. Bay filly Young One Eye, by Edmund Seely's horse Orphan Boy.

1\$33. Bay filly Kent Mare, by imp. Bellfounder. Sold to Mr. Pray.

1834. Bay filly; sold also to Mr. Pray, by imp. Bellfounder. Perhaps there was another foal that died.

The first of her foals, Crabstick, appears to have been wellnamed. His temper was anything but smooth and pleasant. He was sold early to Mr. Ebenezer Pray, of New York, and he soon evinced two traits of character that did not elevate him in the estimation of his owner. He would throw every one off that dared to mount him, and when they did get him under motion he was determined to pace and not trot. On a certain occasion Mr. Rysdyk visited Mr. Pray, and he was urged to try his skill in riding Crabstick and see if he conld make him trot. 'The attempt was long-continued, and embraced up hill, down hill, and level work, but all to no purpose, as pace he would. At last Mr. Pray proposed to put him over rails and stakes, placed on the road at intervals of a good trotting stride, and see if that would make him quit moving one side at a time. Mr. Rysdyk went up the road and got under good headway, but just before he reached the rails the horse threw him. He was not much hurt, mounted again, and then commenced in earnest the fight for the mastery between the horse and his rider. The value of a neck was nothing when compared with the great question of who should conquer. The next attempt was snccessful, and he went over the rails flying. The intervals between them were then extended, and 
he was kept at that most dangerous exercise till he would trot without rails, and until both horse and rider were completely exhausted. The horse was conquered, and although always willful and hard to manage, ever after, when called on to trot, he wonld do it. Mr. Pray sold him to Mr. Vanderbilt, and, although kept as a private driving horse, he was fast for his day, and could go in less than three minutes at any time.

Her next foal was sold also to Mr. Pray when five years old, and was known as the Pray Colt. He was marked just as his brother Crabstick, and, like him, was somewhat vicious and hard to manage.

The third foal, Young One Eye, was by Edmund Seely's horse Orphan Boy, whose pedigree is not now known. One of her eyes was knocked out by Peter Seely, accidentally, when breaking her, just as her dam had lost an eye. She passed out of the hands of the Seely family and her subsequent history is unknown. If this mare ever produced anything, her history and that of her descendants would be of great interest and value.

The question at once suggests itself, Where did Crabstick get his pacing action? It could not have been from his sire, as he was a son of Duroc, so said, but it may have come from Seagull's dam, as we know nothing of her breeding; or it may have come from old Black Jin, the dam of Silvertail. If from neither of these we must then conclude it came from Messenger himself, or rather, through him from some of his pacing ancestors. It is altogether probable that the strong infusion of pacing blood in Messenger's veins was the real element that made him a trotting progenitor when every other imported English horse failed in that respect.

Silvertail, the great-grandam of Hambletonian, was a dark brown mare with white hind feet and a white face. She had a great many white hairs in her tail and hence she was called Silvertail. She was foaled in 1802 and was bred by Mr. Jonas Seely, Sr., of Sugar Loaf, Orange County, New York. She was got by imported Messenger in 1801, the year he stood at Goshen, New York. Her dam was a great, slashing black mare called "Jin" that Mr. Seely had used in his business many years, but her origin and breeding cannot now be found. She must have been a real good one or Mr. Seely would not have taken her to Messenger. In the summer of 1806, as was his custom, he was down at New York with a drove of cattle, and his son Jonas, then a lad of 
eight or ten years old, went along to help drive the cattle and to see the city. He was detained two or three days longer than he expected and it was very important that he should reach home at a certain time. On the rorning of that day he found himself in Hoboken, with his son, and no means of getting home except on Silvertail. So he took the boy up behind him and went home that day, seventy-five miles, by sundown. She was fully sixteen hands high and of very fine style. Her head, neck and ear were bloodlike, and her resolution and will were remarkable even in old age. Her step, at the trot, is not known to have been much developed, but she could gallop all day long. On several occasions she carried her master to Albany in a day. Besides the famous One Eye she produced several superior foals that brought high prices, in those days, but we have only the one line tracing to her as a producer. She died the property of Ebenezer Seely.

In searching for the particulars of this pedigree of Hambletonian and in tracing it back to old "Black Jin," I was necessarily brought into contact with a great many people, some of whom were helpful and some were not. As a matter of course I met with the usual number who professed to "know it all," but. really knew nothing that was reliable. As the whole tracing was in the Seely family, the public may wish to know what kind of people they were. Jonas Seely, first, of Oxford in Orange County, was a large farmer in the last century and an extensive cattle feeder and drover. As there were no railroads or steam boats in those days, much of his time was given to driving cattle, either in collecting them from the interior or in taking them to market in New York. He had use for good horses and he had a fancy for the best. His business brought him into contact with the butchers of New York, and we find he sold many of his horses. as well as his cattle to them. These same business relations were continned under his successor. He left a large family of sons. who seemed to take to the horse as a duck takes to water. Jonas, second, was one of his younger sons and succeeded to his father's business as well as to the homestead. He was born 1797 at Oxford, and his father removed to the farm at Sugar Loaf when ho was a child. He was a thrifty and successful farmer. For a number of years he was engaged with his partner and lifelong friend, Ebenezer Pray, in buying and driving cattle from the West to the New York market. In June, 1882, he passed away and there ended an acquaintance and a friendship of nearly 
thirty years. He was a strictly conscientious and truthful man, and died in the glorious hope of a devoted Christian. His first visit to New York, in 1806, the wonders he saw there, and especially the total eclipse that occurred while he was there, and how he watched it from the Bull's Head tavern, through a piece of smoked glass, and the ride home the next day behind his father on Silvertail, and how he ran down many a hill to rest himself, and how tired he was when they reached home, are incidents that were all detailed to me with the interest and vigor of yesterday.

When One Eye was about fifteen years old the elder Jonas gave her or sold her to his son-in-law, Josiah Jackson, and in due time he bred her to imported Bellfounder and she produced the Charles Kent mare. Mr. Rysdyk thought the elder Jonas gave this mare to his son Charles and that Charles sold her to Mr. Jackson, which is not material. After the Kent mare had been battered about in New York for some years and finally crippled, Charles Kent, a butcher, bought her and bred her to Webber's Tom Thumb, a Canadian horse that was quite a trotter. On one occasion when Jonas II. and Mr. Pray were down in the city, Kent wanted to sell the mare, and Mr. Pray urged Jonas very strongly to buy her and take her home for a brood mare. He concluded to do so if she were not too badly crippled, and they together went over on to the island to see her, when she came again into the Seely family. In 1848 he bred her to Abdallah, in 1849 she produced a bay colt, and in the autumn of that year he sold her with her colt to William M. Rysdyk, who had been employed on his farm for the year, for one hundred and twentyfive dollars, and this colt proved to be the great Hambletonian.

As it is now conceded, not only in this country, but throughout the world, that Hambletonian, as a trotting progenitor, is far and away the greatest horse that has ever been produced, a careful and true analysis of the blood elements entering into his inheritance is a most interesting and instructive lesson for all breeders. First we have the direct cross from Messenger himself in Silvertail; second, we have the cross from a son of Messenger on a daughter of Messenger in One Eye, making her equal to a daughter of Messenger in blood; third, we have the outcross from Bellfounder, that was a total failure as a trotting progenitor, on this double granddaughter of Messenger, and the result is a trotter in the Kent, mare and practically the only trotter 
that Bellfounder ever got; fourth, we have the cross of a grandson and probably a double grandson of Messenger on this trotter, and the produce is Hambletonian himself. These crosses show a stronger concentration of Messenger blood than can be fonnd in any horse of his generation.

BASHAW (GREEN's). - This was a black horse, fifteen and a. half hands high, bred by Jonas Seely, the breeder of Hambletonian; foaled 1855, and given when following his dam to his sonin-law, Colonel F. M. Cummins, of Muscatine, Iowa. He was got by Vernol's Black Hawk, then known as the Prake colt, son of Long Island Black Hawk, and his dam was Belle, the first foal of the Charles Kent mare, that was out of One Eye. In the spring of 1857 he was sold to Joseph A. Green, of Muscatine, and he remained his till 1864. He had one white hind foot and a large, full star in his forehead. He was a smooth, handsome horse in every respect. His head, neck, ear and eye were all good, and free from coarseness. His back and loin had very few equals even among those that are called most perfect at these points. His hip was of great length, and in his buttock there was quite a resemblance on a reduced scale to his kinsman, Hambietonian. His limbs and feet both in shape and quality were admirable, and his disposition docile and kindly. In walking his gait was sling ing, but loose jointed and slovenly, and he was therefore not a pleasant driving horse. But at the trot, whether going slow or fast, his style was very taking and his action remarkably perfect. While owned by Mr. Green he was handled by good, careful men, but they had no experience in developing and driving a trotter, and knew nothing abont that kind of horsemanship. Under these circumstances many a horse wonld have been spoiled, but his gait was always perfect and his popularity as a trotter never waned. He never was started in what might be called regular races, but at State fairs and the principal county fairs he was always in demand and always won. He was, perhaps, the best natural trotter that $I$ have ever seen. He was able to show about $2: 28$, but I think he never won a heat on a half-mile track in better than 2:31, and when sixteen years old he was able to win in 2:35. In 1864 Mr. Green sold him to some parties in St. Louis, Missonri, and they to Mr. Beckwith of Hartford, Connecticut, and while in his hands he was matched against Young Morrill, but went amiss and paid forfeit. He made the season of 1865 at Hartford. The following winter Mr. Green repurchased 
him and he was returned to Muscatine, where he remained till Jannary, 1877, when he was sold to George A. Young, of Leland, Illinois, and died January, 1880.

He left seventeen trotters in the 2:30 list; twenty-four sons that were the sires of fifty-nine standard performers, and thirtyfour daughters that produced forty-four standard performers. As his sire never amounted to anything either as a trotter or a getter of trotters, it is fair to conclude that whatever merit he possessed was inherited from the same souree that made Hambletonian greater than all others.

BeLLe, the dam of Bashaw, 50, was a brown mare about fifteen and three-quarter hands high, with tan muzzle and flanks and some white feet. She was rather short in the body and neek, but she was very stoutly built and had been a fine road mare. She was bred by Charles Kent, the butcher, and I think was following her dam when Mr. Jonas Seely bought her. She was foaled 1843 and was got by Tom Thumb, a Canadian horse, and a trotter that was brought into Orange County by William Webber and left excellent stoek. Her dam was the Charles Kent. mare, the dam of Hambletonian. She produced as follows:

1848. Bay gelding, by Abdallah.

1849. Bay filly Seely Abdallah, by Abdallah.

1851. Black colt Seely's Black Hawk, by Long Island Black Hawk.

1853. Bay filly, (taken West) by Hambletonian.

1855. Black colt Green's Bashaw, by Vernol's Black Hawk.

1857. Bay filly by Black Hawk Prophet, son of Vermont Black Hawk, in Iowa. This filly "as ringboned, and given away.

Nothing is now known of the gelding by Abdallah. The filly of 1849 by Abdallah, ealled Seely Abdallah, was owned by Mr. Charles Backman, and he had her produce for two or three. generations.

The black colt by Long Island Black Hawk of 1851 was sold to Ebenezer Seely, and kept as a stallion. This Mr. Seely died in Chemung County, and the horse died there in the spring of 1859. The filly of 1853 by Hambletonian was one of a pair of Hambletonian fillies bought and taken to Iowa by Mr. Green in 1855 . They developed a very fine rate of speed. 


\section{CHAPTER XXII.}

\section{HAMBLETONIAN'S SONS AND GRANDSONS.}

Different opinions as to relative merits of Hambletonian's greater sons -George Wilkes, his history and pedigree-His performing descendants-History and description of Electioneer-His family-Alexander's Abdallah and his two greatest sons, Almont and Belmont-DictatorHarold-Happy Medium and his dam-Jay Gould-Strathmore-EgbertAberdeen-Masterlode - Sweepstakes - Governor Sprague, grandson of Hambletonian.

There is hardly a prominent sire by Hambletonian that has not been claimed by his admirers to have been the "greatest son" of the most renowned of trotting progenitors, and if a poll of the horsemen of the country could be taken to-day as to what horse was the greatest son of Hambletonian, probably a dozen names would be found to have thousands of supporters each. As with all questions that are largely matters of opinion, and that cannot be decided absolutely by figures, the relative rank of horses as progenitors must always remain open to disputation according as thinkers approach the subject from different points of view and of interest. I shall not enter into any discussion as to the relative merits of the great sons of Hambletonian with a purpose to reach any deduction as to which was or is the greatest; but shall refer the reader to the table given in the preceding chapter, and content myself with briefly giving the history of the more renowned sires of the Hambletonian line, with such statistics as may be necessary to gange their rank as progenitors.

George Wilkes was one of the first of Hambletonian's sons to attract attention, by his performances on the turf, to the value of his sire; and as a progenitor he must be accorded a place in the first rank of all trotting sires. This horse was bred by Colonel Harry Felter, Newburgh, New York, was foaled 1856, and was got by Hambletonian out of the fast road mare Dolly Spanker. (This mare was afterward registered on what seemed 


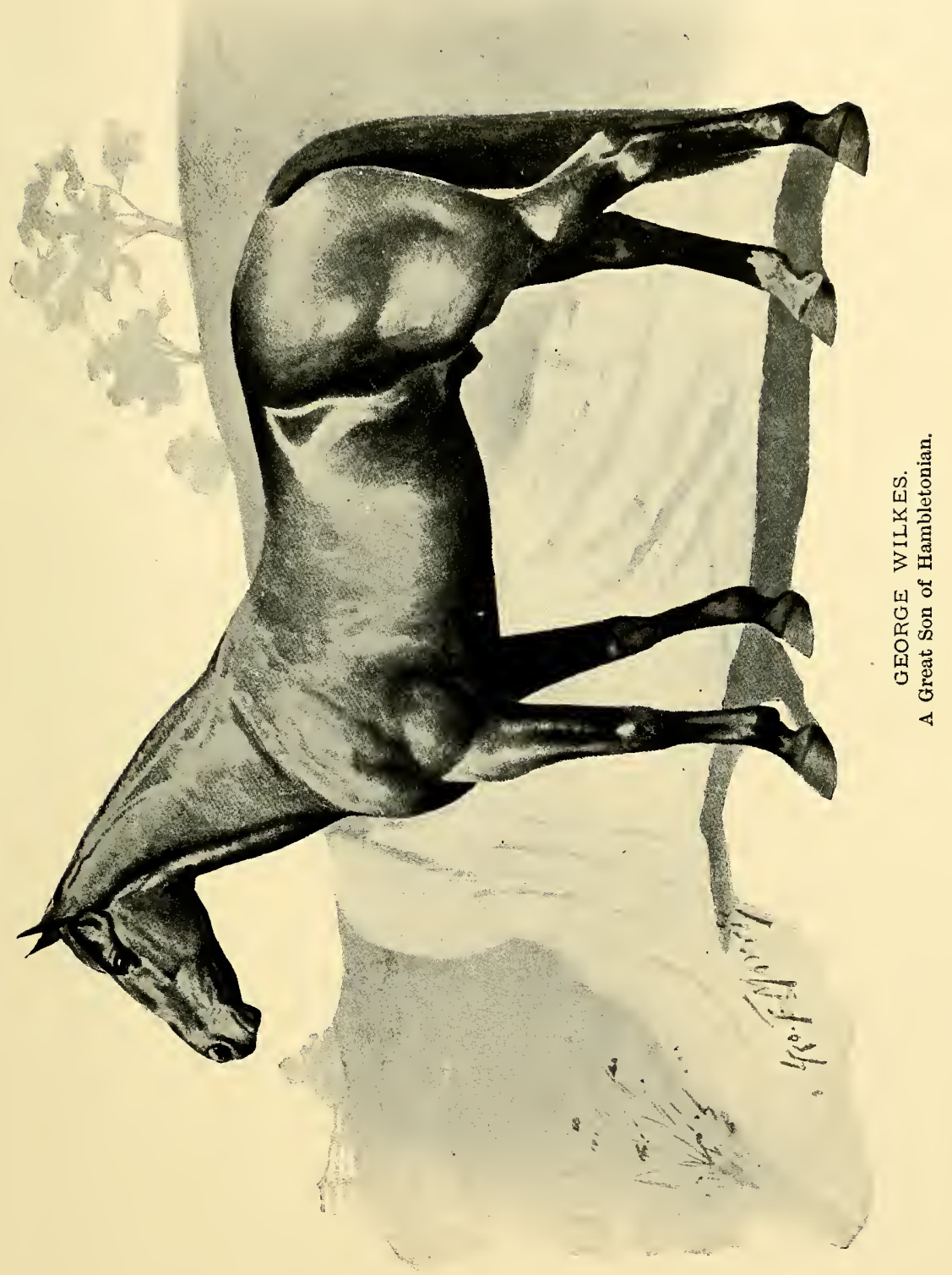



excellent evidence as by Henry Clay, out of a daughter of Baker's Highlander, but more recent investigation has thrown serious doubt upon this pedigree, the subject being fully discussed in the chapter's in this work on "The Investigation of Pedigrees.") After the travail that brought the little brown colt into the world, Dolly Spanker died, and the orphaned youngster, like Andrew Jackson, owed his life to woman's kindly care. He was fed by the women of the farm on Jamaica rum and milk sweetened with sugar, and soon grew lusty, though he was always an undersized horse, never much, if any, exceeding fifteen hands in height, though he was so stoutly and compactly made that he gave the impression of being larger than he really was. He was of that order that has been paradoxically described as "a big little horse." In color he was a very dark brown, and his flanks and muzzle shaded into a deep tan, or wine color. From a detailed description of him published in the Spirit of the Times in 1862, I extract the following:

"He is about 15.1, but all lorse. . . . His traveling gear is just what it should be-muscular shoulders long strong arms, flat legs, splendid quarters, great length from hip to hock, and very fine back sinews. He stand - higher behind than he does forward, a formation we like. . . . He is very wide between the jaws. . . . His coat is fine and glows like the rich dark tints of polished rosewood. . . . His temper $\mathrm{i} ;$ kind. We had the pleasure of seeing him at his work, and unless we are greatly mistaken he will make an amazingly good one. He has a long and easy way of going, striking well out behind and tucking bis haunches well nnder him."

Though from the fact that this writer stated that Wilkes "was as handsome as Ethan Allen," we might suspect him of a tendency to "paint the lily," it will be noted that this was written before the horse had any great reputation to speak of, and it may be accepted as a substantially correct description as far as it goes. In describing his action Charles J. Foster wrote that "his hind leg when straightened out in action as he went at his best pace reminded me of that of a duck swimming." He was then the property of Z. E. Simmons, who had purchased him as a three-yearold for $\$ 3,000$, and another horse.

George Wilkes, or Robert Fillingham, as he was first named, was a trotter from colthood. At four years old he was matched against Guy Miller, but his party paid forfeit, the reason therefor being afterward alleged that they found Fillingham possessed of so much speed that they decided to "lay for bigger 
game." The late Alden Goldsmith, a most competent judge, saw the colt trot at this time and then thought he was the fastest horse he had ever seen. He won a race in August of his fiveyear-old year, taking a record of $2: 33$, and the next year sprang into wide fame by defeating the then popular idol, Ethan Allen, in straight heats, over the Union Course, the fastest heat being in $2: 24^{3}$. In October of that year he started in harness against General Butler, under saddle. Thongh Butler was no match for George Wilkes in harness, with a saddle on his back, and Dan Mace in the saddle, he was almost unbeatable in his day, but it took him four heats to beat Wilkes, who forced him ont in the first heat in $2: 21 \frac{1}{2}$, a record he never after surpassed. Then William L. Simmons and John Morrissey matched Wilkes against Butler, two-mile heats to wagon, the latter having previously beaten the great George M. Patchen a heat in record-breaking time under similar conditions. In preparation for that match George Wilkes was sent a trial over the Centerville Course, concerning which there has been much discussion and probably much romance. Charles J. Foster wrote thus:

"It was a close, sultry day and the stallion was short of work. . . . He went the two-mile trial and I have no doubt it was faster than trotter ever had before, or has since, in any rig. But it 'cooked his mutton,' as the saying is, and for a long time he was George Wilkes no more."

It is said that ever after this trial, whatever it may have been, George Wilkes was inclined to sulk in his races. He raced with fair success in 1863 and 1864, and at the beginning of 1865 was classed among the very best out. He was sent against Dexter and Lady 'Thorn, being beaten by both; but in 1866 he twice defeated Lady Thorn, the last time in a notable wagon race over

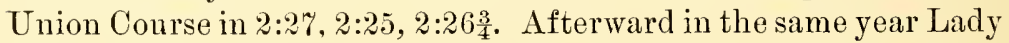
Thorn defeated Wilkes in four successive races, and she beat him again in their only meeting the following year, but in 1868 he defeated the mare in a hard-fought race, she winning the first and second heats and making the fourth heat dead. George Wilkes made his record of 2:22, October 13, 1868, over the Narragansett Course at Providence in a winning race with Rhode Island and Draco. He was kept on the turf with indifferent success until 1872, racing frequently against Lucy, Lady 'Thorn, and American Girl, all of whom outclassed him, at least in the afternoon of his racing career. Just how fast a trotter 
George Wilkes was it is impossible definitely to determine, so many and varying have been the representations on that point. It has been claimed that he went a quarter in twenty-nine seconds to an eighty-five pound wagon. William L. Simmons some years ago stated that of his own knowledge George Wilkes trotted a mile and repeat as a six-year-old at the

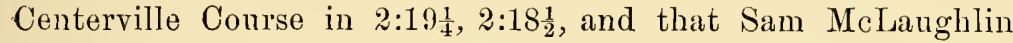

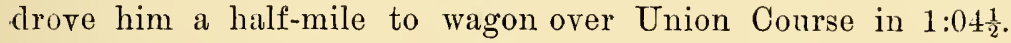
'These statements I give for what may be deemed their worth, contenting myself with the remark that it is safe to conclude that George Wilkes would have trotted well within the 2:20 mark, if he had been managed with a view to bringing out his highest racing capacity, instead of being handled solely for the purpose of smart betting and match-making manipulations.

George Wilkes was taken to Lexington, Kentucky, by William L. Simmons, his owner, in 18\%3, and in his declining years made a reputation so great in the stud that his brilliant turf career is almost forgotten. After having trotted against the best in the country for twelve successive years, proving his titness in the fiery ordeal of turf contest, he, in the nine remaining years of his life, fulfilled the purpose of his being, and demonstrated the truth of heredity by getting trotters in plenty able to do and outdo what he had in his day done.

George Wilkes got a few foals before going to Kentucky, of which the most notable was May Bird, 2:21, the first trotter to bring him reputation as a sire. Of the others got in the North,

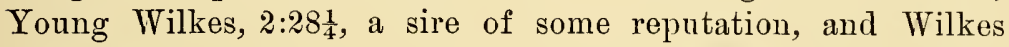
Spirit, who also figures in the table of sires, are the only ones to earn places in the records. Early in the eighties George Wilkes began to assume high rank as a sire, May Bird, Kentucky Wilkes, Prospect Maid, So So, Joe Bunker and others bringing him into prominence. Every year added to his roll of honor and soon he was among the leaders. Blue Bull had surpassed Hambletonian in the number of trotters to his credit in the $2: 30$ list, but at the close of 1886 George Wilkes was even with the Indiana sire, in 1887 he passed him, and for some seasons led all sires of $2: 30$ performers. George Wilkes got seventy-two trotters and eleven pacers to acquire standard records, of which the most noted were

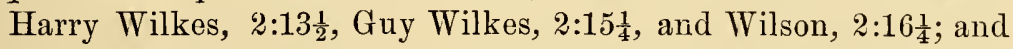
ninety-four of his sons and eighty-one of his daughters have produced, as shown in the table of Hambletonian's sons, 1801 
standard performers. The following table embraces the sons: of George Wilkes that have twenty or more standard performers. to their credit:

LEADING SONS OF GEORGE WILKES.

\begin{tabular}{|c|c|c|c|c|c|c|}
\hline Name. & 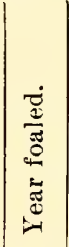 & 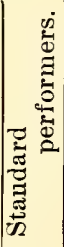 & 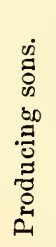 & 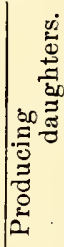 & 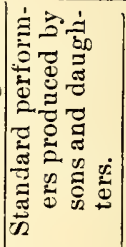 & 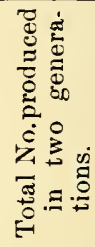 \\
\hline Red Wilkes 2:40.. & 1874 & 127 & 62 & 41 & 267 & 394 \\
\hline Onward, $2: 25 \frac{1}{4} \ldots$ & 1875 & 120 & 64 & 32 & 275 & 395 \\
\hline Alcantara, $2: 23$. & $18 \pi 6$ & 98 & 29 & 15 & 115 & 213 \\
\hline Bourbon Wilkes. & 1875 & 67 & 14 & 12 & 45 & 112 \\
\hline Simmons, $2: 28 \ldots$ & 1879 & 64 & 13 & 6 & 35 & 99 \\
\hline Wilton, $2: 19 \frac{1}{4}$. & 1880 & 61 & 3 & 4 & 8 & 69 \\
\hline Jay Bird, 2:31온. & 1878 & 57 & 10 & 10 & 68 & 125 \\
\hline Alcyone, $2: 27$. & 1877 & 55 & 27 & 9 & 117 & 172 \\
\hline Guy Wilkes, $2: 15 \frac{1}{4}$. & 1879 & 52 & 10 & 5 & 49 & 101 \\
\hline 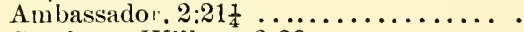 & 1875 & 48 & 8 & 3 & 33 & 81 \\
\hline Ganbetta Wilkes, 2:26. & 1881 & 48 & 11 & 6 & 32 & 80 \\
\hline Baron Wilkes, 2:18..... & 1382 & 47 & 6 & 7 & 18 & 65 . \\
\hline Adrian Wilkes.... & 1878 & 38 & 6 & 7 & 25 & 63. \\
\hline Wilkes Boy, $2: 24 \frac{1}{2} \ldots .$. & 1880 & 37 & 2 & 3 & 8 & 45 \\
\hline Young Jim. & 1874 & 37 & 11 & 19 & 43 & 80 \\
\hline Brown Wilkes, $2: 21$ & 1876 & 32 & 5 & 1 & 39 & 71 \\
\hline 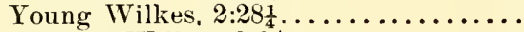 & 1868 & 29 & 6 & 3 & 12 & 41 \\
\hline Favorite Wilkes, $2: 24 \frac{1}{2}$. & 1877 & 23 & 7 & 6 & 21 & 44 \\
\hline Woodford Wilkes.... & 1882 & 23 & 1 & 4 & 12 & 35 \\
\hline Wilkie Collins........ & 1876 & 21 & 5 & 1 & 10 & 31 \\
\hline Lumps, $2: 21 \ldots$ & 1875 & 20 & 3 & 10 & 16 & 36 \\
\hline 'The King, 2:291. . & 1874 & 20 & $\cdots$ & .. & . & 20 \\
\hline Jersey Wilkes...... & 1881 & 20 & . & 2 & 2 & 22 \\
\hline
\end{tabular}

Among the other seventy-one producing sons of George Wilkes: that do not come within the scope of this table are many most. promising sires of rapidly growing prominence, and indeed this. family is branching out wonderfully in every direction. This family is an emphatically improving one. In extreme speed, in racing capacity, and in form the third Wilkes generation is better than either the second or first. Of trotters, such as Beuzetta,

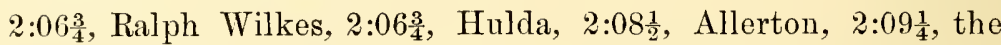
once sensational Axtell, 2:12, and many others of the first rank by sons of George Wilkes sustain this judgment. The pacing. instinct is rampant in the Wilkes blood, as is attested by the fact. that twenty-five per cent. of the performing get of George Wilkes" 


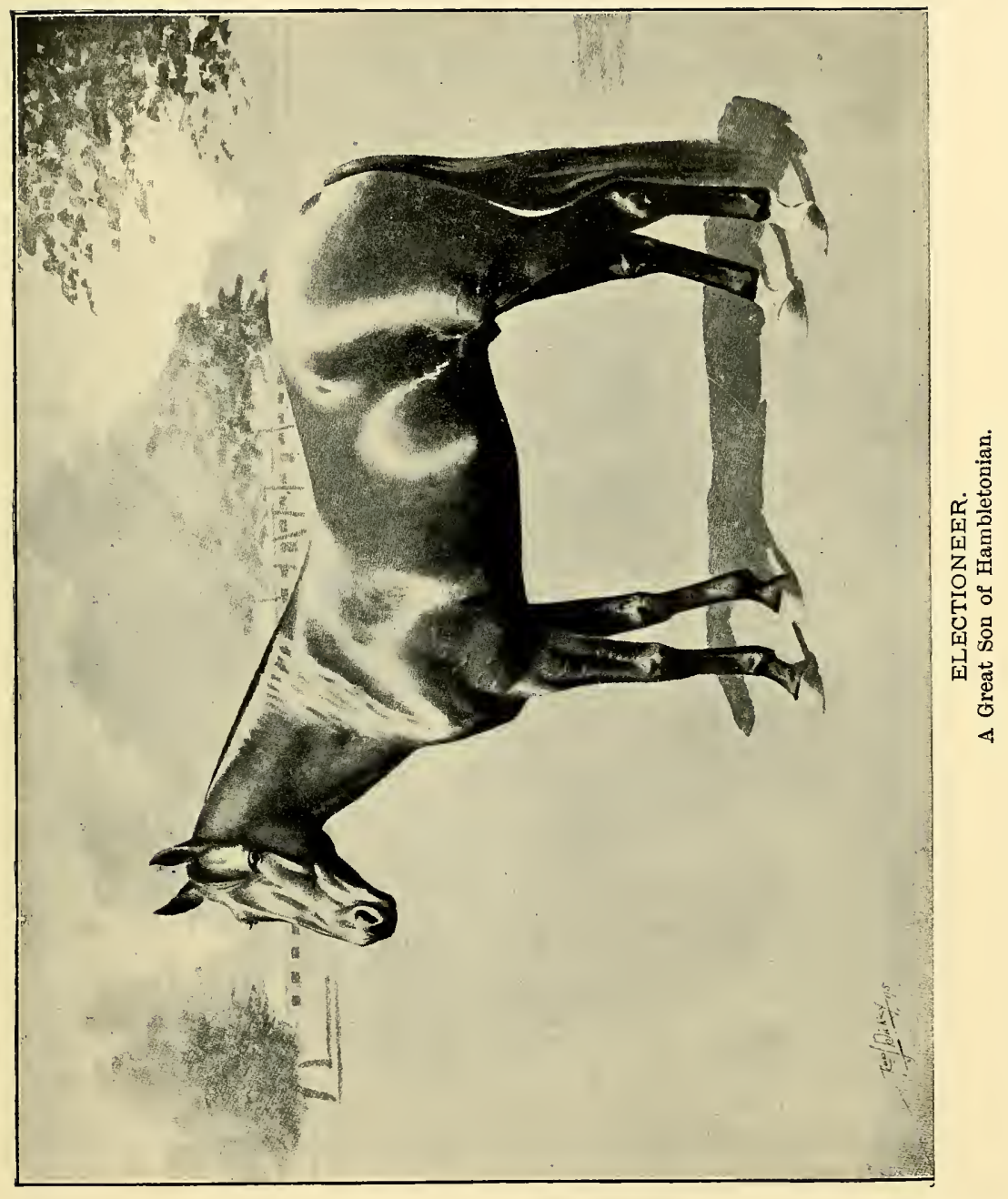



sons are pacers, and frequently pacers of extreme speed, including such as Joe Patchen, 2:03, and Rubenstein, 2:05, while Joln

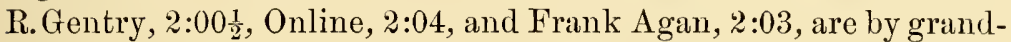
sons of Wilkes. Like his sire, George Wilkes got many sons greater than himself-and after all that is the true test of greatness in a progenitor.

Electioneer has for some years led, far and away, all sires of trotters in the numbers of performers to his credit in both the 2:20 list and 2:30 list, and is generally conceded to have had no equal as a prodncer of early speed-that is, of colts and fillies that trotted fast at tender ages. In many respects this was the most remarkable horse of any age, for besides being phenomenally prolifie in transmitting speed at the trot, and in getting early trotters, he possessed in a higher degree than any sire that has yet lived the ability to control running blood in the dam, and to impress his own instinct and action upon his progeny out of any and all kinds of mares. In speaking on his pet hobby of produeing trotters from thoroughbred running mares, Governor Stanford once said to me: "None of my stallions but Electioneer ean do it;" and of all the hundreds of stallions that hare been mated with thoroughbred mares in the hope of getting a trotter of extreme. speed, Electioneer alone was able to do it. Palo Alto, $2: 08 \frac{1}{4}$, is so far faster than any other trotting horse out of a thoroughbred dam-the one solitary instance on record of a half-bred trotter of extreme speed-that he is significant in one way, and one only, and that is as an evidence of the phenomenal prepoteney of the blood of his sire in controlling instinct and aetion.

Electioneer was a dark bay horse, foaled May 2, 1868, bred by Charles Backman, at his Stonyford Stud, Orange County, New York. He was got by Hambletonian, out of Green Mountain Maid, by Harry Clay, 2:29, grandam the fast trotting mare Shanghai Mary, pedigree not established, but in all probability a daughter of Iron's Cadmus, the sire of the famons old paeer and brood mare Pocahontas, 2:17 $\frac{1}{2}$. (In Chapter XXIX., on the investigation of pedigrees, the history of Shanghai Mary is fully given.) Green Mountain Maid, the dam of Electioneer, has been ealled by $\mathrm{Mr}$. Backman, and with justice, "the great mother of trotters." In all she bore sixteen foals, fourteen of which were by the not remarkable horse Messenger Duroe. Eleetioneer was her second foal and the only one by Hambletonian. Of the other fifteen, nine have records of 2:30 and better, another has a record 
of 2:31, another, Paul, was a very fast road horse, and two died young. Of her four sons kept entire, Electioneer, Mansfield, Antonio, and Lancelot, all are sires of trotters, and her daughters already figure as producers. The figures would seem to point to the daughter of Shanghai Mary and Harry Clay, 2:29, as perhaps the most wonderful of all great trotting brood mares. She was a brown mare, barely fifteen hands high, with a star and white hind ankles, and was finely formed, with an exceptionally beautifully ontlined and expressive head. She had very superior trotting action, the trot being her fastest natural gait. A writer who made a very close study of her history said, on this point, in Wallace's Monthly:

“ Her education was limited to a single lesson when three years old; but previously she had been regularly developed on somewhat the same plan since adopted for early training at Palo Alto, and was probably one of the fastest trotters out of harness that ever lived."

As a matter of fact Green Mountain Maid, while in no sense vicions, was so highly strung, wild and uncontrollable, that her training was abandoned with the "one lesson" referred to, and she never wore harness again.

Green Mountain Maid was a money producer as well as a speed producer. Mr. Backman paid four hundred and fifty dollars for her when she was carrying her first foal, and the writer above quoted states that up to that date (1889) Mr. Backman had received sixty-eight thousand eight hundred and thirty dollars for such of her progeny as he had then sold. This remarkable mare died Jnme 6, 1888, and a fitting monument marks her grave by the banks of the Walkill.

At maturity Electioneer was of that shade of bay that many might call brown, and stood precisely fifteen and one-half hands at the wither and an inch higher measured at the quarter. Many of his get, notably Sunol, are pronouncedly higher behind than at the wither. In general conformation, Electioneer was a stout and muscular horse, standing on fairly short legs. His head was well proportioned, of fair size, and a model of intelligent beanty. The forehead was broad and brainy, the eyes large and softly expressive, and the profile regular, with just the faintest suggestion of concavity beneath the line of the eyes. Electioneer's neck was a trifle too short for elegance of proportion, but not gross. His shoulder was good, the barrel round, of good 
depth and proportionate in length and well ribbed, and the coupling simply faultless. The quarters were marvelous, and Mr. Marvin did not overstate the case when he said they were the best he had ever seen on any stallion. They were the very incarnation of driving power, and recalled Herbert Kittredge's portrait of Hambletonian, except that there was nothing gross or meaty about the buttocks of Electioneer. They were the perfection of muscular endowment and development. The arms and gaskins, like the quarters, were full with muscle laid on muscle, and the legs and feet were naturally excellent. In the last years of his life he went over on his knees a bit, but that was not strange considering his age, and the fact that he had seen considerable track work. Indeed as long as he was at all vigorous he was daily exercised on the track, and in view of his great success in the stud, this fact has a special significance.

As a three-year-old Electioneer was worked some on the Stonyford farm track to wagon, and Mr. Backman, whose word is good enough authority for all who know him, stated that he showed a quarter to wagon in thirty-nine seconds in that year. Little else is known of his history at Stonyford. He was bred to a few, very few mares, and was evidently not greatly esteemed by $\mathrm{Mr}$. Backman. In the autumn of 18\%6, ex-Governor Stanford, who was just establishing his great breeding farm, Palo Alto, in the Santa Clara Valley, California, visited Stonyford to purchase stock-principally brood mares. The governor was a great believer in what I may call horse-physiognomy, or to be more exact, he believed in the importance of the right psychical organization, what we commonly call brain force, in horses, and was attracted by the physical evidences thereof as indicated in the head. Electioneer pleased him in this regard, and in his general make-up, and-when the goveruor's purchase was completed Electioneer went along, being put in at twelve thousand five hundred dollars. He with the other Stonyford purchases arrived at Palo Alto Christmas Eve, 1876.

Though Electioneer never took a record, he was emphatically a developed horse. I do not know whether he was ever driven a full mile or not-Mr. Marvin never drove him one-but it has been stated that one of the other trainers drove him a mile in time somewhere between $2: 20$ and 2:25. However they may be, Mr. Marvin in his book settles the question as to his having been a fast, trained trotter. He says: 
“ Electioneer is the most natural trotter I have ever seen. He has free, aioundant action; it is a perfect rolling action both in front and behind, and he has not the usual fault of the Hambletonians of going too wide behind. Certain writers have said that Electioneer could not trot, and have cited him as a stallion that was not a trotter yet got trotters. . . . I have driven, beside Electioneer, a quarter in thirty-fiveseconds. . . . He did this, too, hitched to a one hundred and twenty-five-pound wagon, with a two hundred and twentypound man, and not a professional driver, either, in the seat. In this rig lie could carry Occident right up to his clip, and could always keep right with hiıl; and it was no trick for the famous St. Clair gelding to go a quarter in thirty-four seconds. Without preparation you could take Electioneer out any day and drive him an eighth of a mile at a $2: 20$ gait. He always had his speed with him. . . . That Electioneer could have beaten $2: 20$ if given a regular preparation is with me a conviction about which no donbt exists."

Mr. Marvin is a conservative and reliable man; he knew whereof he wrote, and his testimony must be accepted as conclusive both as to Electioneer's having been a naturally fast trotter, and as to his having had his speed developed. Undeveloped horses do not trot quarters in thirty-five seconds.

When in 1880 Fred Crocker, one of the seven foals got by Electioneer in his first year's service in California, astonisherl the world by trotting to a two-year-old record of $2: 25 \frac{3}{4}$, his sire became instantly famous, and that fame has increased rapidly and steadily from that day to this. It was not allowed for a moment to wane or lag. After Fred Crocker came an ever-surprising procession of young record breakers. In 1881 Hinda Rose made a yearling record of $2: 36 \frac{1}{2}$, and Wildflower a two-year-old record of $2: 21$. In 1883 Hinda Rose lowered the three-year-old record to $2: 19 \frac{1}{2}$, and Bonita the four-year-old record to $2: 18 \frac{3}{4}$. In 1886 Manzanita lowered the four-year-old record to 2:16; in 1887 Norlaine, granddaughter of Electioneer, lowered the yearling record to 2:31 $\frac{1}{2}$; and in 1888 Sunol put the two-year-old record at 2:18, and the year following took a three-year-old record of $2: 10 \frac{1}{2}$, the fastest to that date. Sunol captured the four-year-old record in 1889, and the world's record, $2: 08 \frac{1}{4}$, in 1891, but what made this the brightest year in all the history of Palo Alto was that Arion lowered the two-year-old record to $2: 10 \frac{3}{4}$ - the most remarkable of all trotting performances-Bell Bird the yearling record to $2: 26 \frac{1}{4}$, and Palo Alto the stallion record to 2:083. Electioneer has now to his credit one hundred and fifty-four standard performers, and in this and in the $2: 20$ list he has a long lead over all other sires. He died at Palo Alto, December 
3, 1890, and I am informed that his skeleton has been articulated and mounted for the musenm of the Stanford University. The following table gives the sons of Electioneer that up to the close of 1896 had ten or more standard performers to their credit:

LEADING SONS OF ELECTIONEER.

\begin{tabular}{|c|c|c|c|c|c|c|}
\hline Name. & 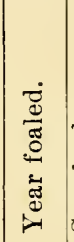 & 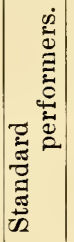 & 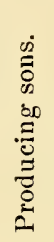 & 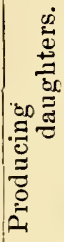 & 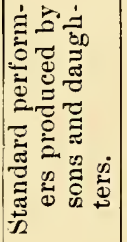 & 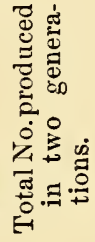 \\
\hline Saint Bell, 2:241 & 1882 & 47 & 1 & & 1 & 48 \\
\hline Sphinx, 2:201.. & 1883 & 43 & & & & 43 \\
\hline Chines, 2:30 & 1884 & 32 & 3 & & 3 & 35 \\
\hline Anteeo, $2: 16 \frac{1}{4}$. & 1879 & 28 & 5 & 3 & 12 & 40 \\
\hline 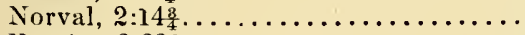 & 1882 & 24 & 1 & & 1 & 25 \\
\hline Egotist, $2: 22 \frac{1}{2}$. & 1885 & 18 & 1 & & 1 & 19 \\
\hline Anteros & 1882 & 16 & $\cdots$ & 2 & 2 & 18 \\
\hline Elector (2170), 2:31 & 1879 & 16 & 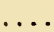 & & & 16 \\
\hline Albert W., 2:20. & 1878 & 15 & 1 & & 1 & 16 \\
\hline Eros, $2: 29 \frac{1}{2}$. & 1879 & 14 & 3 & & 4 & 18 \\
\hline Antevolo, $2: 19 \frac{1}{2}$. . & 1881 & 13 & & 1 & 1 & 14 \\
\hline$*$ Bell Boy, $2: 19 \frac{1}{4} \ldots$ & 1885 & 11 & 1 & & 1 & 12 \\
\hline Fallis, $2: 23$. . & 1878 & 10 & 1 & . & 3 & 13 \\
\hline Palo Alto, $2: 08 \frac{8}{4}$. & 1882 & 10 & & & & 10 \\
\hline
\end{tabular}

* Died at 5 years old.

In considering this table it is necessary to remember that the Electioneer family dates from 1878, and that no family of anything approaching so late a date makes a snowing that will bear comparison with this. In considering the rank of families this question of age is always vital. Electioneer's first crop of foals at Palo Alto-1878-numbered seven, and of these two are represented above, while another was the famous gelding Fred Crocker. The next numbered but twenty-one, and of these Erns, Elector, and Anteeo are in the table, and ten are in the 2:20 list. His third and fourth crops (1880 and 1881) numbered sixteen and twenty-three respectively, and the forty of 1882 was the greatest number he ever got in one year. I am informed that in all Electioneer got less than four hundred foals at Palo Alto; and that, since the first one saw light in $18 \% 8$ this family should in eighteen years make the showing it has with nearly fifty per cent. of its members in the $2: 30$ list, and four hun- 
dred and ninety-three of the second generation also there, is certainly remarkable. Electioneer has to his credit in the 2:15 list

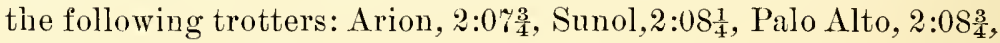

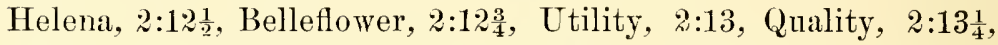
Conductor, $2: 14 \frac{1}{4}$, and Norval, $2: 14 \frac{3}{4}$, an "extreme speed list" greater than to the credit of any other sire, while among the get of his sons are such trotters as Azote, 2:04

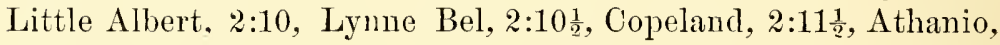
$2: 11_{4}^{\frac{3}{4}}$, Cobwebs, $2: 12$, etc., etc. Sixty-five of his sons have sired four hundred and thirty-seven performers, and forty-three of his dangliters have produced fifty-six performers. With all these facts kept in view the study of the above table will prove interesting and instructive in forming an estimate of the merit of Electioneer as a trotting progenitor.

Alexander's AbDallah was the founder of one of the very greatest of the Hambletonian sub-families, and he stands in the records as a progenitor of the first rank. This was a stout bay horse, about fifteen and one-half hands high. Excepting a right white ankle he was a rich solid bay. The only reliable portrait in existence of tinis horse was a drawing by Herbert Kittredge, made from a photograph taken of Abdallah after he went to Kentucky. The picture of Abdallah published in this work is a faithful reproduction of the Kittredge portrait published in Wallace's Monthly for Niarch, 1881, and in the absence of any reliable detailed description of the horse this portrait must be taken as the best reflection we now have of his individuality. He was bred by Lewis J. Sutton, of Warwick, Orange County, New York, and was foaled 1852. Mr. Sutton had in 1851 a good road mare that he had got at Carl Young's roadhouse in 'Third Avenue, New York. This mare, Katy Darling, had been quite a trotter, and had, it was said, won a match race on Union Course. Her reputation as a trotter and her fine form cansed Mr. Sutton to buy her when, as he describes it, "she was standing on three legs," in the hope of getting a foal from her. He took her home in Narch, 185̃1, and in Angust bred her to Rysdyk's Hambletonian, then a two-year-old colt, and September 22,1852 , she produced the subject of this sketch. Two years later Mr. Sutton sold Katy Darling to James W. Benedict, of Warwick, from whom she was purchased by Hezekiah Hoyt, who took her to Muscatine. Iowa, where she produced a chestnut colt that was gelded, by Hector, son of La Tourrett's Bellfounder. 


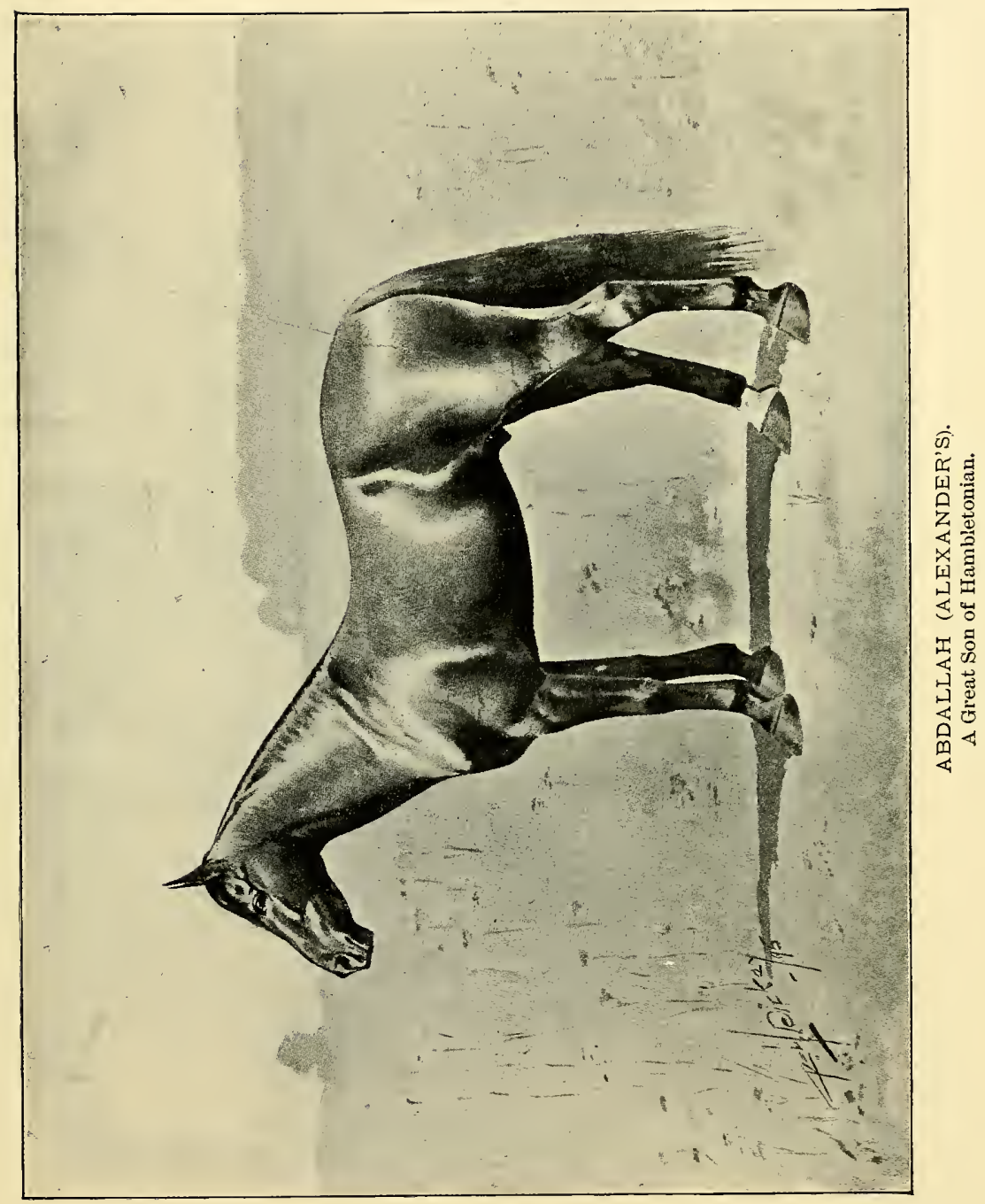



This gelding was her only foal other than Alexander's Abdallah, and Katy Darling died at Muscatine, the property of a $\mathrm{Mr}$. Stewart. A search was long kept up for the pedigree of this mare, and for the full details of what is known of ler history the reader is referred to the different volumes of Wallace's Monthly. 'The conclusion from all the evidence found is that she was probably by a son of Andrew Jackson.

As a foal by his dam's side Alexander's Abdallah attracted much favorable attention by his fine trotting action, and his persistency in cavorting around at that gait. Among those who took great delight in watching the little fellow trot was Mr. Hezekiah Hoyt, and when the youngster was seventeen months old Mr. Hoyt, acting for, or in partnership with, Major Edsall, bought the colt for five hundred dollars, a fine price at that time. Major Edsall kept him until he was seven years old, and I am under the impression that he won some local races during that time, when he was known as Edsall's Hambletonian. He was accorded a fairly liberal patronage in Orange County, and his progeny showed so well that Major Edsail sold him for three thousand dollars in 1859 to Joel F. Love and James Miller, of Cynthiana, Kentucky. The Hambletonian family was just then becoming popular, and the price paid indicates that this horse was already regarded by good judges as one of Hambletonian's best sons. That he was regaried, moreover, as quite a trotter is indicated by the fact that at the close of his second season in Kentucky-1860-Mr. Miller matched him against Albion, a competing stallion, for two hundred and fifty dollars a side. The affair caused quite a sensation at the time, the Cynthiana horsemen going in crowds to Lexington to back Abdallah. The latter was driven by "Jim" Monroe, and Albion by Warren Peabody, and Abdallah won in the hollowest fashion, distancing Albion in $2: 46$. As youngsters Abdallah's first progeny in Kentucky showed very well, and in the spring of 1863 he was purchased by $R$. A. Alexander, and made the seasons of 1863 and 1864 at Woodburn. On the evening of February 2, 1865, Marion's band of Confederate guerrillas raided Voodburn and took away a number of horses, among them Alexander's Abdallah and the then famous young trotter, Bay Chief, by Mambrino Chief. Marion mounted Bay Chief and, crossing the Kentucky River, the band encamped on the farm of a Mr. Bush, in a rough, hilly region, twelve miles from Woodburn. Here the next morning the Federal cavalry, 
that were sent in pursuit after the raid, came up with the raiders, and after a sharp fight routed them. Marion, on Bay Chief, was a conspicuous mark for Federal bullets during the skirmish. Early in the fray Bay Chief was shot through the muzzle, through both thighs, and one hock. In this condition he carried his rider two miles in the retreat, when the horse was so weakened by loss of blood that a Federal cavalryman overtook them. His piece being empty, the soldier aimed a blow at Marion, but missing him, lost his balance, and fell from his horse. The guerrilla leader quickly saw his opportunity, jumped from Bay Ohief, mounted the soldier's horse, and escaped. Bay Chief died about ten days later, despite all efforts made to save him. Meanwhile, Alexander's Abdallah had been found, safe and sound, by a Federal soldier in Mr. Bush's stable. The soldier refused to give him up to Mr. Alexander's men, and declared he would send him North and keep him until he got a large reward for his return. The horse was barefooted and in no condition for hard usage. And so they rode him off, and after going some forty or fifty miles he gave out, and they turned him loose on the road. He was found next day in a pitiable condition by the roadside, and brought back as far as Lawrenceburg on his way home, where he was taken with pneumonia and died a few days later.

Just how great a loss this was to the trotting breed was not realized until long after-until in fact Goldsmith Maid had conquered all before her, and made a record as a campaigner never equaled, and until his two great sons, Almont and Belmont, rose to pre-eminent places in the list of great sires. Other sons of this remarkable progenitor have taken rank as sires, and his danghters proved of the highest excellence as brood mares; but Almont and Belmont have each established such large, important, and popular sub-families that this work would be incomplete without some brief sketch of each.

Alexander's Abdallah got Goldsmith Maid, 2:14, Rosalind, $2: 21 \frac{2}{3}$, Thorndale, 2:221, Major Edsall, 2:29, and St. Elmo, 2:30. Fourteen of his sons have produced one hundred and fifty-fire standard performers, and twenty-nine of his danghters have produced forty-four standard performers, among them being the noted campaigners, Favonia, 2:15, and Jerome Eddy, 2:16:2 the latter also a snccessful sire. The following table gives the families of his most prominent sons: 
LEADING SONS OF ALEXANDER'S ABDALLAII.

\begin{tabular}{|c|c|c|c|c|c|c|c|}
\hline Name. & 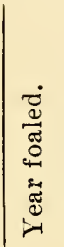 & 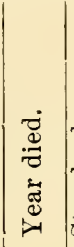 & 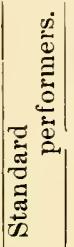 & 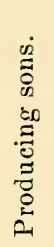 & 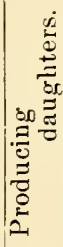 & 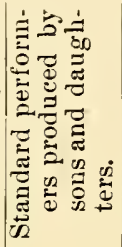 & 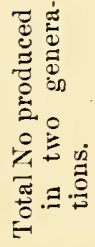 \\
\hline Almont, 2:39분. & 1864 & 1884 & 37 & 95 & 72 & 609 & 646 \\
\hline Belmont. & 1864 & 1889 & 58 & 63 & 48 & 560 & 618 \\
\hline Hambletonian (Wood's) & 1858 & 1885 & 24 & 12 & 13 & 49 & 73 \\
\hline Major Edsall, 2:29 & 1859 & 1886 & 3 & 6 & 3 & 87 & 90 \\
\hline Thorndale, $2: 22 \frac{1}{4}$. & 1865 & 1894 & 10 & 8 & 14 & 47 & 57 \\
\hline Jim Munro....... & 1861 & 1882 & 8 & 5 & 17 & 38 & 46 \\
\hline Abdallah Pilot. & & 1881 & 3 & 1 & 1 & 17 & 20 \\
\hline
\end{tabular}

Almont was bred at Woodburn Farm, was foaled 1864, and was by Alexander's Abdallah out of Sally Anderson, by Mambrino Chief; grandam Kate, a wonderfully fast pacer by Pilot Jr. Colonel R. P. Pepper informed me that he knew Kate as well as any of his own horses, and that her speed at the pace was "simply terrific." Kate, whose dam was called the Pope mare, pedigree unknown, had several foals, among them the "catch filly" that was the dam of Clay Pilot, sire of The Moor, that got the great brood mare Beautiful Bells, $2: 29 \frac{1}{2}$, and Sultan, $2: 24$, the sire

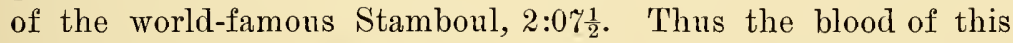
pacing Pilot Jr. mare figures in three great sub-families, the Almont family, the Beautiful Bells family, and the Sultan family. Almont was a beantiful cherry bay, very rich in shade, and without any white whatever. He was fifteen hands two and onequarter inches high at the wither, somewhat higher behind, and stoutly and symmetrically made all over. He could not be called a handsome or highly finished horse, but he was emphatically a well-made one. He had very excellent feet and legs, and these he reproduced with great uniformity, as well as his very intelligent and even disposition. He was trained early at Woodburn, and, like his sire, started but once and distanced his competitor in $2: 39 \frac{3}{4}$, this being in his four-year-old form. He soon after showed 2:32 over the slow Woodburn track, and was sold to the late Colonel Richard West for eight thousand dollars and put in the stud. In 1874 the late General W. T. Withers, Lexington, Kentucky, bought him for fifteen thousand dollars, and a half 
dozen of years later he was very generally regarded as the greatest of living sires, and his prestige made the name of Fairlawn Farm of world-wide renown, and made his owner rich. The fact that ninety-five of his sons have sired standard performers, a greater number of producing sons than is to the credit of any other horse, Hambletonian alone excepted, indicates the high rank Almont must be accorded as a progenitor. In considering his success it is well for breeders particularly to note that good judges considered Almont capable of showing a 2:20 gait any day, and that, like Electioneer, he always was daily given regular and ample track exercise. His gait has been described as bold and open, without an excess of knee action, but with immense display of power behind. Almont died of spasmodic colic, July 4, 1884 , in the fullness of his fame, and at an age when, had he been more discreetly used in the stud, he should have been at his prime as a stock horse.

Almont was hardly a sensational horse in his day, the performance of Westmont at Chicago in 1884, when he paced a mile with running mate in $2: 01 \frac{3}{4}$, being the one sensational performance to the eredit of his progeny. 'This lightning streak of pacing speed that so often crops out in the Almont family can be readily accounted for by the student of breeding. As has been noted, his grandam Kate, by Pilot Jr., was a phenomenally fast pacer, and, as we have indicated, her blood proved potent in more than one line. In addition to this there was a strong tendency to pace among the progeny of Alexander's Abdallah. St. Elmo was first shown at fairs in Kentucky under saddle and as a pacer, and many others of Abdallah's get were known to naturally pace. When we reflect that in Almont this Alexander's Abdallah blood with its pacing predilection was united with the blood of the old lightning pacer, Kate, we need not be surprised at the great number of fast pacers that came from Almont and his sons. Belmont, too, has shown a tendency to get the pacing gait with great frequency, but not in such frequency or at such high rates as his son Nutwood. As there could not be traced any known pacing blood in Belmont's dam, and as the fact that Alexander's Abdallah transmitted an inclination to pace has been generally not known or ignored, some writers have been unable to understand why the Belmonts paced. He got pacers because he inherited that capacity from his sire, and Nutwood got more and faster pacers than Belmont, because in him the pacing inclina- 
tion inherited from Alexander's Abdallah was reinforced by the strong pacing inheritance of his dam, Miss Russell, the granddanghter of Old Pacing Pilot.

As shown in the table of Alexander's Abdallah's sons, Almont got thirty-seven standard performers, ninety-five of his sons sired five hundred and three standard performers, and seventy-two of his daughters produced one hundred and six standard performers. His most successful sons are embraced in the following table:

LEADING SONS OF ALMONT.

\begin{tabular}{|c|c|c|c|c|c|c|}
\hline Name. & 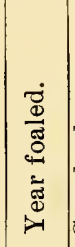 & 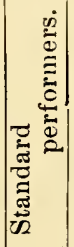 & 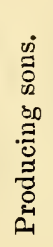 & 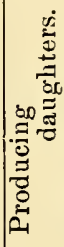 & 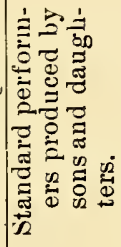 & 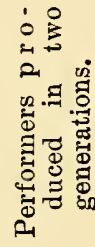 \\
\hline Almont Jr. (1829), 2:26. & 1872 & 44 & 7 & 20 & 39 & 83 \\
\hline Altamont, 2:268 & 1875 & 39 & 7 & 1 & 10 & 49 \\
\hline Atlantic, $2: 21$. & 1878 & 24 & 6 & 12 & 22 & 46 \\
\hline 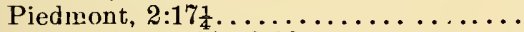 & 1871 & 19 & 3 & 8 & 18 & 37 \\
\hline Almont Jr. (1764), 2:29... & 1871 & 19 & 11 & 11 & 51 & 70 \\
\hline King Almont, $2: 21 \frac{1}{4} \ldots$ & 1874 & 14 & & 1 & 1 & 15 \\
\hline Pasacas, $2: 43$. . & 1870 & 14 & 4 & 6 & 13 & 27 \\
\hline Almonarch, $2: 24 \frac{8}{4} \ldots$ & 1875 & 13 & 2 & 3 & 7 & 20 \\
\hline Allie Gaines..... & 1875 & 12 & 5 & 8 & 17 & 29 \\
\hline Harbinger. . & 1879 & 10 & 1 & 2 & 3 & 13 \\
\hline *Allie West, 2:25. & 1870 & 7 & 4 & 10 & 24 & 31 \\
\hline Abdallah Mambrino & 1870 & 13 & 1 & 11 & 24 & 37 \\
\hline
\end{tabular}

* Died at 6 years old.

This line is justly regarded with growing favor as one of our very best and most productive sub-families, and one that is breeding on excellently, generation after generation.

BELMONT was a bay horse of very superior form and finish, bred at Woodburn Farm, and foaled there in 1864. He was by Alexander's Abdallah, out of Belle (that also produced McCurdy's

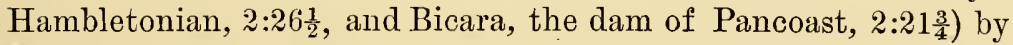
Mambrino Chief; grandam Belle Lupe, by Brown's Bellfounder. Belmont and Almont were of the same age, and, perhaps becanse of his finer appearance, Belmont seems to have been the preferred one at Woodburn, and was retained while Almont was sold. Though Belmont was a successful horse and established a great 
family, no thinking man can contend that he was the equal of Almont as a sire, when all the cireumstances are considered. Almont spent almost his entire stud career at Fairlawn, where there never were five mares worthy in blood to be in a great trotting stud, where there were scores of mares of all kinds of poor and freakish pedigrees, even to "Arabs," and where none of the stock was ever trained. Belmont, on the other hand, was all his life at the head of the most famous, and, in his younger years, unquestionably the best collection of trotting brood mares in the world, and where a training department was always maintained. Remembering these conditions, and contemplating the statistics of the two families, it is interesting to speculate as to how the records would stand had Belmont been at Fairlawn, and Almont at Woodburn.

LEADING SONS OF BELMONT.

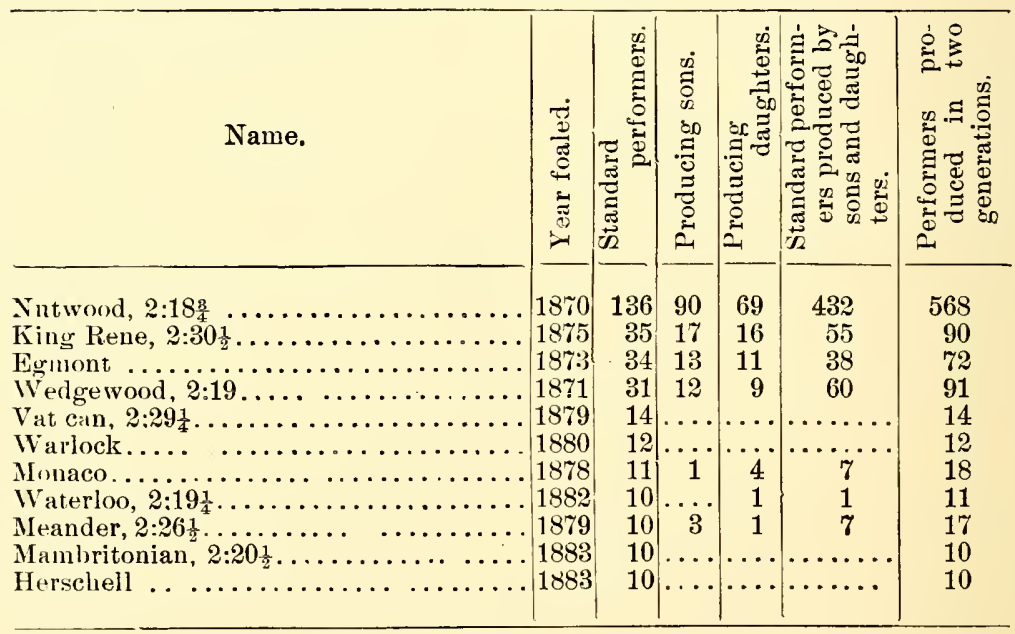

Belmont, besides having the advantage of excellent individuality was also a trotter of no mean speed. He was driven a mile over the working track at Woodburn in $2: 28 \frac{1}{2}$, and was, therefore, a quite well-developed trotter. He never appeared in public, and has, therefore, no public history. The most success. ful of his sons has been Nutwood, whose dam was Miss Russeli. the dam of Maud S. This horse was himself a fast trotter in his day, taking a record of $2: 18 \frac{3}{4}$, and rose to great popularity and success in the stud. Danghters of Belmont, being nearly all out 
of producing mares, are greatly and justly esteemed as brood mares. Belmont died at Woodburn November 15, 1889. Belmont got fifty-eight standard performers, sixty-three of his sons sired four hundred and eighty-nine standard performers, and forty-eight of his daughters produced seventy-one standard performers. The rank of his best sons is shown on the precerling page; all having ten or more in the list of standard performers being included in the table.

VOLUNTEER stands pre-eminent among trotting sires as the one horse against not one of whose get the epithet "quitter" was, as far as I am aware, ever hurled. He did not get speed with remarkable uniformity, nor did his progeny develop speed early or rapidly. They required persistent training, but when speed was developed in a Volunteer you had with it every other quality of a resolute, enduring race horse. They were hardy, rugged, good-limbed horses, and uniformly possessed stamina and resolution in the highest degree. Volunteer had the advantage of being owned by Álden Goldsmith, an ambitions and experienced horseman, and the father of two of the most successful trainers of our day. The Volunteers had, therefore, every advantage that training conld give, and his rise to fame was largely due to Mr. Goldsmith's constantly developing and racing his progeny.

In $1853 \mathrm{Mr}$. Joseph Hetzel, Florida, Orange Connty, New York, bred the bay mare Lady Patriot to Hambletonian, 10, and Volunterr was foaled May 1, 1854. This mare, Lady Patriot, was by a horse called Young Patriot; and out of Mr. Lewis Hulse's trotting mare, and that is all that is known of her pedigree. Her sire's pedigree is wholly unknown. She produced a numerous family, among them being Sentinel, 2:293, and Green's Hambletonian, brothers of Volunteer, and of some rank as sires, and Marksman, by Thorndale, that is also in the table of sires, while her danghter Heroine, sister to Volnnteer, produced Shawmut, 2:26.

Volunteer was a bay horse, with a little white around the left hind coronet, fifteen hands three inches at the wither, and sixteen hands measured at the coupling. He has been considered by many good judges to have been the handsomest of all the sons of Hambletonian. He was a horse of superb form and of great elegance of carriage. With sufficient of muscle and substance, he was built on graceful, finished lines, with a beautiful head 
loftily carried, a long and graceful neck, a body stout but finely molded, and all set off by a handsome mane and tail. His feet and legs were of superb quality, and despite his great age they were, it is said, without fault or blemish to the last. His temper and disposition were good, though he was very high-spirited, and in harness he was especially attractive. As a four-year-old Volunteer was sold to Mr. R. C. Underhill, of Brooklyn, after he had won a premium at the Orange County fair. In April, 1861, Mr. Underhill sent him to Tim T. Jackson, of Jamaica, Long Island, and in Wallace's Monthly for December, 1880, Mr. Jackson gave his experiences with Volunteer, making among others this specific statement:

"I had him at Union Course one day, and met Mr. Alfred M. Tredwell there, and I got him to hold that watch on him. Had him in quite a heavy single-seated wagon, weighing probably one liundred and twenty-five or one hundred and thirty pounds. On the first trial he trotted in 2:33. I said to Mr. Tredwell that he could beat that, and he trotted the next mile in $2: 31 \frac{1}{4}$."

He had previously been trained by William Whelan, at Union Course. It was June 26, 1862, while he was in Jackson's hands, that Alden Goldsmith, in partnership with Edwin Thorne, purchased this horse, then called Hambletonian Jr., and he soon afterward became the sole property of Mr. Goldsmith. Mr. Rysdyk greatly resented his having been called Hambletonian $\mathrm{Jr}_{\mathrm{r}}$, and early regarded him as a possibie rival of Hambletonian, and there was war from the start between the adherents of sire and son. The Civil War was just then at its height, and the patriotic and military spirit rampant, and $\mathrm{Mr}$. Goldsmith aptly named his horse Volunteer. Mr. H. T. Helm, who wrote a very detailed history of Volunteer twenty years ago, credits him with having trotted in 2:36 to wagon at the Goshen Fair in the fall of 1862, beating Winfield, Grey Confidence and others. At Hartford, Connecticnt, in August, 186\%, he beat George M. Patchen Jr., in a single dash in 2:3\% He was, like nearly all the other great sires, a developed trotter.

It is said that his early stud opportunities were so limited that at ten years old he had but eighteen living foals. The first of his get entered the $2: 30$ list in $18 \% 1$, but from that time on his list rapidly grew, and the great campaigners Gloster, Alley, Driver, Bodine, Huntress, the great three-miler, and finally St. Julien, $2: 11_{4}^{1}$, then the fastest trotter in the world, so spread the 
fame of Volunteer that when his sire died in 1876 he was regarded as the greatest living sire of trotters. In 1882 Mr. R. S. Veech, probably the most intelligent breeder in all Kentucky, while on a visit to New York, telegraphed Mr. Goldsmith to know whether it was worth while for him to visit Walnut Grove, with a view to buying Volunteer, and Mr. Goldsmith's answer reveals the regard in which he held his horse. The pith of his admirably written letter was in this paragraph:

"While there is no person that would be more welcome at the farm than yourself, if the only object of your visit would be the purchase of Volunteer, then your trip would not be a profitable or successful one, as no breeder in Kentucky has money enough to buy him. . . . I have as high a regard for money as the most of men for the uses it may subserve, but there are certain things which money cannot buy, as the Teacher of old taught Simon the Samaritan."

And so Volunteer remained at Walnut Grove, and "lagged superfluous on the stage" long after his owner had passed away, and died December 13, 1888, at the extraordinary age of thirtyfour years, seven months and twelve days.

Volunteer sired thirty-four standard performers, and forty of his sons and forty-eight of his daughters produced an aggregate of two hundred and twenty-one standard performers. The most successful of his sons is the Michigan sire, Louis Napoleon, that was ont of the Harry Clay mare, Hattie Wood, dam also of Victor Bismarck and Gazelle, 2:21. Louis Napoleon has twenty-seven in the standard list, and fourteen of his sons and twenty-two of his daughters are producers, his best son being Jerome Eddy,

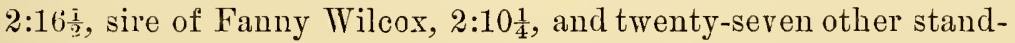
ard performers.

DICTATOR very early in his career attracted attention as the full brother to the famous Dexter, who was his senior by five years, and who was king of the trotting turf, and the most famous trotter in all the world just at the time when Dictator was merging from colthood to maturity. Dictator had thus from the very start the advantage of splendid stud opportunities. He was bred by Jonathan Hawkins, of Walden, Orange County, New York, and was foaled in 1863. He was got by Hambletonian out

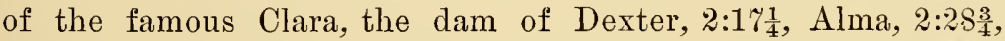
Astoria, 2:291 Kinstry mare, breeding unknown, but that produced Shark with 
a saddle record of 2:273. Dictator was a seal-brown horse with a white rear ankle, and stood scant fifteen hands and one inch. He was made on a small but a fine model, and was, all in all, a handsome little horse, and most of his get partook of his fine quality of structure, though many were unsound. Shortly after Dexter made his début on the turf, Dictator was bought by Mr. Harrison Durkee, a wealthy New York gentleman who had an extensive stock farm at Flushing, Long Island. The colt was then but eleven months old and was left at the Hawkins farm until two years old. Then he was sent to Mr. Alden Goldsmith's place, at Washingtonville, to be broken, after which he was taken to Mr. Durkee's farm. The colt was very fast, but the fame of Dexter was already wide, and, no great importance being attached to development of stallions in that day, he was considered of more value for breeding than for racing. He was worked considerably at Mr. Durkee's farm, and Colonel John W. Conley and H. C. Woodnut, who at different times had charge of him, have both declared that they knew him to be one of the fastest trotters of his day. In 1874 Colonel Richard West sold Almont to General Withers, and to fill his place leased Dictator in the autumn of $18 \% 5$, and he made the seasons of 1876 and $187 \%$ at Colonel West's Edgehill farm, Georgetown, Kentucky. Standing at a higher fee than Almont or George Wilkes, he attracted little outside patronage, and he was returned to Long Island. It has been stated that when at Colonel West's, George Brasfield drove Dictator quarters as fast as thirty-four and one-half seconds. After his return to Flushing he sank from public notice until the appearance of Director as a great three-year-old in 1880. Then a couple of years later came the phenomenal Jay-Eye-See, and close after him Phallas, and with these three great trotters on the turf at once "the sire of Jay-Eye-See, $2: 10$,

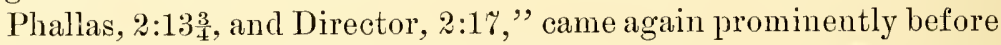
the public. In 1883 he was purchased by Major H. C. McDowell, and Messrs. David Bonner and A. A. Bonner, for a price that was said to have been twenty-five thousand dollars, and taken to Ashland farm at Lexington. Eventually he became the sole property of Major McDowell, and died May 25, 1893.

Dictator did not get speed uniformly. He was what might be called a sporadic sire, but those of his get that raced at all raced well. By far his best son as a producer is Director, 2:17, that was out of Dolly by Mambrino Chief, and is the sire of sixteen 
trotters and pacers with records in the 2:20 list, including the champion trotting, stallion Directum, 2:05 $\frac{1}{4}$, and the one-time champion pacing stallion, Direct, who after being practically crippled in trotting to a fonr-year-old record of $2: 18 \frac{1}{4}$, carrying groat weights to keep him at that gait, was allowed to go at his natural gait and paced in $2: 05 \frac{1}{2}$, and is already a very successful sire. Phallas, $2: 13 \frac{3}{4}$, of whom high hopes were entertained, and who had great opportunities, proved practically a failure in the stud, though his son Phallamont, out of an Almont mare, ranks with Direct as the best of Dictator's grandsons. Dictator got fifty standard performers, forty-four of his sons have produced one hundred and seventy-three standard performers, and forty-two of his danghters have produced sixty-one standard performers.

HARoLD became very famous when Maud $\mathrm{S}$. became queen of the turf with the then marvelous record of $2: 08 \frac{3}{4}$, a record that stood unequaled from 1885 till 1891. This horse was bred by Charles S. Dole, Crystal Lake, Illinois, by whom he was sold, in an exchange of horses, to Woodburn Farm, when he was a yearling. He was foaled in 1864, and his dam was Enchantress (the dam also of Black Maria and of Lakeland Abdallah), by Abdallah. It was long claimed that this mare's dam was a daughter of imported Bellfounder, but investigation exploded this claim. Harold was a bay horse, without marks, just fifteen hands high, stoutly made but very homely of form. He had a finely made head, but otherwise he was exceedingly plain, and when Maud S. came out the late Benjamin Bruce, in the Kentucky Live Stock Record, expressed wonder that "that little bench-legged stud" could have gotten such a mare. Harold's full brother, Lakeland Abdallah, was far superior to him individually, but ranks with Hetzel's Hambletonian, the brother to Volunteer, and Kear'sarge, by Volunteer out of Dexter's dams, in the fore front of the well-bred failures in trotting history. Largely from his individuality Harold was never, even when Maud S. was in the heyday of her renown, a popular horse, and the figures given by the Woodburn management say that in his entire career he was bred to but five hundred and ninety-four mares, or an average of about twenty-five for each of his twentythree seasons. With the exception of Mand S., Harold got nothing of the first class, but in the second generation the family holds better rank in respect to extreme speed production. Ben. zetta, 2:06 $\frac{3}{4}$, Early Bird, 2:10, The Conqueror, 2:13, and the great 
three-year-old Impetuous, 2:13, are out of daughters of Harold,

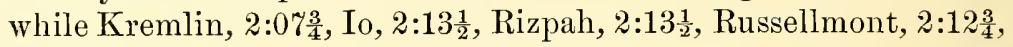
and the great pacer Robert J., $2: 01 \frac{1}{2}$, are among the produce of

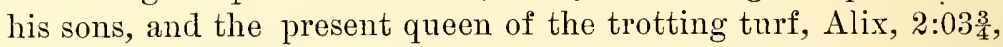
is out of a daughter of Attorney, by Harold. Harold died at Woodburn, October 6, 1893. This horse never trotted in public, but he was worked some for speed at Woodburn. As a six-yearold he is said to have trotted the farm track in $2: 40 \frac{1}{2}$, in which mile it is stated he "grabbed a quarter" and was not worked again. He is the sire of forty-four standard performers, fortythree of his sons have produced one hundred and eighty-one standard performers, and forty-five of his daughters have produced sixty-seven standard performers.

Happy Medium was bred by R. F. Galloway, of Sufferen, New York, and was foaled 1863. He was by Hambletonian, out of the famous old campaigner Princess, 2:30, that trotted ten miles

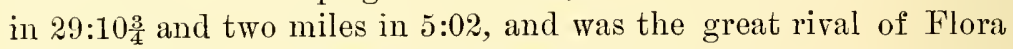
'Temple, 2:193. . Princess was a bay mare, foaled 1846, by Andrus' Hambletonian, son of Judson's Hambletonian, that was by Bishop's Hambletonian, son of imported Messenger; and her dam was the Wilcox mare, by Burdick's Engineer, son of Engineer, by imported Messenger. She campaigned from ocean to ocean, and her career is perhaps the most remarkable of the earlier trotting days. When young she was mixed gaited, alternately pacing and trotting, and was put to work hauling logs. Then her owner traded her for a second-hand wagon, and finally she reached the hands of D. M. Gage, of Chicago. He put her into training, and she trotted some indifferent races as Topsy, was sold, and taken across the plains to California. Here in 1858 she beat New York, taking her record of 2:30. Then she fell into the hands of the notorious "Jim" Eoff, and the next year was matched against the then crack trotter of California, Glencoe Chief, at ten miles to wagon. These were golden days on the coast, and this race was for the enormous stake of thirty-six thou-

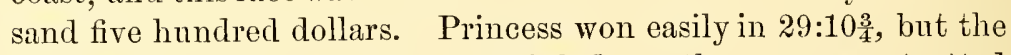
Glencoe Chief party being dissatisfied, another race was trotted the next day at the same distance for five thousand dollars, Princess again winning. 'There was after this nothing on the coast to race with Princess, and Eoff brought her to New York to try conclusions with Flora Temple. Her first race with Flori was at three-mile heats at Eclipse Course, Long Island, Flora 


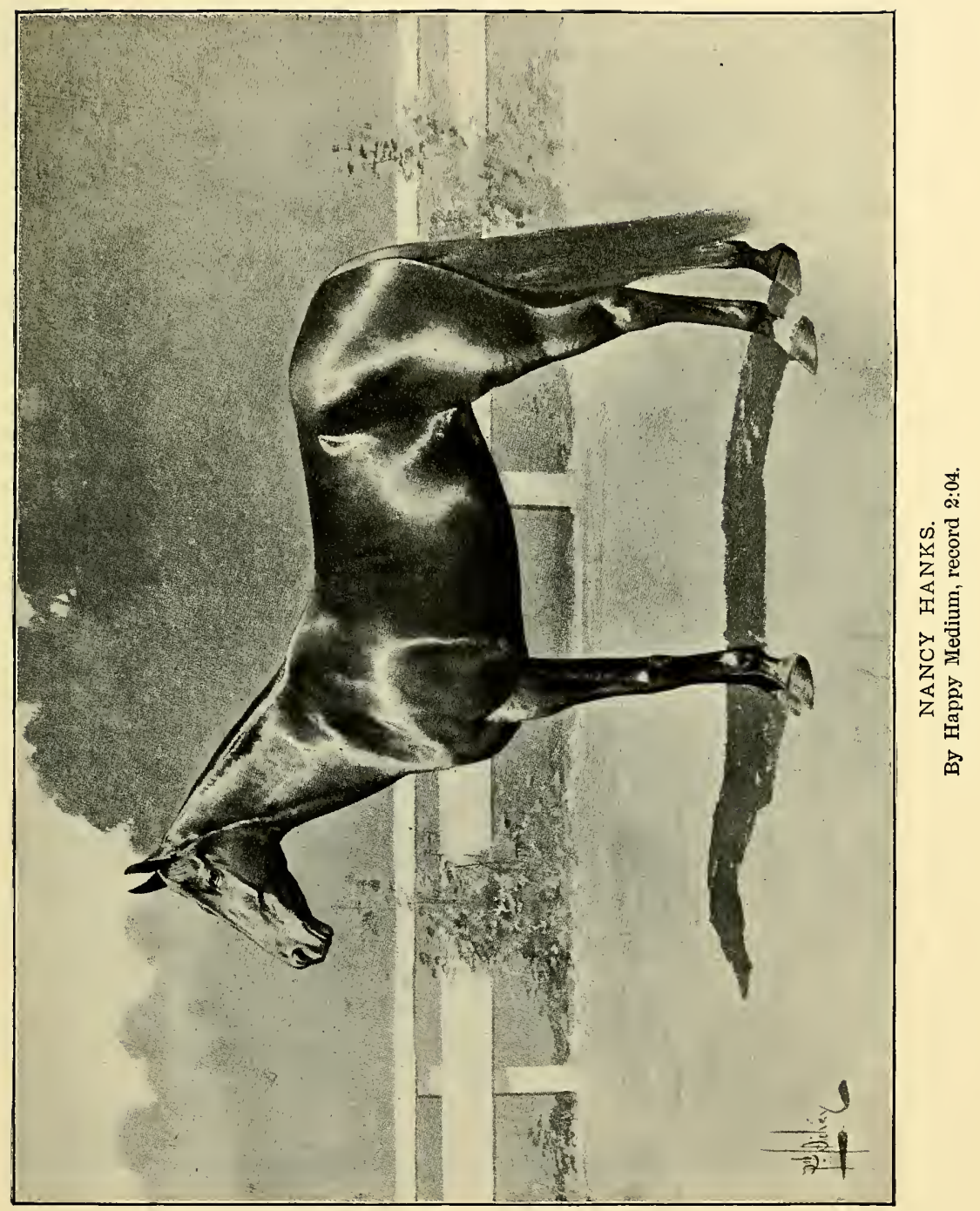



winning, but at two-mile heats a week later Princess won in 5:02, 5:05. In their subsequent races Flora turned the tables, though in a stubborn contest at two-mile heats Princess forced the then queen of the turf to make the long unbeaten record of $4: 50 \frac{1}{2}$. She was then retired from the turf, and after passing through several hands became the property of R. F. Galloway, who in 1862 bred her to Hambletonian.

Happy Medium was a bay horse, with star, snip, and two white rear ankles, fifteen hands two inches in height, and was a shapely, attractive horse, with excellent legs and feet. Some critics have found fault that he was light barreled, and perhaps with some degree of reason, but as a whole he was structurally much above the average of his time. As a four-year-old he started at the Goshen Fair and won, taking a record of $2: 54$, which he lowered to $2: 51$ in 1868. The next year, 1869, at Paterson, New Jersey, he distanced Guy Miller and Honesty in $2: 34 \frac{1}{2}, 2: 32 \frac{1}{2}$, and these three performances, all winning ones, comprise his entire turf career. He was in 1871 purchased at a very large price-said to have been twentyfive thousand dollars-by Mr. Robert Steel, who placed him at the head of his Cedar Park Farm, at Philadelphia. In 1879 he was purchased by the late General W. T. Withers, and taken to his Fairlawn Farm, Lexington, Kentucky, where he remained until he died, January 25,1888 , at which time he had more $2: 30$ performers to his eredit than any horse then living. The Happy Mediums developed speed easily and quickly, and were remarkable for the purity of their gait. The most famous of his get is the mare Nancy Hanks, that lowered the world's record to 2:04 in 1892. The mares bred to Happy Medium never were as a whole of good breeding, and in his early stud career they were largely of inferior blood and quality. His fame has steadily grown, and with ninety-two standard performers to his credit, and his sons and daughters breeding on, the blood of Happy Medium is justly held in very high esteem as a positive speedproducing element. Fifty-one of his sons have produced two hundred and thirteen, and forty-seven of his daughters have produced fifty-nine standard performers.

JAY Gould was one of the most famous of all the sons of Hambletonian on the turf and the sensational trotting stailion of his day, and he now, in turn, takes a high place among producing sons of the great father of trotters. This horse was bred by the late Richard Sears, of Orange County, New York, was foaled 1864, 
and was got by Hambletonian, out of Lady Sanford, by Seely's American Star; grandam Old Sorrel, by Exton Eclipse; third dam by Lawrence's Messenger Duroc, etc. At maturity Jay Gould was a handsome, blood-like horse, fifteen and one-half hands high, and a rich bay in color, with white hind ankles. With his dam he was sold while at her side to Charles II. Kerner, of New York, who soon after traded them to John Minchin, of Goshen, for the then well-known trotter Drift, Mr. Kerner also paying a fair sum in cash. Later the colt came into the hands of A. C. Green, of Fall River, and was by him named Judge Brigham. It is said that Mr. Green first learned that Judge Brigham was a fast trotter through his taking fright at a train one day in $18 \% 0$ and running away with him at a trot. Whatever the facts as to this are, it was soon known that Mr. Green had a very fast trotter, and the next season (1871) he started for a five-thousand-dollar purse at Buffalo, among the other starters being the already famous Judge Fullerton. T'o the general astonishment, Judge Brigham "cut loose" in the second heat, winning it in 2:2\%, thus equaling the stallion record then held by George Wilkes, and placing to his credit the fastest heat ever up to that time trotted by a horse in his maiden race. IIe won the race handily, and was the sensation of the time. He was at once purchased for, I believe, the great price of thirty-five thousand dollars by the late world-famous financier, Jay Gould, H. N. Smith, and George C. Hall. Later Mr. Smith acquired MIr. Hall's interest, and Mr. Kerner bought Mrr. Gould's, and finally, some years after, Mr. Smith, who had established Fashion Stud Farm, at Trenton, New Jersey, and owned the noted mares

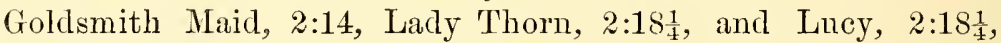
became sole owner of Jay Gould, as Judge Brigham was renamed.

The week following his Buffalo race Jay Gould defeated another strong field at Kalamazoo, Michigan; and in 18\%2 started four times, winning in all his races, lowering his record to $2: 21 \frac{1}{4}$, the then champion stallion record. He was kept in the stud in $18 \% 3$, but being challenged on behalf of Bashaw Jr., the following year, was given a hurried fall preparation, and met his challenger at Baltimore. Bashaw Jr., broke down in the first heat, and Gould of course won an empty victory, but to satisfy the audience was driven a public trial in $2: 19 \frac{1}{2}$. Meanwhile Smuggler had lowered the stallion record to 2:20, and Jay Gould was sent, against it at Boston, trotting under unfavorable circum- 
stances in $2: 20 \frac{1}{2}$ and $2: 21 \frac{1}{2}$. This practically closed his turf career. He made a number of seasons at Fashion Farm, and in his later years at Walnut Hill Farm, near Lexington, Kentucky, and died of old age June 10, 1894. Jay Gould's opportunities were never of the best. In his earlier years in the stud General Knox was more used at Fashion Farm than Jay Gould, and there was no training done at Fashion until 1886. Jay Gould is the sire of twenty-nine standard performers, the most noted of which is the great mare Pixley, $2: 08 \frac{1}{4}$. Fonrteen of his sons have produced thirty standard performers, and twenty-eight of his daughters have produced forty-six performers, among the latter

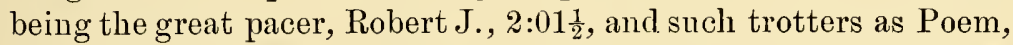

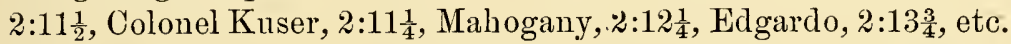
His most noted producing daughter is Lucia, whose dam was the famous old trotting mare Lucy, 2:18 $\frac{1}{4}$, by George M. Patchen,

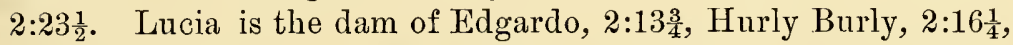
and several others in the 2:30 list, and her blood is breeding on through both her sons and daughters.

STrAтHмоRE, taking all things into consideration, must be rated among the very greatest sons of Hambletonian. He was a solid bay horse, of the substantial Hambletonian type, foaled 1866, bred by Aristides Welch at his Chestnut Hill farm, near Philadelphia, and was got by Hambletonian out of the quite famous trotting mare Lady Waltermire, by North American, and Lady Waltermire's dam was said to have been by Harris' Hambletonian. This North American sired Whitehall, that got the famous trotter Rhode Island, sire of the still more celebrated Govermor Sprague, and in the section treating of the latter the reader will find particulars concerning North American. Lady Waltermire was a noted trotting mare in her day, and it has been claimed that she performed faster than 2:30, but I have never been able to substantiate this claim. When Strathmore was a three-year-oid, in 1869, I visited Chestnut Hiil. Mr. Welch then had three sons of Hambletonian, viz., William Welch, Rysdyk, and Strathmore, who was then called Goodwin Watson. The two former were led out to be shown, but when I inquired for Goodwin Watson, Mr. Welch's reply was "Oh, he's a pacer"-except that he used an adjective in connection with "pacer" that added emphasis, and betrayed some degree of regret, or indeed disgust. The fact that several of Strathmore's sons have gotten many fast pacers need not be marveled at. I am not aware thet 
Strathmore was ever trained, and probably his pacing inclination furnishes the reason. When he was seven years old he was purchased by Colonel R. G. Stoner, of Paris, Kentucky, and named Strathmore, and up to this time, Colonel Stoner states, he had but three foals, one of which was afterward known as Chestnut Hill, $2: 22 \frac{1}{2}$, the first of his get to earn a reputation. His first two seasons were made in Montgomery County, after which he was taken to Paris, in Bourbon County. Colonel Stoner states in one of his catalogues that Strathmore's early opportunities in Kentucky were very inferior; that in 1877 and 1878 the service fees earned would not pay for his keep; that up to 1879 he never served a mare with a record or the dam of an animal with a record, and that it was not until Steinway trotted in 1878 as a two-year old in 2:313, and Santa Claus as a five-year-old in 2:18 in 1879 that any good mares came to Strathmore. At Colonel Stoner's sale, February 9, 1886, Strathmore was sold for two thousand one hundred and fifty dollars to Rockhill \& Bro., of Fort Wayne, Indiana, and they owned him until his death, March 11, 1895. Strathmore has seventy-one in the standard list; twenty-six of his sons and fifty-four of his daughters have produced one hundred and fifty-eight standard performers.

EGBERT is one of the youngest sons of Hambletonian, and has achieved very fair success in the stud. He is closely inbred to the Hambletonian, or rather the Abdallah blood, and is possibly the most notable instance of a successful sire being very closely inbred. Egbert was bred by Hon. J. H. Walker, Worcester, Massachusetts, and was foaled in 18\%. He was sold at the sale of Mr. Walker's horses at Worcester in the autumn of 1877 , when he was purchased for the then great price for a two-yearold of three thousand four hundred and twenty-five dollars by H. J. Hendryx, of Michigan, a representative of Mr. Veech, of Kentucky, being a contending bidder. After the sale Mr. Hendryx sold the colt for four thousand dollars to George IW. Raudenbush, of Reading, Pennsylvania, who I believe still owns him. In the spring of 1880 Egbert was taken by Colonel Richard West to his farm at Georgetown, Kentucky, and kept there a number of years, and indeed the greater part of his stud career has been in Kentucky. I am not aware that Egbert was ever trained. He is individually a superior horse, but is alleged to have an unkind disposition.

Egbert was got by Hambletonian out of Campdown, by Mes- 
senger Duroc (son of Hambletonian); grandam Miss MeLeod

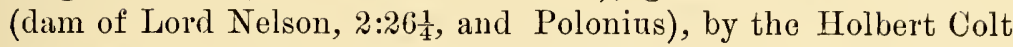
(son of Hambletonian); great-grandam May Fly, by Utter Horse, son of Hoyt's Comet; great-great-grandam Virgo, sister to the dam of Messenger Duroc, by Roe's Abdallah Chief, son of Abdallah, the sire of Hambletonian. The Holbert Colt, son of Hambletonian, was a pacer, and others in Egbert's ancestry paced; and in commenting on his pedigree, from this point of view, at the time Colonel West took him to Kentucky, I remarked in Wallace's Monthly, March, 1880: "Colonel West need not be surprised if he finds quite a number of Egbert's offspring starting off at a pace." 'The facts have borne out the prediction, as a glance at Egbert's long 'list of fast pacers will show. Egbert is the sire of seventy-five standard performers, while twenty-five of his sons, and eighteen of his daughters have produced seventyfour standard performers.

Masterlode, that left a family of some merit in Michigan, was a mammoth bay, foaled 1868, got by Hambletonian out of Lady Irwin by Seeley's American Star. He was a gigantic, coarse horse, and was certainly the largest horse that ever earned a reputation as a sire of trotters. It is said he was quite seventeen hands high and was built on a heavy mold even for his height. He was bred by James M. Mills, Orange County, New York, and passed to A. C. Fisk, Coldwater, Michigan, who owned him until his death in 1892. The most noted of his get

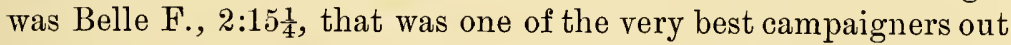
in 1886. He has twenty-eight to his credit in the list, and seventeen of his sons and sixteen of his daughters have produced in all fifty-seven standard performers.

AberDeEN shares with Dictator such honors as attach to the highest success of the "Hambletonian-Star cross" in the stud. This horse was bred by the notorious Captain Isaiah Rynders, at Passaic, New Jersey, and a full account of the investigation of the pedigree of his dam, the noted Widow Machree, 2:29, will be found in Chapter XXIX., on the investigation of pedigrees. Widow Machree was altogether the best trotter of the American Star family, and was especially noted for her gameness. Bred to Hambletonian, it was natural that she should produce a trotter, and Aberdeen was quite a trotter in his day. As a three-yearold he won a stake at Prospect Park, distancing his field in 2:46, and the statement has been published that $h \ni$ later in his career 


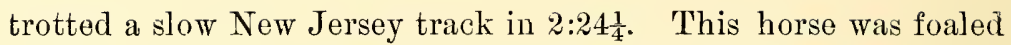
in 1866, and was a bay fifteen hands three inches high, and very stoutly, indeed coarsely made, and was of a dangerously vicious disposition. The good race mare Hattie Woodward, that made a record of $2: 15 \frac{1}{2}$, first attracted attention to Aberdeen as a sire, and in 1881 he was purchased by General Withers and taken to Fairlawn, and before this his stud opportunities had been very limited. He died in 1892. By far the best of his get is the

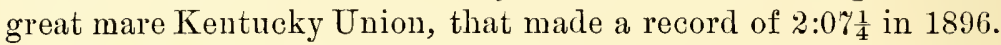
Aberdeen has forty in the standard list, fourteen of his sons have produced fifty-seven, and seventeen of his daughters have produced nineteen standard performers.

SweEptakes must be classed among the successful sons of Hambletonian as a sire of trotters, though in the second generation his family have yet failed of great distinction, nor did Sweepstakes himself get extreme speed. This was a bay horse, foaled 1867 , by Hambletonian out of Emma Mills, that also produced Mott's Independent, by Seely's American Star. He was bred by the late Harrison Mills, near Goshen, in Orange County, New York, and was never, I believe, trained. Indeed it has been stated that he never wore harness, and is perhaps the most. remarkable example of a strictly undeveloped sire of trotters.

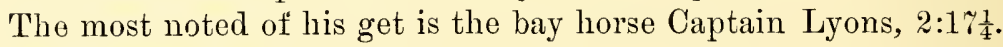
Sweepstakes sired thirty-three trotters and two pacers that are standard performers, four sons have produced eight trotters and two pacers, and twenty of his daughters have produced twentyfive trotters and four pacers.

Governor Sprague is one of the few horses not descended in the male line from one of the great foundation progenitors, and that yet was a trotter of merit and the founder of a trotting family. His dam, however, was a producing daughter of Hambletonian, and this must be regarded as the probable source of his power, though his sire was a fine trotter for his day.

Back in the thirties a Frenchman living at Rouse's Point, New York, near the Canadian boundary line, bred a pacing mare to a hors e that was kept in the same stable with Sir Walter, thoroughbred son of Hickory, and the result was the horse known as North American, or the Bullock Horse. It was long claimed that North American was by Sir Walter, but the best. authenticated version is given in Wallace's Monthly, for 1880. This was the statement of a Mr. Ladd, said to be a reliable man, who 
knew the Frenchman who bred North American. Ladd had formerly lived at Rouse's Point, and kept a little hotel at Benson's Landing on Lake Champlain. Ladd's statement was that the Frenchman had a little pacing mare, from which he wanted to raise a foal, but would not pay more than three dollars for any horse's service. Sir Walter's fee was fifteen dollars, but in the same stable was a large stallion that was used to haul water from the lake to the hotel, and the Frenchman was permitted to have the service of this horse for three dollars, and this is the only reliable version I could ever obtain as to the pedigree of North American. Besides the line we are now considering, this horse got Lady Waltermire, the dam of the great Strathmore, and one of his daughters is the dam of two in the 2:30 list, and Vergennes Black Hawk came from another. North America was said to have been a natural trotter, and quite fast for a short distance. A son of his, named Whitehall, from the name of the place where he was bred, was taken to Ohio from New York about 1854 and there got the noted Rhode Island, $2: 23 \frac{1}{2}$, the sire of Governor Sprague. Rhode Island was a brown horse, foaled about 1857 , and his dam was by a black horse called Davy Crockett that was brought from Pennsylvania, and her dam was called Bald Hornet. This mare, Mag Taylor, was bred to Whitehall twice, one of her foals being Belle Rice, the dam of the stallion Harry Wilkes, sire

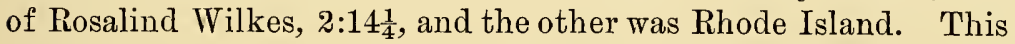
horse trotted many races, and at Fashion Course, New York, October 27,1868 , earned his record of $2: 23 \frac{1}{2}$. He about this time passed into the hands of Sprague \& Akers, and he died in 1875. At this time Governor Amasa Sprague had among his brood mares Belle Brandon, by Rysdyk's Hambletonian out of a daughter of Young Bacchus. This was a bay mare, foaled in 1854 in Orange County, and was a fast trotter and a mare of great general excellence. She was driven as a mate to Sprague's Hambletonian, and Mr. Sprague claimed that he had once driven her a mile in 2:29. Bred to Volunteer she produced Amy, 2:201, and to Rhode Island, produced in 1872, Governor Sprague, 2:201 $\frac{1}{2}$.

Governor Sprague was a black horse, approximating fifteen hands two inches in height, and very substantially built. He is described as having been an exceedingly handsome horse, especially in action, his gait having been pure and beautiful. In 1873 he was sent to Kansas and trained, and so promising was he that he was that year sold to Higbee Brothers and Mr. Babcock, 
of Canton, Illinois, for one thousand five hundred dollars. He was shown and known as a very fast four-year-old, trotting public exhibitions in about 2:22. With the exception of a threeyear-old race at Earlville, Illinois, he did not start in a public race until July 20, 18\%6, when at Chicago he easily defeated a good field, and so promising and attractive did he seem that the late Jerome I. Case, of Racine, paid the great price of twentyseven thousand five hundred dollars for him. At Ponghkeepsie, New York, that season he lowered his record to $2: 20 \frac{1}{2}$, and a few more races ended his short but brilliant turf career. He died at Lexington, Kentucky, May 23, 1883, at the early age of eleven years. His stud career was therefore short, and this fact we must remember in estimating his rank as a sire. Kate Sprague, $2: 18$, and Linda Spragne, 2:19, were about the best of his immediate progeny, and Rounds' Sprague, that has twenty trotters and pacers in the 2:30 list, some of them in better than $2: 20$, seems to be his most successful son. Governor Sprague has to his credit thirty-six trotters and two pacers with standard records, twentytwo of his sons have sired fifty-four trotters and fifteen pacers, and his daughters have produced twenty-three trotters and six pacers. There was nothing in the inheritance of Rhode Island to justify a supposition that he wonld transmit speed uniformly, and, like Smuggler, the speed-getting power with him was sporadic. But from his dam, Belle Brandon, Governor Sprague received the blood of Hambletonian through an individual that had speed herself and naturally produced speed; and this strain, combined with the blood of a horse that was good enough in his day to beat Lucy, American Girl and George Wilkes, gave Governor Sprague a right to be all that he was. 


\title{
CHAPTER XXIII.
}

\author{
MAMBRINO CHIEF AND HIS FAMILY.
}

Description and history of Mambrino Chief-The pioneer trotting stallion of Kentucky-Matched against Pilot Jr.-His best sons-Mambrino Patchen, his opportunities and family-Woodford Mambrino, a notable trotter and sire-Princess-Mambrino Pilot-Other sons of Mambrino Chief.

Mambrino Chief was a dark bay or brown horse, got by Mambrino Paymaster, grandson of imported Messenger, and his dam was a large, coarse mare that was brought from the West in a drove, and absolutely nothing was known of her blood. The theory was once advanced in print that she must have been by Stevens' Messenger Duroc, but I think it was never repeated. The basis of this theory was, that the horse referred to was large and coarse, with a long thigh bone, and as the mare was large and coarse, with a long thigh bone, she must have been a daughter of his. There are some obvious difficulties about accepting this "thigh-bone" pedigree. In the first place, the inventor of it never saw either the horse or the mare, and how could he have put his tapeline on their "thigh-bones" and thus ascertained they were of the same length? In the second place, it is not known, nor was it known to the inventor, that the horse ever had been within three hundred miles of the dam of this "daughter", of his. It is not much wonder that the "horse business" is hardly considered reputable when an educated man will advance such senseless gabble as the basis of a pedigree. This mare produced another colt called Goliah that developed some speed, but this was not the Goliah that was on the trotting turf.

Mambrino Chief was bred by Richard Eldridge, of Dutchess County, New York, and was owned by Warren Williams; in the spring of 1851 he passed into the hands of James M. Cockroft and G. 'T. Williams; was kept two or three seasons in Ulster County; trotted, under the saddle a trial in 2:36; sold to James B. Clay of Kentucky, in the winter of 1854, and then to Gray is 
Jones, 185\%, for five thousand and twenty dollars, and died 1861 . Soon after his arrival in Kentucky he was matched to trot against Pilot Jr., and the match stirred up a great deal of interest among the breeders. He was so big and coarse and so far removed from the type of the running horse that very few believed he could show any speed at any gait, for the distance of a mile and repeat. He was placed in the hands of Dr. Herr, who had had some experience in handling trotters, for preparation. When the day came there was quite an assemblage to witness the race but the Pilot Jr. party came forward and paid forfeit. . This was a sore disappointment to those who thought the big horse conld not trot, and to satisfy them that he could trot and trot fast, Dr. Herr drove him to show his gait, and notwithstanding his quarter cracks he satisfied all that he really was a trotter. This was an auspicious opening of a successful career extending through the remaining six years of his life.

In the sense of success, Mambrino Chief was really the pioneer trotting stallion of Kentucky. True, "Old" Abdallah had been there fourteen years earlier, but he was in bad shape and breeders did not like him. He was very plain in his appearance and only left some half-dozen of foals behind him when he was brought back to Long Island. The breeders all turned to his stable companion, Commodore, that was more after the pattern of the running horse, and would not look at Abdallah. This Commodore filled the blue-grass fields with his foals, but none of them conld trot. $\mathrm{He}$ was a son of Mambrino, by imported Messenger, and was an inbred Messenger, if his pedigree was right, but he was a failure as a trotting sire. Mr. Marcus Downing took his horse, Bay Messenger, there about the same time and he was a failure also, notwithstanding he was a grandson of imported Messenger. Both Commodore and Bay Messenger shonld have been trotting sires, but either one of two reasons was sufficient to prevent that consummation. First their blood and physical structure were all right, but the mental structure-the instinct to trot-was lacking; they inherited from some ancestor that could not and was not inclined to trot. Second, Kentuckians of that period knew nothing about trotters and they may have lacked in the requisite knowledge, skill and patience to develop them. It is true that old Pacing Pilot and some other pacing tribes were there that would occasionally throw a pacer with the diagonal motion, like Pilot Jr., but there was no other blood there that trotted before the 
arrival of Mambrino Chief. 'This pacing element was a very valuable element upon which to build up the trotter, but unfortunately and wherever it was possible, a running pedigree was tacked on to the pacer, and thus, in the estimation of Kentuckians it was the running blood that did it.

The six years of his services in Kentucky gave sufficient time to establish his value as a trotting sire, but not sufficient to build up a large family. This limited period must be further restricted, in estimating his value, by the fact that the war broke out in 1861, at the very time when the larger part of his offispring were just at the right age for development. 'This important fact has been very generally overlooked when estimating the true value of this horse. The question has often been asked why this horse succeeded in Kentucky when he had not succeeded in the North? This is too broad a question to be considered in this historical sketch, but will be considered at another place in this volume. In passing it, some very intelligent writers have attributed it to what is called "the climatic outcross," and there may be some real value in this point, but the great cause, aside from the new surroundings and expectations of his progen 7 , may be found in the fact that his own speed was never developed until the very eve of his transfer to Kentucky. His instinct to trot and to trot fast had remained dormant, practically, during the whole period of his Northern service, and when he reached Kentucky he was, in a sense, a new horse and conscious of his powers as a trotter. The salutary effects of development, at whatever gait, have been shown in ten thousand instances and will continue to be shown as long as the interests and ambitions of man shall prompt him to strive to surpass his neighbor.

At one time it was maintained right vehemently by the owners of the stock of Mambrino Chief, as well as some others, that as a stock horse he was not only equal but superior to Hambletonian. In 186\%, when the battles were raging between Dexter and Lady Thorn, this view showed little abatement, and notwithstanding the gelding was beating the mare all the time, they still maintained that in the end she would be the conqueror. When Lady Thorn was serionsly crippled and retired from the turf, there were many sad hearts in the Mambrino family and many wonderful stories were told, privately, of what Dan Mace had seen her do, and that he was keeping very quiet till an opportunity came to show the most wonderful flight of speed that the world had ever seen or 
ever would see. With the shroud of what "might have been" about them, they were "of the same opinion still."

Mambrino Chief left six in the 2:30 list; twenty-three sons that put ninety-five in the list and seventeen daughters that produced twenty-four trotters.

LEADING SONS OF MAMBRINO CHIEF.

\begin{tabular}{|c|c|c|c|c|c|c|c|}
\hline Name. & 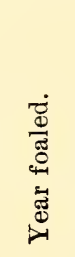 & 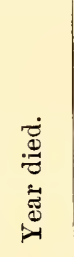 & 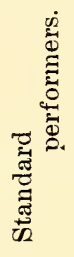 & 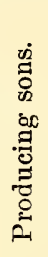 & 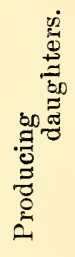 & 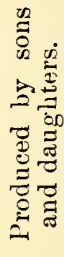 & 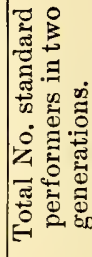 \\
\hline Mambrino Patchen & 1862 & 1885 & 25 & 51 & 90 & 259 & 284 \\
\hline Woodford Mambrino, $2: 21 \frac{1}{2}$. & 1863 & 1879 & 13 & 23 & 24 & 172 & 185 \\
\hline Mambrino Pilot, $2: 34 \frac{8}{4} \ldots .$. & 1859 & 1885 & 9 & 17 & 15 & 71 & 80 \\
\hline Clark Crief.............. & 1861 & 1871 & 6 & 12 & 25 & 43 & 49 \\
\hline Ericsson, $2: 30 \frac{1}{2} \ldots \ldots$ & 1856 & $188-$ & 6 & 4 & 15 & 25 & 31 \\
\hline Mambrino Chief Jr. (Fisk's). & 1861 & $189-$ & 5 & 6 & 14 & 34 & 39 \\
\hline
\end{tabular}

Mambrixo Patchen was the best son of Mambrino Chief and

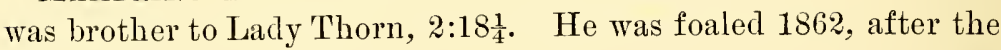
death of his sire, and was bred by Levi T. Rodes. His dam was by Gano, a running-bred son of American Eclipse; his grandam was a pacing mare by a colt of Sir William, but what Sir William is not known; his great-grandam was an inveterate pacer and never was known to strike any other gait. Mambrino Patchen was so much smoother and handsomer than his sire, and was so much of a failure as a trotter, that a very strong conviction prevailed among the friends and neighbors of his owner that he was not a son of Mambrino Chief, nor a brother of Lady Thorn. To this story that he was a Denmark and not a Mambrino Chief I never have given any shadow of credence. The attempt of his owner, Dr. Herr, to make him a trotter was patient and persistent, extending throngh several years, but with all his skill and experience he failed. Nobody was ever able to "catch" him a mile, but it seems to have been conceded that he might go somewhere in the "forties." While this persistent and long-continued training failed in its original purpose of giving the horse a record of reputable speed, there can be no donbt, nnder the law that governs, that this development did great good to the horse, as a progenitor 
of trotters. The conditions being a handsome horse, with the banner constantly flying over him, "full brother to Lady 'Thorn," an industrious and very capable owner, in the heart of the greatest breerling region in the whole country, it is easy to account for a very wide and lucrative patronage. Still, as a getter of speed he was not a great success, and as a getter of high speed he was a failure. With all the facilities for development, only twenty-five of his progeny have found a place in the 2:30 list, the fastest of which has a record of $2: 20 \frac{1}{2}$. Of his sons, fifty-one are the sires of one hundred and twenty-six trotters, and of his daughters, ninety have produced one hundred and twenty-nine standard performers. He has proved himself a very great sire of brood mares, and when his danghters are bred to horses of stronger inheritance, they stand among the best.

Woodford Mambrivo.-This son of Mambrino Chief was a large brown horse, foaled 1862. He was bred by Mr. Mason Henry, of Woodford County, Kentucky. His dam was also the dam of other trotters, was got by Woodford, son of Koscinsko, and her dam was a farm mare withont any known breeding. Woodford was a large, strong horse used only for farm work, to which he was well suited. After spending a good deal of time and labor on his pedigree I am constrained to say that while he may have been a son of Kosciusko, his dam's breeding is worse than unsatisfactory. Woodford Mambrino made a record of 2:21 $\frac{1}{2}$, and placed thirteen of his get in the $2: 30$ list. He left twenty-three sons that were the sires of standard performers, and twenty-four daughters that produced twenty-seven standard performers. His son, Princeps, owned by Mr. R. S. Veech, of Indian Hill Farm, near Louisville, Kentucky, was in the stud far and away the best of his sons, and although he had no record of his own he placed in the list forty-four trotters and four pacers, many of them with fast records.

Mambrino Pilot was a very large and very coarse horse. $\mathrm{He}$ was a brown, got by Mambrino Chief, foaled 1859, dam Juliet, by Pilot Jr.; grandam by Webster, son of Medoc; great-grandam by Whip. He was bred by Thomas Hook, of Scott County, Kentucky, and after passing through the hands of Dr. Herr and others he was sold to C. P. Relf, of Philadelphia, and, I think, remained in his family till he died, 18s5. He had a record to saddle of $2: 2 \% \frac{1}{2}$. He put nine of his get into the $2: 30$ list, and seventeen 
of his sons left fifty-one performers and fourteen of his daughters produced twenty performers.

Many others of the descendants of Mambrino Chief might be noticed, but it is not the purpose of this volume to dwell npon matters that are accessible in the current literature of the trotting horse. The foundations of breeds and the leading heads of tribes must command my labor. The table shows the rank of the other sons of Mambrino Chief that achieved any degree of success, and of these clearly the best was Clark Chief, that died at ten years old. 


\title{
CHAPTER XXIV.
}

\author{
THE CLAYS AND BASHAWS.
}

The imported Barb, Grand Bashaw-Young Bashaw, an inferior individualHis greatest son, Andrew Jackson-His dam a trotter and pacer-His history-His noted son, Kemble Jackson-Long Island Black Hawk-Henry Clay, founder of the Clay family-Cassius M. Clay-The various horses nawed Cassius M. Clay-George M. Patchen-His great turf careerGeorge M. Patchen Jr.-Harry Clay-The Moor, and his son Sultan's family.

THIs family is no longer prominent in trotting annals and its blood has been practically absorbed by other strains that have proved themselves more potent in transmitting and more uniform and more speedy in performing. The name "Bashaw Family" is a misnomer and it should never have been used, but as it has represented, for many year's, the oldest line of developed speed, it seems a necessity to recognize it here. A branch of this family, designated as "The Clay Family" has perpetuated itself in some strength and will be considered in this chapter.

Grand Bashaw, the horse that gave this family its name, was imported from Tripoli by Richard B. Jones, who was the American consul at that port. Mr. Morgan was associated with him, and they imported at the same time two other Barbs, Grand Sultan and Saladin. Grand Bashaw was kept in Lower Merion, Montgomery County, Pennsylvania, several years; Grand Sultan was kept in New Salem, New Jersey, for a time, and Saladin was taken to North Carolina and afterward died in Georgia. From these three horses nothing has been left to the horse history of the country but one single attenuated line. Grand Bashaw was a black horse, fourteen hands and an inch high, with a star and a snip on his nose. He was kept all his life in the vicinity of Philadelphia, and died at Newtown, Pennsylvania, 1845.

Young Bashaw was a grey horse, about fifteen and one-quarter hands high, and is the only descendant of Grand Bashaw through which we can trace to that horse. He was foaled 1822 and was 
bred by Thomas Logan, of Montgomery County, Pennsylvania. His dam was Pearl, by Bond's First Consul, a famous running horse, his grandam Fancy, by imported Messenger, and his greatgrandam by imported Rockingham. This is the pedigree under which he was advertised, but it has never been authenticated in any of its crosses. Judging by the horse himself and his progeny there can hardly be a doubt that there was a Messenger cross in it, but just where cannot be determined.

He made his first season in Salem, New Jersey, 1826. He was then four years old and by no means handsome or attractive in his form. His head, ear and neck were his worst features; but in addition to these defects he was flat on the ribs and habitually carried his tail to one side. His limbs and feet were as good as ever were made, but his great redeeming quality was his trotting gait. When in Salem he was only a rough, partly developed, four-year-old colt, but he showed then a step and a rate of speed so remarkable as to induce a few to breed to him, notwithstanding his ungainly appearance. He did not cover more than a dozen mares that season, and all-told he got eight foals. Out of these eight, seven proved to be superior trotters for that day. Andrew Jackson was the best, but there was another that could go below 2:40. The common remark was, wherever he touched a mare of Messenger blood, there was sure to come a trotter. This was the general rule, but the best hit he ever made, probably, was when he covered Joseph Hancock's black pacing mare and got Andrew Jackson.

In looking over his blood elements we can see nothing in his pedigree to justify these trotting qualities except the grandam, Fancy, by Messenger. First Consul was a great race horse, but neither he nor his descendants ever evinced a disposition to trot. The horse Rockingham was contemporaneous with Messenger and a constant rival while Messenger was about Philadelphia. He was not wholly running-bred, as he was by Towser, afterward called Counsellor, and out of a hunting mare. As a stock horse he was esteemed as only second to Messenger on the Delaware, where he stood many years.

The fame of Young Bashaw did not cease nor die ont after the exploits of Andrew Jackson, Black Bashaw, Charlotte Temple, Washington and others from his own loins. The Clays, the Long Island Black Hawks and the Patchens have kept spreading it wider and wider until of late years we find that only the one 
great Hambletonian family has overshadowed them all. Young Bashaw, after eleven years in the stud along the Delaware River, above and below Philadelphia, died at Morrisville, Bucks County, Pennsylvania, June, $183 \%$.

ANDREW JACKSUN was the most noted son of Young Bashaw. He was a black horse, fifteen and a half hands high, with three white feet and a strip of white in his face. He was very well formed in every point and was strong, compact, short-legged and handsome. He was foaled 1827, and was bred by Joseph Hancock, of Salem, New Jersey. His dam was a strong, compact black mare that both trotted and paced, and was noted for her speed at the latter gait. This mare was brought in a drove from Ohio, in the spring of 1820 and on the twenty-first of June of that year she was sold to Mr. Hancock, of Salem, New Jersey, for one hundred dollars. He kept her a little over six years, and in the spring of 1826 bred her to Young Bashaw, and in the fall of that year sold her to Powell Carpenter; and soon after he sold her to Daniel Jeffreys, a brickmaker on the Germantown road, near Philadelphia. She was then in foal by Young Bashaw, and the next spring she dropped the colt that became famons as Andrew Jackson.

The incidents connected with the history of this mare are here given, perhaps in unnecessary detail, but as Andrew Jackson was very extensively advertised under a fraudnlent pedigree from about 1834 till the time of his death, and as I had at one time accepted it as true, it is better that it should be made very plain, especially as I had been severely criticised for changing it. The correction made, as above, was founded on information received from two separate and distinct sources and both thoroughly reliable. The fraudulent pedigree of this mare represented her as "by Whynot, son of imported Messenger, and her dam by Messenger" himself. This was just such a pedigree as so great a horse should have had, but there was no truth in it. The attack was led by quite a large breeder in one of the prairie States, who had at number of animals remotely descended from Andrew Jackson. He did not even pretend to know anything at all about the truth of the matter, but simply urged most vehemently that the pedigree should be restored because it was old. The fact of the matter was the man wanted the old lie instead of the new truth maintained because it would help to sell his stock, which was the very object for which the lie was originally invented.

Daniel Jeffreys was very much addicted to trotting horses, and 
when he bought the black mare that was then carrying Andrew Jackson he kept her for his own driving and named her "Charcoal Sal." She was no doubt among the fastest of the road horses, but there is no record of her ever being in a race. How much Jeffreys drove Charcoal Sal that autumn cannot now be determined; probably too much for the physical, but not too much for the mental, organization of the foal she was carrying.

About the break of day, one morning in the following April, somebody was passing Jeffreys' brickyard (my recollection is, it was George Woodruff himself), and he heard a splashing in the water accumulated in one of the clay pits, and Charcoal Sal circling round in great distress. She had dropped her foal, and in its weak efforts to get on its feet, it had rolled into the pit. It was at once pulled out and the family aroused, and no time was lost in rubbing it dry and wrapping it in warm blankets. Some of the mare's milk was poured into it from time to time, and toward noon it was so much revived and strengthened as to manifest a disposition to get on its feet. This was due, principally, to the womanly care and good nursing of Mrs. Jeffreys. But, when helped up, he appeared to have strength enough everywhere but in his pastern joints, and there he had no strength at all. In this condition the colt remained a day or two, a most pitiable and most helpless object, standing on its pasterns instead of its feet. One morning at the breakfast-table Mr. Jeffreys said he would give any of the boys a dollar if he would put that colt out of misery and bury it out of his sight. Mrs. Jeffreys, whose womanly feelings and sympathies were all enlisted, replied to her husband's remark that "the boy who would kill that colt never could eat another mouthful at that table." What a grand exhibition of true womanly instincts! Day by day her unremitting care was rewarded by seeing a little more strength gathering in the weak places, and at last her kind, motherly heart was gladdened by seeing him skip and play, a strong beautiful colt.

Mr. Jeffreys kept the colt till he was some five or six years old and then sold him to John Weaver, whose residence was about. half a mile from the old Hnnting Park Conrse. He remained the property of Mr. Weaver till he died, September 19, 1843. In his stud services he was kept on both sides of the Delaware, in the region of Philadelphia, and made one season, perhaps two, on Long Island. As a trotter he stood as the first of all stallions of his day. 
His first race took place October 19, 1832, over the Hunting Park Course for a purse of two hundred dollars for green horses, to saddle. He was entered under the name of "Brickmaker," was ridden by George Woodruff ("Uncle George"), and beat Jersey Fagdown, son of Fagdown, by Messenger. Time 6:30, $6: 23$.

The next year he beat Jersey Fagdown again for the same purse and over the same course.

October, 1834, he again won the same purse, over the same course, at two miles to saddle, beating Sally Miller. Time 5:26, $5: 25$.

The next October, 1835, over the same course, the same conditions, he beat Lady Warrenton, by Abdallah, and Daniel D. Tompkins, by a son of Winthrop Messenger. Time 5:20, 5:19.

These performances have been extended far enough to give a just conception of his speed and his staying qualities. His races seem to have been pretty much all to saddle and two-mile heats. In that day most races were to saddle. George Woodruff told me he was on his back when he made Edwin Forrest trot in $2: 31 \frac{1}{4}$ to win, but whether it was in a race or a trial I cannot now recall. Mr. George Woodruff was an uncle of Hiram Woodruff and a very worthy man. To him I an indebted for all the de. tails of the early life of Andrew Jackson, and they were of his own personal knowledge.

KEMBLE JACKSON.-About the year 1853, of all the idols of the trotting-horse world, perhaps no one had so many worshipers as Kemble Jackson. In 1852 he was beaten by O'Blennis, three-mile heats in harness, and in April, 1853, he was beaten by both Green Mountain Maid and Lady Vernon, mile heats in harness, bnt in June following he achieved a great triumph. The race was on the Union Course and there was a vast concourse of people there to see it. The purse and stake was for four thousand dollars, three-mile heats to two hundred and fifty-pound wagons. The interest was very intense, as O'Blennis, Boston Girl, Pet, Iola and Honest John were in it. Each horse in the race made better time than he ever made before, and yet Kemble Jackson took the lead and maintained it from end to end, without a skip or a break. After the first heat even, the friends of O'Blennis would not hedge their money, for they had faith that the gallant son of Abdallah would win. The finish of the second heat was in the order above given. The time was 8:03, $8: 04_{\frac{3}{4}}^{3}$. 
Faster time has since been made to wagon, but probably not with this weight and at this distance. As a weight-puller for three miles I believe he stiil remains the champion. He was a very strongly built chestnut horse, and was got by Andrew Jackson the last year of his life.

The pedigree of his dam was in confusion for a long time. Her name was Fanny Kemble. There were a number of running-bred mares named after that very popular actress, and everybody who had anything tracing to "Fanny Kemble" was sure that that particular mare was the dam of Kemble Jackson. In the first volume of the "Register" he is given as out of Fanny Kemble by Sir Archy, and in the second volume there was some fairly good evidence that he was ont of Fanny Kemble by Hunt's Eagle, tracing on through running lines. It is true he was out of a mare called Fanny Kemble, but neither of the two foregoing. Her blood was wholly unknown. The Hon. Ely Moore was a member of Congress, and when on his way to Washington in 1839 he saw a very fine, stout-looking mare hitched to a gig in the city of Baltimore. She was a ehestnut and showed such ability to handle a great heavy gig with ease and rapidity that he bought her. He bought her for what she was herself and not for what. her blood was. There was no evidence asked or given as to how she was bred. This mare produced several foals to Andrew Jackson, the youngest of which was Kemble Jackson. While he was still a colt, Mr. Moore presented him to his son-in law, G. U. Reynolds, who still owned him when he died. Mr. Reynolds is an intelligent and very reputable man, and this is the history of the origin of Kemble Jackson as given to me in person by him. Mr. Moore paid two hundred and fifty dollars for this. mare Fanny Kemble, and she was so handsome and so fast on theroad that he considered her a very eheap mare. The eompany never was too hot nor the road too long for her.

Everybody has heard of "The Kemble Jackson Check" and nearly everybody, until within the last few years at least, has been using it withont knowing just why or when it can be used with advantage. When in the hands of Hiram Woodruff, Kemble Jackson got into the habit of bringing his chin back against his breast, and in that shape Hiram could pull on him all day without getting control of him. In this dilemma, Mr. Reynolds suggested an overdraw check which might prevent the indulgence of this bad habit. Hiram took the suggestion, had 
one made, and it was a success, in his case. In twenty-four days after the performance which made him a great name from one end of the land to the other he died of rupture. As be was only nine years old and as he was just beginning to be appreciated as a stallion the breeders of the country sustained a great loss. Up to this point in his history he had no reputation, had been iittle patronized and left but $\mathrm{ow}$ of his progeny to perpetuate his name.

Long Islani) BLACK Hawk.-This son of Andrew Jackson was foaled 1837 and his dam was the distinguished trotter Sally Miller, by Tippoo Saib, son of Tippoo Saib by imported Messenger. This mare was bred in Bucks County, Pennsylvania, and trotted as a three-year-old in 1828 on the Hunting Park Course, Philadelphia. She was distinguished in her day, beating many of the best, and was the first three-year-old trotter of which we have any account. She was finally owned on Long Island, but I have never been able to learn the name of her owner. Black Hawk trotted some famous races on Long Island, the most noted of which, perhaps, was his match with Jenny Lind in which he was to pull a two hundred and fifty-pound wagon, and the mare the usual weight. In this match he beat her in straight heats. Time 2:40, 2:38, 2:43. In 1849 he beat Cassius M. Clay, time $2: 41,2: 38,2: 41$. This horse was owned for a time by Jonas Hoover, of Germantown, Columbia County, New York, and was there called Andrew Jackson Jr., or Young Andrew Jackson. He made some seasons in Orange County, and died at Montgomery in that county July, 1850. His progeny were not numerous and but two of them from his own loins entered the 2:30 list. His son Jupiter put five in the 2:30 list; Andrew Jackson Jr., two; Mohawk, three; Nonpareil, two; Piow Boy, one; and Vernol's Black Hawk, one; to which we may add the fact that this last named was the sire of the famous Iowa stallion, Green's Bashaw. Although his life was not long and his stud career was probably up to the average, it cannot be said that he was a great progenitor of trotters.

Henry Clay, the nominal head of the tribe that has taken his name, was a black horse, foaled 1837, got by Andrew Jackson, son of Young Bashaw; and his dam was Surrey, or Lady Surrey, as she is sometimes called, a pacing mare that was bronght from Surrey, New Hampshire, to New York, and was converted to a trotter, or possibly she may have been double-gaited from her 
birth. It has been generally stated in years past that this mare was brought from Canada, and as there have been many disputes about her origin, I will try to give what authentic knowledge we have concerning her.

Mr. Peter W. Jones, one of the "old-time" horsemen and a very reliable man, said that David W. Gilmore, formerly a grocer at City Hall Place and Pearl Street, New York, bought a pacing mare, five years old, of Mark D. Perkins, of Mount Vernon, New Hampshire, which eame from Surrey, New Hampshire, and henee her name "Lady Surrey." Gilmore rode her to New York, with a young man named Lovejoy. He gave less than one hundred dollars for her. She was a superior saddle mare, and as Mr. Gilmore appreciated horseback riding he bonght her for that purpose. Frank Gilmore, who was a deputy sheriff under Sheriff Orser, of New York, said that Lady Surrey was the mare his brother rode from New Hampshire, and after he sold her she turned out to be a trotter.

This is the story as told by Mr. Jones, and judging from its source I have no doubt it is substantially correct. This leaves us without any knowledge whatever of the blood of the mare, but only that she was both a pacer and a trotter. She was engaged in some races and was quite well known to the trotting men of that day, and she must have been a pretty good one to have been owned by such a horseman as George M. Patehen and by him bred to Andrew Jackson. It is said Surrey and Sally Miller were coupled with Andrew Jackson the same day; they both stood, and the one produced Henry Clay and the other Long Island Black Hawk.

While Henry Clay remained the property of his breeder he was trained and was looked upon as a promising young horse, but I have not been able to determine what rate of speed he was able to show. He certainly did not stand anywhere near the fastest, and he does not appear to have ever won a race, and perhaps never started in one. Still, he was esteemed as one of the best horses on Long Island and was liberally supported while there. When about eight years old he was sold for a fine price to General Wadsworth, of Livingston County, New York, and he was kept at various points in that part of the State till he died of old age and neglect in 186\%. He came into the world when trotters were few and he lived till they were many. He left a numerous progeny, but as the sire of trotters he was a pronounced failure. 
In examining the $2: 30$ list I find a single one of his get, before he left Long Island, with a single heat of even $2: 30$. And in examining the list of his get during the twenty-odd years of his life in Western New York, I find a single representative, with a single heat in even $2: 30$, and this one was out of a mare by old Champion, a very noted trotting progenitor. He left three sons that appear as sires: Andy Johnson, with three just inside of the 2:30 list, Henry Clay Jr., with a single one to his credit, and Cassius M. Clay, with one very fast one to his credit. This Cassius M. Clay was the sire of the famous George M. Patchen. 'Three of Henry Clay's daughters produced six 2:30 trotters, and for a time it was held that the dam of the very famous George Wilkes was a daughter of his, but that claim has not been sustained by later developments.

The name and memory of the horse Henry Clay would have been perpetuated in horse history through an attenuated line of descendants, as a fairly good horse, thongh unsuccessful as a trotting progenitor, had his bones been left to rest and rot where they were buried. Unfortunately, about the time of his death, there sprang up a most voluble enthusiast whose special mission on earth seemed to be to extol the superlative greatness of Henry Clay, and the contemptible worthlessness of "Bill Rysdyk's bull," as he designated Hambletonian. He commenced pouring his endless contributions into the columns of the breeding press and writing interminable letters to as many prominent breeders as would receive them, and all about the Clay blood being the only blood from which the trotter could be bred. These effusions were written with some skill, abounding in great prodigality of fancy and still greater economy of truth. It was astonishing how many men believed what he said and how few understood that the "old man" was in it as a "business." He had gathered up ail the cheap sons of the old horse and wanted to sell them at a handsome advance, and for a time the game won.

To keep the interest from falling off and the Clay blood moving, he secured access to the purses of two wealthy gentlemen who were possessors and admirers of Clay blood, and the bones of the horse were taken up, mounted and set up, and presented to the United States National Museum at Washington, D. C. The bones are still there, and the inscription on the pedestal when last seen was as follows: 


\section{“The progenitor of the entire family of Clay \\ Horses, and the foundation of the \\ American Trotting Horse."}

Then follow the names of the two gentlemen who presented the bones to the Museum, but as a kindness to them their names are omitted. The first clanse of the inscription is true, but the second is not true, and I very serionsly doubt whether they ever authorized the second clause. INenry Clay was not the "foundation" of anything, except the airy fabric of a fortune for our enthusiast. The scheme as an advertising dodge was well worked, and the schemer conld well exclaim, "Where now is Bill Rysdyk's bull?" In the nature of things such shams cannot last; this one had its fleeting day, and in the end the sheriff sold its worthless accumulations.

Cassius M. Clay.-This son of Henry Clay was quite a large bay horse, taking his color and much of his shape from his dam. He was foaled 1843, and his dam, Jersey Kate, was the dam of the trotting horse John Anderson. Jersey Kate was a bay, about fifteen hands three inches high, with a clean, bony head, long neck, well set up, and when in driving condition was a little high on her legs. She was used in livery work, and when a good and fast driver was wanted, Jersey Kate was always in demand. In the same stable a pair of "Canuck" ponies were kept that were driven in a delivery wagon. They were duns with white manes and tails and about fourteen and one-half hands high, quick steppers with no speed. One of them slipped his halter one night and got Jersev Kate with foal. While she was carrying this foal she became the property of Mr. Z. B. Van Wyck's father, and when she had dropped her colt and was put to farm work it was found that she was too rapid and spirited for his other horses, and he sold her to Joseph Oliver, of Brooklyn. The colt she dropped was weaned before the sale of the dam and remained in the family till he grew up. He was a grey, a little below fifteen hands, and as the boy, Z. B. Van Wyck, had broken and ridden him he got it into his head that he wonld make a trotter, so he bought him from his father for eighty dollars. He continued to improve and he sold him to Timothy $\mathrm{T}$. Jackson and he to Charles Carman. who trotted him in many races. When Mr. Oliver, then owner of Jersey Kate, saw her "catch" colt by a "Canuck" pony able to beat many of the good ones on the island, he concluded to breed her to $\mathrm{Mr}$. 
Patchen's horse, Henry Clay, and the produce was Cassius M. Clay. From her appearance, form, and especially her action, it was the universal opinion she was by Mambrino, son of Messenger, and it is probable she was, but in the absence of proof she must be classed as "breeding unknown." Had it not been for the speed of little John Anderson, there would not have been any Cassius M. Clay.

When the colt grew up, Mr. Oliver, his breeder, sold him to Mr. George M. Patchen, of Brooklyn, and he became a very popular stallion. After the death of Kemble Jackson and Long Island Black Hawk he was considered the best trotting stallion on Long Island. He was in a good many races, some of which were reported, but more that were not, and as against stallions, he was with the fastest. In temper he was disposed to be vicious and had to be watched. In form he could not be considered beantiful, but powerful. When the artist was modeling the equestrian statne of Washington that stands in Union Square, he had a great search for a horse to serve as a model, and he selected Cassius M. Clay as the best representative of majesty and power that he could find. Althongh the bronze is of heroic size, it is, no doubt, a fair representation of the ontline and structure of the horse. He died at Montgomery, Orange County, New York, July, 1854, in the same stable where Long Island Black Hawk had died four years before. The three great horses, Long Island Black Hawk, Kemble Jackson and Cassius M. Clay, died just as they entered on what should have been the period of their greatest usefulness, the first at the age of thirteen; the second at the age of nine; and the third at the age of eleven. If these horses had lived throngh the usual period of horse life, doubtless the records of performers would bear very different relations from what they do to-day, but the really great sire had not yet made his appearance.

Considering the short period Cassins M. Clay was in the stud he left a numerous progeny, but only one of them, George $\mathbf{M}$. Patchen, achieved greatness on the turf. He placed thirty-four heats in $2: 30$ or better to his credit and made a record of $2: 23 \frac{1}{2}$ in 1860, which was the fastest for any stallion of his day. This was the only one in the 2:30 list from the loins of Cassius M. Clay. Nine of his sons became the sires of eighteen trotters, and more than a dozen of his sons were named "Cassius M. Clay 
Jr.," thus leading to great confusion and oftentimes uncertainty as to identity.

Cassius iI. Chay Jr. (Neave's).-This was a brown horse foaled 1848, got by Cassius M. Clay; dam by Chancellor, son of Nambrino; grandam by Engineer, sire of Lady Suffolk. He was bred by Charles Mitchell, of Manhasset. Long Island, owned by Joseph Godwin, New York; stood in Orange County, 1852, in Dutehess, 1853, and was taken to Cincinnati that fall. He was owned by Mr. Neave, made a few seasons, broke his leg in the hands of Mr. Mickelvy, and had to be destroyed. Mr. Godwin represented this horse to me as very fast until four years old, when by an accident he was thrown into the Harlem River when hot and was stiff ever afterward. He put four of his get into the $2: 30$ list, and four of his sons got ten trotters and one pacer. His early death was esteemed a great loss, for he was better bred than most of the other sons of his sire.

Cla Y PIlot, by Cassins M. Clay (Neave's), was ont of a catch filly, whose dam was the famous Kate, the grandam of Almorit. From the noted old trotting mare Belle of Wabash, whose history will be fornd in Chapter XXX. on the investigation of pedigrees, Clay Pilot got The Moor, himself a fast trotter and a successful sire. He died at ten years old, leaving among others the famons Beantiful Bells, $2: 29 \frac{1}{2}$, that, mated with Electioneer, prodnced a remarkable family; and Sultan, 2:24, sire of the great. Stamboul, $2: 07 \frac{1}{2}$, and of thirty-eight other performers, and of thirteen prodneing sons and twenty producing danghters. The Moor founded an excellent family.

From a sister to Crabtree Bellfounder, by imported Bellfounder, Neave's Cassius M. Clay got the black stallion Harry Clay, 2:29, that was quite a reputable trotter in his day, and left. five standard performers, sixteen producing sons and twentythree producing daughters, among the latter the famous Green Mountain Maid, the dam of Electioneer.

Cassius M. Clay JR. (Strader's). - This was a handsome brown horse, foaled 1852, by the original Cassins, and his dam was. a black mare by Abdallah, that passed through the hands of A. Van Cortlandt and afterward became the property of Joseph Godwin; grandam by Lawrence's Eclipse; great-grandam the Charles Hadley mare by imported Messenger. This pedigree. has been questioned withont assigning any reasons or facts, but. as it came to me circumstantially and from unquestionable sources. 
I have no reason to doubt it. He was bred by Joseph H. Godwin, of New York, and foaled the property of Dr. Spanlding, of Greenupsburg, Kentucky. He made some seasous in the hands of Dr. Herr, of Lexington, Kentucky, was bought 1868 by R. S. Strader, and passed to General W. T. Withers, of Lexington, where he died 188\%. He was engaged in several races and made a record of $2: 35 \frac{1}{4}$. He put four in the $2: 30$ list, and he left sixteen sons that were the sires of forty-six trotters and seven pacers. His daughters have produced well, thirty-four of them having produced forty-two trotters and seven pacers. This shows him to have been a better horse than his sire and better than any of the other sons of his sire.

George M. Patchen was a large bay horse, fully sixteen hands high and heavily proportioned. He was bred by H. F. Sickles, Monmouth County, New Jersey, for Richard F. Carman, of New York, the owner of his dam. He was got by the original Cassius M. Clay, and his dam was a light chestnut mare, owned and driven on the road by Mr. Carman. As the blood and origin of this mare was for many years unknown, it is necessary to go into some particulars concerning it. From 1835 two brothers, Thomas and Richard Tone, were contractors on the streets in the northern part of New York City. Two or three years afterward Richard bought or traded for a large, strong sorrel mare to work in one of their dirt carts. It was represented that she had lost a foal shortly before and she was thin in flesh and looked coarse. When she moved out of a walk she always went into a pace, and that seemed to be her natural gait. They kept this mare at work in the cart for several years and sometimes turned her out to pasture in a small field at the foot of "Break-neck" hill, adjoining a pasture owned by the Bradhurst family. One morning a twoyear-old stallion colt, owned by Samuel Bradhurst, was found in the pasture with the big pacing mare. He had broken down the fence between the two pastures and gotten the big mare with foal. In due time she dropped a light chestnut filly, and when weaned, Thomas Tone bought this filly from his brother Richard, and at two years old commenced working her to his wagon. She had very severe treatment for so young an animal and went amiss, when Thomas sold her to James Scanlon, a blacksmith, and after a time he sold her to Richard F. Carman for a driving mare. Like her dam, when she started off she would pace, but after going some distance she would strike a trot and go very fast. 
Mr. Carman paid one hundred dollars for her and he drove her beside another that he paid fifteen hundred for, and his fast daily drives from Carmanville down to the city soon tested the respective merits of the two mares. The hundred-dollar mare could outlast the other and had to help her along toward the end of the drive. In time she was foundered and permanently stiffened and that was the reason she was sent to Mr. Sickles to be bred.

We must now look after the two-year-old colt that was the sire of this mare. Robert L. Stevens, of Hoboken, owned the famous race mare, Betsey Ransom, and with others he bred from her the two fillies, Itasca and Frolic. In 1837 these two mares were owned by Samuel Bradhurst, who manifested a sporting disposition, very much against the wishes of his father. In 1837 he bred these two mares to imported Trustee, then standing at Union Course, Long Island, and the prodnce were Head'em and Fanny Ransom. It is not known what became of Fanny Ransom, but he continued to own Head'em fờ some years and ran him in 1841 at the Union Course and beat the imported colt. Baronet, by Spencer. There seems to be no other trace of his. running or his stud services. It was in 1840 , therefore, that he jumped the fence and in 1841 that the dam of George M. Patchen was foaled. George Canavan, Mr. Bradhurst's coachman, says there were no other foals of any description bred by Mr. Bradhurst. These facts were gleaned personally and separately from Tone and Canavan, and as they complement and sustain each other, they must be accepted as the best information extant on the breeding of this great horse. His dam was by Head'em, a son of Trustee, out of a mare by American Eclipse, a grandson of Messenger, and she was a pacer and a trotter. His grandam was a pacer of unknown breeding.

In 1851 he was purchased for four hundred dollars from Mr. Sickles by John Buckley, of Bordentown, New Jersey, and a few months afterward he sold a half interest in him to Dr. Longstreet, of the same place, and he remained their joint property till 1858, when Mr. Buckley sold his half interest to Mr. Joseph Hall, of Rochester, New York. He commenced his remarkable career on the turf in 1855 and it continued till 1863 . In 1858 he was. engaged in the first race that gave him a national reputation. This was against no less a celebrity than Ethan Allen, and he was distanced, leaving Ethan with a clear title to the stallion championship. In 1860 he turned the tables on his old rival and beat 
him in straight heats in $2: 25,2: 24,2: 29$. The next week the contest was renewed and Patchen again won in straight heats, and this gave him the unchallenged right to the rank of the fastest trotting stallion in the world. His triumphs, however, were as wide as the trotting turf and not limited to sex. He was able to beat and did beat all the best but the indomitable little Flora Temple, and althongh he beat her twice, she was too fast for him and beat him many times. It is not my purpose to give a history of his achievements. It is sufficient to say he made a record of

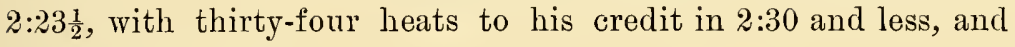
two miles in $4: 51 \frac{1}{2}$.

It cannot be said that he was a very great success in the stud as we now measure success. Four of his get were able to enter the 2:30 list, and among them was the great Lucy, with her record of $2: 18 \frac{1}{4}$. Fifteen of his sons became the sires of sixtytwo trotters and three pacers, and four of his daughters produced five trotters. It is hardly fair to compare the stud services of a horse of Patchen's generation with many of the great sons of Hambletonian, but at the same time we must not forget that Patchen was foaled the same year as Hambletonian. On the first of May, 1864, when Dan Pfifer was preparing him for the racing season then about to open, he died of a rupture, just as his sire had died.

George M. Patchen Jr. (Califormia Patchen) was a bay horse by the foregoing; dam Belle by Top Bellfounder, a grandson of imported Bellfounder, of which little is known. He was bred by Joseph Regan, Mount Holly, New Jersey, and taken to California 1862 by William Hendrickson; returned to New York 1866, sold to Messrs. Halstead, Poughkeepsie, 1867, and by them to W. A. Matthews in 1869, and taken to San Jose, California; then sold to P. A. Finnegan, of San Francisco, and died the property of J. B. Haggin, Sacramento, 188\%. He was campaigned quite extensively during the years 1866 and 1867 in the East, and carried away a good share of the winnings from the best. His best record was 2:2\% In the stud he was more successful than his sire, which may be accounted for by his more numerous progeny and his longer life. From his own loins he put ten trotters into the $2: 30$ list, and, although there was no Lucy among them, Wells Fargo made a record of $2: 18 \frac{3}{4}$; Sam Purdy, 2:201 $\frac{1}{2}$; Vanderlyn, $2: 21$, etc., showing a better average than the get of his sire. Ten of his sons got twenty-three trotters 
and two pacers, and eleven of his daughters produced twentyfive trotters and three pacers.

Several of the other sons of George M. Patchen left valuable and fast trotting progeny, and among them I will name Godfrey Patchen, with nine trotters to his eredit and his descendants breeding on; Henry B. Patchen, with seven to his eredit; Seneca Patchen, with sixteen trotters and one pacer to his credit, perhaps more than he is honestly entitled to; Wild Wagoner, with four to his credit; and Tom Patchen with three and his family transmitting speed.

In considering the founders of the Clay family, there are two or three important facts that should be kept in view, bearing upon the grwwth, or the decadence of the family. In a breeding sense this appear's to be the longest line of developed speed that we have in any of our trotting families. While we know that there were developed trotters and pacers many years before Abdallah and Andrew Jackson were foaled, we are not able to connect them in lines of descent, generation after generation. As Andrew Jackson with his developed speed stands at the head of this line, the question naturally arises, Where did he get his ability to trot? The only answer we can give is, from the danghter of Messenger that was the grandam of his sire, and from the fast pacer, Charcoal Sal, that produced him. Even if we accept the pedigree of Young Bashaw, with his Messenger grandam, when we get to Andrew Jackson we are a long way from the Messenger source of trotting speed; hence, we must look to the pacing speed of his dam-Charcoal Sal from Ohio-as the more probable source.

Andrew Jackson was bred upon the converted pacer Surrey, and produced Henry Clay, then Henry Clay was bred upon Jersey Kate, of unknown blood, but a producer of trotting speed, and prodnced Cassius M. Clay. Then Cassins M. Clay was bred upon a mare "full of Messenger blood" and produced Strader's Cassius M. Clay-the best of the Clay name by the record. Cassius M. Clay (the original) was also bred on "Dick Carman's mare" and produced the famous George M. Patchen. This Carman mare was by a rumning-bred son of Trustee. She was both a pacer and a trotter and her dam was a natural pacer. George M. Patchen was bred on the Regan mare and produced California Patchen. This mare was, practically, of unknown breeding. California Patchen was bred on Whiskey 
Jane and the produce was his best son, Sam Purdy. This mare Whiskey Jane was quite a trotter and she was undoubtedly pacing bred, but I will not here enter into the details of her origin.

We have here before us a condensed view of the trotting inheritance of the Clay and the Patchen families from Andrew Jackson to Sam Purdy, and its most remarkable feature is its poverty in recognized trotting blood. On the maternal side, the pacing habit of action seems to prevail in almost every succeeding generation. The second thought is that the tribe has not held its vantage ground of the first and the longest line of developed trotting speed. The third is that it has failed to transmit speed with uniformity, but rather sporadically. This may be accounted for by the general character and uncertainty of the maternal side, and suggests the question whether animals so bred can be relied upon to transmit with uniformity an inheritance received sporadically. From its place in the first rank as to time and popularity, this family has not been able to hold its own and it has declined to a place among the minor families of trotters and bids fair to be absorbed by tribes of stronger trotting inheritance. 


\section{CHAPTER XXV.}

AMERICAN STAR, PILOT, CHAMPION, AND NORMAN FAMILIES.

Seely's American Star-His fictitious pedigree-Breeding really unknown-A trotter of some merit-His stud career-His daughters noted brood maresConklin's American Star-Old Pacing Pilot-History and probable origin - Pilot Jr. - Pedigree-Training and races-Prepotency-Family statistics. summarized -Grinnell's Champion, son of Almack-His sons and performing descendants-Alexander's Norman and his sire, the Morse HorseSwigert and Blackwood.

OF all the hundreds of difficult and obscure pedigrees that I have undertaken to investigate and straighten out, I have given more time, labor and money to that of Seely's American Star than to any other horse. In 1867 I got his pedigree from a gentleman in Morris County, New Jersey, who claimed to have bred him, and this pedigree and the history accompanying it embracing several details that were interesting, I published it, at full length, in the Spirit of the Times. This represented the horse as a light chestnut about fifteen hands high, with star and snip and two white hind feet. He was represented to have been foaled 1837 and to be by a horse called American Star, son of Cock of the Rock, by Duroc; dam Sally Slouch by Henry, the race horse; grandam by imported Messenger. As there was no horse of that. name, so far as I knew, by Cock of the Rock, but as there was one of that name by Duroc, I wrote to know whether this was not. the breeding of the sire, and the answer came that it might have: been so.

After the appearance of this pedigree in the "Register" I was. greatly surprised that nobody believed it, and the more a horseman knew of the horse and his history the more positive he was. that it was a mistake. Several years passed away, and while I kept insisting it was true, the unbelievers became more persistent than ever in their opposition to the pedigree. The concensus of the opinions of horsemen seemed to be that the horse was part. "Canuck," and this was the view held by his owner, Edmund Seely, as long as he lived. At last the following story came to 
me from different responsible persons, all of whom were personally cognizant of the facts they related, as follows: On a certain occasion a street contractor had a foree at work, grading with shovels and carts, near the foot of 'Twenty-third Street, I think, New York City. Among the cart horses there was a Canadian stallion and a frisky, high-strung bay mare that wouldn't work kindly. One day during the noon hour, the "boys" for amusement brought this stallion and mare together and in due time the mare proved to be with foal, and she was sent over to Jersey the next spring. The foal she there dropped was Seely's American Star. When I asked to whom the mare had been sent to be taken care of, the answer came back quickly naming the same man whom I had represented as the breeder. As the contractor had no use for tho colt, as a matter of course, the keeper of the mare would take the colt for the keeping. There is nothing umnatural nor unreasonable in this story, and it bears a pretty strong resemblance to the way the dam of the famous George M. Patchen came into the world.

When the horse was four or five years old he began to show a fine trotting step and he was sold to John Blauvelt, of New York, for a driving horse. His feet not being strong, in the course of a year or two he developed a couple of quarter cracks and he was sent back to the man who raised him to be cured. In the winter of 1844-5 he was sold to Cyrus Dubois, of Ulster County, New York, who kept him in the stud the seasons of 1845, 1846 and 184\%. His advertisement for the year $184 \%$ reads as follows:

"American Star is a chestnut sorrel, eight years old on the 11th day of April, 1847, near 16 liands high, etc. . . . He was sired by the noted trotting horse Mingo, of Long Island, who was got by old Eclipse. American Star's. dam, Lady Clinton, the well-known trotting mare of New Jersey, was sired by Sir Henry."

Here we have the third pedigree of this horse, and now the question arises, Where did this pedigree come from? Cyrus Dubois is dead, but a living brother of his says this is the pedigree that Cyrus brought with the horse from New Jersey. As this same quasi-breeder was the man who delivered the horse to Dubois, the statement of the living brother comes very near proving that the first and the third of the pedigrees here given were the work of the same man. Again, in 1844, this same quasibreeder kept this horse at Warwick and New Milford, in Orange County, New York, and nobody in that region seems to have. 
ever heard of either of these pedigrees. And again, this quasibreeder wrote me that after Edmund Seely had brought the horse to Goshen he went to see him, and after fully identifying him as the same horse he had bred he gave the pedigree to Mr. Seely as he had given it to me. If this be true it is a very strange thing that Mr. Seely never seemed to know anything about it, but persisted in giving the pedigree as by a Canadian horse and out of a mare by Henry. Upon the whole, I long ago concluded that my first and earliest correspondent on the question of American Star's origin was unfortunate in having a mental organization that placed him "long" on the ideal, and "short" on the real.

IIis stud services may be summarized as follows: In 1844 he was kept at Warwick and New Milford, Orange County, New York. In 1845, 1846 and 1847 he was in Ulster County, and on the borders of Orange. In 1848 and 1849 he was at Hillsdale, Columbia County, New York. In 1850, 1851, 1852 and 1853 he was at Goshen and other points in Orange County. In 1854 he was at Elmira, New York. In 1855, it is said on good anthority, he was kept ten miles below Hudson. Others say he was at Piermont, Rockland County, that year. In 1856 he was at Mendota, Ilinois. In 185\%, 1859 and 1860 he was again in Goshen. In February, 1861, he died at Goshen, the property of Theodore Dusenbury. In Orange County his service fee ranged from ten to twenty dollars, and at last twenty-five dollars, and he was liberally patronized. An unusually large percentage of his foals were fillies, and he was essentially a brood-mare sire from the start. Opinions differ very widely among horsemen as to his capacity for speed, some maintaining that he could trot in $2: 35$ while others insisted on placing him ten seconds slower. In trying to harmonize these conflicting views it is probably safe to conclude that, when fit, which seldom occurred in his whole life, his speed was about 2:40. He was always a cripple from defective feet and limbs, and his whole progeny were more or less subject to the same troubles.

He left four trotters that barely managed to get inside the 2:30 list and eight sons that put sixteen inside of the list. But his strong point was in the producing character of his daughters. Thirty-six of these daughters left forty-five of their produce inside of $2: 30$. The disparity in the producing power of the sexes in this family is very remarkable and, in a breeding sense, very instructive. In the light of what has been developed in this 
tamily in the past fifty years, we are certainly ready to form a safe estimate of its value as a factor in the combination that goes to make up a breed of trotters. Star mares gave us a Dexter and a Nettie, and all the world thought that was the blood that was to live on and on in the new breed. But, while Hambletonian was able to get great trotters from Star mares, he was not able to get, through their attenuated trotting inheritance, sons that would be as great as himself. To his cover Star mares produced no such great sires as George Wilkes, Electioneer, Egbert, Happy Medium, and Strathmore. In the instances of Dictator and Aberdeen there was a reasonable measure of success, but all the others-and there were many of them-proved comparative failures. There is a lesson taught here that any one can interpret.

American Star (Conklin's) was a chestnut horse, foaled 1851, and got by Seely's American Star, and his dam has been variously represented, with nothing established as to her blood. He was bred by a Mr. Randall, of Orange County, and was among the first from his sire to attract attention. He came into the hands of E. K. Conklin when young, and was taken by him to Philadelphia, and was owned by him during his lifetime. $\mathrm{He}$ gave early promise of making a trotter, and from 1865 to 1868 he was on the turf, more or less, and left a record of 2:33. His stud services were confined to the region of Philadelphia till the year 1872 , when he was taken back to Orange County and died there. Three of his get entered the 2:30 list; two of his sons got one trotter each and four or five of his daughters produced one each.

At one time the name "American Star" was very popular, and quite a number of stallions were so named that were bogus; but his son Magnolia put two in the 2:30 list; one son got three trotters, and three daughters produced five performers. His son Star of Catskill got two performers, and his son King Pharaoh got four pacers and all of them fast. The family has not grown strong either in numbers or in merit. It has been carried, so far, by the influences of stronger blood, and it seems destined to complete absorption and extinction in more potent strains.

PILOT, the head of the Pilot family, was a black pacing horse, and of later years he has been generally designated as "Old Pacing Pilot." He was foaled about 1826, and nothing is known of his origin or his blood. From his make-up and appearance he was generally considered a Canadian, as was the custom at that time, 
and I think I have used this term myself in referring to the horse, but there is really no foundation for erediting him to that source. The earliest information we have of him is from an unpublished source, to the effect that he was well known to certain sporting men about Covington, Kentucky. He next appears in New Orleans, hitched to a peddler's cart, but really looking for a match as a green pacer. To promote this object, Major Dubois, a sporting man, was taken into the confidence of his owner, and it is said the horse showed him a mile in $2: 26$ with one hundred and sixty-five pounds on his back, and the major bought him for one thousand dollars. In 1832 Dubois sold him to Glasgow \& Heinsoln, a livery stable firm of Louisville, Kentucky, and he remained the property of that firm till he died, about 1855. It has been asserted with some semblanee of authority that he could trot as well as pace, but this seems to be wholly apocryphal, and on this point I am prepared to speak without hesitation or doubt. A large breeder in the vicinity of Louisville, whom I have learned to trust implicitly, through the intercourse of many years, has assured me repeatedly that he knew the horse and his master well, and that he had seen him very often, for years, that he would not trot, and that his master could not make him trot a step. On the occasion of a very deep fall of snow he was taken out to see whether that would not compel him to trot, and he went rolling and tumbling about with no more gait than a hobbled hog.

He left a numerous progeny, most of them pacers, with some trotters. We know but little of their merits, as at that period pacing and trotting races were carried on, generally, on guerrilla principles, and no records kept, except at a few of the more prominent occasions. His fastest pacer, probably, was Bear Grass, and there is a little history here that will be interesting further on. My late friend, Edmund Pearce, had always, from childhood, been a great admirer of the grand old saddle mare, Naney Taylor. She had been bred to Old Pilot and produced a colt foal, which Mr. Pearce bought when young and named him Bear Grass. This was the first piece of horseflesh he ever owned, and he didn't think he had ever owned a better one. He was amazingly fast, and could go away from all competitors, but unfortunately an accident befell him that ended his career before he reached maturity. Bear Grass had a half-sister called Nancy Pope, being the daughter of Nancy Taylor, that 
was afterward bred to Old Pilot, and she produced the famous Pilot Jr., that was the fastest trotter from the loins of the old pacer. Pilot, Jr. took the diagonal form of the trot from his dam and never paced. It is worthy of noting that Naney 'Taylor and Nancy Pope-mother and daughter-produced old Pilot's fastest pacer and fastest trotter.

Prlot JR. (Alexander's) was a grey horse, foaled 1844, "got by old Pacing Pilot; dam Nancy Pope, grandam Nancy Taylor." This is the literal version of his pedigree as given by his first owners and as given by W. J. Bradley and others who had him in charge year after year in the region of Lexington, according to the different advertisements, and no change ever appeared till the horse was bought and taken to Woodburn Farm. 'Then, for the first time we learned that Nancy Pope was got by Havoc, thoroughbred son of Sir Charles, and that Nancy 'Taylor was got by Alfred, an imported horse. This was not the work of Mr. R. A. Alexander, an honorable man, but the work of the professional pedigree manufacturer, who exploited his inventive skill very widely through the early catalogues of that great establishment. As a matter of historic fact, Pilot Jr.'s dam was Nancy Pope, but nothing is known of her sire, and Nancy Pope was out of Nancy Taylor, about whose pedigree nothing whatever is known. But as the subject of Pilot Jr.'s pedigree is exhanstively treated in Chapter XXIX., the details need not be further dealt with here.

The training of Pilot Jr. commenced when he was five years old, and after the close of his stud seasons he was kept at it, in a moderate way, for several years, and it is said he never manifested any inclination to strike a pace. He was engaged in some races, and his advertisement claims he won several, giving the names of horses he had beaten, but the time made seems to be carefully avoided. He could probably trot in about 2:50 or a little better. He and all his family, so far as I can learn, were willful and hard to manage in their training, and were, therefore, in danger of becoming unreliable, but they were fast for their day, and dead game campaigners. There is one particular in which this horse seemed to surpass nearly all others and that was in his power to eliminate the rumning instinct and to plant the trotting instinct in his progeny from rumning-bred mares. It is doubtless true that many of those mares, so classed, were only running bred on paper; but the fact still remains, and it is 
supported by a sufficient number of authentic instances, to justify the conclusion that his potency in this direction was remarkable.

During the troublous times of the war many of his early progeny were lost or destroyed, but from his own loins he put eight. performers in the 2:30 list and others not far away. Six of his sons became the sires of forty-one performers, and eighteen of his danghters produced forty-one performers. Although the official records do not show that Pilot Jr. got any pacers, it is nevertheless true that he did get some very fast ones. But when we get past the period when the pacer was considered a bastard and kept out of sight, we meet with some astonishing facts. As. an example, take Miss Russell, the greatest of all the Pilots. First, she produced a pacer that was changed to the diagonal instead of the lateral step, and then stood for years as the champion trotter of the world. Second, her son Nutwood has placed twenty pacers in the 2:30 list; her son Mambrino Russell has placed five there, and her son Lord Russell has placed five there. This brief and hasty exhibit of what the descendants of Miss Russell are doing seems to upset ail the laws of heredity, provided always that her dam was a thoroughbred mare. The evidence: that the breeding of this reputed "thoroughbred" mare is wholly unknown is considered in another part of this volume.

In a few odd instances, in the male lines of descent from Pilot. Jr., the trotting and pacing instinct seem to be transmitted in stronger measure than in any of the other minor families, but the day of its submersion is not far distant. The survival of the fittest is the law of Nature.

Champion, the head of the Champion family, was a beantiful golden chestnut, sixteen hands high and without marks. He was bred by George Raynor, of Huntington, Long Island, and was foaled 1842. He was gọt by Almack, son of Mambrino, by Messenger; dam Spirit, by Engineer Second, son of Engineer, by Messenger, and sire of the famous Lady Suffolk. This is enough Messenger blood to please the most fastidious, but I think there was still more beyond the Engineer mare. When eighteen months old this colt showed phenomenal speed when led behind a sulky, and when three years old he was driven a full mile to harness in 3:05, a rate of speed which, at that time had never been equaled by a colt of that age. This made him "champion" as a three-yearold and William T. Porter named him Champion. After this performance Mr. John Sniffin, a merchant of Brooklyn, bought. 
him, and in June, 1846, Mr. William R. Grimell paid two thonsand six hundred dollars for him and took him to Cayuga County, New York. After keeping Champion in that comnty till the close of the season of $1849, \mathrm{Mr}$. Grinnell concluded to sell the horse, as in all that time he had not covered one hundred mares. Mr. Grinnell complained that the farmers did not appreciate the horse, and many of them failed to pay for his services. But the fanlt was not all on the part of the farmers, for the price, to them, was very high, and he was a very uncertain foal getter.

In April, 1850, he was sent to New York and kept in the stable of Mr. Van Cott, on the Harlem road. He had been very badly handled, and Mr. Van Cott says he had been abused and illtreated, and when he came to his place he was as vicious and savage as a wild beast. The horse was kept there for sale, and in his daily exercise Mr. Van Cott says he could "show' considerably better than 2:40 at any time." In 1851 he was sent over to Jersey and kept for public use at a fee of fifty dollars, by Samuel Taylor, at Newmarket, Metuchen, Boundbrook and Millstone. After making three or four seasons in the region of Boundbrook, in the year 1854, Mr. Grinnell, who still owned him, sold him to Mr. James Harkness, of St. Louis, Missouri, for about seven hundred and ifty dollars. On reaching St. Louis he proved to be as dangerous as ever, and no man dared to go into his stall, except Mr. Harkness and one assistant. In 1858 Mr. Harkness sold him to Thomas T. Smith, of Independence, Missouri, for one thousand dollars. He was there stolen by "jayhawkers" and taken to Leavenworth, Kansas, where he made two seasons and died 1864. Although he lived to be old, he left comparatively few colts, but a large proportion of that few were of excellent quality and many of them trotters.

Champion (Scobey's also known as King's Champion) was the best son of Grinnell's Champion, the son of Almack, and he came out of a mare called Bird, by Redbird, son of Billy Duroc. He was foaled 1849, and was bred by Jesse M. Davis, then of Cayuga County, New York, and sold to David King, of Northville, New York, and by him in 1861 to Mr. Kellogg, of Battle Creek, Michigan. He was repurchased by Messrs. Backus, Scobey and Burlew in August, 1865, and soon became the property of Mr. C. Scobey and died his in May, 1874. It has been claimed this horse had speed and a record of $2: 42$ in 1857 , but I have no data to determine how fast he was. From his own loins he put eight per- 
formers in the 2:30 list, two of which were phenomenaily fast, although their records do not show it. Here I allude to Nettie Burlew and Sorrel Dapper, more generally known as "The Auburn Horse." The latter was a long, leggy, light chestnut, with a tremendons stride, and Hiram Woodruff did not hesitate to say he was a faster horse than Dexter. This Champion was a sire of excellent quality, although but a few of his progeny were developed. He left six sons that were the sires of forty-fonr trotters, and seven daughters that produced nine performers.

CHAMPION (GOODNG's) was a bright bay horse with black points, standing fifteen and three-quarter hands high. He was got by Scobey's Champion, dam the trotting mare Cynthia, by Bartlett's Turk, son of Weddle's imported Turk; grandam Fanny, by Scobey's Black Prince; great-grandam Bett, by Rockplanter, son of Duroc; great-great-grandam Kate, represented to be a. Messenger mare. He was foaled 1853, and was bred by Almeron Ott, Cayuga County, New York, and traded to Mr. Stearns, from. whom he passed to his late owners, T. W. and W. Gooding, Ontario County, New York. He died June, 1883. This horse was pedaled about in Seneca Connty at a fee of five dollars, and had a very light patronage among the farmers. At list he was sold, with difficulty, at Canandaigua, for three hundred dollars to the Messrs. Gooding, and he bronght them a handsome income as. long as he lived. As his reputation as a sire of speed spread abroad, the quality of the mares brought to him improved, and among them were some with good trotting inheritance. Of his. progeny, seventeen entered the $2: 30$ list, the fastest in $2: 21$, and they were good campaigners. It is a remarkable fact that only one of his sons proved himself a trotting sire, and he left but a single representative. On the female side of the house he was more successful, for six of his daughters produced seven performers.

CHARLEY B. was a bay horse, sixteen hands high, and was bred by Charles Burlew, of Union Springs, New York. He was foaled 1869, and was got by Scobey's Champion, son of Champion, by Almack, and proved himself the best son of his sire. He was out of a mare well known as "Old Jane" that was the dam of Myrtle with a record of $2: 25 \frac{1}{2}$. Several pedigrees have been provided for this mare that did not prove reliable, and they were all careful to endow her with plenty of Messenger blood. After searching for the facts through some years, the only version of it. 
that seemed to be worthy of credence showed that her sire was a horse called Magnum Bonum and there it ended. In his racing career this horse was started sometimes under the name of "Lark." He has six heats to his credit in $2: 30$ and better, and a record of $2: 25$. From his own loins he has twenty-two trotters in the 2:30 list. Considering the respectable number this horse shows in the 2:30 list, his great nervous energy, his vigorous constitution, and the number of years he was liberally patronized in the stud, it is a most notable fact that he has but two sons that are producers. Six of his danghters have produced. As a propagator of speed in the coming generations, this horse seems to be even a greater failure than his half-brother, Gooding's Champion.

Night Hawk was a chestnut son of Grinnell's Champion. He was bred by John S. Van Kirk, of Newark, New Jersey, and his dam was by Sherman's Young Eclipse, son of American Eclipse. He was foaled 1855-6. In $1862 \mathrm{Mr}$. Van Kirk took him to Kalamazoo, Michigan, thence to Paw Paw in 187\%, and in 1879 he was returned to Kalamazoo, owned by A. T. Tuthill. He was something of a trotter, and had a record of $2: 36$, under the name of Champion, when he was controlled by Mr. D. B. IIibbard, I think. He was shown at a State fair, held at Lansing, on a poor half-mile track, it is said, and trotted a mile in $2: 31 \frac{1}{4}$, and for this performance he received a piece of plate from the society testifying to this fact. He has but two representatives in the 2:30 list, and three of his sons have five trotters to their credit, while six of his daughters have produced seven performers. He lived to an old age.

The merits and demerits of this family are very marked. The head of it seems to have possesssed great nerve force and an unmistakable instinct to trot, but he was irritable and vicious in his. temper. Both these qualities-the desirable and the undesirable alike-he seems to have transmitted to his offspring. I have seen Gooding's Champion, and he had the temper and disposition of his grandsire. It appears that the original Champion was a shy breeder, and I am disposed to think he inherited this infirmity from his sire, Almack, and whether the inability of his sons and grandsons to get sires of trotters may be accounted for from this canse would be a very difficult question to answer. There are several others of this family, East and West, that have single representatives in the $2: 30$ list, that $I$ have not enumerated, bit. from the statistics, as they now stand, it seems probable that 
whatever is good in this family will be swallowed up in other tribes that are more prepotent and positive in the trotting instinct.

Noryan, or The Morse Honse,-This horse was originally named "Norman," but in later years he was more generally and widely known as 'The Morse Horse. His family is not large, but some of his descendants have shown great speed and great racing qualities. His origin and breeding as given below have resulted from a wide and laborious correspondence, and, I think, can be accepted as trustworthy. He was bred by James McNitt, of Hartford, Washington County, New York, who was a large. farmer and distiller. He was foaled 1834, got by European; dam Beck, by Harris' Hambletonian; grandam Mozza, by Peacock, son of imported Messenger. He was fifteen and threequarter hands high, a dark iron grey when young, and became white with age. He had plenty of bone, was handsome and a natural trotter. Something of the history of the animals entering into this pedigree is important and I will try to give it in as brief form as possible.

The breeder, $\mathrm{Mr}$. McNitt, was in the habit of visiting Montreal at least once a year with the products of his farm and his distillery. On one occasion he brought back three horses with him, two "Canucks" and a very elegant grey horse that he called European, that was evidently somewhat advanced in years and was a little knee-sprung from the effects of hard driving. The two "Canucks" were fast trotters, but European could beat either of them. Mr. McNitt represented that this horse had been imported into Canada from Normandy in France and doubtless he believed it, but there were none of the French, characteristics about him. He was purchased in Montreal about 1829 and died in Washington County about 1836. The dam and grandam of the Morse Horse were bred by Mr. Joseph T. Mills, of the town of Argyle, in Washington County. Beck, the dam, was a bright bay mare about sixteen hands high. At weaning time Mr. Mills sold her to Robert Stewart, of Greenwich, and at three years old he sold her to Mr. MeNitt. She 'was got by Harris' Hambletonian, when he was kept by John Williams, Jr. This is established quite satisfactorily and circumstantially. Mozza, the dam of Beck, was a chestnut mare, without marks, and was got by Peacock, a son of imported Messenger that was owned by Mr. 
Emerson in Saratoga County and was afterward burned up in his stable. This son of Messenger, called Peacock, was entirely new to me then $\mathrm{I}$ was investigating this pedigree in $18 \% 6$ and $\mathrm{I}$ was. disposed to reject it, but Mr. Mills certainly had a horse of that name and he represented him to be a son of Messenger, and he probably was, but I do not know that he was so bred.

Mr. MeNitt sold the colt at three years old to Martin Stover, who lived on his place, for eighty dollars; the next year Stover sold him to James Mills. In 1840 Mills sold him to Mr. Tefft. and Zack Adams, and they sold him not long after to Philip Allen and Calvin Morse, of White Creek. Mr. Morse had him a number of years and when old sold him to Mr. Grant, and he died at Spiegletown in Renssalaer County, New York. He was a very perfect, natural trotter, and his speed was developed to some extent. In August, 1847 or 1848, Mr. Morse put him into the hands of John Case, of Saratoga Springs, the driver of Lady Moscow, to prepare him for the State Fair, at which he expected to meet the famons Black Hawk. Mr. J. L. D. Eyclesheimer, a. very intelligent gentleman, formerly of the region of Saratoga, wrote that while the horse was in Case's hands, he, with Mr. Morse, timed him a full mile in $2: 40 \frac{1}{2}$. At the State Fair he was all out of fix and Black Hawk beat him in the second and third heats. He won the first heat in $2: 52 \frac{1}{2}$. In the rivalries between stallions at agricultural fairs, however, is a very poor place to look for fair work and fair judgment, either from the stand or from the spectators.

General Taylor was a grey horse, foaled 1847 , got by the Morse Horse, dam the trotting mare Flora, a New York road mare of unknown breeding. He was bred by the brothers Eyclesheimer, then of Pittstown, New York. He was taken to Janesville, Wisconsin, 1850, and thence to California, 1854, where he trotted thirty miles against time in one hour forty-seven minutes and fifty-nine seconds. He also beat New York a ten-mile race

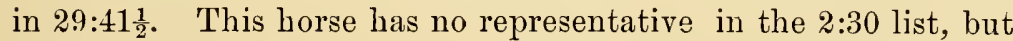
his blood has always been very highly esteemed in California for its speed, but more especially for its game qualities. Honest Ance was another son of the Morse Horse that did a great deal of racing in California, although he bas no record in the 2:30 list. He was a chestnut geiding, and was managed by the notorious Jim Eoff, who was always ready to win or to lose as the: money seemed to suggest. 
Norman (Alexa nder's) was a brown horse, foaled about 1846, got by the Morse Horse, son of European; dam one of a pair of brown mares purchased by John N. Slocum of Samuel Slocum, a Quaker of Leroy, Jefferson County, New York, and represented to be by Magnum Bonum. These mares passed to Mr. Russell, and from him to Titcomb \& Waldron, who bred the better of the two to the Morse Horse, and the produce was Alexander's Norman. This colt passed through several hands till he reached Henry L. Barker, of Clinton, New York, and abont 1860, he sold him to the late R. A. Alexander, of Woodburn Farm, Kentucky. He died $18 \% 8$. The original version of this pedigree, as put upon Mr. Alexander and advertised by him, as were many others, was wholly fictitious on the side of the dam. He was not retained long at Woodburn Farm. He does not seem to have been a uniform transmitter of speed, but when it did appear it was apt to to be of a high order. He left but two representatives in the 2:30 list, Lula, 2:15, with fifty-six heats, and May Queen, 2:20, with twenty-five heats. He left four sons that became the sires of fifty-eight performers and thirteen daughters that produced nineteen performers. Such sons as Swigert and Blackwood speak well for his transmitting powers.

Swigert was a brown horse, foaled 1866, got by Alexander's Norman,'son of the Morse Horse; dam Blandina, by Mambrino Chief; grandam the Burch Mare, by Brown Pilot, son of Copper Bottom, pacer. He was bred at Woodburn Farm, Kentucky, and when young became the property of Richard Richards, of Racine, Wisconsin, where he remained many years and passed to F. J. Ayres, of Burlington, Wisconsin. As a prepotent sire this horse stands high in the list of great horses. This may be accounted for in great part by the speed-producing qualities which he inherited from his dam. I am not informed as to the amount of training he may have had, nor of the rate of speed he nray have been able to show. He placed forty-four trotters and two pacers in the 2:30 list. Thirty-three of his sons became the sires of sixty-one trotters and fourteen pacers. Twenty-three of his danghters produced twenty-one trotters and six pacers. From the number of his sons that have already shown their ability to get trotters, it is fair to presume that his name will be perpetuated. He died in 1892.

BLACK WOOD was a black horse, foaled 1866, got by Alexander's Norman, son of the Morse Horse; dam by Mambrino Chief; 
grandam a fast trotting dun mare, brought from Ohio, pedigree unknown. He was bred by D. Swigert, Spring Station, Kentucky, and foaled the property of Andrew Steele, of Scott County, Kentucky. At five years old he was sold to John W. Conley, and by him to Harrison Durkee, of New York, and was afterward owned at Ticonderoga, New York. He made a record of $2: 31$ when three years old, which, at that day, was considered phenomenal for a colt of that age. His opportunities in the stud were not of the best, but nine of his progeny entered the 2:30 list; eleven of his sons got twenty performets, and twenty-five of his daughters produced thirty-seven performers. 


\title{
CHAPTER XXVI.
}

\author{
THE BLUE BULL AND OTHER MINOR FAMILIES.
}

Blue Bull, the once leading sire-His lineage and history-His family rankThe Cadmus family-Pocahontas-Smuggler-Tom Rolfe--Young Rolfe and Nelson-The Tom Hal family-The various Tom Hals-Brown HalThe Kentucky Hunters-Flora Temple-Edwin Forrest-The Drew Horse and his descendants-The Hiatogas.

BuUe Bulu, the real head of this family, was one of the most remarkable horses that this or any other country has produced. He was a light chestnut, just a little over fifteen hands high, with one hind pastern white and a star in his forehead. He was strongly built and his limbs were excellent, except perhaps a little light just below the knee. He was foaled 1858 and died July 11, 1880. He was bred by Elijah Stone, of Stone's Crossing, Johnson County, Indiana. For a time he was owned by Lewis Loder and Daniel Dorrel, before he passed into the hands of James. Wilson, of Rushville, Indiana, who kept him many years and whose property he died. At one time he stood at the head of the list of all trotting sires in the world, and yet he could not trot a step himself, but he could pace amazingly fast, and it was claimed he could pace a quarter in thirty seconds. He was the first and only horse that was ever able to snatch the scepter from the great Hambletonian family, but after a brief reign of a couple of years he had to surrender it again to that family, where, from present appearances, it is destined to remain.

The breeding of this horse is very obscure, and after we have told all that is known about it we will not have given very much information. He was got by a large dun pacing horse that was. known as Pruden's Blue Bull, and he by a blue roan horse known as Merring's Blue Bull, or Ohio Farmer. The latter was taken to Butler County, Ohio, from Chester County, Pennsylvania, and it has been said, without confirmation, that he was of Chester Ball stock. He was a large, strong farm horse, a natural pacer, as were many of his progeny, and dun and roan colors were very prevalent among them. He died the property of Mr. Mer- 
ring abont 1843. ' His son, Pruden's Blue Bull, was of a dun color and a natural pacer, but his dam has never been traced. He was large, strong, rather coarse, and had some reputation as a fast pacer, for a horse of his size, and his color was quite prevalent among his progeny. He was bred in Butler County, Ohio, and abont 1853 was taken to Boone County, Kentucky. In 1861 he became the property of G. B. Loder, of the same county, and in 1863 he traded him to James Pruden, of Elizabethtown, Onio.

The pedigree of Wilson's Blne Bull, the liead of the family on the side of the dam, is equally unsatisfactory so far as the blood elements are concerned. We know that this dam was called Queen, that she was bred by Elijah Stone, and that she was got by a horse called Young Selim, but we know nothing about Young Selim. We also know that the dam of Queen was called Bet, and that Mr. Stone bought her of Mr. Sedan, and there all knowledge ends. Since the days of the great racing progenitor, Godolphin Arabian, of whose origin and blood nobody, living or dead, had a single shadow of knowledge, down to the day of Wilson's Blue Bull, no horse equally obscure in his inheritance has ever been able to prove himself really 'great as a progenitor of speed.

In the days of Blue Bull's rising fame, and indeed till his death, there was developed such a condition of muddled morals as one seldom meets with in a lifetime. Whenever a horse of nuknown breeding, in any one of three or four States, began to show some spee $\vec{u}$, his owner at once called him a Blue Bull, and if he went fast enough to enter the $2: 30$ list, he was at once credited to Blue Bull by his friends, and they were all ready to fight for it. If the books of Blue Bull's services did not show that the dam of the "unknown" had ever been within a hundred miles of that horse, it was all the worse for the books. With a large number of men interested financially in Blue Bull stock, ready to claim everything in sight and anxiously looking for something more to appear, it became a most laborious task to keep this class of frauds out of the records. Another canse of dissent and dissatisfaction among the "boomers" of Blue Bull blood was the final discovery of the breeder in Elijah Stone and that there was no "thoroughbred" blood in his veins. At that time a very large majority of the horsemen of the country honestly believed that all speed, whether at the pace or the trot, must come from the gallop. It was not the truth, therefore, that these people were 
looking for, but something to support that ignorant and stupid theory.

A careful study of the statistics of this horse will teach a valuable lesson. He put fifty-six trotters into the 2:30 list, varying in speed from $2: 30$ to $2: 17 \frac{1}{4}$, and five of this number in $2: 20$ or better. He also got four pacers with records from $2: 24 \frac{1}{2}$ to $2: 16 \frac{1}{4}$. It thus appears that this horse, without any known trotting blood, got fifty-four trotters to four pacers, which clearly shows that an inheritance of speed at the pace may be transmitted at the trot, as well as the pace. When we come to his progeny, we find that forty-seven of his sons have to their credit one hundred and four performers, making an average of a little more than two each. These sons are all past maturity and some of them dead of old age, and not one of them has ever reached mediocrity in merit as a sire. He left seventy-seven daughters that have produced one hundred and seven performers, and if we had time to trace out these performers we would find that they were generally by strains of blood stronger and better than the blood of Blue Bull. While, therefore, we can acknowledge Blue Bull's greatness as a getter of speed from his own loins, we must acknowledge that his sons and daughters as the producers of speed are failures. It is possible that some representative of the tribe may spring up and restore the prestige of the family, but as the source is sporadic and as the country is filled up with trotting elements that are more prepotent, it is more likely to be swallowed up and lose its family identity.

Cadrus (known as Irons' Cadmus) was the head of a very small family that occasionally developed phenomenal speed either at the pace or the trot. He was a chestnut horse nearly sixteen hands high, strong and active, with four white feet. He was foaled 1840 and was got by Cadmus, the thoroughbred son of American Eclipse, and was bred by Goldsmith Coffein, Red Lion, Warren County, Ohio. His dam was a chestuut pacing mare that Mr. Coffein got in a trade, from a traveler, and nothing was ever known of her breeding. A pedigree was shaped up for her that seemed to make her thoroughbred and her son took a prize on it once, as a thoroughbred, but it was wholly untrue. Mr. John Irons of the same county became joint owner in this horse, and he became widely known as "Irons' Cadmus." To close this partnership he was sold, 1850, and taken to Richmond, Indiana; then 
to George Shepher, of Butler County, Ohio, and next to a company in Wheeling, West Virginia, where he made two seasons, and was sold to St. Louis, Missouri, and died without further service, in 1858. From birth he was double-gaited, inclining more to the pace than to the trot. From unskillful handling his gaits became mixed up so that it was never known whether he might have been able to show any speed or not.

Pocahontas, the pacer, was the most distinguished of his get, and if there were no others of merit from her sire this one alone would be sufficient to command a place in the volume. She was a large, strong chestnut mare with four white legs, a white face, and a splotch of white on her belly. She was bred by John C. Dine, of Butler County, Ohio, and was foaled 184\%. Her dam was a very strong mare got by Probasco's Big Shakespeare, a horse over sixteen hands and very heavily proportioned, a very valuabie farm horse with good action, many of whose tribe were disposed to pace. The grandam was also a descendant of Valerius, that was brought to Ohio from New Jersey. Pocahontas passed through several hands at very low prices and was used for all kinds of heavy farming and hauling until she reached the hands of L. D. Woodmansee, when her speed began to be developed. She was soon matehed against Ben Higdon, the fast pacing son of Abdallah, and beat him in 2:32. In December, 1853, she was taken to New Orleans, and beat several celebrities there early the next spring. Before her last race it was discovered she was in foal, and some two months afterward she dropped Tom Rolfe. In the autumn of 1854 she was brought to the Union Course, Long Island, and it was not till June, 1855, that her owners and managers could get a match with her. At last Hero, the famous son of Harris' IIambletonian, met her for two thousand dollars, he to harness and she to wagon. In the first heat she distanced the gelding in $2: 17 \frac{1}{2}$, and it was maintained by her driver that she could have gone at least five seconds faster, if it had been necessary. For racing purposes she was no longer of any value, for nothing would start against her. She was then sold and became a brood mare at Boston, Massachusetts, and produced the sires 'Tom Rolfe and Strideway, Pocahontas, 2:263. and the dams of May Morning, 2:30, and Nancy, 2:231 , thus ranking as a great brood mare.

Shanghai Mary, that has become so famous as the dam of Green Mountain Maid, one of the very greatest of all brood 
mares, was probably a daughter of this same horse, Cadmus. This: mare, Shanghai Mary, was a trotter of speed, not far from a $2: 30$ gait, and she won some races, but she was hot-headed and unreliable. Notwithstanding continuous searches, for years, her origin remained a profound mystery, until of recent date certain facts point to Mr. Coffein as her breeder and Cadmus as her sire. This has not been established historically, but when the circumstances are understood and taken in connection with the internal evidences, which are amazingly strong, and had been pointed out. and applied to this sire long before the recent developments, there remains hardly a moral doubt that she was by Cadmus. The fact that this mare is the maternal grandam of Electioneer, the greatest of all trotting sires to date, makes her pedigree a matter of special interest, and for details of the various investigations the reader is referred to Wallace's Monthly, and to Chapter XXIX. of this volume.

Pocahontas seems to have produced but five foals that reached maturity: 1855, Tom Rolfe, of which hereafter; 1859, Young Pocahontas, by Ethan Allen, a very fast trotter; 1860, May Queen, by Ethan Allen; 1861, May Day, by Miles Standish; 1863 bay colt Strideway, by Black Hawk Telegraph. This was a very fast and promising young horse, and doubtless would have stood among the fastest stallions of his day, but he died on the very eve of his public appearance on the trotting turf.

Tom RoLfe had a checkered existence from his conception. His dam, Pocahontas, was bred to Pugh's Aratus, by Abraham Pierce, her then owner, May 10, 1853, and ten days afterward she was sold without her new owner's knowing she had been bred. He was thus carried in his mother's womb, during her training and through her racing campaign in New Orleans, until a little over two months of the time he was dropped. During most of this period those handling the mare did not know she had been bred, and hence the story that Tom was a "catch" colt. He was a bay, abont fifteen hands two inches high, and came to his speed with very little handling. In private trials, it is said, he had frequently shown a mile in $2: 23$. While on exhibition in a small ring at Dayton, Ohio, he met with an accident, from which he was ever afterward a cripple. In this condition however, he afterward made a record in $2: 33 \frac{1}{2}$. His sire, Pugh's Aratus, was a large, handsome farm horse, sixteen hands two inches high, and weighing one thonsand three hundred pounds. He was got by 
Phares' Aratus, ont of a fast pacing mare. There is no evidence whatever going to show that Phare's Aratus was a son of Aratus by Director. The type of the family did not indicate the possession of any running blood. Tom Rolfe put four trotters and three pacers, all with fast records, into the 2:30 list, and three of his sons left twenty-nine performers. In the latter years of his life he was sold by Mr. Woodmansee to Mr. Wesley P. Balch, of Boston, and died 18\%\%.

Young Rolfe was the best son of Tom Rolfe. He was a bay, foaled 18\%6, and came out of Judith, by Draco, son of Young Morrill, and she out of Lady Balch, by Rising Sun. He was bred by Wesley P. Balch, passed to C. H. Nelson, of Maine, then back to John Sheppard of Boston, and died 1884, when only eight years old. He was one of the best horses of his day, as a race horse, and his early death was universally considered a great loss to the breeding interests of the country. He has to his credit nine representative trotters in the $2: 30$ list.

NeLson, the great son of Young Rolfe, was bred and owned by C. H. Nelson, Waterville, Maine. He is a bay horse, foaled 1882, and out of Gretchen, the daughter of Gideon, by Hambletonian, 10 , and she ont of the fast trotting mare Kate, by Vermont Black Hawk. This horse Gideon, the son of Hambletonian, was, like his sire, very strongly inbred to old Messenger, tracing through mares by Young Engineer and Young Commander, both grandsons of Messenger, to the William Hunter mare, that was by Messenger himself. When the pedigree of Nelson is compared with the pedigree of Hambletonian, according to the rules of arithmetic, it may be found to contain nearly or quite as much Messenger blood as Hambletonian possessed, but, unfortunately, we know nothing of the trotting capacity of the intervening mares. If we had a "One Eye" and a "Charles Kent Mare" coming next to the William Hunter mare, we would have much greater expectations. But, as it is, when we consider the superlative capacity of Nelson himself, with his record of 2:09, and his nineteen trotters and seven pacers already to his credit, it is probable he will found a large and valuable family.

Through his son Blanco, sire of Smuggler, we have another notable line to Irons' Cadmus. Smuggler was in his day the champion trotting stallion, taking a record of $2: 15 \frac{1}{4}$ when owned by Colonel Russell, of Boston, and driven by Charles Marvin, who after long and painstaking efforts converted him from his 
natural gait, the pace, to the trot. Wearing twenty-four ounces on each fore-foot to keep him at the trot, Smuggler defeated all the best horses of his day, including Goldsmith Maid. He was by Blanco, out of a pacing mare of unknown blood. As might have been expected, he failed to found a great family, though fourteen of his get are standard performers, and twelve of his sons and seventeen of his daughters have produced thirty-eight performers.

'Tox HaL.-The original Tom Hal was taken to Kentucky, as. early, probably, as 18:4, and as was the custom in those days, he was called a Canadian, like all other pacing horses. The tradition is that Dr. Boswell got him in Philadelphia and rode him home to Lexington, Kentucky. Another statement is that he was taken to Kentucky by John T. Mason, and this statement appears in the advertisement of the horse for the year 1828. As the horse was in the hands of William I. Breckenridge that year, and as his advertisement was practically a contemporaneous record, we must give the preference to the Mason representation. He was a roan horse, as I understand, a little over fifteen hands high, stont and stylish. He was very smooth and pleasant in his gait and a very fast pacer. He was for some time in the hands of Captain West, of Georgetown, Kentucky, and then passed to Benjamin N. Shropshire, of Harrison County, and after some years he died his property.

BALD Stockings, also known as Lail's Tom Hal, was a chestnut horse with a bald face and four white legs. He was foaled early in the "forties," and was got by the original Tom Hal, and his dam was by Chinn's Copperbottom. He was bred by Higgins Chinn, Harrison County, kept for a time by John Lncas, and owned by Mr. Lail, of the same county. He was one of the prominent links between the old and the new, and was a fast. pacer.

Sorrel Tou was a son of Bald Stockings (Lail's Tom Hal) and bore the same color and markings. He was bred and owned by John Shawhan, of Harrison County, Kentucky. His dam was a grey mare from Ohio, of unknown breeding. He was kept at Falmouth, Indiana, the seasons of 1857 and 1858, and was very widely known in that region as "Shawhan's Tom Hal." He was quite a large horse, and to take the description as given him, "he could pace like the wind." He was then taken back to Kentucky, leaving a multitude of good colts behind him, among. 
them the famous pacing gelding, Hoosier Tom, $2: 19 \frac{1}{2}$. One of his Indiana sons passed into the hands of William Gray, of Rush County, Indiana, and became known as Gray's 'Tom Hal. Nothing is known of the dam of this horse. He was the sire of Little Gipsey, trotter, $2: 2 \%$, and Limber Jack, pacer, $2: 18 \frac{1}{2}$, besides six daughters that produced nine performers.

About 1863-4 Mr. Shropshire, Jr., a son of the owner of the original Tom Hal, brought a little roan Tom Hal horse to Rush. ville, Indiana, where he stood a number of years and was known as Shropshire's Tom Hal. This horse was probably by Lail's Tom Hal, as he was too young to be by the original of the name. He was a fast pacer, but nothing is known of his progeny or history. The locating of this Indiana branch of the family is of particular interest, for it shows a concentration of pacing blood that was doubtless a strong reinforcement to Blue Bull.

ToM HaL (KitTrell's) was a large bay horse and a pacer, bought by Major M. B. Kittrell in 1850 of Simeon Kirtly, near Centerville, Bourbon County, Kentucky, and taken to Middle Tennessee. His sire was represented to have been a large pacing bay horse that was brought from Canada, thereby implying that he was the original of the name, brought to Kentucky. While it is possible that the original Mason horse may have been the sire of Major Kittrell's horse, the size and color of that horse do not correspond with what has been accepted as facts. It is altogether more probable that the sire of the Tennessee horse was a son of the original Tom Hal, as the roan color seems to be strongly fixed in all branches of the family.

Tom HaL JR. (Gibson's) was a roan horse, foaled 1860. Got by Kittrell's Tom Hal; dam (bred by John Leonard), by Adam's Stump, pacer; grandam said to be by Cummings' Whip, pacer. Bred by H. C. Saunders, Nashville, Tennessee; kept a number of years by T. D. Moore, Petersburg, Tennessee, afterward owned by Polk Bros. and Major Campbell Brown, of Springhill, Tennessee. Adams' Stump was a roan horse and a fast pacer and he was not only the sire of Julia Johnson, the dam of this horse, but also of the dam of Bonesetter. He died of old age, July, 1890. The strong concentration of pacing blood in his veins gave him unusual power in trinsmitting his inherited habit of action. He put fourteen representatives in the 2:30 list, and what is unprecedented, they are all pacers.

Brows HAL is a brown hor'se, as his name indicates, foaled 
1879, got by Gibson's Tom Hal; dam the pacing mare Lizzie, the dam of the pacer Little Brown Jug, by John Netherland, son of Henry Hal; grandam Blackie, by John Hal, son of John Eaton; great-grandam Old March, by Young Conqueror. Bred by R. H. Moore, Culleoka, Tennessee, passed to M. C. Campbell and Campbell Brown, Springhill, Tennessee. Here we have a still stronger intensification of the pacing instinct, for this horse not only has a pacing record himself of $2: 12 \frac{1}{2}$, but he put twenty of his progeny into the standard list, and all of them pacers. It is not shown by the Year Book that either this horse or his sire has any trotters to his eredit, but it can hardly be doubted that some of their progeny took naturally to the diagonal trot, and not showing encouraging speed, were never developed.

If the question were asked, "What is to result from this intensely pacing family?"' it wonld be very difficult to frame a satisfactory answer. At present this family shows all the vigor of youth in its new development, but, judging by others that have come and gone, it too, in its tnrn, will be submerged in more prepotent strains, that will more nearly meet the wants of their master's. The pacer has been lifted from obscurity and made the equal of the trotter as a race horse; his blood has contribnted to an unknown extent in giving speed to the trotter, but he must be as good a horse for all uses as the trotter, or nobody will want him.

Kentuck H Huter, the head of the family bearing this namo that, at one time, was very prominent in Central New York, was foaled 1822, and was bred by Louis Sherrill of New Hartford, New York, and was got by Watkins' Highlander. His dam was a mare bought from a conple of dealers who were passing throngh New Hartford with some six or seven horses for sale, and they represented this mare to have been brought from Kentucky. On this representation she was called "a Kentucky mare." She was a fine saddle mare and for this reason she was used chiefly for that service. From her superiority as a saddler, I think it is safe to conclude she was a pacer and could go the saddle gaits. Kentucky Hunter was a chestnut horse, a little above medinm size. Mr. Sherrill sold him when young to Messrs. Bagg and Goodrich who kept him two years and sold him to William Fergnson, of Oriskany Falls, New York, and Mr. Ferguson continued to own him till he died in 1838 .

During the lifetime of this horse the pacing gait was considered 
an evidence of bad breeding, and this prejudice has continued for many years. The saddle was going out of use and wheels were coming in. After Flora Temple electrified the trotting world, writers had a great deal to say of her origin and family, but no one ever intimated that her grandsire was a pacer. From sources that I have no reason to doubt, I have been informed he was not only a pacer, but a fast pacer. This habit of action was not popular with breeders, and Mr. Ferguson kept it concealed as much as possible. When the pacer, Oneida Chief, from his own loins, was beating Lady Suffolk, three miles in $7: 44$, to saddle, and many of the other cracks of that day, his sire was dead and nothing was then to be made by proclaiming from the housetops that Oneida Chief was by old Kentucky Hunter.

Very little is known of Watkins' Highlander, the sire of this horse. He was brought to Whitestown, New York, 1821, by Julius Watkins, from Connecticut. Some of the older men who knew the horse insist that Mr. Watkins represented him to be by a son of imported Messenger, and out of Nancy Dawson by imported Brown Highlander. This is possible, indeed probable, but it is not established.

Bogus Hunter was one of the younger sons of Kentucky Hunter. He was a chestnut horse of good size and came out of a mare by Bogus. But little is known of this horse, and that little is rendered still more uncertain by the unreliable character of his owners, the Loomis brothers, of Sangerfield, New York. It is certain, however, that a horse owned by the Loomises and called by this name was the sire of the famous world beater, Flora Temple. This fact rests upon the testimony of $\mathrm{Mr}$. Samuel Welch, a reputable and trustworthy man who owned the dam of Flora and had her coupled with this horse, under his own eye.

EDWIN ForRest, the most prominent representative of, this family, was a large and rather loosely made bay horse, foaled 1851, got by Young Bay Kentucky Hunter, son of Bay Kentucky Hunter, that was by the original Kentucky Hunter. His dam, Doll, bred by Mrs. Crane, of Whitestown, Oneida County, New York, was by Watkins' Highlander; grandam a chestnut mare owned in the Crane family, by Black River Messenger, son of Ogden's Messenger. The identification of this grandson of imported Messenger was secured after the appearance of the fifth volume of the "Register." This same mare, Doll, the next year 
produced Wamock's Highland Messenger, that was taken to Kentucky, and was a valuable element in the road-horse blood of that State. Edwin Forrest was bred by Barnes Davis, Oneida, Madison County; owned two years by H. L. Barker, of Clinton, New York, sold to Marens Downing, of Kentucky, by him to Woodburn Farm, and after a time he passed to a company at Keokuk, Iowa, and then to George W. Ferguson, of Marshalltown, Iowa, where he was burned up in $18 \% 4$.

It has been said this horse was a pacer and converted to a trotter, but this does not seem to be sustained by the facts. He was shown as a three-year-old at the Oneida County Fair, and he was then a square natural trotter and was considered very fast, for he was fully able to distance all the other colts of his age. The story of his being a pacer probably grew out of the fact that there was a strong pacing strain in the family, as the original Kentucky Hunter was undoubtedly a pacer. Many of the Kentucky Hunters were speedy travelers and a few of them were fast. Black River Messenger was a horse of vory wide local reputation for the superiority of his progeny as rapid travelers. The mion of the Messenger blood with pacing blood produced excellent results in this, as well as in thonsands of other cases. As was the common usage before the establishment of the "Trotting Register," this horse was advertised with two fictitious crosses added to his pedigree-- his grandam was given as by Duroc, and his great-grandam as by imported Messenger. Only two from his loins were able to enter the $2: 30$ list; six of his sons got seven performers and twelve of his daughters produced fifteen trotters.

Snenandonh (afterward called Kentucky Hunter) was a bay horse, foaled 1854, got by Brokenlegged Hunter, son of the original Kentucky Hunter; dam not elearly established. He was bred by Mr. Sykes, near Canastota, and passed through several hands to Henry Dewey, of Morrisville, New York, who trotted him in a number of races in Central New York and then took him to California, where he was kept in the stud a number of years under the name of Kentucky Hunter, and died there $18 \% 1$. He got one trotter; one son that left two performers and seven daughters that left nine performers.

Drew Horse, commonly cailed "Old Drew," was a brown bay horse, foaled 1842, and was about fifteen and one-quarter hands high and well-formed. He was bred, or rather raised, by Hiram 
Drew, then of Exeter, Maine, who kept him all his life. The story of his supposed sire was one of those woakly devised fictions, so common in that day, and especially where the Canadian border could be made effective in rounding it out. To show that the mysterious colt that became the sire of Drew Horse was "thoronghbred," the stereotyped "British Army officer" is made available, for the hundredth time, as having brought a mare from England in foal to a thoroughbred horse, the foal was dropped and at three years old he was traded by the aforesaid "officer" to the party that bronght the colt to Maine. Unfortumately for the story, the party who made the trade and the story had a bad memory, and sometimes he located the trade at St. Johns and sometimes at Fredericton, New Brunswick. But the fiction served its generation and was not exposed till long after the Drew Horse was dead. The facts in the matter seem to be simply these: a stallion colt was running in a pasture adjoining Mr. Drew's pasture, and that colt got over the fence, was found with Mr. Drew's mare, and in due time she dropped the colt known as the "Drew Horse." The fence-breaker was soon after made a gelding and sold, and nothing is known of him, either before or after this escapade. The dam of the Drew Horse was a bay mare about fifteen and one-half hands high, foaled about 1836, and bred by Mark Pease, of Jackson, Maine. Her sire was called Sir Henry and was represented to be by a son of American Eclipse, that was taken to Maine from Connecticnt by Dr. Brewster and sold to General F. W. Lander. She was known as Grace Darling and afterward as Boston Girl. She was on the turf and was quite a trotter, and it is claimed she made a record of 2:3\%, and her dam was Lady Jane by Winthrop Messenger. While I don't know what the inheritance of this horse was on the side of his sire, I do know that he had a trotting inheritance on the side of his dam. He lived till 1866 and then had to be destroyed on account of a broken leg.

This horse was, never trained, and it is not known what he might have been able to do as a trotter. He put two of his sons in the 2:30 list, Dirigo and General McClellan. Of his sons, two put five trotters and three pacers in the list, and of his daughters left six representatives there. Besides these he left a number of others with records a little short of the limit of speed, and many without records that were fast and very game roadsters.

Dirigo, at first called George B. McClellan, under which name 
he made his record, was the best son of Drew Horse. He was a brown horse, and in appearance much like his sire. He was foaled 1856 and came ont of a mare that has not been traced, but. was doubtless a pacing mare. He was bred by Horace McKinney, Monroe, Maine, and passed to David Quimby, of Corimna, Maine, and died 1854. He made his record of 2:29 in a single heat and never was on the track again. Four trotters and two pacers by him entered the 2:30 list. Two of his sons became the sires of three trotters, and five of his danghters each produced a performer. He left others with and without records that were fast and stylish drivers.

Hiray Drew, at first called Bay Morgan, was a son of Old Drew, and his dam was a small bay mare, owned near Bangor and said to be of Morgan blood. This horse was on the turf some years and was engaged in some locally important contests, but never was able to make himself standard either by his own or the performances of his progeny. His best performance, I believe, was $2: 31 \frac{1}{2}$.

Winthrop was a bay horse, foaled 1864, got by Drew Horse; dam by the Eton IIorse and grandam by Stone or Simpson's Mes senger. He was bred by E. J. Greene, Newport, Maine; taken to California 18\%, and there owned by Judge W. E. Greens and L. E. Yates, of Stockton. It does not appear that he ever was. trained, and consequently has no recurd. His opportunities, probably, were not very great, but whether or not, he was not snccessful in the stud. He left one trotter and one pacer and the dams of one trotter and one pacer.

This family never was large, and its popularity was up and down just as a few individuals might be successful or unsuccessful on the turf. To start with, it had a very weak inheritance of trotting instinct, and that weakness did not strengthen in succeeding generations. Of late years it has failed to maintain itself as a trotting family, and is now practically out of the reckoning of trotters.

Hintoga, generally known as Rice's Hiatoga, was a bay pacing horse and was bred in Rockingham County, Virginia, and taken to Fairfield County, Ohio, by Edward Rice, some time about 1836. He har the reputation of being a fast pacer, and was sold to William Shiruo, of the same county, and by him to William Munger, in whose possession he died. He was got by a horse: 
known in Virginia as Hiatoga, and also American Hiatoga, but nothing is known of the blood of his dam. Nothing is known of his speed or his progeny except through the two sons here given.

Hiatoga, generally designated as "Old 'logue," was got by Rice's Hiatoga; dam by Thunderbolt, grandam by Black or Bold Rover. He was foaled $18+3$ and was bred by David W. Brown, of Perry County, Ohio; sold 1849 to John Joseph, Kirkersville, Ohio, where he made some seasons and was sold 1855 to Alvah Perry, Lancaster, where he remained till 1863 , and was sold to Harvey Wilson, and two years later to William MeDonald, Columbus, Obio, where he died 18\%1. This horse left excellent stock and many of them fast pacers, but they never cut much figure on the turf.

Hiatoga (Hanley's) was a bay pacing horse of good size and quality and was very popnlar as a sire. He was foaled 1849, got by Rice's Hiatoga; dam an elegant bay mare sixteen hands high and represented to be of "Sir Peter and Eclipse blood." 'This mare was formeriy given as by Firetail, but the present rendering, whatever it may mean, comes from sources with opportunities to know. He was bred by John Bright, of Fairfield County, sold to Joseph Watt, and taken to Harrison Connty and then to Jefferson County, and sold to James Davis Tweed. He next passed through the hands of David Rittenhouse and Moses Hanley, of Hopedale, Ohio, and after three or four years in the stud Mr. Hanley sold him to David Rittenhouse, John Wiley and Samuel Hanley for two thousand five hundred dollars, and he died the property of Mr. Rittenhouse near Hopedale, Ohio, 1858. Two of his progeny entered the 2:30 list; three of his sons left thirteen performers, and three daughters prodnced five.

Hiatoga (ScotT's) was a bay pacer foaled 1858, got by Hanley's Hiatoga; dam by Blind Tuckahoe (pacer); grandam by Consul. This horse was quite fast and paced nuder the name of 'Tuscarawas Chief. He was the best of the family and was bred and owned by Samuel Scott, East Springfieid, Jefferson County, Ohio. He put five trotters and four pacers in the 2:30 list; seven of his sons and seventeen of his daughters were producers.

The Hiatoga family seems to have no trotting inheritance except from the pacer. It is a useful family and still has vitality. 


\section{CHAPTER XXVII.}

THE BLACK HAWK OR MORGAN FAMILY.

Characteristics of the Morgans-History of the original Morgan-The fabled pedigree-The true Briton theory-Justin Morgan's breeding hopelessly unknown-Sherman Morgan-Black Hawk-His disputed paternity-His. dam called a Narragansett-Ethan Allen-His great beanty, speed and popularity-The Flying Morgan claim baseless-His dam of unknown. blood-His great race with Dexter-Daniel Lambert, the only successful sire of the Black Hawk line.

Fifty years ago there was no family of horses so popular as the "Morgans." They were carried into all parts of the country at high prices and they gave their purchasers general satisfaction. They were small, perhaps not averaging over fourteen and a half hands high, but compact, trappy movers and had most. excellent dispositions. Many of them were ideal roadsters, where speed was not in great demand, for they were kindly, tractable and always on their courage. Many of them carried themselves in excellent style, and notwithstanding their diminutive size, it is not probable we will ever again see a better tribe of every-day, family horses. In all their outline and in every lineament they were the very opposite of the blood horse, and when bred on any strain outside of their own family, they almost universally failed to impress their own characteristics on their progeny. This failure I observed with deep regret more'than forty years ago. The step conld be extended and the speed increased by crossing with the long striders, but in securing this we lost. the Morgan. In advance of their general distribution they had the misfortune to be heralded as great trotters, and in this respect, at least, they failed of meeting expectations. They went, largely, into the hands of inexperienced men, who knew nothing about how to cultivate speed, and the little, short, quick steps of their new trotters gave. them all the sensations of going fast, without the danger incident to rapid traveling. In regard to the matter of speed, through the overzealous and not too conseientious. 
editors and others to say nothing of the advertisements of those who had them for sale, they suffered greatly by too mueh praise. The result is that the original type has been extinguished, and it is doubtful whether a fair speeimen eould be found, even among the mountains of New England. Next to the injury which the family sustained from the exaggerated claims of speed put forward by its too sanguine friends, there was another and even greater injury from the asburd and foolish claims made for his blood. It is impossible to make a thinking and sensible man believe that a little hairy-legged "nubbin" of a pony, weighing eight hundred and fifty pounds, hired for fifteen dollars a year to drag logs together in a elearing, at which employment he was a great suecess, had the blood of the race horse in his veins. This was always a stumbling block to my immature enthusiasm for the Morgan horse. From an experience of a great many years and from the developments of horse history during that time, I find the "stumbling block" no longer worries me, for it has rotted away and disappeared. Although the family has eeased to exist as a factor in eurrent horse history, it had a history in the past; and, as a historian, I must consider its origin as well as the deeds it has aceomplished or failed to accomplish.

Mr. Justin Morgan, the eentral figure in this investigation, was born in West Springfield, 1747, where he married and lived till 1788, when he removed to Randolph, Vermont, where he died, Mareh, 1798. He was a reputable eitizen, fairly well educated for his time, and taught school for a living. He owned a house and lot in his native town, where he kept a wayside house of entertainment, and during the early summer he usually had a stallion to keep on the shares. In the spring of 1785 he had eharge of the horse True Briton, or Beautiful Bay, and I will here add that three years later, John Morgan, Jr., had charge of the same horse at Springfield, for the seasons of $1 \% 88$ and $1 \% 89$. This John Morgan; Jr , removed to Lima, New York, late in 1790 or early in 1791. Justin had sold his place in West Springfield to Abner Morgan, on long payments, and in the summer of 1795 he came back to West Springfield to eollect some money that was due him, presumably on the priee of his former home, but he failed to get money and took two eolts instead. One was a three-year-old gelding and the other was a two-year-old bay eolt, entire. He led the three-year-old with a halter and the twoyear-old followed. The date of this visit to the old home is the 
key to the main question to be settled, and it is fixed by Justin Morgan, Jr., then a lad of the right age to remember such things, and by Soloman Steele and Judge Griswold, who fix the date in the late summer of 1395. The horse was sold and resold and sold again, as a foal of 1793 , and that date never left him till he died in 18\%1. I look upon this date as perfectly immovable, and every attempt that has been made to overthrow it has not been based on any reasonable evidence, nor prompted by a desire to get at the truth, but only to make a fictitious sire a possibility. This was the original Morgan Horse, and this date was thoronghly fixed by Linsley, without knowing that it upset the pedigree he had labored so hard to establish. After a lapse of fifty years an attempt was made to fix up a pedigree for the "Original Morgan Horse," claiming that he was got by True Briton or Beautiful Bay-represented to be a great race horse, stolen from the great race horse man, Colonel De Lancey, in the Revolutionary War. I must, therefore, consider, briefly, this part of the fiction.

First-As a starting point in the pedigree, it is assumed that the race-horse in question was stolen, during the War of the Revolution, from James De Lancey, perhaps the largest and most widely known of all the colonial horsemen of that day. He was the first man to import race horses into this colony, and his name and the fame of his horses were discussed everywhere. He was very rich, in politics a Tory, and on the eve of hostilities he sold out every horse he owned, of whatever description, went back to England and never returned. This disposes of the false assumption that the sire of the original Morgan horse was stolen from him.

Second-There was another James De Lancey, cousin to the preceding, and not a rich man, who was colonel of a body of Tory cavalry operating in Westchester County from 17\% to the close of the war in 1782. It is not known whether he ever owned a race horse in his life, but it is certain he was a dashing fighter, and at the head of the cowboys he was known to the inhabitants of all that region. His name is not to be found anywhere in connection with horses. He bore, in full, the same name as the distinguished horseman, and was mistaken for him, although he was on the other side of the ocean.

Third-It is claimed that "one Smith" stole the horse in question from Colonel De Lancey and sold him to Mr. Ward, of Hartford, Comecticut, who kept him a few years and sold him 
to Selah Norton, of the same place, and remained his till he died. Who was this "one Smith", and where did be belong? Where is the evidence that this "one Smith" stole a horse from Colonel De Lancey?

Fourth-In the New York Packet, then published at Fishkill, under date of October 19, 1780, we find the following: "Last week Lieutenant Wright Carpenter and two others went down to Colonel James De Lancey's quarters and lay in wait for his appearance. He accordingly came and having tied his horse at the door, went into the house; upon which Carpenter seized the horse and mounted. When De Lancey discovered him, he im mediately alarmed his men, who pursued him to White Plains, but in vain," etc., etc. This Lieutenant Carpenter was a dashing young fellow and was promoted next month to the position of first lientenant in Captain Lyons' company, of the Second Regiment of New York Militia, of Westchester County, and still commanded by Colonel Thomas. This is the man who stole the horse, this is the contemporaneous evidence of it, and "one Smith" had nothing to do with it.

In these four points we have what may be considered the first chapter of this investigation and, as will be readily seen, each of them must be fatal to the pretentious claim that has been maintained for about a hundred years. Avoiding all circumlocution, I think it is safe to say that this so-called pedigree did not originate this side of Hartford. The Second Regiment of New York Militia, called "The Skinners," was made up of Westchester" County men, and as Colonel De Lancey had been sheriff of that county, everybody knew him and knew that he was not the race horse James. We must, therefore, look further on for the time when and the person by whom this pedigree was manufactured.

In 1784 this hor'se was advertised at Lanesboro, Massachusetts, under the name of Beautiful Bay, and no attempt was made to give a pedigree or origin of the horse.

In 1785 he was at West Springfield, Massachusetts, in charge of Justin Morgan, still called Beautiful Bay, and still no pedigree.

In $1 \% 88$ and $1 \% 89$ he was in charge of John Morgan, Jr., of Springfield, Massachusetts, and here, for the first time, he is designated as "the famous full-blooded English horse, called True Briton or Beautiful Bay," but no pedigree is given.

In 1791 he was advertised at East Hartford, Connecticut, by 
his owner, Selah Norton, and his pedigree is here given for the first time as follows: "True Briton, or Beautiful Bay, got by imported Traveler, dam De Lancey's racer." After advertising the horse for seven years without a pedigree, at last Mr. Selah Norton manufactures one and gives it over his own signature.

In 1793 he is again called Beautiful Bay, but no pedigree, at South Hadley, Massachusetts.

In 1794 and 1795 he was kept at Ashfield, Massachusetts, by Mr. Norton himself, and ealled Traveler, and his pedigree is again given in amended form as follows: "Sired by the famous old Traveler, imported from Ireland, dam Colonel De Lancey's imported racer."

This is the last trace we have of the horse Beantiful Bay, for that seems to be his honest name, and now I must ask some questions. These advertisements cover a period of eleven years and they are worthy of careful study. From 1784 to 1791 there is no attempt at giving any pedigree at all. With the exception of three seasons he seems to have been let, probably on shares, to different keepers, in different parts of the country. From first to last Selah Norton seems to have been his owner. If he had received the pedigree, and the romantic story of his theft, from "one Smith," as claimed, is it conceivable that he would have concealed that story from the public when it would have added so much to the patronage of his horse? How does it come that not a single man having this stallion in charge, except Selah Norton himself, ever gave his pedigree? What prompted Selah Norton to withdraw the horse from public service, in Hartford, immediately after he first gave his pedigree? Was it because everybody there knew it was a frand? When the horse was taken to South Hadley in 1793, why did his keeper there refuse to accept either the name True Briton or the new pedigree? It will be observed he was advertised there simply as Beantiful Bay and no pedigree given. The next two years we find him at Ashfield, Massachnsetts, to which point it would seem his owner had removed from Hartford. For some reason that can be better imagined than explained, the names Beautiful Bay and True Briton are there dropped and he is rechristened as 'Traveler. 'To this change of name the old pedigree is attached, with a very important ehange in that also, as foliows: "Sired by famons old Traveler, imported from Ireland, dam Colonel De Lancey's imported racer." These three words, "imported from Ireland,", 
are very important in two particulars, for they not only knock out the "featherheads" who have been always maintaining that the imported Traveler meant Lloyd's Traveler of New Jersey, son of Morton's Traveler, that was imported from Yorkshire into Virginia about 1750 , but it convicts Selah Norton of inventing this pedigree, for there was no such horse brought from Ireland. It is certainly unnecessary to say another word in illustration of Selah Norton's character. When we study these advertisements it becomes as clear as the light of day that nobody believed him or the story that "one Smith" stole the horse from Colonel De Lancey. The crimes of horse stealing and desertion wore exceedingly common during the period of the revolution and it is quite possible that "one Smith" may have stolen a horse out of somebody's stable and sold him to Mr. Ward or Mr. Norton as the same horse that Lieutenant Carpenter stole from Colonel De Lancey, but neither "one Smith" nor "one Norton" knew anything more about his pedigree than he did about the man in the moon, and I will here end the second chapter of this investigation.

I am clearly of the opinion that Justin Morgan was an honest man and that he would not tell a lie, even if he knew it might. accrue to his present and personal advantage. He was poor, feeble in health, and had hard scuffling to get along. As a means of livelihood, in part at least, it seems to have been his business for a good many years to keep stallions on shares for different owners. As late as 1795 he had a horse from Hartford, Connecticut, called Figure, to which we will refer later on. In 1788 he sold his little place in West Springfield, Massachusetts, and removed to Randolph, Vermont, where he died in March, 1798 In the autumn of 1795 he visited West Springfieid again, for the purpose of collecting some money that was still due him there, probably some deferred payments of his former home, and as he was not able to get the money he took two horses in lieu thereof. One was a three-year-old gelding, and the other was a two-year-old bay colt, entire. He led the gelding beside the horse he was riding and the colt followed all the way. The evidence that fixes the date of this trip in the antumn of 1795 and the age of the colt that followed seems to me to be completely bomb-proof. This evidence not only embraces the recollections of Justin Morgan's neighbors, but when he died the colt, in 1\%93, was sold by his administrators as a five-year-old. In all the- 
changes of ownership that took place through his life and at his death, in 1821, he was represented as foaled in 1793 . He died from the effects of a kick that was neglected, and not from old age.

The only serions attempt that has been made to controvert the date of 1793 was that made in the name of John Morgan, of Lima, New York, in 1842, he being then eiglity years old, in the Albany Cultivator. Unfortnnately the editor fails to publish the letter he professes to have received from John Morgan and only gives his construction of it, which any child knows is no evidence at all. The editor represents him to say "that the two-year-old stud which he (Justin) took with him to Vermont was sired by a horse owned by Selah Norton, of East Hartford, Connecticut, called 'True Briton or Beantifnl Bay." Jnstin Morgan removed to Randolph, Vermont, in the spring of 1788, and this John Morgan removed to Lima, New York, abont February, 1790. They were not brothers, but distant relatives. If John means to say that Justin "took with him" when he removed to Vermont a two-year-old son of Beautiful Bay, that colt must have been foaled in 1786, which wonld make him twelve years old instead of five when he was sold upon the death of his owner, and thirty-six years old instead of twenty-nine when he died from a kick. Now, if we concede that Jnstin did take with him a two-year-old son of Beautiful Bay, the dates render it impossible that he should have been the founder of the Morgan horse family and we have no trace of him whatever.

Another anthority has very recently come to the front, and in order to avoid the difficnlty of dates and still retain the possibility of the horse being by Beantiful Bay, insists that he was foaled 1789 and bred by Justin Morgan himself. Under this new light he was foaled in Vermont and didn't have to travel there at all. He insists further that he named the horse Figure and kept him in the stnd till his death in March, 1798, when the horse was sold and his name changed to Justin Morgan. It is true that Justin Norgan, still seeking to make a living, kept a stallion two or three years owned in Hartford, Comnecticnt, and advertised him as "the famous horse Figure, from Hartford." Now, if this horse was foaled the property of Justin Morgan and owned by him as long as he lived, why should he advertise him as "from Hartford?" All these efforts to fix dates by shifting abont so as to make it possible for the bogus stolen horse to come in as a sire, 
have already received more attention than their importance demands and I will therefore call this the close of the third chapter.

There are several incidents comnected with the life of the colt of 1793 that fixed his identity and age upon the recollections of the neighbors and friends of Justin Morgan. Solomon Steele, Evans, Rice and others who knew the colt well, all agree that the colt followed his companion and playmate from West Springfield to Randolph in the antumn of 1795 and that he was not then halter broken. 'They all agree that Evans hired him for fifteen dollars a year to draw logs in his clearing, in the place of a yoke of oxen. They all agree that Justin Morgan died in March, 1\%98, and that the colt was then sold as a five-year-old. The death was an immovable date fixer around which everything in connection with these events must be determined. And when the horse died in 1821 nobody had ever doubted that he was foaled 1793.

Justin Morgan, Jr., was in his tenth year when the colt was brought home, and he was twelve years old when his father died. In 1842 Justin Morgan, Jr., in a communication to the Albany Cultivator, says: "One was a three-year-old gelding colt, which he led; and the other a two-year-old stud colt, which followed all the way from Springfield. The said two-year-old colt was the same that has since been known all over New England by the name of the Morgan Horse. I know that my father always, while he lived, called him a Dutch horse. I have a perfect recollection of the horse when my father owned him and afterward, and well remember that my father always spoke of him as of the best. blood."

When he made these clean-cut and emphatic declarations Justin Morgan, Jr., was fifty-six years old, and it has been suggested that he was too young, at the time, to have remembered about the colt. 'This is a grave mistake, for farmer's boys remember a thousand things better then than they ever do afterward. I don't think that my own memory is remarkable, but today, at over three score and ten, I can, with the utmost distinctness, recall the names, color, markings, size, peculiarities and, in some cases, the history of most of the horses that were on the farm when I was eight years old. I can, therefore, have no hesitation in accepting Justin Morgan's evidence on account of his youthfulness, at the time of which he speaks.

Did Justin Morgan know what he was saying when he "always, while he lived, called his horse a Dutch horse?" And did he 
understand the historical meaning of his words when "he always spoke of him as of the best blood?" To answer these questions we must make some reference to history. The Dutch horses were a breed wholly distinct from the horses of the other colonies. The colony of New Netherlands (New York) received its supply from Utrecht, in Holland, commencing in 1624 and a few years following. In forty years they had so increased that the colony was well supplied. These horses were about fourteen hands and one inch high, which was about one hand higher than the horses supplied to the English colonies. They were not only higher, but they had more bone and muscle, and, I think, more shapely necks. In every respect they were better, except that they were not so good for the saddle, for the reason, as I think, that they were not pacers. The standard that determined their superiority was the higher prices at whick they were bought and sold, over the New England horses, as shown by the official reports of the colony. When the colony passed under British rule, the first governor immediately established a race course on Hempstead Plains, Long Island, and there in 1665 the first organized race in this country took place. This was long before the English race horse had reached the character of a breed, and a round hundred years before the first representative of that breed reached New York. The horses that ran at Hempstead Plains were undoubtedly Dutch horses, for the inhabitants of New York and Long Island attended these annual meetings in great numbers, and as they were nearly all Dutch they would not have gone a stone's throw to see an English horse run. These annual race meetings were kept up a great many years by the successive governors.

In 1635 two shiploads of Dutch horses, from the same quarter, chiefly mares, reached Salem, Massachusetts, and were sold at prices enormously high as compared with the prices of those sent from England to the same colony. These two shiploads added materially to the average size of the horses of the colony of Massachusetts Bay, as shown by statistics, as well as the other colonies getting their foundation stock from that source. We may safely conclude, I think, that some of the descendants of these shiploads were taken to the valley of the Connecticut when Hartford was planted, for we not infrequently meet with the term "Dutch horse" in the old prints of that valley. Besides this source the valley of the Hudson was full of them. They 
retained their distinctive appellation till about the beginning of this century.

Mr. O. W. Cook, of Springfield, Massachusetts, did a great deal of fundamental investigation on the origin of this family, away back in 1878-9, etc., and I am under special obligations to him for being the first man to open my eyes to the great confidence game that has been played for a hundred years, and all originating in the fabulous story of "one Smith." Among other important things he mearths an advertisement of Young Bulrock that was adrertised to stand at Springfield, 1792, as follows: "Young Bulrock is a horse of the Dutch breed, of a large size, and a bright bay color, etc." In speaking of his pedigree, Mr. Cook most pithily remarks: "In view of the three-fold concurrence of time and place and breed, it fits into the vacuum in the Morgan's lineage as a fragment of pottery fits into its complement." There was another horse advertised in Springfield that year, but he had neither name nor breed and in color he was gray. The advertisement of Young Bulrock fits in time, fits in color and fits in breed; and thus removes all reasonable doubt that he was the sire of the original Morgan horse. This is the reason why Justin Morgan "always, while he lived, called him a Dutch horse;" and the little scrap of history given above will show why he always spoke of him as "of the best blood." $\mathrm{He}$ was right in the former and he was right in the latter declaration. It is not possible, at this day, to prove, technically, these matters of a hundred years ago, but after considering all the facts in the case, we must conclude that they are satisfying to the human understanding, and that Justin Morgan told the truth.

For the past fifty or sixty years the breeding of the original Morgan horse has been a subject of apparently unending controversy. The real facts concerning his origin, however, have never been bronght to light and fully developed until within the last few years, and it is probable that nothing of material value will ever be added to the foregoing tracing. We hare found from contemporaneous history that Lieutenant Wright Carpenter stole a horse from Colonel James De Lancey and was successful in carrying him into the camp of the patriots at Fishkill, and that is all we know about that particular horse. After the war was over it is stated that "one Smith" sold a horse to Mr. Ward, of Hartford, and represented that he had stolen the horse from Colonel De Lancey, and Mr. Ward sold that horse to Selah Nor- 
ton, who seems to have owned him as long as he lived. It must. be accepted as true that Lientenant Carpenter captured a horse from Colonel De Lancey, but we cannot accept it as true that. this was the same horse owned by Norton. We must first know how and where "one Smith" got him. Norton had this horse and advertised him in different parts of the country for public service seven or eight years before the romance of his history and pedigree was given to the world. As this romance would have been a grand feature in an advertisement of a stallion, Mr. Norton was too slow in evolving it, and when he did bring it out. nobody believed it. At that period many portions of New England abounded in stallions with bogus pedigrees and histories, and if we judge Norton by his acts in giving his horse three different names at different times and places, we must conclude he was ready to conceal or invent anything that would add to his horse's popularity and patronage.

Shermax Morgan.- - In his history of the Morgan Horse, Mr. Linsley names this and three or four other sons of the original, that were kept for stock purposes, but none of them seems to have attained any eminence, except Sherman. As he never made: any pretensions to being a trotter, he would have been forgotten long ago, had it not been for the lucky circumstances that he. was the sire of Black Ilawk, and thus his name has been preserved. He was scant fourteen hands high, with heavy body on short legs, and carried his head well up. He was a chestnut and foaled about 1809. There has always been a doubt in the minds: of many as to whether he was the sire of Black Hawk, but that. question will be considered when we reach that horse. His dam was a very handsome mare, brought from Naragansett, a pacer, and a very desirable saddle mare. In the trotting "Register," threerepresentations are given as to the breeding of this mare, namely, that she was of the Spanish breed; that she was an imported English mare; and that she was brought from Virginia on account of her beauty and speed. The first claim seemed to have. the best historical support, and besides this she was brought from Providence, Rhode Island, and was a very fine pacer. The theory was then prevalent that the Narragansett pacers were of the "Spanish breed." The elimination of that foolish notion from the history of the pacers does not affect the plain statement. that she was a Narragansett pacer. It is not known that this 
mare ever produced anything else, either by the original Morgan or by any other horse.

BLACK Hawk.-As his name indicates, this horse was a jet black, and was something over fifteen hancis high. He was foaled 1833, was got by Sherman Morgan, and was bred by Benjamin Kelly, of Durham, New Hampshire. As the question of his paternity has been the subject of a great deal of bitter controversy, continued through many years, and participated in by men of intelligence, on both sides, I must give the history, as I understand it. Mr. Kelly kept a tavern at Durham and Mr. Bellows, the owner of Sherman Morgan, made this house one of his points of stopping as he traveled his horse, in his circuit of the season. Along with Sherman he had another horse called Paddy, black as a raven, that did some service at seven dollars, while the price for Sherman was fourteen dollars. On one of his visits, Mr. Kelly's black mare, called "Old Narragansett", was bred to Sherman and proved to be in foal. Not long after this Mr. Kelly sold the mare to Mr. Shade Twombly, living about two miles from Durham, and a part of the agreement was that if the mare should prove to be with foal, Mr. Twombly was to pay for the services of the horse. The next spring the mare dropped a fine black horse colt, and Mr. Twombly claimed the colt was by Paddy and not by Sherman, hence, he refused to pay fourteen dollars for the services of Sherman, but was willing to pay seven dollars for the services of Paddy. This resulted in a lawsuit in which it was proved that Sherman was the sire of the colt, and Mr. Twombly's estate had to pay the money. The colt was kept by Mr. Twombly's heirs, at pasture in Greenland, New Hampshire, till he was about two years old, when he was sold at auction to Albert Mathes, of Durham, for seventy dollars and from him he passed to Benjamin Thurston, of Lowell, for two hundred dollars. In Thurston's hands he became quite noted, locally, as a trotter, and in 1844 he became the property of David Hill, of Bridport, Vermont, where he became altogether the most popular stallion in the United States, and died there November, 1856. He was the first horse to command one hundred dollars for his services; and many of the great mares of the country were sent to his embrace, among them the world-renowned Lady Suffolk, but unfortunately she failed to produce.

To understand why the fight against the Sherman Morgan paternity of this horse should have been so bitter and so per- 
sistent, we must eonsider the condition of the horse interests in New England at that time. When Black Hawk eame to the front the Morgans of the real Morgan type had already attained some degree of popularity and here eame a horse overtopping them all, with no trace of the Morgan type about him. He and his family attracted the attention of purehasers and threw a shadow of doubt over the little punchy, hairy-legged fellows that knocked out many a sale. Besides this, it was a serious and real question in the minds of a great many honest and intelligent. men, as to whether Sherman Morgan, so typical of his family, conld possibly have been the sire of a horse so eompletely outside of the family, not only in appearance and formation, but in his ability to trot. In $184 \%$, Black Hawk was pitted against the Morse Horse, mile heats, best two in three, at the Saratoga State Fair. He won the first heat in $2: 50 \frac{1}{2}$ and the seeond in $2: 43 \frac{1}{2}$. He was then fourteen years old and this was very fast, for a stallion of that period. It is but justice to say that the Morse Horse eontingent elaimed that Black Hawk was set back in the first heat for rumning and that the heat was given to the Morse Horse in 2:521 and that the seeond and third heats were won by Black Hawk in 2:541 and 2:56. Just what the truth is in this disagreement I am not able to determine. As we look at this horse, so distinet from all his tribe; and as we consider the very indistinct knowledge of the laws of generation as held by the masses in that day, we eannot wonder that the paternity was so vehemently disputed. Neither can we wonder, as his descendants pass in review before us, that this dispute has never been settled to the satisfaction of the eontending parties. 'The old Morgan type never reappears in the descendants of this family.

But, we must not forget that we have eonsidered only half of the inheritance of this horse. He had a dam as well as a sire. To that half of his pedigree we must now give some attention. The story of the "half-bred English mare, brought from New Brunswiek" has had its day and we may as well lay it aside as a. humbug. Mr. Allen W. Thomson, of Woodstock, Vermont, has brought out the facts with regard to this mare in a form that is very elear and satisfactory. In $18 \% 6 \mathrm{Mr}$. Thomson visited Albany for the purpose of examining everything that had been said in The Country Gentleman newspaper tonehing on the paternity of Black Hawk. In this search for the sire he would neessarily find many referenees to the dam and among these referenees he 
was greatly surprised to find she had been described as "a pacing mare." He goes on to say: "In our visit the same fall to Durham, Dover, Portsmouth and Greenland to learn more of her, we found a number that knew her when owned in Durham, and they said she was then known as the 'Old Narragansott Mare.' They said that Benjamin Kelly, deceased, brought the mare into Durham, that he had a son John L. living in Manchester, New IIampshire, and that he would know more about her, etc.", After learning that Mr. John L. Kelly was a very intelligent and responsible man, having been city marshal and mayor of Manchester, and known as "Honest John," he wrote him and received the following reply:

"In answer to your inquiries about the dam of Black Hawk, I will gire you my best recollections, aided somewhat by a dairy which I kept at that time. I returned to Durbam from a sea voyage in the fall of 1830 . In the following spring I went to Boston wit" 1 my father with a lot of horses. We stopped over night at Brown's Hotel, at Haverhill, Mass., where we met a teamster. from Portsmouth, N. H., with a team of four horses. In the hind span was a large gray horse and a dark bay mare. Among fatter's horses was one which was a good match for the gray horse. The man noticed it and told father that. the mare was too fast for the horse, was worth two of him for speed and bottom, yet he would trade with father for his gray horse. After a good deal of talk, with the aid of Mr. Brown, the trade was made and we drove the mare in the carriage to Boston, leading the others. We found her to be a splendid roadster, and as she was not in good condition to sell, we took her back to Durham. At this time she was chafed and bruised up yery badly with the heavy hames, yet in a few months she came out of it, with no traces of it, except a few white spots on her back and breast. The teamster said she was a Narragansett mare. She would weigh 1.000 pounds. Father kept her as one of his stable horses. She was found to have great speed as a trotter, and father was. always bragging about her. One day, late in the season, Israel Esty, of Dover, drove up to Durbaw with a trotter, and bantered father for a trot, mile heats on Madbury Plains, between Durham and Dover. I had great faith in the mare and pleaded with father to accept his offer, and he did, and fifty dollars. was staked on the race. John Speed was father's hostler, at the time, and he columenced getting the mare ready for the race. He had only three weeks to do it in. At the time specified, a large collection of people from Dover and Durham collected to witness the race. Dr. Reuben Steele was one of the judges. The Esty horse won the first heat, the Kelly mare won the next two, distancing the horse in the last one. In the spring of 1832 John Bellows came to Durhain with the old Suerman Morgan, and I persuaded father to have the mare bred to him. He did, as I saw the horse cover her. I was 21 in 1832; went to sea again that fall. My recollection of the dam of Black Hawk is she was a very fine pointed dark mare, with a nostril so large, when excited, that. one could put his fist into it. JOHN L. KELLY.

“Manchester. N. H:, August 25, 1876." 
The only "trip" in this letter is where Mr. Kelly speaks of the mare as "a dark bay," but as the identity of the mare is fully maintained by other witnesses, this shade of color is not material and is, doubtless a slip of the pen. We don't know she was a Narragansett mare, but we do know that she was called a Narragansett. It is wholly possible she may have been a bastard Narragansett, or she may have been called a Narragansett merely becanse she was a pacer. At that date there were still many descendants of the old Narragansetts to be found, of greater or less degree of purity in their breeding. Among Mr. Thomson's gleanings from persons who knew the mare there are some bearing upon her color and gait that are in order at this point of our inquisition. Mr. John Bellows, the owner of Sherman Morgan, says: "She was a good-sized black mare, a fast trotter, with a swinging gait, and resembled in appearance the Messenger stock of horses." The following description was gathered from several persons who knew the mare well and among them Mr. Wingate Twombly, son of her former owner. "She was a large, rangy mare, a little coarse and brawny, did not carry much flesh, might have weighed some over one thousand pounds and was a trifle over fifteen and one-half hands high. Head and ears rather large, neck long and straight, withers low and thin, medium mane and tail, had more hair on the fetlocks than her son, was called black a little way off, but close to one could see her grey hairs mingled with her coat and close to she was called a steel mixed. She had a white strip in her face and some say a little white on one hind foot. She was smart to go, but her gait was not a smooth, square trot. Some called it a sort of a pace, others that she single-footed. She went with her head low when trotting fast. One person said it was about a straight line from her back to her head when she was going fast. She was called the Narragansett Mare when Mr. Kelly owned her. From other sources and from men who personally knew the mare and had ridden beside her, we have undonbted evidence that she was very fast, but all throngh there is some confusion about the character of her gait. Mr. Bellows, who ought to know something about the gait of a horse, says: "She was a fast trotter, with a swinging gait." Now just what he means by the phrase "swinging gait" is hard to determine. Putting all these bits of evidence together, the reasonable conclusion seems to be that she was 


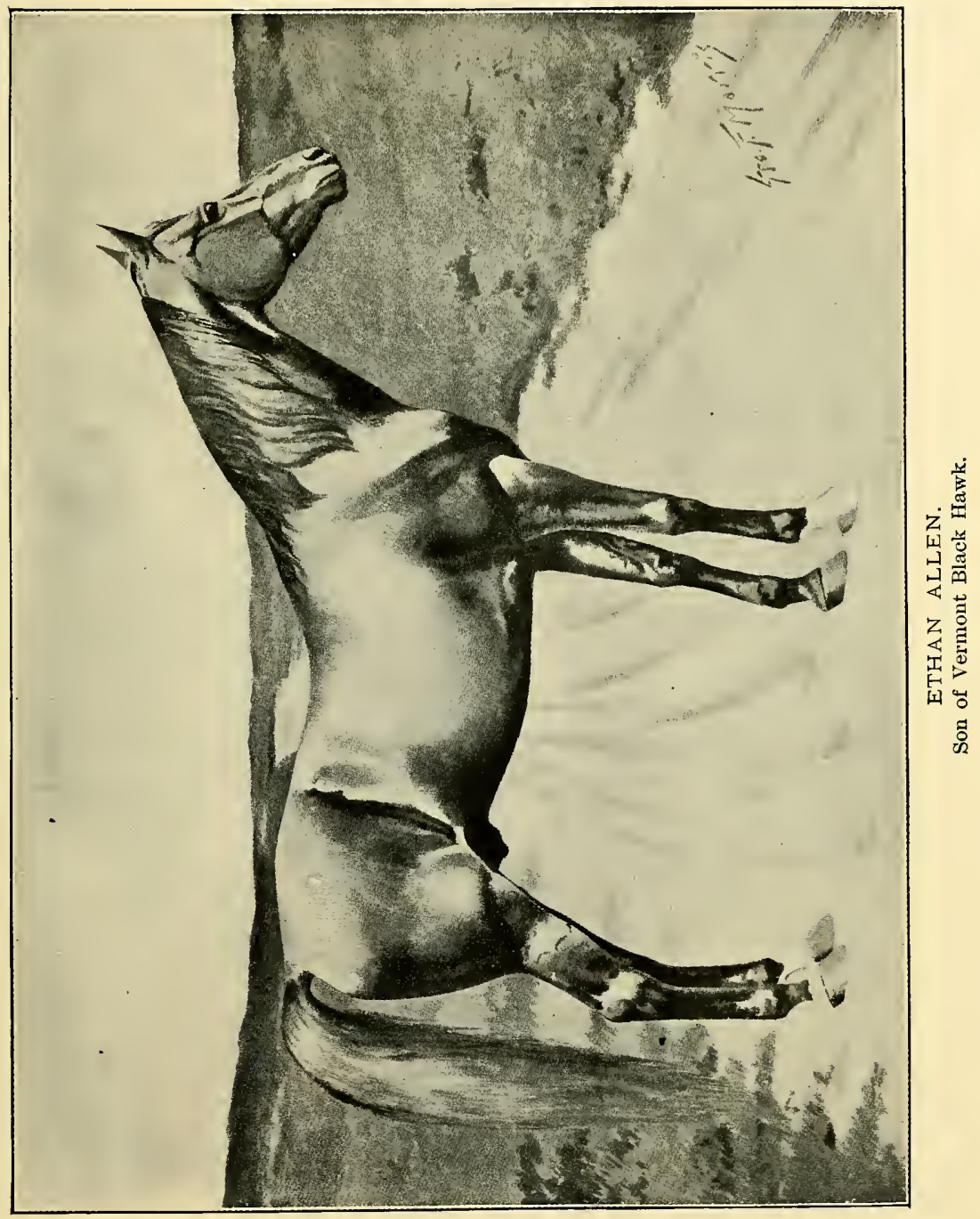



double-gaited, and when speeded she would go from the trot to the pace or from the pace to the trot as the case might be.

From this synopsis of all that has been developed in the blood lines of Black Hawk, there can be no longer any mystery about where he got the characteristics making him so intensely different from the representatives of the typical Morgan. His sire was out of a high-class Narragansett pacer, and his dam was probbly a fast Narragansett pacer, thus giving him presumably seventy-tive per cent. of Narragansett blood and twenty-five per cent. of Morgan blood. The fight that was made against him all his life, as not being a genuine Morgan, had its foundation in justice and truth. He was not a Morgan in either blood or character. He founded a very valuable line of trotters, something that no other branch of the Morgan family has ever accomplished, and of right his descendants should be designated as "the Black Hawk Family," and not jumbled up with the heterogeneons mass of nondescripts still called "the Morgan Family." Black Hawk's gait was splnttery and uneven, rather than square and mechanical. A few of lis progeny were very perfectly gaited, but a great many of them manifested their evil inheritance, which, together with unskillful handling, destroyed all possible valne as trotters. He placed three in the 2:30 list; fourteen of his sons were sires of $2: 30$ performers, six of them with two or more, and two danghters produced 2:30 performers. He died November, 1856.

Ethan Allen, 43.-This was a handsome, bright bay horse, less than fifteen hands high, with three white feet and a star. He was foaled 1849, got by Black Hawk, 5; dam, a fast trotting grey mare of unknown pedigree. With a list of all the celebrated American horses before him, it would be very difficult, if not impossible, for the best-informed horseman to select an animal that has been so great a favorite with the American people, and for so long a time, as the famous Ethan Allen. When four years old he gave the world a sensation by eclipsing everything that had appeared before him at that age; and again when he was eighteen years old he renewed and intensified the sensation by trotting in 2:15 with a running mate. These sensations of his youth and his old age, did much to give him a standing with the people; but his wonderful beanty and remarkable docility and kindness, with the elegance and ease of his action, made him the favorite of everybody. His trotting gait was recognized by the 
best judges and experts as probably more perfect than that of any horse of his day. Others have gone faster singly, but no one has done it in greater perfection of motion. In his great flights of speed he was not bounding in the air, but down close to the ground, with a gliding motion that steals from quarter pole to quarter-pole with inconceivable rapidity. He was bred by Joel W. Holcomb, of 'Ticonderoga, New York, and as the result of a practical joke he played, for the purpose of annoying his uncle, David Hill, the owner of Black Hawk, against whom he had some pique just at that time, many well-meaning and no doubt honest people once believed, and possibly still believe, that Ethan Allen was by Flying Morgan and not by Black Hawk. The fact that Ethan Allen was the same color as Flying Morgan and that there was some resemblance in size and style of action of the two horses, lent a strong suggestion to the joke as a truth. I am indebted to Mr. I. V. Baker, Jr., of Comstock's Landing, S. B. Woodward, then of Ticonderoga, and B. H. Baldwin, of Whitehall, New York, for the details of the way the Flying Morgan story started, and need only say the narrator was an eye-witness to the whole affair. In the spring of 1852, in the barroom of S. B. Woodward's hotel, at 'Ticonderoga, quite a number of the villagers being present, Mr. Joel W. Holcomb came in and said he was going to write a letter to R. M. Adams, of Burlington, Vermont, the owner of Flying Morgan, and he was going to have some fun with him; and, going to the desk in the room, he wrote, snbstantially as follows: "I don't know but I have made all the reputation for David Hill and old Black Hawk that I care to. I am willing to have the credit go where it belongs. and desire to let yourself and the public know that my colt Ethan Allen is got by your horse Flying Morgan."

"There," he said, "you will see this in all the Vermont papers next week. Won't Uncle David be mad?"

"What!" exclaimed some of his neighbors, after hearing it read, "you won't put your name to such a falsehood as that? It's a shame."

"Well, well," said Holcomb, "I'll add a postscript." And going to the desk he wrote below his signature, leaving a good wide space between his signature and the following words:

"Flying MLorgan never corered the dam of Ethan Allen, never smelt of her and never saw her, consequently Ethan Allen was 
not by Flying Morgan, but he can beat Flying Morgan or any other stallion in the State of Vermont."

The next fall Mr. Adams visited many of the fairs with his horse and showed IIolcomb's letter, and, it is said, with the postscript torn off. Every man in Ticonderoga knew as well as Mr. Holcomb how Ethan Allen was bred, and this letter created much indignation. But Holnomb was a reckless man and cared for nothing more than what he called a good joke, and the more it hurt any one's feelings the better it suited him.

This account of the "joke" was written down by Mr. Baker, at the dictation of Mr. Woodward, April 22, 1875, and I have implicit confidence in its substantial accuracy. It has been said that the reason Holcomb did this was out of ill feeling toward Mr. David Hill, the owner of Black Hawk, and Holcomb's uncle, becanse he dunned him for payment of the horse's services in getting Ethan Allen. One day at the Fashion Course, in the spring of 1867 , as I was looking at Ethan while he was taking his daily exercise, either Mr. Holcomb or Mr. Roe, his partner-. I knew them both by sight as the owners of Ethan Ailen, but not well enough to distinguish one from the other, but I think it was Mr. Holcomb-came up to me and expressed a good deal of solicitude to know how I was registering the horse. He appeared gratified when I assured him I had no doubt he was a son of old Bỉack Hawk and would so enter him. He remarked "that was right," and said the Flying Morgan story originated in a practical joke and should not be permitted to go into history as a fact. This is the full history of the basis of the controversy, and certainly, to a reasonable man, it does not leave a single peg on which to hang a hope for the Flying Morgan story.

But, the paternity of Ethan Allen is not left to the uncertainties of recollection nor to be trifled with by practical jokers. The books of Black Hawk's services show that the dam of Ethan Allen was bred to him on a certain day or days of the season of 1848 , and was taken away believed to be in foal. This fact is conceded on all hands. as wholly indisputable, but it is claimed that Flying Morgan was kept in Holcomb's stable one night, after the mare returned from Bridport, and the two were there surreptitiously coupled. I have studied this claim in all its details, I have examined every detail minutely, and I do not hesitate to say there is not a single shadow of evidence to support the claim. In Vermont, as in Kentucky, there are many people who can re- 
member things that never occurred, but in the former State these people are at a great disadvantage, for they are not able to get so many to agree with and support their remarkable memories. The Vermonters are very far from being all honest, but they are very much disposed to make up their own minds, whether right. or wrong.

In searching for the breeding of the little flea-bitten grey mare, "called a Messenger," that produced Ethan Allen, I have not been sparing of either time or labor. I have assiduonsly followed every clew that presented itself, and waded throngh "sloppy" correspondence "knee deep," but I never have been able to reach a single point that was relevant and tangible. From the first that is known of her at Hague, New York, her identity has been maintained by a spavin on one leg and one hip knocked down, and thus she has been traced through the hands of many owners till she reaches $\mathrm{Mr}$. Holcomb, of Ticonderoga, New York. A pretence has been set up that she was by some Morgan horse, but this was only a wish of the originator, and not. a fact founded on reasonable evidence. It is said she was quite a fast trotter, in her younger days, and that she conld beat all the farmers' horses against which she was started. That she had a trotting inheritance, and probably from Messenger, there: can be no reasonable dunbt.

Ethan Allen made his first appearance as a trotter at the Clinton County Fair, as a three-year-old, and made a record, over a. very bad track, of 3:20—3:21. In May following, then four years old, at the Union Course, he beat Rose of Washington in $2: 36$ 2:39-2:42. This was then the fastest time ever made by a fouryear-old. He then retired to the stud and did not again appear. till October, 1855, when, over the Cambridge Park Course, he beat Columbus, Sherman Black Hawk, and Stockbridge Chief for the stallion purse in $2: 34 \frac{1}{2}-2: 3 \%$. Three of the contestants here: were sons of Black Hawk. The next season he defeated Hiram Drew twice, to wagon, making a record of $2: 32 \frac{3}{4}$. October 15, 1858, at Boston, he beat Columbus Jr., and Hiram Drew, 2:3\%2:35-2:33. The same month, on the Union Course, he beat. George M. Patchen, to wagons, distancing him the first heat in 2:28. At the Union Course, Long Island. July 12, 1860, he beat Princess, distancing her the second heat in $2: 29 \frac{1}{3}-2: 25: \frac{1}{2}$. This. is his fastest record. He was frequently beaten by George M. Patchen, Flora Temple, etc., and it was thought by many that, 
he could not take up the weight and "hold the clip" for the full mile ont. His most famous performance was made in 1867, and as I had the pleasure of witnessing it, from a very eligible position, I will here repeat the description as then made:

"On the 21st of June, 186\%, on the Fashion Course, it was my good fortune to witness the crowning event of his life. Some three weeks before, with running mate, he had beaten Brown George and running mate, in very fast time, scoring one heat in 2:19. This made horsemen open their eyes, and there at once arose a difference of opinion, about the advantage to the trotter of having a runner hitched with him, to pull the weight. This resulted in a match for two thousand five hundred dollars to trot Ethan Allen and running mate against Dexter, who was then considered invincible. As the day approached the betting was about even; but the evening before the race, word came from the course that Ethan's running mate had fallen lame and could not go, but they would try to get Brown George's running mate, then in Connecticut, to take the place of the lame rumner. As the horses were strangers to each other, it was justly concluded that the change gave Dexter a great advantage and the betting at once changed from even to two to one on Dexter. Long before noon the crowd began to assemble; the sporting men everywhere were shaking rolls of greenbacks over their heads, shouting "two to one on Dexter." I met a friend from Chicago, who sometimes speculated a little, and when he told me he was betting two to one on Dexter, I took the liberty of advising him to be cantions, for I thought the team would win the race, and that its backers knew what they were doing. Before the hour arrived I secured a seat on the ladies' stand, from which every foot of the course, and the countless multitudes of people, could be taken in at a glance. The vehicles in numbers were simply incalculable, and the multitudes were estimated at forty thonsand people. Upon the arrival of the hour, the judges ascended the stand and rang up the horses, when the backers of the team came forward, explained the mishap that had befallen the runner, that they had Brown George's mate on the ground, but, as he and Ethan had never been hitched together, they were unwilling to risk so large a sum, and closed the race by paying one thousand two hundred and fifty forfeit. When this announcement was made there was a general murmur that spread, step by step, through all that vast multitude. The betting fraternity 
were just where they started and every spectator realized a feeling of disgust at the whole management. As soon as this had. time to exert its intended effect npon the crowd, the backers of the team came forward again and expressed their unwillingness to have the people go away dissatisfied, and proposed a little match of two hundred and fifty a side, which was promptly accepted by the Dexter party; and when it was known there would be a race after all the shout of the multitudes was like the voice of many waters.

"This being a new race, the betting men had to commence de novo. The surroundings of the pool stands were packed with an eager and excited crowd, anxious to get on their money at two, and rather than miss, at three to one on Dexter. The work of the anctioneers was short, sharp and deeisive, and the tickets were away up in the hundreds and oftentimes thousands. But the pool-stands did not seem to accommodate more than a small fraction of those anxious to invest, and in all directions in the surging crowd, hands were in the air, filled with rolls of greenbacks, and shouting "two to one on Dexter." I was curious to note what became of these noisy offers, and I soon observed that a quiet-looking man came along, took all the party had to invest and then went quietly to another of the shouters, and then another and so on, till I think that every one who had money to invest, at that rate, was accommodated. The amount of money bet was enormous, no doubt aggregating a quarter of a million, in a few minutes.

"When the horses appeared on the track to warm up for the race, Dexter, driven by the accomplished reinsman Budd Doble, was greeted with a shout of applanse. Soon the team appeared, and behind it sat the great master of trotting tactics, Dan Mace. His face, which has so often been a puzzle to thousands, had no mask over it on this occasion. It spoke only that intense earnestness that indicates the near approach of a supreme moment. The team was hitched to a light skeleton wagon; Ethan wore breeehing, and beside him was a great strong race horse, fit to run for a man's life. His traces were long enough to allow him to fully extend himself, but they were so much shorter than Ethan's that he had to take the weight. Dexter drew the inside, and on the first trial they got the send off without either one having six inches the advantage. When they got the word, the flight of speed was absolutely terrific, so far beyond anything I had ever 
witnessed in a trotting horse, that I felt the hair rising on my head. 'The ruming horse was next to me, and notwithstanding my elevation, Ethan was stretehed ont so near the ground that [ conld see nothing of him but his ears. I fully believed that, for several rods at this point, they were going at a two-minute gait.

"It was impossible that this terrible pace conld be maintained long, and just before reaching the first turn Dexter's head began to swim and the team passed him and took the track, reaching the first quarter-pole in thirty-two seconds, with Dexter three or four lengths behind. The same lightning speed was kept up throngh the second quarter, reaching the half-mile pole in 1:04, with Dexter still farther in the rear. Mace then took a pull on his team, and came home a winner by six or eight lengths, in $2: 15$. When this time was put on the blackboard, the response of the multitude was like the roar of the ocean. Although some distance away, through the second quarter of this heat I had a fair, unobstructed side view of the stallion and of his action, when going at the lightning rate of 2:08 to the mile. I could not observe that he received the slightest degree of propulsion from the running horse; and my conviction was then, and is now, that any such propulsion would have interfered with his own unapproachable action, and would have retarded rather than helped him. The most noticeable feature in his style of movement was the remarkable lowness to which he dropped his body and the straight, gliding line it maintained at that elevation.

"The team now had the inside, and in the first attempt they were started for the second heat, but they did not appear to me to be going so fast as in the first heat. Before they had gone nany rods Ethan lost his stride and Dexter took the track at the very spot where he had lost it in the first heat. The team soon got to work, and near the beginning of the second quarter collared Dexter, but the stallion broke soon after and fell back, not yards, nor lengths, but rods before he caught. Incredible as it may seem, when he again got his feet, he put un such a burst of speed as to overhanl Dexter in the third quarter, when he broke again and Mace had to pull him nearly to a standstill before he recovered. Dexter was now a full distance ahead and the heat appeared to be his beyond all peradventure. I was watehing the team in its troubles very closely and my idea of the distance lost was the resnlt of a deliberate and eareful estimate at the moment; 
and the query in my mind then was whether the team could save its distance. At last the old horse strnck his gait, and it was like a dart out of a catapult, or a ball from a rifle. The team not only saved its distance, but beat Dexter home five or six lengths in $2: 16$.

"In the third heat Mace had it all his own way throughont, coming home the winner of the race in $2: 19$. The backers of Dexter, up to the very last, placed great reliance on his wellknown staying qualities; but the last heat showed that the terrible struggle told upon him more distressingly than upon the team. It is said by those who timed Dexter privately that he trotted the three heats in $2: 1 \%, 2: 18$, and $2: 21$. As an opinion, I will say that if ever there was an honest race trotted this was one, but there was such an exhibition of sharp diplomacy, of the "diamond cut diamond" order, as is seldom witnessed, even among the sharp practices of the turf. It is not probable that Ethan's running mate fell amiss at all, the evening before, as represented; and if she did, it was not possible to send to Connecticut for another horse and have him there early in the morning as was pretended. This was a mere ruse put out to get the advantage of the long odds. The managers of the team knew just how the horses would work and knew they had speed enough to beat any horse on earth. When the race was called and they came forward and paid forfeit, it was merely to give the 'two to one on Dexter' money encouragement to come out. It did come out most vociferously and was all quietly taken. It was said John Morrissey was the manager in chief, and that his share of the winnings amounted to about forty thousand dollars."

I have here given my personal impressions of this race, not because the performance was of any special value, as a test of speed, but because the time was then phenomenal, even with this kind of hitch, and as an illustration of what certain horses can do when relieved of all weight. This was among the first of the contests of this kind, and although some effort was made to introduce this plan by which a poor horse conld beat a good one, it never has received much enconagement. With all his perfection of gait and wide popnlarity, extending from early life to old age, Ethan Allen was not a snecess as a progenitor of speed. $\mathrm{He}$ placed but six in the $2: 30$ list, and the best-Billy Barr-with a record of $2: 23 \frac{3}{4}$. He left but one son equal to himself as a sire, and several daughters that became the producers of single per- 
formers. He was kept several seasons in Kansas and died there September, 1876.

Daniel Laybert, 102, was a chestnnt horse, foaled 1858; got by Ethán Allen, 43; dam Fanny Cook, by Abdallah; grandam by Stockholm's American Star, etc. His color was a light chestnut, and his mane and tail were of the yellow, flaxen shade. He was about fifteen hands high and long and light in the body, with no indications of Morgan blood about him nnless it was in the kinkiness of his mane and tail. But why should he not resemble almost anything else than the little nondescript Morgan, when he had only one-sixteenth of his blood in his veins? He had more Messenger than Morgan blood, and according to the rules of arithmetic it is a misnomer to call him a Morgan. More than this, his dam was a daughter of the great Abdallah, far and away the greatest trotting sire of his generation. When we consider that he had four times as much of the blood of Abdallah as he had of the original Morgan, we can see the absurdity of sticking to the right male line after that line has been wiped ont by other lines far more potential. Lambert was bred by Mr. John Porter of 'Ticonderoga, New York, and as a colt he showed great promise on the ice, and was thought to be the fastest and best of the get of Ethan Allen. He was known far and wide as the "Porter Colt," and he was the popular heir to very great expectations. "To have created so much enthusiasm he must have shown great speed for a youngster, and he is credited with a record of $2: 42$ as a three-year-old. As a sire of trotters he stood very high at one time and was even with Blue Bull in his number of representatives in the 2:30 list, but in the end the little "plebeian" pacer outstripped him a long way. Lambert put thirty-seven trotters into the 2:30 list, but when we come to study this list we are not very favorably impressed, for abont one-third of the animals have but a single heat inside of the mark, with only five or six reputable campaigners and a single one-Comee-that ranked among the real good ones. Comee had seventy-one heats to his credit and a record of $2: 21 \frac{1}{4}$. Thirty-three of Daniel Lambert's sons have put one hundred and thirty-six in the list, and forty-four of his daughters have produced seventy-four performers. 


\section{CHAPTER XXYII.}

THE ORLOFF TROTTER, BELLFOUNDER, AND THE ENGLISH HACKNEY.

Orloffs the only foreign trotters of merit-Count Alexis Orloff, founder of the breed-Origin of the Orloff-Count Orloff began breeding in 1750-Suetanka, Polkan, and Polkan's son, Barss, really the first Orloff trotting sireThe Russian pacers-Their great speed-Imported Bellfounder-His history and characteristics-Got little speed-His descendants-The English Hackney-Not a breed, but a mere ty pe-The old Norfolk trotters-Hackney experiments in America-Superiority of the trotting-bred horse demonstrated iu show-ring contests.

IT may be a little outside of the field of our discussion to include the Orloff 'Trotter, but as a few of them have been brought. to this country, and as that is the only organized and recognized breed of trotters in all the world beside our own, it seems to be necessary to give a brief synopsis of the origin and history of that breed, so far as we may be able. An additional and probably a more cogent reason for making this foreign detour is the fact that there are now many American trotters on the turf in Europe, and practically their only competitors, whether on the turf or in the breeding studs, are the Orloffs of Russia.

"Wallace's American Trotting Register," the first volume of which was issued in 18\%1, was an individual enterprise. Two years afterward the director-in-chief of the Russian Imperial Studs submitted a series of questions to different scientific gentlemen, whose studies were in the right direction, soliciting their views. on the practicability and advisability of establishing a governmental standard by which the Orloff trotters should be classed and officially registered. The report was favorable and the Russian trotting register was established under governmental direction. This was the second movement toward establishing a breed; not merely by writing a lot of names in a book, but by writing those names on the turf of two continents. A delegation from France once visited me to consult about establishing a Register in that country, and to learn how to commence such an enterprise. When I asked them what strains of blood they had that could 
trot, they did not seem to know of any particular strains, or any one strain better than another, to serve as a foundation, but they were sure they had plenty of trotters. This was the first I ever had heard of French-bred trotters, and it was the last I ever heard of the French trotting register.

The stalwart Alexis Orloff took a very active part in making Catherine II. Empress of Russia-for which he was loaded with honors as well as lucrative offices. In the war with the Turks in $17 \%$ he was given command of the Russian fleet, and with the assistance of the English fleet under Admiral Elphinstone, he achieved a great victory and captured the pasha in command of the Turkish fleet. Owing to some unusual kindness Count Orloff was able to extend to the captured Turkish commander, or his family, he presented the count with a pure white stallion, said to be a Barb, which he took home with him and placed in his stud of horses, that he had established but a short time before. Another story is that the count bought this white horse, which he called Smetanka, while he was in Greece and paid a large price for him. I am not able to say which representation is the more probable, and it is not material to our history, as there is no dispute about the identity of Smetanka as the nominal head of the Orloff breed of horses, and neither story gives any information about his blood. No doubt he was a Turk. Count Alexis commenced his breeding stud in 1\%\%, and there appears to have been a good deal of system about it or else a large amount of very free guessing. When first established, the horse breeders say, it consisted of stallions and mares as follows: Arabs, 12 stallions, 10 mares; Turkish, 1 stallion, 2 mares; English, 20 stallions, 32 mares; Dutch, 1 stallion, 8 mares; Persian, 3 stallions, 2 mares; Danish, 1 stallion, 3 mares; Mecklenburg, 1 stallion, 5 mares. From this it will be seen that he had more English rinning blood than all the other varieties put together, and yet no trotters came from that source. From this great variety of composite material the count had free rein in his grand experiment cf producing the type of horse that best pleased his fancy. As a matter of course the indiscriminate commingling of these different strains and types would produce a mongrel lot, from which a few superior animals might be selected, and donbtless were selected, for breeding purposes.

The different writers who have discussed the result of this experiment seem to agree, substantially, that two distinct types 
were the result-the galloper for the saddle and the trotter for harness-but they assume what appears to me to be a very unreasonable conclusion that both these types were indebted to the super-excellence of Smetanka. The count was one of the most prominent sporting men of his day, an inveterate horse-racer and cock-fighter, and under this kind of management it is hardly eredible that the twenty English thoronghbred stallions should have been put aside for the little white horse of positively unknown origin. But whatever may have been the predominating blood in the saddle department, it is certain that the trotter is lineally descended from Smetanka. He was bred on a Danish mare and produced Polkan (Volcan), without anything new or striking in his characteristics. Polkan was bred on a Dnteh mare and produced Barss, and this was the first to manifest a disposition to extend himself to his ntmost at the trot and to stick to it. Barss became a great favorite with his master; for, although stumbled upon, he was a new creation and is the real progenitor of all the horses that bear the name Orloff. His component elements are easily expressed. He had twenty-five per cent. of the blood of Smetanka; twenty-five per cent. of the blood of the Danish mare, and fifty per cent. of the blood of the Dutch mare. It seems to be reasonable to conclude, therefore, that the trotting instinct must be found in the unknown elements of the Dutch mare.

Some years ago Prof. - - (the name I cannot now recall), from the Imperial Agricultural College, near Moscow, Russia, paid me several visits for the purpose of gathering up what information he conld obtain abont the origin and history of the American Trotter. He was very intelligent and thorough in his methods of obtaining information, and each succeeding day he came back to me with a new series of questions hinging upon previous interviews, and all carefully prepared. These questions were so adnirably shaped to reach the vital points of the subject that I became greatly interested in the man. When it came my turn to ask questions, my first one was, What was the origin and lineage of the Dutch mare that produced Barss? He replied, "Ah, the scientific men of Russia would give a great deal to be able to answer that question." We both agreed, perfectly, that the living instinct of the trotter came from that mare, but he was not able to tell me anything of her history or habits of action. He told me there were many pacers in Russia and that the best ones 
came from the province of Viatka and from the region of the Volga River.

As the true source from which the Russian trotters have drawn their ability to trot fast has not been developed nor determined by history, we must consider the problem in the light $0:$ the surrounding conditions, and possibly our American experiences may lead to its solution. In 1873 Prof. Von Mittendorf, at the request of the director-in-chief of the imperial stud, prepared a very able paper on the scientific questions involved in the establishment of a Government Register for the Orloff trotters. In this paper he discusses the pace and the trot as both original and natural gaits and insists that there are no outward indications in form or shape by which the animal, when at rest, can be decided to be a pacer or a trotter. In his own words he says:

"In answer to the question whether, from the form of a horse at rest, it can be ascertained what gait would be easiest assumed by it, viz., trotting or pacing, I must confess that I have never seen, read or heard of such niarks, and, indeed, there never are any symptoms or signs of inclination for pacing in the proportions of any horse with the single negative exception, viz., that great speed in one-sided motion does not agree with a large frame, which is more adapted to leaping, and hence fast pacers are never found among large horses."

This is the view as taken by a Russian scientist of the distinction, or rather lack of distinction, between the trotter and the pacer. I have not quoted this paragraph from Prof. Mittendorf because it contained anything new in the economy of breeding, but to prove that there were pacers in Russia and that their relation to the trotter was considered in the formation of the rules of admission to the Orloff trotting register. A very intelligent writer, evidently a Russian and one who knew what he was talking about, contributed an interesting article to the New York Sun of July 9, 1877, from which we get a clear and strong light on the practical side of the Russian pacer, and I will here again quote:

"Up to the middle of the last century horses in Russia were not scientifically bred; they ran wild in many parts of the country.. Those caught on the steppes of the river Don, and in the wilderness of the district of Viatka. obtained early celebrity, which they still maintain. The Don horses are those famous Cossack steeds about which so much has been written of late. The Viatka horses, or Bitugues, as they are called, are the genuine trotters of Russia. They are all pacers, equally remarkable for their speed and their en- 
durance. But since the Orloff breed has been introduced, the Bitugues have been excluded from all matches, on the ground that their pacing is not orthodox.

"It is with these Bitugues that the peculiar troika team, of which a specimen was shown in Fleetwood Park, on Saturày, originated. A fast, sturdy Bitugue is put in shafts, and a light running horse from the steppes harnessed on each side of him. A good Bitugue trots so fast that the wild steppe runners have to be whipped all the time to force them to keep up with him. The idea of putting an Orloff trotter in the place of a Bitugue is very queer, as no square trotter can equal the speed of those famous pacers of Viatka, and keep abreast with side runners."

From these three several sources we learn a number of facts that may have a more or less important bearing upon the true origin of the Orloff trotter. (1) That there are now, and have been for generations past, plenty of pacers in Russia. (2) That these pacers have a common habitat, north and east of the Don. (3) That they are a very old race, rumning back in the centuries away beyond the knowledge of man or the records of history. (4) That they are a very fast and very enduring race, and that they have been trained for generations as the shaft horses of the troika and their speed so well developed as to requiro good running horses to keep abreast with them. (5) That they are of smaller size than the average and lack symmetry, and thus, notwithstanding their great speed and bottom, they and their blood are excluded from registration with the Orloffs. (6) That they are also excluded from eompeting for any prizes that may be offered, and no other reason is suggested than that they would be sure to win.

Russia and America both have pacers and they are both carrying forward the breeding and development of the trotter with great intelligence and success. No other nation has been able to make even a beginning in this field of animal economy except by the introduction of the foundation stock from one or other of these two conntries. It may be taken as historically true, and as applying to every nation on the face of the earth, that where there are no pacers there are no trotters. Hundreds of unmistakable experiences in this country go to show that the pacer is a great source of trotting speed. At one time a pacing stallion of obscure pacing origin stood at the head of the list of all stallions as the sire of the greatest number of trotters with fast records. A great multitude of our fastest trotters at maturity were foaled pacers from trotting parents. It is no longer a mat- 
ter of wonder or surprise that with two animals from the same parents one of them should be a fast trotter and the other a fast pacer. Neither is it any longer remarkable that a fast trotter with a very fast record should turn around and make just as fast a record at the pace. The American people are just beginning to realize, in its full force, the declaration of more than twenty years ago, that the trot and the pace are simply two forms of the same gait, in the economy of motion. The only difference that has been observed as between two brothers, the one a pacer and the other a trotter, is that with the same skill in handling the pacer will come to his speed much quicker than the trotter, which is of itself a strong suggestion at least that the pace is the more natural and easier form of the one gait.

Now, in view of the fact that Smetanka was of Saracenis origin -a strain of blood that has always been antagonistic to the pacer, and never produced a pacer or a trotter; and in view of the fact that his grandson, Barss, is accepted as the first of all Orloff trotters; and in view of the further fact that in thonsands of American experiences the trotter has come from the pacer, it seems to be a reasonable conclusion that the "Dutch Mare" that produced Barss had a strong pacing inheritance, and possibly had her speed fully developed, as the Bitugue in the count's own team.

Among all the pleasures which Count Orloff derived from his experiments in breeding, whether of gamecocks, or race horses, or saddlers, or trotters, Barss was his greatest favorite because he was his highest achieveme't in the art of breeding. This judgment of his master has been confirmed in the experiences and history of all succeeding generations for a hundred years, and the name of Barss will be known through the coming centuries as the founder of a mighty breed of trotters. I once possessed a fine pictnre of Barss hitched to a sleigh and driven by his breeder, Count Orloff, himself; and I have seen it stated somewhere that this picture was a copy of a bronze statue erected to the memory of the Connt Orloff and the greatest horse of Russia.

It has been stated by some writers, but with what measure of authority I do not know, that for abont thirty years after the appearance of Barss his daughters were bred to English thoronghbreds, to Arabs, to Anglo-Arabs, and, indeed, to all the hishly bred crosses that the great establishment was able to furnish, and there was no improvement in either the quality or 
the speed of the produce. From this it is evident that the count and his managers were at that period entangled in the same foolish notions that befogged the minds of so many very worthy gentlemen in this country some years ago, viz., that the way to improve the trotter was to go to the runner-the horse that never could trot. This foolish notion, that never had a spark of reason in it, naturally and necessarily weakened the trotting instinct of the descendants of Barss, and wonld have wiped it ali out if it had been followed persistently, and there would have been no Orloff trotters to-day.

After this narrow escape from the annihilation of much of the good that Barss had done, the management then began to look for the same blood and the same habit of action that the "Dutch Mare" transmitted to her son, and, with this element to the front, progression was resumed. Out of his great variety of forms and of strains of blood the count and his managers could pick and choose for the size, shape and forms they wanted, but they were not able to transfer with the size, shape and form the instincts and psychical nature of the horse. The count seems. to have carried forward his. great enterprise rather with a view to experimentation than its ccmmercial possibilities. Smetanka lived but a year or two, and when he stumbled upon the production of Barss, a magnificent individual and a great trotter, his head seems to have been turned, as he evidently supposed that. he could breed any kind of horse he wished to breed, and be able to do anything he wished him to do. At his death, in 1808, he left no male heir to succeed him, but he provided in his will that. his stud should not be dispersed. It was kept intact till about 1845, when it was purchased by the government, and finally divided among a number of prominent breeders in different portions of the empire.

Without having any knowledge on the subject that is definiteand specific, I am led to infer that the rules on registration and racing in Russia are a hindrance to the breeding and development of the trotter. As I understand it, no horse can be registered unless he is purely descended from Barss. And I understand further, that he must possess the same requirements in order to enter and start in a public race against the Orloffs. If it be true that these restrictions are really in existence and are enforced, we can understand why the American trotter is so far ahead of the Orloff in speed and in the markets of Europe. The: 
Orloff is restricted to certain lines of blood and is protected against competition from others that might beat him. The American is free from all restrictions of blood and gathers up all that is best and fastest. He neither asks nor accepts protection from any quarter, but throws down the glove to all comers.

Bellfocnder was imported from England, July, 1822, by James Boott, of Boston, Mass. IIe was placed in the hands of Samuel Jarines, Jr.- - a very shrewd manager who understood the use of printer's ink and did not hesitate about employing it liber. ally. In his advertisement for 18:3 he says: "This celebrated horse is a bright bay with black legs, standing fifteen hands high." From this we are safe in concluding he was not more than fifteen hands, and from another contemporaneous source it is learned that he was a little below that measurement. On this point the recollections, or perhaps impressions, of Orange County horsemen are not very trustworthy, as one of them places his height at sixteen hands and others at fifteen and a half. His pedigree was given on the card which was distributed by his groom in the form following: "Got" by old Bellfounder, out of Velocity by Haphazard, by Sir Peter out of Miss Hervey by Eclipse." "Velocity trotted on the Norwich road in 1806, sixteen miles in one hour, and although she broke five times into a gallop, and as often turned round, she won her match." Although after diligent search I have not been able to find this performance of Velocity, it may be irue that a mare so named may have trotted as represented, but she was not a danghter of Haphazard. The dates make this utterly impossible, and Mr. Jaques was smart enough never to put this humbing pedigree in his elaborate advertisements that appeared in the leading agricultural papers of the country, year after year.

As the great mass of people of that day knew nothing and cared but little about pedigrees, the astute manager of the horse struck an expedient in the way of adrertising that was very effective. He had a cut made of a horse trotting loose on the road, at the rate of a hurricane, and in the background was an entablature with the legend "Seventeen and a half miles an hour," which anybody and everybody wonld interpret to mean that this was a record made by imported Bellfounder, and there he was doing it. This cut in reduced form went the rounds of the agricultural press, and in 1831 made its appearance in the 
"Family Encyclopedia of Useful Knowledge." This dodge was. exceedingly effective, and as it appeared in a book it must be true. Thousands of people interpreted the picture to mean that imported Bellfounder had trotted seventeen and a half miles in an hour. Mr. Jaques did not say this in letters and figures, but he said it even more plainly in a picture. The basis of this deception is found in the advertisement itself, where, in speaking of the speed of old Bellfounder in England, he says: "His owner challenged to perform with him seventeen miles ard a half in one hour, but it was not accepted." Here we have a possible challenge of the sire transmuted into an actual performance of the son, for the sole purpose of securing public patronage.

There can be no doubt that this horse was a true representative of what was then known as the Norfolk Trotters and at this time designated as IIackneys or Cobs. Bellfounder was of a quiet, docile disposition, with a display of great nervous energy in his movements when aroused. His knee and hock action was high and showy, giving the impression of a great trotter, without. much speed. At several points his form was measurably reproduced in Irambletonian, especially in his low, round withers and his great, meaty buttocks. In seeing these points so plainly developed in his idol it is not remarkable that Mr. Rysdyk should have placed too high an estimate on Bellfounder blood as a factor in the American trotting horse. If he had thoughtfully asked himself the question, What has Bellfounder blood done in its own right in the way of getting trotters? the illusion would have: vanished.

Bellfounder was in the control of Mr. Jaques for six years, and never in my knowledge of trotting stallions have I known one so. widely and successfully advertised. The name "Bellfounder" was heard and known everywhere. From 1829 to 1833 , inclusive, he was under the control of Mr. T. T. Kissam, of Long Island. After that time he seems to have gone "a-begging" wherever there seemed to be a chance to earn his oats. At last, at Jamaica, Long Island, he died, having made twenty-one seasons in this country-one more than Messenger. The question was once raised as to where Hambletonian got his aversion to the chestnut color, and it was flippantly assigned to Bellfounder. The truth is, quite a number of Bellfounder's get were chestunts, perhaps as large a percentage as would naturally come from the average stallion. 
It is the testimony of several gentlemen who were familiar with trotting afficirs in the time of the Bellfounders, that a nnmber of them were skillfully and persistently trained and none of them could trot faster than about $2: 50$. The one exception to this fact so widely established is the case of the dam of Hambletonian. After this filly passed into the hands of Peter Seely he gave some attention irregularly to the development of her speed, and before he sold her he gave her two trials to saddle on the Union Course and she trotted in 2:43 and 2:41. As she was then but four years old it is safe to conelude that she wonld have made a trotter, beyond all donbt. This is the only one, old or young, from the loins of Bellfounder that ever trotted so fast. I once put the question direetly to Mr. Rysdyk as to whether the Kent Mare was as good and as fast as her dam, One Eye, and he promptly replied that One Eye was much the faster and greater mare. To this answer he added that One Eye, under the same circumstances, would have been the equal of Lady Thorn or any other that ever lived. This may acconnt for the superiority of the Kent Mare over all the other Bellfounders, and it may aceount for the superiority of Hambletonian over all other stallions.

Bellfounder (Brown's or Kissay's), was a bay horse, foaled 1830, got by imported Bellfounder; dam Lady Alport, by Mambrino, son of Messenger; grandam by 'Tippoo, son of Messenger; great-grandam by imported Messenger. With such breeding he should have been a great horse. He was bred by Timothy T. Kissam, of Long Island, and sold along with a full brother one year younger, named Bellport, about 1834-5, to L. F. and A. B. Allen, of Buffalo, New York. Bellfounder was a bay horse, sixteen hands high, and Bellport was sixteen and one-half hands, but was poisoned and died at four years old. Bellfounder passed into the hands of some parties at Cleveland and then to Mr. Brown, of Columbus, Ohio, made most of his seasons in that portion of the State, and died September, 1860. This was altogether the most valuable son the imported horse left-indeed the only one that made any mark in the world. He was not much of a trotter and did not get trotters, but got colts that were excellent types of the coach horse, and for that purpose was very highly esteemed. Some of his sons and daughters, especially the latter, are met with sometimes in trotting records as having produced something that had more or less speed.

Conqueror was a bay gelding, foaled 1842 , and got by Lat- 
tonrett's Bellfounder, a grandson of the imported horse, and out of Lady McClain by imported Bellfounder, and she out of Lady Webber by Mambrino, and she out of a mare brought from Dutchess County and represented to be a daughter of imported Messenger. This gelding had been pounded about in slow races for years and had the reputation of being a stayer. In 1853 a match was made with him to trot a hundred miles in nine hours. The race was started and the horse won in $8 \mathrm{~h} .55 \mathrm{~m}$. and 53s., and he died three or four days afterward. This is the only instance that I know of in which the advocates of Hackney blood can point to a trotting record made in this or indeed in any other country.

In closing the account of this family-for out of courtesy we have called it a "family" - we find we have nothing left but a name with nothing in it. The name that was more widely known than that of any other horse of his generation has now practically ceased from the earth, with nobody so poor as to do it reverence.

The type of horse now known as the "Hackney" is found ehiefly in the shires bordering the northeastern coast of England - Norfolk, Lineoln and Yorkshire. The name now given is not only new but it is appropriate and applies to any one part of England as well as another, and applies to any one horse, suited to the general use of a Hack, as well as another, no difference what his blood or what his country. The name "Norfolk Trotter" fifty or a hundred years ago was often applied to horses of this type coming from that part of the country, but it did not follow that they were "trotters." In the discussions of the association preceding the adoption of a name it was urged that the qualifying word "trotter" would imply the ability to trot fast, and as the material to be registered could not do this, it would subject the whole movement to ridicule and contempt. It was also urged that the name "Norfolk" would give that particular region an advantage over all other parts of England in the prospective sales of registered stock, and thus the old title was filly disposed of. When the name "cob" was suggested, it was conceded that it represented just what they had, but it was too common, as everybody in all England, rich and poor, had "colss." Then came the term "Hackney," which meant the same kind of a horse as the cob, but as it was not in such universal use it was 
adopted. On this point it must be admitted that it is an honest name.

The Hackney is a good horse for all the uses to which he is adapted. He is short on his legs and stont, with a good share of nervons energy. He is symmetrical, and, we might say, handsome, if we can use that word withont any show of fine breeding, for he is far short of the ideal blood horse. But he is not a saddle horse, he is not a hunter, he is not a rumner, and he is not a trotter. As against these desirable and useful qualifications, he has been bred and trained when in action to jerk up his limbs to the highest point anatomically possible, and put them down again with a thud at a point but little removed from where he started. In this showy, undesirable action he exhausts his nervons energy, pounding the earth withont covering much of the distance. In this excessive knee action every element of easy, graceful and rapid progression is wanting. 'This fad will have its day and then along with the barbarons excision of the candal appendage they will disappear together as they came, and we will know them no more forever.

There are two points in advocating the merits of the Hackney with which every Englishman is thoroughly familiar and which he will call to your attention on the slightest provocation: (1) Bellfounder was a Hackney and it was his blood that gave us the greatest trotting sire that the world has ever produced. This is the Englishman's estimate of Bellfounder when he has a Hackney for sale, and especially if the prospective purchaser be an American. (2) $\mathrm{He}$ is descended from a long line of distinguished trotters. To the first of these reiterated and parrot-like claims an answer will be found in the chapter relating to that horse, where his twenty-one years of stud service have been carefully considered, and where he is shown to have been a monumental failure. In the second claim there is some truth and we must consider it very briefly.

Of all the elements entering into the families of horses locally and indefinitely called Norfolk Trotters, there were two that might be looked upon as the founders-Useful Cub and Shalesfor they were more conspicuous and valuable than any others. Mr. John Lawrence was not only a practical horseman, but he was the most intelligent and reliable of all the writers on the horse in the latter part of the last century. He was the only one who gave any attention to the trotter and trotting affairs. 
He says: "To old Shales and Useful Cub the Isle of Ely, Cambridgeshire and Norfolk are indebted for their fame in the production of capital Hackneys." Useful Cub was bred by Thomas Jenkinson, of Long Sutton in Lincolnshire, and was foaled about. 1865-\%0, and was got by a Suffolk cart horse, doubtless a light. weight, and his dam was by Golden Farmer, a son of the famous. half-bred Sampson, that was the great-grandsire of Messenger and beat most of the best horses of his day. Mr. Lawrence knew Useful Cub well, and was beaten by him in Hyde Park. We have no details of this horse's performances, but it seems to be conceded that he trotted fifteen, sixteen and seventeen miles in the hour. Old Shales, or Scott's Shales, as he is sometimes called, is described by Lawrence as "the bastard son of Blank," son of Godolphin Arabian, but Mr. Euren, the compiler of the Hackney Stud Book maintains that he was the son of Blaze and not the son of Blank. The reasons given for this change I do not remember, but they would have to be well founded before I could throw overboard the contemporaneous evidence of Mr. Lawrence. It will not do to say that Mr. Lawrence mistook the name Blaze for Blank and so wrote it by mistake, for he knew all about both horses. This distinction, however, is of but little practical value. The horses Shales and Useful Cub were both fast. and successful trotters, in their day, and they both became distinguished sires of trotters. By this I do not mean that they were the sires of all the trotters, for there were many that were wholly unknown in their breeding.

Judging from the numbers of leading contests that were reported in the Sporting Magazine and other publications, we must. conclude that trotting contests reached their height as well in numbers as in public interest about the last decade in the last. century. The contests were all to saddle, on the road, and the leading ones were made under the watch and over a long distance of ground, specifying such or such a distance to be made inside of an hour. To form a correct estimate of the speed of those: horses, I will copy one paragraph, entire, from the description. given by Mr. Lawrence concerning his own mare Betty Bloss:

"My own brown mare, known by the name of Betty Bloss, was the slowest. of all the capital trotters, but at five years old trotted fifteen miles in on hour, carrying fourteen stone, although iairly mistress of no more than ten. She afterward trotted sixteen miles within the hour, with ten stone, with much ease to herself and her rider. She was nearly broken down at four 
years old, had bad feet, and, besides, too much blood for a trotter, having been got by Sir Hale's Commoner, out of a three-part-bred daughter of Rattle, son of Snip."

In this paragraph, from the best-informed man of his generation, it will be noted incidentally that the ery, "no more running blood in the trotter," is not new, but more than a hundred years old. The best performances were about sixteen miles in the hour, but there was an occasional one that reached sixteen and. a half. A black gelding called Archer was recognized as the fastest of that period, and on one occasion under a stop watch he trotted the second one of two miles in a little less than three minutes. From my gleanings I find but a single instance from which we might be able to approximate the money value of trotting horses of that day, and this is given as a phenomenal price, viz., Marshland Shales, a paternal grandson of the riginal Shales and out of a mare by Hue and Cry. He had beaten Reed's Driver in a match of seventeen miles for 200 guineas. He was foaled 1802 and in 1812 he was sold at auction for 3,051 guineas-\$15,255. He was a great horse, but this price was just as startling to Englishmen of that day as the $\$ 105,000$ was in our own day, when Axtell was sold. This seems to have been the culmination of the "boom" in Norfolk Trotters, and from then till the present there has been a steady deterioration in the trotting step of the Norfolk horse. In the earlier part of this period of eighty or ninety years, possibly some exceptions may be found, but they are only individual exceptions and do not controvert the broad fact that must be apparent to all observers. They had been breeding and training their horses to strike their chins with their knees-the up-anddown motion-instead of getting away and covering some ground in their action. I have stood and watched scores of them in the show-ring, on their native heath, with their grooms at the ends of long lines running and yelling like wild Indians to rouse up their horses, and they called this training the trotters. When I privately expressed the wish that saddles might be put on a few of the best and the ring cleared so that the trotting action might be studied, I was very kindly and politely assured that they did not show their trotters that way in England. Thus with the taut check-rein, the long leading-line and the whoops of the groom they got the up-and-down action upon the perfection of which the prizes were awarded. This explained why the splendid. 
foundation of a breed had been lost by non-use and why England had prodnced no trotters in the past fifty or eighty years.

While our English consins know they have no trotting horses of their own they seem to be exceedingly anxious, possibly for commercial reasons, to make it appear that the American trotting horse is the lineal descendant of the Norfolk Trotter. This effort is not restricted to the idle twaddle about Bell ounder, which everybody on this side of the Atlantic estimates at its true value, but it has taken an official and widler range, which, trifling though it be, my duty as a historian impels me to expose. Mr. Henry F. Euren, the compiler of the Hackney Stud Book, wrote to the Commissioner of Agriculture, at Washington, D. C., in 1888, taking exceptions to some conchusions reached in an article written by Mr. Leslie E. Macleod, in my office, on "The National Horse of America," and published in the report of the Department of Agrienlture for 1887; Mr. Euren claiming that the American trotting horse came originally from Norfolk, in England. In proof of this he says: "I beg to inclose you a cutting which confirms my idea." And now for the "cutting" which he offers as proof:

"It appears from an Act of Parliament, passed December 6, 1748, in the Iegislature of the State of New Jersey, America, that on and after the publication of this Act, all Norfolk pacing or trotting of horses for lncre or gain, or for any sum or sums of money at any time (excepting such times as are hereafter expressly provided for by this Act), shall be and are hereby declared public nuisauces, provided always that at all fairs that are or may be held within this province, and that on the first working day after the three great festivals of Christmas, Easter and Whitsuntide, etc., etc."

'The act passed by the provincial legislature of the colony of New Jersey in 1748 embraced very stringent regulations against dice, lotteries, etc., as well as horse racing. It is divided into several sections, and at Section 4 we reach the provision against racing as follows:

"And be it further enacted by the authority aforesaid that after the publication of this Act. all horse racing, pacing or trotting of horses for lucre or gain, or for any sum or sums of money at any time (excepting such times as are hereafter expressly provided for and allowed by this Act), shall be and are hereby declared public nuisances, and shall be prosecuted as public nuisances, in manner hereinbefore directed. Provided always, and it is the true intent and meaning of this Act, that at all fairs that are or may be beld within this province, and that on the first working day after the three grand festivals of Christmas, Eacter and Whitsuntide, etc., etc." 
These quotations are sufficiently extended to afford an unmistakable comparison, and on their face evidence that cannot be doubted for one moment that they both purport to be copied from the same act of the Jersey Colonial legislature. In the official printed copy which is before me as I write, the mandate is against "all horse racing, pacing or trotting of horses for lucre or gain." In Mr. Euren's "cutting" the mandate is against "all Norfolk pacing or trotting of horses for lucre or gain," etc. The substitution of the word "Norfolk" instead of "horse racing," is in the nature of a forgery, and I cannot believe that Mr. Euren would be guilty of any such execrable piece of trickery. It must have been conceived and written by some horse sharp who was trying to sell a Hackney to an American with a pocket full of money, and after he had effected his sale he could mutter quietly, when at a safe distance from his victim, the couplet from "Hudibras:"

“'The paltry story is untrue

And forged to cheat such gulls as you."

Unfortunately, however, for Mr. Euren, he indorsed the trick, and not only indorsed it, but sent it to the Commissioner of Agriculture with the hope and possible expectation that it would receive public recognition and become part of the horse history of this country. Did he not know that somebody would be nosing round among the old laws and expose the dirty deception? But, on the basis that Mr. Euren was deceived by this wretched interpolation of a fraud into the law, could he not see that the date of the law-1748 - was before old Shales or Useful Cub was foaled, and long before the very first "Norfolk trotter" was ever heard of either in Norfolk or in any other part of England?

The exposure of this foolish attempt, wherever it originated, to incorporate into an old New Jersey statute a fiction, or a forgery, as it may be called, carries with it a punishment that should be felt by the most unscrupulous of horse sharps; but when we find it unequivocally indorsed and given to the world as true by the compiler of the Hackney Stıd Book, it destroys all confidence in the accuracy and reliability of that work. This is a misfortune that the friends of the Hackney in England as well as in this country must feel as a blow at the value of the whole interest. Opinions may change with new light, and opposing 
conclusions may be honestly reached from different standpoints, but running against a fixed and certain date, as in this case, is like rumning against a two-edged sword.

In conclusion, the Hackney is merely the dear-bought and farfetched fashion of the hour. A few years ago he was "something new in horses," just as the modiste has "something new in dresses." He was found in England, where there are no flies, without a tail, and as that was the fashion in England we must have horses in America withont tails, notwithstanding the millions of torments they have to endure without the natural means of defense. As hack-a-bouts they are good horses, but their "churn-dasher" style of action will never become acceptable to the American people.

A few years since a quite persistent attempt, backed by unlimited wealth and all the prestige that metropolitan "fashion" and "society" could bestow, was made, particularly in New York, to create a Hackney "boom" in America. All that element in the social life of our great cities that affects a disdain for things distinctively American, and particularly for American horses, and that glories in the stultifying habit of aping things "English, ye know," took up the Hackney fad with unbounded enthusiasm. As a park and road horse the American horse-the incomparable trotting-bred driver-was to be incontinently crowded ont of the driveways, the markets and the shows. The National Horse Show Association, whose annual show at Madison Square Garden is the great social fête of the year in New York, lent all its powerful influence to forward the Hackney "boom," which was, it must in fairness be said, consistent; for the miscalled National Horse Show has always catered more to foreign horses and foreign customs in horsemanship than to American horses and horsemen. Men of great wealth and prominence established extensive Hackney studs, imported famous prize-winning stallions and mares, and there was only one thing left to be done, and that was to convert the American people to the belief that the driving horse they had been breeding and developing with a special purpose and care-the fleetest and most versatile harness horse in the world-was inferior to an imported nondescript. In that attempt the Hackney advocates have failed in America as completely as did Mr. Blunt and others in England, when they sought to make racing men believe that the Arab was a better race horse than the English thoroughbred. 
Perhaps nothing illustrates better what I have called the versatility of the trotter than this contest with the Hackney in the latter's own especial field-if he may be said to have any. Of course there could be no contest between the horse of a special breed and the nondescript as a harness horse for speed or usefulness on the road, whether the distance were half a mile or a hundred miles; but in the show-ring the Hackney men claimed absolute pre-eminence for their "high-acting" horses. They did not dare contest with the trotter in the matter of road speed, so to have any contest at all the trotting horse men had to "carry the war into Africa." This they have done with a vengeance. They have taken the pure-bred trotting horse, dressed him in the fashion dictated by the Hackney "faddists," taught him the Hackney tricks, the preposterous Hackney action and all that, and have beaten the Hackneys not once but time and again right on their own ground, viz., at the National Horse Show in Madison Square Garden. In almost all cases in classes where trotters hare been admitted to compete with Hackneys, the former have carried off the honors within the past two years. Many notable instances might be cited, but one will suffice. At the National Horse Show, 1896, a class was offered for "half-bred Hackneys," sires to be shown with four of their get. The Hackney end of the argument was upheld by Mr. A. J. Cassatt's renowned prize-winner, imported Cadet, with four of his get. Against him was entered the well-known trotting sire Almont Jr., 2:26, with four of his get, and though the judges were gentlemen identified more or less with the Hackney interest, so superior in form, action and style were the four youngsters by the trotting sire that they carried away the honors from the chosen progeny of one of the most noted Hackney show horses in the world.

In the sale ring this verdict has been corroborated. The highest prices-the record figures-paid in the fashionable New York market for park horses, "high steppers," or by whatever name the merely spectacular harness horse may from time to time be called, have been paid for trotting-bred horses; and in advertised sales of "Hacknevs" it has become somewhat common to encounter half-trotting-bred and full-trotting-bred horses.

While no genuine American and horseman can without regret see a typical American horse mutilated and his action perverted in the manner required to bring him into "Hackney" classes at 
the National Horse Show, or in the markets where New York society people buy their stub-tailed horses, it is some compensation to know that these experiments have demonstrated the superiority of the American-bred horse even in the field claimed as especially that of the Hackney. And the Hackney "fad" in America, while it lasted, accomplished a good end in so far as it. directed the attention of American breeders more to the importance of form and style, and taught them that in their own trotting families they have the material from which may best be: produced, in form and style and quality as well as in speed, pre-eminently the most excellent park horses in the world. 


\section{CHAPTER XXIX.}

\section{INVESTIGATION OF DISPUTED PEDIGREES.}

Tendency to misrepresentation-The Bald Galloway and Darley ArabianGodolphin Arabian-Early experiences with trotting pedigrees-Mr. Backman's honest metlods-Shanghai Mary-Capt. Rynders and Widow Machree - Woodburn Farm and its pedigree methods-Victimized by "horse sharps" and pedigree makers-Alleged pedigree of Pilot Jr. conclusively overthrown-Pedigrees of Edwin Forrest. Norman, Bay Chief and Black Rose-Maud S.'s pedigree exhaustively considered-Captain John W. Russell never owned the mare Maria Russell-The deadly parallel columns settle it.

A FEw years more than forty have slipped away since I first began to give serious attention to the subject of horse history and to contribute an occasional article to the press on that subject. Among my very earliest observations, or I might say, experiences, was the realization of the fact that exaggeration as a habit of thought and utterance was practically universal among horsemen. Sometimes I have thought this tendency to the untrue resulted from the ammoniacal exhalations of the stable, but this thought is not a satisfactory solution, for some of the greatest liars about horses have never known anything about stables. Then, again, I have thonght that a really skillful metaphysician might write a learned disquisition of the question and satisfy himself as to the cause of this moral delinquency, but nobody wonld be able to understand him when he had completed it. This wretched vice, so prevalent everywhere, was not restricted to the professional country "hoss jockey," ready to "swap" with every man he met on the road, but it reached up to men of otherwise excellent character, and these men would "stretch the blanket" tremendously about the blood and other qualities of the horses they were selling. The only way we can account for an otherwise honest and truthful man exaggerating the merits and blood of his horses must be (1) in the fact that he has become attached to him and thinks him better than he is, or it may be (2) that he bought with a false pedigree and withont examin- 
ing it, he assumes it is true and represents it accordingly. But moderlying all this, the representation cannot be disproved, and (3) it may add to the market value of the horse.

This weakness of human nature, so pervasive of all interests. connected with the horse, did not originate in this conntry, but came from the old world. We inherit it from our ancestors. "The fathers hare eaten a sour grape and the children's teeth are set on edge." Take the case of the little bald-faced, pacingbred horse known in the old records as "The Bald Galloway" and while it is not probable he had a single drop of Saracenic blood in his veins, he is fitted out with a grand pedigree, full of that. blood. Although I have already referred to this horse as an exemplification of the dishonesty of the early records of English pedigrees, I will again look at it in a more specific manner. $\mathrm{He}$ was nothing more nor less than a little native horse, belonging to a tribe of noted pacers in the southwestern part of Scotland and in the northern part of England. These Galloways were probably the very last remnant of pacers to be found in Great Britain. He is represented in the books to have been by a horse called "St. Victor's Barb;" dam by Whynot; grandam a Royal Mare. The Bald Galloway was foaled not later than 1\%08, and it. was probably a few years earlier. His reputed sire, "St. Victor's Barb," is not to be found anywhere and was probably fictitious. His dam was represented to be by Whynot, and this horse was not foaled till 1744-thirty-six years after his grandson was foaled. The grandam is given as a "Royal Mare," which in that day was a convenient way of rounding out a pedigree, just as we now attempt to round them out when we know nothing of the blood by saying "dam thoroughbred." "The Bald Galloway" was one of the most successful stallions of his day, and yet he was nothing in the world but a good representative of the old pacing Galloways of that portion of Scotland then called Galloway. $\mathrm{He}$ was low in stature, but he was esteemed as one of the greatest and most valuable racing sires of his generation. One of his sons-the Carlisle Gelding-was still a race horse when he was eighteen years old.

"The Darley Arabian" was contemporaneous with the Bald Galloway, and they commenced service in England about the same year. It is said he was brought from Aleppo, in Syria, or, perhaps I had better say Asia Minor. Aleppo is but a short distance from the borders of ancient Cappadocia and Cilicia, coun- 
tries that were famous in history for the great numbers of fine horses that they produced far more than a thousand years before the first horse was taken to Arabia. This horse is called an "Arabian," and in the brief record of his importation we have the same venerable "chestnut" served up to us that has served so many generations of speculators in "Arabian blood." The record says that Mr. Darley had a brother who was an agent for merchandise abroad, who "became a member of a hunting club, by which means he acquired interest to procure this horse." This "gag" has been played too often to give éclat to horses claimed to be brought from Arabia, in the past two hundred years, to have much effect on the minds of people who have any sense. That it required great social or political influence to induce the old Arab sheik to part with him, was intended merely to secure the attention of prospective customers to his superlative excellence in order to obtain their patronage. This horse probably never was within five hundred miles of the nearest part of Arabia, and to call him an Arabian is a misnomer wholly unjustifiable. He came from a country where horses were abundant. and cheap on all sides, and of a quality far superior to any Arabian. He was simply a Turk, he was for sale, and it required no influence to buy him except the contents of the purchaser's purse. This horse has always been classed as one of the two great founders of the English race horse. His progeny from well-bred mares were not numerous, and his greatest distinction is in the fact that he was the sire of Flying Childers. In accordance with the truth, he should be known in the records as. "Darley's Turk."

The horse bearing the dishonest misnomer of "Godolphin Arabian" was really the greatest regenerator and upbuilder of the running horse that England ever possessed. There seems to be no historical doubt that he was brought from France, and that is all we know about his origin and early history. It may be laid down, therefore, as a safe proposition, that the odds are as a thousand to one that he was a French horse. The only evidence that. can ever be furnished as to the strain of blood that he may have. possessed must be found and studied in his portrait, which appears in this volume. I believe this portrait to be a correct and true delineation of the $\mathrm{r}$ orse, and there is not a single lineament in or about it that indicates the blood of either the Arabian or the Barb. His pedigree is in his picture, and, from what is 
known in history and from what has been preserved in art, instead of "Godolphin Arabian" his true title should be "Godolphin Frenchman." Eut this subject has been discussed at greater length in the chapter on the English Race Horse, to which my reader is here referred.

In the chapter on the American Race Horse, I think sufficient attention has been given to the frauds and impossibilities that are to be found everywhere in the extended pedigrees of our own running horses to satisfy any one that the remote extensions of pedigrees are a great mass of dishonest rubbish, with scarcely a speck of truth to be found. I will, therefore, pass along to the consideration of some of the difficulties, of the same nature, that have been developed in investigating and recording the pedigrees of the American 'Trotting Horse. In entering the untrodden wilderness of trotting-horse history it became the ambition of my life to reach the truth in every possible instance and to cut off and reject all frauds wherever they showed their heads. This meant war from the beginning with a great many horsemen, but it also meant the enthusiastic support of a great many honest men. The trouble, at this point, was in the fact that a number of prominent, wealthy and influential breeders insisted upon their right to state their pedigrees in their own way and thus compel me to indorse them by inserting them in the Trotting Register. When at work on the early volumes of the Register, especially the first, if a man of unblemished reputation and intelligence sent me a list of his stock to be registered, I assumed that he had too much regard for his reputation and standing as a breeder to print a lot of pedigrees in his catalogue that he did not know to be correct, and hence I accepted many a pedigree that was based upon fiction. In course of time it began to dawn upon my understanding that there were many men in the world of unsullied reputation, as they were known in their business relations, who would stand up boldly for a fiction or a frand in the pedigrees of their stock. It is but just to say that all the men who uttered fraudulent pedigrees were not equaliy guilty, for in some cases the owners had been victimized by unscrupulons rogues from whom they had purchased, and in others they had been betrayed by the still more unscrupnlous rogues whom they had employed to make up their catalognes on the supposition that they were capable and honest. This state of things soon leveloped another line of thought and observation in my mind 
which evolved a rule by which I could determine the difference be tween the degrees of honesty among horsemen. One man, when a fiction in a pedigree was pointed out, would go to work and carefully investigate it; while another would hang and higgle about it and finally investigate, not to find the truth, but to find how many old rummies, swipes and negroes he could get together, who would support his claim and swear to it for a halfdollar each. The first man investigates to find the truth wherever it may lead; while the second man investigates merely, not. to find the truth, but to find some kind of evidence to sustain the untruth. In the everyday affairs of life these two men may stand on the same plane, but, at heart, the one is honest and the other a rogue.

When Mr. Charles Backman founded the great Stonyford breeding farm in Orange County, New York, he was an excellent horseman, in a general sense, although he did not pretend to know much about pedigrees. About 1869 he placed all his pedigrees in my hands with the request that I would give them a careful examination, strike out everything that was wrong and note everything that was doubtful or uncertain, that it might be investigated and the truth fully determined, no difference where it might lead. Many investigations followed which were conducted by his secretary, Mr. Shipman, either by mail or by personal visitation-so many, indeed, that Mr. Shipman became quite an expert in this kind of difficult work. As an illustration of the methods pursued, one instance will serve to show how it was done, and more than this, it is a very interesting history in itself. In the first volume of the Register I had entered Green Mountain Maid, the dam of the famous Electioneer and all that family, as "by Harry Clay, dam said to be by Lexington." This was the form in which Mr. Backman had received the pedigree, except that it was stated positively and without any "said to be" that the dam was by Lexington, the great running horse. After a time I called Mr. Backman's attention to this "said to be" and suggested that if the mare was really a daughter of Lexington she could certainly be traced and established. The next day, Mr. Shipman started to Western New York and to Ohio. On his trip he found the mare had been known in Western New York as the "Angelica Mare" and afterward as "Shanghai Mary," that she was a trotter, well known locally, and that she had trotted a race and won. 
at a State fair, in very fast time for that day. She had been brought from Ohio by some sheep-dealers, who were able to give her exact age, and it was thus found that she was older than her reputed sire. Several expert horsemen, from a picture secured by Mr. Shipman on his trip, have not hesitated to give it as a strong conviction that she belonged to the Cadmus family, in Southern Ohio. In the last two or three years a correspondent of the Chicago Horse Review brings out some local facts that make it almost morally certain that she was bred by Goldsmith Coffein, of Red Lion, Ohio, and that she was got by Iron's Cadmus, the sire of the great Pocahontas. The final nail has not been clinched in establishing this pedigree, and probably never will be, but the circumstances are so fully detailed as to scarcely leave room for a doubt that she was a half-sister to the famous Pocahontas.

From what has here been said about the methods of $\mathrm{Mr}$. Backman, the leading breeder of that period, in the North, it should not be inferred that all Northern breeders were like him. The first real battle I ever had against fraudulent pedigrees originated in Orange County, New York, with the notorious Captain Rynders, in which the pedigree of the once famous Widow Machree, the dam of Aberdeen, was involved. The pedigree of this mare had been registered as obtained from Mr. James W. Hoyt, who once owned her, and her dam was given as by Durland's Messenger Duroc. When Aberdeen came before the public for patronage, his owner, Ryuders, advertised him as out of Widow Machree and she out of a mare by Abdallah. This was challenged as untrue by Mr. Guy Miller and Mr. Joseph Gavin, of Orange County, and I was called upon to demand the evidence upon which the change had been made from Messenger Duroc to Abdallah. As a matter of course "the fat was in the fire" at once, and out came Rynders with a terrific explosion of anger, abounding in threats and deuunciations against anybody and everybody who attempted to interfere with his "business." The good names of Guy Miller and Joseph Gavin carried too much weight as against that of Isaiah Rynders, and, as bis last card, he brought out a duly and formally executed affidavit, sworn to by a man whose name I will not here mention, stating that he bred the Abdallah mare; all of which was the very rankest perjury, which was so easily exposed that it did Rynders far more harm than good. At last the whole truth came out in a 
form that was complete and conclusive, showing that the mare in question was bred by Garrett Duryea, of Bethel, Sullivan Connty, New York, and was got by a horse known as Pintler's Bolivar. Rynders had been a leader in New York polities so long that he knew just how to manage things where the truth must be suppressed. He was a liberal advertiser, the two sporting papers were needy for patronage in that line, and their columns were closed to any and all communications against lis side of the question. But all this failed to suppress the truth and uphold a fraud, and I doubt whether there is a man living to-day who does not believe that the fight was fairly and honestly won. This contest taught me a very important lesson, and that was, that if I expected to fight bogus pedigrees I must have a channel of communication of my own. Hence Wallace's Monthly, which, in its day, was not only able to expose bogus pedigrees, but lead intelligent thought and experience on all breeding subjects, till it fell into the hands of an unscrupulous neocracy, where it soon died for want of brains.

Having given a very brief illustration of the methods which governed Mr. Backman in ascertaining and determining the blood elements which entered into the foundation of his great breeding establishment, and the care and promptness with which errors were eliminated, it is now in order to take a glance at the methods pursued at the great Woodburn Farm, foumded by $R$. A. Alexander in Kentucky. These were the two earliest establishments, of any prominence, for breeding the trotter, in the whole country. The one was the northern center of the interest and the other the southern, and they together may be considered as representative of both sections. Mr. Alexander, I think, was reared and educated in Scotland, and there inherited a large estate. Upon coming into this inheritance he determined to transfer his interests to Kentucky, where he bought up a cluster of farms and shaped them for the purpose of building up a mammoth establishment for the breeding of all varieties of domestic animals of the highest type and excellence. I think his fancy ran more to Short Horn cattle than to any other line of breeding, probably because he knew more about the value and merit of the different tribes of that breed than he did of any other variety. The founding of an establishment so immense, and for the grand purpose of the breeding and improving the varieties of domestic animals, was the agricultural sensation of the period, and every- 
body, from one end of the land to the other, soon knew of and applauded the great enterprise. There had been great enterprises on similar lines before, and there have been even greater ones since, but Mr. Alexander's Woodburn Farm, of Kentucky, may always be looked upon as the real pioneer in stock breeding on a large and methodical scale, and without limit as to resonrces. A university education in Scotland, with all its training in the refinements of logical distinctions, did not bring to Mr. Alexander a knowledge of the pedigrees of Kentucky horses, nor did it train him in the detection of the tricks of Kentucky horse dealers, and thus as a purchaser of his breeding stock he was looked upon by the "sharps" as a fat goose, ready to be plucked. After these "sharps" had secured their pluckings, Mr. Alexander called in a professional pedigreeist to put the lines of the blood the had purchased in order and print a catalogue. This "professional" was not a pedigree tracer, for he: never traced anything in his life, but a pedigree maker, and wherever he thought that anything was needed he added it, whether true or not, and it went to the world in that form. This. is more conspicuously true in the department of trotting pedigrees, as will appear below. Thus the acts of an incapable and dishonest employee were given the indorsement of an honorable: and eminent name; falsehoods were made to appear as truths; counterfeits were put in circulation that are still circulating as. genuine coin, with many people. Under the circumstances, Mr. Alexander could hardly be blamed, for, knowing nothing of such matters of his own knowledge, he employed what he supposed was the best anthority then to be found. For my own part, when I came to register the Woodburn stock, I was ready to accept as true whatever I found in the catalogue, believing that. Mr. Alexander was incapable of publishing to the world a misrepresentation. In this estimate of his character I was right, and I have never changed my opinion on that point, but when I came to examine the structure of his catalogne I found there was rotten wood all through it. A few examples that have been carefully investigated will serve to show the value of the work done by the "pedigree maker" for Mr. Alexander.

Pilot Jr. was a gray horse, foaled 1844, was got by Old Pacing Pilot and attained the distinction of being the head of a wellknown family of trotters. He was foaled 1844, bred by Angereau Gray, and owned a number of years by Glasgow \& Heinsohn, of 
Louisville, Kentucky. He was kept a number of years about Lexington, Kentucky, by Dr. Herr, Mr. Bradley, and perhaps others, and always advertised as "by Pilot (the pacer), dam Nancy Pope, grandam Nancy Taylor." Nobody then ever pretended to know what horse was the sire of either Nancy Pope or Nancy Taylor. He was then owned by the parties who afterward sold him to Mr. Alexander, and it is evident they did not then know anything about the sires of these mares. Mr. Alexander bought him in 1858, and immediately his "pedigree maker" furnished the sires of these two mares; Nancy Pope was given as by Havoc, son of Sir Charles, and Nancy Taylor as by imported Alfred. The controversy about this pedigree was long and sharp, the one side, headed by the modern management at Woodburn, as usual laboring to sustain the infallibility of the Woodburn catalogues, and the other to reach the exact truth, whatever it might be. 'The Board of Censors of the National Breeders' Association sent out a call for information on certain abstract points and finally reached a decision as follows: (1) 'That Havoc, the reputed sire of Nancy Pope, the dam of Pilot $\mathrm{Jr}$., died in 1828. (2) That Nancy Pope was not foaled till 183\%. (3) That the breeding of Nancy Taylor, the dam of Nancy Pope, was unknown. These dates were fixed by undoubted evidence, and, as afterward developed, another might have been added with equal authenticity. Imported Alfred, the reputed sire of Nancy Taylor, was not imported till several years after Nancy Taylor was foaled, and thus it was clearly shown by the absolntely insuperable difficulties of dates that both the sires inserted in the pedigree were nothing more than very stupid fictions.

Edwin Forrest seems to have held second place in the list of stallions in the Woodburn Stud at that period, and the remote extensions of his pedigree were also fictitions. His grandam was represented to be by Duroc, the famous son of imported Diomed, and his great-grandam by imported Messenger. The first two crosses were technically inacurately stated, but the second two, as given here, were purely fictitious.

Norman, the third stallion in the catalogue, had his sire correctly given as the Morse Horse, but his dam was given as by Jersey Highlander and his grandam as by Bishop's Hambletollian, son of Messenger, both of which were wholly fictitious. His dam was by a horse called Magnum Bonum, a representative of a family of that name, and that is all that is known of his 
pedigree. A full showing of this pedigree will be found in the "'Trotting Register," Vol. III.

Bay Chief was a bay son of Mambrino Chief, with a bald face, and was often called Bald Chief. He was the sensational trotter of the whole Mambrino Chief family, and I believe it is true that when four years old he showed a half-mile on Mr. Alexander's track in 1:08 and repeated in 1:08 $\frac{1}{2}$. In the catalogue he is given as foaled in 1859, got by Mambrino Chief, dam by Keokuk, son of imported Truffle; grandam a thoroughbred mare by Stamboul Arabian. As this was found in Mr. Alexander's eatalogue I took it for granted it must be true, but I never had heard of a running horse called Keokuk before, and I kept hunting for ever so many years without finding hide nor hair of him, until 1885, when the whole mystery was developed. Mr. Richard Johnson, of Scott County, Kentucky, had business interests in Keokuk, Iowa, in the early fifties, probably locating land warrants, and he bought a pair of mares in Keokuk to travel over the prairies, and when he was through with his work he brought the tean home with him to Scott County. He knew nothing whatever of the breeding of those mares, but they were a good pair of drivers and one of them was quite a smart roadster that he called "Old Keokuk." He bred this mare, Keokuk, in 1858 to Mambrino Chief, and in 1859 she produced the colt called Bay Chief. In 1862 he was bred to some sixteen or eighteen mares, and the fall of that year Mr. Alexander bought the colt at public auction, paying one thousand doliars for him. He was taken to Woodburn, put in training and never covered any more mares. In the spring of 1865 he was killed in a raid of Southern troops upon the horse stock at Woodburn. (For further particulars of this little sketch the reader is referred to Wallace's Monthly for 1885, page 285.) To fix up a pedigree for the maternal side of this colt was no easy matter, but Mr. Alexander's "pedigree maker" proved himself fully equal to the occasion. There was the nasty name Keokuk fastened to the old mare, and it would stick as tight as wax to the end of her days, coming from a region where there was no drop of rumning blood; so he made a "thoroughbred" horse, right on the spot, and gave him the name of Keokuk, which would account for the name of the mare, and pronounced him a son of imported Truffle. To supply a "thoroughbred" grandam was comparatively easy, for Mr. Johnson had long been a resident of Scott County, and the horse Stamboul had been kept 
in that county, hence there could be no doubt that she was a "thoroughbred" daughtor of that horse. With this review of the misfortunes of Mr. Alexander in placing tho arrangement and, I might say, care of his pedigrees, in dishonest hands, we will pass whatever may remain of his early stallions, and take a glance at some of the pedigrees of his brood mares.

Black Rose proved to be one of the best brood mares ever owned at Woodburn. I am told she was a pacer, and certainly all that is known of her blood was paeing blood. She was sought after and procured by Mr. Alexander because she had produced several trotters, and it can be read all through his purchases for the trotting stnd, that he had undoubting confidence in the theory that trotters must come from trotters. When this mare first appeared in the Woodburn catalogue no dam was given to her, but meantime the "pedigree maker" had come around, and the next year she was fitted out with the following, in fine style.

“ Black Rose,' bl. m., foaled about 1847 ; got by Tom Teemer ; dam by Cannon's Whip ; g. d. by Robin Gray, son of imp. Royalist."

The pedigree stood in this form a number of years, and probably would still be so standing had it not been that in trying to learn something more about the sire, Tom Teemer, I received some intimations that made me doubtful about the maternal side. On a certain occasion I asked Mr. R. S. Veech, of Kentucky, what he knew about it, and he replied that he had made a trip to Clark County for no other purpose than to trace and investigate the pedigree of Black Rose, and he was not able to get a single syllable of information about her dam, any more than if she never had a dam. Some time afterward I wrote to Mr. Brodhead, manager at Woodburn, inqniring where the pedigree of Black Rose as given and perpetuated in the Woodburn catalogues came from and on what basis it rested. He replied promptly and briefly that Mr. Veech had made a trip to Clark County in search of this pedigree and the result of that search was what appeared in the catalogne. These are the facts, substantially, as giren me by these two gentlemen, and this is the first time I have ever given them to the public. I have known Mr. Veech intimately and trustingly for twenty-eight years and I know him to be em. inently truthful. I have not known Mr. Brodhead so long, and if he had not published the fraudulent extension of this pedigree in his catalogues every year for more than ten years, before Mr. 
Veech made his trip to Clark County, I might at least express my sympathy with him in having so bad a memory. Mr. Brodhead had nothing to do with either the original construction or ntterance of this frand, for he was not then connected with the management of Woodburn. My readers can employ their own terms in characterizing, as it deserves, the fraudnlent act of manufacturing a pedigree out of whole cloth; and they can also exercise their own ethical discrimination in determining whether the man who executes the frand is any worse than the man who maintains and supports it after he knows it is fraudulent.

We pass on to Sally Russell, the grandam of Maud S. It is not a pleasant task to review an old controversy, whatever it might bring to light; but a controversy which involves the true lines of descent of so great a family as that of Mand S., Nutwood, Lord Russell, etc., is worth preserving for the enlightenment of fnture generations. It all turns upon the breeding of Sally Russell and the identity of her breeder. She was a little chestnut mare, represented to have been foaled 1850, got by Boston and out of Maria Russell, by Rattler, and so on, claimed to be thoroughbred. She was bought by Mr. Alexander from the foreman on Captain John W. Russell's farm, with the pedigree giren as above. The name of her breeder was not given to Mr. Alexander, I think, but Bruce has it that her dam, Maria Russell, and this mare Sally Russell were both bred by Benjamin Luckett. In 1863 this mare was offered, with others, to the highest bidder, at Mr. Alexander's annual sale, being then thirteen years, old according to the records of the establishment, and the anctioneer was not able to coax a bid of ten dollars on her and she was led out unsold. Five years later-1868-I attended the Woodburn sale, and a little scrubby-looking old mare was brought into the ring, represented to have been stinted to imported Australian, and when this was announced a subdued whisper went round the ring, "She'll never raise another foal." 'The anctioneer was eloquent upon the value of the Australian blood on the Boston blood, and the possibilities of the coming foal, but all to no purpose, as the mare was led out of the ring the second time, with no person willing to bid a dollar. I was astonished that such an animal should have been put up at auction, for she had all the appearance of being twenty-eight instead of eighteen. She died that summer, apparently of old age, and I have no shadow of doubt that she sank under the weight of years. On two separate 
occasions great crowds of practical horsemen had, in this manner, proclaimed that Mr. Alexander had been victimized in the age of the mare, and fifteen years later I determined to settle the question as to whether this judgment was right.

As the supposed age and breeding of Sally Russell has been made to turn and rest upon the ownership of her dam, Maria Russell, it is important that we should have the antecedent circumstances set out in the plainest possible manner. Captain John A. Holton and Captain John W. Russell were farmers in Kentucky, living a few miles apart, and I think they were both river men at one time or another; certainly Russell was in command of a snag boat on the Ohio and Mississippi along about 1836-40. Like many other Kentucky farmers, they both bred a few running horses, but not enough, singly, to justify the expense of separate training establishments, so they united their strings in one stable, sharing the expense and dividing the profits, if any, equally. The partnership did not extend to the joint ownership of any of the horses, but simply to the losses or profits of training and racing, and Major Benjamin Luckett was in their employ as trainer.

Before going to work in earnest on this investigation, I learned that Mr. Llewelyn Holton, a son of Captain John A. Holton, still resided on the old farm and that he was old enough to know all about the origin and history of Maria Russell, as well as the other stock belonging to his father at that time. This was very encouraging, but I wanted to know whether he was a man who could be relied upon to tell the truth. On this point I addressed an inquiry to the late Colonel R. P. Pepper, and his reply is as follows: "Your letter of the 29th received. I regard L. Holton, of this county, as a man of honor, integrity and intelligence, and the peer of any gentleman of my aequaintance. In my opinion any statement he will make upon any subject, as to his own knowledge, will be accepted in this community as readily as that, of any gentleman in it. $\mathrm{He}$ is a man who sometimes gets on sprees from intoxicating liquors, but $\mathrm{I}$ have never heard of it affecting his intelligence, honor or integrity, and, as above stated, his word will be accepted in this community at this time as soon as the word of any gentleman in this county or commnnity."

With this very high indorsement I did not hesitate to send a commissioner to interview Mr. Holton and get from him the 
exact facts in the case, witiout any leading questions and without any shading of the truth or bias on either side. What this commissioner learned will be given further on.

Let us now turn to the other side and see how Mr. Brodhead manages to get Maria Russell into the ownership of Captain John W. Russell. Under date of April 30, 1883, he wrote to the Turf, Field and Farm as follows:

"A Colonel Shepherd, of the South-New Orleans, I think-gave or sold to Captain J. W. Russell and Captain J. A. Holton a Stockholder mare, out of Miranda, by Topgallant, etc. This mare was called Miss Shepherd. 'They owned and bred this mare in partnership. Among the produce thus owned were Maria Russell by Rattler, Mary Bell by Sea Gull, and Swiss Boy by imported Swiss. Captain Russell sold his half of Swiss Boy to Mr. Taylor, son-in-law of Ben Luckett, for $\$ 750$. Maria Russell was owned and run as a partnership mare by Holton and Russell, but was trained by Major Ben Luckett."

Then follows a lot of stuff, without any relevancy whatever, going to show that Ben Luckett trained her at three years old, but had no connection whatever with the family, all of which is known to everybody, and then he again asserts that "in the division of the partnership property, Maria Russell fell to Captain Russell." 'The next dash that Mr. Brodhead makes is for a negro seventy-five years old, who had been in the Russell family from his birth, named Jesse Dillon. Jesse was no exception to his. race, or indeed to many of the white race, for whenever any information is wanted from them they are always ready to give it, as they expect at least one half-dollar, and if they tell the story "right up to what is wanted" they expect two. Jesse was sharp enough to discover just what his interviewers were after, and he was ready to supply "the long-felt want." Jesse was able to tell just how the mare got her eye knocked out and just how he took her to Blackburn's and had her bred to Boston. In all this, including the loss of the eye and tine trip to Blackburn's, Jesse may have had in his mind Captain Russell's one-eyed mare, Mary Churchill, while his interviewers were thinking about Maria Russeli. It is no uncommon thing for white people as well as black, at seventy-five, to get names of forty or fifty years past confused.

This is all of Mr. Brodhead's case so far as what he presents has any relevancy to the point at issue, namely, the identity and ownership of the mare Maria Russell. The pedigree was not made at Woodburn; Mr. Alexander in this case as in many others 
was simply the victim of the sharper. The only shadow of evidence that has been presented that the pedigree might be true is the evidence of a superannuated negro, Jesse Dillon. For the Woodburn side of the case the reader is referred to Walluce's Monthly for June, 1883, page 366. In replying to this case I will try to summarize the different considerations as briefly as possible.

First. The case is opened with the assumption that Colonel Shepherd presented the mare Miss Shepherd, by Stockholder, to Captain J. W. Russell and Captain J. A. Holton. We might laugh at this by asking which half he gave to Russell and which half to Holton? This is merely constructing a theory by which the ownership of Russell might be maintained. It is safe to say the mare was given to Holton and to Holton alone, and here is the proof of it. There is a silver eup, now in possession of Mr. Bowen, grandson of J. A. Holton, with this inscription: "J. A. Holton, awarded by Franklyn Agricultural Society, 3836, for filly Maria Russell." Where is Captain J. W. Russell's ownership at that date?

Second. When S. D. Bruce was compiling his Stud Book, Captain John W. Russell had his thoronghbred stock entered there. There were several brood mares with their produce under them, but where were Maria Russell and her daughter Sally Russell? They appear as the property of Ben Luckett, when everybody knows he had nothing to do with them. As Captain Russell did not have them entered when he was entering his other stock, I must take it as prima facie evidence that he did not own them at that time.

Third. It is now in imperishabie evidence that John W. Russell did not own Maria Russell in 1836, and that he did not own her at the time Bruce was compiling his Stud Book, and now the question is, was there ever a time when he did own her? To answer this question we must turn to Llewellyn Holton, the only man then living who knew and had a right to know all about the history of this mare. His statement is as follows:

"Forks of Elkhoun, May 24, 1883.

"This is to certify that my father, Captain John A. Holton, was, for a number of years, interested with Captain John W. Russell in a number of thoroughbreds, and they raced them in partnership. When they dissolved and divided the stock, I an positively certain that my father retained all the descendants of the Stockholder mare-among them Maria Russell, and all her produce- 
and I know to my certain knowledge that Captain Russell never owned or had in his possession the mare Maria Russell, or any of her produce; and I further know to my certain knowledge that said mare, Maria Russell, had two good eyes from the time of her foaling until the day of her death. If my fatlier bred a mare to Boston in 1848 , I incline to the opinion that it was a bay mare called Limber, for the reason that she, Limber, was very uncertain, having missed several seasons. There is one point, however, that I feel very certain upon, and that is that neither my father nor Captain Russell, during their racing or breeding career, ever owned a Boston filly. As Boston was the most famous horse of his time, it is not at all possible that there could have been a Boston colt or filly on my father's farm and I not knowing of the fact. I was born in the old homestead the 15 th of November, 1820 , and have resided either there or adjoining all my life; therefore I had constant opportunity to know all about my father's stock of horses.

L. Holton.

"I hereby attest that the above is my father's signature.-J. A. HoLToN, son of Llewellyn Holton."

Fourth. With the foregoing clear and decisive statement before us, it is not necessary to determine whether the partnership between Holton and Russell embraced the joint ownership of the racing stock or whether the running colts of the two farms were brought together from year to year, and as a matter of economy and profit, trained and raced as one stable. This latter view of the question seems to be made plain. In his interview with Mr. Holton my commissioner reported as follows: "The horses were always trained by Captain Holton at his private track at the Forks of Elkhorn. That he, Llewellyn Holton, always went after the colts that were on the Russell farm when the training season commenced, and at the close of the racing campaign of the year he always took those back that came from the Russell stock, while those from Captain Holton's stock were kept on the home farm. When the partnership between Captain Holton and Captain Russell was dissolved, Mr. Llewellyn Holton is positively certain that Captain Russell retained his own stock and Captain Holton his own, the latter consisting of the produce of the Stockholder mare, among them Maria Russell, and all her produce. And he is still more positively certain that neither the mare, Maria Russell, nor any of her produce was ever in the hands of Captain Russell." At the close of each season the owners, respectively, took their own stock home till the next spring, and after a series of years each owner took his own stock home, and that was the end of the arrangement.

Fifth. In the summer of 1883 I met Mr. John W. Russell, son of Captain Russell, at the house of Mr. R. S. Veech, near 
Louisville, Kentucky, and we had some conversation on the question of the pedigree of Sally Russell, which had then been in hot controversy for some months. The subject was not a pleasant one to him and he either parried or negatived the few questions I asked. A year or two after this I met him at the Galt House in Louisville, and we had a very pleasant conversation. The controversy about Sally Russell had then subsided, and I asked him if he remembered his father's thoroughbred mare Mary Churchill. "Oh, yes," he said, "she was the first horse I ever rode, and my folks were very much afraid I would fall off and get hurt." I then asked him if Mary Churchill was blind of one eye, and he answered he "could not remember." My next question was, whether he recollected anything about Maria Russell, and his reply was: "Nothing that is definite." Then followed the inquiry, "whether there were any traditions in the household going to show that his father ever owned Maria Russell," and he replied: "There are no traditions that are reliable." These replies were a most grateful surprise to me, and if I have not given the precise words used I certainly have given the precise meaning.

Sixth. Llewellyn Holton was sixty-three years old in 1883 and he was afflicted with physical paralysis, but his mind seems to have been perfectly sound and memory good for a man of his age. Before he had the slightest intimation that a pedigree was being investigated that might call him into controversy, he was asked about Maria Russell by one of the most prominent and distinguished of all the breeders of Kentucky, and that breeder wrote me as follows:

"I Lave seen Mr. L. Holton, the son of Captain Joln A. Holton, of this county, and he says his father bred and owned Maria Russell; that she was by Rattler, and out of a mare by Stockholder, and was foaled 1834 . He says lie thinks a man by the name of William Duvall can give some information about these mares. I will see him to-morrow, and write you."

As this information about Maria Russell was elicited from Mr. Holton on the spur of the moment, and as he gave her pedigree correctly, and not only this, but gave the year in which she was foaled correctly, his memory, at least so far as this mare is concerned seems to hava been remarkably good.

Seventh. My correspondent wrote a few days later: "I have just learned from William Duvall, who trained for Captain J. A. 
Holton in 1842, that he remembers the mare Maria Russell, and he thinks she was by Seagull, and out of Limber, by Whipster; he also remembers a mare owned by Holton that was by Rattler, but cannot remember any more about her." This confirms Mr. Holton's recollections in a very striking and satisfactory manner. As a trainer Mr. Duvall did not handle the brood mares, but only their produce. He recalled a Seagull mare and a Rattler mare, that Captain Holton owned, but he attached the name "Maria Russell" to the wrong one. 'This kind of impromptu inaccuracy is almost always an element of strength, for it goes to prove that the witness has not been "coached." He remembered there was a mare by Rattler in the field, and as there was no other Rattler mare owned by either Holton or Russell, the identity of Maria Russell is clearly established as the property of Captain Holton in 1842.

Eighth. With the high indorsement of Mr. Llewellyn Hoiton as a man of truth and honor, given on page 421 of this chapter; and with the evidence before me of his clear and unclouded memory in giving correctiy not only the pedigrees but the year in which Maria Russell was foaled, and all this before there was any pressure or suspicion on his part as to where his disclosure might lead, I cannot, as an honest man, fail to believe that he told the truth. Thus, after leaving out all the minor evidences, we have the three major points fully and clearly established, namely, (1) the inscription on the silver cup that Captain IIolton owned her in 1836; (2) the evidence of William Duvall that he owned her in 184\%; and (3) the statement of Llewellyn Holton that he owned her always and that she died his.

Ninth. At the Woodburn sale of 1863 and 1868 there were certainly at least two hundred experienced horsemen and breeders present who were able to discriminate concerning a mare represented to be thirteen years old when she looked ten years more; or concerning a mare represented to be eighteen years old when she looked as if she were twenty-eight. Hence, no man was willing to bid five dollars on her. This I take it, was the personal judgment of every man who thought anything about it, and when she died a few weeks after the last sale, nobody could doubt that she died of old age, and nobody could doubt that Mr. Alexander represented her to the public just as she had been represented to him, both in age and breeding, by the rogue who victimized him. 
The mare Sally Russell, the grandam of Mand S., had been sold to Mr. Alexander by the foreman of Captain Russell's farm, and it does not appear that he represented her as having been bred by Captain Russell. Indeed, it was not claimed at Woodburn that Captain Russell bred her until a representative of that establishment called at my office to examine the service books of Boston and there found that "John Russell's one-eyed mare" had been bred in 1849. If a fraud, therefore, was established the Russell family must bear the odium. Hence all evidence from that source must be considered in the light of the fact that every member of the family is deeply interested. But notwithstanding the efforts of the Russell family to preserve the father's name from obloquy, and notwithstanding the trip in search of some superannuated darkey who could remember anything and everything in consideration of the pour-boire that would be forthcoming, there stood that terrible statement of Llewellyn Holton that could not be met by evidence. The whole matter was against him, and Mr. Brodhead was not happy. He knew he could not prove him wrong, and the only course left open was to get him to take back certain things that he had said on the ground that his memory had failed and that the fight was between "Old Kaintuck" and outside parties who had no business to interfere with Kentucky affairs. On an appointed day, therefore, all who were supposed to have any influence with Mr. Holton, in the whole countryside, met Mr. Brodhead, and they came down on "the poor old paralytic" hammer and tongs. They asked him what he remembered about all the horses, each in his turn, in the whole neighborhood, whether he had ever heard of them before or not. This was kept up a long time, but they could not prevail on him to take back a single specific statement he had made. He had said Captain Russell had never owned Maria Russell or any of her produce, and he would not take it back. He had said Maria Russell had two good eyes when she died, and he would not take it back. At last when the poor old invalid was worn out they sprung the patriotic dodge of "Kentucky against the world" upon him and this had some effect, but not enough to save the anxious "bulldozers" from a feeling of great depression. At last Mr. Brodhead seized a pen and indited a letter for him to sign, addressed to me, with the request that I would publish it. I am not able to say how many attempts were made to get such a letter as he would be willing to sign, but 
several different drafts were made, and sick and worried, and in order to get rid of his tormentors, he signed, and the letter came to me, and I published it as follows:

“MR. J. H. WALLACE.

“Forks of Elkhorn, June 12, 1883.

“DEAR SIR: In answer to your letter to my son, of May 21, 1883, there are three points suggested. First, in regard to her produce (Maria Russell's). I have no recollection any further. I have no data from which $I$ could find out concerning them. Second. I have no remembrance of her death nor the manner of it. Now, in regard to the statement I made to Mr. John K. Stringfield. I think he has made it too strong, for I told him my statement was from memory unly, and that I could not nor would not swear to it. Since that time I have har sufficient proof to overbalance my mentory, and circumstances called to mind that have convinced me I was in error. I simply stated what I believed to be true at that time. I have no interest in the matter whateveronly want to be understood. I trust that you will oblige me by publishing the aiove letter. Yours truly,

\section{“L. Holton."}

It must have been a most pitiful sight to see six. or eight ablebodied men, headed by the stalwart Brodhead, acting as chief inquisitor, circling round the reclining form of a poor old invalid, trying to convince him that he had no memory and that he was a liar, prodding bim with questions about horses that he never had heard of, and when he failed to tell them, torturing him with remarks that if he couldn't answer that question how conld he know so well about Maria Russell? But with all their tortures they conldn't force him to say his father did not own Maria Russeli all her life and that she did not die with two good eyes. It was simply a little Spanish Inquisition on the waters of the Elkhorn from which came the cry, "Recant, Recant," dinged into the ears of the helpless paralytic. Still, helpless as he was against so many, he obeyed his conscience and maintained his integrity, notwithstanding all the satanic arts of Torquemada. When all else had failed the war-cry was shouted in his ear: "New York is trying to destroy the breeding interests of Kentucky, and all true Kentuckians must stand by each other or we all go under." The old man brightened up and said: "I'm a Kentuckian, but you mustn't try to make me a self-convicted liar.". The piece of patchwork given above, in the shape of a letter, was then shaped up by his tormentors, for the old man was not able to write a line, and dispatched to the office of Wallace's Monthly, where it was printed just as it was received. Each one of the 
tormentors made a copy of it, and no one of them was satisfied with it; even the inquisitor-general said it fell far short of what they wanted, but that by industriously speaking of it as a recantation, the public would soon come to treat it as a recantation.

When, after years of fruitless effort, Mr. Brodhead, manager at Woodburn Farm, got control of registration, he made an early move to have the clond removed from the pedigree of the stallion Lord Russell, and brought the matter before the neocracy of his own creation, of which he was himself the head and brains, and the action thereon was published in Wallace's Monthly for February, 1893. The presentation is imposing in length and abounds in many things that have no possible bearing on the question at issue. Unfortunately I have no means of determining the extent to which the crime of the interpolation or excision has been made manifest except in two of the exhibits which I will give. In Exhibit 1 (Holton's letter above) the following words are interpolated: "and in justice to all I correct my statement." These words are not very important to the meaning, but they are very important as indicating the accuracy, and hence reliability, of a witness. In the same exhibit Mr. Brodhead says: "I insist that you will oblige me," etc., while the original uses the word "trust" instead of "insist." Again, Mr. Brodhead has his letter dated June 11, 1893, instead of June 12, 1883, as it is in the original. The variation of the dates here seems to have had a purpose, whatever it may have been. This letter must have been a great trouble, for I have seen three or four copies of it, so called, and no two of them alike.

I was duly notified that the question of Sally Russell's pedigree would be brought up at that meeting, and requested to be there to sustain my view of that question. The court and the jury were made up of Brodhead's creatures, and organized simply to register his edicts. The wise man said, "Surely in vain the net is spread in the sight of any bird." The bird looked on, from a safe distance, and saw the fowler impaled in his own snare, by his own act, and his true character revealed to the world. It is very difficult to understand just why it should have been deemed necessary to cut out the very pith and heart of Mr. Holton's letter, when he knew that it would make no difference with his court whether there was any evidence at all. Under the law of retribution, a man's character may be determined by his own acts. 


\section{HOLTON'S 'TRUE STATEMEN'T.}

"Forks of Elkhorn, ilay 24, 1883.

"This is to certify that my father, Captain John A. Holton, was for a number of years interested with Captain John Russell in a number of thoroughbreds, and they raced them in partnership. When they dissolved and divided the stock, I am positively certain that my father retained all the descendants of the stockholder mare -among them Maria Russell and all of her produce AND I KNOW TO MY CERTAIN KNOWLEDGE THAT CAPTAIN RUSSELL NEVER OWNED OR HAD IN HIS POSSESSION THE MARE MARIA RUSSELL, OR ANY OF HER PRO. DUCE. And I further know to my certain knowledge that said mare, Maria Russell, had two good eyes from the time of her foaling until the day of her death. If my father bred a mare to Boston in 1848, I incline to the opinion that it was a bay mare we owned called Limber, for the reason that she, Limber, was very uncertain, having missed several seasons. There is one point, however, that I feel very certain upon, and that is, that neither my father nor Captain Russell, during their racing or breeding career, ever owned a Boston filly. As Boston was the most famous horse of his time, it is not at all possible that there could bave been a Boston colt or filly on my father's farm and I not knowing of the fact. I was born in the old homestead the 15th of No. vember, 1820 , and have resided either there or adjoining all my life; therefore I had constant opportunity to know all about my father's stock of lonses. L. HoLton.

"I hereby attest that the above is my father's signature.-J. A. HoLtoN, son of L?ewellyn Holton."

\section{BRODHEAD'S REPRESEN'TA'TION} OF I'T.

“Forks, Elkhorn, May 24, 1883.

"'This is to certify that my father, Captain Jobn A. Holton, was for a number of years interested with Captain John Russell in a number of thoroughbreds, and they raced them in partnership. When they dissolved, and divided the stock, I am positively certain that my father retained all the descendants of the Stockholder mare, among them Maria Russell and all her produce, and I know to my certain knowledge that said Maria Russell had two good eyes from the time of her foaling until the day of her death. If my father bred a mare to Boston in 1848, I incline to the opinion that it was a bay mare he owned called Limber, for the reason that she, Limber, was very uncertain, having missed several seasons. There is one point, however, that I feel very certain upon, and that is that neither my father nor Captain Russell during their racing or breeding career ever owned a Boston filly. As Boston was the most famous horse of his time, if is not at all possible that there could have been a Boston colt or filly on my father's farm and I not knowing of the fact. I was born in the old homestead the 15 th of November, 1820 , and have resided either there or adjoining all my life; therefore I had constant opportunity to know all about my father's stock of horses. L. HoLTON.

"I hereby attest that the above is my father's signature.-J。 A. HoLton, son of L. Holton." 
The deadly parallel columns tell the whole story. The central and most important fact in Mr. Holton's statement has been deliberately and carefully cut out by Mr. Brodhead, and the evidence that he did so cannot be wiped out either by money or by the torture of invalids. The testimony of cold type remains forever. Has Mr. Brodhead, it is asked, professed to have given the whole of Mr. Holton's statement, and suppressed a vital part of it? He has given every word and letter of the statement, from the date line to the signature, except the one sentence that is the life and sonl of the whole statement, and that sentence I have printed above in capital letters, so that it may be easily distinguished and compared. For years I have known that Mr. Brodhead possessed most remarkable visual powers. When he wanted to see a thing he conld see it through a stone wall and without any assistance from the " $X$-rays," and when he didn't want to see a thing he couldn't see it even when held up to his very nose under an arc light. The deception practiced here might justly be designated by a harder name, for it was deliberately planned and carried out in order to gain an end by suppressing the truth. Why did he not free himself from his marvelous powers of vision, and looking out of the natural eyes of his mind, see the imminent danger of a terrible exposure? In keeping back part of the truth with the pretension that he had given it all, how could he avoid recalling the fate of Amnanias and Sapphira for keeping back part of the price with the pretension that they had given it all?

As an exercise in ethical athletics I will submit the following abstract question to the debating clubs, especially in Kentucky, viz., "Is the man who suppresses the truth in order to sustain a fraudulent pedigree any more worthy of belief than the man who made the pedigree and sold the horse upon it?", 


\section{CHAPTER XXX.}

\section{INVESTIGATION OF DISPUTED PEDIGREES.-(Continued.)}

How Belle of Wabash got her pedigree-Specimen of pedigree making in that day and locality-Search for the dam of Thomas Jefferson-True origin and history of Belle of Wabash-Facts about the old-time gelding Prince--The truth about Waxy, the grandam of Sunol-Remarkable attempts to make a pedigree out of nothing-How "Jim" Eoff worked a "tenderfoot"-Pedigree of American Eclipse-Pedigree of Boston-Ton Bowling and Aarou Pennington-Chenery's Gray Eagle-Pedigree of George Wilkes in doubt.

Aт Louisville, Kentucky, October, 1860, a ten-mile race was trotted which excited a good deal of local interest and comment. The contestants in this race were entered as follows:

"Captain Magowan, by imp. Sovereign, dam by American Eclipse."

"Gipsy Queen, by Wagner, dam by imp. Glencoe."

"Belle of Wabash (Indiana Belle), by Bassinger, dam by imp. William."

The names of the parties making the entries are given in the entries of the first and second, and the Louisville Journal of the week before remarks that "J. J. Alexander will represent his State honorably with the Belle of Indiana." Captain Magowan held the lead from start to finish, and at the end of the eighth mile, some say the seventh, Belle of Wabash was drawn. It will be observed that, so far as given, each one of these animals was furnished with a first-class race-horse pedigree; for it was then held as firmly as any religious tenet that no horse could go that distance at any gait unless he was strictly thoroughbred, and, in Kentucky, if he did not have such a pedigree they gave him one on the spot. At that time they never bothered their heads hunting up the breeder of an animal to learn how it was bred. They simply wanted to see the performance and then make the pedigree to suit it. These three pedigrees were all bogus in all their elements, and I knew so little of the ways of the horse world, at that time, that $I$ accepted and recorded them as genuine. 
Captain Magowan was a roan gelding, willful and bad tempered, and all that seems to be known about his origin is the conceded fact that he was bred in Kentucky and that he was probably descended from the tribe of Copperbottoms, or possibly the Tom Hals. The roan color prevailed in both tribes and the horse himself looked.like the Copperbottoms.

Gipsy Queen, at the time of the above race in 1860 , was owned by a "sporting man" named George Bidwell, of Chicago, or at least she raced under his direction. About the time of this race, Mr. Thomas J. Vail bonght the mare and took her to Hartford, Connecticut. He bred her to Toronto Chief and she produced a black colt. The mare and colt afterward passed into the hands of Mr. William B. Smith, and this colt grew up to be the famous Thomas Jefferson-"The Whirlwind of the East." In connection with Mr. Smith I devoted a good deal of labor to a futile search for the origin and pedigree of this mare, and the result of our search amounted to nothing more than a reasonable probability that she was bred at Rochester, New York; was got by a son or grandson of Vermont Black Hawk and was taken from there to Chicago. This latter point of the transfer to Chicago seemed to be quite circumstantially fixed in Mr. Smith's mind.

Mr. Allen W. Thomson, of Woodstock, Vermont-a man of great industry and a lover of the truth for the truth's sake-also made an exhaustive search, and from a recent contribution to the press be evidently thinks he has found it, and possibly he has; but while I generally agree with Mr. Thomson's conclusions, and prize them as honest and carefully reached, I am forced to dissent in this case. Without going into details, he brings the mare from Williamstown, Vermont, and takes her to Woodstock, Illinois, where she is paired with another black mare, and after passing through two or three hands they at last land in a public livery stable in Chicago, and there the identity of the suppositious Gipsy Queen is lost, and so far as known she never came out of that stable. One or two years afterward a black mare from Chicago, in possession of George Bidwell, appeared in some public races, notably the one given above, and the conclusion is at once reached that this black mare, Gipsy Queen, was the black filly brought from Williamstown, Vermont. To this all the intermediate owners between Williamstown and Behrens' livery stable were ready to insist that this black mare was the 
Williamstown filly, but not one of them had ever seen the mare that George Bidwell was handling, and some of them evidently were not worthy of belief if they had seen her. There is the "missing link" between Behrens' stable and George Bidwell, that has not been supplied and probably never can be supplied. The chances that the Williamstown filly was the real Gipsy Queen, all things considered, seem to stand as about one to a thousand. We must, therefore, conclude that we have no satisfactory information as to how or where this mare was bred.

Belle of Wabash.-My first inquiry about this mare was made more than twenty-five years ago, and I did not then suppose that her pedigree would ever become a question of any general interest. In the first volume of the Register I had entered her as a black mare, foaled 1852, got by Bassinger, son of Lientenant Bassinger, and dam said to be by imported William IV. She was then owned by George C. Stevens of Milwankee, Wisconsin. After her son-The Moor-proved himself a great sire of trotters in getting Beautiful Bells, Sultan and other good ones, her pedigree became a question of very great importance. As the search for it would occupy more space, in detail, than I can give to it in these pages, I will here give the references in Wallace's Monthly, where the principal correspondence may be found: Vol. XIV., p. 510; XV., p. 441; XV.I., p. 43; and for a complete understanding of the matter the references here given should be carefully examined.

Mr. S. D. Puett, of Indiana, was the first to give me a starting point in the investigation of the pedigree of this mare. In all that had been said about her I never was able to find a man who really knew anything about her origin, until Mr. Puett gave me the address of Cyrus Romaine, who had owned her when very young and handled her for speed. He says "she was sired by a colt from her own dam, that was got by a Copperbottom stallion from Kentucky." He was not able to give any information abont the sire of the dam, and as to the gait of the dam he says: "Her dam was a natural pacer. I cannot say as to her sire, as he was unbroken at the time." He bought the mare at three years old. handled her one year and sold her to Mr. J. J. Alexander, of Montezuma, of the same county (Parke), in 1856. Mr. Alexander still owned her in 1860 when she trotted in Louisville, and after his death Williams, his trainer, married his widow and still controlled the mare. Mr. Romaine failed to give the name of 
the breeder of the mare, which will be explained further on. Soon after he wrote, April 26, 1880, he removed to Nebraska and $I$ have not heard from him since. In 1857 she was trained for Mr. Alexander by John Williams on Stroue's track at Rockville, Indiana, the county seat of Parke County. In 1860 she was entered by Williams in several races at Indianapolis and at other points, and made a record of $2: 40$. About 1865, or perhaps a year or two earlier, she became the property of George C. Stevens. In his catalogue for 1868 she is entered merely as "Old Belle," and he knew nothing of her origin or history till I gave it to him, along with the humbug pedigree that I had copied from the entries at the Louisville ten-mile race.

Through the kindness of $\mathrm{Mr}$. Puett I received the following letter from Mr. Henry C. Brown, a very reputable business man and a grain dealer in Rockville, Parke County, Indiana. This letter from Mr. Brown has in it such evidence of . candor and intelligence that I will here insert it entire:

"DeAr SIR : In reply to your inquiry of the $23 \mathrm{~d}$ ult., as to what I know of the 'origin and history of the mare called Belle of Wabash,' I will give you the following fucts:

"In the year 1855 , or ' 56 , I am not positive which, this mare, when a threeyear-old, was purchased by Cyrus Romaine, then a resident of this county, of an old farmer in Clay County, this State, paying $\$ 85$ for her. This farmer lived at that time about a mile and a half north of Brazil, the present'countyseat of Clay County.

"As to this farmer's name, neither myself nor Romaine can tell. He was an old man at that time, and undoubtedly has gone to his reward long ago. Neither do we know anything at all about the pedigree of the mare.

"There is no person living, so far as I or Romaine know, that can tell anything about her ancestors, and in my opinion it would be impossible, at this late day, to find any one in Clay County that could give us any information in regard to her.

"The country around Brazil at that time was almost a wilderness; now the city is spread out, and covers, no doubt, the farm where the mare was foaled. Clay County is now the center of the Indiana coal-fields, and, of course, the entire face of the country about there is changed wonderfully since 1856 ; consequently it would be almost if not quite impossible to find the exact location.

"After keeping the mare eight or nine months, Romaine sold her to John Alexander, of Montezuma, this county, for $\$ 160$. Alexander soon after commenced training her, and in about one year I think he, or his trainer, John Williams, took her to Kentucky, and entered her there in some kind of races. Since then you know her history much better than I do.

" At the time Romaine bought the mare he and I were trading in stock together, boarding at the same house and sleeping in the same bed. I mention this only that you may understand that I know what I an writing about. 
"I am truly sorry that I cannot give you the true pedigree of the mare, but it camnot be cone. There is no man here or anywhere else that can tell you anything more than I have stated herein.

"You will no doubt think that there is considerable of superfluous matter in this letter, bat I do not see how I could tell you what I wanted to in fewer words.

" Everything stated herein is truth, and, if necessary, I am willing to make aifidavit to the same at any time.

Very truly yours,

"Henry C. Brown."

Mr. Romaine's representation amounted to nothing definite or satisfactory about the pedigree of Belle of Wabash, because he failed to give the name and location of her breeder, but Mr. Brown's letter elears this all up on the grounds that Mr. Romaine really did not know the breeder's name. Whatever her sire and whatever her dam, we may feel sure they were not trotting-bred, although she was a trotter. We are left, therefore, to conclude that, as in a thousand other cases, this mare was a pacing-bred trotter. The one point that is vital is settled by Mr. Brown, as he was with Mr. Romaine when he bought the mare and knew all about the transaction. He cannot remember the breeder's name, but he locates him as "living a mile and a balf north of Brazil," and that it is now all cut up into residence and mining lots. This seems to fix the location of the breeder beyond all doubt. This old man seems to have been a pioneer in a very poor county and still a comparative wilderness when this transaction took place. At that time the coal fields had not been touched, and it is wholly beyond belief that he took his unknown old mare ont of his own county, across the adjoining connty of Parke and into Vermilion County, wherever in it Mr. Weisiger lived, to have her bred to his part-bred stallion Bassinger. And then when he came to sell the foal at three years old for $\$ 85$, when horses were high, can we believe he would do so without ever mentioning how the filly was bred? The chain of ownership is complete, as she passed from her unnamed breeder to Mr. Romaine, from him to Mr. Alexander, in whose hands she did her trotting, and then to Mr. Williams, and there is no place for the Louisville humbug pedigree to come in. She got her bogus pedigree at the same time and in the same way that Magowan and Gipsy Queen got theirs, and there was not a single shadow of truth in any one of them. The tenacity with which some people hold on to " "thoroughbred" origin for their trotters when the evidence is all against them has long been a mys- 
tery to honest folks, who are able to look at things as they are; but it is not difficult to understand the phenomenon when we analyze the reasons for it. First, the owner is anxions to hold on to all he can possibly claim in the way of aristocratic descent with the hope that it may help his sales; and second, there are always a few "featherheads" with golden pockets ready to buy that kind of stuff, becanse they have never gone far enough in horse history to be able to kick themselves loose from the swaddling elothes of their infantile prejudices.

Prince.-The chestnut gelding Prince was one of the great trotters in the early "fifties." He was pitted against Hero, the pacing son of Harris' Hambletonian, Lantern and others. As usnal at that time he was given a thoroughbred pedigree, which I was then led to accept, without really knowing anything about his origin. He was represented to have been bred in Kentucky, and owned by R. Ten Broeck of that State. Then would natnrally follow a thoroughbred pedigree coming from that State, and nobody doubted it for a long time. He was represented to be by Woodpecker, son of Bertrand; dam by imported Sarpedon; grandam said to be thoroughbred. When he started in his tenmile race against Hero, William T. Porter said he was by Woodpecker, and ont of that grew the pedigree above. In the old Spirit of the Times, of October 11, 1856, there is a short communication signed "Hiram," in which is the only circumstantial account of the origin of Prince that $I$ have ever seen. It is inplied by the writer that he was bred by a Mr. Dey, of Chantauqua County, New York, for he says he was got by "an old chestnnt horse called Duroe, from Lung Island," and came of the Dey Mare. It seems that Dey sold the colt to a young man named Worden, and he was first known as "the Worden colt." He was then sold to Manley Griswold, and from Griswold to Daniel Vanvliet, who sold him in Buffalo to Bennett \& Jones (or Thomas), for one thousand dollars, and they sold him to William Whelan, of Jong Island, for fifteen hundred dollars. "Hiram" carries the history of the horse no further, as he had then placed him in the hands of the great artists of the trotting world. Of his sire, "Old Duroc," he says he was taken from Long Island to Villenova, in Chautanqua County, by a merchant of that place, named George Hopkins, and after getting about twenty colts he died. Among these twenty we find Prince and another afterward known as the Walker Horse, which achieved a high local 
reputation as a sire of trotters and I have frequently met with his cross in the pedigrees of good animals. This showing is not absolutely complete, but it is infinitely better than any other that has ever been given to the public.

WAXY, the grandam of Sunol. When the two-year-old filly Sunol in 1888 came out and trotted a mile in $2: 18$, it fairly took one's breath away, and the first question on every tongue was, "How is she bred?", She was represented to be by Electioneer, out of Waxana by General Benton, and she out of Waxy by Lexington, and "thoroughbred." When asked who bred her and how it was known that Waxy was by Lexington, the answer came back that the breeder was not known-that she had been taken across the plains by a man who died on the way. The search then commenced for the breeder of Waxy and the identification of her dam. As the search progressed there were some very curious things developed. When it started in the spring it was a yearling stallion colt, and when it reached California, in the fall, it wås a two-year-old filly. More than this, it was shown by indubitable proofs, such as they were, that she had two dams, and then shown that she had no dam at all. With such a Kentucky muddle on hand there was an excellent opportunity for a controversy that might possibly become somewlat heated. This controversy is famous in the history of the exposnres of untruthful pedigrees, and I will give a brief outline of it, with some specimens of the evidence adduced to sustain it.

Early in the spring of 1864 Mr. John P. Welch, an intelligent man, trained to the profession of civil engineer, reached the blue grass region of Kentucky for the purpose of securing and taking across the plains a band of well-bred horses to California. In this venture he was backed by Mr. John Anderson, a wealthy gentleman of the latter State. Mr. Welch was successfnl in perfecting his arrangements, and when on the very eve of starting he sent forward a complete inventory of all the animals he had in his band and sent this inventory to the California Spirit of the Times, in which paper it was published May 14, 1864, and is as follows:

1. Bay mare, 6 years old, by imp. Sovereign, dam by Glencoe, g.d. Ann Nerry.

2. Bay filly, 3 years, by Vandal, dam Miss Singleton by Old Denmark, g.d. Bellamira by Monarch.

3. Bay filly, 2 years old, by Manbrino Chief, dam by Commodore. 
4. Bay Lorse, 3 years old, by Mambrino Chief, dam by Gray Earle.

5. Black colt, 2 years old, by Kt. of St. George, dam (dam of Capitola) by Margrave.

6. Bay mare, 9 years old, by imp. Glencoe, dam by Rudolph, g.d. Belle Anderson.

7. Bay filly, 2 years old, by Revenue, dam Sally Morgan by Emancipation.

8. Chestnut filly, 4 years old, by Vandal, dam by Gray Eagle, g.d. Churchill.

9. Chestnut mare by Wagner (dam of No. 11).

16. Bay mare by Sovereign.

11. Black colt, 2 years old, by Kt. of St. George, dam No. 9, by Wagner.

12. Chestnut filly, 3 years old, by Jack Gamble, dam Betty King by Boston.

13. Bay mare, 6 years old, by imp. Sovereign, dam by Mirabeau, g.d. Arabella.

14. Captain Beard, b.s., 9 years old, by imp. Yorkshire, dam by imp. Glencoe, g.d. by imp. Leviathan, g.g.d. by Stock!ıolder.

15. Gray mare by Gray Eagle, dam Mary Morris, by Medoc.

16. Hope, ch. m. by Glencoe, dam Susette by Aratus.

17. Bay mare by Sovereign, dam by Gray Eagle.

18. Chestnut filly, 2 years old, by Bob Johnson, dam by Brawner's Eclipse.

19. Chestnut filly, 3 years old, by Kt. of St. George, dam by Gray Eagle.

20. Bay colt, one year old, by Lexington, dam ly Gray Eagle, g.d. Mary Morris.

21. Ch: c.. 2 years old by Ringgold, dam Hope by Glencoe.

22 and 23. Pair 3:00 six-year-old trotting mares.

24. Black uare, trotter, 8 years old: time, 2:50.

25. Bay gelding, trotter, 5 years old; time, near 3:00.

26. Bay mare for show, but not to go.

From this inventory we must conclude that Mr. Welch was a careful and methodical man. He knew he had twenty-six animals ready to start, and after he had written off the descriptions and pedigrees of these twenty-six animals he verified his work by numbering them from one to twenty-six inclusive, and then he knew he had not omitted any one. This inventory is the basis of the whole truth in this matter, and is the only evidence in the wide world of what animals Mr. Welch started with to California. As this is the vital and only starting point to reach the truth, I trust my readers will examine it again carefully and see whether it includes any filly or mare by Lexington, of any age. When you ask any of these "more-running-blood-in-the-trotter" people who took Waxy, the phantom daughter of Lexington, to California, you will get an evasive answer, and when pressed they will at last say, John P. Welch. Now, as to John P. Welch, "he being dead yet speaketh." From his unknown grave he tells these people they are trying to establish what is not true, 
and with his ghostly finger points to the inventory and demands, "Where is the Lexington filly in that list? You are trying to displace the truth with a falsehood," and he drives this charge home to the heart of each one of them.

Here we might close this case and leave it to the enlightened judgment of all intelligent and honest people, for there is not a scintilla of evidence that any two-year-old daughter of Lexington was taken to Caiifornia in 1864. Until this evidence is adduced, no attempt to overthrow the contents of John P. Welch's inventory has a single peg to stand on. But I am not yet done with some of the peculiarities that have been developed in this case, for long ago I learned in this pedigree business,

“That for ways that are dark,

And for tricks that are vain,

The heathen Chinee is peculiar."

At this point the case bifurcates, one fork leading to the Grey Eagle mare as the dam of Waxy, and the other to the Brawner's Eclipse mare, and I think my language will not be wholly unparliamentary when I pronounce them both frauds. Mr. Levi S. Gonll, a worthy business man of Boston, whom I have always. esteemed as honest, was the first to dig up this whole matter in the columns of the California spirit of the Times. and the first to give the above inventory to the priblic. He traveled thousands of miles and claimed to have traced Waxy to the stable of her breeder, Philip Swigert, of Frankfort, Kentucky. The full account of his laborious trip was published in Wallace's Monthly for March, 1889, p. 1\%. In the inventory he found one animal got by Lexington, but this was a bay colt of 1863, and ont of the Grey Eagle mare, but he wanted a chestnut filly. After studying the matter over, he concluded that this "bay colt" was a. typographical error for "chestnut filly" and that this established the pedigree of Waxy. He interviewed a number of people who. had known of, or had been in some way connected with, the Welch venture, and they were all able to confirm his discovery of the typographical error, and could recount to a nicety their distinct recollections of the sorrel filly by Lexington, ont of the Grey Eagle mare. These people seemed to possess the most astonishing memories, and the color, breeding and age of a filly they had not seen nor heard of for a quarter of a century all came. back to them with as much freshness as though the events had 
occurred yesterday. Then there was a peculiar element in their memories, for they could recall everything about this one filly and nothing about any of the others. At last Mr. Gould reached Mr. Brodhead, of Kentucky, where the "finishing touches" were put upon the pedigree of Waxy. Mr. Satterwhite did not reach Woodburn till after Mr. Gould had left, but that did not prevent him from making a "statement" that exactly fitted the theory of the pedigree as matured by Mr. Gould and Mr. Brodhead. He had been Mr. Philip Swigert's foreman in 1864, and had a light to know something of the transfer of some eight or ten head of stock from Mr. Swigert to Mr. Welch in the spring of that year. Satterwhite was quite too good a witness, as he disclosed his cramming frightfully. He remembered "the light chestnut filly, by Lexington and ont of the Grey Eagle mare," with great distinctness and was sure she was foaled in 1863. In no single case was he certain except in the filly by Lexington, and in no single case was he able to give the ages of the other young things correctly. After Satterwhite made his visit to Woodburn, Mr. Brodhead wrote Mr. Gould as follows:

"Satterwhite says Dick Jackson was with Welch. I think, with what you have, the pedigree of Waxy is conclusively proved, and you can get your article ready. The sooner it is published the better. I forwarded soune letters to you, and I bope they gave you additional information."

It will be remembered that Mr. Gonld started ont on the assumption that, as there was but one animal in the inventory by Lexington and that was a bay colt of 1863 , that "colt," he argned, was a typographical error, and instead of "bay colt" it should read "sorrel filly." On this very uncertain basis he worked throughont. On this basis he collected all his futile statements. On this basis, and to lend a helping hand, Satterwhite testified; and on this basis Brodhead wrote, "With what you have, the pedigree of Waxy is conclusively proved." Now that Mr. Brodhead is satisfied and that Mr. Bruce promptly entered Waxy in his Stud Book as by Lexington and out of the Grey Eagle mare, we must drop the whimsical idea of the "typographical error" and consider whether the bay colt of 1863 , by Lexington, did really become a sorrel filly of 1862 when he reached California a few months later.

1. The bay colt, No. 20, of the inventory, was the only animal in the band by Lexington. He was a foal of 1863 , and was a year younger than any of the others. 
2. In speaking of the losses, by death on the route, of some of the more noted animals, Mr. Anderson enumerates the noted stallion Captain Beard, and a very fine yearling colt by Lexington, called Frank. Here perished the only foal by Lexington in the band, and we may as well bury Mr. Gould's and Mr. Brodhead's "typographical error" with him, for the colt kicked it to death before he died.

3. When the band reached California there were several additions smuggled into it as being part of the originals from Kentucky, and among these additions was the light chestnut filly that has been since known as Waxy, given as a foal of 1862, and got by Lexington, dam unknown.

4. As Mr. Brodhead had proved conclusicely, from the records at Woodburn, that Mr. Swigert's Grey Eagle mare was barren in 1862, the "typographical error" parties found themselves placed "between the devil and the deep sea."

'I'his outside filly that had been smuggled into the band of Kentnckians was advertised along with them, as a foal of 1862 , in the fall of 1864; she was sold as a foal of 1862 ; she was entered in a sweepstake for three-year-olds as a foal of 1862; she was exhibited at a horse show as a foal of 1862; she started to run the only race she ever attempted as a foal of 1862, and proving herself utterly worthless as a race mare, she was given away on the spot as a foal of 1862 .

As the only representative of Lexington in the band was "the yearling bay colt Frank," as shown by Mr. Anderson, the partner of Mr. Welch; and as the records at Woodburn had clearly and distinctly shown that Swigert's Grey Eagle mare was barren in 1862 , the bottom was out of the conspiracy and it was abandoned. There was a little fussing about the possibility that there might have been a mistake and that Waxy might have been a foal of 1863 after all, but it amounted to nothing more than the enfeebled squeak of an asthmatic mouse and then all was quiet.

Before passing to the other branch of the investigation, this seems to be the proper place to speak of the incidents of the sale and its sequences at the Fair Grounds at San Jose, January 3, 1865. There were some twelve or fifteen head, that had been previously advertised, offered at public sale, and a number of those were sold, all indeed in which this inquiry has any interest. When the stock arrived at San Jose, there was a good deal of confusion, and it is just possible that some of them were not. 
correctly placed. The only discrepancy which I have found between Mr. Welch's inventory and the facts is in the color of the filly No. 18, that appears in the inventory as a chestnut, but is advertised and sold as a bay. 'This mistake in color is not infrequent in the spring of the year before the old coat is shed, and I think it may be reasonably accounted for on this ground. James. L. Eoff, weil! known from ocean to ocean as the king of all "horse sharps," seems to have taken a good deal of interest in assorting the animals and in pieking up scraps of information from the boys who had come with them. At the same time he was an excellent judge of racing stock, and as silent as the grave to the victims whom he sought to mislead and then beat. In this way he soon knew more about the breeding of the animals than those in charge of them. Mr. William Woodward seems to have been his friend (?) with plenty of money, but a perfect "tenderfoot" in the mysteries of the race horse. No doubt he pointed out to Mr. Wcodward the so-called Lexington filly and advised him to buy her, assuring him that he wanted her himself, but if he wanted to take a little fly in racing he would not bid against him. The sale came off, and Eoff ran up the Revenue filly, out of Sally Morgan, to three hundred and twenty-five dollars and got her, it is said, for Theodore Winters. When they came to the filly by Bob Johnson, out of the mare by Brawner's Eclipse, Eoff bought. her at two hundred and fifty dollars for himself, and named her Lilly Hitchcock. The next animal sold was the filly by Lexington, dam nuknown, and she was bonght by William Woodward at two hunched and fifty dollars, and he named her Waxy. The sale was slimly attended and much of the stock was bid in for the owner, Mr. John Anderson. That night the wine flowed very freely, as it was the initiation of the "tenderfoot," Mr. Woodward, into the ranks of running-horse men. After they all "got hot" (except Eoff), a sweepstakes was opened for the three fillies, Ada C. (the Revenue filly), Lilly Hitcheock and Waxy, at two hundred and fifty. dollars each, and Eoff was careful to see that it was made "play or pay." The race was a dash of a mile and a quarter, and it took place nearly twelve months after the mateh was made. Eoff won easily with Lilly Hitcheock, and Waxy was so badly beaten that Woodward gave her away on the spot and "swore off" ever owning another runuing horse. Thus Eoff's cunning carried his plot through, without a break at any point. From the hour he bought this filly he stontly maintained 
she was by Lexington and out of the Brawner's Eclipse mare. She ran all her races under this pedigree and never was challenged, and if ever there was a mare in California bred in this way, this is likely to be the mare. We can understand just how he conld have discovered where Waxy came from, and that she never saw Kentucky, and on this knowledge he based the game he played on poor Woodward.

After the failure to establish the claim that Waxy came out of Philip Swigert's Grey Eagle mare and publicly confessing that the evidence upon which Mr. Gould and Mr. Brodhead based their conclusions was fallacions and the conchusions themselves incorrect, the advocates of "more running blood in the trotter" pulled themselves together for another bout. What purported to be an old document was dug up somewhere-indeed I am told there were two of them dug up, one in Kentucky and the other somewhere on the Pacific coast-purporting to be duplicates of an agreement entered into, in March, 1864, between John P. Welch, of California and Philip Swigert, of Kentucky, by which Welch agreed to take certain blood horses to California and sell or breed them on the shares, etc. This document possessed all the paraphernalia of authenticity, with government stamp, witnesses to the signatures of the contracting parties, etc. This document (I don't know which "duplicate") was shown to me in April, 1891, and at the first glance, and without reading a word except the date, it astounded me. There was a paper purporting to be twenty-seven years old, and it looked as bright and fresh as though it had been written within twenty-seven hours. There was no fading of the luster of the ink and there was no ageing in the color of the paper. Having devoted a great deal of time to the examination of writings, varying in age from one day to a hundred years and more, and this experience extending through many years, I ought to be a fairly competent judge of the effects of age on ink and paper. Here was a paper purporting to be over a quarter of a century old with all the newness of yesterday, and when Mr. J. C. Simpson showed it to me I was impressed with the belief, on this one point of evidence alone, that it was spurious, and that Mr. Simpson had been made a victim by some rascally scrivener. With so much for the appearance of the paper, on its face, we will now examine the contents and see whether any evidence can there be found that will throw further light on the question of its authenticity. Unfortunately I have not what 
purports to be the original of this document before me, and I must therefore depend upon my memory and upon what Judge Halsey, as attorney for Mr. Brodhead, has printed as the contents. In giving the list of animals I will follow the order of the "dlocument" and place before each one, for convenience of reference, the number attached to that animal in Mr. Welch's original inventory.

15. One gray mare, by Grey Eagle, out of Mary Morris.

16. One sorrel mare, Hope, by Glencoe.

17. Sovereign filly, out of Grey Eagle mare, four years old.

8. Vandal filly, out of bay Grey Eagle mare, four years old.

18. One two-year-old filly, by Bob Johnson, out of bay Grey Eagle mare.

19. One two-year-old filly by Lexington.

20. One yearling colt, by Lexington, out of Grey Eagle mare.

21. One two-year-old filly, by Ringgold, out of Hope.

In looking over this list there are several points suggested for remark and they all have a bearing, more or less direct, on the question at issue. The list seems to have been prepared, if prepared by Mr. Swigert, very hurriedly and without sufficient regard to completeness or accuracy. He started off, possibly to make a careful list, as he gave the color of the two-year-old mares at the head and then dropped all purpose of completeness and gave no colors nor descriptions to those that followed. He gives No. 21 as a filly when it was a colt, and so appears in the inventory, was sold as a colt with pedigree at San Jose, January, 1865, and again, with the same pedigree, at The Willows, February, 1866. Under ordinary conditions the statement of the breeder should be conclusive against all others, but in this case the evident hurry and absence of descriptions have destroyed the value of the whole list, in great degree, as evidence that could be accepted with safety. We must, therefore, look for something in the way of evidence more deliberative and descriptive in its preparation, and this we find in the joint work of Mr. Swigert and Mr. Welch, as embodied in the inventory. When the descriptions of the animals were taken, both men were equally interested in accuracy and completeness, both were present, and probably the animals were before them. Hence my infinitely greater confidence in the deliberative work of the two, as found in the in. ventory.

The one point about which all this hubbub has been raised is the so-called "Lexington filly," that appears as the sixth in the 
above list. She has no number attached to her name, and this means that she was not in the inventory, and it means more than this; for it is, in a manner, the dying testimony of an honest man that he took no Lexington filly to California, and fortunately this testimony has been preserved. The methods introduced to prove that Welch did take her are the methods of the imbecile. Let us admit, for the moment, that Swigert had a Lexington filly and that she was in a contract with Welch to be taken to California; does that prove that Welch took her, when he says he did not? 'There are hundreds and hundreds of people every year who buy steamship tickets to go to Europe who fail to go. The records of $\mathrm{Mr}$. Swigert's ticket office show that the ticket was bought, but they fail to show that the purchaser went aboard the ship. You must go to Purser Welch and get a list of passengers actually on board in order to determine who did and who did not go. Accidents, sickness and death are all factors in the movements of horses just as they are in the movements of human beings. It is the observation of a long lifetime that horsemen are never so near their best as fools as when they attempt to establish a frandulent pedigree by evidence that utterly fails to cover the case. They claim to have found a ticket that would carry Waxy to California, and whether gennine or counterfeit they rely wholly on this ticket as evidence that she went. The master of the vessel affirms she was not aboard his vessel, and in support of this he shows a complete list and desoription of the passengers numbered from one to twenty-six inclusive. This is the whole thing in a nutshell. The proof is clear and conclusive that Mr. Welch did not take any danghter of Lexington to California. Now, will the prominent and active supporters of Waxy's pedigree, as a daughter of Lexington, come forward and in a manly way answer this question of five words? "Who took Waxy to California?" If Welch, prove it. If anybody else, prove it. We may be able to catch a few gulis with chaff, the first attempt, but we can't repeat it. If the question can be answered, it is well, and if not, honest people will form their own conclusions that it is not sustained and is no more worthy of belief than the "Grey Eagle mare" form of the same pedigree, which is now universally conceded to be a fiction.

American Eclipse.-It is not my purpose to frighten people by overthrowing landmarks that have stood for years, but it is my purpose to tell the truth and expose falsehood in pedigrees 
wherever I meet it. As a satisfaction and guide to breeders in the future it is important to know just how the early stock were bred, althongh they may have belonged to past generations. A breeder never can know too much of the lines in which he is operating. This great horse was a good chestnut, with a star and left hind foot white. He was stout, with heavy limbs, and somewhat coarse, and not of the best quality, but possibly better than the average of the Durocs. He was a fraction of an inch below fifteen two. He was foaled 1814, got by Duroc, son of imported Diomed; dam Miller's Damsel, by imported Messenger; grandam a mare by PotSos, imported by Mr. Constable along with the horse Baronet, in 1795. This is just as far as we can go with any certainty, and this leaves the greatest race horse of his day far short of being thoroughbred. When Mr. Constable bought the Pot8os mare in England he got no certificate of pedigree, but he was told there she was out of a mare by Gimcrack. Mr. Cadwallader R. Colden was the best-informed man of his day on the history, blood, and performances of the bloodhorse, was a very intimate and warm friend of Mr. Constable, and he did everything that could be done to straighten out and extend this pedigree, but he utterly failed. He thought it probable that the mare was thoroughbred, but he believed the Gimcrack cross was a fiction. Some eighteen or twenty years ago, when in London, Mr. Tattersall suggested to me that if Lord Grosvenor bred a filly by Pot8os in 1792 that was thoroughbred, there could hardly be a doubt that she was entered in some of the stakes for three-year-olds. Then and there we searched the old records, but nothing could be found to support the supposed pedigree. It was not till 1832 that any special effort was made to establish the pedigree through the press, and in January of that year the famous Patrick Nesbit Edgar, of North Carolina, wrote as follows to Mr. Skinner, editor of the American Zurf Register :

"The authority I had for sending the remote pedigree of American Elipse for publication was that it was furnished me lately by a gentleman in England, who put hinself to uncommon pains to procure it. He resides near Bath, in that country. All the authority requisite I have at this time in $m$ r possession. The Pot8os mare was got by Pot8os; her dam, foaled in 1778, by Gimcrack, out of Snap-Dragon, sister to Angelica by Snap. (See English Stud Book.)"

Mr. Edgar wrote more on the same subject after he was 
pressed to it by Mr. Colden, but he failed to produce any evidence whatever that he was teliing the truth. Accordir ro his representations his correspondence on the subject had been very extensive, and he complained that he had paid out forty shillings in postage.

It will be observed how cleverly Mr. Edgar conceals the sources of his information while he pretends to give them, and that has been the favorite "dodge" of all rascally "pedigree makers" from that day till the present. Mr. Constable always insisted that the mare was bred by Lord Grosvenor, and that she was by Pot8os, but he did not insist that she was out of a mare by Gimcrack. As Lord Grosvenor was one of the most prominent of all breeders of race horses in his day, and as he evidently kept the records of his stud with more care than most of his contemporaries, we might reasonably expect to find some trace of this mare if she was thoroughbred. After a careful and diligent search of all the records of that period, it is found that Lord Grosvenor never bred a Gimcrack filly to PotSos. This disposes of Mr. Edgar's humbug story, and when we state the pedigree of American Eclipse we can simply say he was got by Duroc; dam Miller's Damsel by Messenger, and grandam the imported Pot8os mare, and there we must stop.

For years past I have observed that the less a man knows about horse history and horse achievements, the more importance he attaches to the word "thoroughbred;" and of all the millions and millions of lies that have been told about pedigrees nine-tenths have been concocted and circulated for the one purpose of enhancing the supposed value of the animal by claiming "thoroughbred" blood. The "instinct" to lie about pedigrees, so common among certain classes of horsemen, seems to be "the sum of inherited habits" that has come down from generation to generation. If you ask one of these mendacious gentlemen whether American Eclipse was a thoroughbred he will answer, with a strong marked expression of contempt and pity for your ignorance on his countenance, "Certainly he was thoroughbred." If you then ask him about his pedigree he will answer, "I don't know anything about his pedigree." Then you venture to ask how he knows he was thoronghbred if he does not know anything about his pedigree, and he will squelch you completely by saying, "No horse not thoroughbred could ever have done what American Eclipse did." Here we get at"the real basis 
of the upiversal mondacity on this subject. The preacher wrote a great " $\mathrm{k}$ called "The Perfect IIorse" in which he maintained that the Morgan Horse was thoroughbred. The lawyer wrote another great book on "The American Roadster" in which he maintained that Dexter was a thoroughbred. With two gentlemen of intelligenee and education writing such miserable stuff, what are we to expect from the masses?

Now here is the horse American Eclipse, the greatest horse of his day in his racing achievements, that in his blood is very far from being "thoroughbred," under any rule that has ever been suggested or devised. Now, with this taint on his escutcheon, it follows that no one of his descendants for at least five generations can be classed as thoroughbred. As a progenitor, Eclipse cannot be considered a great horse, either in his immediate or more remote descendants. Medoc was about his best, and he was better than his sire. Another son, called Monmouth Eclipse, was grandly bred on the side of his dam, was sold, it was said, for fifteen thousand dollars for stock purposes, and proved a most lamentable failure, never having got a colt that was worth fifteen dollars as a race horse. The great fame of American Eclipse, therefore, rested upon what were then designated as "his mighty achievements upon the turf." A reasonably complete history of this horse may be found in Wallace's Monthly for March, 1877, p. 160. His great race against Henry, in which he represented the North as against the South, was doubtless the most memorable turf event that ever took place on this continent, and a very brilliant description of it will be found at the reference given above. This race of four-mile heats took place on the Union Course, Long Island, May, 1823, for twenty thousand dollars a side, and it was, in effect, Eclipse against the world. Eclipse, fit or not fit, must start, while his oppnnents had several prepared to start against him and all they had to determine was to select the fastest and best of the whole party. At the last hour Henry was chosen as the champion of the South, and he won the first heat by about a length in $7: 37 \frac{1}{2}$. A change was made in the rider of Eclipse and he won the second heat by about two lengths in $\%: 49$. In the third heat the instructions to the rider of Henry were not to hurry the gait, but to trail to near the finish and then pull out and win in a rush. The rider of Eclipse understood the tactics of the enemy and he hurried the pace every step of the way, in order to tire out his younger opponent. When 
near the finish Henry made his dash and covered Eclipse's quarter with his head, but he could get no further and abandoned the contest. Eclipse had been punished unmercifully from start to finish, and the time of the heat was 8:24. This shows an average rate of speed in the third leat of two minutes and six seconds to the mile, a rate which half a dozen trotters and a round dozen of pacers have beaten for a single mile. It shows also the cruelty, to say nothing of the absurdity, of heat racing at the distance of four miles. Still American Eclipse was the greatest running horse of his generation.

Bostor was a chestnut horse, foaled 1833, and bred by Mr. John Wickham, the very eminent jurist, of Richmond, Virginia. He succeeded to the great fame of American Eclipse, and although about two generations, in a racing sense, after him there was no horse between them that was the equal of either of them. He was a terror to all competitors whether of the North or the South. But it is only my purpose here to put on record the real facts abont his pedigree and to expose a glaring frand that has been propagated concerning his breeding for many years. Mr. Wickham, the breeder of Boston, bought a mare by imported Alderman (1802 or 1803) from John Randolph, of Tuckahoe (not "Roanoke" as sometimes stated). This mare was out of a mare by imported Clockfast, and here, to sum it up and give Mr. Wickham's exact language, as he wrote in 1827: "This mare, a dark bay, foaled about 1799, was got by Alderman, her dam by Clockfast, out of a mare said to be full-blooded, of the Wildair blood." This Alderman mare he bred to Florizel, and she produced the race horse Tuckahoe, and a filly that was bred to Timoleon and produced Boston. 'Then Boston's pedigree stands; Got by 'Timoleon; dam by Florizel; grandam by imported Alderman; great-grandam by imported Clockfast; great-great-grandam "said to be of the Wildair blood." This is down to "hard pan," and there is no authority in the wide world to add anything to it. If we admit the Wildair mare to be genuine and anthentic we are still one degree short of the thoroughbred standard. The six additional crosses that have been added to this pedigree are entirely fictitious. They were copied from the advertisement of a stallion descended from this maternal line, that had neither indorsement nor name attached to it. This was seized upon by the late Benjamin Bruce, and boasted of as a "discovery" of the extension of Boston's pedigree. After the appearance of this 
advertisement Mr. Wickham prepared and published a full list of his stock, with their pedigrees, from the first of his breeding operations, and when he reached the Wildair mare he stopped, just as I have stopped at that point. Here we have the two authorities -Mr. John Wickham, distingnished for his eminent character as a man and a jurist; or a nameless stallion advertisement without any shadow of truth or responsibility.

Timoleon, the sire of Boston, was one of the most distinguished sons of the great Sir Archy, his dam was by imported Saltram, and his grandam by Wildair, but beyond that the pedigree is a hopeless muddle, embracing some features that are absolutely impossible.

Tou Bowling and Aaron Pennington.-The first of these horses was by Lexington, the second was by 'Tipperary, son of Ringgold, and they were both out of Lncy Fowler, by imported Albion, grandam by imported Leviathan, great-grandam by Top Gallant, great-great-grandam Eli Odom's saddle mare, which means, in that country, she was a pacer. Tom Bowling was probably the best race horse of his year, and Pennington may be classed as mediocre, but as the latter is eredited with some pacers or trotters that have come within the $2: 30$ list, his pedigree becomes of interest on this account. I will, therefore, give the facts in some detail, which go to show the truth about what the pedigree contains and what it does not contain.

In 1869 the late William R. Elliston, of Nashville, Tennessee, furnished me the following facts, which he obtained personally from Mr. Eli Odom. It was very fortunate that Mr. Elliston obtained these facts when he did, for Mr. Odom was advanced in years and died not long afterward. He was a brother-in-law of the once very famous breeder and race horse man, Colonel Elliott, of Tennessee, and in early life had charge of his establishment and knew more about Colonel Elliott's stock than he did himself. He lived to old age, highly respected by all who knew him, and was a man of truth. He kept for his own use a pacing saddle mare whose blood he knew nothing about, and he bred her to Top Gallant, son of Gallatin, and the produce was a filly. This filly he bred to imported Leviathan, and in due time there came another filly which he bred to imported Albion, and the next filly was Lucy Fowler. This filly passed through the hands of a Mr. Fowler and perhaps one or two others, and at last became the property of Price McGrath, of Lexington, Kentucky, and was the dam of Tom Bowling, Aaron Pennington and others. Starting 
in with the pacing mare, Mr. Odom bred all that followed until we reach Lucy Fowler, and there we find she had seven parts of running blood and one part of pacing blood. While an animal bred in this way is certainly not "thoroughbred," nobody can deny that he is "running-bred," for there are hundreds of instances on record where animals of even shorter pedigrees than Tom Bowling have been noted race horses. But there is another fact connected with this family that is very interesting. When the running qualities of Pennington were exhausted, McGrath presented him to a kinsman of his, somewhere in Western Nissouri. After awhile I began to hear of an occasional trotter from this horse and I wrote his owner (whose name I cannot now recall), and he replied that "he went all the saddle gaits and was. a pacer." Here was a tidbit that I thought well worth looking. after, and I wrote the owner again for specific information of the character of his pace and whether it was a clean and pronounced side action, but for some reason or other I never was able to get. a reply to my questions. There can be no mistake about his going the "saddle gaits," but whether this was the result of training or whether he took to them naturally as inberited from Mr. Odom's old pacing mare, is a point about which I have never been fully satisfied.

Grey Eagle (Chenery's). - When Mr. Winthrop W. Chenery, of Boston, bought this horse, about 1866, he got with him the following pedigree.

"Got by Grey Eagle; dam by imp. Trustee: g.d. by Columbus; «.g.d. by Stockholder; g.g.g.d. by Pacolet. Bred in Kentucky, and passed throngh many vicissitudes, both as a runner and a trotter, beating his competitors at both gaits; owned for a time in Ohio, now the property of Winthrop W. Chenery \& Co., Boston."

This was a correct type of the pedigrees of that time, lackingdate, location, breeder and all other things necessary to trace and determine its value. The horse had certainly trotted in $2: 31$,

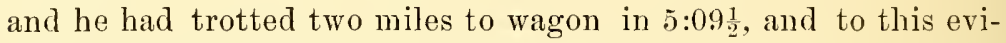
dence of his trotting ability it was ciaimed that he had run and won many races at all distances. This was such a combination of abilities as I never had heard of before, and in attempting to solve the riddle I became deeply interested. The search then institnted has been kept up over since, and I must say that after all these years I know absolutely nothing about the breeding of this horse. His first known owner was a petty gambler and general 
outlaw in the noighborhood of Portsmouth, Ohio, and the story he told will be found in Wallace's Monthly, Vol. I., p. 53, and Vol. VII., p. $59 \%$, besides other references. The scarch has been so barren that $I$ have not even the shadow of a theory as to what his blood may have been. He got two or three trotters and one or two pacers, I think, and here we have to leave him as the most completely unknown horse in all my experience.

George Wilkes.-It is a grievous misfortume that the pedigree of this great progenitor should be in doubt. The misfortune is not in the fact that his descendants lose the supposed Clay cross in his dam, for that was not of very great value, but in the fact that we should not know just what belongs in its place. In December, 187\%, I had the good fortune to meet with Mr. Harry Felter and Mr. William L. Simmons at a breeders' banquet, and it was not long until we were in conversation about the blood of the dam of George Wilkes. I knew that the breeding of that horse had never been established, but I was greatly surprised that these two gentlemen-one the breeder and the other the owner of Wilkes-had never made any effort to trace and establish so important a fact. Mr. Felter stated that he had bought the mare from Mr. W. A. Delevan, and that Mr. Delevan had bought her from Mr. Joseph S. Lewis, of Geneva, New York. Thereupon I wrote to Mr. Lewis and the following is his response:

"Some twenty-six years since I bouglit a brown mare from a gentleman by the name of James Gilbert, then living in the town of Phelps, in this county, for a friend, and very soon after sold her to W. A. Delevan, of New York. She was then about five years old, a fine roadster, and could speed in about 3:30. He took her to New York, and after driving ber some time sold her to my esteemed friend, Harry Felter. I think she passed into the bands of his father, and met with an accident. She was put to breeding, and had a colt by Rysdyk's Hambletonian, that grew up to be the famous George Wilkes. For the benefit of many persons in New York I lost no time in looking about to learn the pedigree of the mare and of the horse that got her. On seeing Gilbert I learned that he got the mare of an old man who is now dead, by the name of Josiah Philips, of Bristol, in this county. I lost no time in sending a man, who lived with us at the time, hy the name of Jobn S. Dey, to Bristol, to get all the facts in the mare's pedigree that he could get hold of. He learned through Philips that the father of this mare was the old Wadsworth Henry Clay, owned for many years by General Wadsworth, of Genesee. There is no mistake about this, as I have since learned from his neighbors that she was a Clay colt. Philips further stated that the mother of the mare was got by a horse called Higblander, a good horse, and owned in that section of country. 
I have no doubt about this, as there was such a horse in that section about that time. When I go to Buffalo, where fillsert now lives, I may be able to get at more facts in regard to your inquiry, and if I can get hold of anythingthat will give more light on the subject before I am down in New York, I will drop into your office to see you.

Very truly yours, etc.

"J. S. LEWIS."

The receipt of this letter, so straightforward and clean-cut in its statements, developed a mystery that was incomprehensible to me. Dates, names, places, cireumstances, all stand out as evidences of the truth of the representations, and also as evidences. that Mr. Lewis had fully investigated the matter, and given the results of his investigations to his friends in this city; still, those friends had never heard the facts, or had entirely forgotten them. As there was a strong prejudice against Clay blood in certain quarters, it occurred to me that possibly that cross had been left. in abeyance so long that it really had been forgotten. This did not clear up the mystery, however, and I determined to have the whole matter investigated from a different starting point. I submitted the matter to Mr. John P. Ray, a very capable and very honest man, and he kindly and without reward undertook the investigation. The Philips family lived in the vicinity of Bristol, and the first of the family met by Mr. Ray was Mr. E. V. Philips, nephew and adopted son of Joshua Philips (not Josiah, as Mr. Lewis had it), and he enumerated several head of Clays. that had been owned by his uncle Joshua, among them a mare that was bred by Mr. Clark Philips, bought of him when a yearling by E. V. Philips, sold as a four-year-old to his uncle Joshua, and by him the next year to "some man from the eastern part of the country." He next met Mr. Clark Philips, who fully confirmed E. V. Philips about the Clay filly already referred to and said she was got when old Henry Clay was owned by Kent. and Bailey of Bristol, and that her dam was "Old Telegraph" by Highlander, etc. In his original report to me of his investigation Mr. Ray uses the following language:

" When Henry Clay was being brou lit from the East to his home in Western New York, he stopped one night at the hotel then kept in Bristol by Dr. Durgan, deceased (the breeder of Castle Boy), and made a season at this place the following year, when he became the property of Kent \& Bailey. He was kept in that town for several years, etc."

Now, as between the original and voluntary statement of Captain Lewis and the investigation carried through by Mr. Ray, 
there is no conflict and all is smooth sailing, and upon the information derived from these two sources the pedigree of George Wilkes was decided as established by the Board of Censors. But more recent discoveries made by Mr. Ray, in which I have no doubt he is thoroughly conscientions and possibly thoroughly right, have raised a conflict that is irrepressible, for dates are involved and insisted upon that make the pedigree impossible. In his original statement Mr. Ray says that Henry Clay made the season of 1846 at Bristol, "when he became the property of Kent \& Bailey. He was kept in that town for some years." $\mathrm{Up}$ to this point there is no contradiction and no impossibility; Ray agrees with Lewis and Lewis agrees with Ray. But in the past two or three years Mr. Ray believes he has secured additional information, and this places Captain Lewis in a very unenviable position. The whole point of Clark Philips' evidence is that he bred his mare "Old Telegraph" to Henry Clay when that horse was owned by Bailey Brothers, of Bristol, and I suppose they were the successors of Kent \& Bailey of an earlier date. Now, as Mr. Ray told us in his first investigation that Henry Clay passed into the hands of Kent \& Bailey in 1847, and as he tells us later that he did not pass into their hands till nine or ten years after that date and then fails to fix the precise year, it must be conceded by all that his information is not wholly satisfactory. Recollections may be ever so honest, but they are of various degrees of reliability. The best and final evidence is the service book of the horse. My best judgment of the whole matter is that Mr. Ray's later information is probably correct, but until all doubt is removed by the production of some contemporaneous record covering the case there must remain an element of uncertainty attaching to the pedigree. 


\section{CHAPTER XXXI. \\ HOW THE TROTTING HORSE IS BRED.}

Early trotting and pacing races-Strains of blood in the first known trotters -The lesson of M:und S.-The genesis of trotting-horse literature-The simple study of inheritance-I'Le different forms of beredity-The famous quagga story not sustained-Illustrations in dogs-Heredity of acquired characters and instincts-Development of successive generations necessary - Unequaled collections of statistics-Acquired injuries and unsoundness transmitted.

As preparatory to taking up the consideration of the breeding problem, it may be well to look back a little and see what had transpired in the trotting-horse world, leading up to the serious consideration of how he was bred. It has been generally accepted as true that there were no trotting contests in this country till about the second decade of the present century, but this impression has grown out of the fact that the newspapers, down to that period, failed to report such contests. It is historically true that pacing races were a common amusement among the people of different portions of the colonies nearly two hundred years ago. This is established by the legislative action of some of the colonies, in the first half of the last century, in suppressing all "pacing and trotting races." It is well to note, in passing, that pacers and trotters of that early period were commingled, just as they are to-day, with the former the more prominent, and the more highly prized. Of that hundred years of silence we have no details and but few historical references that were contemporaneous with the events. Hence we are practically dependent upon the legislative action of the colonies to establish the truth beyond question.

When we reach the period when the newspapers began to report some of the more conspicnous and important trotting events about Philadeiphia and New York, we find a condition of things for which we are hardly prepared. The pacer has lost his prominence and is but little in evidence, and all the best trotters seem 
to be descended from the imported horse Messenger. The best performers of that period were as follows:

Topgallant
Paul Pry
Lutchman
Jersey Fagdown
Commander (Bull)
Gipsy
Bull Calf
Lady Warrenton

These were all descended from Messenger, and with the exception of Edwin Forrest and one or two others, believed to be descended from pacing blood, they were the leading performers of their day. All of the above animals were not equally strong in Messenger blood as three of them were by sons and out of danghters of Messenger, five were by sons of Messenger, and all the others had more or less of his blood. More than eighty years ago the descendants of Messenger, wherever known, were recognized as a family of trotters and this broad fact became a kind of universal belief among horsemen. This belief, being founded on a truth, was all right, but a plausible deduction from it, which was not a truth, inflicted a terrible penalty upon the pockets of otherwise intelligent men for a period of more than fifty years before they discovered their error. The postulate was in this form: "Messenger was a thoroughbred horse and founded a great family of trotters, hence, any other thoroughbred horse, under the same conditions, would have accomplished the same results." This "stock" form of the argument was plausible and it was in everybody's mouth from one end of the land to the other. Every stable boy, every breeder, every editor believed the deduction was sound, and, I may as well own it, I believed it myself until I had gathered together all the accessible trotting statistics of this country and reduced them to order and method, so that they might be studied and their true teachings be drawn from them. As an illustration of the ignorant intolerance and dis. honesty with which certain editors and their followers maintained, less than twenty years ago, that all that was of any ralue in the trotter was inherited from the rumner, take the following: In the autumn of 1878 the famous Maud S., then four years old, came out and trotted a mile in $2: 17 \frac{1}{2}$, which was then a world's wonder. She was a pacer of the plastic type, but she 
harl to wear toe-weights through all her brilliant career to keep lier on her gait as a trotter. Everybody was astounded at this phenomenal performance and went wild over it as something that had never been done before, by a four-year-old, and probably never would be done again. On this performance I simply remarked, in the Monthly:

"Her trotting inheritance is very strong and well defined on both sides of the house, and she has a right to trot, and trot fast, and her 2:17 $\frac{1}{2}$ shows that she trots instinctively, and without much training; and in this she is phenomenal. She is simply a little in advance of her time; for no truth is more fully sustained by analngy and reason than that, in a few generation of judicious selections, such mares will not be phenomenal."

From this four-year-old record of $2: 17 \frac{1}{2}$ in 1878 , we pass on to the two-year-old record of $2: 10 \frac{3}{4}$ in 1891. A four-year-old now

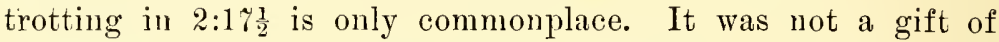
"prophecy" nor an overwronght enthusiasm, therefore, that enabled me to determine that $2: 17 \frac{1}{2}$ for a four-year-old would become commonplace, but a study of the laws of breeding in the light of all past trotting experiences. When this performance was made the late B. G. Bruce, of Lexington, Kentucky, then editor of a sporting paper, went into ecstasies over it and was at once able to show, to his own mind, that it was all owing to the running blood in Maud $\mathrm{S}$. that enabled her to show phenomenal speed. He figured this all out and showed that she possessed eleven-sixteenths of what he called "pure blood," to five-sixteenths of what he called "cold blood." In winding up his article, he says:

"In conclusion we deem it evident from her form and action that the great power of Maud $\mathbf{S}$. comes from her pure blood; that her breeding back on the form and action, courage and endurance of the blood horse is the very reason why she is so superior to all four-year-olds that have ever appeared. And another point is obvious: the pure blood matures so much earlier than the cold blood that years are gained in development over the cold-blooded trotter."

Now instead of Maud S. possessing eleven-sixteenths of "pure blood," as claimed by Mr. Bruce, it has never been shown and never can be shown that she possessed one single drop of "pure blood." When Sally Russell, the grandam of Maud S., was sold to Mr. R. A. Alexander, she was sold under a fraudulent pedigree, and when Pilot Jr. was sold to Mr. Alexander an utterly impossible pedigree was manufactured for him. In both cases he was the victim of sharpers, for in his life and character he 
stood away above all snspicion. The pedigrees of Pilot Jr. and Sally Russell have been fully considered in Chapter XXIX. of this volume.

After publishing "The American Stud Book" in 1867, and the first volume of the "Trotting Register" in 18\%1, and having carefully compiled all past trotting races and trotting experiences, up to the close of 1872 , it began to dawn upon me that possibly I had been handling a great many fictions and thereby given them an indorsement to the world as truths. This "gave me pause," as well as many a sleepless night and anxious day. The old adage, "What everybody says must be true," gave me 110 comfort, for I had just found that Mr. "Everybody" was a great liar. Then a higher and purer maxim suggested itself to my mind, "One, with the truth on his side, is a majority," and under this banner I enlisted for the war which I knew was coming. Having compiled the pedigrees of all rumning horses and all trotting horses, so far as known, up to $18 \%$, and more especially having gathered up all past trotting experiences and statistics, I felt that I was equipped to enter the lists with everybody against me. I knew I was liable to meet antagonists on every side, and some of them of great ability, but at the same time I knew they had neither the armor of truth nor the weapons of facts at their command. Mere prejudices and the limping opinions that spring from them have no force in an earnest combat. The platform upon which I stood was aggressive, but simple and easily comprehended, viz., "The English horse Messenger, in his own right and by his own power, founded a family of trotters-something which no other English horse had ever been able to take the first step toward accomplishing." This was the central point around which the battle raged, and to it I added the pacer as a subsidiary or minor source of speed, equally certain in fact, but not equally well defined in lines of descent, nor equally important in numbers and value. From these major and minor sources it is literally true that all our trotters have descended. In confirmation of this, a very capable and careful writer in the New York Sun, within the past few months, has said: "Hambletonian is the progenitor of ninety per cent. of the fast trotters now on the turf." When we start with Hambletonian, the triple great-grandson of Messenger, we are safely within the period of records of both blood and performances, and we are relieved from some possible uncertainties in the earlier period of Messenger himself, hence 
the writer quoted above is at bed-rock in the sources of his information. This makes my major proposition so plain and so triumphantly sustained that it is doubtful whether there is now living an intelligent horseman who would even think of disputing it.

In the spring of 1872 I wrote a series of articles under the caption of "Ilow shall we breed the Trotting Horse?" which was published in the Spirit of the Times in February and March of that year. These papers were revised and enlarged and published, as an introductory treatise on breeding the trotter, in the second volnme of the "American Trotting Register." This treatise is the genesis of all discnssions in which the laws governing the breeding of the trotter are considered. Up to that period contributions to the press on breeding subjects were generally transient and confined to the writer's own experience. If he was trying to breed trotters a comparison of his material always corresponded with his arguments, and the only thing he demonstrated was his own inability to see over the fence surrounding his own paddocks. I love a man who loves his horse, and, as a man, I cannot dislike him because he thinks his horse is the very acme of all equine perfection, although he may be a worthless brute; but when a man spends a whole lifetime in trying to breed trotters from blood that cannot trot, I lose all respect for his mental operations. The man who cannot widen out and take profit from the demonstrated experiences of the whole trotting world, had better turn his attention to some bnsiness suited to his capacity. Not a single thought advanced nor a position taken in the article referred to has ever been successfully controverted, although they excited much opposition. An attempt was made to langh the phrase "trotting instinct" ont of court, but that little phrase not only held the fortress, but became, as it were, the basis of the whole system of thought represented in the treatise. It had a meaning and a fitness in what it meant that put it in everybody's mouth, and there it stays for all time. Instinct is "the sum of inherited habits;" and these five words express the best practical definition of its meaning that I have ever met with.

The Laws that Govern. - In all animal life the resemblance of the offspring to the parents is the universal law. The law is not only true in the physical conformation of the offspring, but it is also true in the mentality and instinctivity of the offspring. 
In former years it was very aptly termed the law of inheritance, but the more general usage is now the law of heredity. In casting about for a definition of this newly coined word, I have not been able to find anything more comprehensive and expressive than that given by Ribot, in the opening sentence of his work on this subject. He says:

"Heredity is that biological law by which all beings endowed with life tend to repeat themselves in their descendants; it is for the species what personal identity is for the individual. By it a groundwork remains unchanged amid incessant variation; by it Nature ever copies and initates herself."

'This has been the law ever since the command went forth, "Let the earth bring forth the living creature after his kind, cattle and creeping thing and beast of the earth after his kind." Hence sprang the varieties, species, genera and orders into which naturalists have sought to classify the animal kingdorn. In generations long past our ancestors used such phrases as "Like father, like son," "Trot father, trot mother, trot colt," "Like begets like," etc., meaning just what we mean to-day by the word "heredity." While heredity is a universal law of animal life, it must be remembered that its results cannot be pre-determined by any rule of arithmetic. Every colt has a sire anā a dam, four grandparents, eight great-grandparents, and then sixteen, and next thirty-two progenitors. Here we have five generations embracing sixty-two different animals, and the experiences of many years have gone to show that if these sixty-two animals are all purely bred in the breed which you are seeking to secure there is a ressonable certainty that your prospective colt will be a good representative of that breed. By this I mean that with this number of generations there is bnt little danger of your colt following some undesirable type outside of and beyond thes five generations. The only way to study this problem intelligently and with satisfaction is to tabulate the pedigrees of the two animals you propose to couple and then stndy each individual of the different generations and see what each one has done in the direction you are breeding. If you are breeding for a Derby winner you want every one of the sixty-two to have proved himself or herself a first-class runner, and you don't want a single drop of ontside blood in any of them. If you are breeding for the twominute trotter, you don't want any blood but the fastest trotting blood. If you are breeding for the two-minute pacer you want 
nothing but the fastest pacing blood. But, possibly you may be breeding for size, style, and beauty, and in that ease you must be particularly careful to have your tabulation full of animals possessing these qualifications. In times past many breeders have been led to their own hurt in making ill-considered attempts at improvement by mating animals of antagonistic instinets. The fast runner and the fast trotter have nothing in common between them in the way of gait. In physical structure there may be no antagonism that we can see, but in mental or psychical structure there is nothing but what is inharmonious. Each animal and each line of blood must be considered as it stands separate from the other, and the question must be not only asked but answered: "What has this line of blood done in its own right and by its own power?"

In studying these tabulations it certainly is not necessary to remind any thinking man of the comparative value of near and remote individuals. The first and second generations are the important factors in the character and value of the proposed colt, and, as a rule, the four grandparents are not given that weight. in making up a sound judgment to which they are entitled. A tabulated pedigree may show a general equality or average goodness all over, in the direction we are looking; although it may embrace but few stars it is not a pedigree that should be hastily rejected. The student should never lose sight of the truth that. bad qualities are just as certain to be transmitted as good ones. Bad feet, bad limbs, bad eyes and bad respiration should be sufficient cause for prompt rejection. Derangement or unhealthiness of the internal viscera or any of them is just as likely to be transmitted as an external malformation or disease.

In some instances the qualities sought seem to emanate entirely from the sire or the dam, and this prepotency seems to appear more frequently as the work of the sire than of the dam, perhaps because the opportunities are greater in the $n$ mber of services. Thousands of stallions have failed to get trotters ont of running-bred mares, but as many as you could count on the fingers of one hand, probably, have sucreeded in a few instances. Of these Pilot Jr., Almont and Electioneer occur to me at this time as the most prominent. These horses, so far as we know the lines of their blood, were strictly trotting and pacing bred, with no tincture of running blood in their veins. On a certain occasion Senator Stanford wished to demonstrate to the writer 
that Electioneer could get trotters out of running-bred mares, and after showing the step of the famous Palo Alto, he remarked: "None of my other stallions can do that. Electioneer alone has the power to get trotters out of some thoroughbred mares, but not all." This ability to get a trotter out of a running mare is the highest test to which the prepotency of a trotting sire can be put, as is shown by the very small number that have ever succeeded.

Direct Heredity. - While it is true that all inheritance must come throngh the parents, it is also true that phenomena of form, character and quality are not infrequently presented that the parents do not seem to possess, and upon looking further we find those phenomena in some of the more remote ancestors. When we find the character of the offspring a practical reproduction of one or both the parents, we designate this as a case of "direct heredity" merely for the convenience of description and elucidation. Ideal or perfect heredity never has been reached and never will be. There are two sources to the life of the new being, and each of these sources is made up of never-ending variations. There may seem to be a very complete coalescence of the elements of the sire and dam in the foal, but it is not like either of them and yet it may resemble both. A mere physical resemblance to a great sire is no evidence that the colt will be equally great. I have seen many of the sons of the great Hambletonian, and among them all the one that bore the strongest physical resemblance to him was of the least value, either as a performer or a progenitor. Hambletonian left many great sons behind him, some of them even greater than himself, and while they all possessed certain family characteristics, I cannot recall a single one that strikingly resembled him in his physical conformation. From this incident, as well as a thousand other similar ones, we cannot avoid the conclusion that heredity controls the whole animal, man or beast, in his mental as well as in his physical constitution.

Cross Herenity is one of the forms of direct heredity, and is not very well exemplified in trotting experiences, nor very valuable in the lessons it is supposed to teach. In its first form it embraces instances where the character of the sire is transmitted to his daughters and the character of the dam is transmitted to her sons. Long ago I established a table in the "Year Book" to embrace the sires of mares that produced two or more animals in the 2:30 list, but had failed to place any representa- 
tive there from their own loins. The development of this table simply showed an array of sires that were not able to get 2:30 trotters, but when their danghters were bred to horses of stronger inheritance, horses indeed that were able to get trotters from almost any kind of mares, they produced foals that came within the circle. This was a grandsire's table and depended upon second causes, that is, the horses that gave it life occupied secondary positions in it, and it presented but little that was of value to the student of horse history. In the discussion of this particular form of heredity the books are filled up with instances of vicious fathers begetting vicious danghters and vicious mothers producing vicious sons, with more or less uncertainty as to the individual origin of the parties in question.

Indirect and Collateral Heredity.-When a child or a colt does not resemble its parents, but "takes after" the grandfather or some more remote ancestor, it is said to be a case of atavism, or indirect or collateral heredity. Twenty years ago I visited, by appointment, a branch of my family at the old homestead of my great-grandfather, on the maternal side. There never had been any knowledge of each other or intercourse between these two branches of the family. On arriving at my destination I was warmly greeted by a gentleman who came forward from the crowd and named me. As there were a good number of people alighting from the train at the same time I asked my cousin how he knew me, and he repiled that I bore such a striking resemblance to my grandfather that at a single glance he could have picked me ont of a hundred men. This grandfather was the father of my mother and he died when I was a small boy. But there was a still greater surprise awaiting me. My kinsman was an intelligent man of excellent sense, and during the few days I spent in his family he was to me a most interesting study. In a hundred ways he reminded me of my brother, not in resemblance of face, for there was, practically, no resemblance; but in the action of his mind, in his way of putting things, and especially in his unstudied and peculiar gestures of his hands in conversation, the one seemed to be a perfect reprodnction of the other. They were both born and reared on farms, they were both heads of families, and they were both elders in the Presbyterian church. The one was the third and the other the fourth remove from their common progenitor. I have read carefully descriptions of many cases of mentai heredity, but this case, 
coming under my own observation and deliberate study, seemed to be more thoronghly convincing than any or all others.

The fact that certain qualities may lie dormant through several generations and then be unexpectedly developed was well known to the ancients more than two thousund years ago. Plutarch mentions a Greek woman who gave birth to a negro child and was brought to trial for adultery, but it was discovered that she was descended in the fourth degree from an Ethiopian. Montaigne expresses his astonishment at this, and remarks:

"Is it not marvelous that this drop of seed from which we are produced should bear the impression, not only of the bodily form, but even the thoughts and inclinations of our fathers? Where does this drop of water keep its infinite number of forms? How does it bear these likenesses through a progress so haphazard and so irregular that the great-grandson shall resemble the greatgrandfather, the nephew the uncle?"

The most prolific and satisfactory sources of evidence in support of indirect or reversionary heredity are to be found in the crosses between the white and the black races. They abound in all quarters wherever the two races are to be found, and many a proud family has been humbled to the dust when the long-concealed "black drop" makes its unexpected appearance. There are hundreds of such cases in the world, and it is impossible to make even an approximation of the number of generations that would be required to wash out the stain.

Heredity of INFLUENCE.- When the subject of "How to Breed the Trotting Horse" was in its infancy there was a wonderful amount of mystery about it. Nobody could understand why one horse of the same general conformation should not trot just as fast as another. When it was found that this way of looking at the problem would not meet the facts, one thought it was owing to the length of certain bones, another that it was all in the hind quarters, another that it was "the trotting pitch," another that it was "a happy nick," etc. When it was all made plain that a horse was able to trot fast because his ancestors were able to trot fast, the seekers for the mysterious had nothing left that suited their taste but the effects of first impregnations, resting on Lord Morton's story of the quagga and the mare, which is here dignified with the title "Heredity of Influence." Now, just how "influence," two or three years after the event, should become a controlling factor in the paternity of a colt, is a mystery sufficiently profound to satisfy our friends of earlier years, so 
intent upon finding something mysterious. For about threequarters of a century the story, coming from so reputable a source, has been cited in many scientific bodies and accepted by many scientific men and writers without a question or doubt. No writer, so far as I know, has ever attempted to controvert it, and if the facts be well founded it demolishes in its conclusions all the laws of generation, to say nothing of the universal law of heredity. The point to be considered is, whether the first impregnation influences the offspring of subsequent and different impregnations. In other words, whether the children of a widow by her second husband will partake of the characteristics of her first husband. Ribot says "that from the psychological point of view, we are skeptical in regard to this form of heredity. The fact seems to be perfectly out of the order of things." He then goes on to consider it as though it might be true, and cites any number of the veriest fables in support of it, without ever stopping to inquire whether they have any foundation of truth. In every assemblage of breeders brought together for the purpose of discussing how best to breed and rear our domestic animals at. a profit, there is always somebody to bring in the everlasting story of the mare and the quagga, not because it may have any relevancy to the subject, but it is an opportunity not to be lost. to show one's learning. As this story has served the purpose of showing off the learning of so many thousands who never saw it, I will here give it in its original and official form. A communication from the Earl of Morton was read before the Royal Society of London, November 23, 1820, and published in "Philosophical Transactions" for 1821, p. 20, and is as foliows:

"I yesterday had an opportunity of observing a singular fact in natural history, which you may, perhaps, deem not unworthy of being communicated to the Royal Society.

"Some years ago I was desirous of trying the experiment of domesticating the quagga, and endeavored to procure some individuals of that species. I obtained a male; but being disappointed of a female, I tried to breed from the male quagga and a young chestnut mare of seven-eighths Arabian blood, and which had never been bred from; the result was the production of a female hybrid, now five years old, and bearing both in her form and in her color very decided indications of her mixed origin. I subsequently parted with the seveneighths Arabian mare to Sir Gore Ousley, who has bred from her, by a very fine black Arabian horse. I yesterday morning examined the produce, namely, a two-year-old filly and a year-old colt. They have the character of the Arabian breed as decidedly as can be expected, where fifteen-sixteenths of the 
blood are Arabian; and they are fine specimens of that breed; but both in their color and in the hair of their manes they have a striking resemblance to the quagga. Their color is bay, marked more or less like the quagga, in a darker tint. Both are distinguished by the dark line along the ridge of the back, the dark stripes across the forehand, and the dark bars across the back part of the legs. The stripes acioss the forehand of the colt are confined to the withers and the part of the neck next to them. Those on the filly cover nearly the whole of the neck and the back as far as the flanks. 'I'he color of her coat on the neck adjoining the mane is pale, and approaching a dun, rendering the stripes there more conspicuous than those on the colt. The same pale tint appears in a less degree on the rump; and in this circumstance of the dun tint also she resembles the quagga.

"'l'he colt and filly were taken up from grass for my inspection, and owing to the present state of their coats I could not ascertain whether they bear any indications of spots on the rump, the dark pasterns, or the narrow strips on the forehead, with which the quagga is marked. They have no appearance of the dark lines along the belly or the white tufts on the side of the mane. Both their manes are black; that of the filly is short and stiff, and stands upright; and Sir Gore Ousley's stud groom alleged it never was otherwise; that of the colt is long, but so stiff as to arch upward, and to hang clear of the side of the neck, in which circumstance it resembles that of a hybrid. This is the more remarkable, as the mane of the Arabian breed hangs lank and closer to the neck than those of most others. The bars across the legs, both of the hybrid and of the colt and filly, are more strongly defined and darker than those on the legs of the quagga, which are very slightly marked; and though the hybrid has several quagga marks which the colt and filly have not, yet the most striking, namely, the stripes on the forehand, are fewer and less apparent than those on the colt and filly. These circumstances may appear singular, but I think you will agree with me that they are trifles compared with the extraordinary fact of so many striking features which do not belong to the dam, being in two successive instances communicated through her to the progeny not only of another sire, who also had them not, but to a sire probably of another species; for such we have very strong reasons for supposing the quagga to be"

This is Lord Morton's original quagga story without abridgement, the substance of which has been quoted and printed millions of times, but I never have seen anything like an analysis of it, either for or against its value as determining any fact or principle in breeding. The elements are: a young chestnut mare, "seven-eighths Arabian blood," was bred to a quagga and produced a hybrid. She was afterward bred to a black "Arabian" and produced a colt and a filly that were supposed to be marked like the quagga; hence, first impregnations influence all subsequent foals; and hence "the heredity of influence," as called by some scientists. Lord Morton has given an intelligent and, no. 
doubt, faithful deseription of the colt and the filly that came out of the mare that had previously produced the hybrid quagga; but he has failed to show that none of the near-by ancestors of the sire and dam of this colt and filly were of a dun color and were marked just as the colt and filly were marked. Until it is shown that the peculiar markings of this eolt and filly could not have been inherited from their natural ancestors, the half-formed theory that they were the result of the coupling with the quagga, years before, wholly fails to satisfy the human understanding. When Lord Morton tells us that the dam was seven-eighths, and the sire full Arabian, he seems to think he has covered that point; but be has not, for he has not shown that there was a single drop of Arabian blood in either of them. It must not be forgotten that at the period here referred to all Eastern and Southern horses were called Arabians, when not one in fifty of them ever saw Arabia either through his own eyes or throngh the eyes of any of his ancestors. The composite material ont of which the English race horse was built up was of all colors, including the dun, with the dark stripe on his back, the short stripes or patches on his shoulders, and the transverse bars on his legs. A horse of this color, I am told, once won the Derby. The Kattywar horses of Northwestern India, Mr. Darwin informs us, are from fifteen to sixteen hands high, of all colors, with the several shades of dun the most common, and when one of them fails of having the spinal stripe, the shoulder stripes, and the leg stripes the purity of his breeding is donbted. This is the type of horse the British officers ride, and when their term of service expires sometimes bring home with them. There are many duns in Persia and in Eastern Asia Minor, I am informed, and the stripes seem to belong to the color. In Norway the color of the native horse is dun and the stripes are considered evidence of pure breeding. Many of the mountain horses of Spain are duns, with the stripes. 'The dun color prevailed, to a greater or less extent, among the native English horses of three hundred years ago, and some of them were brought to this country in the early colonial period. Mr. Darwin, in his "Animals and Plants under Domestication," fully describes the dun horses of Devonshire, and in order to be elearly understood he figures one of them showing the dark stripes on the shoulder and the transverse bars upon the legs. I have seen numbers of dun horses so marked, in this country, the most conspicuous that I can now recall being Wapsie, 
the distinguished son of Green's Bashaw. The fact that horses of this color and marking are to be found in all parts of the globe, has led many thoughtful writers to the conclusion that these characteristics are among the very earliest in the history of the horse. To bring this instance to a close, I must say:

1. Beyond the color alone of the sire and dam of this colt and filly, there is no evidence whatever that they might not have inherited, by ordinary generation, the color and markings from some of their ancestors.

2. The miscegenous breeding of the ass upon the mare has been practiced, we know, for more than three thousand years, and yet in all that time, and down to our own day and experiences, there has been no established indication that the first impregnation of the filly by the ass had any influence whatever upon her subsequent produce by the horse.

This theory of the first impregnation having an influence on all subsequent produce is probably more generally maintained among dog fanciers than any other class of breeders. In some instances when a valuable maiden bitch gets astray she is banished from the kennel and either destroyed or given away. For this foolish notion some antique authority might be cited. Burdach, a French writer on physiology, says:

"If a bitch be once put to a $d o g$ of another race, every litter of puppies afterward will include one belonging to that other breed, except the first time she be put only to dogs of her own breed."

This is a kind of pseudo science that is only calculated to mislead, for the vital facts are omitted. What was the pedigree of the bitch? She may have looked like a well-bred pointer and a. high price may have been paid for her, but her sire may have been a mongrel, or, possibly, a miserable cur. No dog breeder or dog dealer has ever been known to drown the results of a. mésalliance if it was a fairly good-looking puppy. It goes into the records as a thoroughbred and finds a market. When a dog and a bitch, seeming to be well-bred and costing a high price, bring into the world a litter of puppies showing a mixed inheritance, the fancier at once jumps to the conclusion that there is something mysterious abont it, and as he has heard of the evil results of first impregnations, he thinks he has discovered the source of the trouble and straightway this is another example resulting from first impregnation. He then goes back on the 
dealer, or possibiy the breeder, and there to conceal the fact that the blood of his kenmel was not pure, he would naturally play the rogue and admit that the young bitch might have got astray. This satisfies the unsophisticated owner, and another trick of an unscrupulous "clog jockey" goes on record as a case of "heredity of influence," when in fact it was nothing more nor less than a dirty fraud in the breeding of the dog or bitch, or both.

Some of the early French writers on scientific subjects, as Burdach, Michelet, etc., advanced the theory more than a hundred years ago that the children of a second marriage, in some, cases, inherited the resemblance and character of the first husband. In the nature of things this theory could have but very feeble support and that chiefly among scandalmongers. In connection with this phase of "heredity of inflnence" I will give a little instance of my personal experience. Twenty years ago, or more, I was making an address before an association, in a New England city, on the subject of "How to Breed the Trotting Horse." The audience was very large and composed exclusively of gentlemen. At the opening it was annonnced that at the close of each specific topic an opportunity wonld be given to any one in the audience to ask questions on the thoughts presented. The signal had hardly been given when a gentleman arose in the audience and raised the question whether I had not omitted an important fact in heredity? He then went on to rehearse the everlasting quagga story, with a most confident flourish of his learning and a sure grasp on a triumph.

"The quagga story," I remarked, "is well known to everybody, but there are some facts about it that are not known to anybody. The mare herself may have been from a dun tribe of horses, or the horse to which she was afterward bred may have been from such a tribe, hundreds of which have stripes on the back, the shoulder's and the legs, and thus the stripes might be accounted for by indirect heredity; not because the quagga had stripes, but because the dun horse ancestry had stripes. Most people, probably, look upon it as a freak of nature, and as the case has never duplicated itself, in all the years before or since, it fails to be a practical question, and in our personal experiences as breeders, we need not be afraid of suffering harm from it."

"Your explanation," replied my interlocutor, "fails to cover the case, I think, for I have seen, with my own eyes, instances of it in the human family and I will relate one. A dozen years 
ago, or more, a friend of mine married a lady who was a brunette in complexion, with black eyes and black hair. He was of florid complexion, with blue eyes and sandy hair, just abont the color of my own. After three or four years the husband died leaving two children of his own complexion and color of eyes and hair. In course of time the widow married a man with black hair and black eyes, and there came a second set of children that were as perfect reproductions of the first husband as his own children were in complexion and color of hair."

"How long have you personally known this family, and have your ever seen these two sets of children?"

"I have known the family intimately ever since the first marriage and I have seen both sets of children very often."

"You certainly have had abundant opportunity to know whereof you affirm, and the facts seem so plain that it would be a refinement on folly to undertake to contradict them; but there is one element in this case that has not been explained, and it is a vital one. How are we to know whether some man of 'sandy complexion' and with 'hair and eyes just the color of yours,' is not the father of this second set of children?"

This ended the colloquy in a "roof-raising" shout, and I never have been called upon since, in a public meeting, to even allude to the "lheredity of influence." With the experiences of thousands of years of miscegnatious breeding between the ass and the mare and no indication among the writers of the ancients as to the evil and abiding effects of first impregnations; and with the experiences of more than a century in this country, with the same results, we are compelled to throw over all claims of this kind until furnished with full and complete pedigrees of the sire and dam, showing the color and markings of each individnal for a number of generations.

Heredity of Acquired Characters and Instincts.-On this point there is a lack of unanimity, among the promoters of the "primordial germ" theory, and the principal advocate of the negative side of this question appears to be Professor Weismann. Mere opinions of men, no difference how profonnd their learning, cannot be of any valne, unless they are sustained by actual experiences, on questions of this kind. To determine this matter we are not dependent upon any of the explanations of the central Darwinian hypothesis of creation without a Creator, for we have all around us, safely within the historic period of human 
observation and experience, mountains of evidence, so to speak, heaped upon us, going to show that ${ }^{66}$ acquired character and instincts" are transmitted and become hereditary.

Dr. Pritchard, in his "Natural History of Man," gives the following illustration on this point:

"Two other very important observations made by M. Roulin, in South America, were pointed out by M. Geoffrey St. Hillaire, in his report to the Academy of Sciences. They refer to the fact of the hereditary transmission of habits originally impressed with care and art upon the ancestors. Of this fact I will adduce other examples in the sequel; at present I only advert to $\mathrm{M}$. Roulin's observations. 'The horses bred on the grazing farms of the table-lands of the Cordillera are carefully tanght a peculiar pace, which is a sort of running amble. This is not their natural mode of progression, but they are inured to it very early, and the greatest pains are taken to prevent them from moving in any other gait; in this way the acquired babit becomes a second nature. It happens occasionally that such horses becoming lame, or no longer fit for use, it is then cnstomary to let them loose, if they bappen to be well grown stallions, into the pasture grounds. It is constantly observed that these horses become the sires of a race to which the ambling pace is natural, and which requires no teaching. 'The fact is so well known that such colts have received a particular name; they are termed 'aguilillas." '

The fact that there were some pacers in South America came to me from many sources, and especially from gentlemen of intelligence and character who had spent years in that country, and was for a long time a puzzle to me. All the evidences of history went to show that the horse stock of South America was Spanish, and no evidence could be found that the Spanish horse was a. pacer, or that there was any tendency to pace in the blood of the Spanish horse. This report to the French Academy of Sciences was made in the early part of this century and is really the first information I have ever had of Spanish horses pacing. Dr. Pritchard was one of the earlier modern writers on natural history and stands very high as a man of conscience as well as learning. The surprising feature in this South American experience is the wide and, apparently, immediate measure of success that seems to have followed the training to the pacing gait in its transmission. It may be taken as a rule that the changing of the gait from the diagonal to the lateral, or vice versa, is a slow process, and it seems to me that with few exceptions it wonld require several generations before the new habit of action would become fixed in the breed. It is just possible, however, that there may 
have been a tincture of pacing.blood in the Spanish horses of the sixteenth century. The Visigoths, one of the early Asiatic lordes that overran Europe, first settled in Scandinavia, and the southern part of Sweden is still called "Gothland." After a long stay in that country they became dissatisfied with soil and climate and determined to seek another. According to the historians, they first migrated in a southeastward direction and from there in a southwestward till they reached the sonthern part of France, from which they soon passed over into Spain, which they subdued, and established there a dynasty which lasted two hundred years. In A.D. 711 the Saracens from Africa crossed over, and after a very bloody battle lasting two days, defeated Rhoderic, the last of the dynasty, and cut his army to pieces. In Scandinavia, and especially in Norway and Sweden, we find plenty of dun horses that are pacers, and they are recognized as a very old breed. In the mountains of Spain we also find small dun horses, and it is, perhaps, not an unreasonable possibility that the Visigoths may have carried some of their horse stock with them in their migration from the North to the South of Europe, and thus this habit of action that may have remained for centuries latent in the breed may have been unusually plastic in its restoration. This, however, is a mere surmise as to a possibility and eannot displace the historic observations reported by M. Roulin and presented before the French Academy. The gait of the South American pacers, as I understand it, is not that of the pure pace, with two strokes completing the revolution, but is more like the "saddle gaits" that we find in the West and Southwest of our own country. The true pace seems to be exceptional, because that is not a saddle gait. It is a fact often observed in this country that foals from parents trained to the saddle gaits will take to those gaits naturally and as soon as they are dropred. In a preceding part of this work I have given some consideration to the fact that three or four hundred years ago the horses of our English ancestors were largely pacers, and to the methods adopted in that day for changing the action from the diagonal to the lateral gait-the hopples, rattles, weights, etc. The descendants of those horses, brought to this country by the colonists, as will be seen at another place, were nearly all pacers.

The following letter, addressed by Dr. William Huggins to Charles Darwin and by him published in "Nature" twenty years ago, very strongly illustrates the heredity of instincts, and as it 
is authentic and true beyond question I will here insert it. Dr. Huggins says:

"I wish to communicate to you a curious case of mental peculiarity. I possess an English mastiff, by name Kepler, a son of the celebrated Turk out of Venus. I brought the dog, when six weeks old, from the stable in which he was born. The first time I took him out he started back in alarm at the first butcher's shop he had $\epsilon$ ver seen. I soon found he had a violent antipathy to butchers and butchers' shops. When six months old a servant took him with her on an errand. At a short distance before coming to the loouse she had to pass a butcher's shop; the dog threw himself down (being led by a string), and neither coaxing nor threats would make him pass the shop. The dog was too heavy to be carried, and as a crowd collected, the servant had to return with the dog more than a mile, and then go without him. This occurred about two years ago. The antipathy still continues, but the dog will pass nearer to a shop than he formerly would. About two nonths ago, in a little book on dogs, published by Dean, I discovered that the same strange antipathy is shown in the father, Turk. I then wrote to Mr. Nichols, the former owner of Turk, to ask him for any information he might have on the point. He replied: "I can say that the same antipathy exists in King, the sire of Turk, in Turk, in Punch (son of Turk), out of Meg, and in Paris (son of Turk out of Juno). Paris has the greatest antipathy, as he would hardiy go into a street where a bntcher's shop is, and would run away after passing it. When a cart with a butcher's man came into the place where the dogs were kept, although they conld not see him, they all were ready to break their chains. A master butcher, dresssd privately, called one evening on Paris' master to see the dog. He had hardly entered the house before the $\operatorname{dog}$ (though shut in) was so much excited that he had to be put into a shed, and the butcher was forced to leave before seeing the dog. The same $\mathrm{dog}$, at Hastings, made a spring at a gentleman who came into the hotel. The owner caught the dog and apologized, and said he never knew him to do so before, except when a butcher came to his house. The gentleman at once said that was his business. So you see that they inherited these antipathies, and show a great deal of breed."

Some ancestor, not far removed, of these three generations of dogs must have suffered a life of oppression and cruelty at the hands of an unfeeling master, and that master must have been a butcher. We fail to understand and appreciate the mentality of the $\operatorname{dog}$ and the horse, and as they are above the average of the brute creation we fail of a word midway between instinct and reason to express that mentality. We call it "instinct," and correctly, too, but this grade of instinct requires a more expressive word to represent it. That a feeling of antipathy should have been so deeply seated in the nature and life of a dog that the resentment and hatred should have been transmitted to his de- 
scendants for three generations in succession is a very remarkable instance of the heredity of instinct. As a companion piece to the foregoing and as showing the difference between the hatred of one dog and the gratitude and love of another, I will relate an instance that came undèr my own observation and knowledge more than forty years ago. General John G. Gordon was a merchant in Muscatine, Iowa, and Dr. George Reeder was a physician of great skill and very large practice. These two gentlemen were among my most intimate personal friends. On a certain occasion one of Gordon's well-to-do farmer customers brought him a puppy a few months old as a present. He had no use for a $d o g$ and didn't want one, but he was not willing to forfeit either the good wishes or the custom of his farmer friend, so be accepted the gift with thanks. When he took the puppy home in the evening there was consternation in the household, and in a family conference it was decided that he should not be allowed to run through the house with his dirty feet, and thereupon he was consigned to the cow stable, and that became his home as long as he lived. Every night and morning he got a liberal ration of milk fresh from the cow and they soon became inseparable friends. In cold nights, as if by mutual agreement, he always slept cuddled up close to the cow. At that time in the history of the town, the country was open and pasture abundant in every direction, and everybody kept a cow. In the mornings these cows would start out to their grazing grounds, in bands, radiating in every direction, and in the evenings could be seen "the lowing herds wind slowly o'er the lea." Gordon's dog never missed a day for years in going with his friend the cow and returning with her in the evening.

Dr. Reeder used two or three horses in his practice, and his stable was on the same alley, and some ten or twelve rods distant from Gordon's cow stable. One day in winter time he was having his bins filled with corn in the ear, and to make room for it all he had to fill up a large dry-goods box that stood in one corner of the atable. While he was supervising the delivery of the corn Gordon's dog came in, reared up on his hind legs, seized an ear of corn and made off with it. The doctor was very much surprised at this act of the $\mathrm{dog}$ as he never had seen or heard of a dog eating corn. While he was thinking about this strange act of the dog, he came back again and seized another ear and made off with it. This time the doctor watched him, and he carried it 
direct to his friend the cow, dropped it before her, and she soon made away with it. 'This phenomenal exhibition of the attachment of one animal to another of entirely different nature aroused the doctor's desire for a further confirmation of what he had seen. Concealing himself behind the door he awaited further developments and in a little while the dog came back, seized the third ear, and whippiag past some other cows, carried it safely to his friend. I have seen this dog a hundred times, and he was a mongrel nondescript, about the size of the average pointer, with nothing remarkable about his appearance; but in all the illustrations of all the naturalists I have not met with any authenticated instance where character in a dumb animal was so beautifully exhibited. In history we have many touching examples of the attachment of the dog to his master and of his heroism in defending the weak against the strong, but this case seems to be mique. Here is a character developed that is far more than "the sum of inherited habits." We may call it instinct, but that word fails to express it. In whatever light we view this character, it has in it an element of reason and we have no word that expresses it.

The oldest written evidence we have of the origin of the setter dog dates back about two hundred years, in which we find Jobn Harris agreeing to teach Henry Herbert's "spaniel bitch Quand" to set game. Allusions are made in the old writers to dogs used for this purpose long before, but the setter certainly has an ancestry dating back at least two hundred years. The pointer is of much more recent origin and seems to have come from an ancestry wholly distinct from that of the setter, and yet, in the field, it would be very difficult for the most competent jury to decide which stands to his game with the greater steadiness. It is agreed, I think, among experienced sportsmen and breeders that the best dogs are the result of couplings made in the midst of the hunting season when the instincts of the parents are aroused and active under the gun. Puppies so bred are already halftrained when they are whelped. The instinct to point the game instead of rushing upon it is an instinct acquired at an earlier or later date, well within the historic period, and we know that it is transmitted and inherited under the laws of heredity. We know also that this instinct is strengthened and improved by training and nse; and at the same time it is weakened, if not obliterated, by neglect and non-use for a few generations.

The Scotch collie, with plenty to do, is altogether the most 
useful, and hence, in a utilitarian sense, the most raluable of all the varieties of the canine race. In understanding his master's commands and the motions of his hand in the management of the flock, he evinces an intelligence, an instinct, that is almost human. There is a marked distinction between the instinct of the pointer and the collie. The former acts chiefly by his innate mental endowments, while the latter is at his best when carrying out the will of his master. In both cases the instinct was acquired in comparatively recent years, and it is now fixed in the breeds and is transmitted with great certainty.

The most remarkable results in the development and use of an instinct that was practically latent, or never developed, are to be found in the history of the American Trotting Horse. Fifty-one years ago Lady Suffolk was the first trotter to cover the mile in $2: 29 \frac{1}{2}$. Four years later Pelham, a converted pacer, trotted in 2:28, and four years still later Highland Maid, a converted pacer, trotted in 2:2\%. In 1859 Flora Temple trotted in 2:193\% in 1874 Goldsmith Maid trotted in 2:14; in 1885 Mand S. trotted in 2:083; in 1892 Nancy Hanks trotted in 2:04; and in 1894 Alix

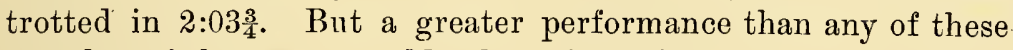
was that of the two-year-old colt, Arion, when in 1891 he covered the mile in $2: 10 \frac{3}{4}$. I have no hesitation in pronouncing this the greatest performance ever made, to this date, not because it was the fastest, as shown by the watch, but because it was made by a two-year-old, and from this fact there had been no time for prolonged and skillful training. He was essentially the product of heredity and not the result of education.

Fifty-one years ago there was but one animal in the 2:30 list, and at the close of 1896 there were over fifteen thousand within that limit and far more than fifteen thousand others hovering on its border. This astounding result must be attributed primarily to a trotting inheritance, but this inheritance has been constantly strengthened, reinforced, fortified by the acquired capacities resulting from the development of the trotting speed of succeeding generations. This is not a mere estimate of what has resulted from acquired characters and instincts, for if we put all the observations of all the writers on subjects of natural history, large and small, together, they make but a meager and unsatisfactcry showing when compared with the fifteen thousand actual experiences, officially noted and recorded on the spot and printed in "Wallace's Year Book." In all the world there is no other 
collection of statistics so vast, so accurate and so valuable as is there to be found, touching the question we are considering.

While the heredity of acquired characters and instincts is thus clearly and fully established, there is another truth intimately connected with it that shonld not be forgotten. In an inheritance springing from recent acquisitions there seems to be less of adbesive strength than in one that hascome down through many generations. This being true, it follows that whether the lines of inheritance be long or short there must be an intelligent and constant exercise of good judgment in strengthening them by bringing the best and strongest together and uniting them in the prospective foal. When this lhas been done it is possible that the foal may not be of much value, but the chances of success are in exact proportion to the strength of all the lines of inheritance that are united in the foal. Beyond the chance of failure and beyond the average chance of an average production, there is a chance for something better than any of the ancestors. This latter hope always has been and always will be the inspiration of the breeder. In his structure and form he may be an improvement on his parents, but his value as a trotter can only be determined by the development of his instincts and speed as a trotter. Without such development he may transmit what he inherits, but he adds nothing to his inheritance except by the development of his own powers. These accretions, growing ont of the development of succeeding generations, are the material cause that has placed the American Trotter at the very edge of two minutes to the mile, and with wise management will eventually carry him away beyond that rate of speed. This whole topic may be summed up in a single sentence: every acquisition of eminence anci superiority adds something to the valne of what is transmitted.

Heredity of Bad Qualities, Unsoundness, etc.-Under the laws of inheritance no distinction can be made between the desirable and the undesirable, nor between the earlier or later acquisitions, as they are all liable to be transmitted and to become hereditary. The bitter must go with the sweet. Dropping below is just as liable to occur as rising above what might be considered the average inheritance of the immediate parents. This may result from following or throwing back to some undesirable or unsound cross that may exist in some of the lines of inheritance which possibly may be distant several generations. As a 
practical consideration it makes but little difference whether a tendency to, or a fully developed, unsoundness has been in the inheritance for generations, or whether it may be the result of some recent accident or injury, it is liable to be transmitted. It is known to everybody that the great rumning horse Lexington was blind, and it was urged that his blindness was not congenital, but the result of an accident; hence it was argued by those interested that it would not be unsafe to breed to him. It was stated and repeated a hundred times that while in training he got loose in his stable and stuffed himself at the oats bin, and without knowing this his trainer took him out next morning and ran him a trial of four miles, from the effects of which he lost his sight. Without giving full credence to this as the cause of his blindness, it is nevertheless true that he filled the country with blind horses. If, for example, a joint or a ligament or a muscle of the hind leg be sprained by overexertion or by a misstep, a spavin or a curb may develop, or possibly something still worse, and this is a blemish and generally an unsoundness that is likely to be transmitted, if not in a developed form, then in an unmistakable tendency in that direction, which, in turn, will make its appearance in succeeding generations. The horse world, and I might say, the whole animal kingdom under domestication, abounds in examples, seen and unseen, of unsoundness originating in injuries to the parents. 


\section{CHAPTER XXXII.}

\section{HOW THE TROTTING HORSE IS BRED (Continued).}

Trotting speed first supposed to be an accident-Then, that it came from: the runner-William Wheelan's views-Test of powers of enduranceThe term " thoroughbred" much abused-Definition of "thoronghbred" - How trotters may be made "thoroughly bred"-How to study pedi grees-Reward offered for the production of a thoroughbred horse that. was a natural pacer-The trotter more lasting than the runner-The dam of Palo Alto-Arion as a two-year-old-Only three stallions have been able to get trotters from running-bred mares-" Structural incongruity"-The pacer and trotter inseparable-How to save the trot and reduce the ratio of pacers-Development a necessity-Table proving this proposition-The "tin cup" policy a failure-Woodburn at the wrong end of the procession.

BEFore the question of speed in the trotter began to be considered, either from a historical or a philosophical standpoint, or, in other words, a question involving scientific truths, there was a universal concurrence in the idea that speed at the trot was an accident and that there was nothing of inheritance or heredity about it. This idea was greatly strengthened by the performances of such horses as Boston Horse, Rattler, Edwin Forrest, Dutchman, Confidence, Moscow, Pelham, Flora Temple, Tacony, etc., whose origin and blood were wholly unknown, while they were on the turf. Contemporaneous with these there were such splendid performers as Topgallant, Screwdriver, Lady Suffolk, Sally Miller, O'Blennis and many others that were known to be descended from Messenger, a horse that was looked upon by everybody as a "thoroughbred." Hence, the conclusion that the flying trotter was either an accident in breeding, or his speed qualities came from the English running horse. The fact that. such champion trotters, in their day, as Pelham, Highland Maid, etc., had originally been pacers and changed from the lateral to the diagonal gait was sedulously concealed from the public, during their day, and only after they had passed away was this bar- 
sinister in their origin brought to light. Doubtless this same fact might have been devoloped in the origin of Edwin Forrest and others, if action had been taken in time. In that day-say the first half of this century-it is not remarkable that the plebeian origin of some of our most famous early trotters was concealed, for everybody was claiming a thoroughbred ancestry, and the more famons the performer the more certain he was to be furnished with a thoroughbred pedigree.

"Whatever is of value in the trotter must come from the runner, and whatever is of value in the runner must come from the Arab," was the view that was nniversally accepted when I was a boy. And yet there were thonsands of fast trotters and fast pacers in this country long before the first running horse was brought from England, and England itself was abundantly supplied with horses several hundred years before there was a horse in Arabia. These two facts are historical, and the dates make them incontrovertible. Some forty or fifty years ago William Wheelan, a successful trainer and driver of trotting horses in this country, took some trotters over to England, to try his "luck," as others had done before him, in making matches and winning stakes. He was quite successful, and when he came home he was kept busy answering questions about English horses and why they did not have more trotters there. He replied that "there were plenty of horses that could trot as well or better than our American horses, if they were trained; they had plenty of blood and most of them good limbs and feet, with all the substance that was needed." This made William Wheelan an anthority, and his opinion was quoted all over the land; which went to prove that the way to breed the trotter was to get plenty of running blood into his veins. About this time the English running horse Trustee was bred on a famous trotting mare, Fanny Pullen, a daughter of Winthrop Messenger, of Maine, and the produce was the gelding Trustee, the first to trot twenty miles within the hour, or at least the first to make that distance regularly and to rule. This gave a tremendous "boost" to running blood, as everybody except Hiram Woodruff ascribed the result to the great powers of the imported running horse. All subsequent experiences fully demonstrated that Hiram Woodruff, although alone, was right; for although Trustee's blood commingled more kindly with trotting blood than most of the other running horses, he left no trotters but this one. The highest rate of 
speed of which this gelding was capable was about 2:40, and at last, in a race of mile heats with some fifth-rate old pelter, at Cincinnati, Ohio, on a very hot day, he fell exhausted on the track and died from the effects of the heat. But the great fame of being the only horse able to trot twenty miles within the hour did not long remain with this son of imported Trustee. Five others have done the same thing, viz., Captain Magowan, Controller, John Stewart, Mattie Howard, and Lady Fulton, all of whom went faster than 'Trustee, except Lady Fulton.

There have been many crucial tests of the "staying qualities" of running blood in the trotter, as against the trotter without any running blood, in which the rumning blood has uniformly been worsted. The last of these which $I$ now recall was a match for two thousand dollars between Scotland, a half-bred son of imported Bonnie Scotland, and Lizzie M., by Thomas Jefferson, and out of a pacing mare. The race was two-mile heats, best three in five-a very unusual race, and admirably adapted to test the staying powers of the contestants. Scotland was a fast and well-seasoned trotter; while the mare had, probably, a little higher flight of speed she never had been tried at such a distance, and in her breeding she was short, and had not a single drop of running blood in her inheritance. The mare won the first and second heats in 4:56-5:03, and the gelding the third heat in $4: 55 \frac{1}{2}$, the fastest in the race, but he was not ajle to come again, and the last heat was won by the mare in $4: 58 \frac{1}{2}$. This race took place at Philadelphia in 1883, and if, at that time, there still remained any advocates of "more rumning blood in the trotter," they have not since been in evidence, with two or three addle-pated exceptions.

In looking back over the many years I have devoted to the literature of the horse, and especially to the breeding of the trotting horse, I can find no word in the English language that has been so much abused as the word "thoroughbred." A minister wrote a great, pretentious book on the horse in which he maintained that the Morgan horse was a "thoroughbred." A lawyer wrote another pretentious book in which he maintained that the trotting horse Dexter was a "thoroughbred." With these two shining lights in the learned professions writing books on the horse and pronouncing this family or that individual "thoroughbred" without knowing the meaning of the term, we should not deal too severely with uneducated men for following their exam- 
ple. The minister and the lawyer evidently had always heard the term "thoroughbred" applied to what men considered the best, and when they were discussing their favorites which they considered the best, they naturally called them "thoroughbreds" without knowing what they were saying. 'This was more than twenty years ago, and was really the popular conception of the meaning of the term at that time. Not one man in a thousand then knew that the term had any other meaning than the individual superiority of the animal, and that it applied only to the pedigree, or concentration of blood in the veins of the animal, was quite foreign to the popular conception. After the founding of Wallace's Monthly the light began to dawn on this as well as on many other questions, and to-day the true meaning of the term is very generally understood.

To constitute a "thoroughbred" of whatever variety or species the animal must possess a certain number of uncontaminated crosses of his own breed, and this applies to all kinds of domestic animals that are bred for special uses or qualities. There is no law determining the number of these uncontaminated crosses, except the law of usage. The cattle men, I think, were the first to establish a rule on this subject, in this country, and they did it on enlightened and scientific principles. It was found in experience that the danger of atavism, or throwing back to some undesirable ancestor, was diminished in the ratio of the number of pure crosses through which the animal was descended. At two crosses it was found that there were many reversions to some type ontside of the breed; at three crosses there were not so many; at four there were very few, and at five reversions had practically disappeared. While some required another cross the majority drove the stake at the fifth generation, proclaiming thereby that an animal bred through five uncontaminated generations of ancestors was free from the dangers of reversion, and hence was "thoroughly bred." This is the formula and this is the principle, and it applies with equal propriety to the colt, the calf, the pig, the puppy, the chick, or the birdling. In this phrase "thoroughly bred" we have the origin, reason and meaning of the term "thoroughbred." The formula of this rule, if tabulated, would show two parents; next, four grandparents; next eight great-grandparents; next sixteen ancestors and next thirty-two, making in all sixty-two ancestors, all of which must be "thoroughly bred." This rule of breeding is not limited to 
the running horse alone, but applies to all the varieties of our domestic animals; and whenever the point is reached at which the danger of reversion has been overcome the animal is "thoronghly bred," and the term "thoroughbred" applied just as. properly to one kind of domestic animal as to another.

The question here arises as to whether the American Trotting Horse can be so thoroughly bred as to be entitled to be ranked as a thoroughbred trotter? This question is already affirmatively answered when we say the rule "applies to all the varieties of our domestic animals." This is the general fact, but the trotting horse bas a qualification, already determined, that serves as a fixed starting point in giving him rank. The standard as origimally adopted and honestly administered was the mighty engine that wrought the revolution in breeding the trotter. It fixed a certain qualification that had to be complied with before an animal conld be admitted to standard rank, and that qualification was in brief to either perform or produce a performer that could cover a mile in $2: 30$. It excluded no strains of blood, but it admitted the animals only that had fully demonstrated the ability to trot or to produce trotters. The standard is now antiquated, and far behind the speed of the trotters, which is a elear demonstration of the wisdom of its construction and adoption, but to this topic I will refer at another place more at length. With the standard, then, and the unmistakable evidence it furnished of the possession of what we will call "trotting. blood," we have a more definite and satisfactory starting point than can be claimed for any kind or variety of domestic animal. With this demonstrated ability to trot fully established, we can commence to count the generations of standard amimals in a trotting pedigree, and if we find five generations of ancestors, with every animal standard bred, we ean safely and intelligently say the animal is "thoronghly bred" as a trotting horse. With these sixty-two progenitors all legally established as standard animals, who will say this is not a thoroughbred trotting horse? He is not only thoroughbred, but he is more distinctly and completely thoroughbred than any other domestic animal, because the fifth generation of his ancestors, and the fourth and the third and the second and the first have all proved that they are either trotters. or the producers of trotters. No other breed has ever been established on so good a foundation, for they have fairly won their initial honors by what they have done. But this is one 
degree higher and embraces one gencration more than the formula usually prescribed as necessary to constitute the rank of thoroughbred. Five "generations of ancestors" do not include the representative product of those generations. The product would be the sixth generation, which is one more than the generally accepted usage requires. An animal representing five generations of standard trotting blood, complete and without contamination, is "thoroughly bred" and is justly entitled to be classified as a "thoronghbred trotting horse." At this point of breeding it is considered that the danger of reversion is practically eliminated, and hence this distinctive classification. At the time of this writing (1897) there should be, in this country, qaite a number of youngsters fully entitled to rank as thoroughbreds.

All intelligent breeders have long been aiming at this point, not merely for the name "thoroughbred," but for the greater certainty of nniformity in producing what they want-the ability to perform; and the quality of these thoroughbred trotters must be determined by the ability to perform and the quality of each and every one of the ancestors. If each and every one of the four or five generations of ancestors was able to go out and win himself or herself, there could hardly be a doubt that the colt could do the same, but some of those ancestors may be in the standard merely from reflected honors, which are good, but not a crucial test of superiority in the individual. There is nothing like the animal that "has gone out and done it" himself, over and over again, and when we sit down to tine study and comparison of pedigrees in the thoronghbred rank we find great differences in the quality of the lines of descent. The reflected honors of an uncle or an aunt are of much less value than the honor of a direct ancestor. While the blood of all the ancestors is tested blood, the individuals may not all have been tested, and hence are less certain in transmitting the true trotting instinct. While the standard has done wonders in teaching the true art of breeding, like all other human devices it has its imperfections. Jast like the runner, the trotter may be strictly thoroughbred, and yet in taking after some of the imperfections of one or more of his ancestors, he may be of but little value as a performer. This truth has been verified in a thousand experiences in the runner, and it is just as liable to be verified in the trotter. Hence the supreme importance of looking well to the qualities and capacities of every animal in the inheritance. 
At the very inception of the idea that the trotting horse could be bred and developed into a breed, an opinion prevailed everywhere that it could not be done. The theory that speed at the trot came from speed at the gallop was universally held and advocated. In $1868 \mathrm{I}$ made a tour among the breeders and horsemen of Tennessee and Kentucky, for the purpose of gathering information about both runners and trotters. 'Those States were then beginning to pull themselves together after the war. At General Harding's, anıng others, I was shown a large, heavyboned colt, and the General remarkerl that if he did not make a race horse he would make a capital stallion to take to the West and breed on trotting mares. At Balie Peyton's I was shown a great big, coarse horse that had run some races and won in very slow time, and that was unsound at many points. He was over sixteen hands high, and had very bad limbs. Mr. Peyton remarked that "he was too big for a race horse, but he would do well in the West as a trotting sire." This was the remark everywhere as applied to big colts that couldn't run. About the same time Mr. Joseph Cairn Simpson, then in the employ of a sporting paper in New York, as an editorial writer, expressed his sorrow that Hambletonian did not have a thoroughbred cross, close up, and his opinion that such a cross would have made him a much greater sire. Thus, East and West, North and South, the opinion prevailed everywhere that the way to breed t! te trotter was to go to the runner. 'This universal belief, wholly withont foundation, soon generated the ery, "more running blood in the trotter," and the instincts of all the rogues in the country were quickened to make their pedigrees conform to the popular belief of what was best. This resulted in a period of fictitious claims, for when a man had a. colt out of a mare of unknown breeding the rule was to say, "dam thoronghbred," and if the owner was nnusually conscientions and knew the breeding for one or two crosses, he wonld give them correctly, but seldom failed to tack on two or three thoroughbred crosses that were wholly fictitious. After all my years of experience with the pedigrees of horses, it is my deliberate and candid opinion that no word in the English language has been so much abused as the word "thoroughbred." It has been the medium of more deceptions and downright falsehoods than any other word in the vocabulary. For many years it was the word above all other words that the unscrupulous jockey employed to defrand his inexperienced victim. And if there had been no strong hand 
to take the improper and dishonest use of the word by the throat there would be no breed of trotters, and the whole business of breeding and developing the trotting horse would be to-day just where it was thirty years ago. The old, threadbare stock argument was in everybody's mouth, to the effect that "Messenger was an English thoroughbred and he founded a family of trotters, hence any other English thoroughbred could do the same thing under the same circumstances." When this ancient formula was submitted to the test it was found to be Tiatally unsound at both ends, as has been shown in another chapter. Messenger was found to be far short of being thoronghbred in his inheritance; forty other English thoroughbreds had been in competition with him and bred upon the same mares, yet no other English thoronghbred, in the experiences of a hundred and fifty years, ever founded a family of trotters. The two ablest advocates of "more running blood in the trotter" that this conntry has produced, Mr. Charles J. Foster and Mr. Joseph Cairn Simpson, when challenged to produce an English thoroughbred horse that had founded a family of trotters, conceded the whole contention by naming Bishop's Hambletonian and Mambrino, both sons of Messenger and the principal channels throngh which Messenger had founded his family of trotters. This knocked all the noise out of the famous formula, and instead of the braying of an ass we have heard nothing since on this subject but an occasional and very feeble squeak of a mouse.

In the earlier portion of the period when the American Trotter was beginning to assume the shape and character of a breed, the term "thoroughbred," meaning English racing blood, was adhered to with astonishing tenacity, as an indispensable element in the breeding of the trotter. A few men of clear and independent minds commenced to study the question in the light of experiences, and they were not long in reaching the truth; but, as a rule, the less a man knew of the question, whether a breeder or a writer, the more blatant and vociferous he was in maintaining that all trotters were dependent for their speed on the blood of the "thoroughbred English race horse." When Mand S. made her four-year-old record and astonished the world, the acclamations of this class went up in tremendous volume pointing to the Boston blood of her grandam as the element that did it. Now, it never has been shown, and it never can be shown, that there was a single drop of Boston's blood in her veins. Besides all 
this, Boston was not a thoroughbred horse, for neither his sire nor his grandam was thoronghbred. A curious phase of the interest attached to the mere word "thoroughbred" was brought out by a Catholic priest, in New Jersey, in a very cranky and ill-natured letter addressed to the editor of Wallace's Monthly protesting against the frequent use of the term "running-bred" instead of "thoronghbred." Priests are generally educated men, but this poor man struck out into a field where he was entirely ignorant. A horse with two or three immediate and direct running crosses may be properly and truthfully called "running bred," becanse that blood predominates in his veins, but to be justly and truthfully called "thoroughly bred" he must have at least five direct and distinct crosses, and each and every one of them pure and without any contamination from any other blood. As an illustration of what results from this definition of the word "thoroughbred," we may take the very cream of our old American racing families and not one in fifty is "thoronghly bred." American Eclipse was far short of being thoronghbred, even if we admit that Messenger was thoronghbred. Timoleon, the greatest son of Sir Archy, had an impossible and untruthful pedigree on the side of his dam. His great son Boston was short and deficient on both sides, and with these taints bow could be get the great blind horse Lexington and make him a thoroughbred? 'These horses were distinctively "running bred," but not technically "thoronghbred." It is not to be presumed the priest was angry because I preferred not to use a word that conveyed an untruth and to use one that told the exact truth, for he was not qualified to judge which was true and which was not true, but like hundreds of others he feared the value of his property might be affected by the refusal to apply the term "thoronglbred" to some supposable cross in some of his pedigrees.

"Uore rumning blood in the trotter" was a "fad" that has been completely extinguished by all the experiences of later years. It was a freak that never had any foundation either in nature or in reason. No animal can transmit to his posterity qualities and capacities which he has not inherited, or which he does not possess by acquirement. This is a rule which seems to be perfectly plain to the comprehension of everybory, and in observation and experience it proves itself true every day of the year. To breed a horse that can go fast at the trotting or pacing gait we must go to the horse and the blood that has gone fast at one or 
the other of these gaits. It seems like a needless work to expend any time or space on what is self-evident in all human experiences. A few years ago I offered a money reward, of sufficient amount to justify some labor in a search, to any one who wonld report to me any thoroughbred running horse, with the proofs, that had ever made a trotting record of a mile in three minutes, and there was no response. Some years later I renewed the offer, donbling the amount of the former offer, and still there came no response. I regret now that I did not make the offer for a mile in four minutes instead of three, for I very much doubt whether there ever was a thoroughbred horse able to trot a mile in four minutes. What is the nse, then, of giving further attention to the consideration of the value of thoroughbred rumning blood in the trotter?

But after conceding that the instinct to stick to the trot and the step of the trotter must come from the trotter, the advocates of "more running blood in the trotter" plant all their heavy guns on the proposition that running blood is needed to give the trotter more courage, endurance, and beauty of form. In all the past years we have had so many grand panegyrics on the will power and undying courage of the "courser of the desert" that they have become threadbare and have an "ancient and fish-like smell," and we would prefer to exchange them for something more recent and practical. When we go to a race meeting and see so many contests at varions distances less than a mile, a few at something over a mile, and all these merely single dashes, we naturally and justly conclnde that the distance of ground to be covered in each contest is adjusted to the courage and stamina of the racers. I cannot conceive of any fairer criterion by which to determine the measure of gameness and pluck of running horses than simply to consider the distance chosen, and that for a single dash. Trainers and owners know just where each horse will quit, if hard pressed, and they will not enter him in any distance beyond the point where they know his courage will fail. With the data of distances for these single dashes already fixed for the accommodation of horses with different degrees of staying qualities, and after making a liberal allowance for age and lack of condition, we seem to have a solid foundation for a safe conclusion that the crucial test of the speed of the average race horse fails him before he reaches the first mile-post.

When the trotter starts ont for his summer's campaign he has no 
choice as to the length of his races, and he is not looking about for single dashes of four, five, six or seven furlongs, but enters the fiehl boldly and throws down the glove to all the best strains of trotting and pacing blood. Every race will be mile heats, best two in thrce or three in five, and it often requires six, seven or eight heats before the victor is declared. This experience is repeated, week after week, during the whole season. Such a weekly experience as this, continued through twenty consecutive weeks, would probably destroy the best and stoutest running horse now living. This is the test to which the trotter is subjected, and no man can say it lacks in severity in determining his qualities as a race horse, in his stamina, his courage and his gameness. In touching this point I will here take the liberty of entering my protest against what I consider the unnecessary severity of this test. We want all these tests, and from the standpoint of the breeder we cannot progress without them, but we want them to stop short of injury to the animal. When a contest is drawn out to six, eight or ten heats, it not only becomes cruel as a sport, but it is liable to inflict irreparable injury to the soundness of the animal. Unsoundness, either external or internal, is liable to result from all stich abuses. This is a dominant fact, and while we may not be able to see the injury with the eye, we are likely to see the evil results in the progeny. Animals of the kind most likely to be subjected to this over-severity of test are the hope of the future as producers, and by all means wise and possible we should seek to preserve them in their pristine sonndness and vigor. As breeders we cannot afiord to let them go without development and test, neither can we afford to impair or destroy their producing qualities, in the test. This can be done only by shortening the race; not the distance of gronnd, but the number of heats that can be trotted. With an inflexible rule that not more than five heats should be trotted in any race, and that at the conclusion of the fifth heat the money should be divided according to the places of the contestants, I would not be particular as to whether the race was for the best two in three, or the best three in five. The invariable results have been that in longdrawn-out contests of many heats there have been bargains and combinations for or against certain horses, and all managed by and in the interest of the so-called "speculators." If this were done the combinations of the gamblers would be checkmated, the eruelty of the sport would be eliminated, and our best horses 
would eome through the campaigns ready and fit to propagate their species.

In breeding for a particular purpose or qualification all experience goes to show that the elements entering into the new ereature must be carefully selected as possessing the quality that we seek to propagate. Nobody would think of breeding a running mare to a trotting horse if he was seeking to breed a running colt. No thoughtful and intelligent man would think of breeding a running horse upon a trotting mare if he were seeking to breed a trotting colt. The runner to the runner and the trotter to the trotter has been demonstrated ten thousand times as the right way. The cross-bred or half-and-half-bred animal may be something of a trotter or something of a runner, doing neither well; and this uncertainty never can become a certainty as to which it may be till you try him. 'The evil of half-and-half breeding does not cease with the life of the animal, for the division in his own inheritance will manifest itself in his progeny for generations, or till it is bred out. But, strange as it may seem, there are still a few old men living who, from pride of opinion advanced in their younger days, still maintain that trotting speed must come from the "thoroughbred" and "point with pride" to the great horse Palo Alto as the complete illustration of their belief. In relation to the breeding of Palo Alto I will here tell a little story, premising that I neither accept it as true nor reject it as false, for I know nothing about it. The late $\mathrm{Mr}$. William $\mathrm{H}$. Wilson, of Cynthiana, Kentueky, was in many respects a remarkable man. He was full of energy and push, and his brain seemed to teem with formidable ideas, chiefly relating to his prospects, and the management of his own business. He was intelligent in horse matters, and very well informed on loeal horse history. He did a great deal of work for me in the way of straightening out tangled skeins, and in tracing obseure pedigrees. In this way I came to know Mr. Wilson very well, and as I never found him wrong on these questions I came to place great confidence in his word and his judgment in all pedigree matters that he had investigated. Some time about 1889, probably, he asked me to investigate the pedigree of Dame IVinnie, the dam of Palo Alto, for, he said, he had every reason to believe she was not by Planet, but by a trotting-bred horse that he named, but that name has escaped me. I replied that I had not time then, but I would think about it. Some months afterward he was again in my 
office and he again urged the investigation. My reply was that there were some very upright and honest men in Kentucky as well as some great rogues, and if I were to undertake to investigate this pedigree the rogues could get forty men, if so many were necessary, for a bottle of whisky or a half-dollar a head, who could remember jurst what it was necessary to remember, and forget just what it was necessary to forget in order to prove that the mare was by Planet. I recalled my experience with suborned evidence in the past, and knew just what I might expect in the future, and so I had concluded to make no more investigations in certain portions of Kentucky until I had an opportmnity to cross-examine the witnesses. Dame Winnie was a plain, common-looking mare, with nothing about her to indicate high breeding, and if we lay aside Mr. Wilson's story and accept the pedigree as usually given she was strongly running bred, but at several points in her pedigree she fails of being thoroughbred. The internal evidence as to the breeding of this mare, brought to light in the performance of her produce, suggests very strongly the probability that she possessed some trotting blood, from some source not far removed. She has five representatives in the $2: 30$ list, and this of itself strongly supports Mr. Wilson's untold story, that I would not listen to. In passing I will say I would be glad to listen to it now; for this solid foundation of experience is so stoutly corroborative of what he suggested as to justify an effort to reach the exact truth. When it was known in Kentucky that Senator Stanford had sent his representative down there to gather up a lot of "thoroughbred" mares from which to breed trotters in.California, every dealer in the State had just what he wanted. He was looking for pedigrees, and it was a very easy matter to shape up the pedigrees just to suit him.

Whatever may have been the breeding of his dam, Palo Alto was a great horse, but he came to his speed slowly, and this would seem to indicate that if his dam had any trotting inheritance it was weak in the direction of attaining a high rate of speed. From the day he was weaned till the day he died he was Senator Stanford's idol, and with this horse as an object lesson he was going to teach the world how to breed the trotter. At two years old he was driven a mile privately in $2: 22 \frac{3}{4}$, and his owner, feeling that his dream was realized in breeding the greatest horse the world had produced, named him "Palo Alto," as. 
he deemed him worthy of being at the head of the greatest breeding establishment of the world. He was in the hands of the most skillful and careful of all trainers, and the training went on without respite, year after year. When four years old he went through the Eastern circuits, winning the larger share of his purses, and making a record of $2: 20 \frac{1}{4}$. Now let us consider for a moment whether the Senator did not make a great mistake and select the wrong horse as the typical representative of his great establishment. In 1888 he bred a colt by Electioneer out of Lula Wilkes, grandam the famous trotting mare Lula, 2:15, by Norman, etc., intensely trotting bred, and when he was three years old he made a record of $2: 16$. This is better than $2: 20 \frac{1}{4}$ as a four-year-old, for this fellow had not to take one-half the training that Palo Alto was subjected to. The next year he bred another colt by Electioneer called Arion, out of a mare by Nutwood; she

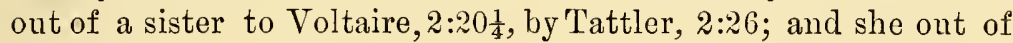
the famous trotting brood mare Young Portia, by Mambrino Chief; and the next dam Portia by the pacer Roebuck. This colt came out and trotted a mile in 2:103 as a two-year-old. The four-year-old had a great "boom" and was considered by many as the phenomenal colt of his year, but when we place his record of $2: 20 \frac{1}{4}$ beside the $2: 16$ of the three-year-old, it looks very sickly, and when we compare it with the $2: 10 \frac{3}{4}$ of the twoyear-old it is shaded into a deathly pallor. The four-year-old is largely the result of skill and art; the two-year-old is the result of nature. Arion is the best horse, by the record, that the world has ever produced, and the Senator was mistaken in his dream. We must judge of the value of a fast performance by the degree of naturalness which it represents and the measure of its freedom from the arts of the trainer. The "born trotter" is what we want, and at two years old Arion, or any other colt, was at the right age to determine whether a fast performance was the result of nature or of art.

It is a fact well known to everybody that some trotting-bred stallions have shown greater power in controlling the action of their progeny than others that seemed to be equally well bred. If out of the great mass of stallions, past and present, that have been more or less successful as trotting progenitors, we pick out thirty of the very best, as shown by their progeny, it will probably surprise many of my readers to learn that only three of that number have been able to triumph in the supreme test of getting 
trotters out of running-bred mares. Of these three Electioneer stands first, Almont second, and Pilot Jr. third. After making all allowance for the anxiety of certain Californians and certain Kentuckians to prove the need of "more rumning blood in the trotter," and their manifest willingness to help along with pedigrees in that direction, I am fully convinced that these three horses, in some cases, were able to meet and overcome the hostile elements of the galloper. Not in every case, certainly, nor in a majority of cases. When Senator Stanford was showing me the step of Palo Alto, on his own track, as a three-year-old, I remarked, "Well, Electioneer certainly triumphed in that case," and the Senator replied, "Yes, but none of my other stallions can do it, and there are some thoroughbred mares upon which Electioneer can't do it." When approached by others on this subject in the riper years of his experience, he was in the habit of replying: "There are thoronghbreds and thoroughbreds; some of them will produce trotters to Electioneer, and some will not." He accepted everything as thoroughbred that had been bought by his agents as thoroughbred, whether in Kentucky or California, and he elaimed to be able to pick out those that would produce trotters by their appearance. When pressed to give the characteristics by which he was able to make his selections, he spoke of the shape of the animal, in a general way, and especially by the head and the expression of countenance. In selecting his mares to put in the trotting stud by their "appearance" he would naturally select such as had the "appearance" of trotters, and as he personally knew no more about their pedigrees or the inheritance of the animals than the mares knew themselves, he was very liable to be deceived in the breeding of the animals as he selected them. In selecting a mare by "appearance" as indicating that she might throw trotters to Electioneer, there is a strong suggestion that this "appearance" may have been a legitimate "inheritance" songht to be covered up by that sadly abused term "thoronghbred." Whether this suggestion ever entered the Senator's mind I have no means of determining. But whether some of the mares called "thoroughbred" had really a mixed inheritance or not, the fact remains that the three horses named above did succeed in getting some trotters from mares that were strongly running bred. 'Then the question arises: Why did these three horses succeed where all others failed? We are not able to give an answer to this question that is complete and 
irrefutable, for there is so much in the laws of generation that we do not and cannot know. Take two brothers, for example, and one is a great success and the other a great, failure, and often the failure is the better formed and the better looking horse of the two. All that science teaches us here is that one took after some ancestor, near or remote, that was good, and the other after some ancestor that was not good. Electioneer, Almont and Pilot Jr. all had short pedigrees composed exclusively of trotting and pacing blood, except possibly a few drops of running blood that may have trickled down from the runner through trotting or pacing channels. Their instincts to stick to the trot had been encouraged and more or less completely developed. Electioneer and Almont both had pacing blood some distance away, and Pilot Jr., so far as we know, had nothing but pacing blood, and yet he never paced a step in his life. This embraces all we know of the three horses that proved themselves the most prepotent in overcoming all antagonisms of race or blood. Others equally great, no doubt, have come up since their day, but as breeding is now better understood and as the laws of nature are now more carefully followed, tests of this kind are not often made.

After all the "wiring in and wiring out" of the tortuous advocates of "more rumning blood in the trotter" had found that their efforts had borne no fruit and that all intelligent breeders had ieft their theories away behind, a remarkably brilliant genius struck out a new line of thought and argument, which unfortunately died "a bornin" " just as the attention of all intelligent breeders was turning away from "more running blood in the trotter" as a senseless "fad," and looking to the pacer as a possible source of increased trotting speed. In formulating and exploiting his idea, our genius seems to have reasoned afier this manner: "The crisis is here, the breeders are all turning away from the thoroughbred as a source of trotting speed and considering the pacer, and now if I can convince them that the pacer is at least half-thoroughbred I will beat the standard and win the day." Here we have the motive and the subject, and now we are ready for the manipulation. In due time the article appeared, and I must do the writer the justice of saying I never have been fully satisfied that he believed a single word of it himself. $\mathrm{He}$ starts out to show that the pace is not the result of hereditary transmission but the result of "structural incongruity." $\mathrm{He}$ 
declared that this "structural incongruity" is the result of breeding the thoroughbred horse on the slab-sided, ill-shapen mares of the West and Southwest. From the inheritance, part of the animal is structurally formed to run and the other part structurally formed to trot, and between the two a compromise is marie on the pace. In this "structural incongruity," between the two parts the pacing gait originated, and hence whatever speed the pacer may possess comes from the "thoroughbred;" and, therefore, of necessity, whatever speed the trotter gets from the pacer comes from the "thoronghbred." There are many humbugs in the literature of the horse, but this is the craziest humbug I have ever met with. What a pity he left his work unfinished, and failed to tell us which end of the horse was running bred and which end trotting bred, so that we might locate the "incongruity" and eut it out! But to Iook at this "structural incongruity" seriously, it lacks but little of a scandal on the intelligence and honesty of American writers on the horse. Here is a gentleman of reputed intelligence, who wields a facile pen and has been writing on breeding subjects for about thirty years, and much of his work was well done; and now at the close of the nineteenth century he undertakes to tell us how the pacer originated in this country. The veriest tyro in horse history knows that pacers abounded in England in the twelfth century, and indeed long before that. Every colony in this country was full of pacers a hundred years before the first thoroughbred crossed the Atlantic. But wild and absurd theories can safely be left to the public judgment.

It required several years of labor and iteration to convince the breeding public that the trot and the pace were simply two forms of one and the same gait. When first advanced it was received by the more intelligent breeders as an abstraction that had nothing practical in it, while those of less ability to think for themselves only laughed at it. Since then the inevitable processes of experience have demonstrated its truth, and the question of today is how to separate these two forms of the same gait and to breed either form, as we may desire, as a distinct and certainly transmissible gait. With a few it will still remain a matter of indifference whether the colt comes a pacer or a trotter, but witl: the great mass of breeders the question of profit in breeding the harness horse must be considered. Everybody knows that in the market for road horses the clean-stepping trotter is worth more 
than the smooth-gliding pacer. 'This is not a question to be determined by fashion, but a fact of universal experience that the trotting action is better suited to harness and the pacing action better suited to the saddle. Fashions may change, but these two facts are unchangeable, for they are founded in the nature and mechanism of the two forms of action. The difficnlties in the way of separating the diagonal from the lateral form of the trot are very great, and there is no use or wisdom in attempting to blink this fact. Speed at both forms of the gait comes from the same sonrce, the same blood, the same inheritance; and source, blood and inheritance, in a breeding sense, are the hardest things in nature to overcome. So far as experience teaches there is but one method or treatment that has ever been successfnl in wiping out the pacer. In the first half of the seventeenth century England was full of pacers, and about a hundred years later she did not have one. The trouble about this remedy is that the trotters were wiped out also, and to-day England has neither a pacer nor a trotter. When she now wants a trotter she has to send to this country and get some of the blood of the little despised pacer that was shipped from her own shores in the early colonial days. 'The blood of the Saracenic horse has not lost its potency as a pacing expunger, as shown by modern experiments, and all our breeders have to do is to use it in copious effusions, and we will soon be rid of the pacer, and the trotter along with him. The pacer and the trotter are never found separate from each other, so far as my information goes. In Russia they breed trotters methodically, and they have a full supply of very fast pacers that are used as shaft horses in their droskies. As in the past, so in the future, we never need expect to see the two forms of the gait entirely separated.

Our people, however, are not ready, and as long as the horse is used for business and pleasure never will be ready to dispense with the trotter; and even though some considerable number might deplore the presence and prominence of the pacer, every one of them would welcome him with great joy if they knew he was a necessary adjunct of the trotter. When we consider the problem of reducing the ratio of pacers and increasing the ratio of trotters in what we produce, there is so much that is old and still imperfectly known in what we incorrectly call our "earlier" period of trotting that we find nothing encouraging in the study. The origin of the principal trotters of the early part of 
this century, except the direct descendants of Messenger, was so sedulously concealed that it was entirely natural for so many men to conclude that the trotter was not bred, but made by the trainer. When Flora Temple was the queen nobody knew that her speed came from a pacer. Old Kentucky Hunter was a very fast pacer. When Pelham was king nobody knew he had been a pacer. When Highland Maid eclipsed all records nobody knew she was pacing bred and had been a pacer herself. When Vermont Black Hawk was the most popular sire of his day nobody knew that his dam was "Old Narragansett," a pacer. When Ethan Allen stood at the head of all young trotters the old grey mare, his dam, was, and still remains, entirely unknown, but everybody believes that a large share of his speed came from that mare. Andrew Jackson, the head of the great Clay family, was out of a fast pacing mare. And thus we might extend the list indefinitely. But away back, more than a hundred years before the period of which we are here speaking, pacing and trotting races had become so numerous that they had to be suppressed by legislative enactment. More than two hundred years ago there were pacing races and trotting races in this country, and then as now it seems evident that the form of the action of the prospective colt, whether lateral or diagonal, was nncertain until it appeared. This condition of uncertainty about the secrets of the womb has existed for centuries, as it exists to-day; and if we were furnished a complete list of all the great trotters of the last two decades that were born pacers we would hardly be willing to believe our own senses. The following short list of such animals as have gone fast at both forms of the gait will serve to illustrate the oneness of the two forms:

Pacing. Troting.

Jay-Eye-See, bl. g. by Dictator................. 2:06 $\quad 2: 10$

Direct, bl. h. by Director..................... $2: 05 \frac{1}{4} \quad 2: 18^{\frac{1}{4}}$

Monbars, b. h. by Eagle Bird.................. 2:16 $\quad 2: 11 \frac{8}{4}$

George St. Clair, b. h. by Betterton............... 2:101 $2: 1 \frac{1}{4}^{\frac{1}{4}}$

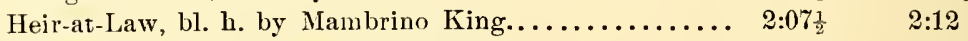

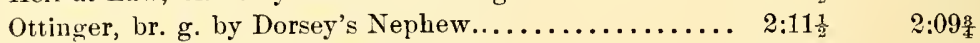

Bert Oliver, b. h. by Ashland Wilkes............. 2:08䍃 $\quad 2: 19 \frac{1}{4}$

Vassar, gr. h. by Vatican .................. $2: 07 \quad 2: 21 \frac{8}{4}$

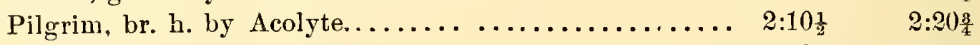

San Pedro, bl. g. by Del Sur.................. 2:10 $\frac{8}{4} \quad 2: 14 \frac{1}{2}$

Wardwell, b. g. by Almont Jr.................. 2:16 $\quad 2: 14 \frac{1}{4}$

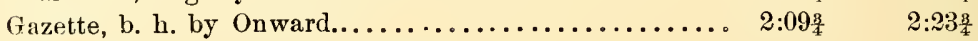

Welcome, b. h. by Arthur Wilkes.............. $2: 10 \frac{1}{2} \quad 2: 2 \tau_{\frac{1}{4}}$ 
Pacing. Trotting.

Story's Clay, b. h. by Everett Clay............... 2:14是 $\quad 2: 18 \frac{1}{4}$

Captain Crouch, ch. h. by General Smith. ......... 2:13 2:25

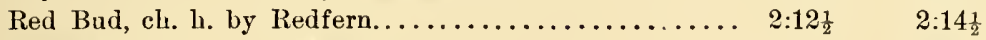

Cleveland S., b. h. by Montgomery.............. 2:10 2:24

Connor, bl. h. by C. F. Clay.................. 2:14 $2: 13 \frac{1}{4}$

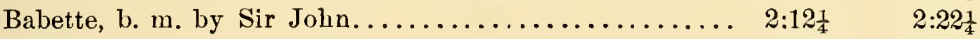

This exhibit might be further extended, but the foregoing will suffice for the purpose intended. The only remark that seems needed by way of explanation is that all the animals named, except. two (San Pedro and Wardwell), made their records first as trotters.

In surveying the whole situation there is but little encouragement in attempting to solve the problem of how to reduce the ratio of the pacers and at the same time avoid the reduction of the speed of the trotters. The central point in the problem is the development of speed; and so long as the pacer comes to his speed so much quicker and easier than the trotter, and so long as the best pacer is a little faster, as he has always been, than the best trotter, there is no probability that his speed will not be developed. All efforts at repression or exclusion of the pacer from contesting for prizes at public meetings would be futile and, in a sense, unjust. Moreover, this would not be in the province of the breeder and he must work out his plans within the boundaries of his own domain. The laws of heredity apply to either of the two forms of the lrot-the lateral and the diagonal-just as certainly as they apply to the two forms united. This is the breeder's opportunity, and if he grasps it he will make progress slowly but surely. In his breeding selections he must lay it down as an inviolable rule that all pacers, especially pacers with their speed developed, must be excluded, no difference how strongly they may be bred in the best trotting lines. If a horse produces some fillies that, like Maud S., Sunol and hundreds of others, are halfway, or more than halfway, inclined to pace, he must rigoronsly keep them at the trot and nothing but the trot, unless he sells them. He must study intelligently the pedigrees and produce of the generations away back, and make such seleetions as are most likely to promote his object and least likely to violate the rule laid down. Of all the varieties of the horse on the face of the globe the American trotter is the typical harness horse. Our civilization no longer requires the saddle to climb through mountain passes, and to follow seldom-trodden paths 
through the wilderness. For either business or pleasure we travel on wheels, and we want the bold, bounding trotter to propel us. The pacer is the early and only saddle horse in the world, but he is not a harness horse. Aside from the few that will be used as gambling machines, his value will recede while that of the trotter will always advance. In the hands of a man of intelligent and fixed purpose it is certainly possible to breed a family of trotters in which the appearance of a pacer from birth would be of rare occurrence, and the longer such careful selections and purposes are continued the more rare will be the recurrence of the lateral habit of action.

That the development of the speed of the parents was very important, if not necessary to the increased speed of the progeny, was a proposition that was long disputed. Generally. as on other questions, each man argued it from the standpoint of his own stable, but not a few men of clear minds took that side of the question without regard to the potency of the law of heredity. In the early stages of the discussion of this question it was a difficult one to handle effectively. At that time very few sires, and still a less proportion of dams, had ever been regularly developed as trotters, hence the field for generalization was nurrow and many of the instances quoted were disputed. For a time the battle raged quite fiercely around Hambletonian, as he was the most prominent stallion of that period, and if a man was trying to build up another family he would rave till he got black in the face against "Bill Rysdyk's bull." It is but just to say that the man who led in all this froth and fury against Hambletonian was engaged in breeding what he called "Clay Arabs," and after dodging his creditors for a number of years his last hoof was sold from him by the sheriff. On the other hand, Hambletonian made his master a rich man, and he left a large estate. Hambletonian was only partially developed, but sufficient to show he was a fast colt for his period. (For full particulars see his history in another chapter.) Abdallah was a very great sire of speed and he was not a developed trotter, but his dam, old Amazonia, was quite fully developed. She won many races and was the fastest trotter of her day. Whether her speed came from a fast pacing ancestry, or whether it came from the reputed "son of Messenger," as stated when she was bought near Philadelphia, never can be determined. The "son of Messenger" story seemed to be straight, but her form was coarse and plain, 
and her legs were so hairy that many who knew her best condemned the story; hence, all we can say about her is simply that she was a fast developed trotter. Andrew Jackson had but little trotting inheritance from his sire, and his dam was a fast pacing mare of unknown breeding, but his speed was very fully developed as a trotter, and he became the progenitor of the Clay and the Long Island Black Hawk families, that became famous in trotting history. While this reasoning was true in experience and sound under the canons of science, it was not strong and convincing, for the one and only reason that the basis of the generalization was too narrow and lacked in a sufficient number of cases to convince the understanding of the skeptical. We have had to wait for the accumulation of the experiences of a. number of years, and now we have the evidence that is so complete as to be really startling and which no man can gainsay. The following little table embraces all the breeding farms in this country that have produced three or more trotters with records. of $2: 15$ or better, and here the rate of speed is certainly high enongh and the foundation is certainly broad enough to furnish just and safe conclusions:

Leland Stanford.............18

Fashion Stud Farm ........... 13

William Corbitt............. 9

Wm. H. Wilson............ 8

C. J. Hamlin.............. 7

Glenview Farm............. 6

Timothy Anglin............. 5

Henry C. Jewett............. 4

Wm. C. France............. 4

Woodburn Farm............. 4
Robert G. Stoner............. 4

R. S. Veech................. 3

C. W. Williams ............. 3

Highland Farm (Lee, Mass.)..... 3

Fairlawn Farm............. 3

E. W. Ayers ................ 3

Charles Backman............. 3

George H. Ely............... 3

Mrs. S. L. Stout............. 3

Monroe Salisbury............ 8

Quite a number of other breeders have produced one or two that have made records in $2: 15$ or better, but I think the above list embraces all that have bred three or more with trotting records of 2:15 or better. The table will be a surprise to everybody, but I doubt whether it will be a greater surprise to anybody than it is to myself. At the head of the list stands the late Senator Stanford's great establishment with eighteen to its credit, but this is not a fair basis of comparison with any other establishment in the whole country, for he had about three hundred mares in the trotting department of his breeding studabout six times as large as the average of the larger studs of tho: 
country. The average number of horses in training, the year round, was about eighty, exclusive of yearlings and the kinclergarten. In attempting to institute a comparison, therefore, with the average breeders of the country, we might as well compare the daily receipts of John Wanamaker's store with those of the little green-grocer on the corner. But at the head of this establishment stood the great Electioneer with his strong breeding and trotting speed well developed, and indeed, in many respects the greatest horse of his generation. He was the sire of eleven in the list, and the remainder were either by his sons or out of lis danghters.

Mr. Henry N. Smith, of New York, a prominent Wall Street man, became greatly interested in trotting sport, and in 1868 he organized a trotting stable of his own, which contained some romarkable animals, as will be seen below. His stable was very successful, and this success naturally increased his attachment to the trotting interests. He then determined to establish a breeding farm, and about the year 1869 he purchased the famons old Fashion Course adjoining Trenton, New Jersey, enrbracing one hundred and forty-five acres of land and provided with an excellent mile track and much stabling that had been constructed years before for running horses. This property he very appropriately named the "Fashion Stud Farm," and on it he placed the grandest assemblage of developed trotters, for breeding purposes only, that had ever been brought together in this or any other country. His stallions were Jay Gonld, 2:20 $\frac{1}{2}$, Tattler, 2:26, and Gen. Knox, 2:31 $\frac{1}{2}$. This was Knox's fastest record, but it was known he had trotted miles, in races, faster than this. The speed of all three horses was developed, and it is evident at a glance that there was only one first-class horse among them. But the great strength of the establishment was in the grand galaxy of mares, some of which I will enumerate, namely, Gold-

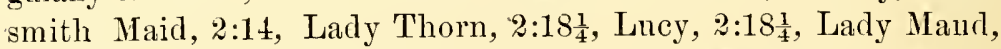

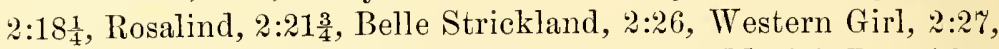
Idol, 2:27, Big Mary, 2:28 $\frac{1}{2}$, Daisy Burns, 2:28, Music's Dam (that had prodnced $2: 21 \frac{1}{2}$ speed), besides others with slower records or known to have had their speed developed as fast road mares, making in all abont thirty mares on the farm, and Mr. Smith claimed that every one of them had shown more or less speed as trotters.

Mr. Smith neither knew nor cared much about pedigrees, in a 
general sense, and when you came to talk to him about "nicks" and "trotting pitch" and all that kind of tomfoolery, his mind simply recurred to the old adage nttered generations ago: "Trot fathér, trot mother, trot colt." His whole philosophy was wrapped up in the one central truth that the horse that could go out and trot fast, when bred on the mare that cculd go out and trot fast, would produce a colt that would go ont and trot fast. This was sufficient for him or indeed for anybody else, for it contans and expresses the whole substance of the laws of heredity. Mr. Smith's great mares acquired in their training and development new characters and new capacities which they never would have possessed hacl it not been for the care and skill expended in their training. Here we touch the very marrow of a question around which the scientists of to-day are warring. Darwin tanght that such acquisitions were transmissible, of the truth of which I have no doubt, but a post-Darwinian school has arisen which controverts this position, and claims that it weakens and destroys the whole evolution theory of creation. But it matters not about the hypothesis of evolution concerning things we know, for it is simply an attempt to show how all things might have been created without a Creator. I have read a great deal about evolution and the transmissibility of acquired characters, but in all I have read I never have met with a lessoin so broad and so strong as that furnished by Henry N. Smith's great mares, proving that acquired characters are transmitted.

In instituting a comparison between the high-class products of the Palo Alto and the Fashion Stud Farms, it seems to be necessary to place the premier stallions of the two side and side. They were half-brothers on the side of the sire, but Electioneer had the greatest speed-producing dam of her generation. She was a fast natural trotter herself, and was out of a fast and fully developed trotter. Jay Gould was out of a good road mare by American Star, but nobody has ever said she had any speed, and she was out of a nondescript mare that we know nothing about. Gould's dam never produced any other trotter with a reputable rate of speed, so far as I have been able to learn. Electioneer was trained and developed by Mr. Backman, but he never was in a race, and consequently he has no official record. After he was taken to Palo Alto he was given quite regular work, and it is beyond all doubt that when in stud condition he could show a quarter in a little better than a $2: 20$ gait. The difference in 
the rate of speed, therefore, as between the two horses was not very great, but whaterer it was must go to the credit of Jay Gould. But the offspring of Electioneer had a very great advantage over those of Jay Gould in the methodical and skillful development of their speed. In his maternal inheritance as a trotter, as already indicated, Electioneer had a marked superiority, and on an equally high class of developed mares he would have far ontstripped his rival. Now, with this attempt at a clean-cut description of the two horses, we are ready to consider the question in its arithmetical elements, and it will be found a plain question of "simple proportion" which anybody can solve in a minute, as follows: "If the Fashion Stud Farm from thirty mares produced thirteen trotters with public records of $2: 15$ or better, how many of equal capacity should the Palo Alto Farm have produced from three hundred mares?" The answer is one hundred and thirty, but the facts, up to the close of 1896, furnish us with the beggarly number of eighteen.

The grand assemblage of so many great trotters at the Fashion Stud Farm, and all ior the purpose of breeding, was the subject. of inuch comment among breeders from one end of the land to the other, and not a few pronounced it all wrong and that it would be succeeded by failure. Mr. Smith lacked some of the elements that go toward making a man popular, and hence, in many cases, there was not much sympathy between him and bis brother breeders, but he held tenaciously to the central truth that the way to breed high-class trotters was to mate high-class. trotters. His experience has clearly demonstrated the soundness of this canon of breeding, and it has just as clearly demonstrated the unsoundness of the notion that high-class trotters can be bred from animals that never trotted and never conld be made to trot. The law, as we have tanght it for years, has been vindicated, and that by experiences so wide and so complete that it can no longer be controverted. Mr. Smith has achieved a great honor, and as a prodncer of high-class speed he stands at the head of all American trotting-horse breeders.

As we have now considered a great triumph, with the causes that led up to it and the lesson it has taught, it seems to be in order to give an example of a great failure and the causes which have produced it. For more than forty years Woodburn Farm, in Kentucky, has been breeding trotters, and up to the close of 1896 just four with records of $2: 15$ or better have hailed from 
that great establishment. During all these years, and until Palo Alto Farm was established, Woodburn was the largest establishment in this comntry. With thousands of broad acres of the most productive soil, with the possession and control of money withont limit, and with the experiences of forty years in which to select and breed only to the best, it is the natural and reasonable expectation of everybody interested in the question of breeding the trotter to look to Woodburn as leading all other establishments in the whole world in the production of first-class trotters. And what has Woodburn done? With her experiences of forty years, with all her broad acres and boundless wealth, up to the close of 1896 she has produced just four trotters with records of 2:15 or better. Instead of leading all others, she is at the wrong end of the procession, and if we consider the proportional advantages involved, we find that "all others," little and big, are leading her. By referring to the above list of breeders that have produced three or more with records of $2: 15$ or better, we find that Henry N. Smith has produced thirteen, that William Corbett, from his little stud in California, has produced nine, and that the late William H. Wilson, of Cynthiana, Kentucky, from his little band of mares, and without either broad acres or money, has produced eight within the past twelve or fifteen years, and all except one by the same horse. This places Mr. Wilson first among all Kentucky breeders. In the short period of its existence Glenview Farm produced six, and the quite unpretentious farmer, Mr. Timothy Anglin, produced five; W. C. France and Colonel R. G. Stoner produced four each-the same number as Woodburn-but they did not require forty years to accomplish it. Thus the breeding world, with "the little fellows" on top, has gone away ahead and left Woodburn to mumble over her "tin cups," and exult in the many triumphs she has won against the watch in 2:30. The policy of Woodburn for years past seems to have been to hold the lead of Kentucky breeders in the production of 2:30 trotters, and to this end the youngsters are put in training in the early spring and kept at it till the frosts come, when such of them as are sure to win are brought ont and started against the watch, for a "tin cup," and these are the victories that Woodburn wins. Nobody has ever heard of Woodburn entering a youngster in a stake where he would have to win on his merits. That wonld be bringing him down to an equality with the colts of such people as William H. Wilson, Colonel R. 
G. Stoner, Farmer Timothy Anglin, and all the other "little fellows." Woodburn has made a great deal of money out of these humbug tin-cup records, and as registration and the standard are now absolutely under the control of her manager, the 2:30-tin-cup still remains the evidence of a fast trotter, worthy of standard rank. 'I'rue, everybody nowadays laughs at the idea that $2: 30$, with the "tin cup," is any evidence of even reputable speed, but as they have given a certain kind of preeminence and made money in the past, the twins will not be separated, but will hold their places just as long as the standard is under the present control.

From this brief examination of the symptoms I think a safe diagnosis can be made. 'T'he trouble seems to be twofold, or it may be said there are two troubles, either one of which is dangerous, but the two together may prove fatal in the end. It is a well-known fact in veterinary science that there are certain diseases among horses that may be communicated to the men who have them in charge. There is one disease, vulgarly called "bighead," that comes creeping upon its victim before he is aware of its existence or approach, and against the insidious steps of this destroyer the manager at Woodburn should be affectionately warned. Sham records of 2:30 for standard rank are no longer welcomed with enthusiasm in this country. The other trouble is not so much with the manager as with the material which he manages, which seems to be affected with what may be called "dry-rot." This view of the non-productive character of the Woodburn breeding stock, when measured by first-class performers, seems to be borne out by the fact that the names of those gentlemen who have depended most largely on Woodburn blood do not appear on the foregoing list as the producers of first-class. trotters. For about forty years the fame of Woodburn as the greatest of all our breeding establishments has been as wide as the boundaries of the nation. But notwithstanding the weight. and influence which great wealth and an unblemished name may have secured, the records up to the close of the year 1896 have deposed her from the first rank as a breeder of trotting horses, and sent her away to the rear, where she now occupies her true place in the eighth rank. It is well known to everybody that, since the days of the first Mr. Alexander, Woodburn has never entered a colt in a stake nor started one against other people's colts, prize or no prize. This air of assumed superiority is. 
sought to be explained on high moral grounds against the evils of horse-racing. This is like the man who never tasted whisky for conscience' sake, in view of the great evil it was doing in the world, and yet he was the chief owner in a large distillery. At the great local meetings in Kentucky practically all the breeding establishments of that region, except Woodburn, are represented in the stakes, and while they are being contested Woodburn will come in with a string of youngsters, between the heats, and win sham records in 2:30 for "tin cups." Depending on this kind of test and this kind of development, it is not remarkable that all the small breeders of the State have left Woodburn in the rear. This shining example of failure teaches unmistakably the necessity of honest and full development of breeding. stock in order to produce high-class trotters. 


\section{CHAPTER XXXIII.}

\section{HOW THE TROTTING HORSE IS BRED (Continued).}

Breeding the trotter intelligently an industry of modern development-Plethora of turf papers, and their timidity of the truth-The accepted theories, old and new-Failure of the "thoroughbred blood in the trotter" idea"Thoroughbred foundations," and the Register-"Like begets like," the great central truth-Long-continued efforts to breed trotters from runners -New York the original source of supply of trotting blood to all the States-Kentuicky's beginning in breeding trotters-R. A. Alexander, and the founding of Woodburn-'The "infallibility" of Woodburn pedigrees -Refusal to enter fictitions crosses in the Register and the results-The genesis and history of the standard-Its objects, effects and influenceEstablishing the breed of trotters-The Kentucky or " Pinafore" standdard-Its purposes analyzed-The "Breeders' 'Trotting Stud Book" and how it was compiled-Failure and collapse of the Kentucky projestAnother unsuccessful attempt to capture the Register-How honest administration of the Register made enemies-The National Breeder's Association and the Chicago Convention-Detailed history of the sale and transfer of the Register, the events that led up to it, and the resultsPersonal satisfaction and benefits from the transfer, and the years of rest and congenial study in preparing this book-The end.

All that American breeders know about producing the trotting horse they have learned in the past twenty-five years. In that short period this interest has developed from practically nothing into a great national industry that has placed this country in front of all the nations of the earth in the character, quality and speed of the light harness horse. It is true we had the "raw material" ont of which to build up this new breed, and this had been in our possession we may say for generations, but we didn't know how to nse it. There may be some apparent indelicacy in making the remark, but I think every intelligent man who is acquainted with the subject will sustain me in saying that, had it not been for the compilation of the "Trotting Register" and Wallace's Monthly, with the facts, statistics and reasonings which were developed through them, we would know no more about the trotter to-day than we did thirty years ago. The trot- 
ting horse, therefore, as we contemplate him in his position of superiority to all others of. his kind, is simply the result of great. labor in collecting the facts and sound reasoning from the lessons taught by those facts. With all the facts placed in his hand, any breeder of intelligence, if he were honest, could not fail to reach the truth; but, unfortunately, all breeders have never learned to divest themselves of their prejudices, and to accept the plain teachings of the facts, just as they are.

To be able to think intelligently and honestly and to reason soundly, is the first requisite to success in breeding the trotter. It is a seeming paradox, but it is nevertheless true, that many men who are able to think a little are not able to think honestly. It is easy to understand why a man may act dishonestly, for there is the hope of gain to impel him; but why he should think dis. honestly is not so apparent. Let us illustrate this matter of thinking dishonestly. On an occasion a correspondent asked a breeding journal to give a list of the thoroughbred horses that had sired trotter's. A list of horses, represented as thoroughbred in the reply, was given, embracing some ten or twelve, about half of which were either unknown or dependent npon the most flimsy kind of representation as to their blood. It is not with the actual misrepresentation of the blood of most of the animals named, but with the use that was made of the list that I will now speak. After accepting the list as true and genuine, the correspondent comes before the public with his conclusions. He shows that these dozen performers from about as many horses made an average record of $2: 24$ and a fraction, and then triumphantly raises the question whether any single trotting-bred sire can show as many performers with as low an average record. Having satisfied himself that all the rumning-bred sires, real and imaginary, put together could more than equal any one trottingbred sire in the average high rate of speed, he reaches the profound conclusion that the way to breed the trotter is to go to the runner. This is a real and not an imaginary instance of a few years ago. No doubt this man thought he was thinking when he reached this conclusion, and that he had solved the problem of breeding the trotter; but, poor man, he was simply trying to adrertise a half-and-half-bred stallion he had in his stable.

I have no old scores to pay off against the breeding and sporting press, for I generally managed to pay them off as we went along, and the triumph of the views I advanced and sustained. 
has become sufficiently complete to satisfy the most fastidious. It seems to be a real misfortune that there are so many weekly journals in this field and most of them leading a precarious existence. It may be observed in most directions that the management of these journals is hesitating and timid, as though afraid that somebody might be offended and a five or ten-dollar advertisement lost thereby. It is all right to make the advertising patronage remunerative, but it is all wrong when that department is placed in control of all the others, from the fear that somebody may be offended if the truth be told. In the present depressed condition of the breeding interests, and indeed of all interests, the horsemen of the whole country feel that they are carrying too heavy a burden in supporting so many papers, and the question of the "survival of the fittest" is already imminent. But, whatever the present financial and intellectnal condition of the breeding and sporting publications of the country may be, a number of them have had their part in the discussions and wrangles that were naturally coincident with the progress of the revolution on the question of breeding the trotter, which finally brushed everything ont of its way and fully established the truth of the laws of inheritance. Twenty-five years ago there was a good number of intelligent and capable writers on the horse, and they were either engaged in editing horse papers or contributed to them, and one and all they were handicapped with the idea, inherited from their fathers, that whatever of excellence that was found in the American horse came from the English race horse, and that all the speed, at any gait, that he was able to show came from the same source. From this absurd fallacy, it naturally followed that speed at the trot was merely the result of accident or of the persistent skill of the trainer. This was, substantially, the view of the general public at that date.

When, therefore, it was announced that the horse was far more than a mere machine, that he had a mental as well as a physical organization, that these were both equally matters of inheritanee, that one horse ran fast becanse his ancestors ran fast and that another horse trotted fast becanse his ancestors were able to trot fast, and that no fast runner was ever a fast trotter, there was a tremendous hubbub. This was a new gospel, and it threatened to annihilate the stupid Anglo-Arabian fetish that all that was good in horsedom must of necessity come from that source. For generations the belief had been universal that the only way to 
improve the horse for any purpose under the sun was to "breed up" to the running horse and thus get back to the blood of the pure Arabian. On the other hand, and as opposed to this ancient fallacy that the way to breed the trotter was to go to the runner, it was urged, with a thousand proofs at the back of it, that the way to breed the the rumer was to go to the horse that could run, and the way to breed the trotter was to go to the horse that could trot. Here was a direet issue squarely made, and it was not to be expected that such men as Charles J. Foster, Peter C. Kellogg, Joseph C. Simpson, ete., all writers of ability, would quietly surrender without a battle. They had committed themselves to the running-blood traditions, some rich men had shaped their breeding studs in that direetion, and without deeiding whether a rich man had necessarily more sense than a poor one, they knew instinctively that a rich man could be more liberal in advertising, and that he could be more generous in properly recognizing the little courtesies that might be extended in the way of keeping his establishment before the public in an approring light. Thus, with an eye to the weather-gange, the editors were able to maintain their own consistency. As the experienees of every succeeding year added thousands of proofs to the plain proposition that the trotter inherits his speed from a trotting ancestry, the "irreeoneilables" began to shift their ground, coneeding that there must be trotting blood to give the action, but that there must be "speed-sustaining" blood from the thoroughbred to give eourage and enduranee. This was the second position, and in a commereial sense it was shrewdly chosen for the advantage of certain localities. This position furnished the "thoroughbred foundation" argument, and for a time it had its supporters. This theory also furnished its promised commercial advantages to such localities as had formerly bred running horses, and it was but a week till everybody in those localities had "thoroughbred foundations" for their trotting pedigrees, and those who did not have them could easily procure them. 'This brought an avalanche of pedigrees, especially from Kentucky, with "thoroughbred foundations," consisting of long strings of dams by famous horses, bnt withont names, dates, breeders or histories, and many of them impossible. To eheckmate this inundation of manufactured foundations, in the office of the Register, a rule was adopted requiring satisfactory identification and history of each dam, and where that could not be given the 
pedigree would be cut off. This rule saved the "Trotting Register" from becoming the mere dumping place for countless frauds, but it aroused such a feeling of antagonism on the part of the manager of Woodburn Farm that he, at once, started an opposition Register to be compiled at the farm, under his own personal direction. Of this, and what came of it, I will speak further on. It is but just that I should say here, that from a wide knowledge of men and from a study of their moral fiber extending through many years in connection with horse affairs, I have found many Kentuckians that were thoroughly truthful and reliable in pedigree matters; but at the same time it must be admitted that the conditions there for generations past have not been favorable, among horsemen, for the cultivation of the highest type of truthfulness. Many of them have been making their own pedigrees for so long, and padding them out with nameless dams by suppositious sires, to suit themselves-and the market-that they don't take kindly to any restraint in what they consider their own business.

The great central truth in reproduction, whether of animals or plants, is summed up in the homely but axiomatic phrase, "like begets like." With the rank and file of intelligent breeders who were able to think, this axiom was soon accepted as a fundamental and basic truth. The phrase "trotting instinct" was soon in everybody's mouth, and the broad, plain distinction between that and "running instinct" was so palpable and easy of practical comprehension that the fallacy of a "thoroughbred foundation" was buried out of sight. When it was considered that the instinct of the one was to put forth his supreme effort at the trot, and of the other to put forth his supreme effort at the gallop, the irreconcilable antagonism between the two gaits was apparent. The cnmulative evidences furnished year after year by the official records of performances on the tracks, and all going to show that the trotting horse must have a trotting inheritance, soon became so overwhelming in the uniformity of their teachings, and so completely unanswerable in the force of numbers, that no man able to observe and think conld any longer doubt the truth of the position taken. But, unfortunately, some men can neither observe nor think, and, what is still more unfortunate, they not infrequently undertake to fill the rôle of public teachers and leaders of public thought. We can understand how a man of average intelligence may be wise in many 
things and foolish in others. When we come to study the phenomena he presents, we find he has studied the subjects on which he is wise, and he is ignorant on the subjects on which he is foolish. Like "Brother Jasper," the negro preacher, he is ready to maintain against all comers that "the sun do move." Another class of men in the writing frateruity, but fortunately they are restricted in numbers, have brains enough to apprehend the facts surrounding them and their teachings, but they have not conscience enough to lift them above their toadying instincts, for fear they might miss the crumbs from a rich patron's table. Another type of man, generally a beginner in the breeding business, has a half-and-half-bred stallion at the head of his little stud, and he is uniformly an enthusiast for the "thoroughbred foundation." As might be expected, he fills the columns of all the papers accessible with his "views of breeding," which are always shaped to fit his own stallion and bring him patronage. We might here go on and point out other types of would-be "teachers" that would be entertaining, but certainly not profitable or instructive. We might follow the vagaries of different writers and show the origin and reason for those vagaries, but as the breeding world has become far more intelligent, and I think more honest, than it was twenty-five years ago, one vagary after another has disappeared and been buried out of sight. All such trumpery as, "to breed the trotter you must go to the rumner," "more running blood in the trotter," "thoroughbred foundation," etc., are phrases that are never heard in our day among intelligent breeders. A mile in two minutes and thirty seconds is "played out" as an evidence of trotting speed, but it is still held in its place as such evidence to suit the blood and methods of development at one particular establishment, and to gather in the money for registration from the little fellows.

Anything slower than "two-twenty" is no longer looked upon as of any value in a trotting sense.

This astonishing increase of speed has come hand in hand with a closer and more careful observance of the law of inberitance, or heredity. If we breed the merino ram upon a merino ewe, we know that the produce will be a merino. If we breed the cotswold on the cotswold we know the produce will be a cotswold, but if we breed the merino on the cotswold the produce will be a mongrel. The phsyical inheritance is destroyed, and in propagating from this mongrel confusion, uncertainty and disappoint- 
ment always follow. If we go a step higher and consider those types of domestic animals endowed with a species of mentality that we call instinct, we find the illustrations still more marked and effective. The finely bred greyhound coupled with the finely bred pointer produces neither a greyhound nor a pointer, but only a nondescript cur. Sometimes the instincts of the greyhound and sometimes the instincts of the pointer may be the more masterful, but the inheritance is broken and divided, and the mongrel should never be used for propagation. If we couple the very best specimen of the English race horse with the very best and fastest American trotting mare, the produce would be literally half-and-half bred. The sire never conld trot a mile in four minutes and the dam never could run a mile in two minutes, and what is the produce good for? Once in a hundred times the running instinct might predominate and develop something of a runner, and once in a hundred times the trotting instinct might predominate, as in the case of Bonnie Scotland and Waterwitch, and produce something of a trotter, but of what value would the half-and-half progeny be for breeding purposes? Whatever might be the characteristics of their progeny, physically, they would undoubtedly and invariably inherit and transmit not only divided, but antagonistic, instinets that would require generations of careful selection and training to get rid of. While the "featherheads" may, for the sake of personal consistency, which is a very weighty matter of public concern, still advocate "more running blood in the trotter;" and while one great concern may still look one way, on this question, and row the other, it being literally true that she has not added a single drop of running blood to her trotting stud in a quarter of a century, it is safe to say that the whole body of intelligent breeders of this country have come to accept and obey the great central truth that the American trotter has reached his present state of perfection by the development of his unbroken and undivided trotting inheritances. These inheritances have been cumulative and thus made stronger in each developed generation of ancestors, and if this high development of speed is kept up for a series of snccessive generations the speed of the American trotter will be placed at a point of which we have never yet dreamed. The inherited and developed instinct to stick to the trot as the fastest gait of which the horse is conscious, coupled with skillful preparation 
and handling, are the two factors that will always put the American trotting horse in the front rank and keep him there.

In the early chapters of this work we have considered the horse in his original habitat and his distribution among the different peoples of the then known world, but we have not considered the distribution of the trotter through the different regions of our own country. Fifty or sixty years ago the trotting horse was hardly known outside of a limited territory embracing the cities of New York and Philadelphia. In the New England States the trappy little Morgan filled the place of the driving horse with very great acceptance, but he had no speed as a trotter. We then began to see and hear something of the "Maine Messengers," that were trotters in reality and able to demonstrate their speed and courage on the track. Occasionally a converted pacer would strike a trot and show speed that was phenomenal in that day, but it was uniformly treated as "accidental." There was a great deal of high-class trotting blood in the region of Philadelphia, and for a time that was the leading center of the trotting interest, but it did not receive that measure of encouragement and support that was necessary to its permanent growth, and the seat of empire was transferred to Long Island and Orange County, New York. South of Mason and Dixon's line the trotter was tabooed, as a mongrel nondescript, and "not worthy of the attention of a gentleman, sah." They bad runners and they had pacers, and as all excellence in the shape of a horse, at whatever gait, as they argned, must come from the running horse or his progenitor, the Arabian, they had already the very best material in the world for the production of the fast trotter. The belief as expressed in their motto, "Speed at the gallop was a guarantee of speed at any other gait required," pervaded all minds and directed all action in matters of breeding. Thus they worked away for years trying to breed trotters from blood that never could and that never did trot, and, strange as it may seem, there are still some people in that region, at the close of the nineteenth century, trying to breed trotters from runners. From New York as a common center all the breeding States obtained their supplies of trotting blood, and they in time became sources of supply. The only exception to this is that of the pacer, which eventually developed into a trotting element of some prominence and value, especially in the West and Sonth.

The prominence of Kentucky as a breeding center is wholly 
due to the trotting blood she obtained from New York. She had plenty of pacing blood that was good, of its kind, but it was so uncertain and sporadic that it did not commend itself to the breeders of that section as a source of trotting speed. From an early period in the history of the State the habits and fancies of the people, in the richer portions, had been "horsey," from their knowledge and familiarity with running races for many years, and thus when the demand came for trotters they struck out vigorously to meet that demand. When Mr. R. A. Alexander organized the great Woodburn Farm he established a department. of trotters, which was among the very first of any magnitude in the State. As he had been reared abroad he knew nothing about. American pedigrees, and in making his purchases of breeding stock he was victimized by every sharper who came along with a. brood mare to sell. He was a man of honest purpose and excellent natural judgment which told him to buy such breeding animals as could trot themselves or had produced trotters, and if he had been content to stop with what little he knew of their breeding he would have been all right; but, meantime, the professional pedigree-maker-the successor to the famous Patrick Nesbitt Edgar-came along and tricked them out in an excellent quality of pinchbeck pedigrees containing plenty of running blood that had never trotted nor produced a trotter. When the first Mr. Alexander died he was succeeded in the proprietorship of the great estate by his brother, a very worthy gentleman who made it a law to the establishment that none of his horses should ever start in a race. His fancy and knowledge were all in the line of cattle, and he seemed to neither know nor care anything about horses. Soon after this change in the ownership of the estate a new manager was placed in charge, and it was soon manifest that however absurd and untruthful the pedigrees of breeding stock might be, they must not be questioned nor corrected by any authority whatever. This doctrine of infallibility as applied to Woodburn pedigrees was wholly incompatible with what I conceived to be my duty to the breeding public. I had accepted the Woodburn pedigrees, at the start, as trustworthy, on the grounds of the eminence and high character of the first Mr. Alexander, and it was far more than a surprise to me when I discovered something of the extent to which the pedigrees of the whole establishment had been honeycombed with the dishonesty of "sharpers" and "pedigree-makers." These fictions 
antedated any compilation or known authority of trotting pedigrees, and there can be no doubt they were accepted as honest statements of the blood of the animals in question, while many of them were wholly fictitious and all of them contained crosses on the maternal side that were merely imaginary. These embellishments, to call them by no harder name, were uniformly in one and the same direction, all stretching out to embrace as much of the blood of the running horse as possible, and often a great deal that was impossible. Here I may state the general fact that all Kentuckians had claimed and exercised the right so long to shape up their pedigrees to suit themselves and to bring the most money in the market that a number of them still claimed that as a right and became somewhat restive when told that their pedigrees would be recorded just as far as they were proved, and no further. Two or three breeders expostulated against this rule, and in reply they were assured that they had a perfect right to shape their pedigrees as they pleased, but that insertion in the Register was the same as my personal indorsement, and that this indorsement could not be given to any pedigree that I did not know or believe to be honest and true. This ended all doubts about the position and character of the Register, and I think that every breeder of any standing in Kentucky submitted to the rule, with the solitary exception of Woodburn Farm. The manager of that establishment was not only unwilling to have the infallibility of Woodburn pedigrees called in question, but he aspired to the control of the pedigrees of all other breeders in the whole country. When the National Association of Trotting Horse Breeders was organized in December, 18\%6, he was not only asked, but pressed, to become a member and take part in its management and control. But no, he would be "boss," or he would be nothing. New York was not the right place to organize it. It should be organized in Kentucky, and with the manager of Woodburn at the head of it. The arrogance of this young manager was something amazing, his intrigues to get control of registration were continued for a number of years, and the means employed to accomplish his ends were of such a character as clearly to demonstrate that of all the men in the world he was the last one who should be placed in the control of such a trust. As this controversy extended through the period of building up the breed of trotters, it is of necessity a part of the literature of the formation of that breed, 
and as some of the more salient points seem to be of sufficient importance to hand down to future generations, I will here consider them very briefly. In doing this I am conscious of some feeling of embarrassment on account of the personal matters that must enter into the recital, but it is a part of the trotting history of the times, and I prefer that the truth may be preserved, whatever may be the teachings of the canons of taste.

In the collection and registration of pedigrees that seemed to be more or less closely allied to trotting blood, embracing all contained in the first, second and third volumes of the "Trotting Register," there was no guide or rule to determine what was worthy of registration, in a trotting sense, and what was unworthy. I had a general conception of the families that had produced trotters and those that had not, but I had no rule by which I could decide what to admit and what to reject, except that all actual performers of reputable speed must be admitted. To undertake, on individual responsibility, to determine what amount of trotting blood should be requisite to admission, and how that amount shonld be measured, was quite too hazardous, except when backed by a strong moral and numerical force of breeders. Hence my active interest in the organization of the National Association of Trotting Horse Breeders, and my earnest. desire that it might be composed of breeders of high standing and character from all parts of the country. Upon the organization of the association, its character was so entirely acceptable to me that I did not hesitate to place in its hands the supervisoryo control of the registration of pedigrees for the "Trotting Register," to be exercised by a Board of Censors to be appointed annually. The first board was appointed and entered on its functions January $15,187 \%$, by formulating the first set of rules relating to the requisites necessary to the acceptance of pedigrees, in their form and completeness. The third volume was then approaching completion and the Board of Censors commenced their supervisory duties on that volume.

'The members of the Breeders' Association were generally men of intelligence, and capable of thinking, and every suitable opportunity was improved to get their individual views on the question as to whether a set of rules could be adopted by the association that would distinguish between animals that had trotted themselves or produced trotters in say 2:30, and animals that had not. Not many had ever thought of the subject, but all 
were ready to think of it more. The only objection urged was that such a scheme would certainly reduce the fees for registration in large degree. To this I assented as doubtless true for the time being, though in the end it would largely increase them, but declared that it was not for the fees I was working, but to establish a breed of trotting horses. When satisfied that a good number of the leading breeders were thinking favorably of the subject, it was presented to the public in a very modest and unpretentious way. In discussing "The Future of the Breeders" Association," in Wallace's Montllly for April, 1878, the following language occurs:

"In addition to the thought and labor necessary to secure such an organization as the interest demands, there is another topic that will require great deliberation and wisdom, in the near future. The association must fix a standard of admission to the official record of pedigrees. Up to the present time there has been no standard of blood requisite to secure a place in the Register. This matter has been left wholly to the compiler, without even so much as advice on the subject. The Register, therefore, has no value as a classification of blood, but only as a reliable record of the pedigrees of the animals it contains, whatever their blood may be."

This is the first intimation ever given to the public, so far as I know, that any body of men ever contemplated the construction of a standard to control the admission of trotting horses to specific rank and registration. The question was thus placed openly before the public and it was looked upon favorably by those most immediately interested. In due time, at a meeting of the Breeders' Association, a committee was appointed to whom was referred all the suggestions that had been made for the proposed scheme. Soon afterward (November 19, 18:9) the committee reported the standard to a large, enthusiastic and harmonions meeting of the Association, and it was unanimously adopted as follows:

\section{THE STANDARD OF ADMISSION TO REGISTRATION.}

(Established by the National Association of Trotting-Horse Breeders, November $19,1879$.

In order to define what constitutes a trotting-bred horse, and to establish a BREED of trotters on a more intelligent basis, the following rules are adopted to control admission to the records of pedigrees. When an animal meets the requirements of admission and is duly registered, it shall be accepted as a standard trotting-bred animal. 
First.-Any stallion that has, himself, a record of two minutes and thirty seconds (2:30) or better; provided any of his get has a record of 2:40 or better; or provided his sire or his dam, his grandsire or his grandam, is already a standard animal.

SECOND.-Any mare or gelding that has a record of $2: 30$ or better.

THIRD. - Any horse that is the sire of two animals with a record of 2:30 or better.

Fourth.-Any horse that is the sire of one animal with a record of $2: 30$ or better; provided he has either of the following additional qualifications :

1. - A record himself of $2: 40$ or better.

2. - ls the sire of two other animais with a record of $2: 40$ or better.

3.-Has a sire or dam, grandsire or grandam that is already a standard animal.

Fifth.-Any mare that has produced an animal with a record of 2:30 or better.

SIXTH. - The progeny of a standard horse when out of a standard mare.

SEventir. - The progeny of a standard horse out of a mare by a standard horse.

EIGнтн. - The progeny of a standard horse when out of a mare whose dam is a standard mare.

Nintu.-Any mare that has a record of 2:40 or better, and whose sire or dam, grandsire or grandam is a standard animal.

Ten'sh. - A record to wagon of 2:35 or better shall be regarded as equal to a 2:30 record.

In this, its original form, the standard was administered successfully and smoothly through the period of the compilation of volumes four, five, six, and seven of the "Trotting Register," when it was revised by the Breeders' Association as follows:

THE STANDARD.

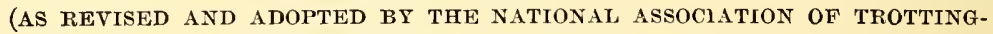
HORSE BREEDERS, DECEMBER 14, 188\%.)

In order to define what constitutes a trotting-bred horse and to establish a BREED of trotters on a more intelligent basis, the following rules are adopted to control admission to the records of pedigrees. When an animal meets the requirements of admission and is duly registered it shall be accepted as a standard trotting-bred animal.

Finst.-Any stallion that has himself a record of two minutes and thirty seconds (2:30) or better, provided any of his get has a record of $2: 35$ or better, or provided his sire or bis dam is already a standard animal.

SECOND.-Any mare or gelding that has a record of 2:30 or better.

THIRD.-Any horse that is the sire of two animals with a record of 2:30 or better.

FodRTH.-Any horse that is the sire of one animal with a record of 2:30 or better, provided he has either of the following additional qualifications: (1) A record himself of 2:35 or better. (2) Is the sire of two other animals with a 
record of 2:35 or better. (3) Has a sire or dam that is already a standard animal.

FifTH.-Any mare that has produced an animal with a record of $2: 30$ or better.

SrXTH.-The progeny of a standard horse when out of a standard mare.

SEVEnTH. - The female progeny of a standard horse when out of a mare by a standard horse.

Erghtт.-The female progeny of a standard horse when out of a mare whose dam is a standard mare.

NinTH.-Any mare that has a record of 2:35 or better, and whose sire or dam is a standard animal.

From the indefinite and unsatisfactory starting point, and without any rule or guide as to what should be admitted, except the pointless phrase, "well related to trotting blood," it soon became evident that the Register would soon contain as much chaff as wheat. Through the Monthly, which was established for that purpose, I did not despair of the success of my aim in leading the intelligent breeders of the country up to the point of recognizing and establishing the American trotting horse as a BREED. The road was long, steep, rough in places, and beset with prejudices on all sides, but labor conquers all things, and we have in the standard and its revision, as given above, the culmination and perfection of the implements that were to effect this purpose. To reject a horse from registration merely because he was running bred would have been "flying in the face" of the prejudices of nearly everybody, but to reject him because neither he nor any of his tribe had ever been able to trot, was philosophical and just; and as it gave no section of the country an advantage over any other section, and no theory an advantage over a fact, no man could gainsay or criticise its justice or its truthfulness. This was the wedge that split the rock of ignorance and prejudice, and thus exploded the theories of generations as to the value of running blood in the trotter. As I look at it to-day, the undertaking to gather up a great lot of fragments and convert them into a breed was a tremendous one, and although it was backed up with brains and influence, it is doubtful whether many of its promoters had any very clear conception of the results that would follow-either its success or its failure. It assumed to direct and control the trotting-horse breeding interest of the whole country, and to leave its impress for all time. It required no gift of prophecy to see this as the result of success, and neither did it require any gift of prophecy to foresee that 
failure would wipe out the work already done in both the Register and the Monthly. It was the crucial period in the history of these publications. A misstep or an unwise provision would have brought a disastrous end. To found a breed of horses resting primarily and wholly upon performance and the blood descended directly from performers, or the producers of performers, was something that never had been attempted in the world. The basis was wholly unique, but it commended itself to the public judgment as a just one, and as the only foundation upon which the proposed breed conld be successfully established. The basis was wisely chosen and the superstructure erected thereon was equally wise in all its provisions. Never have we known a set of men to work more earnestly or more unselfishly for the common purpose.

After very careful consideration in a large and intelligent committee, the finished labors of that committee was reported to the Association on November 19, 1879, at the Everett House, in this eity, and the standard was then and there adopted without so much as a question and without a voice or a vote being raised against it. Thus the standard was launched in unity and wisdom, and from that day it went forward on its mission of educating the people. The "Trotting Register"' has done much and the Monthly has done something in the way of education, but the standard has been the special formula through which all these teachings have been brought home to the breeder, great and small, in a manner that educated both his mind and his pocket. If we could conceive of the brightest mind directing the most pointed pen for the period of a hundred years in the special department of how to breed the trotting horse, we feel sure he would fail to accomplish as much as this little, practical formula called the "standard" accomplished in the first dozen years of its existence.

When the standard was adopted and put in operation there was a material advance in the market value of all animals registered under its requirements, and it thus became not only a matter of honor, but of profit, to breed only in the standard ranks. Everybody was willing to pay more for a good horse that was standard in his breeding than for one equally good that was not standard in his breeding. A record of 2:30 was then accepted as evidence of a high rate of speed, everywhere. 'There was a grand rush for standard rank and the number of fraudulent performances sent 
forward in order to secure such classification was overwhelming. This led to many rejections of performances, adroitly shaped up to deceive, and every rejection made a batch of enemies. But great as this evil was, there was another that began to manifest itself very strongly. The Register was rapidly filling up with colts under rules seven and eight, and every one of them, as soon as he was able to stand up, wanted his number, for he was to be kept as a standard stallion. The public attention was urgently called to the preponderating numbers of these feebly bred colts, as a menace to the hitherto unimpeded progress of the grand purpose of establishing a breed. The Breeders' Association thereupon took up the standard and revised it, wholly in the direction of higher qualifications and more stringent requirements. By comparing the revised standard with the original, above, it will be observed that rule ten was stricken out, and that rules seven and eight were restricted to fillies only, thus cutting off the source of danger altogether. The rates of subsidiary speed were advanced and there was a tightening up of the requirements in other directions. This revision did not suit all interests, especially beginners who were just starting to breed their first colt by a standard horse, but as every one knew there would never be a time when there would not be just such groundless complaints, the action received the hearty indorsement and support of all breeders who kept in view the central object of the standard in building up a breed of trotters.

When fast horses began to multiply by the thousand, annually, say abont 1890-91, we began to hear an increasing number of gibes at the standard as "a slow coach," "away behind the times," "a 2:30 horse was no longer considered a trotter," etc., and every one of these taunts had an element of truth in it. The standard, as the teacher of the breeders of the country, had not only produced trotters, but great trotters, with marvelous rapidity. At one time it was the ambition of all breeders to place their stock inside of the limits of the standard, not only because it was an honor, but becanse it added materially to the bank account and to the value of every animal, so bred, in the establishment. But breeders both great and small are no longer stimulated to enter a standard with the antiquated $2: 30$ rate of speed that is everywhere received with a sneer. When the standard was formed on the basis of $2: 30$, it was within about fifteen secouds of the fastest performance, and if the same ratio were 
now preservel, " $2: 30$ " would be stricken out and " $2: 20$ " inserted instead. The breeders would again be stimulated to look forward with hope, and not backward with regret.

Of the numerous criticisms of the standard after its adoption, there were none of any special force or practicability, but from one source there was a persistent war made upon it, not because it was unfair in its, principles or administration, nor because it lacked vigor in its support, but evidently because it was not controlled in Kentucky, and that the pivotal authority of that control was not placed in the hands of the manager at Woodburn. It is but just that I should say here that many of the stanchest and most enthnsiastic supporters of the standard and the Register were Kentuckians, and with the exceptions of two or three breeders who stood well in their community, and a few others. who were bankrupt in character and morals, there were no enemies to engage in this war. I would gladly skip over this period, for it is of necessity more or less personal, but to omit it would leave the history of the times and of the formation of the breed of trotters incomplete, and liable to misrepresentation by those who may come after us.

The first public suggestion or demand for a standard, and the first use of the word "standard" in connection with rules for registration, was addressed to the Breeders' Association, in the paragraph quoted above, from the Monthly for April, 1878. In that paragraph, while no specific rules were formulated, the whole scope of such rules was foreshadowed.

In the course of correspondence with breeders all over the country as to their views about the provisions of the proposed standard, I received from Mr. Henry C. McDowell, of Kentucky, a little slip of paper, perhaps as large as your hand, marked "copyrighted," on which were printed a number of rules that purported to be rules for the admission of certain animals, trotters and runners, to some book that was not named or described. This little paper was courteously received and commended as a step in the right direction.

The idea of inserting the word "copyrighted" seemed to be that it might serve as a "scare head" and thus deter all makers of books from attempting to make a book under the provisions of these rules. These rules were strictly tentative, and they were peddled about for months, and changed several times to see 
whether they would be acceptable or not, and every revised and corrected edition was marked "copyrighted."

Some of the rules that were, we might say, self-evident, were not very objectionable, but others again were simply intended to give Woodburn and those who had their breeding stock from that establishment a great advantage over all other brecders. The selfish object of the fourth rule is palpable, as follows: "Any mare, the dam of any mare or stallion that has produced or sired a horse, mare or gelding, with a record of two minutes and thirty seconds or better."

To the original draft of six rules, "rule seven" was afterward added, which reads: "The full sister of any animal entered under rules one, two, three, and four." This was the capsheaf of absurdity, for it not only made the grandams of trotters standard trotting brood mares, but all their sisters also. This not only embraced a large number of running mares, genuine and bogus alike, in Kentucky, but it reached across the Atlantic and made one of the greatest of English dams of running horses, and all her famous sisters, standard trotting brood mares in America. Bonnie Scotland, the great racing sire, never was able to get a trotter except from old Waterwitch, and upon the strength of that scratch, his sisters and his mother and his aunts were all made standard trotters. No wonder this marvelously stupid production eame to be known as the "Pinafore Standard." [A more extended review of the "Pinafore Standard" may be found in Wallace's Monthly for December, 1879, page 831.]

But when we come to consider the uitimate result intended to be reached, the scheme was not "marvelously stupid"-it was not the work of a fool, but of the other kind of fellow. The admission of the grandmothers and all their sisters was not specially intended to bring in the great English racing mare and all her sisters as standard-bred American trotters, but it was intended to bring in a great host of Kentucky rumning-bred mares that never could trot a mile in four minutes, and place them on an exact equality of rank with mares that had records of $2: 20$ or less. This would not only place Kentucky away ahead of the North in the length of her lines of inheritance, but would place Woodburn away above all competitors, either North or South, and with a little help of the. Edgar-Bruce type, we would soon have had "twelfth dam, fifteenth dam," etc., not one of them named and not one of them honest. Great local, and especially personal, 
advantages were to accrue, and the theory that Kentucky running blood was not the best trotting blood in the world was to be smashed, and here we reach "the milk in the cocoanut." So far as we can understand the conditions as they then existed and so far as we can analyze the facts developed, this seems to be a fair interpretation of the impelling motive. In an unfortunate hour I took up this bantling of the young manager and exposed its absurdities, addressing the exposure to a highly esteemed personal friend whose name was connected with the movement, and just as soon as the gentlemen interested could be got together, every vestige of the "Pinafore" features was eliminated, the poor old grandmothers and their sisters being ruthlessly turned out in the cold. This was the first set-back which Mr. Brodhead received in his enterprise, which was to accomplish so much for Woodburn, and which ended so disastrously.

There was another feature embraced in the "Pinafore," and protected by the same "copyright," that was of special significance. It was provided that time made in a public trial, against the watch, should be accepted as of equal value with time made in a race with other horses. It is not worth while to stop to consider the question as to whether these two kinds of performance are of equal merit, and should receive equal honor, for every honest man will call such a claim a bald absurdity on its face. Then why has Woodburn, from time immemorial, it will be asked, always refused to enter a colt in a stake or start one against others? If you ask the manager he will tell you that Mr. Alexander, the owner, is opposed to racing in all its forms. Then why does Woodburn, in one form or other, hold so much stock in the Kentucky Breeders' Association, one of the most notorious gambling concerns in the whole country? We will not press this question too closely. There can be no shadow of doubt, therefore, that this feature of the "Pinafore" was the special product of the mind of the manager at Woodburn, for no one of the other gentlemen would be willing to own it.

The quasi-organization from which, nominally, the "Pinafore Standard" emanated consisted of the five gentlemen following: Lucas Brodhead, Henry C. McDowell, Richard S. Veech, James C. McFerran, and Colonel Richard West. The names of these five gentlemen when appended to any matter connected with their enterprise and given to the public had no rank assigned to them, except "Committee on Rules." This implied that. 
there was an organization behind them that had appointed them to this duty, but there never was even a shadow of such an organizaíion. Mr. Brodhead was manager at Woodburn and ambitious to control the trotting pedigrees of the whole country, and for the methods employed the reader is referred to page 430 of this volume. Mr. McDowell is simply Mr. Brodhead's echo. In December, 187\%, he attended the annual meeting of the National Association of Trotting Horse Breeders, and out of compliment to Kentucky he was elected president. He was about the city two or three days, and before he left for home he resigned without ever intimating any reason why he resigned. Mr. Veech is a man of undoubted integrity and plenty of brains, and was identified with the Breeders' Association from the start. Mr. McFerran and Colonel West are both dead, and while it was not my privilege to know them intimately, I knew enough of them to trust them as honorable and honest men. Not long after the appearance of the original suggestion in the Monthly, as given above, that a standard of qualifications for admission to registration was of paramount importance, and that the preparation of such a standard was in the special province of the National Association of Trotting Horse Breeders, Manager Brodhead caught the idea and the situation, and with Mr. McDowell hurried away to spend a night with Mr. Veech, near Iouisville, and thus forestall the action the Breeders' Association might take in the premises. They were all of one mind as to the importance of keeping Kentucky in the foremost position as a breeding State, but they were not all of one mind as to the means best adapted to that end. Mr. Veech was very clear and pronounced in his views that the way to breed the trotter was to go to the trotter and not to the runner, but what Brodhead said McDowell said, and that left him in the minority. Seated around a table, each with a copy of Wallace's Monthly containing the table of 2:30 trotters under their sires, they commenced forming some rules. With "The Great Table" before them they could not fail to strike the self-evident requirements of a standard, and two or three of their rules were very good, but as a matter of course the scheme of the majority to get in all the running-bred mares possible and enter them as standard trotting mares had to prevail. Hence the provision for admitting the grandams. Imported Bonnie Scotland was kept many years in the trotting latitudes, and just got one trotter and no more at any rate of speed, hence he was a 
standard horse according to this scheme, and his dam, Queen Mary, in England, was a standard trotting brood mare. Now if the dam thus became a standard trotting mare, why should not Iago, his sire, become a standard trotting sire? This would have been too glaring and open, and would have been ridiculed as an absurdity by everybody. The trick had to be carried through cinietly or it could.not succeed. At a later period the sisters of all the standard mares were made standard, and then came the very appropriate and expressive titie of the "Pinafore Standard," for it literally embraced "his sisters and his mother and his annts." This scheme would have almitted a vast herd of so-called trotting mares in Kentucky that had no trotting inberitance, had never trotted themselves, and never produced a trotter. This part of the scheme was certainly not the work of the "Committee on Rules," but the work of an individnal for the purpose of carrying out a selfish and inadmissible scheme to promote local and personal interests. When the exposure of this scheme came out Woodbnrn, with all its influence in Kentucky, could not stand against it an hour, and every "Pinafore" feature was promptly eliminated.

When the processes of emendation and change in the "Pinafore," and each change "copyrighted," were going forward, the views of the different members of the "Committee on Rules" did not always harmonize, and when it came to the selection of a man to do the work, part of the committee insisted the work should be placed in the hands of John H. Wallace, and after some discussion a committee consisting of Mr. Brodhead and Mr. McDowell was deputed to tender this work to Mr. Wallace on such terms as would be equitable and just. In due time a communication was received from these gentlemen, informing me of the business upon which they had been appointed and wishing to know for what compensation I would engage to compile the book, laying down the conditions upon which it must be done. Without having a copy of this correspondence before me I can only give the substance from memory. First, the copyright was to be in the committee or some member of it; second, the compilations were to be as the committee directed; and third, the book was to be the property of the committee when completed. This was a stunner, but I concluded to play out the rôle they had assigned me and see what they would do. In my reply I put the case substantially as follows: "Your proposed book, 
if ever made, must be made almost, if not quite wholly, from the first three volumes of the "Trotting Register,"' and these volumes are carefully protected by copyright. I have spent several years of hard labor in compiling them, and a large amount of money in traveling over the country tracing and verifying the facts which they contain. You ask me, in effect, to take my three volumes and to skim all the cream out of them to make one volume for you. Now, before going an inch further, we must understand what you are willing to pay for my property, before I can entertain any proposition to dump it into the lap of your committee." Sometimes I have been disposed to lament my hard fate in coming so near the exalted position of "hired-man" to two such distinguished characters as Henry C. MeDowell and Lucas Brodhead, but I missed it. To this letter I never received any reply, nor did these gentlemen ever make any report of their negotiations with me to the "Committee on Rules."

The next news we had from the "Pinafore" was the announcement that the book would be compiled at Woodburn, by LeGrand Lucas, and on inquiry as to his capacity and knowledge of the subject it was learned that he was a young kinsman of Brodhead's, perhaps still in his "teens," who was employed there as a kind of clerk or bookkeeper. He was evidently an innocent lad, for he had been installed in his new office only a very few days when he wrote me for certain numbers of the Monthly, in duplicate. In reply I wrote him that each volume of the "Register" and each number of the Monthly was legally covered by copyright and that I could not consent to his taking my property to make up his new book, and that he must do as I had done-commence at the beginning and hunt for himself. Poor boy, what could he do? If he were debarred from the use of the Wallace publications, where on the face of the globe could he get the information? If cribbing had to be done in order to carry out the scheme, it would be very indiscreet to do it under the very roof of Woodburn and under the supervision of its manager. Thus the work languished for months, and little or no progress was made.

In Chicago there was one James H. Sanders, publishing a paper, whom I had known for years. He never had an idea of his own in the world, but he was one of the most notorious and shameless plagiarists that $I$ have ever known. As an illustration of what I knew about him in this department of industry and 
thought, I will give a single example that will honestly represent many others in my own experience. At one time he was employed several months as editor of Wilkes' Spirit of the Times, and during that time $I$ wrote an article for that paper that had some pith and point in it, but I was afraid to send it for fear Sanders would steal it, so I called in a capable friend and told him the situation, had him read it carefully and make some notes of the order of thought that he might know it if he ever saw it again. The paper was then signed and sent forward. In two or three days I received an acknowledgment of the communication effusively thankful for the favor, remarking that by a singular coincidence our minds had been running in the same channel and that when my communication was received he already had an article in type taking the same view of the subject. When the paper came my friend looked it over and remarked "that man is nothing more than a shameless plagiarist."

In a short time work on the book, if it were ever begun, came practically to an end for want of material, and this was probably brought about by a hint from the proprietor, Mr. Alexander, that Woodburn, with all its strength, conld not afford to sacrifice its good name for honesty, by taking the property of another man, without his consent. At this juncture J. H. Sanders, of Chicago, wanted a job, for ready money, and knowing the situation in Kentucky, published an editorial going to prove that pedigrees could not be copyrighted, for they belonged to the owners of the horses, or some other such brainless argument as this. Brodhead and his echo saw in this the opportunity of their lives, for Sanders wanted the job, and if my work were to be appropriated they could blame it all on him. So they hied away to Chicago, and the three worthies, all fully inspired with the animus furandi, were not long in reaching an agreement. Sanders did not want any share in the book or in the profits it might yield, but he was ready to do the work for a fixed compensation, in cash, and to be free from all responsibility for damages or loss. The compensation, as represented by Sanders, was three thousand dollars. The negotiations were consummated, announced through the press with a brilliant flourish of trumpets, and the two gentlemen returned to Kentucky in high feather. Work on the compilation (?) was soon commenced, and, as related by an eyewitness, the methods were very simple and expeditious. Mr. Sanders sat at one side of a table with the three volumes of 
"Wallace's Trotting Register," and Wallace's Monthly open before him, and as he read out the pedigrees in their alphabetical order, his clerk, on the opposite side of the table, wrote them down. In a very few weeks the work was done and Sanders put his three thousand dollars in his pocket. 'Thus the clerk was paid, his employers were in possession of his dishonest work, and J. H. Wallace was robbed of the labor of years, but the instinctive: honesty of the public conscience had not yet been reckoned with.

The book was published under the title of "The Breeder's. Trotting Stud Book." 'The clerical work was well done, closely following the copyrighted sources from which it was drawn, so. closely indeed as to furnish strong prima facie evidence that it was copied. But this feature of excellence, if that word can be applied to theft in any form, furnished literally hundreds of evidences, clear, unmistakable and conclusive, that from beginning to end it had been copied from the "Register" and the Monthly. Like all works of the kind, those rolumes were not. free from errors, the spelling of a name might be wrong, the initials of a name might have been misplaced or reversed, a date or a location may have been incorrect, and as all these errors were copied and not one of them corrected, and there were hundreds of them, each one stood up as a competent and undisputed witness and told the story of the theft. But, knowing the character of the people with whom I had to deal, I was prompted to adopt the methods of the detective in using marked bills, and then finding those bills on the person of the culprit. Fortunately there was a very easy way of applying this effective and conclusive method and I adopted it. Instead of marking bills, I marked pedigrees, by inserting imaginary crosses. As an illustration, there was a horse in Delaware called Frank Pierce Jr. Nobody ever knew anything about the blood of his dam, and I supplied the place with "dam by Tom Titmouse, pacer," and then waited for my marked pedigrees to make their appearance. Nobody ever heard of a horse called "Tom Titmouse" in Delaware or any other country. In due time the book appeared and there my "marked bills" came to light in the possession of Lucas Brodhead and Henry C. McDowell. The piracy was a clean sweep and the evidence of it was just as complete as the depredation itself. As a matter of course I did not delay in raising the shout "stop thief," and after one or two broadsides from the Monthly giving the extent of the theft and examples of the evidence to. 
sustain the charge, the moral sense of the breeders of the whole country, including Kentucky, was aroused, and I was really surprised at the sudden death of the bantling and its burial out of sight, but still more surprised that no man opened his head in explanation or defense of the piracy, and thus was practically confessed the truth of all that was charged against them. It is said that Mr. Alexander, the proprietor of Woodburn, tightened the reins on his over-ambitious manager, at this point, and admonished him that his course had done great injury to the good name of Woodburn, and that he must change it, and not attempt any defense of what he had done. Whether this really occurred or not I am not able to say, but it was just such a course as any wise employer would adopt toward a reckless employee whose course was destroying the good name of an establishment. It then appeared to be my duty to go forward and under a decree of the courts have this stolen property confiscated and destroyed, according to law, but as the bantling was already very dead and growing deader every day, with nothing left of it but a trace of its putrescence in the nostrils of all honest men, I concluded that the game was not worth the candle.

Among the amusing things that were developed in the progress of this controversy was Mr. Brodhead's peculiar views as to what "copyright" really meant. He got the idea of restricting admission to the "Register" to animals possessing certain qualifications from the Monthly, and he formulated this idea into five or six rules, expressed in eight or ten short printed lines and, as he claimed, copyrighted this idea. He evidently seemed to think he had invented a rat-trap and got his patent on it. and that no man dare make any rules restricting registration, so long as he safely held the patent on his rat-trap. He could see no difference between a patent right and a copyright. An "idea" cannot be copyrighted, no difference whether it be expressed in one printed line, or in a dozen. The copyright law is constructed for the special and only purpose of protecting the author in the results and products of his labor. The work of seeking, tracing and establishing the pedigrees of trotting horses had been pushed forward persistently, laboriously and expensively for more than twelve years, and it had grown into a vast accumulation of facts of imperishable value to the whole horse world, and every line of it was protected under the copyright law; but because it didn't conform to his "rat-trap" idea he seems to have persuaded him- 
self that it would be justifiable to hire and pay a man to transfer it from my possession to his own.

During its very short life and while the memory of the book was retained in the recollections of the horsemen of that period, it was very generally, if not invariably, spoken of as "The Tom Titmouse Stud Book." It has already been suggested how this name would aptly fit in among my "marked bills," but the reason for it has not been made apparent. In Warren's romance called "Ten 'T'housand a Year," his "delectable," or to speak soberly, his "detestable" hero was named "Tittlebat Titmouse," and as one of the gentlemen involved in this controversy strongly reminded me of Warren's hero, by his arrogance and ignorance, I involuntarily wrote in the "marked bill" "dam by Tittlebat Titmouse;" but upon looking at it I concluded it was not good bait, for it was doubtful whether any man in the world who ever owned a horse would name him after so contemptible a character. Hence, to make it less conspicuous it was changed to read "dam by Tom Titmouse, pacer," and the bait was swallowed in a twinkling. The Kentucky scheme, from its very inception, had its motive in securing a local and personal advantage over the breeders of every other section of the country and hence the provisions of the "Pinafore" standard, from which the promoters. were only driven by exposure and ridicule. "The piracy was consummated as proved by a hundred witnesses that will never die, and of which the "marked bill" element, such as "Tom Titmouse, pacer," is an unmistakable representative. With the inception and consummation both understood and named, how could we find another name so fit as "The Tom Titmouse Stud Book?" To this might be added, on an amended title-page: "Edited by a clerk employed by Lucas Brodhead and Henry C. McDowell of Kentucky.",

Some three or four years after the death and burial of the "Tom Titmouse" book and when its odoriferous memory had become less offensive, another effort was made to get control of the registration business, by the same parties in Kentucky. Mr. Brodhead did not appear prominently in this move, but worked through his echo, McDowell. The plan was to present a monster petition to the National Trotting Assuciation, composed chiefly of track owners and track followers, to establish a trotting register. This petition purported to be from breeders, but in fact it embraced all the "swipes" and stable-boys about Lexington and 
Woodburn, I was told, and there were very few actual breeders in the list, and that few were men who were trying to breed trotters from runners. The movement was inspired and engineered in good degree from Woodburn, and Brodhead's friends were at work in all directions securing the names of the "rag, tag and bobtail" whose names appeared on the petition, and a very great noise was raised about what was going to be done. Whether the association took any action on the petition, or what it was, I have no recollection, but whatever the disposition made of the petition, it never was heard of again. To the reader not familiar with the condition of things in Kentucky at that time, these persistent and renewed attempts to get control of the registration of trotting horses can hardly be comprehended. They did not grow out of ruffled tempers merely, as the result of friction, but out of strictly business considerations. Kentucky had a great variety of brood mares from which they were trying to breed trotters, and practically every one of them was tricked out with more or less running blood as tail-pieces to their pedigrees, while others were paraded with pedigrees showing a dozen or more successive crosses by thoroughbred horses, and not one of them with a name, a history or a breeder. There were many purchasers flocking to Kentucky with more money than knowledge for the purpose of buying a few animals to serve as the nucleus for a breeding stud, and it was no uncommon thing for such purchasers to estimate the value of a pedigree by its length. When the purchaser got home with his stock, his next step was to send them to me for registration, and here came in the "business" consideration. The pedigree having reached the office of the "Register," unless it were already known to me, every cross had to be established circumstantially and specifically before it conld be accepted, and at the precise point where reasonable information failed the pedigree was cut off. 'The purchaser then goes back upon the seller, and there the trouble begins. He writes me an indignant letter. "You're interfering with my business, sah; that pedigree is just as I got it from Colonel Jones, sah; and he's a gentleman, sah." It was very seldom, indeed, that a man of this type could be mollified by assuring him that all pedigrees were judged by the same rule and requirement, whether they came from Maine or California or Kentucky. He generally remained an enemy to the "Register" because "it interfered with his business." From early in the century, three or four counties 
out of about one hundred and twenty in Kentucky bred running horses and grades and raced them, but no records were kept of their breeding and nobody knows with certainty to-day anything about the more remote crosses. For a time the union of two or three trotting horses upon the top of a line of nameless dams extending ten or fifteen generations was looked upon as the perfection of a trotting pedigree. This notion, foolish as it was, gave Kentucky a great advantage over the breeders of all other sections of the country, and every exposure, with the evidence, that in nine cases out of ten these lines of nameless dams were in whole or in part pure fictions, was cutting the ground from under their supposed superiority in the breeding of their trotters. Under the arguments and illustrations of the Monthly, supported by the incontrovertible statistics of the "Year Book," the Kentucky cry for "more running blood in the trotter," was silenced as the child of ignorance and prejudice, and instead of looking for pedigrees tracing back to Godolphin Arabian, everybody began to look for pedigrees that traced to individuals and families distingnished for producing trotters, no difference what blood they possessed. Here the public mind reached the truth, and in grasping it the boasted predominance of Kentucky was crushed, and producing trotting blood was again placed on an equality in all parts of the land. The loss of the pretensions of one section could not be of any specific pecuniary advantage to any other section, but the establishing of the truth was of inestimable advantage to all. The loss of mere "pretentions" would not, in ordinary affairs, be considered a very great loss, but in this instance it was looked upon as a grievous wrong, because it interfered with their "business." Every slippery fellow who failed to pass a bogus pedigree complained that it interfered with his "business." Every gang of cheats that got together and hired the use of a track for a few days for the purpose of giving their horses bogus records, when detected, cried out vigorously that this was interfering with their "business." Besides these, there were scores, perhaps hundreds, of others, ready for some such game to cheat the public, but when they learned the ordeal was severe, their courage failed and they contented themselves by threatening the "Register" for interfering with their "business." Here was an army of jockeys and cheats, and all they needed to make their numbers formidable was a leader with courage and money, and whose "business" was their own, to seize regis- 
tration and thus recoup the losses they had sustained in their "business."

In considering the conspiracy that resulted in the sale and transfer of the Wallace publications to the American Trotting Register Association, which means simply Lucas Brodhead, there are some antecedent conditions connected with these publications that need a brief explanation. The first volume of "Wallace's American Trotting Register" was published in this eity in $18 \% 1$ and the second in 18\%4. An office was opened in this city in $18 \% 5$ and the first number of Wallace's Monthly was issued in October of that year. The National Association of Trotting Horse Breeders was organized December 20, 1876. The attendance was large and many of the States were represented by men of influence and standing. Mr. Charles Backman was elected president, and L. D. Packer secretary. From the favor with which the idea of a national organization was received and from the character of the men participating in it, I voluntarily and withont judicial advice placed in the association the authority to appoint annually a Board of Censors to examine and decide all questions relating to disputed pedigrees sent for registration. The plan worked smoothly and satisfactorily for several years, in some of which there was not a single case to be examined. My publications were soon past the critical point, and they seemed to grow from their inherent strength, and not from pushing or advertising. 'The Breeders' Association seemed to take the opposite chute, and after three or four years it became merely a name. At first there was trouble in finding a man to take the presidency, but at last a rich dry goods merchant was found who was willing to take the presidency, and add five hundred dollars a year to some stake for the honor conferred; and the secretary, L. D. Packer, was the mere satellite of the president, and was willing to give two weeks' work every year for the privilege of drawing a thousand dollars a year from the treasury. The annual meetings became a mere formality, with an attendance of three or four and the two officers, who seemed to re-elect each other year after year, until the association was finally buried somewhere out in Michigan, I think, and the money that had accumulated in the treasury was, on his petition, donated to the secretary in consideration of his valuable services for so many years in carrying the association from the cradle to the tomb.

Owing to my relations to the Breeders' Association, I felt that. 
I was in honor bound to maintain its good name in the minds of the people, while every publication in the whole country was langhing at it, and that this was my duty as well as my interest until the time came for a final separation from it. True, when I made these efforts to uphold it I had to put my tongue in my sheek, for I knew that its management, like "the Old Man of the Sea," was riding it to death. As my business continued to grow and prosper, I began to consider the propriety of forming a joint stock company of breeders, to own and control the property absolutely when I was ready to retire. Greatly to my surprise this proposition gave offense to the two gentlemen who managed the association, for I had not alluded to that in any possible manner. When explained to me it became perfectly plain that the offense was in the fact that making a legal corporation to own and control the property would leave no "position" for the president, no salary for the secretary and no further need for the N. A. of T. H. B.

The Wallace Trotting Register Company, in due time, was incorporated under the laws of the State of New York, and commenced business October 1, 1889. The publications of the company were the "Register," the Monthly and the "Year Book." The capital stock of the company was fixed at one hundred thousand dollars, and as work came pouring in upon us more rapidly than we could handle it, labor became a burden and I had no time to distribute this stock among the breeders of every State, as I intended. This was the condition of things in the office in the following spring when, to my horror, I discovered I had been robbed of something over fifty-four thousand dollars and the thief escaped to Cuba. The blow was a stunner, and messages of sympathy came pouring in from all quarters, with many tenders of pecuniary assistance all of which were thankfully acknowledged, but all tenders of assistance were declined.

The capitalization at one hundred thousand dollars, and the robbery of fifty-four thousand dollars, and the company still not crushed, gave Mr. Brodhead a new view of the possibilities of the future, and inspired him with a new hope that he might yet reach the ambition of his life and gain control of the registration of all the trotting pedigrees of the country. Without much violence to the processes of Brodhead's mind we can imagine the way in which he reasoned out the problem. "This has become a valuable property and is bound to be still more valuable," he doubtless 
reasoned, "and it is possible it can be bought, but if bought it must be done before that stock is scattered among the breeders of the different States. There are Russell Allen and Malcolm Forbes and a whole lot of rich fellows just coming into the trotting horse business and I can show them that this property would be a good investment. With the money in one hand and the bluff of starting an opposition Register in the other, it is possible the property might be got for something like its value." He next. probably reasoned: "The first thing to consider here, is how to. make that bluff sufficiently imposing and effective, in an anthoritative way; and shall it be a mass meeting or a delegate meeting, and where shall it be held? I have seen Packer and he evidently wants to know what there is in it for him and Mali, in case they agree to call a National convention. They want to perpetuate their offices in their present so-called National Association. If it should be a mass convention, and held at Chicago, I could send up a few carloads of farmers' sons from around here and every one of them would swear he was a breeder. If it should be a delegate convention from State Breeders' Associations, there are several States that have no such associations, but I could get a few friends to organize for the purpose of sending delegates. The horse papers would be a unit on our side, for they have been 'set on' so often and so hard that they would like to see the old bear superseded. Beside this, every one of tbose papers has at least the one man who is competent to succeed Wallace, and every editor who has been in the business six months thinks he is fully qualified for that place. But the real roar of the shonting would come from the angry men whom Wallace has disappointed in refusing to accept their pedigrees or their performances because they were irregular. These men are very numerous and we must have as many of them present as possible. I think this plan will work," he doubtless reasoned with himself, "if we can only keep Wallace in the dark till we get things fixed, and to throw him off his guard I will send him three or four pedigrees to register."

Thus the plan of the conspiracy, with all the elements to be employed, were evidently matured in Mr. Brodhead's mind. There were two points about which he was speciaily solicitons. The first was that I should be kept wholly in the dark as to his movements and purposes, and the second was some apparently official authority for calling a convention at Chicago that wouid 
be of a nominally "national" character. On invitation Secretary Packer visited Woodburn, and for a promised consideration it was all arranged that the President and Secretary of the N. A. of T. H. B. would call a convention. With the initial step thus safely provided for, $\mathrm{Mr}$. Brodhead was everywhere, east and west, north and south, beating up recruits. In a short time, evidently by preconcerted arrangement, there was an unusual number of horsemen in town, some of them very rich men, while the greater number were blowers of the Dr. Day type with a grievance. 'The horsemen were hustled together by Secretary Packer, in what was called an impromptu meeting, and there President Mali, after some apparent hesitation, fulfilled his part of the agreement and called the convention at Chicago, and thus Mr. Brodhead secured his share-and we will see how the other side fared further on.

When the convention assembled at Chicago it was indeed a motley mass. President Mali took his place as president, and called the convention to order, and Secretary Packer took his place as secretary. This, as I understand, was not by the choice of the convention, but by virtue of their positions in the N. A. of 'T. H. B. It was eventually determined that the meeting should be composed of delegates from State associations, and when the associations were called, several of them had never been heard of before and never have been heard of since. They were bogus associations, and were gotten up especially for the occasion. Some of the delegates bore names that never had been heard of in the office of the "Register," and it may be inferred they never bred a standard horse. The names of others, again, were well known in the office from their efforts to get spurious and unknown crosses accepted. All these men were anxious for a new management. One man whom I had discharged from my office a few weeks before represented a New England State. He was guilty of a flagrant attempt at deception. He was a fawning sycophant, always laughing at his own supposed wit, and he was known in the office as "Uriah Heep." The man who dominated the convention from beginning to end had not been appointed a delegate by his own association. The whole thing, as a convention, was about as hollow a sham as was ever enacted in Chicago. Next behind the gentlemen who by courtesy may be designated as delegates, sat the moneyed men who were anxionsly looking for a good investment for some of their loose funds, and 
Brodhead had told them this property was paying twenty-five per cent. on a capitalization of one hundred thousand dollars, and he thought it could be made to pay more. Like many other fools, they thought it was a machine that when fired up in the morning would run itself. Next to the rich men sat a good sprinkling of farmers' sons, some carloads of whom had been brought from Kentucky, and all ready to swear they were breed. ers. As Brodhead explained this incident to a gentleman who stated it to me: "If there was any attempt to pack the convention he was ready to do some packing himself, with these young men he had brought from Kentucky.",

On the outside circle there was a large number of young men and some older ones watching the proceedings with great intensity. They were restless, and some of them looked hungry, and every one of them was looking for a place if the purchase went through. One had a copy of the Bungtown Bugle in his pocket containing a report of the racing at the last county fair, written by him, and he thought that was sufficient evidence that he was qualified to take charge of the Monthly. Another had made, with his own hands, as he asserted, a tabulated pedigree on a large scale and shaded the letters beautifully and artistically with pokeberry juice; and what evidence could be more satisfactory that he was qualified to take charge of the department of registration? Every one of them seemed to think that there would be a good place for him in the new deal, and hence his enthusiasm at every incident that seemed to point in that direction. Thus the little cormorants as well as the big cormorants were all anxious for the prey.

While the soreheads were wrangling over how best to get hold of my property, and what they would do with it when they got it, I had several hours in the privacy of my own apartments to look over all the conditions of the situation, and the conclusions I then reached I have never had reason to change. It, therefore, may be of interest to all to know just what I thought at that crucial period, and I will give these thoughts as contemporaneous with the event:

"This meeting is a miserable sham, but the action of Mali and Packer has given it a psendo-type of regularity as a national convention of horsemen, and this idea of 'regularity' will carry weight with many who know nothing of the bottom facts.

"The members of the press will, substantially, be a unit against 
me, and ring all the changes on 'the National convention' at Chicago, and labor to make it appear as an uprising of the horsemen of the whole country against me.

"The meeting is packed by Brodhead with his own satellites whose expenses he has paid, and embraces a good many rogues who have failed in passing upon me dishonest pedigrees and spurious records. Besides these there are several men here, and very active, whose names have never been heard of before in the horse world.

"Taking these elements together, they are in numbers more formidable than dangerous, but when led by Brodhead, with what they consider a fair price in one hand and a club in the. other, with the demand 'take the price or we'll take the property,' the occasion becomes serious.

"The latter alternative means a battle that may last ten years. Ten years ago these same people employed a man who purloined my literary property and it was found in their possession. The evidence of the piracy was so clear that it never was denied.

"Have I time enough, am I strong enough, am I young enough to enter upon this long battle? Ten years ago I was robbed of my property, but I was then vigorous and strong; one year ago another thief robbed me of my money and it was a terrific and lasting strain upon my vitality.

"The days of my years number nearly threescore and ten, so there is no time to enter upon the uncertainties 'of the law's delays.' From overwork and the anxieties growing out of family afflictions and the robbery, my health is shattered. It is time, therefore, that I should seek to rest rather than to struggle.

"And what about the work to which I have devoted the best years of a long life? Will it be attacked? Certainly it will be attacked for the reason that it does not suit Woodburn. Will it be overthrown? No, the laws of nature cannot be overthrown. The trotter can come only from the trotter and nobody but an ignoramus or a fool can doubt the truth of this declaration. The experiences of every year, of every track, and in every race confirm this central truth and will continue to do so as long as the world stands."

From the above reasonings and conclusions, when the offer of one hundred and thirty thousand dollars was made, in a business form, it was accepted.

When the property was transferred it was on the individual. 
and joint responsibility of some half a dozen rich men, and they were as gleeful and happy over their investment as though they had obtained a gold mine for a song. But, while these men were rejoicing over their acquisition, there were many others cursing the deception that had been practiced upon them by promising them places and perquisites and, in short, whatever they wanted in order to secure their adherence to the conspiracy. Of all this numerous class, Messrs. Mali and Packer had so little sense as to make the nature and terms of their agreement public, namely, that they were to be clothed with the power to annually appoint the Board of Censors for the new organization. Poor fools! they didn't know Brodhead. For a consideration of place they had betrayed a trust to him that as honorable men they should have sacredly guarded, and the more they complained the more bitterly they were condemned by all right-thinking men. Hence, after they had served his purpose he kicked them aside as he would an old shoe, and thus he punished the traitors with whom he had dealt. When the multitude of writers, statisticians, etc., who had received private assurances of "something equally as good" in the new deal, saw the fate of Mali and Packer, they had sense enough to keep their mouths shut. A man who knew anything about the trotting families and their lines of descent was not the kind of man that Mr. Brodhead wanted to put in charge of registration. The only man who could suit Mr. Brodhead was the man who would implicitly and without doubt follow his instructions, right or wrong. When Mr. J. H. Steiner was appointed Registrar it was wholly evident that this was the purpose of the proprietor, for of all the men in my knowledge, in any way connected with trotting horse interests, Mr. Steiner seems to be the most profoundly ignorant of horse history and horse lineage, and till this day he does not seem to have learned anything thereof.

At this point the public confidence received a shock from which it has never recovered, and never will recover. From that day till the present the estimate of value of the publications of the company, in the minds of breeders, has been on the "down grade," and coupled with this is the ever-obtruding doubt as to whether these publications are managed for the advantage of the general breeding public, or for the little clique of which Woodburn is the center. The lack of knowledge displayed has resulted in a profound disgust. This has been shown most con- 
clusively in the fate of the poor old Monthly. It started out under its new owners to controvert breeding history and breeding law in which the public had been thoroughly and conscientiously indoctrinated. The sham pretense of using the title Wallace's Monthly instead of Brodhead's Monthly was "too thin" to deceive any one except the most ignorant. The labored productions of the weaklings hired to overthrow the truth only tended to deepen the disgust. The price was lowered as an inducement to support, but nobody wanted the miserable thing about his house, and thus it died withont a tear except from the eyes of the rich fools who put their money into it supposing it would live and prosper in the hands of ignorant and incompetent men.

It is natural for the rich men who put their money so gleefully into this publishing enterprise, at the instigation of Mr. Brodhead, to try to get some of it back before the final smash, which is evidently not far removed, and hence the ignorant and blundering emasculation of the Year Book, in order to reduce its cost. "The Great Table," as it was called for years, embraces all others, and all others are merely subsidiary to that. This table should be restored in its entirety, for it is worth the whole of them and double as many more. With every other table thrown out and this one restored, complete, the breeders would be content. The Year Book-the great instructor of the past-I have just learned is no longer published for the breeders or for the press, but for the tracks. The operation is explained as follows: Every year the secretaries of the National and the American Trotting Associations send out by express a lot of blank books, blanks, etc., to each track in good standing and in this outfit for the year is a copy of the Year Book, which is charged at the long price. The tables of fastest records, I am told, are quite carefully made in the offices of these associations themselves, and the book is thus made a convenience for the tracks. Thus, by this system of forced loans on the tracks, the Year Book is kept alive. This method of financing the company will not last long.

A different method has been adopted in order to secure funds from registration. Money for registration must come from the breeders themselves directly, and there is no way of forcing them to put up through the manipulation of intermediary officials. Hence the plan has been tried of scaring them into it, but with what success I am not informed. At the annual meeting in 
April, 1895, I think it was, a committee was appointed, consisting of Messrs. Brodhead and Boyle, if $\mathrm{I}$ remember, to consider and report to the next meeting amendments to the standard advancing the requirements for registration, and everybody was advised to hurry in their pedigrees or they might be excluded. At the meeting in 1896 the committec did not report, but $\mathrm{Mr}$. Brodhead reported in a series of resolutions, in which the number of standard dams was advanced, which suited Woodburn exactly, but there was no advance in the time to be made, and the tin-cup record against time was carefully protected. The resolutions were adopted unanimously, and went before the breeding public as the new advanced standard that would be decided at the next annual meeting. From time to time the breeders were duly informed of the proposed advance and cautioned many times to get in while they could. The annual meeting in April, 189\%, came, and instead of a rush of breeders interested one. way or another in the proposed advance, the same stereotyped half a dozen men were there who had been manipulating the scare for two years, and not one of them, even Brodhead himself, voted for the advance. This is no advance at all, in a practical sense, and would accomplish nothing, and would do no good to anybody except Woodburn or some other establishment that like her has been breeding trotters for forty years. It was merely intended for a scare, and it failed under such circumstances as to fully disclose the object in placing it before the brceders. The scare is all out of this kind of humbug and deception, and now what? When the standard was adopted on the basis of $2: 30$ that rate of speed was sixteen seconds behind the fastest record then made. To-day if the standard were placed at $2: 20$ it wonld be about sixteen seconds slower than the fastest time now on record. But this real advance, which is imperatively demanded by all the considerations of philosophy and progress, will never be made so long as the standard is under the control of Woodburn. The reason for this is made obvious by reference to page 504, etc. Mr. Brodhead's ambition has been fully gratified, he is in full and absolute control of the registration of the country, he has completely demonstrated his incompetency for such a position, and he has the satisfaction of knowing, if it be a satisfaction, that no sensible business man on the face of the globe would be willing to pay ten per cent. of the cost for the property he now controls. 
And who will say this is not a righteous retribution for the disreputable means employed, first and last, to obtain this control?

My life-work in building up a breed of trotting horses and thereby adding many millions to the value of the horse stock of the country had been more effective than I had even hoped for. I knew that I had laid the foundation on the bed-rock of truth, and I knew that the superstructure had been honestly erected, but I did not know what a decp root my teachings had taken in the minds of all intelligent and thinking men. In transferring the property the chief source of my unhappiness was in the thought that heaven and earth would be moved to destroy what I had done and overthrow what I had taught. But I had builded wiser and stronger than I knew, and when the "featherweights" were hired to pull the house down and tear up the very roots of the seed I had planted, the people would not listen to them and nobody would read their vapid utterances. And thus the effort ended in the death of the Monthly. The harvest of thought was much nearer the reaping time when the transfer was made than I had supposed, and since then it has been ripening and ripening, and to-day if any man were heard advocating more running blood in the trotter, he would with very great unanimity be pronounced either an ignoramus or a fool, on that question at least.

But, much as I disliked to surrender my life-work to a man whose moral fiber I had tested and found brittle, the transfer was really "a blessing in disguise." It gave me rest, it gave me health, and it gave me leisure to prosecute the study of the horse of history in fields hitherto untrodden. The years thus employed in digging after the very roots of history in the libraries, at home and abroad, have glided by, affording a continuous enjoyment in the discovery of many things that are very old and yet entirely new to this generation. Very often, when the work went slowly, I thought I could again hear the quiet, sympathetic voice of a Pennsylvania Friend gently prompting me with the remark, "Thee should remember that thee is no longer a young man." And now that my long-promised and pleasant undertaking is completed, it is my very earnest wish that the thousand friends who have been waiting for it may enjoy the pleasant surprises it will furnish them as much as I have enjoyed their exhumation from the archives of long-buried centuries. 



\section{A P P E N D I X}

\section{HISTORY OF THE WALLACE PUBLICATIONS.}

\section{BX A FRIEND OF THE AUTHOR.}

Mr. Wallace's early life and education-Removal to Iowa, 1845-Secretary Iowa State Board of Agriculture-Begins work, 1856, on "Wallace's American Stud Book," publisbed 1867-Method of gathering pedigreesTrotting Supplement-Abandons Stud Book, 1870, and devotes exclusive attention to trotting literature-“ Americau 'Trotting Register," Vol. I., published in $1871-V$ ol. II. follows in 1874 -The valuable essay on breeding the forerunner of present ideas-Standard adopted 1879-Its historyBattles for coutrol of the "Register"- Wallace's Monthly founded 1875Its character, purposes, history, writers, and artists-"Wallace's Year Book" founded 1885-Great popularity and value-Transfer of the Wallace publications, and their degeneration.

THE history of the series of works known as the Wallace publications, even in the brief form here contemplated, involves in a large degree the biography of Mr. Wallace. It is indeed more than the sketch of a long and indefatigably industrious life-work. It involves as well, in the forty years of creative labor, the development of a great productive industry, and of a distinct branch of literature. Mr. Wallace's labors in the field of gathering and systematizing American horse history began at a day when there was no breed of trotters, or no trotting literature. When he laid aside active work there were both, well established and clearly defined factors in the nation's progress, and in all the years from the commencement he was the central figure in the work of establishing a breed of trotters, and incomparably the clearest and strongest force in the direction and upbuilding of a trotting literature. That is the simple truth of history, which the verdict of time will render it puerile to deny.

JoHN H. WALlace was born August 16, 1822, and reared on a farm in Allegheny County, Pennsylvania. As a boy he evinced no particular liking for farm work, but had a great fondness for reading. He was educated chiefly at the Frankfort Springs Academy, where he was prepared to enter the junur class at college. There occurred a little incident at this time that illustrates how seemingly slight a thing may change the current of a life. The then member of Congress for that district, Mr. Dickey, a scholarly man, advised Professor Nicholson, of the Academy, that if he had a young man in his institution whom he could recommend, he (Mr. Dickey) would appoint him a cadet to West Point. Mr. Wallace was selected, provided his father's consent was forthcoming. When Mr. Wallace, Sr., was approached on the subject his reply was, 
" John, I think there is some better employment in the world for you than studying the most approved methods of killing men "-and that ended the West Point incident. Young Mr. Wallace, about this time, became alarmed, however, at his then persistently delicate health, and decided to seek an outdoor life rather than one of study. In 1845 he married Miss Ellen Ewing (who died in 1891), of Fayette County, Pennsylvania, and settled on a farm at Muscatine, Iowa. Iowa was then a new country, and Mr. Wallace did much in the way of organizing the industrial and educational interests of the State. There, as related below, he began work in the line in which he became famous. With an invalid wife he returned to Allegheny in 1872; and in 1875 in company with the late Benjamin Singerly, of Pittsburg, started Wallace's Monthly at New York, which has been his home ever since. Mr. Wallace in 1893 married Miss Ellen Wallace Veech, a niece of the first Mrs. Wallace ; and since his retirement from active business he has spent his time, at home and abroad, chiefly in prosecuting investigations into the horse history of the remote periods, the results of which are seen in this, his crowning life-work.

We will endeavor here to sketch, in the abstract, the history of Mr. Wallace's publications to as great a degree as possible separately, though they cannot be entirely separated. The "Trotting Register" was an outgrowth of the "Stud Book," and Wallace's MFonthly and the "Year Book" outgrowths of the "Register," and both auxiliary thereto. The career and usefuluess of all were intertwined, yet each had its own peculiar mission, and to that extent their histories will be kept distinct.

\section{"Wallace's American Stud Book."}

During the early "fifties" Mr. Wallace, then in the prime of early manhood, was Secretary of the Iowa State Board of Agriculture, and as such had much to do with the management of State fairs. He was thus frequently called upon for information about the pedigrees of animals, and the need of an authority on horse pedigrees was pointedly and constantly forced upon his attention. If the pedigree of a cow was asked for he had only to turn to the "American Herd Book" to find it, but when the breeding of a horse was wanted there was no authority to which to turn. Mr. Wallace had been dabbling more or less in such horse literature as there was at that day, and in $\mathbf{1 8 5 6}$ began collecting information with the ultimate purpose of publishing a stud book of thoroughbred horses-for the thoroughbred was then here, as in England, supreme as the only horse of literature. He already possessed certain of the publications that were the best horse authorities of the day-a file of the Spirit of the Times, Skinner's American Turf Register and Sporting Magazine, and a number of volumes of the "English Stud Book," and English Sporting Magazine. Added to these, later, were other sources of information and misiuformation most notable in this latter class being the alleged "Stud Book" published by Patrick NesbittEdgar, of North Carolina, in 1833-an utterly unreliable 
work, but the only American stud book in existence prior to Wallace's. From these, and every other available source, Mr. Wallace began to glean and systematically compile the pedigrees of thoroughbred and so-called thoroughbred horses. Of these sources by far the most valuable was Skinner's periodical, begun in Baltimore in 1829. Novice as he was at the time, Edgar's work was regarded with more than suspicion by Mr. Wallace, and, as a matter of caution as well as of honesty, whenever he borrowed pedigrees from Edgar they were so credited.

Modern methods of investigating pedigrees were not dreamed of by our compiler then. His principal aim seems to have been to get as large a collection as possible, and whatever was found in print, whether newspaper, book, or hand-bill, was taken for granted; and pedigrees gathered from private sources were, like the others, submitted to little scrutiny. Neither men's motives nor their knowlerge of what they represented to know were questioned, and in this way, after years of labor, a great mass of pedigrees was gathered, written in new form and order, and the thoroughbred stallions numbered-which was the first instance of numbering horses in registration. While compiling the thoroughbred pedigrees, Mr. Wallace also incidentally seized upon such information as he found about trotting pedigrees and records, and these he arranged as an appendix to his work. Finally, in 1867, "Wallace's American Stud Book," a great, handsome volume of 1,017 pages, bound pretentiously in green and gold, was published in New York.

The trotting supplement embraced about 100 pages, and that the editor was pretty well satisfied with it is shown by a sentence in the preface: "It is believed that this compilation of trotting horses, embracing over 700 animals, is very nearly perfect, but it is not claimed to be entirely so." of course, from the method of its compilation it was decidedly imperfect, but it was the best and only compilation of trotting pedigrees up to that time.

Meanwhile Mr. Wallace was pushing forward the compilation of the second volume of the "Stud Book," and in this traveled much, making personal investigations. In 1870 this was completed, all the ground up to that year having been gone over, but in the course of the work "a great light" began to dawn upon the compiler. He found that he had been proceeding on a wrong plan entirely. Experience in compiling and investigating taught him that a pedigree may be printed in a newspaper, or even in a book, and still not be true. Hediscovered that the sources from which he had drawn were largely unreliable, that hundreds of pedigrees, through ignorance or dishonesty, or both, were fabrications and frauds, especially in their extensions in the maternal lines, and with the realization in full force of this knowledge came the determination, even though the last page of the manuscript for the second volume of the "Stud Book" was complete, that it should never see the light.

At the same time Mr. Wallace had discovered that the trotting sup- 
plement was the part of his "Stud Book" most used and appreoiated. He saw that the trotter was coming to be the horse of the American people, and that there was a great and new field opening in which a literature had yet to be formed. His experience with the "Stud Book" gave him the training necessary for the work before him, and thus equipped, with little capital outside of his newly acquired knowledge, and marvelous natural industry and perseverance, with an unusual capacity for hard work, he turned in 1870 to the work before him-the literature of the trotter.

\section{"WALlace's American Trotting Register."}

He had as a nucleus the supplement to Volume I. of the "Stud Book," added to which was the work done and knowledge gained in compiling the second volume, together with an increasing library and written data. Thus in incidentally adding a few pages of trotting pedigrees to his "Stud Book," Mr. Wallace had builded better than he knew, but he even now had little conception of the extent and richness of his new field of exploration. He traveled all over the country, levying upon every source of information for his "Trotting Register;" but, taught in the dear school of experience, depended chiefly upon personal investigation, taking monthly and yearly less and less for granted. He gradually became more trained in meeting the natural human fondness for embellishing, extending and completing pedigrees without reference to fact or evidence, and the equally common predilection for stating as known facts those things concerning pedigrees that were only of common report. This work was excellent training for the more extended duties of the future, and it gave $\mathrm{Mr}$. Wallace an insight into methods of the olden time, and a knowledge of men and horses that later made him, backed by uncompromising honesty, absolute fearlessness, and a quite unusual disregard for "policy," a "terror to evil-doers" in the realm of manufacturing in whole or in part fraudulent pedigrees.

Still the knowledge, the caution, the system that made it almost impossible in the last years of Mr. Wallace's administration to impose a fraud upon the "Register" were of slow, gradual, but constant growth. The work improved with every volume, with every year of experience, and the evidence that would be accepted in the compilation of the early volumes would not suffice later. Mr. Wallace had also the quality of just as remorselessly overthrowing his own errors as those of others, and thus a system of correction was continually going along, in which work Wallace's Monthly, founded in 1875, was a particularly effective agency.

The first volume of the "Trotting Register" was published in 1871, and was a neat book of 504 pages. It contained, besiles the pedigrees gathered, tables of all trotting and paeing performances up to the close of 1870 , and this was the first time in which the records of the trotting turf were 
collected and published. This part of the work entailed a vast amount of research, including a tholough review of all sporting papers, annuals and other sources where contemporaneous record of racing would be liable to be made, but it was a very valuable feature; and, besides serving as a basis for $\mathrm{Mr}$. Wallace's future compilations, was unscrupulously seized upon by imitators who, from time to time, sought to publish " record books."

There was also an introduction to the volume entitled, "An Essay on the True Origin of the American Trotter," which showed a glimmering of understanding of the truths of history and of breeding as now understood by students well grounded in the subject. In the second volume, however, was an essay that marks an epoch in the literature of breeding. Written less than three years after the introduction to Volume I., it betrays the fact that in the intervening years the author had risen suddenly and broadened infinitely in his study of the science of breeding, and his understanding of the application thereto of the facts of trotting history. It advanced then entirely new views, and it was the first article published, as $\mathrm{f} \approx \mathrm{r}$ as the writer is aware, that rose to an appreciation of the supremacy of biological laws in horse breeding, and suggested such a thing as psychical heredity in the transmission of habits of action. It originated the term "trotting instinct," so generally used thereafter, began the discussion of the problem of the increasing number of fast trotters from pacing ancestors, and wound up with ten sound propositions or conclusions based throughout on the law that like begets like. It opened up new and endless lines of investigation and thought, and at once elevated the discussion to a scientific plane. This article, written by $\mathrm{Mr}$, Wallace originally for the Spirit of the Times, marked the advent of the school of thought on breeding now almost universal.

The second volume of the "Register" was published in 1874, and the third in 1879. The first three volumes of the "Register" contained about 10,000 pedigrees, and the statistical tables in the second and third volumes were greatly improved and amplified over those in the first. Volume II. gave a table of sires of 2:30 horses, with the number to the credit of each sire, and the number of heats to the credit of each performer-a sort of vague foreshadowing of the famous "Great Table of Trotters under their sires," later to be conceived and developed by Mr. Wallace, and destined to become the most valuable single trotting compilation yet designed, and the one now universally used, adopted and imitated. This volume also gave a table of 2:25 trotters to the close of 1873, arranged in the order of their speed. The first table of trotters under their sires was published in Wallace's Monthly, covering the statistics to the end of $\mathbf{1 8 7 \%}$.

The third volume was much larger than its predecessors. The industry of breeding trotting and pacing horses was, under the stimulus of the "Register" and Wallace's Monthly, and other agencies with which Mr. Wallace was identified, and of a general era of prosperity then dawuing, advancing and extending now at rapid strides, and about this time certain 
events of almost inestimable influence on the future of the business transpired.

In the autumn of 1876 there was formed at New York the National Association of Trotting Horse Breeders, an organization in which $\mathrm{Mr}$. Wallace's influence predominated from its inception until a short time before its dissolution, for lack of an excuse for existence. This organization was broadly representative of the best elements in the breeding business in its virile and useful days, and accepted a sort of advisory and supervisory control orer the "Trotting Register;" and Volume III. and subsequent volumes were compiled under its authority. Questions of disputed pedigrees and other such issues affecting breeding and the record of pedigrees were decided by a Board of Censors appointed by this association; and, aside from its usefulness in connection with the "Trotting Register," it contributed largely to the advancement and encouragement of breeding by inaugurating colt stakes, and other stakes designed more especially to attract the breeder than the professional campaigner.

Before the third volume was through the press the need of some measure for restricting registration became apparent to Mr. Wallace. The economics of the "Register" demanded it, but beyond this the need of systematizing and establishing a specific breed called for some definition as to what rightfully belonged to that breed. Up to this time the only rule was the indefinite provision that "anything well related to trotting blood" might be acceptable as eligible by the compiler of the "Register." The problem that confronted those who took a broad and comprehensive view was to edncate public opinion up to that point where the possibility of establishing a breed of trotters would be appreciated. As early as April, 1878, Wallace's Monthly strongly urged the necessity of a standard, and this was the first suggestion of one that had been made. At the November meeting of the National Association of Trotting Horse Breeders that year the Board of Censors in their report presented a letter from Mr. Wallace advising the adoption of a standard, a recommendation which the Board indorsed. Meanwhile the matter was being agitated and discussed in Wallace's Monthly, and affairs were gradually shaping for action. In the March, 1879, number of the Monthly a standard formulated by certain Kentucky breeders and forwarded by Major H. C. MeDowell was printed and commented upon. It was fair on its face, but under discussion its weak points were made clear. For instance, its fourth rule made standard "Any mare the dam of any mare or stallion that has produced or sired a horse, mare, or gelding with a record of $2: 30 . "$ It was pointed out that nnder this rule the celebrated English thoroughbred mare Queen Mary would become a standard trotter, for her son, the race horse Bonnie Scotland, had sired the trotter Scotland. As other provisions made the sisters and brothers of standard animals standard, the defects of the Kentucky standard were made patent, and the Breeders' Association failed to approve it. Instead, at a meeting at the Everett House, New 
York, Norember 19, 1879, the standard as printed on pages 519-20, in the framing of which Mr. Wallace and General B. F. Tracy did the active work, was unanimously adopted.

Under this standard the work of compiling Volume IV., which involved bringing forward animals registered in preceding volumes, that met its requirements, and numbering stallions, was carried on.

Meanwhile, some Kentucky gentlemen failed to acquiesce in the standard decision, and had, or believed they had, other grievances against the compiler of the "Register." They proceeded to plan to control the "Register," but as in the last chapter of this work Mr. Wallace gives full details of this and subsequent battles for the control of registration, this history need not be here repeated.

In the meantime the breeding interest was enjoying remarkable prosperity, and this was reflected upon and through the "Trotting Register" and Wallace's Monthly. In 1882 Volume IV. was published, Volume V. in 1886 , and Volume VI. in 1887 , these containing about 6,000 pedigrees each. Volume VII. appeared in 1888, Volume VIII. in 1890, and Volume IX., the last published by Mr. Wallace, appeared in 1891.

While an adequate discussion of the standard is neither necessary or possible in this article, it was so obviously part and parcel of the "Trotting Register" that its history must be briefly outlined. The standard formulated in 1879 served its purpose well, but it was but an initial step, and it was fully recognized by Mr. Wallace at the time that it would have to be revised and strengthened from time to time so as to keep pace with the progress of the breeders. If the standard to-day is held in slight esteem, or even in contempt, it is clearly because it has been allowed to lag far behind the progress of the breed.

Evils grew out of the standard, even in its early years, simply through a quite general misunclerstanding of its purposes and its full meaning. Standard rank became instantly so popular and so sought after that thousands of breeders aimed solely to breed into the standard, without much regard for other necessary qualifications. They seemed to forget that it was merely a definition of the blood that was eligible to the "Register," and not, nor ever intended, to be taken as a general measuring stick of value. Soon after its adoption an era of great prosperity came in trotting affairs, with recklessly high prices for standard animals. With an apparently insatiable market there came an abnormal expansion of the industry. Thousands of men began breeding without knowing anything, either practically or theoretically, about the industry, except how to get into the standard. Hence the overproduction of not only standard trotting horses, but all kinds of trotting horses of inferior breeding and little excellence, and the subsequent break in prices, for all of which the standard has been by inconsiderate persons blamed.

Not long after its adoption Mr. Wallace saw these dangerous tendencies, and in the Monthly warned the breeders against them, and early began 
agitating for a revision of the rules. But nothing could stem that rising tide, and at first the opposition to any change in the rules was rehement and general. The obviously easy gateway into the standard was through rule seven, and this became the storm center of the discussion. Mr. Wallace led in the call for the abolition of ( his rule, and did it so persistently and well that gradually the leading breeders and thinkers were won over, but the outcry against a change was so earnest and so general among the smaller breeders that the National Association hesitated long. Though a Committee on Revision was appointed as early as December, 1885, it was not until December 14, 1887, that a revision was finally effected, the standard being then adopted as printed on pages 520-21.

Every reader can observe, by comparison with the previous standard, that there was a wise and conservative strengthening of the rules all along the line. The next step contemplated by $\mathrm{Mr}$. Wallace was not only a further restricting revision on blood lines, but also an increase in the speed rate required, an advance from $2: 30$ to $2: 25$, then ultimately to $2: 20$, his purpose being that the standard should keep pace with the progress of the breed. But before any of these steps were made the "Register" passed into other hands-and other theories and practices have prevailed, with the result that the standard is to-day held in derision and the value of the "Register" has sunk to the vanishing point. But before reaching this phase of our history some account of Mr. Wallace's other publications is in order.

\section{"Wallace's Monthly."}

At a very early period in the history of the "Trotting Register" Mr. Wallace perceived the necessity of there being some medinm of communication with the breeders which he could control. This was one of several reasons, which need not here be detailed, the outcome of which was the establishment of the publication which has played a greater part than any other in developing tue trotting literature of to-day, and in leading American thought on the science of breeding-Wallace's Monthly. The first number came out in October, 1875, with Benjamin Singerly, publisher, and John H. Wallace, editor. Mr. Singerly was an uncle of Hon. William II. Singerly, of the Philadelphia Record, and had large printing establishments in Harrisburg and Pittsburg, Pa. The first twelve numbers of Wallace's Monthly were printed in Harrisburg, though published from the outset from New York. Benjamin singerly died in August, 1876, from which time Mr. Wallace carried on the publication himself, from the little office at 170 Fulton Street, overlooking St. Paul's chur'chyard.

In accordance with the time-honored custom in journalism, the first number of Wallace's Monthly contained a salutatory outlining its purposes and its policy, and in almost every detail that policy was honestly lived up to while Mr. Wallace controlled the magazine. The horse was to be made the leading, but not the exclusive feature; full trotting and running summaries 
with indexes were to be published; correspondence was invited; and, as a cardinal principle of poli:y, gambling in any and all forms was to be uncompromisingly fought against. This last detail of policy Mr. Wallace rigidly adhered to always. He opposed public betting in any form and Inder any pretense, and believed, and acted up to the belief, that if racing could not be maintained without betting it were better that grass should grow on the tracks. The first number of the Monthly contained a descriptive article by "Hark Comstock," and some selected matter, but was chiefly the editor's work-mostly concise historical matter, dealing with the early progenitors of the trotting breed.

With each number the Monthly strengthened, until soon it had gathered around it the brightest writers in the country. Notwithstanding this, however, the editorial department was always its strongest feature, and it rapidly became a power in the lan!l. Among the earliest contributors were "Hark Comstock" (Peter C. Kellogg), always a fluent writer, and one of the most versatile special pleaders on horse topics known to the turf press; Charles J. Foster, the gifted "Privateer," whose work, from a literary standpoint, was oftentimes a model of finish; "Yah Amerikanski" (Spencer Borden), and "S. T. H." (S. T. Harris), both brilliant, especially in controversy; H. T. Helm, Levi S. Gould, and many others prominently known in turf literature a quarter of a century ago.

Spirited controversy early became a feature of the Monthly, and in these passages-at-arms the editor was generally found taking a leading hand. As a writer Mr. Waliace was always above all things forceful. He fortified himself in theory and fact amply, and his style was so direct, yet compre. hensive, that every shot told, and even those who disagreed with him were forced to read and admire these spirited discussions. Mr. Wallace moreover early impressed the public with his uncompromising honesty, and with the fact that, above all things, he had the courage of his convictions. There was no dodging issues, no dallying or compromising with humbug of any sort; a spade was called a spade, and no consideration of "policy" brought a note of indirection into the Monthly's editorial pages. The personality of the editor was ineffaceably stamped on his magazine, and its influence became potent for good far beyond the limitations of mere circulation.

The magazine became quickly the leader in thought on breeding subjects, and hardly an advanced idea that to-day prevails in this field of literature but can be found first suggested in the Monthly. The first taple of trotters under their sires was published in Wallace's Monthly for 1877; the standard was first suggested in its pages; the pacer as an origin of trotting speed was first advanced in February and March, 1883; it was the first to formulate and adrocate and put to the test a scale of points for judging horses; and above all it was the power that educated breeders to an understanding of breeding on truly scientific principles, and brought about an acceptance and appreciation of the laws of heredity as applied to 
breeding the trotter. And, interspersed with this continual seeking for the light and the right, there was an amount of historical matter published that would make the compilation of a valuable book on the American trotter possible from the Monthly alone. It was, moreover, continually exposing frauds of history and of pedigrees, and was as potent in guarding as it was in discovering the truth. It was the recognized enemy of fraud, of humbug, of false pretense everywhere, and attacked them in high places as well as low, and that its editor incurred the enmity of many whose designs attracted the Monthly's searchlight, and were thwarted by it, is a fact known of all men.

This, in brief, was the character of the Monthly from its foundation, until it passed out of Mr. Wallace's hands. To follow its detailed bistory through the nearly sixteen years of Mr. Wallace's editorship is not the purpose of this article, but the rather to group the salient factors that made it what it was, and that have secured for it an enduring place in trotting history.

The Monthly was from the first illustrated, and the progress in horse art is well demonstrated by tracing through its pages. Its first drawings were made by James C. Beard, who came of a race of artists, but whose attempts at horse portraits were wretched caricatures, one and all. Still, they seemed to be the best, or rather the least bad, then obtainable. Mr. Wallace, howerer, was painfully cognizant of the lack of truthful portraits of horses, and was not less delighted than surprised when, one September day in 1878, a young man came into his office, and exhibited drawings that were so obviously truthful portraitures that they were a revelation in horse art. A rapid questioning as to whether he had drawn them, and where he had hidden his light so long, developed that the young genius was Herbert S. Kittredge, of Pennsylvauia. He was immediately engaged, and his work in the Monthly was the first reputable horse portraiture in American literature. This gifted, self-educated genius died in May, 1881, long before his prime, and when his powers were daily developing. He was the forerunner of Whitney, Dickey, Morris, and others whose ability to faithfully portray horses is acknowledged to-day. $\mathrm{He}$ had not the mechanical aids-notably the camera-or processes which they so freely call into play, but in true artistic ability to draw faithfully, it is doubtful whether this undeveloped master was the inferior of any artist who has yet made horse portraiture a specialty in any country.

From year to year the contributory staff of Wallace's Monthly increased, and always had in its membership a number of the leading breeders and students. For many years Mr. Wallace did practically all the editorial work himself, as in fact he did the registration work. But this gradually outgrew him, and soon his office staff began to increase. First he removed the office to 212 Broadway, not far from its first location. Then in May, 1887, the final move was made to commodious offices in the Stewart Building, at Broadway and Chambers Street, when the office staff had grown 
until more than a dozen assistants were employed on all the publications.

Among the earliest editorial assistants on the Monthly was C. T. Harris, later trotting editor of the Spirit of the Times, aud still more recently of The Horse Review, a faithful and conscientious worker. Later Gurney C. Gue, a clever writer, and exceptionally well grounded in facts of pedigree and record, occupied a desk with the Monthly, and is now one of Mr. Dana's "bright young men" on the Sun. In 1886 Leslie E. Macleod became associate editor, and continued in that capacity until 1890 . He subsequently became managing editor of The Horseman, and later editorial writer of The Horse Review.

Of contributors, among the best known may be named, in addition to those enumerated as identified with the Monthly at the start, General B. F. Tracy, Allen W. Thompson, Samuel Hough Terry, "Mark Field" (Jas. M. Hiatt), "O. W. C." (O. W. Cook), Thos. B. Armitage, "Mambrino" (H. D. McKinney), Otto Holstein, "Bill Arp," "Aurelius" (Rev. T. A. Hendrick), A. B. Allen, "Fidelis," Harvey W. Peck, Benjamin W. Hunt, "Roland" (Leslie E. Macleod), Major Campbell Brown, F. G. Smith, Judge M. W. Oliver, Prof. Chas. T. Luthy, Colonel F. G. Buford, John P. Ray, "Vision" (W. H. Marrett), H. C. Goodspeed, and others.

The last number of Wallace's Monthly issued under Mr. Wallace's editorship was published in July, 1891. It then passed to the American Trotting Register Company, at Chicago, and its degeneration was rapid, and in a few months it died for lack of brains. Robbed of its virility and of its purpose, without editorial direction, and aiming only to lead a harmless existence, and to say or do nothing to offend any one of a score of directors and hundreds of stockholders, it soon began to lead a useless existence, and dropped out of the notice of thinking men. It became the antithesis of all that it had been, and its end was a pitiable one for a publication with a history of sixteen years of fearless, honest, able direction.

\section{" Wallace's Year BoOK."}

Early in the history of the Monthly Mr. Wallace decided to drop running summaries, and give exclusive attention to trotting and pacing statistics. These grew so rapidly that they soon became burdensome, and an outlet became inevitable. Furthermore the adoption of the standard, depending as it did on records of performances, necessitated for its application a bureau of statistics, and these considerations and others-not the least of which was the recognition of "a long-felt want"-prompted Mr. Wallace to start "Wallace's Year Book." The first volume of this valuable annual was published in May, 1886, covering the performances for 1885, and contained, besides summaries of all races in which a heat was trotted in 2:50 or less, a 2:30 list for the year, and the Great Table of Trotters under their sires. The book contained 273 pages, was bound in flexible cloth, and sold at $\$ 1$. 
An improvement of the greatest value and importance was made in the Great Table in the first volume of the "Year.Book." This was the addition after the list of performers under each sire of the names of his sons that had sired performers, with the number to the credit of each, and of the performers out of his daughters. It furnished at a glance what a horse had done, not only of himself, but through his sons and daughters, and the Great Table thus improved became at once the gange of trotting blood by which breeders everywhere estimated the comparative values of the different families and different sires. It was the most clear, condensed, yet comprehensive and perfect summing up of all the facts and experiences of trotting history imaginable, and so apparent is this fact that nothing originai has ever been attempted to replace it, while all compilers, without exception, imitate it. The Great Table of itself would have carried any book to success.

The second volume of the "Year Book," 330 pages, contained in addition to the same class of matter as its predecessor, tables of sires and dams, great brood mares, and fastest records. Still further improvements were made in every year. Volume VI., published for 1890 , was a handsomely bound book of 642 pages, with summaries of all races in which heats were trotted or paced in 2:40 or better, list of best records slowcr than 2:40, complete 2:30 lists with extended pedirrees, the Great Table with the pedigrees of the sires extended, list of $2: 20$ trotters according to records, list of 2:20 trotters under their sires, list of great brood mares, sires of dams, mares the dams of producing sons or daughters, tables of fastest records, champion trotters from 1845 to 1890 , champions at all ages from yearlings to five-year-olds, champion stallions, table of 2:20 pacers, and of 2:30 pacers under sires. No such comprehensive and raluable mass of statistics was ever arranged, and this volume was in itself a perfect encyclopedia of trotting literature.

No eulogy of the "Year Book" is necessary, for every farmer's boy knew before it was three years old that it was indispensable to all horsemen. It instantly bounded into a place of authority, and to thousands who felt the "Register" out of reach it was at once "Stud Book" and "Racing Calendar," and none of Mr. Wallace's creations performed a wider public service, or attained a popularity so broadcast and sudden. The new work was peculiarly fortunate in having back of it the authority of the "Register," and the prestige of a name that had already become world-wide as rendering everything it bore authoritative-but even allowing for these advantages the quick popular indorsement of the "Year Book" was an eloquent testimony to the wisdom of its plan.

\section{Conclusion.}

The Wallace Trotting Register Company, with a capital of $\$ 100,000$, was organized in 1889, and October 1, of that year, all the publications be- 
eame the property of this company. The last chapter of this book details the final transfer to the American Trotting Register Association in 1891.

With the fortunes of the Wallace publications since that transfer it may be, perhaps, questioned whether this sketch has anything to do, and yet it would seem incomplete without the sequel. As already stated, Wallace's Monthly degenerated to nothing and died. The "Year Book" has been emasculated until it is but a shadow, incomplete and unsatisfactory, of what it was, and is notoriously published at a loss. Its once great tables are cut from their compl te state to be merely the tables of a single year, and where one complete "Year Book" was in the Wallace régime the only hand-book necessary, now the student must rummage through half a dozen, more or less, to ascertain the simplest series of facts. The standard has been mismanaged, revisions have been made and rescinded, and no advance has been made in the speed qualifications, though 2:20 trotters are as common to-day as 2:30 trotters were in 1891. In consequence, registration has fallen away, and from being a good purchase at $\$ 130,000$ in 1891 , the "Register" properties to-day are rated so dubiously far below par as to make the expression of their value in figures hardly possible. That a period of "hard times" came shortly after the purchase of the "Register" is true-but the practical wrecking of the Wallace publications cannot be accounted for solely on the theory of business depression.

Such in brief outline has been the story of the founding of these works, which in their own upbuilding helped incalculably to upbuild one of the nation's great industries. The present works may be destroyed or pass away, but the true Wallace works cannot. Mr. Wallace's works have a place in horse history, secure, unique, alone. Created, we might say from nothing, they each and all grew and prospered in his care and guidance, and became powers for good and auxiliaries of industry. If he is a benefactor who causes two blades of grass to grow where one grew before, how much the more is he whose labor and genius have enriched ten thousaud farms, and been the most potent single influence in developing a productive industry the extent of which can only be estimated in millions. Mr. Wallace's works will live after him. In speaking once on the transient nature of fame, a distinguished lawyer, a man of national reputation, said: "After I am gone I will be remembered as a successful lawyer among many other successful lawyers, but Mr. Wallace's name will live as long as a horse exists on the earth." We rarely judge contemporaries justly. It needs the softening perspective of time in which to lose the dimming prejudices of the present; and however much these works may be appreciated to-day, their true worth, what they accomplished, and the productive, genius, purposeful industry, and plain, consistent honesty from which they were evolved will only be clearly seen and fully conceded by the historian of the future. 



\section{INDEX.}

Aaron Pennington, 451, 452

A bdallah, 20, 237, 261, 267, 275, 311, 316, 332, 336, 389,414

Abdallah (Alexander's), History of, 272, 294, 296, 297, 298, 299.

Abdallah Chief'(Roe's), 311.

Abdallah, History of, $255,261$.

Abdallah Mambrino, 299.

Abdallah Pilot, 297.

Aberdeen, 275, 311, 414.

Abiri (strong borses), 39

Abraham in Egypt, 36.

Acquired Characters and Instincts, 471.

Acrelius, Rev. I., Colonial Writer, 137, 179.

Ada C., 443.

Adams, L. B., 266.

Adams, R. M., $382,383$.

Adams' Stump, 359.

Adams, Zach., 349.

Administrator, 275 .

Adrian Wilkes, 288

Adval, Johannes, 28

Advance of Standard, 523, 524 .

Advertiser, 493.

Aguilillas, 472 .

Albert W. 293

Albion, 295,451 .

Alcantara. 288.

Alcyone, 288.

Alderman. 450.

Aleppo, 59, 410 .

Alexander, A. J., 526, 530, 532 .

Alexander, R. A., 295, 296, 343, 350, 415, 416, 417, $420,421,422,458,506,516$.

Alexander, J. J., 432, 434, 436.

Alexander's Abdallah. (See Abdallah, Alexander's.)

Alexander's Edwin Forrest. (See Edwin Forrest.)

Alexander's Norman. (See Norman.)

Alexander's Pilot Jr. (See Pilot Jr.)

Alfred (Imported), $343,41 \%$.

Algeria, 44.

Alix, 306, 47\%.

Allen, A. B., 557.

Allen, A. B. \& L. B., 399

Allen, Philip, 349.

Allen, William Russell, 538.

Allerton, 288 .

Allerton, Isaac, 110, 121.

Allie Gaines, 299

Allie West, 299.

Alley, 302 .

Almack, 20, 237, 259, 344.

Almonarch, 299

Almont, 304, 463.

Almont, History of, 297 .

Almont Jr. (1764), 299.

Almont Jr. (1829), 299, 407.

Almont's Leading Sons, 299.

Altamont, 299

Ambassador, 288

Amble, The, $15 \%$. 158, 159, 160, 161, 162, 163, 192 Ambling Horses, 157, 158, 159, 160, 161, 162, 163 . 192
Ambulatura, The, 157.

"America Dissected," Extract from, 176

American Commander, 243.

merican Eclipse, 318, 334, 363, 432, 446, 447, 448, $449,450,488$.

American Eclipse, Pedigree of, 446-450.

American Girl, 286.

American Hiatoga, 365

American Native Race Horses, 96, 105.

American Pacer and Relation to American Trotter, $172-189$

American Race Horse, Origin of, 92, 96-105, 106.

American Race Horse, The, \&, 42, 90-10\%.

American Saddle Horse, 190-195

American Star (Seely's), 303, 308, 311, 312, 338, $339,340,341,503$

American Star (Conklin's), 341.

American Star Family, 338-341.

American Star (Seely's), History of, 338-341.

American Star's Services, 340 .

American Stud Book (Bruce's), 104.

American Stud Book. 'See also Wallace's American Stud Book.

American Stud Book (Wallace's), 101-104, 459.

American Trotting Register, 390, 412, 459, 460 .

American Trotting Register Association, 536$545,557-559$

American Turf Register, 97.

American Wild Horses, 196-204.

Amy, 313.

Ancestors of Messenger, 205-221.

Anderson, John, 438, 439, 443.

Andrew Jackson, 327, 329, 336, 498.

Andrew Jackson, History of, 323-325.

Andrew Jackson, Jr., 32\%.

Andrus Horse, 265

Andrus, Mr., 265.

Andy Johnson, 329

Angelica Mare, 413

Anglin, Timothy, 501, 505.

Anteeo, $\therefore 93$.

Anteros, 293.

Anterolo, 293

Antiquity of American Racing, 90

Antiquity of Narragansett Pacers, 180 Antiquity of the Pacing Horse, 16, 154-171, 180 ,

Antiquity of Trotters and Pacers, 481.

Arab Rarb, 93

Arabia (see also Arabia Felix, Arabia Deserta, and Yemen), 2, 5, 39, 40, 41, 42, 43, 44-95.

A rabia (no horses at Christian era), $27-42$.

Arabia Deserta (see also Arabia), 4, 40, 55.

Arabia Felix (see also A rabia. Arabia Deserta, and Yemen), 2, 4, 42, 43, 55 .

Arabia, First Horses in, 28 .

Arabian Blood (see also Arabia, etc.), 167, 168

Arabian Horse, The, 51-66.

"Arabians," so-called (imported), 93, 94, 95. Arabian Horse. (See Arabia, Arabia Deserta,

Arabian (Lindsay's). (See Lindsay's Arabian.)

Arab Horses, A. Keene Richards', 64, 65, 66 .

Arabian Traditions, 5, 455. 
Arab Horses, President Grant's, 64.

Arab Horses in America, 64, 65, 66.

Arabs (English Foundation Stock), 68-72.

A rabia. Wild Horses of, 26.

Ararat, $11 t ., 28,32$.

Aratus (by Director), 35̃.

Aratus (Phare's), $35 \%$.

Aratus (Pugh's), 356.

Alcher, 402.

Argyll, Captain, Raids Port Royal, 142.

Arion, 292, 294, 47\%, 493.

Armenia, 2, 3, 28, 29, 30, 32, 33, 34, 39.

Armenian Kings, 29

Armitage, Thomas B., 557.

Arnold, Azariah, $236,260$.

Art in Portraying Horses, 556.

Amazonia, 20,25\%, 259 .

Appendix: History of the Wallace Publicacations, 54 -559 .

Ashford, W. H., 151.

Asia Minor, Eastern, 30.

Asia, Western, 32.

Assyria, 39.

Astor, Henry, 229.

Athamo, 294 .

Atkinson, William, 248.

Atlantic, 299.

Auburn Horse, 346.

"Aurelius," 55\%.

Australian (Imported), 420.

Austin. G. A., 265.

Ayers, E. W., 501.

Ayres, F. J., 350.

Axtell, 288

Azote, 294 .

Babcock, Mr., 313

Backus, Scobey \& Burlew, 345.

Backman, Charles, 283, 289, 290, 291, 413, 414, $415,501,503$

Badger (Imported), 95.

Bad Qualities, Heredity of, 478.

Bagg \& Goodrich, 360.

Bailey Brothers' English Racing Register, 83.

Baker, I. V., Jr., 382.

Balch, Wesley P., $35 \%$.

Bald Chief. (Fee Bay Cheif.)

Bald Galloway, 84, 85, 163, 213, 410.

Bald Stockings (Tom Hal), 358, 359 .

Baldwin, B. H., 382.

Banerof $\tau$, Historian, on Wild Horse, 201.

Barbs (English Fouvdation Stock), 68, 72, 80.

Barbs, 81, 82, 85.

Barker, Henry L., 350, 362

Baronet (Imported), 334, 447.

Baronet, 259

Baron Wilkes, 288.

Barnes, Mr., 150.

Barss, 392, 395, 396.

Bartlett's 'Turk, 346.

Bashaws, 21 .

Bashaw (Iniported), 92

Bashaw (Green's), 282, 283, 327, 469.

Bashaw Jr., 308.

Bashaws and Clays, 321-337.

Bassinger, 432. 436 .

Bathgate, A., 151

Bay Chief, 295.

Bay Chief, Pedigree of, 418

Bay Kentucky Hunter, 362.

Bay Messenger (Downing's), 316.

Bay Morgan, 364 .

Beard, James C., Artist, 556.

Bear Grass, 342.

Beautiful Bay (True Briton or Traveler), 367763 .

Beautiful Bells, 297, 332.

Beck, 348.

Beckwith, Mr., 282.
Belgrade Turk, 69.

Bell Bord, 292.

Bell Boy, 293 .

Belle (dam of Green's Bashaw), 276, 283,

Belle (dam of Belmont). 299 .

Belle (by Top Bellfounder), 335 .

Belle Brandon, 313, 314 .

Belle F., 311.

Belle Loup, 299 .

Belle Rice, 313

Belle Strickland, 502.

Belle of Wabash, $432,434,435,436,437$.

Bellflower, 294 .

Bellfounder (Imported), 282, 335.

Bellfounder Family, 396, 397, 400, 401.

Bellfounder (Brown's), 299, 399,

Bellfounder (Kissam's), 399.

Bellfounder (La Tourett's), 400.

Bellows, John, 3\%7, 380.

Belmont, 297, 298, 299.

Belmont's Leading Sons, 300.

Benedict, James IV., 294

Beuger, Thomas, 224, 225.

Ben Higdon, 355.

Ben Hur, Famous Pen Picture from, 66.

Bennett \& Jones, 437.

Bertrand, 437.

Bet, 353.

Bett, 346.

Betty Bloss, 402.

Betsy Baker, 23\%.

Betsy Ransom, 334

Beuzetta. 283, 305 .

Beverley's History of Virginia, 111.

Bidwell, George, 433.

Big Mary, 502.

Big Shakespeare (Probasco's), 355.

"Bill Arp." 55\%".

Billington, $11 \%$., 150.

Billy Duroc, 345 .

Bird, 345 .

Bishop, Isaac, 234

Bishop's Hambletonian. (See Hambletonian.)

Bitugue Horses (Russian), 393, 394.

Black and All Black, 261 .

Black Arab Barb, 93 .

Black Bashaw, 322

Black Hawk, 349, 376, 377, 381, 433, 498.

Black Hawk Family, 366, 389 .

Black Hawk (Vernol's), 282, 32\%.

Black Hawk (Seely's), 283.

Black Hawk Prophet, 265.

Blackie, 360 .

Black Jin, 279, 280

Black Messenger, 249 .

Black River Messenger, 361, 362.

Black Prince (Scobey's), 346

Black Rose, Pedigree of, 419

Black Warrior (Warrior), 149, 150.

Blackwood, 350 .

Blanco, 357, 358

Blandine, 350 .

Blank, $\tau 0,402$.

Blauvelt, John G., 250, 339

Blaze, 208, 209, 211, 402.

Blessing, The, Voyage of, 109.

Blind Tuekahoe, 365 .

Bloody Buttocks, 70 .

Blue Bull (IVilson's), 352, 353, 354 .

Blue Bull, 274 .

Blue Bull Family, 352, 354.

Blundeville, Thomas, Early English Writer, $159,160,161,170,175$.

Blunt, Wilfred S., Experiences of, with Arabian Horses, $5,6,7,61,62,63$.

Board of Censors, 518,552

Bob Johuson, 439, 443.

Bodine, 302.

Bogus, 361

Bogus Hunter, 361. 
Bolingbroke, Lord, 216.

Bolivar (Pintler's), 415 .

Bonesetter, 359.

Bone Swinger, 261.

Bonita, 292.

Bonner, A. A., 304.

Bonner, David, 304

Bounie Scotland, 482, 514, 525, 527, 552.

Boott, James, 397.

Borden, Spencer, 156,555 .

Boston, 420, 422, 424, 450, 451, 487, 488.

Boston Girl, 325. 363.

Boswell, Dr. 358 .

Bourbon Wilkes, 288 .

Bradhurst, Samuel, 333.

Bradley, w. J., 343.

Brasfield, George, 304

Brawner's Eclipse, 439, 443

Breckenridge, William L., 358.

Breeders'Association, National. (See National A. T. H. B.)

Breeding the Trotter a New Industry, 508.

Breeding the Trotting Horse, 456.

Breeding from Developed Parents, 499, $50 \%$.

Breeders of 2:15 Trotters, 501.

Breeders' Trotting Stud Book, 528, 533.

Brewster, Dr., 363.

Brickmaker (Andrew Jackson), 325.

Bright John, 365.

Bright Phobus, 233, 252.

Bristol Horse, 150.

Bristol Grey, 261.

Britain, Early Horses, 48, 49

Britain, First Horses of, 157-171.

Britain, Time of Julius Cæsar, 157.

British Horses, Early, 164, 165, 166.

Brodhead, lucas. 419, 420, 422, $427,428,429,431$, $441,444,526$, et seq.

Brokenlegged Hunter, 362.

Brown, Mr., 399.

Brown, David W., 365.

Brown, Henry C., 435, 436.

Brown, Major Campbell, 359, 557.

Brown's Bellfounder. (See Bellfounder.)

Brown George, 385.

Brown Hal, 359.

Brown Highlander (Imported), 361.

Brown Pilot, 350.

Brown Wilkes, 288.

Bruce (traveler), 31

Bruce, G. Benjamin, 305, 450, 458

Bruce's Stud Book, 104.

Bruce, Sanders D.. 100, 104, 420, 423, 441.

Buckley, John, 334 .

Buffon, 26.

Buford, Col. F. G., 557.

Bull Calf, 243.

Bullock, Mr., 216, 222, 223.

Bunbury, Sir Charles, 76 .

Burch UIare, 350 .

Burckhardt (traveler in Arabia), 54.

Burdach, 469

Burlew, Charles, 346

Burlew, Scobey \& Backus, 345.

Burton, A bram, 261.

Burton Horse, 261.

Burtsell, Dr. Alex., 59.

Bush, Charles, 24\%.

Bush, Philo C.. 244. 245.

Bush Messenger, 20.

Bush Messenger. (See Ogden Messenger.)

Bush Messenger. (See Messenger, Bush's.)

Byerly Turk, 68.

Cade, $70,84,163,213$.

Cadet, $40 \%$.

Cadiz (Gades), 44.

Cadmus (by American Eclipse), 354.

Cadmus (Iron's), 354, 358, 414.
California Patchen. (See George M. Patchen Jr.)

Camel ("the ship of the desert"), 52 .

Camilla, 246

Campbell, M. C., 360 .

Campdown, 310 .

Canada, $13,15,16$

Canada, Early Horse History, 142, 143.

Canadian Maritime Provinces, 152.

Canadian Pacer, Origin of the, 142, 143, 151, $152,153$.

Canavan, George, 334.

Cannon's Whip, 419.

Cappadocia. (See Cappadocian Horses.)

Cappadocian Horses, 2, 28, 27, 29, 30, 31, 32, 33, $34,42$.

Captain Beard, 439

Captain Lyons, 312.

Captain Magowan, 432, 433, 482.

Carỉisle Gelding, 410.

Carman, Charles, 330.

Carman Mare, 333-336.

Carman, R. F., 333, 334.

Carpenter, Lieutenant, 369, 375, 376.

Carpenter, Powell, 323.

Carthage, Horses of, 44, 45, 48.

Case, Jerome I., 314.

Case, John, 349

Cassius M. Clay, 327.

Cassius MI. Clay, History of, 330-333.

Cassius MI. Clay, 329, 333

Cassius M. Clay Jr. (Neave's), 332.

Cassius M. Clay Ji'. (Strader's), 332, 333, 336.

Cedar Park (Estate), $\% 4$

Celtac and Iberi (Spanish tribes), 46.

Centaur, False Pedigree Given, 100, 101.

Central Truth in Breeding, 512.

Chamich, Rev. M., 28.

Champion (Grinnell's), 259, 344, 347.

Champion (807), 274 .

Champion Family, $344-348$

Champion (Gooding's), 346, 347, 348.

Champion (Nighthawk), 347 .

Champion (Scobey's or Ǩing's), 345.

Charcoal Sal, 324, 336.

Charles Hadley Miare, 332.

Charles Kent Mare. (See Kent Mare.)

Charles II., King, $7,14,5 \pi, 58,68,135,162,168$.

Charley B., 346.

Charlotte Gray, 250.

Charlotte Temple, 322

Chenery, W. W., 452.

Chenery's Grey Eagle. (See Grey Eagle.)

Chestnut Arabians, 70.

Chestnut Hill, 310.

Chestnut Hill Farm, 309

Childers (Imported), 95.

Childers. (See Flying Childers.)

Chimes, 293.

Chincoteague Ponies, The, 111.

Chincoteague Wild Horses, 10, 11.

Chinn, Higgins, 358.

Cholmondeley, Marquis of, 76

Cilicia, 30, 410

Clara (Crazy Jane), 149.

Clara (Dexter's dam), 303

Clark Chief, 318 , 320 .

Clays and Bashaws, 21, 321-337.

Clay, James B., 315.

Clay Pilot, 297,332

Cliff Dwellers, 199 .

Clockfast, 450 .

Cobs, 398, 400 .

Cobwebs, 294.

Cock, Daniel T., 234, 241, 251.

Cock, Townsend, 234, 236 .

Cock of the Rock, 338.

Cockroft, James M., 315 .

Coffein, Goldsmith, 35t, 356, 414.

Coke, Mr., 70-73. 
Colden, Cadwallader R., 98, 233, 234, 244, 247. Colden's Magazine, 98.

Coles, Gen. Nathaniel, 232, 233, 251, 252.

Collateral and Indireet Heredity, 464.

Colonial Horses, 9, 11, 108-141.

Colonial Horse-History, 108-141.

Colonial Running-Stock, 96.

Columbus (Old), 151.

Commander, 243.

Commissioner of Agriculture, 404, 405.

"Committee on Rules," The Kentucky, 526, $527,528,529$.

Commodore, 316.

Compton Barb, ro.

Conductor, 294 .

Conestoga Horses, 136.

Couklin, E. K., 341.

Conley, John W., 304. 351.

Connecticut, Colonial Horse History, 131-133.

Conqueror, 399.

Constable, Mr., 44\%, 448

Constantius, Emperor, Sends Horses to Arabia, $2,28,31,42,43,55$.

Consul, 365 .

Contemporaries (Runningbred) of Messenger, 220.

Controller, 482.

Copperbottom, 195

Copperbottom (Chinn's), 358.

Copperbottoms, 433 .

Copeland, 294.

Cook, O. W., 132, 375, 557.

Coomb Arabian, 70 .

Cooper, Amos, 253.

Cooper, Benjamin B., 229.

Cooper, J. F., Describes Narragansett Pacers, 181.

Cooper, Richard Isaac, 248 .

Cooper's Gray, 253.

Corbitt, William, 501, 505.

Cossack Horses, 393.

Cortez Expedition and Horses, 18, 202.

Coriander, 251 .

Count Byram, 69.

Count Thoulouse, 69.

Crabstick, 278, 279.

Crabtree Bellfounder, 332.

Crane, Mrs., 361.

Crazy Jane (Clara), 149.

Crott's Bay Barb, 69.

Cropped Fagdown, 252.

Cross Heredity, 464 .

Cruger, H. N. 247.

Cuba, Pacers Exported to, 173, 182.

Cullen Arabian, 70.

Cumberland, Duke of, $77,166$.

Cumming"s Whip, 359 .

Cummins, Col. F. II., 282.

Curwen's Bay Barb, 69, 84.

Cuyler, 275.

Cynthia, 346.

Dabster (Imported), 95.

Daisy Bur'ns, $50 \%$.

Dame Winnie, 491, 492.

Dam of Ethan Allen, 381.

Dam of Jay Gould, 503.

Dam of Messenger. (See Messenger.)

Daniel Lambert, History of, 389.

Daniel D. Tompkins, 241, 325.

baniels, P. F., 248.

Danish Horses, 165, 391.

I'Arey White Turk, 68.

D'A rey Yellow Turk, 69.

Darius, the Mede, $30,50$.

Darley, Mr., 58, 59, 69 .

Darley Arabian, 58, 59, 69, $72,106,208,410$.

Darwin, Charles, 468, 4r1, 503.

Dauntless, $2 \%$.
Davis, Jesse M., 345.

Davis, Barnes, 362.

Dean, Silas, on American Saddle-Horse, 190.

Dearing, Jas., 243.

DeLancey, Mr., Early Turfman, 125, 126.

DeLancey, James. 368, 369, 370, 371, 3r5, 376.

Delevan, W. A., 453.

Delight, 250

Denmark (Gaines'), 194, 195, 318.

Desceudants of Mlessenger, 255.

Description of Electioneer, 290

Description of George Wilkes, 285.

Description of Hambletonian (10), 268-270.

Description of Messenger, 226-228.

De Soto, Ferdinand, 18.

De Soto, Expedition and Horses, 202.

Developed Speed, Breeding from, 499-507.

Development, Value of, 499-507.

Dewey, Henry. 362.

Dexter, 303. 317, 482 .

Dexter's Race with Ethan Allen 385-389.

Dey, Mr., 437.

Deyr, Syrian Horse Market. 5, 62, 63.

Diekey, Robert L., Artist, 556.

Dictator, 275,311 .

Dictator, History of, 303, 304.

Dillon, Jesse, 422, 423.

Dine, John C., 355.

Diomed (imported), 41\%, 447.

Direct Heredity, 464.

Direct, 305

Directum, 305.

Dirigo, 363.

Disputed Pedigrees, Investigation of, 409-455.

Distribution of Horses, Early, 36-50.

Distribution of Trotters in United States, 515.

Doble, Budd, 386.

Dodsworth, 68.

Doherty, Mr. (see Royal George), 150.

Dole, Charles S., 305.

Doll, 361.

Dolly, 304

Dolly Spanker, 284, 285.

Don Horses, 393.

Dorrel, Daniel, 352

Dover Messenger, 251.

Downing, Marcus, 316,362

Draco, 286, 35\%.

Draft Horses o Pennsylvania, 136

Drennon (Brinker's), 195.

Drew Horse, 362, 363, 364

Drift, 308

Driver, 302 .

Driver (Reed's), 403.

Dubois, Cyrus, 339.

Dubois, James, 250

Dubois, Major, 342

Duke of Cumberland, 77 .

Duke of Leeds, 76 .

Duke of Newcastle, $57,58,70,80,81,8 \% .162,167$, $1 \% 0$.

Duke of Newcastle. (See Newcastle).

Durgan, Dr., 454.

Durkee, Harrison, $304, \$ 51$.

Duroc, $338,362,417,447$.

Duryea, Garrett, 415.

Dusenbury, Theodore, 340.

Dutch Horses, 11, 12, 129, 172, 374, 375, 391, 392, 396.

Dutch Horses in America, 91, 120, 121, 123.

Dutch Horses in New England, 128, 129.

Duvall, William, 425, 426.

Eagle (Hunt's), 326.

Earl of Cumberland, 166.

Early Bird, 305.

Early Distribution of Horses, 36, 50.

Early English Racing, 83.

Early British Horses, 79, 157, 171, 164, 165, 166. 
Early English Pacers, 158-171.

Early Exportations of Pacers, 173, 182.

Early Colonal Pacing Races, 177, 178.

Early Pacing, Philadelphia, 179 .

Early Thoroughbred Importations, 220.

Early American Trotters. 456, 457, 515.

Early Horse History, Canada, 142, 153.

Eastern Asia Hinor, 30.

Echo, 275.

Eclipse (Lawrence's) 332.

Eclipse (Brawner.'s), 439.

Edgar's Stud Book, 99, 100, 101, 102, 104, 447, $448,516,548,549$

Edsall, Major, 295.

Edsall's Hambletonian, 295.

Edward Everett, 275

Edwin Forrest, 325, 361, 362, 417, 457.

Egbert, 275, 310 .

Egmont, 300

Egotist, 293.

Egypt, First Horses of, 2, 30, 36, 37, 38, 39, 41, 43.

Eldridge, Richard, 315.

Electioneer, History of, 289-294.

Elactioneer, 275, 356, 413, 438, 463, 464, 503, 504.

Electioneer's Leading Sons, 293.

Elector, 293.

Elgin Marbles, 156.

Elliot, Colonel, 451.

Ellzey, Prof. M. C., 74

Elphinstone, Admiral, 391

Ely, George H., 501.

Emerson, Mr., 349.

Emma Mills, 312.

Emperor Constantius, 79, 95.

Enchantress, 305.

Enemies Made by Honest Methods, 511, 512, 534. 535.

Engineer (English), 212.

Engineer, History of, $241-243$.

Engineer II., 251, 259, 344.

Engineer' (Burdick's), 243, 266, 306.

England, First Horses of, 157-1\%1.

English Foundation Stock, 8, 68-72-106.

English Race Horse, The, 67-89.

English Race Horses, Native, 82, 86-92, 105, 106.

English Stud Book, 83, 84, 87, 88, 106, 207, 216, $217,218,548$.

English Pacer's, 84, 85, 86, 192, 193, 473.

English Race Horses, First Importation of, 95.

English Trotters, 89.

English Hackney, The, 400, 408.

Eoff, James L., 306, 349, 443.

Eriesson, 318.

Eros, 293

Escape, 146.

"Esopus Horses," 122

Ethan Allen, History of, 381-389.

Ethan Allen, 20, 274, 286, 334, 4॰9.

Ethan Allen's Race with Dexter, 385-389.

Ethan Allen (Drury's), 265.

Eton Horse, 364

Euren, Henry F., 169, 209, 402, 404, 405.

European, 348.

Exportations of Pacers, Early, 173, 182.

Extreme Speed, Breeders of. 501.

Eyclesheimer, J. L. B., 349.

Ezekiel, Prophet, 4, 32 .

Fagdown, 252.

Fairlawn Farm, 300, 501.

Fallis, 293.

Family of Mambrino Chief, 315-320.

Fancy (by Messenger), 322.

Fanny, 346.

Fanny Cook, 389

Fanny Kemble, 326.

Fanny Pullen, 241, 481.

Fanny Ransom, 334.
Fantasy, 294

Fashiou Stud Farm, 308, 501, 502, 503, 504, 505.

Favorite Wilkes, 288.

Feagles, David R., 271.

Felter, Col. Harry, 284, 453.

Fergusou, George WV., 36\%.

Ferguson, Williain, 360 .

Fictions in Early Pedigrees, 104, 105.

Fictitious Pedigrees, 511, 512, 534, 535.

"Fidelis," 557.

Finnegan, P. A., 335.

Firetail, 365.

First Horses in Arabia, 28-31.

First Horses Brought to Anerica, 142.

First Importations in New York, 120, 121, 122, 123.

First Horses in New England, 128, 129, 130.

First American Racing, 12:, 123, 124, 125, 126 134

First American Race Course, 90.

First Racing in Virginia, 109, 110, 113.

First American Hor'se Advertisement, 130.

First Race-Horses in South Carolina, 140.

First Trotting Races, 456, 45i.

First Importations of Thoroughbreds, 95, 96.

First Impregnations, Influence of, 465 .

First Consul (Bond's), 233, 322.

Fisk, A. C., 311

Fitz, Stephen, Early English Writer, 158, 159, 170.

Flanders Horses, 81.

Flanders Mares, 160.

Flora, 306.

Flora Temple, 235-306, 335, 361, 477, 498 .

Florizel, 450.

Flying Childers, 59, 208.

Flying Morgan, $382,383$.

Forbes, J. Malcolnı, 538

Forshee Hor'se, 150.

Foster, Charles J., 99, 218, 219, 221, 285, 286, 487, $511,555$.

Foundation Stock of England, 68-72, 106.

Foundation Saddle Stock, 194, 195.

Founder's of Trotting Families, 274.

France, Early Horses of, 143.

France, William C., 501, 505.

Frank, 442.

Franklin, Benjamin, 136

Frauds in Early Pedigrees, 96-97, 100, 101.

Fred Crocker, 292, 293.

Frolic, 334.

Gades (Cadiz), 44

Gage, D. M.. 306.

Gaits of Saddle Horses, 192. 193, 194.

Gaits, Mechanism of, 154-156, 184, 185-186.

Gait, The Ambling, 15\%, 158, 159, 160, 161, 162, 163,192 .

Gaits of Colonial Horses, 116, 131.

Gait, The Pacing, 157-163.

Gallatin, 451.

Galloway, Samuel, 74 .

Galloway, R. F., 307 .

"Galloways" in Virginia, 113

Galloway Breed, 84, 85. 91, 163, 164, 176.

Gambetta Wilkes, 288 .

Gameness, Trotter and Runner, 482, 489, 491.

Gavo, 318 .

Gavin, Joseph, 414.

General Benton, 438.

General Butler, 286.

General Knox, 265, 309, 502.

General McClellan, 363.

General Taylor, 349.

Gentry, John R., 17 .

George B. McClellan, 363

George M. Patchen, 274, 329, 331, 339.

George M. Patchen, History of, 333-336.

George II. Patchen, Jr., 302, 335-336. 
George Wilkes, 275, 308 .

George Wilkes, History of, 281-289.

George Wilkes, Pedigree of, 453.

George Wilkes' Sons, Table of, 288.

Gibson's Tom Hal, 359, 360.

Gideon, $35 \%$.

Gilbert, James, 453.

Gilmore, David W.. 328.

Gilmore, Frank, $32 \hat{8}$.

Gimcrack, $44 \%$.

Gipsey Queen, 432, 433, 434.

Glasgow and Heinsohn, 342.

(ilencoe (inported), 432 .

Glencoe Chief, 306.

Glenview Farm, 501, 505.

Gloster, 302.

Godfrey Patchen, 336.

Godwin, Joseph H., 33\%, 333.

Godolphin Arabian, 8, 58, 59, 60, 70, 71, 73-78, 81 , $106,353,402,411,412$

Godolphin Arabian, History of, $72-78$.

Godolphin Arabian, Pictures of, $73-78$.

Godolphin, Lord, $70,73, \tau 4,7 \%, 78$.

Gog Magog (Estate), $70,73,76,7 \%$.

Golden Farmer, 40\%.

Goldsmith, Alden, 286, 301, 302, 303, 304

Goldsmith Maid, 308, 358, 47\%, 502.

Gomer, 28, 29, 32.

Gooding's Champion. (See Champion.)

Gooding, T. W. \& W., 316.

Goodspeed, H. C., 5. $\%$.

Goodwin Watson' (Strathmore), 309.

Gordon, Gen. John G., 475.

Gould, Ebenezer, 236.

Gould, Jay, 308.

Gould, Levi S., 410, 442, 444, 555.

Governor Nicolls Establishes Racing, 90

Governor Sprague, History of, 312-314.

Grace Darling, 363.

Grand Bashaw, 3:1.

Grandsons of Hambletonian, 284-314.

Grand Sultan, 321.

Grant's (General) Arabs, $€ 4$.

Grant, Mr., 349.

Gray, Angereau. 416.

Gray, william, 359

Griy's 'Tom Hal, 35 9

Great Tabla of Trotters, 542, 551, 558, 559

Great Table of Trotting Families, 274

Green, A. C., 308.

Greene, E. J., 364.

Green, Joseph A., 282, 283.

Greene, Judge W. E., 364.

Green, Roger, Pioneer of North Carolina, 139.

Green's Bashaw. (See Bashaw.)

Green Mountain Ilaid (by Harris' Hambletonian), 261, 325 .

Green Mountain Maid, 289, 290, 355, 413.

Gretchen (by Gideon), 35\%.

Grey Eagle (Chenery's), 452.

Grey Eagle Mare, 439, 440, 441, 442, 444.

Grey Figure, 253.

Grey Harry, $23 \%$

Gieyhound, 68.

Grey Mambrino, 248.

Grinnell, Williain R., 259, 345.

Grinnell's Champion. (See Champion.)

Griswold, Judge, 368 .

Gi-iswold, Manley, 43\%.

Grosvenor, Lord, 20\%, 214, 215, 216.

Growth of $2: 30$ List, 477 .

Gue, Gurney C., $55 \%$.

Gunn, General, 246.

Guy Miller, 285, 288, 307.

\section{-1}

Hackney, The English, 398, 400-408.

Hackney Stud-Book, 169, 209, 402, 404.

Haggin, J. B., 335.

Haic (Haicus), 3, 29, 32.
Haight, Daniel B., 250, 260.

Haight, Nelson, 260 .

Halcoln (Peter's'), 195.

Hall, George C., 308.

Hall, Joseph, 334.

Halstead, Hessrs., 335.

Hambletonian (Bishop's), 20, 21, 232, 235, 251, $262,265,26 \%, 306,487$.

Hainbletonian (Bishop's) Stud Services, 234 235 .

Hambletoniau (Harris'), 20, 150, 235, 261, 309 348,437 .

Hambletonian (10), History of, 26\%-283.

Hambletonian Speed and Training, 271, 2\%.

Hambletonian (10), 20, 21, 258, 303, 309, 310, 311 , $312,313,314,323-329,398,399,453,459$.

Hambletonian (Green's), 301.

Hambletonian Jr., 302.

Hambletonian (Andrus'), 265, 306.

Hambletonian's Sons and Grandsons, 28t-314.

Hambletonian's Sons (table), 275 .

Hambletonian (IVood"s), 297

Hambletonian (Judson's), 235, 265, 306.

Hambletonian (Parris'), 265

Hambletonian (Sprague's), 313.

Hamlin, C. J., 501 .

Hanchett Horse, 264.

Hancock, Joseph, 322, 323.

Hanley, MIoses, 365 .

Hanley, Samuel, 365.

Hanley's Hiatoga. (See Hiatoga.)

Hannibal's Cavalry, 45, 47 .

Haphazard, 397.

Happy Medium, 243, 266, 2r5, 306.

Harbinger, 299.

Harding, General, 486.

"Hark Comstock" (Peter C. Kellogg), 267, 555.

Harkness, James, 345.

Harmor, Mr., Colonial Writer, 109.

Harold, History of, 275, 305.

Harris, Charles T., 55i.

Harris, S. T., 555 .

Harris' Hambletonian. (See Hambletonian.)

Harris, Russell, 263.

Harrison, Benjamin, 111.

Harry Clay, 289, 332, 413 .

Harry Wilkes (Conn's), 313.

Hartford, Kirst Settlement, 13, 132.

Harrey, Dr. Elwood, 111.

Haselton, William, 249.

Hattie Woodward, 312.

Havoc, 343, 417.

Hawkins, Jonathan, 303.

Hayward, Alvan, 238, 239, 240.

Hazard, I. T., 174, 1\%5, 17\%, 178, 181.

Hazard, Robert, 174.

Head'em, 334

Helena, 294.

Helm, H. T., 302, 555

Helmsley Turk, 68.

Hempstead Plains Race Course, 12, 90, 122.

Hendrick, Rev. T. A., 557 .

Hendrickson, William, 335.

Hendryx, H. J., 310.

Henry, 338, 449, 450.

Henry Clay, 285, 336, 454, 455 .

Hemry Clay, History of, $327-330$.

Henry Clay Jr., 329 .

Henry Hal, 360.

Henry, Mason, 319.

Henry B. Patchen, 336.

Henry VIII., Law of, 81 .

Heredity, 461 .

Heredity of Acquired Habits and Instincis, 471 .

Heledity of Bad Qualities, 478

Heredity of Influence, 465 .

Herbert, Henry, 476 .

Hero, 235, 355, 437.

Heroine, 301 . 
Herr, Dr. Levi, 316, 318, 319, 333, 41\%.

Herschell, 300.

Hetzel, Joseph, 301

It iatoga ("Old Togue"), 365.

Hiatoga (Rice's), 364.

Hiatoga (Hanley's), 365

Hiatoga (Scott's), 365.

Hiatt, James M., $55 \%$.

Hibbard, D. B., 347

Higbee Brothers, 313.

High A sia Not Original Habitat of Horse, 24 .

Highland Farm, 501.

Highland Maid, $47 \%-498$.

Highland Messenger (Wamock's), 362.

Highlander (Watkin's), 360, 361.

Hill, David, 3\%, 382, 383 .

Hill's Black Hawk. (See Black Hawk.)

Hinda Rose, 292

"Hiram," 43\%.

His am Drew, 364

Hiran, King of Tyre, 35, 41, 48 .

History, Colonial Horse, 108-141.

History of Abdallah, 255-261

History of Alexander's Abdallah, 294

History of Almont, $29 \%$.

History of Andrew Jackson, 323-325.

History of Imported Bellfounder, $397-400$.

History of Belmont, 299 .

History of Black Hawk, 3r7-381.

History of Cassius M. Clay, $330-332$.

History of Daniel Lambert, 389

History of Dictator, 303 .

History of Electioneer, 289-294.

History of Ethan"Allen, 381-389.

History of George M. Patchen, 333-335.

History of George Wilkes, 281-289.

History of Governor Splague, 312-314.

History of Hambletonian (10), 267-283.

History of Happy Medium, 306.

History of Harold, 305 .

History of Henry Clay, 327-330.

History of Jay Gould, 307-309.

History of Justin Hol'gan, 367-376.

History of Kemble Jackson, 325-327.

History of Long Island Black Hawk, 327.

History of Mambrino Chief, 315-317.

History of Messenger, 222-231.

History of the Orloff Trotter, 390-397.

History of the Pacing Horse, 15t-171.

History of Pilot . $\mathrm{J}^{2}$., $343,344$.

History of the Standard, 518-524.

History of Strathmore, 309.

History of Tippo, 145-147.

History of Volunteer, 301

History of Wallace's Monthly, 554-557.

History of the Wallace Publications, 547-559.

Hoagland. Sim D., 264

Hobbie, The Irish, 80, 85, 113, 160, 161, 163.

Hobgoblin, 70.

Holbert Colt, 311.

Holcomb, Joel W., 382, 383.

Holstein, Otto, 55i⿱.

Holton, John A., 421-431.

Holton, Llewellyn, 421, 423, 424, 426, 428, 429 , $430,431$.

Honest Ance, 349

Honest Jolın, 325 .

Houesty, $30 \%$.

Honey wood Arabian, 69.

Hook, Thomas, 319.

Hooker, Rev. Thomas, 131.

Hoosier Tom, 359 .

Hoover, Jonas, 327.

Hopkins, George, 437 .

Hopples, 157, 473 .

Hopson, Seth P., 260.

Horse Advertisement, First American, 130.

Horseman, The, $55 \pi$.

Horse Portraiture, Improvement in, 556.

Horse Racing, First in Virginia, 109, 110, 113.
"Horse Review, The," 414, 5.57.

Hotspur, 253.

Ilonglitou Hall, Norfolk, Eng., 76, \%

How the Trotting Horse is Bred, 456, 460

Howard, Rev, Erastus, 146, 148, 149.

Howard, James, 94

Howard, Sanford, on Winthrop Messenger, 238,239 .

Hoyt, Hezeliah, 291, 295.

Hoyt, James W., 414

Hudson, Henry, Explorer, 120.

Huggins, Dr., 474.

Hulda, 288.

Hulse Mare, 301.

Hunt, Benjamin W., 557.

Hunt, John W., 258

Hunt's Eagle, 326.

Hunter Mare, 35\%.

Huntress, 302 ,

Husted, Jacob, 251.

Hutchinson, Mathias, 253.

Huxley, Professor, on Primal Horse, 197.

Hyksos. (See Sheplerd Kings.)

Iberi and Celtæ (Spanish tribes), 46.

Idol, 502.

Importation of Messenger, 223.

Importations, Early, 2:0.

Importations, First, 8-16.

Importations, First to Virginia, 109, 110, 116 117.

Importations of Race Horses, 117, 118.

Importations of Thoroughbreds, First, 95, 96.

Impetuous, 306.

Independent (Iiott's), 312.

Indiana Belle, 432.

Indian Hill Farm, 319

Indirect and Collateral Heredity, 464

Infidel, English Trotter, 214

Influence of First Impregnations, 465.

Inheritance, Laws of, $462,463$.

Instinets and Characters, Acquired, 471.

Investigating Pedigrees, 22

Investigation of Disputed Pedigrees, 409-455.

Iola, 261, 325.

Irish Hobbies, 160, 161, 163, 161.

Irons, John, 354.

Irons' Cadmus. (See Cadmus.)

Isaiah Wilcox Mare, 266 .

Itasca, 334.

Jacleson, Josiah,

Jackson, Tim T., 302, 330

Jackson, Thomas, 24i.

Jackson, Thomas, Jr., 241

James I. King, 7, 70, 163, 167.

Janus (Imported), 95, 243.

Japheth, 3.

Jaques, Samuel, Jr., 39\%, 398.

Jay Bird, 288.

Jay Gould, History of, 275, 307-309.

Jay Gould's dam, 503, 504 .

Jefferson, President, 64, 111.

Jeffries, Daniel, 323, 324 .

Jenkinson, Thomas, 402

Jennet, The Spanish, 160, 161, 174, 175.

Jenny Duter, 253.

Jemny Lind, $32 \%$.

Jerome Eddy, 303.

Jersey Fagdown, 252, 325.

Jersey Highlander, 417 .

Jer'sey Kate, 330, 336 .

Jersey Wilkes, 288

Jewett, H. C., 501.

Jigg, 211.

Jim Munro, 297.

"J. M.," $2 \% 0$

Job, the Patriarch, 39, 40. 
John Anderson, 330.

John Dillard, 195.

John Hal, 360.

John Netherland, 360.

John Stewart, 482

Johnson, Dick, 84, 418, 441.

Johnston, Mr., 150.

Jolly Roger (Imported), 96.

Jones, Hugh, Colonial Writer, 112

Jones, Major William, 236, 246, 247, 256.

Jones, David W., 226, 236, 237, 241, 24\%, 252, 256 .

Jones, Gilbert, 260.

Jones, Peter W., 328.

Jones, Richard B., 321.

Joseph (Patriarch), 29, 36, 38, 41, 43.

Joseph, John, 365 .

Joshua, 40.

Judge Brigham (Jay Gould), 308.

Judge Fullerton, 308.

Judith, $35 \tilde{r}$.

Judson, Dr. Nathan, 265.

Julia Johnson, 359.

Juliet (by Pilot Jr.), 319.

Julius Cæesar's Invasion of Britain, 15\%.

Justin Mlorgan, 367-3i6.

\section{K}

Kate (by Pilot Jr.), 297, 298

Katy Darling, 294, 295.

Kattywar Horses of India, 468.

Kellogg, Peter C., $267,269,511,555$.

Kellogg, Mr. (Battle Creek), 345.

Kelly, Benjamin, 3\% $7-37^{*} 9$.

Kelly, John L., 379

Kemble Jackson, History of, 325-32\%, 331

Kemble Jackson Check, 326 .

Kennebec Messenger, 238.

Kent, Charles, 281.

Kent \& Bailey, 455 .

Kent Mare, History of, 267, 276, 277, 399.

Kentucky Hunter, 360, 361, 498.

Kentucky Hunter. (See Shenandoah.)

Kentucky Methods, Early, 511, 512, 534, 535.

Kentucky Stud-Book. (See Breeders' Trotting Stud-Book.)

Kentucky Standard, The, 524, 525, 526, 527, 528.

Kentucky Trotting Pedigrees, Early, 516, 517.

Kentucky Union, 312 .

Keokuk, 418.

Kerner, Charles H., 308.

King Almont, 299.

King, David, 345.

King James Arabian. (See Markham Arabian.)

King Pharaoh, 341 .

King Rene, 300 .

Kings of Armenia, 29.

King's Champion. (See Champion.)

Kirk, Jacob, 253.

Kissam, B. T., 256.

Kissam, T. T., 256, 398, 399.

Kittredge, Herbert S., Artist, 291, 294, 556.

Kittrell, M. B., 359.

Kittrell's Tom Hal, 359.

Koontz, John A., on the Wild Horse, 200.

Kosciusko, 319 .

Kremlin, 306.

Lady Alport, 399.

Lady Balch, 357 .

Lady Clinton, 339 .

Lady Fulton, 482.

Lady Irwin, 311.

Lady Jane, 363.

Lady MeClain, 400.

Lady Maud, 502.

Lady Moscow, 349 .

Lady Moore, 261.

Lady Patriot, 301.
Lady Sanford, 308.

Lady Shannon, 264 .

Lady Suffolk, $243,251,344,361,377,477$.

Lady Surrey, $32 \%$.

Lady Thoru, 286, 308, 317, 318, 319, 399, 502.

Lady Vernon, 325.

Lady Waltermire, 309, 313.

Lady Warrenton, 325 .

Lady Webber, 400 .

Ladd, Mr., 312.

Lakeland Abdallah, 305.

Land of $\mathrm{Uz}, 40$

Lander, Gen. F. W., 363.

Lantern, 437 .

Lark. ('See Charley B.)

Last Pacel's in Britain, 410 .

Lath, 70, 84, 163 .

Laurence's Eclipse, 332.

Lawrence, John, 157, 159, 165, 170, 209, 211, 212, $214,401,402$.

Laws of Breeding, 512-514.

Laws that Govern, The, 460.

Law of Heredity, 462

Leading Sons of Alexander's Abdallah, 297.

Leading Sons of Almont, 299 .

Leading Sons of Belmont, 300 .

Leading Sons of Electioneer, 293.

Leading Sous of George Wilkes, 288 .

Leavens, Louis T., 146, 147.

Leedes' Hobby, 85.

Leonard, John, 359

Leviathan, 451

Lewis, Enoch, 177,178

Lewis, Joseph S., 453, 454

Lewis, Mr., 112.

Lexingtou, 413, 439, 440,441, 442, 443, 444, 445, $446,451,479,488$

Like Begets Like, $512,513,514$

Lilly Hitchcock, 443.

Limber, 424, 426 .

Limber Jack, 359 .

Lincoln, President, 64.

Lindsay's Arabian, 93, 94, 132.

Lindsay, Captain, 94.

Linsley, Mr., 368, 376

Little Albert, 294.

Little Brown Jug, 360.

Little Gipsey, 359 .

Lizzie (by John Netherland), 360 .

Lizzie M., 482.

Loder, G. B., 35\%.

Loder, Lewis, 352

Logan, Thomas, 322 .

Long island Black Hawk, History of, 282,327 , 331 .

Longstreet, Dr., 334.

Loomis Brothers, 361

Lord Grosvenor, 448.

Lord Nelson, 311.

Lord Russell, Pedigree of, 420-431, 434.

Lord Russell, 344, 429.

Louis Napoleon, 303.

Love, Joel F., 295.

Lovejoy, Mr., 328.

Lovelace, Governor, 122.

Lucas, John, 358.

Lucas, Le Grand, 529

Lucia, 309.

Luckett, Benjamin, 420, 421, 422, 423.

Lucy, 286, 308, 309, 335, 502.

Lucy Fowler, 451, 452.

Lula, $350,493$.

Lula Wilkes, 493

Lumps, 288.

Luthy, Prof. Charles T., 557.

Lynne Belle, 294.

Lyons, Captain, 369.

\section{M}

McDonald, William, 365. 
McDowell, H. C., 304, 524, 526, 527, 528, 529, 531, Medoc, 449. 533,552 .

Mace, Dan, 286, 317, 386, 387.

McFerran, J. C., 526, 527.

MeGrath, Price, 451.

IcKinney, H. D., $55 \%$.

IcKinney, Horace, 364.

McKiustry Mare, 303

MeLauglilin, Sam, 287.

Macleod, Leslie E., 404, 557.

IcLoyd, Charles, on the Wild Horse, 200

MeNitt, Mr., 348, 349.

MeSparran, Rev. Dr., 112, 134, 175, 176, 177, 178

Magog Hills (Estate), 73 .

Maguolia, 341 .

Magnum Bonum, 347, 350.

Mag Taylor, 313

Maine Messengers, 515 .

Maine Messenger. (See Winthrop Messenger.)

Major Edsall, 29\%?

Nali, H. W. T., 538, 539, 542 .

Mambrino, 316, 344, 399, 400, 487, 557.

Mannbrino Chief, $20,21,261,350,418$.

Mambrino Chief and His Family, 315-320.

Mambrino Chief Jr., 318.

Mambrino (English), 19, 20, 213, 214, 215.

Mambrino (Grey), 248 .

Mambrino, History of, 235-237.

Mambrino Jr., 261 .

Mambrino Messenger, 261.

Iambrino Patchen, 318, 319

Mambrino Paymaster, 20, 237, 251, 259, 261, 315.

Nambrino Pilot, 318, 319.

Mambrino Russell, 344

Mambritonian, 300

Manetho, Egyptian Historian, 37.

Mannol, 26.

Manzanita, 292.

Nlaria Russell, 420-431.

Marion's Guerrillas, 295, 296.

Maritime Provinces (Canada), 152.

"Wark Field," 55 \%

Markham Arabian, 57-70, 80, 163, $16 \%$.

Markham, John, $5 \tau$, $70,80$.

Markham, Gervaise, 80, 160, 161, 170, 175, 192.

Marksman, 301.

Marquis of Cholmondeley, 76 .

Marrett, W. H., 55\%.

Marsh's Primal Horse, 197

Marsh, Professor, of Yale, 197.

Marshall or Selaby Turk, 69 .

Marshall, Mr., Studmaster, etc., 69.

Marshland Shales, 403

Marvin, Charles, 291, 292, $35 \%$.

Mary Bell, 422.

Mary Churehill, 422, 425.

Bary Gray (Imported), 96

Mary Morris, 439.

Maryland, 15.

Maryland, Colonial Horse History, 139.

Maryland, Racing Prohibited, 15, 139.

Mason, John T., 358.

Maspero, Professor, 37, 39.

Massachusetts, Colonial Horse History, 128$1: 31$.

Masterlode, 275-311.

Mathes, Albert, $37 \%$

Matthews, IV. A., 335

Matlock, T., 179 .

Mattie Howard, 482.

Nlaud S., $300,305,457,458,47 \%, 487,499$

Maud S., Pedigree of , $420-431$.

May Day (by Miles Standish), 356.

Mlay Fly, 311 .

Mlay Morning, 355.

May Queen, 350,356 .

Meander, 300 .

Mecklenburg Horses, 391

Media, 2, 30, 32.

Yerlian Horses, 29, 30, 33, 34.

Merring, Nir, 352.

Messenger (Imported), History of, 222-231.

Messenger and His Ancestors, 205-221.

Messenger's Descendants, 255 .

Messenger, Description of, 226,227 .

Messenger as a Race-Horse. 22:.

Messenger's Stud Services, 229, 230,

Messenger's Sons, 232-254.

Messenger, (Iinported), Reference to, 18, 19 $316,323,327,332,338,344,348,349,35 \%, 331$, $362,399,417,457,459$.

"Messenger," (the name abused), 254

Messenger (Austin's), 249.

Messenger (Blauvelt's), 250

Messenger (Bush's), History of, 243-245.

Messenger (Coffin's), 261.

Messenger (Cooper's), 253.

Messenger (Cousius'), 250.

Messenger (Hutchinson's). 253.

Messenger (Nesthall's), 146.

Messenger (Ogden's), 361.

Messenger (Pizzant's), 249.

1iessenger (Simpson's), 364.

Messenger (Stone's), 364 .

Messenger's Runningbred Contemporaries, 220

Messenger Duroc, 275-289.

Messenger Duroc (Backman's), 310, 311

Messenger Duroc (Durland's), 414.

Messenger Duroc (Laurence's), 308

Messenger Duroc (Stevens'), 315.

Middletown, 275.

Miland, Colonel, 243.

Miller, Guy, 2\%0, 414

Miller. James, 295

Miller's Damsel, 233, 246, 248, 251.

Millington, Dr., 244.

Mills, James Mi., 311, 349.

Mills, Joseph T, 348 .

Minchin, John, 308.

Mingo, 339.

Minor Families, 21

Miss Hervey, 397.

Miss McLeod, 311 .

Miss Russell, 299. 300, 344, 420, 431.'

Miss Shepherd, 423.

Mittendorf, Prof. Von, 393.

Modesty, 264.

Mohammed, 4

Mohammed, Flight from Mecca, etc., 53, 54, 55, $56,5 \%$.

Mohammed's Mares, 54

Mohammedanism in Northern Africa, 47.

Mohawk, $32 \tau$.

Monaco, 300 .

Monkey (Imported), 95.

Monroe, "Jim," 295.

Montaigne, 465.

Moore, Hon. Ely. 326.

Moore, R. H., 360 .

Moore, T. D., 359

Moors, 46

Morden, Isaac, 146, 147, 149.

Morgan Family, 366-389.

Morgan Horse, The, 482, 515 .

Morgan Tiger, 265.

Morgan, Abner, $36 \%$

Morgan, John, 3r2.

Morgan, Jolnn. Jr., 36r, 369

Morgan, MIr., 321.

Morris, Lewis, 235, 236.

Morris Family. Turfmen, 125.

Morris, George F., Artist, 556 .

Morrissey, John, 286, 388 .

Mor'se, Calvin. 349.

Mor'se Horse (Norman), 348, 350, 378.

Morton, Earl of, $465,466,467,468$.

Mound Bnilders. 199.

Mount Ararat, 28, 32.

Mount Holly, 250. 
Mozza, 348.

Muley, Ishmael, King of Morocco, 69.

Munger, Frank. (See Royal George.)

Munger, William, 364.

II non, Isaac, 262, 263, 264.

Munson Mare. 235.

Muir, William, Historian, 53

Murray, Dr. J. H., 74.

Murrier, D., English Artist, 77, 78.

Musie's Dam, 502.

Mustang, The, 204.

Nancy, 355.

Nancy Dawson. 361

Nancy Hanks, 247, 30\%.

Nancy Pope, $342,343,417$.

Nancy Taylor, $342,343.417$

Narragansett Pacers, 12, 13, 14, 126, 127, 133, $134,173-182$

National Association of Trotting Horse Breeders, 517, 518, 519, 520, 527, 552, 553, 554 .

National Horse Show, 406, 407, 408

National Trotting Association, 533, 534.

Native British Horses, 164, 165, 166.

Native English Race Horses, 82, 86, 96, 105, 106.

"Natural History of Man," 472

Neapolitan Horses, 81-168.

Nelson, $35 \%$.

Nelson, C. H., 357.

Nestor, 250

Nettie Burlew, 346 .

New Amsterdam (Now York), 122.

New Brunswick, 153.

Newcastle, Duke of, $57,58,70,80,81,8 \%, 92,162$, $167,1 \% 0$.

New England, Colonial Horse History, 12, 128 134.

New Jersey, Colonial Horse History, 138, 139.

New Jersey, Racing Prohibited, 14, 15.

Newmarket, The American, 90, 91, 122.

New Netherlands, 11

New York, Colonial Horse History, 120-12i.

New York, First Horses of, 120, 121, 123.

New York the Source of Supply of Trotting Blood, 515 .

NicoIls, Governor, Establishes Racing, 12, 122.

Nichols, Mr., 474.

Night Hawk, 347.

Niles, Stephen, 148, 149

Nissæum, Horses of, $30,34,50$.

Noble, Henry D., 262

Nonpareil, 32\%.

Norfolk Trotters, $76,169,398,400$.

Norlaine, 292

Norman (Alexander's), 35, 417, 418.

Norman Family, 318-3.51.

Norman. (See Morse Horse.)

Norseman, 79 .

North American, 309, 312, 313.

North Carolina, Colonial Horse History, 139. 140.

Northern Africans, $46,4 \tau$.

"Northern Kings," Horses of, 29, 30.

Northern Syria, 38,39 .

Norton, Selah, $369,3 \approx 0,371$, 375.

Norval, 293, 294.

Nova Scotia, 153

Norwegian Horses, 165, 473.

Nubian Horses, 31.

Numidian Cavalry, Hannibal's, 45.

Nutwood, 298, 300, 344, 493.

Nutwood, Pedigree of, $420-431$.

O'Blennis, 325.

Odom, Eli, 451, 452

Ogden, Judge David, 247, 248.

Ogden Messenger, 247 .

ohio Farmer, 352.
Old Columbus, 151

Old Drew. (See Drew Horse.)

"Old Duroc," 437.

Old Jane, 346 .

"OId Keokuk." (See Keokuk.)

OId March, 360.

"Old Narrayansett," 498 .

Old Pilot. (See Pacing Pilot.)

Old St. Lawrence, 151

Old Shales. (See Shales.)

Old Sorrel. 308.

"Old" Spirit of the Times, 99-101.

Old Telegraph, 454, 45.5.

Old Theories of Breeding, 510 .

Old Togue. (See Hiatoga.)

"Old Turfman" (C. R. Colden), 98.

Oliver, Joseph, 330, 331.

Oliver, Judge M. W., 55\%.

One Eye, 21, 235. $26, \dot{\boldsymbol{\prime}}, 27 \boldsymbol{7}, 278,281,399$

Oneida Chief, 361 .

Oneness of Trotting and Pacing Gaits, 498, 499 Oneness of Trot and Pace, 155, 156, 184, 185, 186. Onward, 288.

Origin of American Race Horse, 92, 96, 105, 106. Origin of English Race Horse, 86-92, 105, 106.

Origin and History of the Standard. 518-524.

Original Habitat of the Horse, 2, 24-35.

Orloff, Count Alexis, 391, 395.

Orloff Trotter, The, 390-397.

Orser, Sheriff, 328.

Osborne, Lord Francis Godolphin, 76 .

Ott, Almeron, 346

"O. W. C.," 557 .

Pace, The, 161-189.

Pace and Trot, Varieties of One-Gait, 155, 156 , $184,185,186$

Pacer of Canada, 142, 143, 151, 152, 153.

Pacer, The, in Relation to Trotter, 17\%-189.

Pacers in Colonial Period, 14, 116, 126, 118, 137.

Pacers, E'rly American, 112, 126, 127, 131, 132 $133,134,138,139,141$.

Pacers, English, 84, 85, 86, 157-171.

Pacers, Last in Britain, 410.

Pacers of Rhode Island, 173-182.

Pacers in Russia, 392, 393, 394.

Pacing Ancestry of Sa.̃dle Horse, 191.

Pacing Gaits, Mechanism of, 15t-156, 184, 185 186.

Pacing Horse, History and Antiquity of, 154 $1 \tilde{i} 4$.

Pacing Pilot, 152, 195, 299, 316, 343, 416, 412 .

Pacing Pilot. History of, 341-343.

Pacing and Trotting, Oneness of, 17, 498, 499.

Packer, L. D., 536, 539, 542.

Paddy, $3 \%$.

Palgrave, Historian. 52.

Palo Alto Farm, 289, 291, 293, 294, 491, 492, 501, $503,504,505$.

Parris Horse, 265.

Parthenon at Athens, Frieze of, 16, 156.

Pasacas, 299.

Patchen, George M., 329, 331.

Paul, 290

Paul Pry, 250, 251.

Peabody, Warren, 295.

Peacock, $348,349$.

Pearce, Edmund, 342.

Pearl, 322.

Pease, Mark, 363.

Peck. Harvey W., 55\%

Pedigree of American Eclipse, 446.

Pedigree of Alexander's Norman, 417.

Pedigree of Bay Chief, 418 .

Pedigree of Black Rose, 419.

Pedigree of George Wilkes, 454.

Pedigree of Hambletonian, 26\%.

Pedigree of Lord Russell, 420-431.

['edigree of Maur S., 420-431. 
Pedigree of Messenger, 205-221.

Pedigree of Miss Russell, 4:0-431.

Pedigree of Nutwood, 420-431.

Pedigree of Pilot $\mathrm{Jr} ., 416,417$.

Pedigree of Sally Russell, 420-431.

Pedigree of Sunol, 438-446.

Pedigree of Tippoo, 145-147.

Pedigree of Waxana, 438-416.

Pedigrees, Early Fictions, 8.

Pedigrees, Early Frauds in, 96, 97, 100, 101.

Pedigrees, Investigation of, $22,409-455$.

Pelham. 498.

Penn, William, Arrival of, 14, 135.

Pennsylvania, Colonial Horse History, 135-138.

Pepper, Col. R. P., 397, 421.

Perkins, Mark D., 328 .

Perry, Alvah, 365.

Persian Horses, 49, 50, 391, 468

Pet, 325.

Peyton, Balie, 486.

Pfifer, Dan, 335.

Phallas, 305.

Phallamont, 305.

Pheasant, 232.

Phidias, Greek Sculptor, 16, 156.

Philadelphia. Early Pacing at, 179.

Philips, Clark, 454, 455.

Philips, E. V., 454.

Philips, Josiah, 453.

Philistorglus, $2 \pi, 39,42,95$.

Phœenicia. (See Phœenician Merchants.)

Phoenician Merchants, 4, 38, 35, 38, 39, 40-48, $79,185$.

Photius, Early Writer, 27, 42 ,

Pick's Turf Register, 83, 84, 214, 215, 216.

Pictures of Horses, First Correct, 556 .

Piedmont. 299.

Pierce, Abraham, 356.

Pilot Family, 343, 344.

Pilot Jr., 274, 309, 316, 416, 417, 458, 463.

Pilot, Pacing, 195.

"Pinafore Standard." (See Kentucky Standard.)

Pixley, 309

Place's White Turk, 68 .

Plato, 251

Plow Boy, 32\%.

Plutarch, 465

Pocahontas, 355-358, 414.

Pocahontas (Yourg), 355.

Polk Brothers, 359.

Polkan (Volcan), 392.

Polonius, 311.

Polybius, Historian, 45.

Polydore Virgil, 165, 170

Pope Mare, 297.

Porter Colt. (See Daniel Lambert.)

Porter, John, 389.

Porter, Judge J., 245

Porter's spirit of the Times, 99.

Porter, William T., 98, 99, 235, 259, 344, 437.

Portia, 493.

Port Royal, N. S., Raid on, 142.

Portraits of Horses, First Correct, 556.

Pot8os, 447 .

Potomac (by Messenger), 245.

Pray Colt, 279 .

Pray, Ebenezer, 278, 280.

Pratt, John, 216, 222, 223.

Primal Horse, The, 18, 195-197.

Prince, 437.

Prince Edward Island, 153

Prince of WVales' Arabian Horses, 60 .

Princeps, 319.

Princess, 235, 243, 266, 306, 30\%.

Pritchard, Dr., 472 .

"Privateer," 555

Prophet's Mares, The, 54, 55, 56.

Pruden, James, 353

Purchas, Samuel, 166.
Puett, Mr., 435

Purposes of Kentucky Standard, 524, 525, 526.

Quagga Story, 465.

Quaker Lass, 25:3.

Quarter Racing, Colonial, 115.

Queen Anu, 213.

Queen Mary, 528, 552.

Queen of Sheba, Visit to Solomon, 40, 42.

Queen (dam of Blue Bull), 353.

Quimby, David, 364 .

Race Horse, The American, 90-10 $\tau^{\prime}$.

Race Hor'se, The English, 67-89.

Race Horses, Native American, 96.

Races, Early Colonial Pacing, 177, 178.

Racing in America, Antiquity of, 90, 91. I

Racing in England, Early, 83 .

Racing, First, in America, 122, 123, 124, 125, 126, 134.

Racing, First Established American, 12.

Racing, First, in Virginia, 109, 110, 113.

Racing Prohibited in Maryland, 138, 139.

Racing Prohibited in New Jersey, 138.

Racing Prohibited in Pennsylvania, 136.

Racing Register, Bailey's English, 83.

Rack, The, 192.

Ralph Wilkes, 288.

Randolph, John, 450

Ranger (Lindsay's Arabian), 94.

Rattler, 157, 420, 422, 473.

Raudenbush, George W., 310

Ray, John P., 454, 455, 557.

Raynor Colt, 259,344 .

Raynor, George, 259, 344.

Red Bird, 345.

Red Wilkes, 288.

Reeder, Dr. George, 475 .

Regan, Joseph, 335.

Register Association, The American Trotting, $536-545$.

Regulus, ro.

Regulus Mare and Produce, 206.

Relf, C. P., 319.

Remington Hor'se, 235, 262, 264

Reynolds, Edward, 244

Reynolds, G. U., 326.

Rhode Island. Colonial Horse History, 133, 134.

Rhode Island Pacel's, 173, 174, 175, 176, 177, 178 , $179,180,181,182,286,309,313$.

Rhode Island and Virginia Pacing Races, 177 , 178.

Ribot, Th., 466.

Rice's Hiatoga. (See Hiatoga.)

Rice, Edward, 364, 365.

Richards, A. Keene, 6, $7,64.65,66,93$.

Richard, John, Publisher, 99.

Richards, Richard, 350.

Ridgeway, Benjamin C., 218.

Rip Van Dam's Pacer, 127, 147, 174, 179.

Rising Sun, 357.

Rittenhouse, David, 365.

Robert Fillingham (George Wilkes), 285.

Robert J., 306, 309.

Robin Gray, 419.

Robinson, Governor of Rhode Island, 174.

Rockhill \& Brother, 310

Rockingham (Imported), 322

Rockplanter, 346 .

Roderick, King of Visigoths, 46 .

Rodes, Levi T., 318.

Roe, Seely C., $271,383$.

Roebuck, 493 .

"Roland," $55 \overline{7}$

Romaine, Cyrus, 434, 435, 436.

Romans in Britain, 79,80 .

Rosalind, 500.

Rosalind Wilkes, 313. 
Roulin, Mons., 472, 473.

Pous, Admiral, 4, 67, 71

Roxana, 70, 84, 163, 213.

Ruyal George, 150.

Royal Mares, $58,68,82,84,410$

Ruins, Prehistoric American, 199

Rumning Blood in the Trotter, 481-496, 511.

Running Gait, The, 151-156.

Russell, Capt. John W., 420-431.

Russell, Col. H. S., 35\% .

Russell, Mr., 350.

Russian Pacers, 392, 393, 394.

Rylander, Mr., 238.

Ryuders, Capt. Isaiah, 311, 414.

Rysdyk, Wm. M., 2\%2, 2\%8, 281, 302, 309, 398, 399.

Sabrans, 42

Saddle Gaits, 192, 198, 194.

Saddle Horse, American and English, 119.

saddle Horse, Ancestry of the, 191.

Saddle Horse, English, 192, 193.

Saddle Horse Register, 194.

Saddle Horse, The American, 190-195.

Saddle Stock, Foundation, 194, 195.

Sager Horse (Young Sportsman), 149.

St. Bel, 293.

St. Hillaire, Geoffrey, 472 .

St. Julien, 302 .

st. Law rence (O]d), 151.

St. Marks, Venice, Bronze Horses of, 158.

St. Victor's Barb, 410.

Stladin, 321.

sale of Wallace Publications, 536-545.

Silisbury, Monroe, 501.

Silly Anderson, 297 .

Sally Miller, 325, 327, 328 .

Sally Russell, Pedigree of, 420-431, 458.

Sally slouch, 338.

Saltram, 451 .

Sam Hazzard, 152.

Sam Purdy, 335, 337.

Sampson, 19, 209, 211, 212.

Sanders, James H., 529, 530, 531.

Sanders' Trotting Stud Book. (See Breeders' Trotting Stud Bonk.)

Santa Claus, 310 .

Saracenic Horse. (See Arabs, Turks, Barbs, etc.)

Saracens, 50

Saracens Overthrow Visigoths, 46.

Saracens in Spain, 473.

Saratoga, 250 .

Sarpedon, 437

Satterwhite, Mr., 441.

Saunders, H. C., 359.

Scandinavian Horse, 473.

Scanlon, James, 333

Scape Goat, 147, 149.

Scobey, Backus \& Burlew, 345.

Scobey, C., 345.

Scobey's Black Prince, 346.

Scobey's Champion. (See Champion.)

Scotland, 482.

Scott, Samuel, 365 .

Scott's Hiatoga. (See Hiatoga.)

Scott's Shales. (See Shales.)

Screwdriver, 243.

Seagull, 422, 426.

Sears, Richard, $30 \%$.

Serlan, Mr., 353 .

Sedley Arabian, 70.

Seely Abdallah, 283.

Seely, Daniel, 241.

Seely, David R., 271 .

Seely, Jonas, Jr., 267, 279, 282, 283.

Seely, Jonas, Sr., 278, 279. 280.

Seely, Ebenezer, 280, 283 .

Seely, Edmund, 279, 338, 340 .

Seely, Peter, $27^{\prime} 9,399$.
Seely's American Star. (See American Star.)

Selaby (or Mrarshall Turk), 69.

Seneca Patchen, 336.

Sentinel, 275, 301

Serls, Wilson, 147,148

Services of American Star, 340.

Services of Hambletonian, 272 .

Services of Messenger, $229-230$.

Seward, IV. H., 64 .

Shaftshury, 253 .

Shales, 401, 402.

Shanghai Mary, 289, 355, 356, 413.

Shark. 303.

Shawhan, Jolnn, 358

Shawhan's Tom Hal, 358.

Shawmut, 301.

Sheldon V., 146-248.

Shepherd, Colonel, 422.

Shepherd, John, 355, 35\%.

Shepherd Kings, 36, 37, 39

Sherman, B. B., 265

Sherman Morgan, $175,3 \% 6$.

Sherrill, Louis, 360 .

Shipman, George, 413, 414.

"Ships of Tarshish." (See Tarshish.)

Shiruo, William, 364 .

Stropshire, Benjamin N., 358.

Shropshire, Mr., Jr., 359

Sickles, H. T., 333, 334.

Sidon, 35 .

Silvertail, 21, 235, 267, 279, 281 .

Simmons, 288

Simmons, Wililåm L., 286, 287, 453.

Simmons, Z. E., 285.

Simpson, Joseph Cairn, 218, 219, 221, 444, 486, 45\%, 511.

Singerly, Benjamin, 554.

Sir Archy, 253. 326, 451, 488

Sir Charles, 343,417 .

Sir Henry, 339, 363

Sir Peter, 397

Sir Solomon, 246,251

Sir Wallace, $2 \% 2$.

Sir Walter (by Hickory), 312, 313.

Sir William, 318.

Size of Hor'ses, 11, 12, 13, 14, 111, 113, 114, 115, $129,130,131,136,137,140,168,172,173,179$, 182.

Skenandoah, 362

Skinner, John S., $73,97,98,447$.

Skinner's Turf Register, etc., 73, 76, 97, 101, $221,548$.

Slasher, 253

Slocum. John N., 350 .

Sinetanka, 391, 392, 395, 396.

Smith, Capt. John WV., Pioneer, 142.

Smith, F. G., $55 \%$.

Smith, H. N., 308, 501, 502, 503, 504, 505.

Smith, J. F. D., Colonial Writer, 114

Sunith, Thomas T., 345 .

Smith, William B., 433.

Smuggier, 308, 357, 358.

Snap Dragon, 447.

Snediker, Isaac, 256

Sniffen, John, 344.

Solomon, King, 35, 40, 41, 55 .

Somers, George, Early Pioneer, 109.

Sons of Alexander's Ábdallah (table), 297.

Sons of Almont (table), 299.

Sons of Belmont (table), 300.

Sons of Electione r (table), 293.

Sons of George Wilkes (table), 288 .

Sons of Hambletonian (table), $2 \pi 5$.

Sons and Grandsons of Hambletonian, 284-314.

Sons of Messenger, ‘282

Sophonisba, 259 .

Sorrel Dapper, 346.

Sorrel Tom (Shawhan's Tom Hal), 358.

South Carolina, Colonial Horse History, 140, 141. 
Sovereign (Imported), 432.

Sozomen's Ecclesiastical History, 42.

Spain, Early Horses, 45, 46, 47.

Spanish Horses, 81, 173, 174, 175, 202, 203, 204, $3 \% 6,472,473$.

Spanish Jennets, $160,161,174,175$.

Spaulding, Dr., 333.

Speed of Hambletonian, $2 \% 1$.

Speed, John, 379.

Speed of Narragansett Pacers, 176.

Splinx, 293.

Spirit, 34.

Spirit of the Times, $548,551,557$.

Spirit of the Times (Old), 98, 101.

Spirit of the Times (Porter's), 98.

Spirit of the Times (Wilkes'), 98, 99, 530.

Sprague \& Akers, 313.

Sprague, Hon. Amasa, 313.

Sprague (Rounds'), 313.

Squire Talnuage, 275 .

Stamboul, 29\%, 332.

Stamboul Arabian, 418.

Stamina, Trotter and Runner, 482, 489, 490.

Standard, First Suggestion of the, 519 .

Standard, Origin and History, 518-524.

Standard, The, 542, 544, 545, 552, 553, 554 .

Standard, The Kentucky. (See Kentucky Standard.)

Standard, The "Pinafore." (See Kentucky Standard.)

Stanford, Leland, 291, 463, 464, 492, 493, 501.

Stanford University, 293.

Stanley, Colonel, 238

Star of Catskill, 341

State of Maine, 151.

Statue of Washington, Union Square, 331.

Staying Qualities in Trotter and Runner, 482, 489,490 .

Stearns, Mr., 346.

Steele, Andrew, 351.

Steele, Solomon, 368 , 373 .

Steiner, J. H., 542.

Steel, Robert, 307 .

Steinway, 310.

Stephanides, William (Fitz Stephen), 158

Stevens, Robert L., 331

Stevens, John Austin,123.

Stewart, Robert, 348.

"S. T. H.," 555 .

Stockholder Mare, 422.

Stone, Elijah, 352, 353.

Stoner, Col. R. G., 309, 501, 505.

Stoner, Martin, 349.

Stonyford Stud, 413.

Stout, Mrs. S. L., 501.

Strabo, Greek Historian, 2, 27, 31, 33, 39, 41, 42, 43,95 .

Strader, R. S., 333.

Strathmore, History of, $275,309,313$.

Strype, John, 158.

Strideaway, 355, 356.

Stringfield, John K., 428.

"Structural Incongruity," 495.

Strumpet, 125.

Stubbs, English Artist, 73, 77, 78 .

Stud Book, Breeder's' Trotting. (See Breeders' Trotting Stud Book.)

Stud Book, Edgar's, 99, 100, 101, 102, 104

Stud Book, English. (See English Stud Book.)

Stud Book, Sanders'. (See Breeders' Trotting Stud Book.)

Stud Book, Wallace`s, 101-104.

Stump (Adams'), 359

Subscription Purses, Early, 90.

Sultan, 297, 332.

Sutton, Lewis J., 294.

Sun, The, 557 .

Sunol, Pedigree of, 290, 292, 294, 438-446, 499.

Surre $, 327,328$.

Swedish Horses, 165, 172, 473.
Swedish Horses of Pennsylvania, 137.

Sweepstakes, :275, 312.

Swigert, 350 .

Swigert, Daniel, 351

Swigert, Philip, 440, 442, 444, 446.

Swiss Boy, 4202

Sykes, Mr., 36*.

Tables-Founders of Great Trotting r'amilies, 274

Tables-Sons of Alexander's Abdallah, 297.

'Tables-Sons of Almont, 299.

Tables-Sons of Belmont, 300 .

Tables-Sons of Electioneer, 293.

Tables-Sons of Hambletonian, 275 .

Tacony, 145, 149 .

Tappan, George, 261.

Tarshish, Ships of $4,33,44,49$.

Tattersall, Mr., 447.

Tattler, $493,502$.

Taylor, G., on Early New Englaud Horses, 132.

Taylor. Mr., 422 .

Taylor, Samuel, 345.

Tefft, Mr., 349

Ten Broeck, R., 437.

Terry, Samuel Hough, 557.

Texas, 195

"The American Roadster," 449

"The Blessing," Voyage of, 109.

The Conqueror, 305 .

The King, 288.

The Moor, 297, 332 .

"The Perfect Horse," 449.

Theopholis, 4?.

Thomas, Colonel, 369 .

Thomas Jefferson, 151, 433, 482

Thomson, Allen W., 3 8 , 380, 433, 557 .

Thorne, Edwin, 260, 302

Thorndale, 297 .

Thoroughbred Blood in the Trotter, 481-496, 511.

Thoroughbreds, First in America, 95, 96.

Thoroughbreds, First in New York, 125.

Thoroughbred Foundations, 511, 513.

Thoroughbred, The Term, 483, 484, 485, 486, 48\%, 488

Thoroughbred, What Constitutes a, 483, 484, 485 .

Thoulonse Barb, 69 .

Thurston, Benjamin, 377.

Thutmosis I., 29, 36.

Timoleon, 450, 451, 488 .

"Tin-cup" Records, 506

Tippoo (by Messenger), 399.

Tippo, Canadian Progenitor, 145, 146, $14 \%$.

Tippo Saib, 246, 276, 327.

Tippo Sultan, 233, 234, 246.

Titcomb \& Waldron, 350.

"Titmouse Stud Book." (See Breeders' Trotting Stud Book

Togarmah, 28, 29, 32, 33 .

Togarmah, Land of, 49 .

Tom Bowling, 451, 452 .

Tom Hal, 152, 195, 433 .

Tom Hal Family, 358-360.

Tom Hal (Gray's), 359

Tom Hal Jr. (Gibson's), 359, 360.

Tom Hal (Kittrell's), 359.

Tom Hal (Lail's), 358, 359.

Tom Hal (Shawhan's), 358

Tom Hal (Shropshire's), 359

Tom Patchen, 336.

Tom Rolfe, 355 , 356, 357.

Tom Teemer, 419 .

Tom Thumb, 281

"Tom Titmouse Stud Book." (See Breeders Trotting Stud Book.)

Tom Titmouse, Pacer," 531, 533.

Tone, Richard, 333. 
Tone, Thomas, 333.

Topgallant, $23 \%$, 451.

Torgom, 28.

Toronto Chief, 151, 433.

Tracy, Gen. B. F, 553, 55̃

Training of Hambletonian, $2 \% 1$.

Trajan, Emperor, 43.

Transfer of Wallace Publications, 536-545.

"Travels Through the States," 118.

Traveler (Imported), 95.

Traveler (Lloyd's), 3i1.

Traveler (Morton's), 371

Traveler. (See Beautiful Bay.)

Tredwell, Alfred M., 30\%.

Tredwell, John, 255, 256.

Tredwell Mare, $250,251$.

Trot and Pace, Varieties of One Gait, 155, 156. $184,185,186$.

Trotter in Relation to Pacer, 172-189, 498, 499.

Trotters in England, 89.

Trotters in 2:15 List, Breeder's of, 501.

Trotting Gait, Mechanism of, 154-156, 181, 185, 186.

Trotting Horse, How He is Bred, 456.

Trotting Instinct, 23.

Trotting Races, Early, 138.

Trotting Races, First in Ainerica, 456, $45 \%$.

Trotting Register, 508, 518, 520, 522, 529, 531.

Trotting Register Association, The American, 536-545.

Trotting Register, Enemies Made by, 511, 512, $534,535,543,544,545,559$.

Trotting Register, Transfer of, 536-545.

Trouble, 264

Troye, Animal Painter, 65.

True Briton. (See Beautiful Bay

True John, 264

Truffle (Imported), 419 .

Trustee (Imported), 334, 452, 481.

Tucker, Joseph, 262, 263 .

Tulip Hill (Estate), 74.

Turf Mare. (See Messenger.)

Turf Papers, Timidity of, 510.

Turf Papers Too Numerous, 510.

Turf Register, Pick's, 83, 81.

Turk, 411.

Turk (Bartlett's), 346

Turk (Weddel's), 346 .

Turks, 81, 82, 85, 168, 391

Turks (English Foundation Stock), 68- 2 .

Tuscarawas Chief. (See Scott's Hiatoga.)

Tuthill, A. T., 317 .

Tweed, James Davis, 365.

Tweedie, General, 43 .

Twenty-Mile Trotters, 482

Twombly, Shade, 377 .

'Twombly, Wingate, 380 .

Tyre, 4,35 .

Udell, Colonel, 250

Underhill, Judge, 265 .

Underhill, R. C., 302.

Updike, Mr., Writer, 177.

Upton, Major, 26, 54 .

Useful Cub, 401, 402.

Utica, Algeria, 44.

Utter Horse, 311.

$\mathrm{Uz}$, Land of, 40.

Vail, Thomas J., 433, 434.

Valentine, Native English Runner, 80.

Van Buren, President, 64.

Van Cortland, A., 332.

Van Cott, W. H., 345 .

Vanderbilt, Commodore, 279.

Van der Donck's Description of New Netherlands, 121.

Van Kirk, John S., 347.
Van Raust, C. W., 224, 229, 246.

Vanvliet, Daniel, $43 \%$.

Van Wyck, Z. B., 330.

Vatican, 300.

Veech, R. S., 303, 310, 318, 419, 420, 424, 501, 526, $52 \%$.

Velocity, 397.

Vergennes Black Hawk, 313.

Vermont, 264

Velmont Black Hawk. (See Black Hawk.)

Vernon Arabian, 70.

Viatka Horses (Russiau), 393, 394.

Victor Bismarck, $2 \pi 5$.

Virginia, 8, 9, 10, 11 .

Virginia, Beverley's History of, 111.

Virginia, Colonial Horse History, 108-119.

Virginia, First Importations to, 109, 110, 116, $11 \%$.

Virginia, First Racing in, 91.

Virginia, First Settlement of, 108.

Virginia and Rhode Island Pacing Races, 17\%, 178 .

Virgo, 311

Visigoths and Saracens, 46 .

"Vision," 55̃.

Vixen, 68.

Volvau. (See Polkan.)

Voltaile, 493

Volunteer, History of, 2\%5, 301, 313.

Von Mittendorf, Professor, 393

Wadsw orth, General, 328, 453.

Wagner, 432

Walk, Mechanism of the, 151-156.

Walker Hor'se, 43 .

Walker, J. H., 310

Wallace, Gen. Lew., 66.

Wallace, John H., 528, 547-559.

Wallace Publications, History of, 547-559.

Wallace Publications, Transfer of, 536-545.

Wallace's American Stud Book, History of, $548,549$.

Wallace's American Trotting Register, History of, $550-554$.

Wallace's Monthly, $74,111,132,169,218,233$, $256,255,291,295,356,415,423,428,453,483$, 519-525, $22 \%-531$.

Wallace's Montlily, History of, 554-55\%.

Wallace's Year-Book, History of, 557-559.

Walpole, Sir Robert, 76 .

Wapsie, 252

Ward, ir., 368, 371, 375.

Warlock, 300

Warrior (Black Warrior), 149, 150

Washington, 322.

Washington Statue, Union Square, 331.

Waterloo, 300

Waterwitch, 514

Watkins, Julius, 361.

Watson, John F., 126, 179, 180.

Watt, Joseph, 365

Waxana, Pedigree of, 438-446.

Waxy (grandam of Sunol), 438-446.

Weatherby, Mr., Compiler of English Stud Book, 71, 83, 84, 87, 88, 106, 210, 212, 213, 214, $215,216,217$.

Weaver, John, 324

Webster (by Medoc), 319.

Wedgewood, 300.

Weights, First Use of, 157, 473.

Weisiger, Mr., 436.

Weismann, Professor, 471.

Welch, Aristides, 309.

Welch, John P., 438, 439, 440, 442, 444, 445, 446.

Welch, Samuel, 361 .

Wesley Grey, 70 .

West, Col. R., 297, 304, 310, 311, 358, 526, 527.

Western Asia, 30, 32 . 
Western Girl, 502.

Wlselau, William, $320,437,481$.

Whip (Cannon's), 419.

Whip (Cumming's), 359.

Whisky Jane, 336, 337.

Whitelıall, 309, 313 .

Whituey, Frank, Artist, 556.

Whynot, $323,410$.

Whynot Messenger, 249

Whyte, Mr., English Author, 159 .

Wickham, Mr., 450, 451.

Widow Machree, 311, 414.

Wilcox, Isaiah, 266 .

Wilcox Mare, 266, 306.

Wileox, Mr., 149.

Wildair, 451 .

Wildair Mare, 450.

Wild Deer, 149

Wild Horses of America, 196-204.

Wild Horses of Arabia, 26.

Wild Wagoner, 336.

Wiley, John, 365.

Wilkes Boy, 288 .

Wilkie Collins, 288

Wilkes (Mr.), George, 99.

Wilkes' Spirit of the Times, 99.

Wilkins, Richard, 249 .

William (Imported), 432.

William Hunter Mare, 357.

Williams, C. W., 501.

villiams, G. T., 315

williams, John, 434, 435, 436

Williams, John, Jr., 348 .

Williams, Mr. (Owner of Godolphin Arabian), 73.

Williams, Roger, 13, 133.

Williams' Turk, Sir J., 69

Williams, Warren, 315.

Wilson, James, 352 .

Wilson, Sir R., 31.

Wilson, William H., 491, 501, 505

Wilson's Blue Bull. (See Blue Bull.)

Wilton, 288

Winthrop, 361 .

Winthrop Messenger, 20, 363, 481

I' inthrop Messenger, History of, 237-241.

Wiser, Hon. J. P., 147.

Withers, Gen. William T., 297, 304, 307, 312, 333.
Woodburn Farm, 300, 350, 415, 416, 420-431, 516-532.

Wood, W. H., 271

Woodford, 319

Woodford Mambrino, 318, 319

Woodtord Wilkes, 288.

Woodmansee, L. D., 355, 357.

Wuodnut, H. C., 304 .

Woodpecker, 437.

Woodruff, George, 324, 325 .

Woodruff, Hiram, 326, 346, 481

Woodward, S. B., 38\%, 383.

Woodward, William, 443, 444.

Wooton, English Artist, 76, 77.

Worden, Mr., 437

Wyllis, Colonel, 94

"Yah Amerikanski," 555.

Yates, L. E., 364.

Year-Book, Transfer of, 536-545.

Yemen, 2, 28, 55 .

Yemen (see also Arabia), 40, 42, 43.

Youatt on the Pace, 170, 171.

Young Andrew Jackson, 327.

Young Bashaw, 321, 322, 327, 336.

Young Bay Kentucky Hunter, 362.

Young Bulrock, 375.

Young Commander, 243, 357.

Young Conqueror, 360.

Young, Daniel, 245.

Young Eclipse (Sherman's), 347.

Young Engineer, 357.

Young, George A., 283.

Young Jim, 288

Young Morrill, 357.

Young One Eye, 278, 279.

Young Patriot, 301.

Young Pocahontas (2:263/4), 355, 356.

Young Portia, 493.

Young Rolfe, 357 .

Young Selim, 353.

Young Sportsman (Sager Horse), 149.

Young Wilkes, 288.

Zachary Taylor, 241. 


